\title{
Driewerf zalig Noorden : over literaire betrekkingen tussen de Nederlanden en Scandinavië
}

Citation for published version (APA):

Grit, D. C. (1994). Driewerf zalig Noorden : over literaire betrekkingen tussen de Nederlanden en Scandinavië. [Doctoral Thesis, Maastricht University]. Datawyse / Universitaire Pers Maastricht. https://doi.org/10.26481/dis.19940429dg

Document status and date:

Published: 01/01/1994

DOI:

10.26481/dis.19940429dg

Document Version:

Publisher's PDF, also known as Version of record

\section{Please check the document version of this publication:}

- A submitted manuscript is the version of the article upon submission and before peer-review. There can be important differences between the submitted version and the official published version of record.

People interested in the research are advised to contact the author for the final version of the publication, or visit the DOI to the publisher's website.

- The final author version and the galley proof are versions of the publication after peer review.

- The final published version features the final layout of the paper including the volume, issue and page numbers.

Link to publication

\footnotetext{
General rights rights.

- You may freely distribute the URL identifying the publication in the public portal. please follow below link for the End User Agreement:

www.umlib.nl/taverne-license

Take down policy

If you believe that this document breaches copyright please contact us at:

repository@maastrichtuniversity.nl

providing details and we will investigate your claim.
}

Copyright and moral rights for the publications made accessible in the public portal are retained by the authors and/or other copyright owners and it is a condition of accessing publications that users recognise and abide by the legal requirements associated with these

- Users may download and print one copy of any publication from the public portal for the purpose of private study or research.

- You may not further distribute the material or use it for any profit-making activity or commercial gain

If the publication is distributed under the terms of Article $25 \mathrm{fa}$ of the Dutch Copyright Act, indicated by the "Taverne" license above, 
Driewerf zalig Noorden 


\section{Driewerf zalig Noorden}

\section{Over literaire betrekkingen tussen de Nederlanden en Scandinavië}

\section{PROEFSCHRIFT}

ter verkrijging van de graad van doctor aan de Rijksuniversiteit Limburg te Maastricht, op gezag van de Rector Magnificus, Prof.dr. H. Philipsen, volgens het besluit van het College van Dekanen, in het openbaar te verdedigen op vrijdag 29 april 1994 om 16.00 uur

door

Diederik Christoph Grit

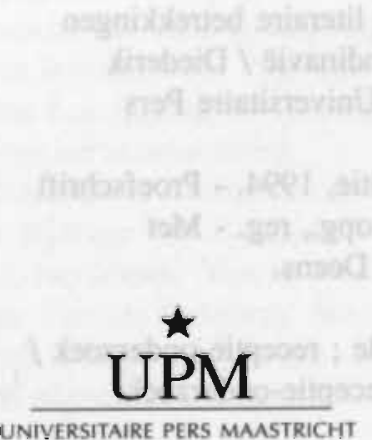




\section{Promotores:}

Prof.dr. J.H.W. Kusters

Prof.dr. G. Laureys (Universiteit Gent)

Beoordelingscommissie:

Prof.dr. A. Labrie (voorzitter)

Prof.dr. H. van den Bergh (Open Universiteit Heerlen)

Dr. W.J.E.M. van Hees (Universiteit van Amsterdam)

Omslagillustratie: Tekening op de band van Als de wegen kruisen, de Nederlandse vertaling van Naar Vejene krydses door J.C.A. Carlsen-Skiødt, 's-Gravenhage 1929.

\section{CIP-GEGEVENS KONINKLIJKE BIBLIOTHEEK, DEN HAAG}

Grit, Diederik Christoph

Driewerf zalig Noorden : over literaire betrekkingen tussen de Nederlanden en Scandinavië / Diederik Christoph Grit. - Maastricht : Universitaire Pers Maastricht. - III.

Ook verschenen als handelseditie, 1994. = Proefschrift

Maastricht. - Met bibliogr., lit.opg., reg. - Met samenvatting in het Engels en Deens.

ISBN 90-5278-132-X

Trefw.: Nederlandse letterkunde : receptie-onderzoek /

Scandinavische letterkunde ; receptie-onderzoek.

๑ Diederik C. Grit, Maastricht 1994 
Hollandske Spraak begyndte oc ved den berømmelige Catz oc andre, meget at florere, oc ligesom at binde Traade til andre Tungemaal.

(uit de voorrede tot: Anders Arrebo, Hexaëmeron, 1661)

Ja zegent hem, gelukkige Oorden,

In schaduw van den throon gerust!

Gezaligd, driewerf zalig Noorden,

Dat zulk eens Konings scepter kust!

Gy boeidet rust en bloei met onverbreekbre koorden,

En hebt de tweedrachtstoorts voor eeuwig uitgebluscht.

(Bilderdijk, De Alleenheersching, 1793)

'Toen volgden de familieromans: de Pinkertonnetjes, de Ravesteintjes 1 en 2, De zes van moeder Tijnagel, en al de andere. De leemte in de meisjeswereld was aangevuld; ik sloeg de blik op het noorden."

'Op het noorden, mevrouw?'

'Op het noorden. Ik maakte kennis met de trilogieschrijvers Knut Knutson, Olav Gulbrand-Olavson, Sigrid Ingridsdochter, en al de anderen. Een nieuwe wereld ging voor mij open: de wereld der trilogieën. [...] Ik reisde naar Scandinavië en ging zeven maanden aan de Norskald-fjord wonen. Daar, in onmiddellijke voeling met de grootse natuur, ontstonden mijn bekende Norskald-trilogieën Winden naderen, Winden trekken voorbij en Winden zien $\boldsymbol{u}$ aan, waarin de Noorse volksziel als het ware uit de bladzijden omhoogschreit. Maar ik wilde nog hoger grijpen [...]. Mijn man [...] kwam op de gedachte om de Hollandse atmosfeer in Noorse trilogieën te verwerken. Zo ontstonden Knut Lavransdochter slaat zich erdoorheen. Sigrid Selmadochter haalt het en Baldur Harold Sigurd Knutszoon zet zijn tanden erin. Ook de meer lichte familieroman De Lavrans Lavrantjes op reis moet van dit gezichtspunt uit bekeken worden.'

'Een verheven gedachte', mompelde ik.

'En dat niet alleen', zegt de heer Van Nieland, fijntjes op zijn achterzak kloppend.

(Godfried Bomans, 'Jo van Nieland-Braat'. In: Kopstukken, 1947) 
Voor Noortje, Anne en Leonie 


\section{Woord vooraf}

Dit boek behandelt een aantal onderbelichte aspecten van literaire relaties tussen de Nederlanden en Scandinavië. De lange voorgeschiedenis ervan begint in 1979. Bij de voorbereiding van mijn eerste colleges Nederlandse literatuurgeschiedenis aan de universiteit van Kopenhagen probeerde ik raakpunten tussen de Nederlandse en Scandinavische letteren te vinden. Op dat moment wist ik maar heel weinig van die raakpunten af, en desbetreffende studies bleken schaars en verspreid. Een vage notie van vroegere populariteit van de Scandinavische cultuur en letteren in Nederland en Vlaanderen, en geconstateerde onbekendheid van de Nederlandse letteren in het Noorden vroegen om verheldering en bijstelling.

Een en ander was aanleiding tot nader onderzoek naar verschillende aspecten van literaire verbindingen, speciaal naar wederzijdse beeldvorming rond de betrokken literaturen. Dit onderzoek, gestart te Kopenhagen en later in Nederland in mijn vrije tijd voortgezet, heeft tussen 1980 en 1992 geresulteerd in zeven in artikelvorm gepubliceerde deelstudies, plus een bibliografie van Deens-Nederlandse literaire vertalingen. De bewerkte versie van de artikelen, waarvan er één is geschreven op basis van de bibliografie, vormt de kem van dit proefschrift. De titel Driewerf zalig Noorden, een uitroep van Bilderdijk, is exemplarisch voor de vaak gekleurde maar vaag omlijnde Nederlandse visies op het Noorden en vice versa, die in dit boek worden belicht en genuanceerd.

Een werk als dit had nooit kunnen worden geschreven zonder de hulp van anderen. Op deze plaats dank ik iedereen die op een of andere wijze aan de totstandkoming ervan heeft bijgedragen. Zonder iemand te kort te willen doen, wil ik enkelen van hen speciaal noemen. Allereerst zijn dat mijn promotoren prof.dr. Wiel Kusters en prof.dr. Godelieve Laureys. Hun kritische commentaar en waardevolle suggesties heb ik graag ter harte genomen. Esther Hagedoom ben ik erkentelijk voor een groot deel van de initiële tekstverwerking, en cand.mag. Birthe Lundsgaard en Phil Hyams M.A. voor de revisie van respectievelijk de Deense en Engelse samenvatting.

Voor de afzonderlijke hoofdstukken is informatic of commentaar geleverd door diverse personen. De aard van hun bijdrage heb ik steeds vermeld in de eerste noot - met asterisk - bij het desbetreffende hoofdstuk. Van hen wil ik wegens de omvang van de bijdrage hier speciaal noemen dr. Gunilla Dahlberg, dhr. Gaby Gyselen, prof.em.dr. Kåre Langvik-Johannessen, prof.em.dr. Amy van Marken, en drs. Paul Roosjen. Amy van Marken dank ik voorts voor de niet-aflatende belangstelling en hulp waarmee zij mijn 


\section{Woord vooraf}

schreden op het Scandinavische pad heeft gevolgd sinds ik meer dan twintig jaar geleden bijvaktentamens Deens en Noors bij haar aflegde.

Familie, vrienden en collega's dank ik voor de belangstelling en de steun waarmee zij de afgelopen jaren het werk aan dit proefschrift hebben begeleid. Voor hun geduld dank ik ten slotte heel speciaal het thuisfront: Noortje, Anne en Leonie. Aan hen wordt dit boek opgedragen.

In het oudst dateerbare werk van de Middelnederlandse letterkunde, Hendrik van Veldekes St. Servaeslegende van circa 1170, wordt van de stad Maastricht vermeld dat deze is gelegen op een kruispunt van vele wegen, waaronder de scheepvaartweg naar "denemerken ende norweghen". Een goede reden om een proefschrift over literaire betrekkingen tussen de Nederlanden en Scandinavië juist in Maastricht te verdedigen. Met deze eerste dissertatie binnen de jonge Faculteit der Cultuurwetenschappen van de zo Europees georiënteerde Rijksuniversiteit Limburg, in deze al even 'Europese' stad, hoop ik te laten zien dat culturele en wetenschappelijke Europese contacten ook vóór en buiten EG-verdragen bestonden respectievelijk bestaan.

Maastricht, februari 1994

Diederik Grit 


\section{Inhoudsopgave}

I Inleiding

1

2

2.1

2.2

2.3

2.4

Aanleiding, thema en opzet

$\begin{array}{lr}\text { Methodologische overwegingen } & 15\end{array}$

Comparatisme

Receptie-onderzoek

Vertaalwetenschap

Conclusies 25

3

Inhoud van het onderzoek

II De Vondelreceptie in Scandinavië $\quad 29$

1 Inleiding 29

2 Scandinaviërs in persoonlijk contact met Vondel 29

$2.1 \quad$ Een onbekende Kopenhaagse Vondeluitgave (1660) 33

3 Vondelopvoeringen in het Noorden 34

$4 \quad$ Weerklank bij Scandinavische auteurs 37

5 Scandinavische Vondelvertalingen 41

6 De Vondelstudie in het Noorden 47

7 Conclusies 51

III Bilderdijk en Denemarken $\quad 53$

$1 \quad$ Inleiding 53

2 Opvattingen over staat, volk, taal en letteren $\quad 54$

3 Bilderdijk en de Noordse letteren $\quad 58$

3.1 Ludvig Holberg $\quad 58$

$3.2 \quad$ Christian Braunmann Tullin $\quad 59$

$\begin{array}{lll}3.3 & \text { A.W. Schack Staffeldt } & 61\end{array}$

3.4 Jens Baggesen $\quad 65$

4 Denemarken en Bilderdijk 66

$\begin{array}{lll}5 & \text { Conclusies } & 71\end{array}$

IV Frederik van Eeden en Scandinavië

$1 \quad$ Inleiding $\quad 73$

2 Stimuli vanuit maatschappij en persoonlijke omgeving $\quad 74$

3 Contacten met Scandinavië en de Scandinaviërs 75

$4 \quad$ Van Eeden en de Noordse letteren 81 


\section{Inhoudsopgave}

4.1 Oudheid en Middeleeuwen

4.2 Klassicisme en romantiek: Holberg, Oehlenschläger, Andersen, Kierkegaard

$\begin{array}{lll}4.3 & \text { De nieuwe letteren. Ibsen, Jørgensen, Strindberg } & 87\end{array}$

5 Conclusies

V Vlaams Scandinavisme en Stijn Streuvels $\quad 93$

$1 \quad$ Inleiding 93

$2 \quad$ 'Het Noorden' in Vlaanderen 94

2.1 De liberale kring 94

2.2 De internationalistische kring 96

$\begin{array}{lll}2.3 & \text { De katholieke kring } & 98\end{array}$

3 Stijn Streuvels 100

$\begin{array}{lll}3.1 & \text { De Bjørnsonvertalingen } & 102\end{array}$

$\begin{array}{lll}3.2 & \text { De 'sagen-bewerkingen' } 105\end{array}$

3.3 Hamsun 108

$\begin{array}{lll}4 & \text { Conclusies } & 109\end{array}$

VI Bestaat de receptie van 'de' Deense literatuur in Nederlandse vertaling, 1731-1990?

2 Een bibliografie van 'de' Deense literatuur in Nederlandse vertaling

3 Bibliografisch zoekwerk

4 Periode 1731-1850: Holberg en andere 'Duitsers'

5 Periode 1850-1920: in de schaduw van H.C. Andersen 118

6 Periode 1920-1960: streekromans

$7 \quad$ Periode 1960-1990: jeugdboeken en ...?

$8 \quad$ Conclusies

VII Makkers en kameraden: een analyse van H.C. Andersens

Reisekammeraten in zeventien Nederlandse vertalingen, 1848-1992

1 Inleiding

2 Reisekammeraten - analyse van de brontekst

Het volkssprookje

Dødningen

Reisekammeraten

2.3.1 Inhoud en structuur

2.3.2 Taalgebruik

De Nederlandse vertalingen

4 Analyse van de Nederlandse vertalingen

4.1 Het analysemodel van Katharina Reiß

4.2 De plaats van 'Reisekammeraten' in het analysemodel 
$\begin{array}{lll}\text { 4.3.1 Stilistische instructies } & 144\end{array}$

$\begin{array}{ll}\text { 4.3.2 Semantische instructies } & 150\end{array}$

$\begin{array}{lll}4.3 .3 & \text { Lexicale instructies } & 154\end{array}$

$\begin{array}{lll}\text { 4.3.4 Grammaticale instructies } & 155\end{array}$

4.4 Extralinguale determinanten 156

4.4.1 Aspect van de oorspronkelijke recipiënt 156

$\begin{array}{lll}4.4 .2 & \text { Kennis van realia } & 157\end{array}$

$\begin{array}{lll}\text { 4.4.3 Tijdsaspect } & 157\end{array}$

$5 \quad$ Samenvatting der resultaten; conclusies 158

Appendix: De vertaling van Annelies van Hees 161

VIII Nederlandse literatuur in Deense ogen, 1900-1990 165

1 Inleiding 165

$2 \quad$ Intrinsieke kwaliteitsgebreken? 168

3 Inventarisatie van Nederlandse literatuur in Deense vertaling, 1900-1990 170

$4 \quad$ Analyse van de beeldvorming $\quad 174$

$\begin{array}{lll}4.1 & \text { Algemeen } & 174\end{array}$

$\begin{array}{lll}4.2 & \text { Periode } 1900-1930 & 174\end{array}$

$\begin{array}{lll}4.3 & \text { Periode } 1930-1960 & 182\end{array}$

$\begin{array}{lll}4.4 & \text { Periode } 1960-1980 & 192\end{array}$

4.5 Periode 1980-1990 204

5 Samenvatting der resultaten; conclusies 210

$\begin{array}{ll}\text { IX Besluit } & 213\end{array}$

Bijlage: lijst van literaire vertalingen Nederlands-Deens in boekvorm, 1900-1990

Noten

Literatuurlijst

- Summary in English

- Resumé på dansk

Personenregister

- Lijst van afbeeldingen 


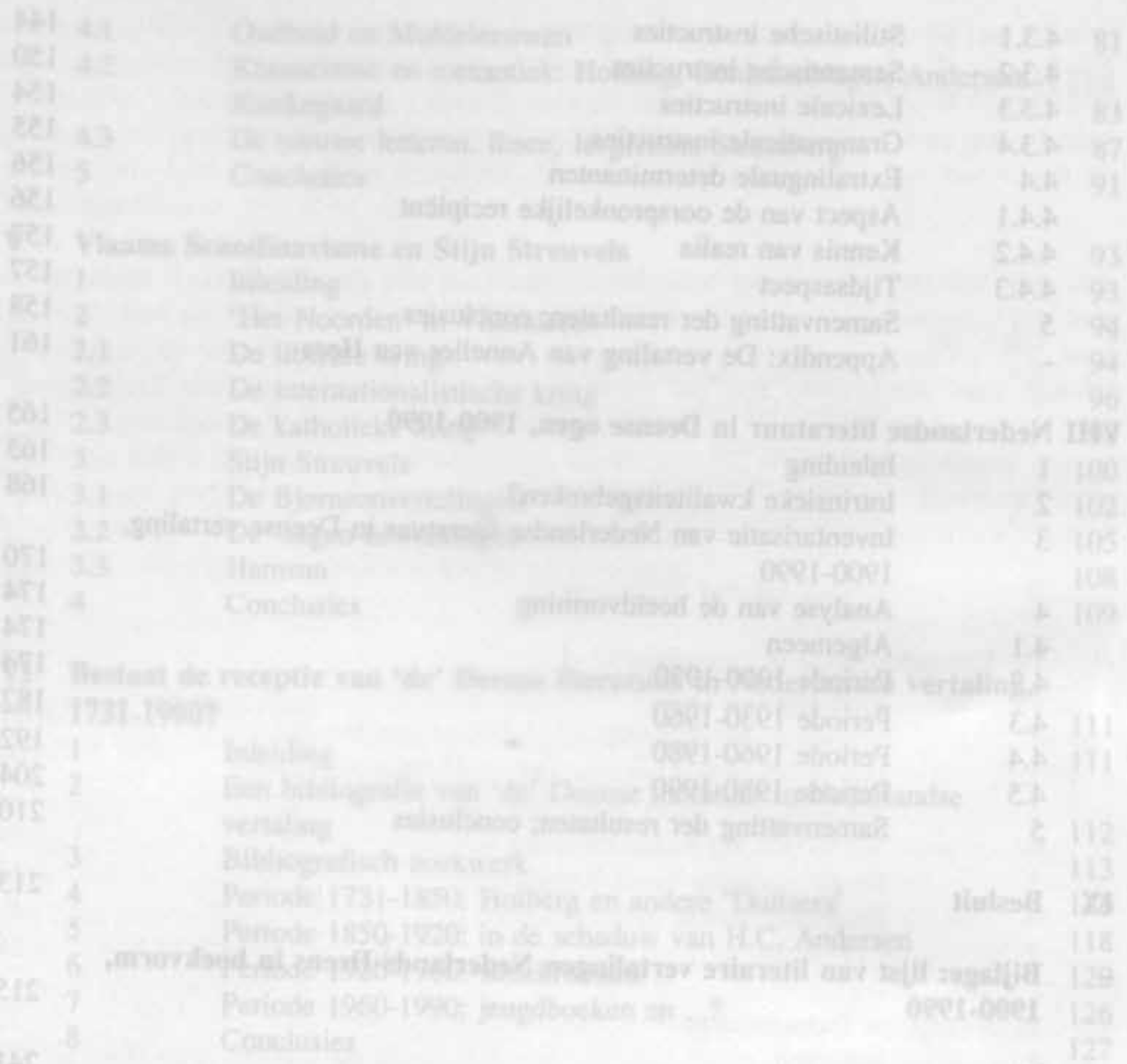

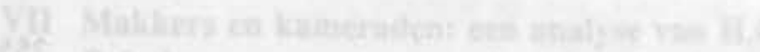

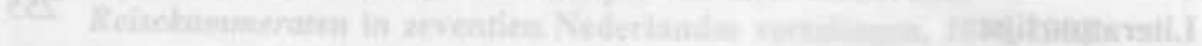

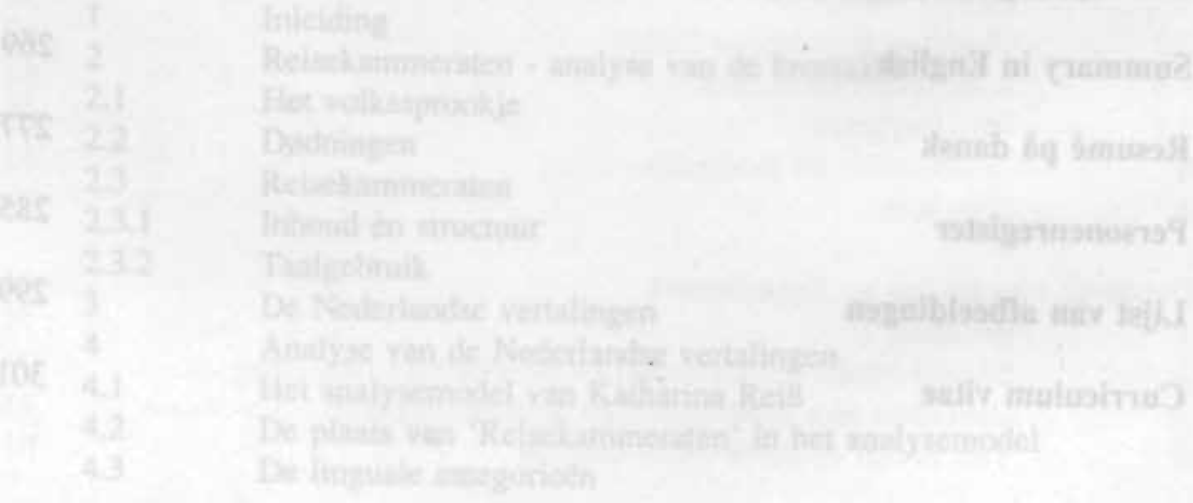

$118+$ 


\section{Hoofdstuk I}

\section{Inleiding}

\section{Aanleiding, thema en opzet}

Wie aan een gemiddelde ontwikkelde Nederlander of Vlaming vraagt wat het begrip 'Scandinavische literatuur' bij hem oproept, zal meestal niet meer te horen krijgen dan namen als Andersen, Ibsen, Hamsun en Strindberg, en wellicht een titel als Winden waaien om de rotsen. En wie een gemiddelde ontwikkelde Scandinaviër vraagt naar namen of titels uit de Nederlandse letterkunde, zal meestal slechts een schouderophalen ten antwoord krijgen.

In vroeger dagen zijn de kennis van en de interesse voor de Scandinavische letteren in de Nederlanden, en vice versa, bij tijden veel groter geweest. Verspreide literairhistorische publikaties leveren samen een wisselend beeld op van grote fluctuaties in richting en intensiteit. Zo was in de zeventiende eeuw kennis van het Nederlands in Scandinavië wijdverbreid: Nederlandse schrijvers las men er in het origineel en Nederlandse tragedies, komedies en kluchten werden er door rondreizende Nederlandse theatertroepen in hun moedertaal opgevoerd. In de achttiende eeuw echter was de Noordse interesse voor de Nederlanden verdwenen. Nu waren het de blijspelen van de Deense schrijver Holberg die grote populariteit bij de Nederlanders genoten, maar Holberg zelf gaf noch in zijn essays noch in zijn memoires blijk van enige bekendheid met Nederlandse auteurs, ondanks een langdurig verblijf in Holland. Na een dieptepunt in de wederzijdse contacten aan het begin van de negentiende eeuw kwam de interesse weer op, ditmaal aan Nederlandse zijde. Potgieter reisde door Zweden en introduceerde na terugkeer met succes de modeme Scandinavische letteren in zijn vaderland. Een gestaag groeiende belangstelling beleefde haar hoogtepunt in de eerste helft van de twintigste eeuw, toen romans van tientallen Scandinavische auteurs een breed lezerspublick in Nederland en Vlaanderen vonden.

Welk beeld hadden lezers uit het ene taalgebied in de onderscheiden periodes van 'de' literatuur van het andere, en in hoeverre hebben afzonderlijke auteurs, als subject en/of object, een rol gespeeld in die beeldvorming? Deze vragen waren voor mij aanlei- 
ding tot een nader onderzoek naar letterkundige betrekkingen tussen de Nederlanden en Scandinavië.

Met bovengenoemde hoofdvragen hangt een aantal subvragen samen. Hebben auteurs contact gehad met het andere cultuurgebied? Hebben ze daarover geschreven; hebben ze uit de vreemde literatuur vertaald? Zo ja, wat, en met welk effect? En wat is er anderzijds over hen geschreven en van hen vertaald, en met welk effect? Of, op het niveau van 'de' literatuur als geheel: wat voor soort werken (welke genres, met wat voor thematiek) werden en worden vertaald; hoe zijn die vertaald en waarom op die manier; hoe zijn ze ontvangen? Welke lezersgroepen lazen welke auteurs en genres? Wat is er over de andere literatuur geschreven en wat voor ideeën blijken daaruit? Zijn er sporen van de ene letterkunde in de andere te vinden?

Dit proefschrift, dat historisch-descriptief van aard is, heeft niet de pretentie al deze vragen in extenso te beantwoorden. Wel tracht het aan de hand ervan enige belangrijke open plekken in eerdere publikaties in te vullen. Het weinige dat is gewijd aan receptie van 'de' Nederlandse literatuur in het Noorden, concentreert zich namelijk vrijwel geheel op de zeventiende eeuw; en waar het receptie van 'de' Scandinavische literatuur in de Nederlanden betreft, gaat het om een beperkt aantal individuele Noordse auteurs. De Zweedse comparatist Wrangel heeft in zijn monografie over de Zweeds-Nederlandse betrekkingen in de zeventiende eeuw (1897) een hoofdstuk gewijd aan de literaire relaties. De Deen Kjærgaard doet hetzelfde voor zijn land in een hoofdstuk van het standaardwerk Holland-Danmark (1945), terwijl de Nederlandse theaterhistoricus Albach (1977) - inmiddels aangevuld door zijn Zweedse collega Dahlberg (1993) - onder andere de reizen van de zeventiende-eeuwse Nederlandse theatertroepen in het Noorden behandelt. Er zijn enige uitgebreide Nederlandstalige studies over Scandinavische auteurs en de Nederlanden: Ferwerda's dissertatie Holberg en Holland (1939), Reesers studie Andersen op reis door Nederland (1976), Claes' artikelenreeks over de weerklank van het werk van Strindberg in de Nederlanden (1981-1983) en Van den Bos' recente proefschrift over de Kierkegaardreceptie in Nederland 1880-1930 (1989). Hiertegenover staan slechts enige korte artikelen over Nederlandse auteurs in hun verhouding tot het Noorden, voornamelijk betreffende Vondels gedichten over Scandinavische vorsten en politiek, en Potgieters relatie met Zweden. Ten slotte is ook over vertalingen uit de Scandinavische talen in het Nederlands en vice versa een aantal artikelen verschenen, maar deze zijn meest van inventariserende aard en gaan - met uitzondering van Bouma's analyse van de Noorse literatuur in vertaling (1976) - niet of nauwelijks in op bovengenoemde vragen.'

Bij mijn streven naar het opvullen van de belangrijkste lacunes in deze publikaties heb ik gezocht naar een redelijke mate van representativiteit, binnen de in de volgende paragraaf uiteen te zetten beperkingen van het onderzoek. Een en ander heeft tussen 1980 en 1992 geresulteerd in een zevental artikelen, alsmede in een door de Koninklijke Bibliotheek te Kopenhagen uitgegeven bibliografie van Nederlandstalige vertalingen van en studies over Deense literatuur verschenen tussen 1731 en 1982. De kem van dit proefschrift bestaat uit de herziene en met recente gegevens aangevulde tekst van de zeven artikelen, die eerder zijn verschenen in De nieuwe Taalgids (1984 en 1988). Spie- 
gel der Letteren (1991), het Tijdschrift voor Skandinavistiek (1980, 1982 en 1992), en in de symposiumbundel Literatuur van elders (1988).

Allereerst is dat een viertal studies over de relaties van enkele steunpilaren van de Nederlandstalige letterkunde - Vondel, Bilderdijk, Van Eeden en Streuvels - met Scandinavië. Naast de reeds door anderen in dit opzicht onderzochte Potgieter zijn er geen andere auteurs van dit kaliber geweest die op vergelijkbare schaal banden met het Noorden hebben gehad. Afhankelijk van het historische literaire overwicht van het ene gebied ten opzichte van het andere is de invalshoek van deze studies enigszins verschillend, zoals al blijkt uit de titels: De Vondelreceptie in Scandinavië; Bilderdijk en Denemarken [i.e. Denemarken en Noorwegen]; Frederik van Eeden en Scandinavië; en Vlaams Scandinavisme en Stijn Streuvels. Het gaat hier dus om 'auteursreceptie', waarbij de auteur object van receptie is (Vondel), subject (Streuvels), of beide (Bilderdijk en Van Eeden). De relatief bescheiden plaats die de Zweedse letteren in dit werk innemen, heeft voornamelijk te maken met de interesse van deze auteurs, die vooral naar Denemarken en Noorwegen uitging. De enige grote auteur voor wie Zweden primair was, Potgieter, ontbreekt, daar hij als gezegd reeds het onderwerp was van studies van anderen, die samen een compleet beeld opleveren.

Dan volgen drie studies over 'literatuurreceptie': de receptie van Scandinavische, in casu Deense, literatuur in Nederlandse vertaling en vice versa. Het eerste is een globale verkenning van de mogelijkheden tot beeldvorming rond 'de' Deense literatuur in de Nederlanden, vooral verricht op basis van bovengenoemde bibliografie van Deens-Nederlandse literaire vertalingen, aangevuld tot en met 1990. Het begrip 'literatuur' is in dit verband ruim opgevat, dus inclusief ontspanningsromans en jeugdboeken. Naar zal blijken, spelen deze namelijk een belangrijke rol in de receptie en beeldvorming. Circa een vijfde van alle Deens-Nederlandse vertalingen betreft werk van H.C. Andersen, en ter illustratie volgt een studie van de concrete 'vertaling als receptie': een analyse van de wijze waarop H.C. Andersens sprookje Reisekammeraten (De reiskameraad) tussen 1848 en 1992 in zeventien vertalingen is vernederlandst. Het laatste stuk is een onderzoek naar de receptie van de, wederom ruim opgevatte, Nederlandse literatuur in Scandinavische, in casu Deense, vertaling van 1900 tot en met 1990.

Naar zal blijken, valt in de beeldvorming, voor zover aanwezig, Deense literatuur grotendeels samen met Scandinavische, en is anderzijds de Deense beeldvorning rond de Nederlandse letteren grotendeels identiek aan die in Scandinavië überhaupt.

In de volgende paragrafen geef ik enige methodologische overwegingen en een overzicht van de inhoud. Na de genoemde zeven studies die de kem van dit werk uitmaken, volgen een appendix, het notenapparaat en de lijst van geraadpleegde literatuur. Samenvattingen in het Engels en Deens plus een personenregister besluiten het boek.

\section{Methodologische overwegingen}

Onderzoeksvragen als de bovengenoemde betreffen alle 'receptic', in de ruime zin van het woord. Men kan trachten ze te beantwoorden aan de hand van verschillende litera- 


\section{Hoofdstuk I}

tuurwetenschappelijke theorieën en methoden, die elkaar voor een deel overlappen, zoals het comparatisme, de receptietheorie (d.w.z. de theorie van receptie in engere zin) en de vertaalwetenschap. In het onderstaande geef ik een korte schets van de hoofdinzichten en richtingen binnen deze theorieën en methoden en van hun onderlinge samenhang, gevolgd door de positionering van het onderhavige onderzoek daarin.

Uitgangspunt bij die positionering is steeds dat het gaat om relatief marginale culturele betrekkingen: de relatie tussen de Nederlandse en Scandinavische literatuur is kwantitatief noch kwalitatief te vergelijken met die tussen bij voorbeeld de Nederlandse en de Franse; die tussen de Deens-Noorse dramaturg Holberg en de Nederlanden niet met die tussen Shakespeare en de Nederlanden; de aantallen literaire vertalingen uit het Deens niet met die uit Engels; en de rol van de Scandinavische letteren voor Bilderdijk, Van Eeden of Streuvels niet met die van de Duitse. Het gaat nergens om complete literaire oeuvres uit de canon, maar om individuele incidentele vertalingen en vaak om subgenres als streekromans en stripboeken; niet om diepgaande invloeden, maar om raakpunten; niet om grondige kennis, maar om bekendwording.

Het woord marginaal is hier echter niet in negatieve zin gebruikt. Zoals zal blijken, zijn de aanwezige marges soms tamelijk breed, bijvoorbeeld als het gaat om het aantal literaire vertalingen in de eerste helft van deze eeuw. Waar we relaties überhaupt niet verwachten, blijken ze aanwezig (Vondel in Scandinavië; Scandinavisme in het negentiende-eeuwse Vlaanderen); en zelfs als ze ontbreken (Nederlandse letteren in het achttiende-eeuwse Scandinavië), kan het interessant zijn die afwezigheid te verklaren. En ten slotte hebben 'marginale' genres als de familie- en streekroman juist een belangrijke rol gespeeld in de wederzijdse receptie. Maar de marginaliteit impliceent wel dat bestaande onderzoeksmethodes in aangepaste vorm moeten worden toegepast en dat de verwachtingen inzake de resultaten navenant moeten worden bijgesteld.

\subsection{Comparatisme}

Onderzoek naar relaties tussen literaturen is vanouds het terrein van het comparatisme of de vergelijkende literatuurwetenschap. In de negentiende eeuw ontstaan uit een ideologisch en sociaal kosmopolitisme, gebaseerd op edelmoedige gevoelens over de verbroedering tussen volkeren, streefde het comparatisme niet het uitwissen van verschillen tussen nationale literaturen na, maar een analyse van de overeenkomsten en verschillen, vanuit een supranationaal standpunt, dat zich met geen der afzonderlijke onderzochte gebieden meer verbond dan met het ander. Dit idee sloeg vooral aan in Frankrijk. De oorspronkelijke nadruk op positivistisch bronnenonderzoek werd daar in de eerste helft van deze eeuw door de comparatistische school rond Femand Baldensperger vervangen door onderzoek waarbij de receptie meer nadruk kreeg. Behalve naar invloeden werd ook gekeken naar beeldvorming rond een auteur of een land; naar het literaire klimaat; naar vertalingen, recensies, etcetera. Daarnaast bepleitte Paul van Tieghem een comparatisme dat zich niet beperkte tot de relaties tussen twee literaturen, maar literaire verschijnselen onderzocht die zich in meerdere literaturen voordoen, zoals de ontwikkeling van genres en de behandeling van literaire thema's en motieven. ${ }^{2}$ 
In de praktijk bleek echter veel comparatistisch onderzoek toch vanuit nationaal perspectief te worden ondernomen, zoals het geval was in Duitsland, waar het eigenlijke comparatisme voor de Tweede Wereldoorlog geen voet aan de grond kreeg. Mede als reactie op het ideologisch misbruik van het begrip 'nationale literatuur' is na de Tweede Wereldoorlog meer nadruk komen te liggen op een wezenlijk supranationaal comparatisme. Naast de Franse school rond de leerlingen van Baldensperger ontstond in de jaren vijftig de Amerikaanse school rond René Wellek, die het zijns inziens valse begrip nationale literatuur aanviel en het concept van de eenheid van de literaire creatie in de westerse wereld ervoor in de plaats stelde. Wellek bekritiseerde de 'boekhouding' van allerlei feitelijke betrekkingen tussen twee literaturen, - betrekkingen die volgens hem vaak niet literair, maar sociologisch of psychologisch van aard waren. In plaats van interculturele studies of ideeëngeschiedenis bepleitte hij tekstimmanent onderzoek naar essentieel literaire kenmerken in teksten uit meerdere taalgebieden.

Het traditionele comparatisme raakte door deze kritiek en door de bloei van de ergocentrische literatuurstudie in een crisis, maar met de opkomst van meer receptiegericht onderzoek in de jaren zeventig heeft het zich weten te herstellen. In latere jaren is dan ook getracht de tegenstellingen tussen de Franse en Amerikaanse school te verzachten. De Belgische comparatist Hugo Dyserinck pleit ervoor, het politiek-geografische literatuurconcept 'nationale literatuur' te vervangen door een cultuurgebonden begrip ('Einzelliteratur') of taalgebonden begrip ('deutschsprachige Literatur'). ${ }^{3}$

Qualitate qua sluit het onderhavige onderzoek aan bij de Franse comparatistische traditie. Onder 'de' Nederlandse literatuur wordt hier de letterkunde van het Nederlandse taalgebied verstaan, dus van Nederland en Vlaanderen, in het besef dat de Vlaamse literatuur ook op zichzelf kan worden beschouwd, zeker in de negentiende eeuw; met Scandinavische literatuur wordt het geheel van de Deens-, Noors- en Zweedstalige letteren bedoeld. Deze literaturen zijn enerzijds zeker apar te beschouwen, maar hangen anderzijds toch ook weer zo samen, zowel in hun interne ontwikkeling als in de beeldvorming buiten Scandinavië, dat ze tevens als een geheel kunnen worden gezien. Dit laatste blijkt ook wel uit handboeken met titels als Nordens Litteratur, An Introduction to Scandinavian Literature en Scandinavische Letterkunde. 'Nederlands' is in dit verband dus steeds te lezen als 'Nederlandstalig' of 'betreffende Nederland en Vlaanderen', terwijl ik de termen 'Scandinavisch' en 'Noords' gebruik voor alles wat specifiek een der drie afzonderlijke talen, culturen of 'Einzelliteraturen' te boven gaat. 'Noords' is bedoeld als een neutraal synoniem van 'Scandinavisch' in de aangegeven betekenis, dus zonder de ideologische lading die dit woord ooit heeft aangekleefd.

Een van de traditionele comparatistische onderzoeksgebieden is invloedstudie: onderzoek naar causale verbanden tussen literaire motieven, werken, genres of stromingen. De invloed wordt daarbij vanuit een 'zender' (émetteur) of vanuit een 'ontvanger' (récepteur) beschreven. Concentreert de studie zich op de algemene invloed die van een tekst uitgaat, dan spreekt men van 'werkingsgeschiedenis'; concentreert ze zich op de mogelijke invloeden op een tekst, dan is er sprake van bronnenonderzoek.

Deze positivistische wijze van onderzoek is echter vanaf de jaren twintig van deze eeuw in diskrediet geraakt. Scherpe kritiek kwam reeds vroeg van de New Critics, en in 1959 van René Wellek in zijn artikel The Crisis of Comparative Literature. De kritiek 


\section{Hoofdstuk $I$}

betrof het vage karakter van het begrip invloed, dat vaak van een te simpele oorzaakgevolg-relatie uitgaat, en bovendien dubbelzinnig is omdat het zowel het proces als het resultaat daarvan dekt. Invloed uit de eerste hand (auteur A beïnvloedt auteur B) is vaak lastig te bewijzen; er kan evengoed sprake zijn van een gezamenlijke beïnvloeding door een derde, of van een geestverwantschap, die zich uit in overeenkomstige concrete vormen. Motieven en thema's zijn meestal zeer algemeen. Ook indirecte invloed (de invloed van A op B via teksten van een ander) is vaak moeilijk aantoonbaar. Er zal op zijn minst sprake moeten zijn van een complex van mogelijke verbanden, voordat tot invloed kan worden besloten. Is er geen sprake van directe invloed, maar zijn er toch overeenkomsten te constateren, dan kunnen we hooguit spreken van verwantschap. ${ }^{4}$

Vooral omdat het in deze studie, zoals gezegd, meer gaat om aanraking en kennismaking dan om vermenging en bekend-zijn, moet het begrip invloed met omzichtigheid worden gehanteerd. Herkenning en tot op zekere hoogte erkenning van auteurs of werken uit de Nederlanden in Scandinavië en vice versa is nog geen invloed. De Nederlandse scandinaviste Boer-den Hoed gaat zelfs zover, elke invloed van de Scandinavische literatuur op de Nederlandse te ontkennen. ${ }^{5}$ In een aantal gevallen is door anderen betreffende de hier besproken auteurs echter een dergelijke invloed gesuggereerd (Vondel-Tömqvist, Bilderdijk-Staffeldt, Holberg-Van Eeden, Hamsun-Streuvels) en ik zal kritisch trachten na te gaan of deze inderdaad aanwezig is. Anderzijds zal ik zelf een enkele maal argumenten aandragen voor sporen van invloed (Andersen-Van Eeden, Ibsen-Van Eeden, Björnson-Streuvels etcetera).

Mutatis mutandis is het invloedbegrip ook slechts in beperkte zin te hanteren voor het type receptie uit de tweede helft van dit proefschrift: de 'literatuurreceptie', in casu de receptie van 'de' Nederlandse literatuur in het Noorden en vice versa. Weliswaar heeft de Nederlandse comparatist Fokkema erop gewezen dat invloedstudie profijt kan opleveren bij cen benadering vanuit de ontvanger: de intrinsieke kenmerken van een nationale literatuur treden duidelijk naar voren als we erin slagen na te gaan op welke wijze en in welke mate externe impulsen door de ontvangende literatuur worden verwerkt, vervormd of afgewezen; de wijze van verwerking zegt iets over de codes van de ontvangende literatuur, daar het hier immers niet gaat om de invloed van de literaire bron als zodanig. doch om de vervorming daarvan. ${ }^{6}$ Maar in ons geval gaat de aandacht meestal uit naar het waarom van de afwijzing en/of het ontbreken van verwerkingen: waarom sloeg de Nederlandse bellettrie in Denemarken niet aan?; waarom hebben de grote aantallen vertalingen Deens-Nederlands per saldo geen of geen wezenlijke invloed op de Nederlandse literatuur uitgeoefend?

Een ander onderzoeksveld binnen de vergelijkende literatuurwetenschap is dat van de imagologie. Deze studie van de transnationale beeldvorming houdt zich bezig met de vraag. welk beeld men in een bepaald land van een buitenlandse literatuur of cultuur heeft. Dit beeld is medebepalend voor de receptie van een bepaald werk uit die literatuur in het ontvangende land. Ook dit type studie is lang in diskrediet geweest, vooral door de ontsporing ervan in de nationaalsocialistische ideologie. De eerdergenoemde Hugo Dyserinck heeft zich sinds de jaren zestig ingespannen om deze smet op het comparatisme te verwijderen en het beeldvormingsonderzoek nieuw leven in te blazen. De imagologische methode, vooral toegepast in Duitsland en Frankrijk, streeft ernaar de verschillen- 
de verschijningsvormen van 'images' (de beeldvorming in tekst of literair verschijnsel X rond literatuur of cultuur $\mathrm{Y}$ ), zowel wat hun ontstaan als wat hun ontwikkeling en effect betreft, vast te leggen. Speciaal gaat het hierbij om de studie van nationale, etnische en culturele beeldvorming, clichés en stereotypen in literatuur en literaire contexten, waarbij ook teksten buiten de literaire canon worden betrokken. ${ }^{7}$ Wat is het beeld dat de voormannen der Vlaamse beweging van het Noorden hadden? Wat is het imago van Scandinavië dat de Scandinavische streekromans (de 'trilogieënlectuur') bij de Nederlandse lezer oproepen?

\subsection{Receptie-onderzoek}

Het receptie-onderzoek in engere zin is aan het eind van de jaren zestig van deze eeuw in Duitsland geïntroduceerd door de zogenaamde 'Konstanzer Schule', met als belangrijkste theoretici Hans Robert Jauß en Wolfgang Iser. Het receptie-onderzoek gaat op systematische wijze de reactie van de lezer op de tekst na. Jauß en Iser trokken hier consequent de lijn door die het Tsjechisch structuralisme reeds getrokken had - van de tekst zelf naar het effect dat die tekst op de lezer heeft. Ook sloten zij aan bij de fenomenologische nadruk op de subjectieve rol van de lezer bij de concretisatie van de literaire tekst. Deze aanpak wijkt af van die van de traditionele literatuurwetenschap, die uitging van de literaire tekst als objectief gegeven, en van de traditionele geschiedschrijving, die uitging van schrijvers en stromingen.

Jauß verzette zich sterk tegen het traditionele receptie-onderzoek zoals dat door de comparatisten werd bedreven, daar de comparatistiek volgens hem van de vergelijking een metahistorische categorie maakt, uitgevonden om het gemakkelijke paradigma van de nationale literatuur veilig te stellen, ervan uitgaand dat die literatuur zich volgens autochtone wetten ontwikkelt. Daarbij ging Jauß overigens voorbij aan het feit dat comparatisten het begrip nationale literatuur al lang vóor hem hadden geproblematiseerd.

Het receptie-onderzoek wordt onderverdeeld in receptiegeschiedenis, receptie-esthetica en empirisch leesonderzoek bij tijdgenoten. De door Jauß gepropageerde receptiegeschiedenis onderzoekt de receptie van teksten sinds de publikatie en de lezers die die teksten hebben gerecipieerd. Vraag is steeds hoe tekst en lezersreactie zich tot elkaar verhouden, dat wil zeggen hoe de verschillende lezers de interpretatiemogelijkheden die het werk in zich draagt, achtereenvolgens hebben gerealiseerd. Het onderzoek kan meer tekstgericht zijn, dat wil zeggen geconcentreerd rond de receptie van een werk in de loop der tijden, of meer lezersgericht, geconcentreerd rond veranderingen in leesgewoonten van groepen lezers.

In concreto onderzoekt de receptiehistoricus bronnen waarin een lezersreactie is vastgelegd. De belangrijkste bronnen voor receptie-onderzoek zijn: aantekeningen van nietprofessionele lezers (bij voorbeeld in een dagboek of in de marge van een literaire tekst); professionele reacties (artikelen, studies); vertalingen: bewerkingen; bewerkingen voor een ander medium; produktieve recepties (verwerking van elementen van een nieuw werk in een ander werk); recensies; verwerking in literatuurgeschiedenissen; opname in bloemlezingen; en verslagen van enquêtes. Afhankelijk van de soort bron varieert het 


\section{Hoofdstuk 1}

Maar hoeveel gegevens ook boven water komen, ze blijven per definitie beperkt. Kloek wijst erop dat historisch receptie-onderzoek op z'n best zeer partieel de reële receptie kan achterhalen, en dat het er dus orn gaat om de hypothetische receptie zo wetenschappelijk mogelijk te funderen, dat wil zeggen controleerbaar gemaakt en kwetsbaar geformuleerd, met erkenning van de onvermijdelijke subjectiviteit van de reconstructie en van omstandigheden die zich aan de waarneming van latere onderzoekers onttrekken; in het besef dat generaliseringen ruwe hulpconstructies zijn; en met een belichting van in de gegeven voorstelling moeilijk te plaatsen gegevens. ${ }^{12}$

De zogenaamde polysysteemtheorie, sinds de jaren zeventig ontwikkeld door de Israelische onderzoekers Itamar Even-Zohar en Gideon Toury en anderen, gaat verder dan bovengeschetst receptie-onderzoek. Deze theorie, die evenals de receptietheorie voortbouwt op ideeën uit het structuralisme, ziet literatuur als een 'systeem', als een gestructureerd geheel van verschillende 'subsystemen' (theoretische en praktische literatuuropvattingen), teksten, genres, thema's, stijlmiddelen etcetera, die voortdurend met elkaar in conflict en dus voortdurend in beweging zijn. Zo kan er sprake zijn van een conflict tussen de literaire canon en en de triviaalliteratuur, en tussen de literaire canon en de vernieuwende literatuur zoals die bij voorbeeld in vertalingen naar voren komt. Voortdurend is er sprake van verschuivingen van waarden en normen, die in bepaalde periodes domineren, en van dominerende en gedomineerde systemen. Er is een duidelijk verband met het historisch receptie-onderzoek: alle literaire opvattingen en praktijken zijn historisch bepaald, of ze nu tot de dominerende of de gedomineerde systemen behoren. Tevens is er een relatie met de comparatistiek, omdat een van de belangrijkste onderzoeksgebieden van de polysysteemtheorie de belangrijke rol is, die vertalingen spelen in de relaties tussen verschillende literaturen, - een rol die door de traditionele comparatistiek overigens relatief weinig is onderzocht. Ten slotte speelt de polysysteemtheorie vanwege de betekenis van vertalingen voor de receptie van vreemde literaturen een heel belangrijke rol in de vertaalwetenschap, - waarover dadelijk meer. ${ }^{13}$

De theorie is bijzonder interessant voor een onderzoeksgebied als het onze, waarin het immers voor een belangrijk dee! gaat om subsystemen: de Vlaamse annex de door Vlamingen vertaalde Scandinavische heimatliteratuur versus de decadente Franstalige literatuur; de Nederlandse familieromans op de Deense literaire markt; Andersen als louter schrijver van verhaaltjes voor kinderen, enzovoort.

Ook met betrekking tot deze theorie geldt echter weer, dat de praktische uitwerking te wensen overlaat. Onderzoeksmodellen zijn er nauwelijks en wat als zodanig is geschetst, is impressionistisch; en concrete toepassingen zijn eveneens zeer schaars. De Nederlandse onderzoekster Luc Korpel heeft onder meer als bezwaar tegen de theorie dat het begrip systeem dermate is 'opgerekt', dat van een echt systeem niet meer kan worden gesproken en dat de interacties tussen systeem en subsystemen door de leidende theoretici worden geformuleerd in termen van universeel-geldende wetmatigheden. Een van de weinige concrete uitwerkingen, Ria Vanderauwera's dissertatie over de wijze waarop circa 50 Nederlandse romans in de periode 1960-1980 in het Engels zijn vertaald en in de Angelsaksische wereld zijn gerecipieerd, is in haar veelzijdige aanpak en door de veelheid aan gegevens weliswaar zeer boeiend, maar is anderzijds bekritiseerd wegens 
het impressionistisch karakter van de vertaalbeschrijving en de aprioristische aard van een deel der conclusies. ${ }^{14}$

\subsection{Vertaalwetenschap}

Ook de vertaalwetenschap kan worden bedreven als receptie-onderzoek in ruime zin. Vertalingen zijn immers per definitie een vorm van receptie: elke vertaling is een interpretatie van de brontekst en als zodanig een receptiedocument. Terwijl de brontekst tekst polyinterpretabel is, maar de meeste concretisaties ervan (de interpretaties van al de verschillende 'gewone' lezers) niet manifest worden, is de vertaling per definitie een interpretatie. De vertaler is gedwongen een keuze te maken uit de verschillende interpretatiemogelijkheden van het origineel, omdat deze niet alle in vertaling weer te geven zijn. Wie als lezer alleen die vertaling onder ogen krijgt, heeft daarmee in principe een beperktere realisatiemogelijkheid dan de lezer van de originele tekst, al ontstaan er anderzijds nieuwe interpretatiemogelijkheden doordat de vertaling zelf ook weer een tekst is. In het geval van de Nederlandse receptie van Scandinavische literatuur en vice versa is vrijwel steeds sprake van deze situatie; het aantal lezers dat de werken in het origineel leest, is relatief te verwaarlozen.

De vertaalwetenschap heeft de laatste decennia een accentverschuiving te zien gegeven. Ging men er voordien meest van uit dat literatuur in essentie onvertaalbaar is en dat vertalingen als vervangingsmiddelen voor de originele teksten gewantrouwd dienen te worden, tegenwoordig neemt men een veel meer doeltekst-gericht standpunt in. Niet het vertaalproces, maar vooral het vertaalprodukt krijgt de aandacht. Ook hier hebben Toury, Even-Zohar en andere polysysteemtheoretici een belangrijke impuls gegeven. Met betrekking tot het vertaalonderzoek kenmerkt de polysysteemtheorie zich methodologisch door drie principes: de aanpak is doelpoolgericht, pragmatisch en beschrijvend. Doelpoolgericht, omdat de belangstelling vooral uitgaat naar de rol van vertalingen in de doelcultuur. Pragmatisch, omdat er geen fundamentele discussie wordt gewijd aan de aard van de vertaling: alles wat zich historisch als zodanig presenteert, wordt als vertaling beschouwd. En beschrijvend, omdat er geen normatief standpunt wordt ingenomen met betrekking tot een 'goede' vertaling. Het gaat niet om de norm van de onderzoeker; deze onderzoekt juist welke normen gehanteerd zijn door de vertaler, welke weerklank de vertaling heeft gehad, en hoe de vertaling zich verhoudt tot de ontvangende cultuur. ${ }^{\text {is }}$

Ook met betrekking tot vertaalonderzoek laat de praktijk van de polysysteemtheoretici echter te wensen over. De Belgische onderzoekers Lambert en Van Gorp presenteerden in 1985 een model voor onderzoek naar vertaalde 'literaturen' in plaats van naar een afzonderlijke vertaalde tekst, om zo het reductionisme van het traditionele vertaalonderzoek te vermijden. In een aantal fasen beogen zij een zo groot mogelijk corpus vertalingen te onderzoeken. Op basis van gegevens uit titelpagina, voorwoord, annotatie en dergelijke formuleren zij hypothesen, die daarop worden getoetst aan onderzoek van de macrostructurele tekstdata als tekstindeling en narratieve structuur, en van microstructurele gegevens als verschuivingen op onder andere grafisch, lexicaal, semantisch, stilistisch en syntactisch gebied. Ten slotte wordt de 'systemische context' onderzocht: de 


\section{Hoofdstuk $I$}

verhoudingen tussen macro- en microstruur, tussen tekst en heersende normen, tussen bron- en doelsysteem enzovoort. De Nederlandse vertaalonderzoeker Van Leuven-Zwart voent echter als bezwaar tegen dit model aan, dat ten eerste de genoemde basis voor de hypothesevorming nogal mager is, met alle kansen van dien op aprioristische cirkelredeneringen, en dat ten tweede nergens concreet is aangegeven met welk instrumentarium de genoemde verschuivingen moeten worden geconstateerd. ${ }^{16}$

De descriptief georiënteerde vertaalwetenschap heeft eveneens een nieuw licht geworpen op de eeuwenoude controverse over de mate waarin en de wijze waarop de vertaling het origineel getrouw dient te volgen. Vertaaltheoretische geschriften namen in dezen voorheen steeds een normatief standpunt in. Tot het eind van de achttiende eeuw is de overheersende norm prospectief. De vertaling dient 'leesbaar' te zijn, dat wil zeggen op de lezers van de doeltekst te worden toegesneden, zelfs als dat te koste gaat van structuur en stijl van het origineel; en te worden aangepast aan smaak en ethiek van de doelgroep, zo nodig door een ingrijpende adaptatie van de brontekst. Tegen het eind van de achttiende eeuw komt een andere vertaalopvatting op, onder andere verwoord door Schleiermacher in 1813 en Von Humboldt in 1816: de vertaling dient de lezer door 'vervreemdend vertalen' in de richting van de (bron)tekst te brengen. De trouw die de vertaler na moet streven is niet de trouw aan het origineel, maar aan de interpretatie die hij eraan heeft toegekend. Aan het eind van de negentiende eeuw roept deze hermeneutische visie haar tegendeel op: de Duitse filoloog Von Wilamowitz-Möllendorf ziet als ideale vertaling een inhoudelijk en stilistisch getrouwe kopie. Onze eeuw vertoont een scala aan visies. Volgens de Tsjechische structuralist Levy (1969) moet de vertaler 'illusionistisch' te werk gaan, dat wil zeggen de literaire kwaliteiten van het origineel reproduceren en die tegelijkertijd zo produceren, dat de lezer de illusie heeft, geen vertaling te lezen, maar een 'echt' literair werk. De neo-hermeneutische visie, in 1982 verwoord door de Duitse vertaalwetenschapper Apel, bepleit dat de vertaler in zijn vertaling uitdrukking geeft aan de wijze waarop hij de brontekst begrepen heeft, in het besef dat dit slechts een van de mogelijke concretiseringen is. ${ }^{17}$

Er zijn aldus twee types vertalingen denkbaar: vertalingen van het adequate, brontekstgerichte type en van het acceptabele. doeltekstgerichte type. Doordat de polysteemtheorie een strikt descriptief standpunt inneemt en elke vertaling die zich als zodanig presenteert inderdaad als vertaling beschouwt, impliceren de termen adequaat en acceptabel echter geen stellingname tegenover beide types. Deze kunnen afhankelijk van de situatie elk op hun manier beantwoorden aan de vigerende behoeften van de betrokken culturen. ${ }^{18}$

Het model voor vertaalkritiek van de hand van Katharina Reiß, dat in dit boek is gebruikt voor de studie naar de Nederlandse vertalingen van H.C. Andersens Reisekammeraten, is slechts ogenschijnlijk in strijd met deze descriptieve en doelcultuurgerichte uitgangspunten. Reiß geeft een uitgewerkte methode voor het kritisch vergelijken van bron- en doeltekst, gebaseerd op een grondige analyse van de brontekst. Haar doel is hiermee is na te gaan of het communicatieve doel van die brontekst ook door de vertaling wordt bereikt. Reiß gaat ervan uit dat bepaalde communicatieve doelen primair zijn, afhankelijk van de tekstsoort. ${ }^{19}$ Voor literaire teksten geldt volgens Reiß over het alge- 
meen het primaat van de vorm: de linguïstische kenmerken zijn belangrijker dan de inhoudelijke.

Hoewel haar benadering dus primair brontekstgericht is, is ze toch te hanteren voor doelpoolgericht onderzoek, zolang geen kwalificatie aan eventuele afwijkingen van de brontekst wordt verbonden. Equivalentie (in de zin van de grootst mogelijke overeenkomst tussen bron- en doeltekst, met inachtneming van de linguïstische en semantische restricties die de doeltaal in dit verband oplegt) is hierbij geen normatief begrip, maar het tertium comparationis om neutraal te constateren of er sprake is van afwijkingen van de brontekst. Alleen door zo te werken kan men vaststellen of die afwijkingen in een vertaling consistent en doelgericht zijn en er sprake is van een samenhangende en doelgerichte aanpassing aan de doelpool, die iets kan zeggen over zowel de norm van de vertaler als van de doelcultuur. Er kan echter ook sprake zijn van onsamenhangende afwijkingen, die niets met die norm te maken hebben. Te weinig houden de voorvechters van een doelpoolgerichte vertaalstudie mijns inziens namelijk rekening met de mogelijkheid dat afwijkingen niet voortkomen uit een welbewuste aanpassing aan de normen van de doelpool (bij voorbeeld een bewerking voor kinderen van een oorspronkelijk voor volwassenen bedoelde tekst, of een vertaling in blank verse van een werk in alexandrijnen), maar uit gebrekkige kennis van de brontaal, foutief tekstbegrip of uit slordigheid; kortom, dat die afwijkingen te beschouwen zijn als onnauwkeurigheden zonder interne logische samenhang. Dat kan zich heel banaal uiten op woordniveau, maar ook, minder doorzichtig, op tekstniveau, bij voorbeeld doordat de vertaler de symboolfunctie van herhalingen en andere tekststructuurkenmerken niet doorziet. Dat dergelijke vertalingen desondanks een rol spelen in de doelcultuur spreekt vanzelf. Mijn primaire doel is dan ook alle bestaande vertalingen van Reisekammeraten te beschrijven, opdat de lezer zelf conclusies trekt: het vertaalkritisch model is primair gebruikt als beschrijvingsmodel.

Van Leuven-Zwart heeft mijns inziens terecht Reiß enigszins in bescherming genomen tegen de kritiek van anderen, die volgens Van Leuven beperkt blijft tot programmatische uitspraken en geen werkbare alternatieven biedt. Lange tijd was Reiß" model eigenlijk het enige gedetailleerde en werkbare instrumentarium voor vergelijkende vertaalbeschrijving en -kritiek. ${ }^{20}$ Dat ik geen gebruik heb gemaakt van het beschrijvingsmodel voor vertalingen van narratieve teksten van de hand van Van Leuven-Zwart zelf, is eenvoudig te verklaren: het betreffende onderzoek van Andersens sprookje vond plaats en werd voor het eerst gepubliceerd voordat dit model in Van Leuvens dissertatie werd gepresenteerd.

\subsection{Conclusies}

Samenvattend kunnen we stellen dat comparatisme, receptietheorie, vertaalwetenschap en polysysteemtheorie voor het onderhavige onderzoek enerzijds een aantal zeer interessante invalshoeken opleveren, maar dat anderzijds de gepresenteerde concrete onderzoeksmodellen binnen met name het receptie-onderzoek en de polysysteemtheorie soms nogal pretentieus zijn, terwijl de de concrete toepassingen over het algemeen veel te wensen over laten. In het licht van deze conclusie neem ik een pragmatisch standpunt in. De hier 


\section{Hoofdstuk I}

behandelde periode (zeventiende eeuw tot heden) is veel te groot dan dat ze voor de verschillende periodes vergelijkbare gegevens oplevert die binnen één model kunnen worden ondergebracht, onderling gerelateerd, en geïnterpreteerd. Deze studie pretendeert dus niet, een alternatief model te bieden, maar gaat eclectisch te werk, binnen de genoemde beperkingen, daarbij strevend naar controleerbaarheid van gegevens en aangegeven verbanden. 'Systemisch' is het onderzoek in zoverre dat zoveel mogelijk aspecten van de literaire relaties erin worden betrokken, zij het dat de accenten van deelstudie tot deelstudie verschillen, afhankelijk van het thema. Het onderzoek is historisch-descriptief en empirisch-documentair van aard, met alle beperkingen van dien, bij voorbeeld wat de mate van beschikbaarheid van onderzoeksmateriaal en de daaraan gekoppelde mate van representativiteit betreft.

Binnen de vraagstelling van de afzonderlijke deelstudies is echter steeds geprobeerd alle achterhaalbare materiaal boven water te krijgen: bij voorbeeld voor de studie van de Vondelreceptie in Scandinavië alle achterhaalbare sporen van Vondel in Scandinavische bibliotheken, archieven, literairhistorische studies, theaterhistorische studies, vertalingen, artikelen, en recensies. Of voor de studie van de receptie van Nederlandse literatuur in Deense vertaling alle 542 vertalingen in boekvorm, alle 468 achterhaalbare recensies en alle achterhaalbare empirisch-literatuursociologische gegevens.

Bij dit alles heb ik er uiteraard voortdurend naar gestreefd, het niet te laten bij een positivistische feitenverzameling, maar de verzamelde gegevens onderling zo systematisch mogelijk te relateren en in een breder cultuurhistorisch verband te plaatsen. Dat al de verzamelde gegevens soms toch nog beperkt of eenzijdig zijn en dat het aanbrengen van een kader steeds met omzichtigheid moet gebeuren, is duidelijk. Wat de hierboven geciteerde Kloek zegt over historisch receptie-onderzoek, geldt voor het onderhavige onderzoek als geheel: de hypothetische receptie dient controleerbaar te worden gemaakt en kwetsbaar geformuleerd, met erkenning van de onvermijdelijke subjectiviteit van de reconstructie. Als auteur kan men alleen maar hopen dat de gemotiveerde conclusies op basis van ruim materiaal of gemotiveerde hypothesen aan de hand van beperkter materiaal door ander onderzoek worden bevestigd, maar er zich voor openstellen dat ze mogelijk worden gefalsifieerd.

\section{Inhoud van het onderzoek}

Voor elk der zeven hoofdstukken die de kem van dit werk uitmaken, zal ik in het onderstaande steeds mijn onderzoeksdoel binnen het in paragraaf 2.3 genoemde kader formuleren, alsmede het materiaal noemen waarmee ik dit doel heb trachten te bereiken.

\section{a. De Vondelreceptie in Scandinavië}

Doel van deze studie is, bloot te leggen welke receptie een zeventiende-eeuws Nederlands dichter, in casu Vondel, in Scandinavië heeft gehad. Met opzet is hier gekozen voor de zeventiende eeuw, omdat in die periode het cultureel verkeer vrijwel geheel eenrichtingsverkeer van de Nederlanden naar Scandinavië was. De receptie wordt bovendien geplaatst in een economisch en politiek kader. Niet alleen de zeventiende-eeuwse 
receptie is echter onderzocht, ook de heropleving in onze eeuw, waarbij de verschillen en overeenkomsten met de eerdere receptie worden nagegaan.

In concreto is gebruik gemaakt van Vondels werken en van zijn biografie (zijn bezoeken aan Denemarken en Zweden, zijn ontmoetingen met Deense en Zweedse hoogwaardigheidsbekleders); Nederlandse en Scandinavische studies over het zeventiende-eeuwse Nederlandstalige toneel in Scandinavië (Vondelopvoeringen in het Noorden); comparatistisch materiaal (de weerklank van de zeventiende-eeuwse dichters bij Noordse auteurs); Scandinavische Vondelvertalingen; en Scandinavische studies over Vondel.

\section{b. Bilderdijk en Denemarken}

Doel van deze studie is, aan te tonen dat reeds een halve eeuw vóór Potgieter, Bilderdijk zich op allerlei manieren bezighield met het Noorden, in casu Denemarken, waartoe in zijn tijd ook Noorwegen behoorde. Deze bemoeienis is des te opmerkelijker omdat de achttiende en vroeg-negentiende eeuw gelden als het dieptepunt in de ScandinavischNederlandse culturele betrekkingen. Bilderdijk, richtinggevend voor een beperkte groep, maar anderzijds vooral ingaand tegen 'de geest dezer eeuw', had niet alleen literaire, maar ook politieke gronden voor zijn romantisch getinte interesse. Bovendien heeft hij, zij het in beperkte mate, sporen achtergelaten in Scandinavië.

Concreet heb ik gebruik gemaakt van Bilderdijks biografie en van Bilderdijkstudies (zijn houding tegenover het Noorden, zijn contacten met Denen, zijn plannen om zich achtereenvolgens in Denemarken en Noorwegen te vestigen); zijn werken (brieven; sporen van het Noorden in het oorspronkelijk werk; vertalingen van Holberg, Tullin, Schack Staffeldt en Baggesen); Deense letterkundige teksten en studies waarin Bilderdijk figureert.

\section{c. Frederik van Eeden en Scandinavië}

Deze studie heeft als doel, weer te geven hoe Van Eeden zich enerzijds in zijn scheppend en beschouwend werk regelmatig richtte op het Noorden, en anderzijds zelf ook weerklank in Scandinavië vond. Anders dan bij Vondel, Bilderdijk en de hiema te behandelen Streuvels, is hier sprake van een evenwichtig tweerichtingsverkeer. Bovendien is Van Eeden een representant van zijn tijd in zijn bewondering voor de zuivere en idyllische Scandinavische samenleving.

Bronnen zijn Van Eedens scheppend en beschouwend werk, zijn dagboeken en brieven, alsmede studies over Van Eeden (zijn bezoeken aan Scandinavië; zijn contacten met Noordse auteurs en politici); Scandinavische publikaties waarin Van Eeden optreedt (interviews, krante-artikelen, essays, recensies, memoires); Van Eedens scheppend werk (sporen van Noordse auteurs); en Scandinavische Van Eeden-vertalingen.

\section{d. Vlaams Scandinavisme en Stijn Streuvels}

Met deze studie wil ik aantonen, hoe de voormannen van de Vlaamse beweging anders dan het Vlaamse lezerspubliek, reeds in de negentiende eeuw belangstelling koesterden voor het Noorden, dat zij zagen als het lichtend voorbeeld voor Vlaanderen: een verwante kleine Germaanse taalgemeenschap, die na een periode van verval nieuwe culturele hoogtepunten had weten te bereiken. Apotheose van deze interesse zijn de succesvolle 
bemoeienissen van Stijn Streuvels om het Vlaamse publiek voor het Noorden te interesseren.

Bronnen zijn een groot aantal primaire en secundaire teksten van respectievelijk over Vlaamse auteurs (directe of indirecte Scandinavische sporen, van Willems tot Rodenbach); Streuvels' autobiografisch werk (zijn reacties op het Noorden en de Noordse literatuur); zijn scheppend werk (sporen van IJslandse en Noorse letteren in zijn eigen werk); zijn vertalingen en bewerkingen van Scandinavische literatuur; recensies van deze vertalingen en bewerkingen.

e. Bestaat de receptie van 'de' Deense literatuur in Nederlandse vertaling, 1731-1990? Doel van deze studie is de grenzen van 'literatuur-receptie'-onderzoek in kaart te brengen, door na te gaan of er in het Nederlands taalgebied sprake is van een coherente receptie van 'de' Deense literatuur, dan wel of de recepties en de recipiënten van verschillende Deense auteurs los van elkaar moeten worden gezien.

Materiaal en uitgangspunt zijn de door mij samengestelde bibliografie van Deense literatuur in Nederlandse vertaling Dansk skønlitteratur $i$ Nederland og Flandern 1731-1982 met 2518 nummers, en Juel Møllers bibliografie van Nederlandse H.C. Andersenvertalingen met 273 nummers, beide uitgegeven door de Koninklijke Bibliotheek te Kopenhagen; aangevuld met bibliografische gegevens tot en met 1990. Daamaast is een groot aantal recensies van de vertaalde werken in het onderzoek betrokken.

Het begrip 'literatuur' is in dit kader ruim opgevat: ook volkssprookjes, kinderboeken, streek- en familieromans, stripverhalen en reisbeschrijvingen worden hieronder begrepen. Nader bekeken zijn de 1654 uitgaven in boekvorm (exclusief herdrukken) in de genoemde periode.

\section{f. Makkers en kameraden - een analyse van H.C. Andersens 'Reisekammeraten' in} zeventien Nederlandse vertalingen, 1848-1992.

Deze studie, waarvan de eerste versie is geschreven in samenwerking met Peter Vingerhoets, wil nagaan hoe de sprookjes van Andersen in de loop der tijd in het Nederlands zijn vertaald, in stilistisch, semantisch, lexicaal, grammmaticaal en extralinguaal opzicht. Materiaal zijn de 17 bestaande vertalingen van het voor Andersens stijl en vertelwijze representatieve sprookje Reisekammeraten (De reiskameraad), gespreid naar tijd (van 1848 tot 1992), plaats (Nederland en Vlaanderen) en aard (brontekstgericht en doelgroepgericht). Het gehanteerde onderzoeksmodel is dat van Katharina Reiß.

\section{g. Nederlandse literatuur in Deense ogen, 1900-1990}

Deze studie wil de receptie van de Nederlandse literatuur in Deense vertaling tussen 1900 en 1990 beschrijven, en speciaal aandacht besteden aan de eventuele beeldvorming bij het Deense publiek: welke factoren spelen in (het ontbreken van) een dergelijke beeldvorming een rol?

Materiaal vormen de 542 vertalingen in boekvorm, de 468 achterhaalde recensies, en gesprekken met uitgevers, onderzoekers, bibliothecarissen, en personeel van ambassades en van de inmiddels opgeheven Stichting ter bevordering van de vertaling van Nederlands letterkundig werk. 


\section{Hoofdstuk II}

\section{De Vondelreceptie in Scandinavië*}

\section{Inleiding}

Wie door het centrum van Kopenhagen of Gotenburg loopt, hoeft niet lang te zoeken naar voorbeelden van zeventiende-eeuwse Nederlandse bouwkunst. Architectuur en stedebouw vormen het meest zichtbare aspect van de Nederlandse Gouden Eeuw in Scandinavië; maar ook de Nederlandse schilder- en beeldhouwkunst, landbouw, scheepsbouw, natuurwetenschappen, filologie en taal hebben duidelijke sporen in de Noordse musea, bibliotheken, archieven en woordenschat nagelaten. ${ }^{21}$

De Nederlandse literatuur lijkt in dezen een uitzondering te vormen. Enkele Catsvertalingen buiten beschouwing gelaten, zijn sporen van zeventiende-eeuwse dichters op het eerste gezicht niet te traceren. Zonder deze ondergeschikte positie van de literatuur te ontkennen, wil ik in het onderstaande pogen, dit beeld te nuanceren waar het Vondel betreft, door een overzicht te geven van de receptie van diens perscon en werk in het Noorden, die naar zal blijken met pieken en dalen doorloopt van Vondels eigen tijd tot in onze dagen. Daarbij zal ik trachten de ontwikkeling in deze receptic te verklaren vanuit de economische, politieke en vooral de culturele relatie tussen Nederland en het Noorden. Hoofdlijnen daarin zijn:

- contemporaine (zeventiende- en vroeg achttiende-ecuwse) Noordse belangstelling voor de aan hun Scandinavische vakbroeders veruit superieure Nederlandse kunstenaars, bij vorsten, staatslieden, letterkundigen en theaterpubliek;

- eigentijdse (laat negentiende- en twintigste-eeuwse) interesse voor de relatie Vondel : Scandinavië en voor Vondel als Europees barokkunstenaar.

Achtereenvolgens komen aan de orde: Scandinaviërs in persoonlijk contact met Vondel: Vondelopvoeringen in het Noorden; weerklank bij Scandinavische auteurs; Noordse Vondelvertalingen; de Vondelstudie in Scandinavië. ${ }^{22}$ 


\section{Scandinaviërs in persoonlijk contact met Vondel}

Het begin van de Vondelreceptie in het Noorden heeft een algemene en een specifieke oorzaak: respectievelijk de algemene verhouding tussen de Nederlanden en het Noorden, en persoonlijke contacten van Scandinaviërs met Vondel.

De zeventiende-eeuwse verhouding tussen de Republiek en Scandinavië was er een van economische, politieke en culturele superioriteit van eerstgenoemde. In economisch opzicht betekende het Noorden voor de Verenigde Nederlanden een bron van welvaart, die berustte op de handel in graan uit het Oostzeegebied. Rond de helft van de schepen die door de Sont voeren was Nederlands. Een vrije Sonthandel was dan ook van levensbelang voor de Republiek, die diverse malen politiek en militair ingreep, wanneer deze handel werd bedreigd. Afhankelijk van het machtsevenwicht koos zij daarbij de kant van Zweden dan wel Denemarken. ${ }^{23}$

Maar ook in cultureel opzicht lagen de Nederlanden voor. Deense en Zweedse vorsten haalden Nederlandse bouwheren, stedebouwkundigen, schilders, beeldhouwers, historici en filologen naar het Noorden. Kennis van het Nederlands was er wijdverbreid, niet alleen als gevolg van de handelscontacten en van de vestiging van Hollandse kolonies in Kopenhagen en Gotenburg, maar ook doordat veel Scandinaviërs aan Nederlandse universiteiten studeerden. ${ }^{24}$

De relatie tussen Scandinavië en Vondel weerspiegelt de drie aspecten van deze verhouding. De eerste contacten van Noorderlingen met Vondel waren van economische aard. Reeds in 1612 handelde laatstgenoemde als kousenkoopman op Denemarken, en hij zou dat zijn hele handelsloopbaan blijven doen. Deense schuldenaren werden tot twee maal toe persoonlijk in het Noorden bezocht door Vondel. Deze verliet in 1628 en 1657 met tegenzin zijn geliefde Amsterdam voor de lange reis naar Scandinavië. Een zakelijk doel dus. Van culturele inspiratie was geen sprake: Vondel haalde zijn culturele voorbeelden uit het zuiden, - in het noorden was in dat opzicht nog weinig te halen, hoogstens te brengen. Zijn vele verzen op het Noorden hebben een politieke toon, geen culturele: nergens noemt hij een Noords kunstenaar bij naam. Het concept 'Noorden' is bij hem negatief gekleurd: het is er koud, woest en onvruchtbaar, ook in cultureel opzicht. Hij bezingt de cultureel geïnteresseerde koningin Christina van Zweden, die vooral Nederlandse kunstenaars en wetenschappers naar haar hof haalde, dan ook als de "Noortstar", die het licht brengt in de noordelijke culturele duisternis. Te Kopenhagen transponeert Vondel dit arctisch klimaat naar Denemarken, en zijn liefste wens daar is "veyligh thuys te rusten by mijn vrou". 25

Toch ligt in zijn Noordse reizen de kiem van de Scandinavische Vondelreceptie. door de directe en indirecte contacten met ettelijke vooraanstaande persoonlijkheden, die hem naar waarde wisten te schatten en zijn roen verbreidden.

Op de terugreis van zijn eerste tocht deed de dichter Gotenburg aan. De Zweedse havenstad was kort tevoren op last van koning Gustav Adolf aangelegd door Nederlanders, die er zo'n grote invloed hadden, dat het Nederlands er de tweede ambtstaal was. In 1626 was de Haarlemmer Jacob van Dijck door Gustav Adolf benoemd tot "burggreve' (burggraaf, stadsoverste). Deze "man van treffelyke geleerdtheit, en een groot Lief- 
hebber van Poëzy" onthaalde Vondel vriendelijk. Als dank schreef deze een gedicht Tot tol van zijne Majesteit van Zweden, betaelt te Gottenburg aen de heer Jacob van Dyck.

Dit vers was het eerste van een zestal Vondelgedichten op de Zweedse vorst, waarin zowel de politieke als de culturele relatie van de Republiek en het Noorden tot uiting komt. Gustav Adolf wordt geschilderd als voorvechter van vrede en van godsdienst- en gewetensvrijheid, - Vondels beeld van de ideale vorst. Het is waarschijnlijk dat Gustav Adolf een of meer van deze gedichten onder ogen heeft gehad. Anders dan zijn Deense rivaal, de krijgszuchtige en ongeletterde Christian IV, die om de hoge Sonttolheffingen niet populair was in de Republiek en van Vondel geen apart gedicht krijgt, was Gustav Adolf een literair en filosofisch begaafd man. Hij beheerste vijf talen, waaronder Nederlands, schreef gedichten en correspondeerde met Hugo de Groot. De mecenas Van Dijck, die twee jaar tevoren twaalf dagen de gastheer van de vorst was geweest, heeft het genoemde lofdicht wel doorgezonden. De Koninklijke Bibliotheek Stockholm bewaart onder haar vele Vondeliana onder andere een uitgave van Lyckoffer van Maegdeburgh. ontsteecken [...] door den onoverwinnelyken Koninglycken held Gustaef Adolf uit 1631, mogelijk uit het bezit van de vorst. ${ }^{26}$

Duidelijker nog zijn de blijken van Vondelkennis van Gustav Adolfs dochter en opvolgster koningin Christina, aan wie de dichter een tiental gedichten wijdt. Opnieuw verwijzen deze naar de politieke en culturele relatie tussen Scandinavië en de Nederlanden. Christina belichaamt voor Vondel alle deugden die een van God gezonden vorst heeft. De intelligente en kunstlievende vorstin stond bekend om haar vredesstreven: onder haar regering werd de vrede van Westfalen gesloten en gedurende haar hele regering (1644-1654) bewaarde zij de vrede. Haar politiek was gunstig voor de Republiek, waarmee haar regering in 1645 een verdrag sloot tegen de Deense Sonttolpolitiek. ${ }^{27} \mathrm{Zij}$ stond bekend als mecenas, met een voorkeur voor Nederlandse geleerden en kunstenaars.

In Afzetsel der koninglycke Printe (gedrukt 1647) geeft Vondel een beschrijving van de vorstin op basis van het in woorden geschetste portret in een brief van zijn vriend Michel le Blon, op dat moment agent van Christina te Londen. Via Le Blon belandde het Afzetsel bij Christina, die de dichter dankte met een gouden keten en medaille, - "de grootste gift, hem ooit geschonken". Op zichzelf hoeft dit geen bewijs te zijn dat Christina zijn vers naar waarde heeft weten te schatten: zij liet zich op bestelling lofdichten toesturen en beloonde vrijwel elk vers op deze wijze, ongeacht de kwaliteit. Maar in het geval van Vondel heeft de vorstin het vers zeker kunnen verstaan, daar zij het Nederlands zeer goed beheerste. Het is zelfs heel waarschijnlijk dat het hier inderdaad om een directe bestelling van Christina gaat: Vondel heeft, blijkens de beginregeis, het verzoek ontvangen een gedicht te schrijven op Christina's deugden, op grond van Le Blons aantekeningen.

Niet alleen via Le Blon heeft Christina Vondeliana in haar hezit gekregen. Haar indrukwekkende boekerij werd verrijkt door de aankoop van drie complete bibliotheken van Vondels intimi: Hugo de Groot, haar ambassadeur in Parijs: Gerard Vossius, haar adviseur in professorsbenoemingen; en diens zoon Isaac Vossius, leraar Grieks van Vondel èn van Christina, in 1648 benoemd tot bibliothecaris van de laatstgenoemde. Daar de bibliotheek in 1697 grotendeels is verbrand en deels door verkoop verspreid is geraakt. is niet bekend om welke Vondeliana het precies ging. Isaac Vossius' catalogus 


\section{Hoofdstuk II}

van Christina's manuscripten bevat onder andere verloren gegane 'Collecten Niederländisch'; en nog steeds bevat de K.B. Stockholm vele contemporaine Vondeldrukken, waarvan de herkomst niet vaststaat. In Christina's contacten met Le Blon, De Groot en Isaac Vossius zal het werk van de beroemde dichter zeker ter sprake zijn gekomen, te meer daar deze tijdens haar regeringsperiode nog een vijftal gedichten aan haar wijdde. ${ }^{28}$

In 1654 doet de vorstin afstand van de troon, bekeert zich tot het katholicisme, en reist via Amsterdam en Brussel naar Rome. De Noorse Vondelkenner Langvik-Johannessen oppert dat Christina op deze reis Vondel heeft ontmoet te Amsterdam. De bekeerling Vondel, door haar verzaking aan de wereldse macht geïnspireerd tot het schrijven van Op den afstant Der Kroone, en het Reizen van Koninginne Christine, zou dit in Christina's aanwezigheid hebben voorgedragen, gezien de woorden "Wat Noordstar gunt ons nu haar licht", "op dit feest", "het is Christine, die ghy ziet". Dit lijkt echter niet waarschijnlijk: na al zijn lofdichten bij portretten zou zo'n groot bewonderaar een dergelijke ontmoeting in levenden lijve wel niet zo cryptisch hebben aangeduid. Wel draagt hij in 1657 zijn vertaling van Koning Davids Harpzangen aan haar op met de nadrukkelijke bedoeling dat zij ze leest:

Gy, die de kerne en kracht van vele tongen,

Ook 't Neêrlantsch kent, zult, zo my d'eer gebeun,

Best smaecken, of ick wel hebb' nagezongen

Den Harpenaer, die heilrijck juicht, of treurt. ${ }^{29}$

In hetzelfde jaar reist Vondel opnieuw naar Denemarken. In zijn economische doel slaagde hij niet, maar de dichter was inmiddels een beroemdheid en werd navenant ontvangen te Kopenhagen. In cultureel opzicht paste hij immers in het kader van de superieure Nederlandse kunst. Zijn Kopenhaagse gastheer was hofschilder en dichter Karel van Mander III, kleinzoon van de gelijknamige schrijver van het Schilderboeck, met wie de jeugdige Vondel bevriend was geweest. Van Manders huis was het voornaamste logies van de stad, waar buitenlandse gezanten op rekening van het hof logeerden, en dat werd gefrequenteerd door staatslieden en kunstenaars. Ettelijke van deze hoge gasten hebben Vondel hier ontmoet, zoals blijkt uit de lofdichten uit zijn bundel Parnas aen de Belt : Verscheide Dichten in Denemerck gedicht, nog hetzelfde jaar uitgegeven. Naar hieronder zal blijken, toont deze bundel hoezeer 's dichters politicke en culturele ideeën met betrekking tot het Noorden onderling samenhingen.

Dat het Deense hof Vondel te zamen met het door hem in een Groete bezongen Nederlands gezantschap onder leiding van zijn kennis Coenraad van Beuningen heeft ontvangen, zoals door de Deense literatuurhistoricus Kjargaard als vaststaand vermeld, is weliswaar niet te bewijzen - de hofarchieven in het Rijksarchief te Kopenhagen vermelden de naam Vondel niet - maar er zijn de nodige aanwijzingen dat dit inderdaad is geschied. Men vergelijke de regels "en ' $t$ oude hof / Ontfing met eere de Gezanten / Gekoren om de peñnen stof / Te geven; ' $t$ zy de geesten zwieren / Op dicht, dat klanck en voeten telt $[\ldots]{ }^{3 .}{ }^{30}$ Genoemd gezantschap kwam Frederik III namens de Staten steun bieden tegen de expansionistische Zweedse politiek van Christina's krijgszuchtige opvolger Karl X Gustav. Maar voor Vondel minstens zo belangrijk was de wetenschap dat het 
Deense vorstenpaar, door hem bezongen in gedichten bij portretten van Van Mander, sterk was geïnteresseerd in wetenschap, literatuur en kunst, en vooral in het theater. Ook Frederik III verstond Nederlands en had al in 1649 voorsteilingen bijgewoond van de beroemde theatergroep van Vondels goede kennis Jan Baptist van Fornenbergh. ${ }^{3 !}$ Vondel had dan ook reeds in 1651 beschreven hoe vorst "Vrederyck"

Genoeght zich met zyn erf, en vaderlijck bezit,

Bemint de jaght, en stilte en kunst en wyze boecken

En hanthaeft recht en trouw, om Godt, der vromen wit.

Waarschijnlijk heeft de dichter reeds met dit vers de aandacht van Deense hofkringen getrokken, en dit zou mede de ontvangst aan het hof verklaren. ${ }^{32}$

Meer zekerheid hebben we over ontmoetingen met andere hoogwaardigheidsbekleders. Vlak voor of tijdens Vondels bezoek veroverden de Zweden de sterkste Deense vesting, Frederiksodde, hetgeen grote verslagenheid te Kopenhagen veroorzaakte. Vondel maakte de hoofdrolspelers in dit drama van nabij mee, getuige de gedichten die hij op hen maakte: Van Beuningen cum suis, kanselier Erik Sehested, rijkshofmeester (eerste minister) Joachim Gersdorff, en diverse gezanten van grote mogendheden. Wijsheid is in deze omstandigheden de grootste deugd. Geen man, betoogt Vondel, is beter geschikt als steun voor de koning dan de geleerde en belezen Gersdorff: "Het Rijck magh op 't ervaeren spoor / Van uwe letterwijsheit draven / Uw taelen en geleerde gaven / Gebruicken [...]". De mecenas Gersdorff, die sterk literair geïnteresseerd was, had gestudeerd te Leiden en Harderwijk; hij zal Vondels werk zeker reeds eerder hebben gekend en het lofdicht hebben weten te waarderen. Hetzelfde geldt de Spaanse gezant en dichter De Rebolledo, die een tijd in Vlaanderen had gewoond. In deze Kopenhaagse kring vierde de dichter zijn zeventigste verjaardag, en blijk van waardering is het portret dat Van Mander bij die gelegenheid van hem schilderde. En hoewel dit schilderij verloren is gegaan, is de wens uit Vondels bijschrift uitgekomen inzake het Noorden: "Zoo kan mijn schijn nog leven na mijn' tijd".

Niet alleen in Denemarken, ook in Zweden was Vondels werk bekend bij politici en kooplieden, zoals uit bibliotheekbezit en boedelbeschrijvingen blijkt. ${ }^{33}$

\subsection{Een onbekende Kopenhaagse Vondeluitgave}

Een duidelijk bewijs dat Vondel in het Noorden in het Nederlands werd gelezen en gewaardeerd, vormt een tot nog toe onbekende Kopenhaagse uitgave van zijn gedicht Triomf over Funen uit 1660 (zie afbeelding 1). Deze uitgave ontdekte ik in de Koninklijke Bibliotheek te Kopenhagen. Ze ontbreekt in de Vondelbibliografie van Unger, in Schuytvlots catalogus van Vondeliana in de UB Amsterdam en in de Centrale Catalogus, terwijl ze voor zover ik heb kunnen nagaan ook nergens in de secundaire Vondelliteratuur wordt vermeld. Wel vond ik haar achteraf opgenomen in de gedrukte centrale catalogus van Deense uitgaven 1482-1830, Bibliotheca Danica, maar daarin is ze blijkbaar nooit door een neerlandicus of historicus opgemerkt. ${ }^{34}$ 


\section{Hoofdstuk II}

De uitgave omvat vier pagina's: een titelblad, en drie pagina's tekst met elk één kolom, en wijkt daarmee wezenlijk af van de Amsterdamse tweekoloms plano-uitgave van 1659. De tekst is ondertekend J.V. Vondel.

$\mathrm{Nu}$ is vermelding van de drukplaats Kopenhagen nog geen bewijs van authenticiteit. Vondel liet bij voorbeeld in enkele van zijn werken als drukplaats Keulen vermelden, terwijl wel vaststaat dat deze gewoon te Amsterdam zijn gedrukt. Maar voor de authenticiteit van de drukplaats Kopenhagen pleiten diverse argumenten. Ten eerste vindt het enig bekende exemplaar zich te Kopenhagen. Ten tweede is de letter W, die in het Deens zelden voorkomt, gezet in een ander type en met een groter corps. Ten derde bevat de tekst enige typische interferentiefouten in de spelling: 'zeevart' in plaats van 'zeevaert' en 'vort' in plaats van 'voort'. In het Deens wordt een gedekte klinker voorafgaand aan een $\mathbf{r}$ vaak sterk verlengd; de tekst lijkt dus gezet door een Deense zetter, die zich afgezien van deze spelfouten trouw aan de originele tekst heeft gehouden. En ten slotte had Vondel na zijn bezoek in 1657 vooraanstaande Kopenhaagse relaties, die waarschijnlijk voor deze uitgave hebben gezorgd.

Vondels sympathie voor de Deense vorst in zijn strijd tegen de expansionistische politiek van Karl X Gustav van Zweden, wiens dreigende hegemonie over de Sont ongunstig was voor de Republiek, uitte zich in een vijftal gedichten, waaronder deze lofzang op Michiel de Ruiters herovering van Funen (1659).

\section{Vondelopvoeringen in het Noorden}

Ging het in het bovenstaande vooral om Vondels bekendheid bij hoogwaardigheidsbekleders, in veel bredere kring verwierf hij in het Noorden bekendheid door de opvoering van zijn drama's. Het culturele kader waarin deze plaatsvonden, was dat van de superioriteit van het Nederlands theater. Opvoeringen van Vondels drama's in het Noorden, en van drama überhaupt, waren het werk van Nederlandse en Duitse theatergroepen: het peil van het zeventiende-eeuwse Scandinavische drama kon zich niet meten met dat van de Nederlanden. Kennis van het Nederlands was dermate verbreid dat de Nederlanders de stukken in hun moedertaal opvoerden.

De eerste voorstellingen van zo'n gezelschap in het Noorden vinden plaats in 1649 aan het hof van de hertog van Holstein, in aanwezigheid van de toneelminnende Deense koning Frederik III en zijn vrouw Sophia Amalia. In 1653 vinden we dezelfde troep aan het hof van koningin Christina in Stockholm en van koningin-moeder Maria Eleonora te Nyköping. ${ }^{35}$ Het gaat hier om de beroemde groep van Jan Baptist van Fornenhergh, een persoonlijke relatie van Vondel. Samen met anderen uit de groep had deze als jong acteur in de Amsterdamse schouwburg gespeeld in Vondels Gebroeders, geregisseerd door de dichter zelf. Waarschijnlijk in 1654 speelt de troep te Amsterdam voor de magistraat, en Vondel schrijft bij die gelegenheid een gedicht De Tooneelhroeders, in de vorm van een toespraak van Van Fornenbergh, die vermeldt dat de "speelrol" van de troep ook is "afgerolt / in 't licht der Denemercksche kroonen", en gezien zijn relaties met de spelers heeft Vondel daarmee mogelijk mede op zijn eigen stukken gedoeld. ${ }^{36}$ 


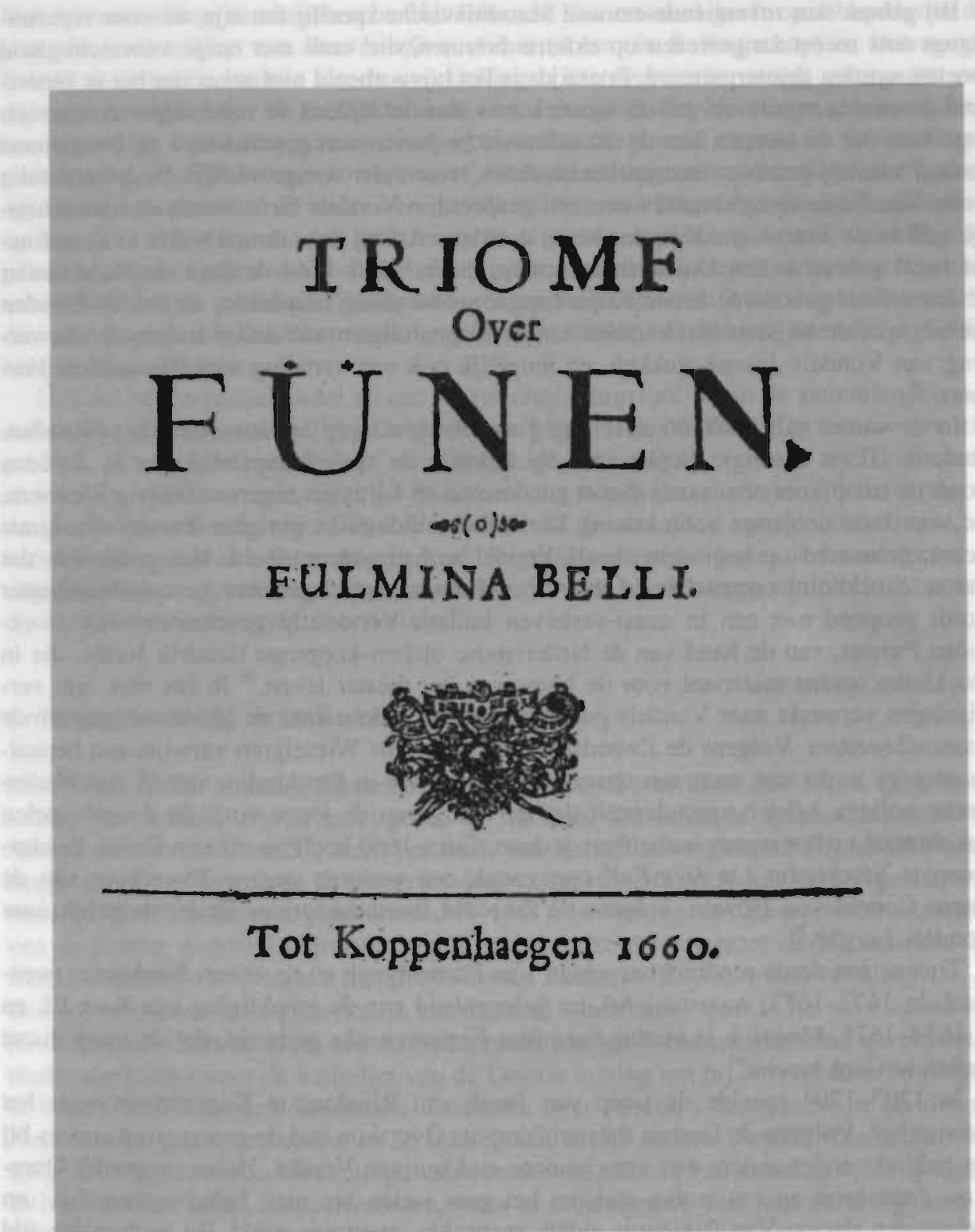

Afbeelding 1. Titelblad van het enig bekende exemplaar van de Kopenhaagse uitgave van 'Triomf over Funen' uit 1660. (Koninklijke Bibliotheek Kopenhagen). 


\section{Hoofdstuk II}

Bij gebrek aan zeventiende-eeuwse Scandinavische speellijsten zijn we voor repertoiregegevens meest aangewezen op externe bronnen, die vaak met enige voorzichtigheid moeten worden geïnterpreteerd. Enerzijds is het bijvoorbeeld niet zeker dat het in Nederland gespeelde repertoire geheel identiek was aan dat tijdens de rondreizen. Anderzijds staat vast dat de troepen aan de Scandinavische hoven een geschakeerd en hoogstaand aanbod van blijspelen en treurspelen brachten, waaronder oorspronkelijk Nederlandstalig werk. Van Fornenbergh had tevoren zelf gespeeld in Vondels Gebroeders en waarschijnlijk ook in de Joseph-stukken, dus het is denkbaar dat hij deze drama's ook in Scandinavië heeft gebracht. Een Duitse theatergroep, die in 1663-1664 de door de Nederlander Andries Wolf gebouwde eerste Kopenhaagse schouwburg bespeelde, en ook in Zweden optrad, speelde blijkens een verzoek aan de Kopenhaagse raad onder andere een bewerking van Vondels Joseph-stukken, en mogelijk ook een vertaling van Hierusalem Verwoest. ${ }^{37}$

In de winter van 1665-66 reist Van Fornenberghs troep opnieuw naar het Noorden. Frederik III en koningin Sophia Amalia belonen de spelers vorstelijk, en in Zweden wordt de troep voor een jaar in dienst genomen door koningin-regentes Hedvig Eleonora, die voor haar tienjarige zoon koning Karl XI een didactisch gerichte dramatische kunst wenst, gebaseerd op beginselen zoals Vondel ze had geformuleerd. Het gedurende dat jaar te Stockholm opgerichte en door Van Fornenbergh ingerichte Lejonkulan-theater wordt geopend met een in quasi-verheven imitatie-Vondelstijl geschreven stuk Stockholms Parnas, van de hand van de Nederlandse dichter-koopman Hendrik Jordis, die in Stockholm tevens materiaal voor de bouw van het theater levert. ${ }^{38}$ In het stuk zijn verwijzingen verwerkt naar Vondels gedichten, onder andere naar de hierboven genoemde Tooneelbroeders. Volgens de Zweedse theaterhistoricus Wieselgren verwijst een bepaalde passage in dit stuk naar een opvoering van Faëton in Stockholm, terwijl zijn Nederlandse collega Albach veronderstelt dat ter lering van de jonge vorst de Joseph-spelen ook ditmaal op het repertoire hebben gestaan. Circa 1660 heeft voorts een Duitse theatergroep te Stockholm Lucifers Fall opgevoerd, een verloren gegane bewerking van de auteur Conrad von Höveln, volgens de Zweedse theaterhistoricus Beijer mogelijk naar Vondels Lucifer. ${ }^{39}$

Tijdens een derde rondreis bezochten Van Fornenbergh en de zijnen Stockholm tweemaal: in 1672-1673, waarschijnlijk ter gelegenheid van de inhuldiging van Karl XI, en in 1674-1675. Mogelijk is hierbij Euripides Feniciaensche gespeeld, dat de troep direct nadien te Gent bracht. ${ }^{40}$

In 1703-1704 speelde de troep van Jacob van Rijndorp te Kopenhagen voor het Deense hof. Volgens de Deense theaterhistoricus Overskou had de groep groot succes bij het publiek, onder andere met verscheidene stukken van Vondel. Helaas vermeldt Overskou geen bron en om welke stukken het gaat weten we niet, behalve mogelijk om Palamedes, dat op Van Rijndorps elders gespeelde repertoire stond. En in dezelfde tijd speelde een Duitse troep te Uppsala een bewerking van Vondels Gebroeders, vermoedelijk van de hand van David Elias Heidenreich. ${ }^{41}$

In de loop van de achttiende eeuw daalt de culturele invloed van de Republiek sterk, en de opkomst van een eigen Scandinavisch theater makt een einde aan de opvoeringen van Nederlands toneelwerk in het Noorden. Het zal duren tot 1970 voor er weer een 
Vondelvoorstelling wordt gebracht. Het Brussels Kamertoneel geeft op 19 april van dat jaar een voorstelling van Den bortforte Adam (Adam in Ballingschap) in Det norske Teatret te Oslo. De traditie van de voorstellingen van eeuwen her wordt voortgezet: ook deze opvoeringen zijn in het Nederlands, maar nu geeft het Noorse programmaboekje een uitvoerige inhoudsopgave en analyse; voorts is "regien så ekspressiv at handlingen taler for seg selv" ["de regie zo expressief dat de handeling voor zichzelf spreekt"], zoals Aftenposten aankondigt. In interviews met dit blad en met Daghladet gaat de regisseur in op Vondels bedoeling met het stuk en op de wijze waarop de regie deze bedoeling oppakt: de acteurs spelen zowel duivel als engel, en verbeelden daarmee de twee aspecten van de menselijke zwakheid. Zoals we verderop zullen zien, sluit deze opvatting aan bij die van degene die deze voorstelling naar Oslo haalde, de Noorse neerlandicus Kåre Langvik-Johannessen.

Hoewel een cultureel kader en een 'verwachtingshorizon' als in de zeventiende eeuw ontbreken, blijkt de voorstelling als autonoom gegeven aan te slaan. De recensenten zijn positief. Aftenposten spreekt van een fijnzinnige voorstelling, van een zeer interessant stuk in een tijdloze versie, en prijst de samenhang tussen de muzikale repliekvoering en de gestileerde choreografie. Dagbladet benadrukt de actualiteit van Vondels thema, de vertwijfelde mensheid. De resencent looft de gestileerde regie: tegen de fraaie decors en uitgekiende scenografie domineert het woord; ritme en klank roepen een plechtige poëzie op in een onconventionele voorstelling. ${ }^{42}$

\section{Weerklank bij Scandinavische auteurs}

Niet alleen bij het Noordse theaterpubliek heeft Vondel weerklank gevonden. Bij diverse belangrijke auteurs zijn Vondelsporen te traceren. De bekende Deense barokdichter Anders Arrebo (1587-1637) heeft het werk van Vondel zeker gekend. Hij las de Nederlandse literatuur en volgde in een groot deel van zijn leerdicht Hexaëmeron (geschreven circa 1630-37, posthuum gepubliccerd in 1661), bewerking van La première sepmaine van de Franse dichter Du Bartas, in stijl en woordkeus nauwgezet de Nederlandse Du Bartas-vertaling van Vondels literaire leidsman Zacharias Heyns, wiens vertaling van $L a$ seconde sepmaine zelfs gedeeltelijk van de hand van Vondel was. In het voorwoord van Hexaëmeron wordt de bloei van de Nederlandse taal en literatuur genoemd als exemplarische aanleiding voor de kanselier van de Deense koning om bij Arrebo deze bewerking te bestellen. Lundgaard Simonsens dissertatic over Arrebo's bronnen wijst op diverse Nederlandse sporen en noemt in de bibliografie onder andere Vondel. Reeds door een tijdgenoot werd Arrebo beschuldigd van overdreven gebruik van samengestelde woorden in Nederlandse trant, "koppelwoorden, waer in onze spraeck niet min geluckigh dan de Griecksche is", zoals Vondel ze in zijn Aenleidinge ter Nederduitsche Dichtkunste aanprees. De Deense filoloog Ole Borch (1626-1690) noemt deze samenstellingen zelfs als de meest karakteristieke directe invloed van de Nederlandse literatuur op de Deense. ${ }^{43}$

Ook de dichter Anders Bording (1619-1667) kende Nederlands. Uit een van zijn gedichten blijkt dat hij voorstellingen heeft bijgewoond van rondreizende Nederlandse theatergroepen, die onder andere Vondel op hun repertoire hadden. Hij was een vriend 


\section{Hoofdstuk II}

van Karel van Mander III en heeft mogelijk Vondel in diens huis ontmoet. Dat de Denen oorspronkelijk Vondel navolgden, blijkt bij de dichter Mathias Worm (1636-1707), die net als bovengenoemde Ole Borch te Leiden had gestudeerd; in zijn Lykønskningstale til Frederik III 18/3 1666 schrijft hij, hoe Arrebo en Bording de Nederlandse voorbeelden inmiddels overtroffen hebben en triomferen, gelijk vroeger de Oudnoorse sagenhelden:

Hid Huygens, van der Veen, Katz, Vondel, Westerbaen,

Hid hvem den krumme Rhin og Mosel støder an!

Nei, nei, bort fremmed Roes, thi vores danske Tunge,

De Fremmede til Trods har ogsaa laert at siunge.

Før Hiarne, Regner og Starchotter Prisen bar,

Nu Krandsen Arrebo og Bording vundet har.

[Herwaarts Huygens, Van der Veen, Cats, Vondel, Westerbaen / Herwaarts, gij die wordt omspoeld door de kromme Rijn en de Moezel! [i.e Maas?, DG] / Nee, nee, wèg lof van vreemden, want onze Deense tong / Heeft, de vreemden ten spijt, ook leren zingen. / Voorheen droegen Hjarne, Ragnar en Starkadr de prijs, / Nu hebben Arrebo en Bording de zegekrans gewonnen.]

Volgens de Deense literatuurcriticus en Vondelvertaler Vilhelm Andersen vertoont ten slotte ook het werk van de psalmdichter Thomas Kingo (1634-1702) in zijn pregnante barokke woordkunst trekken die aan zijn nauwe stamverwant Vondel doen denken. ${ }^{44}$

De Zweedse dichter Haqvin Spegel (1645-1714) reisde en studeerde in de Nederlanden, en in de voorrede van zijn Du Bartas-bewerking Guds Werk och Hwila (1685) vermeldt hij als argument om lokale woorden te gebruiken in poëzie, dat ook Nederlandse dichters als "Vondelen, hafwa uti sina ädlaste Schrifter behållit några af the Orden som theras gemenaste Landzmän plägade bruka" ["...Vondel, hebben in hun edelste geschriften een aantal woorden behouden die hun eenvoudigste landgenoten plachten te gebruiken"]. Hij kende Vondels vertaling naar Du Bartas, De Heerlyckheyd van Salomon, en volgde dit voorbeeld met een eigen bewerking. Bovendien makkte hij aan het Stockholmse hof ongetwijfeld de voorstellingen mee van de Nederlandse theatertroep van Van Fomenbergh, wiens zoon hij er als hofpredikant doopte. ${ }^{45}$

Latere dichters, zoals de didactici Kolmodin, Kruse en Nicander, vertonen volgens de Zweedse onderzoeker Wrangel in hun bijbelse stofkeuze Vondeliaanse invloed. Van het eind van de zeventiende eeuw dateert voorts een Zweeds drama Phaëton, toegeschreven aan Georg Josuae Törnqvist (1668-1739). Volgens de Zweedse theaterhistoricus Wieselgren ontleent dit stuk zijn opzet aan Vondels Faëton uit 1663: anders dan bij Vondels bron Ovidius, speelt zowel in het Nederlandse als het Zweedse stuk Phaëtons moeder Clymene een belangrijke rol, worden Phaëtons zusters er als bijfiguren geïntroduceerd, en krijgt Phebus' verdriet over de dood van zijn zoon er veel aandacht. Vooral de opzet van het vijfde bedrijf vertoont veel parallellen. De verschillen met Vondel (weglating van voor de handeling onbelangrijke dialogen; invoeging van dramatische scènes waaraan bij Vondel slechts wordt gerefereerd) verklaart Wieselgren met de hypothese dat de Zweedse auteur als tussentekst een Nederlandse bewerking onder ogen heeft gehad. ${ }^{46}$ 
Met name het laatste deel van Wieselgrens theorie lijkt echter wel erg speculatief. Tekstvergelijking leert dat de stukken qua handelingsverloop, dramatis personae, stijl en woordinhoud ver uit elkaar liggen: het Zweeds is niet te beschouwen als een al dan niet directe bewerking of verkorting (821 regels tegenover 1558 bij Vondel). Ook de overeenkomst tussen de respectieve vijfde bedrijven is nogal betrekkelijk. Waar Vondel dialogen gebruikt, hanteert de Zweedse schrijver monologen; de rol van de Hemelraad bij Vondel wordt in het Zweedse stuk gespeeld door Mercurius. Terwijl Vondels Phebus slechts door dreigement van Jupiter zijn zonnewagen weer opzoekt, weet de Zweedse Venus hem daartoe met een beroep op de liefde te brengen. Het lijkt er weliswaar op dat de Zweedse auteur zich inderdaad heeft laten inspireren door Vondels thematiek en opzet en soms door de gedachtengang, bij voorbeeld in de woorden van Phebus bij het horen van het droeve nieuws over Phaëtons dood:

Geblixemt, och mijn zoon. och waertge ge noit geboren!

Was my dit ongeluck, dit hartewee beschoren?

Is dit rechtvaerdigheit? Is ' $t$ hemelsch hof zoo dra

Verkeert in een gerecht van wraecke en ongena?

War dät wäl lusten dig o höga himlens drått?

Har du din blixt och skräll därföre äntlig fătt,

Att på en dödlig kropp du skull din macht bedrijfwit?

Bör mig ett sådant tack, för all min tiänst och möda? ${ }^{47}$

Maar al uit dit voorbeeld blijkt dat de formulering het eigen werk is van de Zweedse auteur, die ook verder zijn eigen stilistisch en dramatisch vermogen heeft aangewend.

In de loop van de achttiende eeuw verdwijnt de belangstelling voor Vondel. Niet alleen de economische en politieke rol van de Nederlanden in het Noorden is tanende, maar ook de culturele. Ludvig Holberg (1684-1754), de vader van het Deense theater, verbleef lange tijd in Nederland, maar vermeldt Vondel nergens in zijn geschriften, hoewel de figuur van Van Fomenbergh in een van zijn blijspelen voorkomt. Tijdens de romantiek, een periode van literaire bloei in het Noorden, raakt de Nederlandse literatuur er geheel vergeten. Zo zelfs, dat een Deense leerling en intimus van Bilderdijk, Constant Dirckinck-Holmfeld, in 18.30 onder andere Vondel in het geweer brengt tegen een pamflet waarin werd beweerd dat de Nederlanden geen literatoren van belang kenden. Maar zijn landgenoot Henrik Scharling, theoloog en romancier en eveneens Bilderdijk-adept, woont circa 1864 te Amsterdam een voorstelling van Gyshreght van Aemstel bij en schrijft vol afkeuring over het gebrek aan zowel een hoger idee als aan handeling, en "de âlenlange Replikker paa to eller tre Siders Længde, tilmed i kjedsommelige Alexandrinere, der af de slette Skuespillere fremsiges paa en høist monoton Maade, saa at man mangen Gang har ondt ved at holde Øinene aabne" ["de ellenlange replicken van twee of drie bladzijden lengte, bovendien in saaie alexandrijnen, die door de slechte acteurs op een hoogst monotone wijze worden opgezegd, zodat het vaak moeite kost om de open ogen te houden"]. Scharlings positieve opmerkingen over Vondels lyriek docen aan dit oordeel niet af. Ook Georg Brandes, die de Scandinaviërs de ogen opende voor de mo- 
derne Europese cultuur, wijdt in zijn essays over Nederland en België uit 1892 niet meer dan twee nietszeggende zinnen aan "Just [sic] van Vondel". Spinoza en Rembrandt krijgen bij hem een veelvoud aan tekst. ${ }^{48}$

Maar juist via Rembrandt herleeft in de twintigste eeuw de interesse. De hernieuwde belangstelling voor Rembrandt was doorgedrongen tot het Noorden, dat verscheidene Rembrandtspecialisten voortbracht. Onder invloed van Schmidt Degeners geruchtmakende opstel Rembrandt en Vondel (1919) over de problematische verhouding tussen het eigenzinnige schildersgenie en de plooibare dichter met zijn lofzangen op gezagsdragers, laten twee Zweedse kunsthistorici annex dramaturgen, elk hun fantasie de vrije loop in een stuk over Rembrandt, waarin Vondel wordt voorgesteld als de kwade genius achter de afkeuring van Rembrandts Eedverbond der Batavieren onder Claudius Civilis als versiering van het nieuwe Amsterdamse stadhuis. Dat dit schilderij zo tot de Zweedse verbeelding spreekt, hangt uiteraard samen met het feit dat het hangt in het nationaal museum te Stockholm. Tor Hedberg (1862-1931), de belangrijkste dramaturg in het toenmalige Zweden, was zowel theater- als museumdirecteur, en hield zich in zijn studies bezig met de relatie tussen beeldende kunst en literatuur. Centraal in zijn dramatisch werk staat het conflict tussen ideaal en werkelijkheid. In Rembrandts son (1927) moet Rembrandt het afleggen tegen de harde realiteit, tegen de smaak van de Amsterdamse magistraat, die mede op advies van Vondel boven hem de voorkeur geeft aan Govaert Flinck. Hedberg legt Rembrandt een vemietigend oordeel over de dichter in de mond:

[...] han har aldrig kunnat tåla mig. Han är en förfalskare. Många stora män äro förfalskare. De blända en tid men till slut blir det dock uppenbart [...] Vondel har icke blivit vis. Han förtsätter med maskraden, - våra gode holländare klär han ut til romare, och innbillar oss at så såg de ut. Jag kan inte lida det, jag som älskar dem. Jag vet hur de såg ut - jag vet det. Fick jag blott visa det, skulle de tro mig.

[ [ ...] hij heeft mij nooit kunnen verdragen. Hij is een vervalser. Vele grote mannen zijn vervalsers. Ze verblinden ons een tijd, maar ten slotte wordt het toch duidelijk. [...] Vondel is nooit wijzer geworden. Hij gaat door met de maskerade, - onze goede Hollanders dost hij uit als Romeinen, en hij beeldt ons in dat ze er zó uitzagen. Ik kan dat niet verdragen, ik die van ze houd. Ik weet hoe ze eruit zagen - ik weet het. Kon ik het maar laten zien, dan zouden ze mij wel geloven.]

Het stuk werd in 1928 opgevoerd in Dramatiska Teatem in Stockholm, waar het goed werd ontvangen, en werd daarop in Deense vertaling tevens gespeeld in Det kongelige Teater in Kopenhagen. Hedberg had zijn stof en zijn visie op Vondel ontleend aan een essay van een vriend, de schrijver en kunsthistoricus Axel Gauffin (1877-1964) over het lot van Rembrandts Eedverbond der Batavieren. Gauffin had als directeur van het nationaal museum te Stockholm wel bijzondere affiniteit met dit schilderij. Zijn visie is sterk beïnvloed door zijn Nederlandse collega Schmidt Degener, die het werk bij hem leende voor de Amsterdamse Rembrandttentoonstelling van 1925.

In 1936 schreef Gauffin een eigen drama Batavernas Sammensvärjning, waarin Vondel uitgebreid ten tonele komt als een onsympathieke intrigant. De kritiek op dit stuk liep uiteen. De kunsthistoricus Carl Laurin wijdde er een uitgebreid artikel aan in Ord 
och Bild, waarin hij spreekt van Gauffins grote dramatische begaafdheid en van een harmonisch louteringsdrama. Als sleutelscène citeert hij de dialoog tussep Vondel en Rembrandt, waarin de laatste voorspelt dat hij op de lange duur zal zegevieren over de dichter, omdat hij de zijde van de armen heeft gekozen. De literatuurcriticus Georg Svensson levert in Bonniers litterära Magasin daarentegen kritiek op de schetsmatige en weinig dramatische presentatie van de "Übermensch" Rembrandt en de "pluimstrijkende hofpoëet" Vondel. ${ }^{49}$ Dit negatieve Vondelbeeld werd nog versterkt door de Scandinavische vertalingen van twee biografische Rembrandtromans, waarin de dichter er al evenmin goed afkomt: Theun de Vries' Rembrandt (Deens 1936; Zweeds 1937, 2e druk 1939) en Charles Huygens' Licht en schaduw (Deens 1946; Noors 1948; Zweeds 1948).

In zoverre hadden al deze drama's en romans echter toch een positief effect, dat ze via de aandacht voor de bekende Nederlandse beeldende kunst het Scandinavische publiek attendeerden op het bestaan van zeventiende-eeuwse Nederlandse letterkunde. In Gauffins stuk draagt Vondel een cruciaal fragment voor van zijn Inwydinge van ' $t$ Stadthuis t'Amsterdam, dat opnieuw een bekend beeld opriep bij de Zweedse lezer/toehoorder: het Amsterdams stadhuis, niet alleen als bouwwerk, maar ook als symbool der historische grootheid van de handelsnatie waarmee Zweden zo vaak was geconfronteerd.

\section{Scandinavische Vondelvertalingen}

Gauffins fragment uit de Inwydinge is de oudste bewaard gebleven Scandinavische Vondelvertaling. Van oudere vertalingen is niets bekend; in elk geval beweert Friese in zijn studie over de Noordse barok geheel ten onrechte, dat Vondel in zijn eigen tijd veel vertaald werd in het Noorden. Gauffins tekst is brontaalgericht en wordt gekenmerkt door een grote trouw aan het origineel, niet alleen qua inhoud maar ook qua prosodie: de alexandrijnen, de afwisseling van vrouwelijke en mannelijke rijmparen, het ruim gebruik van enjambement en van de suggestieve klanken $1, r$, a en o:

Hier keert ons trots gevaert zyn aanschijn naar het Oosten,

Den opgang van de zon, die d'aerde komt vertroosten,

Verquicken met haer' glans, waer naer elx oogh verlangt.

De slincke vleugel deckt de Noortzijde, en ontvangt

Den offer uit der zee; de rechte deckt den zegen

Van Beurze en vliet, van wien dees zeestadt heeft gekregen

Haer' naem, de weerelt door gevlogen, en bekent,

Zoo wijdt zy 's weerelts oegst op alle merckten zendt.

Dess skimrande fasad mot österns port sig vänder mot solen som går upp och jorden trösten sänder hugsvalelse så ljuv, mot den vart öga trår.

Den vänstra flygelns blick mot norr, mot havet går vars offer stolt hon tar; mot höger välstånd blänker, som signar börsens id, och flod, som staden skänker 


\section{Hoofdstuk II}

det namn som på sin flykt rundt världen gjort sig känt

när alstren av vår jord kring jorden all hon sănt [...]

Ook de eerstvolgende vertalingen komen uit Zweden, en haken opnieuw aan bij iets bekends: de Zweedse vorsten en de wederwaardigheden uit de Zweedse geschiedenis waaraan Vondel verzen had gewijd. Martha Muusses (1894-1981), lector Nederlands aan de universiteit van Stockholm, protesteert in het Vondeljaar 1937 in een herdenkingsartikel in Dagens Nyheter tegen de presentatie van de Vondelfiguur in Gauffins stuk en schenkt als tegenwicht aandacht aan deze Vondeliana Svecica, en met succes. Een jaar later ruimt de Zweedse publicist en vertaler Ane Randel (1879-1952) in een bloemlezing liefst tachtig bladzijden in voor geannoteerde vertalingen van allereerst de gedichten op Gustav Adolf en Christina, en van Bestand tusschen Polen en Sweden, maar ook van de Vertroostinge aan Geeraerdt Vossius, Kinder-lyck, Uitvaert van mijn dochterken, De Rynstroom, Rey van Bacchanten, Eenzame aendaght in de vasten, Uitvaert van Orfeus en Speelstryt van Apollo en Pan.

Zo wordt de Zweedse lezer via het hem bekende (de motieven uit de Zweedse geschiedenis) geconfronteerd met Vondels dichtkunst, en komt hij gaandeweg ook in aanraking met de meer persoonlijke gedichten. Zó kijkt in Kinder-lyck Constantijntjes lodderoogh over respectievelijk de Nederlanden en Zweden:

\section{Kinder-lyck}

Constantijntje, t' zaligh kijntje, Cherubijntje, van om hoogh, D'ydelheden, hier beneden, Vitlacht met een lodderoogh.

Moeder, zeit hy, waarom schreit ghy? Waarom greit ghy, op mijn lijck?

Boven leef ick, boven zweef ick, Engeltje van 't hemelrijck:

En ick blinck'er, en ick drincker. ' $t$ Geen de schincker alles goets

Schenckt de zielen, die daar krielen, Dertel van veel overvloets.

Leer dan reizen met gepeizen Naar pallaizen, uit het slick

Dezer werrelt, die zoo dwerrelt. Eeuwigh gaat voor oogenblick.

\section{Min döde gasse}

Constantinus, min divinus. Cherubinus högt i skyn. 
muntert ropar, när af glopar han beletts på Guds försyn:

"Hvarför, mamma, fraser stamma sörgesamma vid mitt stoft?

Se, jag svingar mina vingar som seraf mot himlens loft.

Här jag flammar och anammar det som stammar från min Gud.

I sin ifver allt han gifver själarna, som lydt hans bud.

Lär er vandra med hvarandra hän till andra rymders klot bort från jorden, som er vorden stoft för Herren Zebaoth".

Randel hanteert een duidelijk brontaalgerichte vertaalstrategie. Hij handhaaft metrum en rijm, - alle karakteristieke binnenrijmen zijn bewaard gebleven. Anderzijds noodzaakt het ontbreken van een diminutiefsuffix in het Zweeds hem om Constantijntje tot Constantinus te maken, terwijl de rijmdwang hem leidt tot de introductie van 'Herr Zebaoth'. Dit geeft het vers in vergelijking met het origineel een zwaardere toonzetting voor een zwevend cherubijntje, hetgeen nog wordt versterkt door het klankbeeld: terwijl Vondel veel werkt met heldere e-, i- en ij-klanken, bevat Randels tekst voornamelijk zwaardere a's en o's. 50

De tevens door Randel vertaalde Vertroostinge aan Geeraerdt Vossius wordt in 1947 opnieuw verzweedst in Martha Muusses' handboek Hollands Litteraturhistoria, dat een uitvoerig en genuanceerd portret van Vondel bevat, waarin ook andere vertaalde fragmenten uit diens werk voorkomen. Intussen is ook een Deense versie verschenen, van de Deense literatuurcriticus Vilhelm Andersen (1864-1953) in zijn studie van de invloed van Horatius op de Westeuropese letteren uit 1942. Hierin geeft hij een schets van Vondels poëzie met vertalingen van Beeckzang. Rey van Bacchanten en Vertroostinge. Andersen beklaagt zich over de vertaalmoeilijkheden als gevolg van alle diminutieven ("die Horatius haatte bij Catullus") in het eerste gedicht. Meer affiniteit heeft hij naar eigen zeggen met de Vertroostinge, waarvan het motief ontleend is aan Horatius. Hier de eerste strofe in de vertaling van respectievelijk Randel, Muusses en Andersen:

Wat treur ghy, hooghgeleerde Vos,

En fronst het voorhooft van verdriet?

Beny uw soon den hemel niet.

De hemel treckt. ay, laat hem los.

Hur kan du, högtberömda Voss

din panna rynka så av sorg?

Nej, lât din son, när himlens borg

välkomnar honom, kasta loss. 


\section{Hoofdstuk II}

Ack, lärda Vos, vi klagar du.

Och rynkar pannan, full av sorg,

Avundas icke himlens borg

Din käre son, släpp honom nu.

Hvad sørger du, højlærde Voss!

og rynker saa din Pandehud,

fordi din Son gaar hjem til Gud.

Ham drager Himlen. Bort fra os. ${ }^{51}$

De naoorlogse periode wordt geheel bepaald door Noorse vertalingen, met een veel meer doeltaalgerichte vertaalaanpak. In 1954 verschijnt de eerste Noorse Vondelvertaling, en wel van De Havenschendery te Bergen in Noorwegen, van de hand van de dichter Hans Henrik Holm. Ook hier waren aanleiding en thema de politieke en culturele banden tussen de zeventiende-eeuwse Nederlanden en het Noorden. Het gedicht vormde de poëtische afsluiting van een artikel van Kåre Langvik-Johannessen over Vondel og Danmark-Norge. In de jubileumjaren 1979 en 1987 organiseerde Langvik-Johannessen aan de universiteit van Oslo Vondelherdenkingen met lezingen, waarin de dichter in een breder kader werd geplaatst, met muziek van Sweelinck en Huygens, en voordrachten van Noorse vertalingen van Wiltzangk, Rey van Burghzaten (1979) en van Lucifer (1987), van de hand van bekende Noorse dichters: respectievelijk Åse-Marie Nesse, Hans Henrik Holm en Albert Lange Fliflet. De voorgedragen vertalingen zijn tevens in druk verschenen.

Hans Henrik Holm (1896-1980) was een sterk omstreden dichter vanwege zijn eigenzinnige variant van het nynorsk, met frequent gebruik van zeer archaïsche vormen en en een veelvoud aan samenstellingen, die enkel door annotatie voor de lezer duidelijk worden. Zo is zijn Rey van Burghzaten voorzien van 10 voetnoten. Zijn vertalingen van Middelnederlands toneel zijn om deze reden te overdadig, afstandelijk en te weinig volks genoemd, maar dit bezwaar lijkt minder te gelden voor de barokke Vondelstijl, die juist wordt gekenmerkt door zijn vele samenstellingen. Een fragment uit de Havenschendery:

Daer grimtze, uit eene halve maen

Van schepen, hecht aen een gesloten,

En braeckt vast vlam en donderklooten

Ter keele uit, als een krijghsorkaen.

Fram $\mathrm{i}$ ein månebòge sym

det tett av skip på svarte vågar.

Kanonar froser eld og logar

or svelgen $\mathrm{i}$ ein brotvêrsglym. ${ }^{52}$

Áse-Marie Nesse (1934) hanteert een toegankelijker variant van het nynorsk, en haar vertaling van Wiltzangk bereikte via Morgenbladet dan ook een breder publiek, dat Vondel zo van zijn meer lyrische kant leerde kennen. Assonanties en allitteraties weet de vertaalster met een 'versetztes Äquivalent' to handhaven: 


\author{
THORLEIF DAHLS \\ KUITURBIBLIOTEK
}

\title{
JOOST VAN DEN VONDEL
}

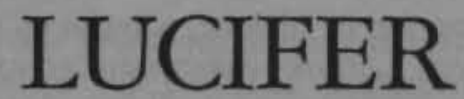

(1654)

\author{
EN TRAGEDIE
}

\section{GJENDIKTNING FRA NEDERLANDSK VED}

ALBERT L.ANGE FLIFLET

\author{
Med et efterord av \\ Kaire Langvik-Jobannessen
}

FORL.AGI AV H. ASCHEHOUG \& CO.

I SAMARBEID MED

FONDET FOR THORIEIF DAHLS KULTURBIBUOTEK

$\propto G$

DET NORSKE AKADEMI FOR SPROG OG LTTHRATUR

OSLO 1987

Afbeelding 2. Titelblad van de Noorse Lucifer-vertaling (1987). 


\section{Hoofdstuk II}

\section{Wat zong het vrolijck vogelkijn}

Dat in den boomgaert zat?

Hoe heerlijck blinckt de zonneschijn

Van rijckdom en van schat! [...]

Kva syng han vel, småfuglen fin

alt på den grønne grein?

Kor fagert sumarsola skin

ein morgon rik og rein! [...]

De complete Lucifer-vertaling van de filoloog, polyglot en vertaler Albert Lange Fliflet (1908), met een nawoord van Langvik-Johannessen, verscheen in een serie Europese klassieken, uitgegeven onder auspiciën van de Noorse Academie voor Taal- en Letterkunde (zie afbeelding 2). In zijn voorwoord en in een interview naar aanleiding van de uitgave zet de vertaler uiteen dat een vertaling moet worden aangepast aan de doelcultuur, zonder te banaliseren; om zowel eenvormigheid te voorkomen als verlies van inhoud door rijmdwang, heeft hij de alexandrijn vervangen door blank verse, en alleen in de reien de originele versvorm gehandhaafd.

Zijn werk kreeg ruime aandacht in de pers en zowel stuk als vertaling werden geprezen: "meesterlijk herdicht", "een solide vertaling", "een interessante en bij tijden meeslepende ervaring, niet het minst dank zij de imponerende, frisse, poëtische herschepping", etcetera. De recensenten vatten de inleiding samen en wijzen op de onbekendheid van de Nederlandse literatuur in Noorwegen.

De met deze onbekendheid samenhangende doelcultuurgerichte vertaalaanpak blijkt onder andere uit de vertaling van Vondels vergelijking van de aanstorming der engelen op de benden van Lucifer met een 'Noortsche waterval'. In de discussie van Vondelspecialisten of 'Noortsch' hier 'Scandinavisch' zou betekenen (een beeld dat mogelijk zou berusten op Vondels persoonlijke waameming), of enkel 'ruw, woest', kiest Lange Fliflet ondubbelzinnig voor de eerste optie:

[...] een noortschen waterval,

Die van de rotsen bruischt, en ruischt, met een geschal

Dat dier en ondier schrickt, in diepgezoncke dalen;

Daer steenen, van de steilte, en dicke waterstralen,

En masten, zonder tal, verpletten, en vertreên

Wat tegens woest gewelt van stroom en hout en steen

Niet opgewassen is [...]

\section{[...] en nordisk foss}

i tvertstrup utfor klippene med dronn

som skremmer dyr og udyr dypt i daler, der sten fra styrtningen. og vannkaskader

og stokker uten ende knuser alt

som ikke motstår en lavines velde [...] 
Met deze laatste vertaling, de eerste in boekvorm, is voor het eerst een potentieel breed receptiekader geschapen. Een der recensenten spreekt de hoop uit op een vervolg met Adam in Ballingschap en Noah, de twee andere delen van de Jozef-'trilogie'. In bovengenoemd interview verklaarde Lange Fliflet inderdaad te denken over een vertaling van Adam in Ballingschap, terwijl Langvik-Johannessen inmiddels een vertaling van Gebroeders heeft voltooid. ${ }^{53}$

\section{De Vondelstudie in het Noorden}

De Scandinavische Vondelstudie neemt een aanvang rond 1880 . Voordien is de wetenschappelijke belangstelling betrekkelijk passief en voomamelijk inventariserend van aard. Het contemporaine Vondelbezit van koningin Christina en de koninklijke bibliotheken van Stockholm en Kopenhagen werd reeds genoemd. In de enige bekende zeventiendeeeuwse studie waarin Vondel optreedt, Dissertationes academicae de poetis (1683), looft de Deense filoloog Ole Borch (1626-1690) Vondels poëzie en behandelt hij zijn invloed op de Deense woordvorming.

In de achttiende eeuw verwerft de Noorse humanist Benjamin Dass (1706-1775) het handschrift van enige gedichten uit Parnas aen de Belt, dat thans als enig Vondelhandschrift in Scandinavisch bezit berust in de bibliotheek van de Det kongelige Norske Videnskabers Selskab, ondergebracht in de Universiteitsbibliotheek van Trondheim. In de verzameling van de Zweedse archivaris Elias Palmskiöld, door de universiteitsbibliotheek van Uppsala in 1724 gekocht, treffen we een handschrift met aantekeningen over Vondel aan. Maar noch bij Dass noch bij Palmskiöld hebben deze manuscripten tot enige publikatie geleid. ${ }^{54}$

Pas aan het eind van de negentiende eeuw komt hierin verandering. De opkomst van de vergelijkende literatuurwetenschap en de hernieuwde belangstelling voor de vaderlandse geschiedenis in beide gebieden leidt in Scandinavië tot publikaties waarin de relaties tussen de Nederlanden en het Noorden aandacht krijgen. Deze zijn inzake Vondel gekenmerkt door twee interessegebieden:

1) de relatie tussen Vondel en Scandinavië, en

2) Vondel als Europees barokkunstenaar.

De Kopenhaagse hoogleraar esthetica Julius Paludan (1843-1926) noemt in een tweetal publikaties, Fremmed Indflydelse paa den danske Nationalliteratur $i$ det 17. og 18. Aarhundrede (1887) en Danmarks Litteratur mellem Reformationen og Holberg (1896) Vondel als een groot renaissancedichter, die in het Noorden bekend is om zijn taalgebruik en opgevoerde toneelstukken, maar wiens invloed voomamelijk beperkt blijft tot het terrein van de woordvorming (het toenemend gebruik van composita door Deense auteurs), en in elk geval minder is dan die van de in het Noorden populaire en nagevolgde Cats. Paludans rivaal om het hoogleraarschap esthetica, de internationaal befaamde literatuurcriticus Georg Brandes (1842-1927) was echter primair gericht op de negentiende-eeuwse literatuur, en van de ouderen had vooral Shakespeare zijn belangstelling. Zijn op het nut gerichte literatuuropvatting liet zoals we reeds zagen weinig ruimte voor iemand als Vondel: het blijft bij een korte verwijzing naar de overeenkomst met Milton. 


\section{Hoofdstuk II}

Brandes' leerling Alfred Ipsen (1852-1922) schenkt in zijn Nederlandse literatuurgeschiedenis van 1901 nadere aandacht aan de tegenstelling Cats-Vondel, waarbij beiden er niet goed afkomen. Ipsen prijst Vondels lyrische werk en zijn nobel karakter in politicis, maar kritiseert zijn "niet altijd gelukkige hang naar het pathetische" en zijn stukken met hun abstract idealisme, die "handeling noch passie" bezitten."

Een veel positiever houding vinden we bij de vader van het comparatisme in Zweden, Ewert Wrangel (1863-1940), hoogleraar esthetica te Lund. Wrangel, telg uit een bekend Zweeds geslacht met oude banden met de Nederlanden, schenkt in zijn studie uit 1897 , Sveriges litterära förbindelser med Holland särdeles under 1600-talet [lees voor "litterär': kunstzinnig \& wetenschappelijk, DG] voor het eerst en op ruime schaal aandacht aan Vondels gedichten op Zweedse vorsten en politiek, en op zijn invloed op Zweedse auteurs als Spegel. De theaterhistoricus en rijksbibliothecaris Oscar Wieselgren (1886-1952) vult deze studie aan in zijn dissertatie van 1909, Bidrag til kännedomen om 1600-talsdramat $i$ Sverige met gegevens over Vondelopvoeringen in Zweden en hun mogelijke invloed op een Zweedse Phaëton. De canonisering van Vondel als gevolg van deze studies blijkt als hij opduikt in encyclopedieën, onder andere in een artikel uit 1934 van de filoloog Hjalmar Psilander, hoogleraar Duits te Uppsala, met speciale aandacht voor juist Vondels gedichten over Zweden. ${ }^{56}$

Rond 1940 treedt Vondel weer op in Deense studies, die vooral aandacht hebben voor de 'Europese' Vondel. De barokexpert Erik Lunding (1910-1981) schrijft in 1940 een studie over de Duitse dramaturg Gryphius, waarin hij een aanval doet op de geschriften rond de invloed van (de overigens door hem in diverse opzichten bewonderde) Vondel op Gryphius, een invloed die volgens hem non-existent is en gebaseerd op algemene zeventiende-eeuwse motief- en stijlovereenkomsten, terwijl de verschillen veel groter zijn. In publikaties van 1951 en 1962 herhaalt hij deze stelling, die daarna door Lieven Rens als ongefundeerd is bestreden, daar ze de aantoonbaar zeer gedetailleerde overeenkomsten tussen Vondel en Gryphius niet verklaart. ${ }^{57}$

De reeds genoemde Vondelvertaler Vilhelm Andersen (1864-1953), hoogleraar Scandinavische literatuur te Kopenhagen, benaden Vondel primair als Europees kunstenaar in zijn studie Horats (1942). Hij gaat in op de controverse Vondel : Rembrandt (de door hem vertaalde Rey van Bacchanten voert hij aan als bewijs van Vondels anti-Rembrandtiaanse en pro-Rubensiaanse gezindheid), en op Vondels pregnante taalgebruik. Toch komt ook Vondels relatie met het Noorden aan de orde, met aandacht voor de Horatiaanse invloed op zijn gedichten op Gustav Adolf, en Vondels mogelijke invloed op de Deense barokdichter Kingo.

Het door diverse experts geschreven standaardwerk Holland-Danmark (1945), synthese van het historisch onderzoek naar vooral de zeventiende-eeuwse relaties, vertoont qualitate qua interesse voor Vondel in zijn relatie tot Denemarken. Vondelopvoeringen in Denemarken komen aan bod in de studie van het Nederlands theater door de theaterhistoricus Torben Krogh (1895-1970), en de bezoeken aan en gedichten op de Denen in de studie van literaire relaties, door de bibliothecaris Helge Kjargaard. Anders dan Krogh is Kjargaard weinig positief in zijn eindoordeel: hij noemt de 'Deense' gedichten weinig geìnspireerd. 


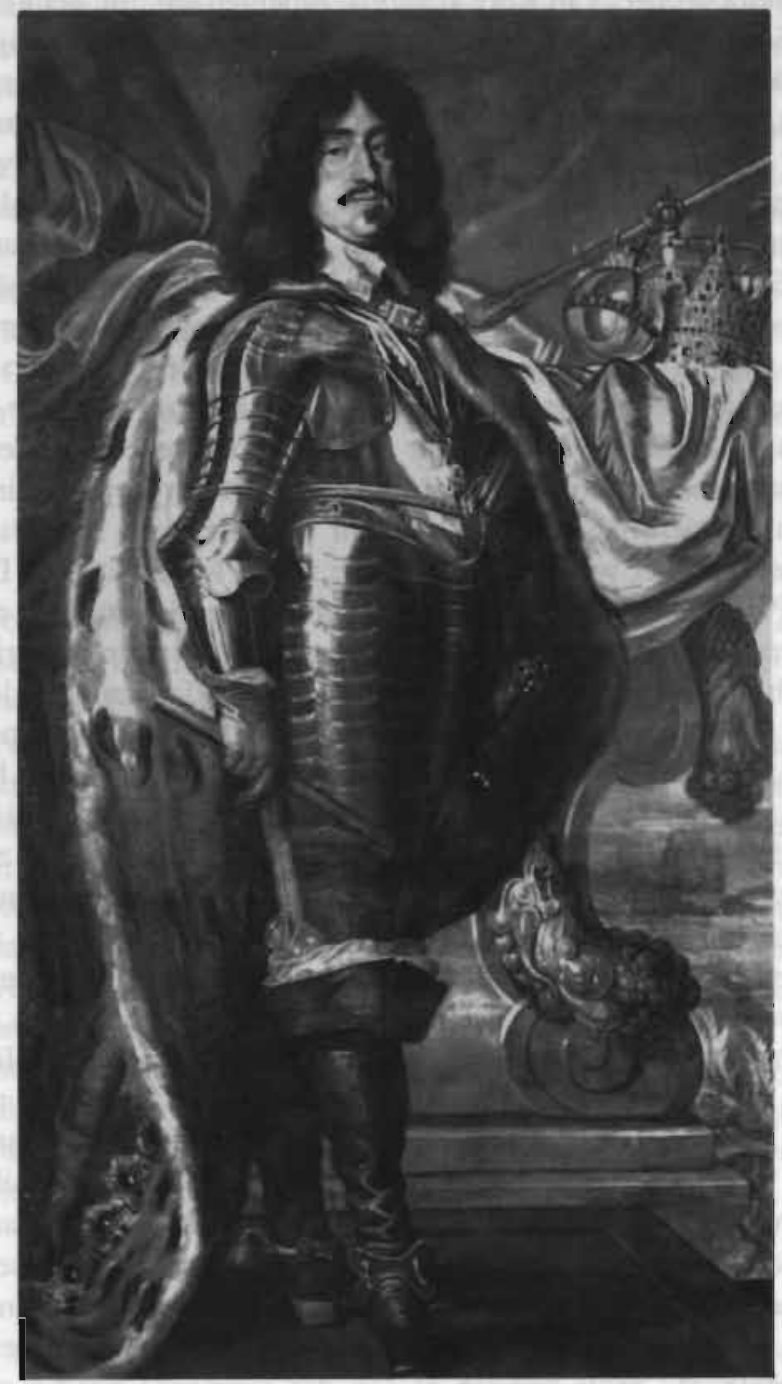

Afbeelding 3. Vondels relatie tot de schilderkunst kreeg aandacht van diverse Scandinavische literatoren en onderzoekers. Bij dit portret van de kunsilievende Frederik III van Denemarken, "met mercken van de Kroon" door Vondels Kopenhaagse gastheer Karel van Mander III schreef Vondel het openingsvers in 'Parnas aen de Belt'. (Nationalhistorisk Museum Frederikshorg. Hillerød). 


\section{Hoofdstuk II}

Mede als reactie op Kjærgaards visie verscheen in 1954 een uitgebreid artikel Vondel og Danmark-Norge, van Kåre Langvik-Johannessen, die als geen ander het beeld van Vondel in Scandinavië heeft bepaald. In zijn studie presenteert hij de bij het Noordse publiek onbekende dichter, plaatst hem als typisch barokkunstenaar in een cultuurhistorische context, en komt tot een veel positiever eindoordeel dan Kjargaard. Een soortgelijk stuk over de gedichten op Gustav Adolf en Christina (1953), werd gevolgd door een reeks andere Vondeliana, in diverse Scandinavische wetenschappelijke tijdschriften. ${ }^{58}$

In 1963 promoveerde Langvik-Johannessen te Oslo op een dissertatie Zwischen Himmel und Erde: Eine Studie über Joost van den Vondels biblische Tragödie in gattungsgeschichtlicher Perspektive, over het psychosymbolisch karakter (de uiterlijke handeling als weerspiegeling van de innerlijke tweestrijd van de hoofdfiguur) in het door Vondel geschapen genre van de bijbelse tragedie, die niet ontstaat door de renaissancistische tegenstelling tussen hemel en aarde, maar door het doorbreken van de barokke synthese daarvan, de kosmische harmonie. De grondige en uitvoerige Scandinavische recensies geven blijk van aanzienlijke Vondelkennis in het Noorden. Net als in Nederland en Vlaanderen ondervond het werk in Scandinavië zowel lof als kritiek. De Noorse theaterwetenschapper Pavel Frænkl prijst Langviks synthetiserend vermogen en ideeënhistorisch inzicht, maar verwijt de auteur bij sommige drama-analyses een aprioristisch uitgaan van zijn symmetrisch model. De Deense filoloog Steffen Steffensen, hoogleraar germanistiek te Kopenhagen, noemt het boek in een uitvoerige recensie zeer boeiend in zijn genrehistorische analyse, doch kritiseert de te schematische opvatting van de begrippen 'synthese' en 'barok', en mist een genuanceerder schets van het humanistisch-idealistische aspect van Vondels christendom. Onverdeeld positief is daarentegen zijn Oslose collega Ole Koppang, opponent bij de promotie, terwijl de Noorse literatuurhistorica Milada Blekastad vraagtekens plaatst bij de neiging, een dichter uitsluitend vanuit de barokke tijdgeest te willen verklaren, maar per saldo vol waardering is over de drama-analyses. ${ }^{59}$

Ook buiten wetenschappelijke kringen heeft Langvik-Johannessen, in 1966 benoemd tot hoogleraar Nederlands te Oslo, de aandacht weten te vangen. Hij schreef ettelijke populariserende artikelen in Scandinavische kranten en tijdschriften, met aandacht voor drie elementen: Vondel als Europees dramaticus, als dichter over Scandinavische personen en politiek, en in zijn relatie tot andere kunsten, speciaal de schilderkunst. In 1970 haalde hij bovengenoemde voorstelling van Adam in Ballingschap naar Oslo, hij hield er drukbezochte Vondellezingen en schreef in het Noors zijn Nederlandse literatuurgeschiedenis (1980) met als onbetwist centrum Vondel: deze krijgt in zijn eentje even veel aandacht als de hele Nederlandse literatuur na 1900, - "een recessieve symmetrie met Vondel als middelpunt" zoals kritisch in een der overigens positieve Noorse recensies werd opgemerkt. ${ }^{(0)}$

Dat hij met dit brede spectrum aan publikaties geen roepende in de Scandinavische woestenij is gebleven, blijkt uit ettelijke recente Vondelpublikaties van andere hand, waarin opnieuw de twee interessegebieden merkbaar zijn: Vondel in relatie tot Scandinavië, en als Europees barokkunstenaar. Kongelige portrcetmalere i Danmark, de dissertatie uit 1971 van de Deense kunsthistoricus Povl Eller, directeur van het nationaalhistorisch museum Frederiksborg, wijdt een paragraaf aan Vondels gedichten bij vorstenportretten van Van Mander. Hans Sørensen, Kopenhaags hoogleraar algemene literatuurwetenschap, 
populariseert in 1972 Langvik-Johannessens studie in een paragraaf over Vondel, met een analyse van Adam in Ballingschap, in een in het Deens en Noors verschenen wereldliteratuurgeschiedenis. Van de classicus Egil Kraggerud, hoogleraar te Oslo, verschijnt in 1983 naar aanleiding van Langvik-Johannessens uitgave van Gebroeders een artikel over Vondels imitatio van de klassieken in dat stuk, dat Kraggerud ziet als exemplarisch studie-object in dezen. De Zweedse theaterhistorica Gunilla Dahlberg, expert op het gebied van zeventiende-eeuwse theatertroepen in Zweden, geeft in een artikel (1984) op grond van tot dan onbekend Zweeds materiaal een nieuwe datering van Vondels $D e$ Tooneelbroeders, en behandelt in haar monografie over het zeventiende-eeuwse theater in Stockholm (1993) onder andere Zweedse Vondelopvoeringen. En van de Gotenburgse lector Nederlands Gerrit Otterloo, gepromoveerd bij Langvik-Johannessen, verschijnt in 1989 een stuk over het ontstaan en de ontwikkeling van de Vondeliaanse alexandrijn. ${ }^{61}$

\section{Conclusies}

Tegen de achtergrond van de beperkte internationale bekendheid van de zeventiendeeeuwse Nederlandse letterkunde in vergelijking met die van de schilder- en bouwkunst, blijkt de Scandinavische bekendheid met Vondel groter dan verwacht. Uit het bovenstaande blijkt hoe de dichter vanaf zijn eigen tijd tot in onze eeuw een relatief brede aandacht in Scandinavië heeft gehad, die er door geen ander Nederlands auteur wordt geëvenaard: van vorstelijke en politieke bewonderaars, theaterpubliek, literatoren, dramaturgen, kunstcritici, vertalers en wetenschappers. De zeventiende en de twintigste eeuw worden daarbij door dunne draden in de tussenliggende periode verbonden. Deze aandacht loopt deels parallel met die in Nederland, maar slaat ook een geheel eigen richting in, met aandacht voor resp. het intemationale aspect (zijn relatie tot het theater en de schilderkunst) en het nationale aspect (zijn verhouding tot Scandinavië).

Vondel is hiermee geen Scandinavisch volksbezit geworden. Maar de verguizing die hem in Nederland door overdaad ten deel is gevallen, ontbreekt hier, waardoor Scandinavische ogen onbevangener staan tegenover die dichter uit de Gouden Eeuw die als geen ander banden met het Noorden heeft gehad. 


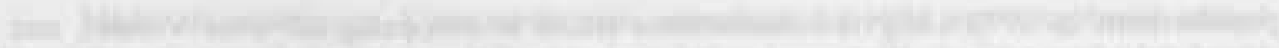

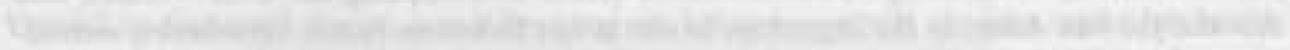

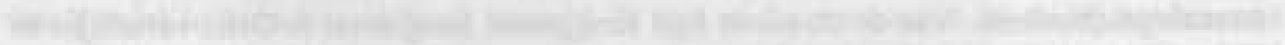

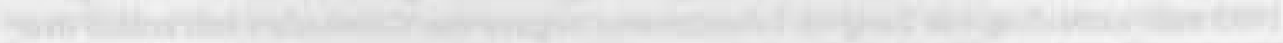

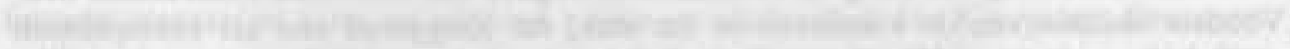
-14

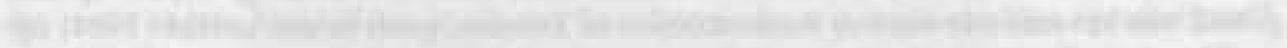
Thin:

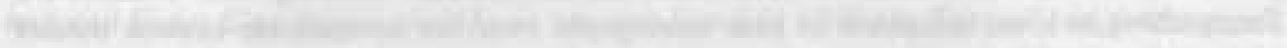

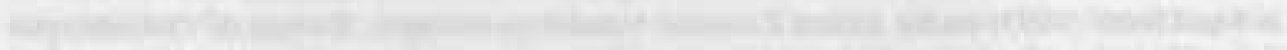

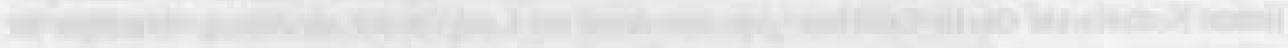
2.

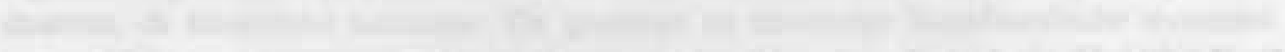

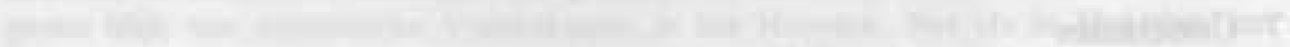

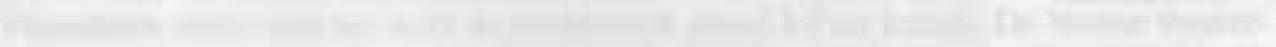
Then 1.

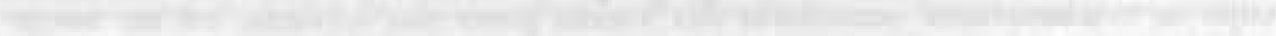

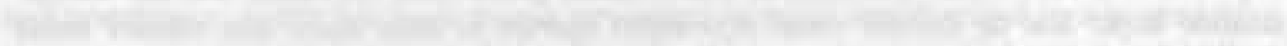
-

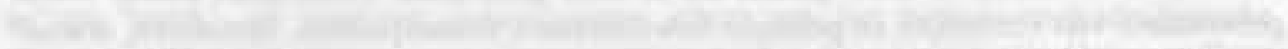

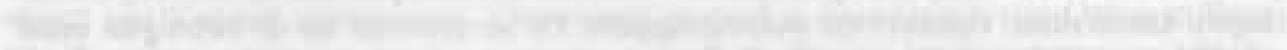

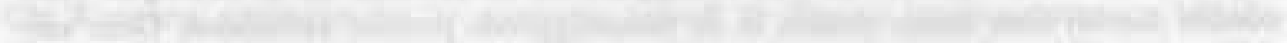

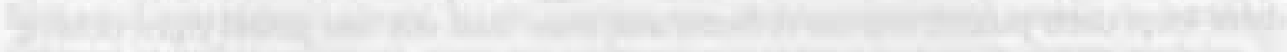

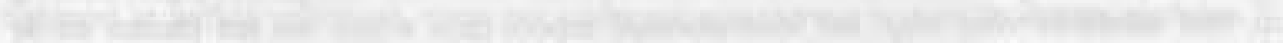

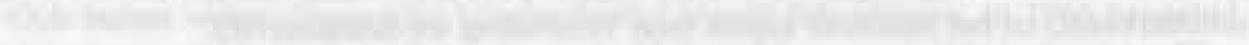

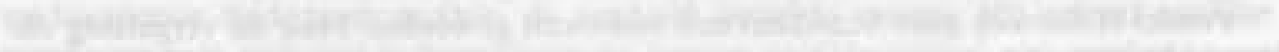




\section{Hoofdstuk III}

\section{Bilderdijk en Denemarken*}

\section{Inleiding}

Publikaties over de literaire betrekkingen tussen de Nederlanden en Scandinavië wijzen terecht Potgieter aan als baanbreker voor de moderne Noordse letteren ten onzent. Het Noorden in omtrekken en tafereelen $(1-2,1836-40)$, Potgieters presentatie van vooral de Zweedse literatuur, vormde de succesvolle start van een gestaag groeiende reeks vertalingen, zowel van Potgieter zelf als van kunstbroeders. Andersen, de jonge Bjørnson, Bremer, Tegnér en andere Scandinavische auteurs werden nu rechtstreeks vertaald, in tegenstelling tot hun achttiende- en vroeg-negentiende-eeuwse collega's, die steeds via het Duits waren vernederlandst. ${ }^{62}$

Toch is de lof aan Potgieter niet geheel terecht, voor zover er de suggestie van uitgaat dat deze de eerste Nederlandse literator is geweest die Scandinavische auteurs aan zijn publiek heeft voorgezet. Dat was decennia tevoren al gedaan door Bilderdijk, en wel met vertalingen van Holberg, Tullin, Schack Staffeldt en Baggesen. Merkwaardig genoeg wordt in slechts een van bovenbedoelde artikelen over de Nederlands-Scandinavische literaire relaties de naam Bilderdijk genoemd, en dan nog slechts met betrekking tot de vertaling van Tullin. ${ }^{63}$ In de specifieke Bilderdijkliteratuur wordt dan weer alleen aandacht besteed aan de vertaling van Holberg, - de enige niet-rechtstreekse.

Binnen Bilderdijks totale oeuvre nemen de vertalingen uit het Deens een zeer bescheiden plaats in. Niettemin zijn ze literairhistorisch interessant, doordat ze een onderdeel blijken van Bilderdijks gespreide, maar intern samenhangende interesse voor Denemarken, die zich niet beperkt tot de letteren, maar zich ook uitstrekt tot staat, volk en taal, en die te herleiden is tot zijn romantisch gekleurde opvatting van een onbedorven samenleving, tegenpool van het gecorrumpeerde Holland. In zijn tijd hoorde ook Noorwegen tot die samenleving: tot 1814 was Noorwegen deel van het Deense koninkrijk, en Deens bleef er nog lang nadien de cultuurtaal. Met zijn interesse vult Bilderdijk dan ook, avant la lettre, Potgieter aan: diens belangstelling ging immers primair naar Zweden uit. Op 
zijn beurt heeft Bilderdijk het Kopenhaagse niet onberoerd gelaten: Deense auteurs hebben over hem geschreven, hem zelfs vertaald.

In het onderstaande zal ik nader ingaan op respectievelijk Bilderdijks opvattingen met betrekking tot Denemarken, zoals deze blijken uit brieven en originele gedichten; zijn kennis van de taal; de keuze uit de Noordse letteren en de ard van de vertalingen; en ten slotte de Bilderdijk-receptie in Denemarken.

\section{Opvattingen over staat, volk, taal en letteren}

Van Bilderdijks politieke ideeën over Denemarken horen we voor het eerst in 1793 , wanneer hij de Deense gezant in Den Haag, Herman Baron Schubart (1756-1832), ter gelegenheid van de verjaardag van de Deense koning een zesentwintig strofen tellende ode toezendt: De Alleenheersching: Aan het volk van Denemarken. ${ }^{64}$ Deze bewerking van Klopstocks lofzang op de Deense monarchie Das neue Jahrhundert bezingt het "Gezaligd, driewerf zalig Noorden", waar men niet als in Holland republiek en democratie omarmt. Bilderdijk roept zijn landgenoten op, afstand te doen van de onzalige erfenis der gebroeders De Witt, en het spoor der Denen te volgen.

In de thans zeer zeldzame originele uitgave van 1793 (in Nederland bezit alleen de universiteitsbibliotheek van Amsterdam een exemplaar) sluit de dichter af met een Deens motto: "Hvi skulde du giöre menniskene som fiske i havet; som orme, der have ingen regentere?" [Bilderdijk voegde zelf de vertaling toe: "Waarom zoudt gy de menschen maken als de visschen der zee? als het kruipend gedierte, dat geenen heerscher heeft?"]. In de Koninklijke Bibliotheek te Kopenhagen trof ik een van de exemplaren die Bilderdijk aan Schubart had gezonden, met eigenhandig geschreven opdracht: "Den Stormagtigste, Høybaarne Monarch og Herre Christian VII, Konge til Dannemarck og Norge \&c.\&c.\&c., i allerdybeste Ydmyghed og Underdanighed ofret" ["De Grootmachtigste, Hooggeboren Monarch en Vorst Christian VII, Koning van Denemarken en Noorwegen etc. etc. stc., in allemederigste Ootmoed en Onderdanigheid aangeboden"] (zic afbeelding 4$)^{65}$. Hoezeer in de ode sprake is van romantisering van Bilderdijks zijde blijkt wel uit het feit dat nu juist Christian VII allerminst een krachtig en wijs monarch was, maar een uiterst zwakke vorst, wiens macht hem aanvankelijk door de minnaar van zijn vrouw, Struensee, en na diens val door zijn moeder en zoon Frederik werd ontnomen.

Als in 1795 Bilderdijk uit Holland wordt verbannen, is zijn primaire gedachte zich in Kopenhagen te vestigen; stellig heeft hij gespeculeerd op een koninklijke dichtergage zoals Klopstock die ter plaatse jarenlang had ontvangen. Reeds in de eerste brief aan zijn achtergebleven echtgenote Catharina Rebecca Woesthoven dringt hij aan op contact met Schubart inzake aanbevelingsbrieven, en in zijn latere correspondentie komt hij er steeds weer op terug. ${ }^{66}$ Schubart biedt zich aan als correspondentiepost tussen de echtgenoten on het onderscheppen van brieven te voorkomen - en bezorgt de balling een aanbevelingsbrief voor de Staatsraad van het Deense hof in Altona bij Hamburg, maar daar blijft het tot Bilderdijks teleurstelling bij: "Het Deensche Hof is goed, maar de politique omstandigheden verbieden mij, daar zonder 't goedvinden van den Prins heen te gaan, en de Ministers zoo hier als elders zijn huiverig. mij in 't publicq [...] te fêteeren", schrijft hij 


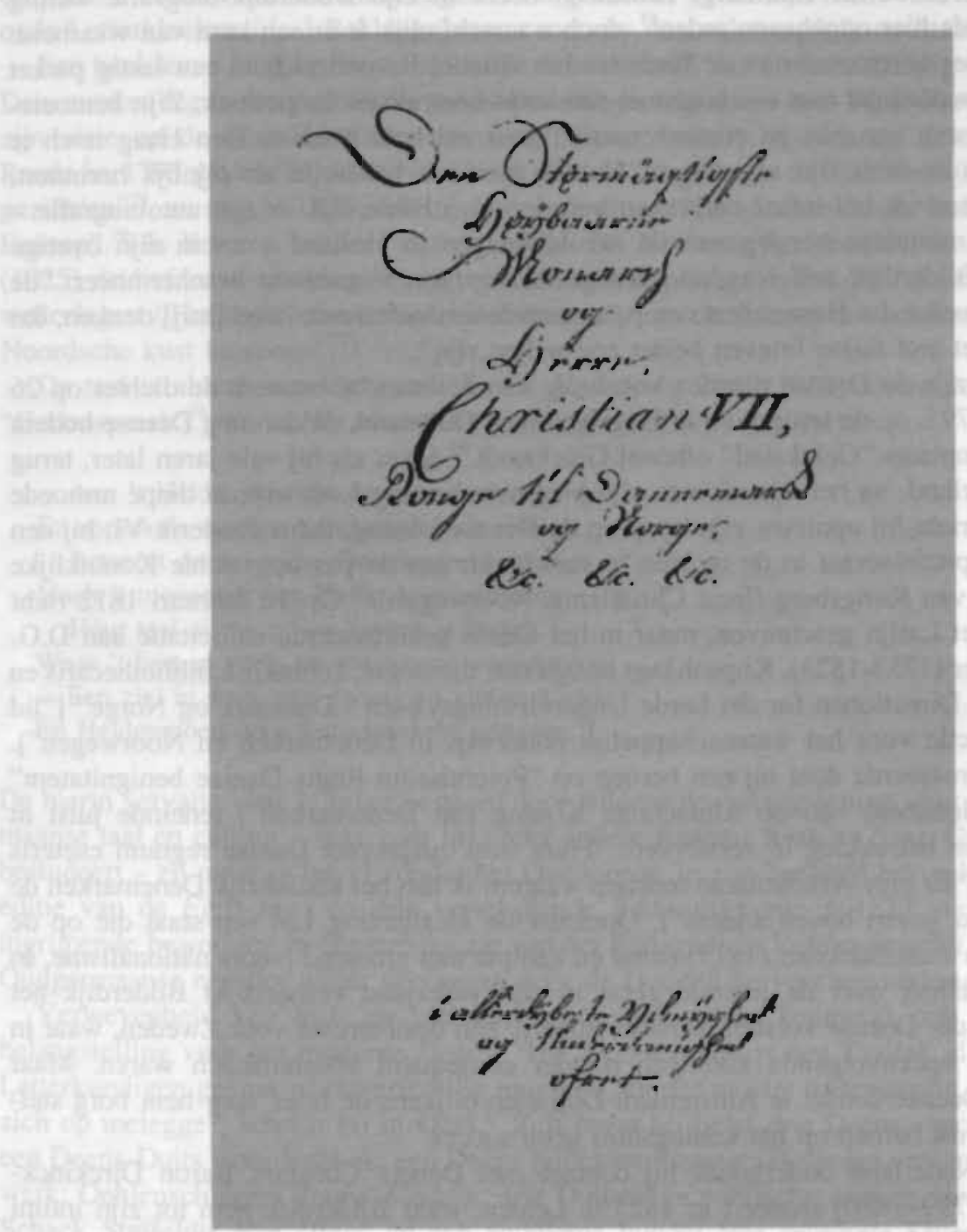

Afheelding 4. "De Grootmachtigste, Hooggeboren Monarch en Vorst Christian VII. Koning van Denemarken en Noorwegen etc.etc.etc., in allernederigste Ootmoed en Onderdanigheid aangeboden": Bilderdijks opdracht in een via de Deense gezant Schubart aan de vorst geschonken exemplaar van zijn lofdicht 'De Alleenheersching: Aan het volk van Denemarken' uit 1793. Zie ook noot 65. (Koninklijke Bibliotheek Kopenhagen). 


\section{Hoofdstuk III}

Catharina Rebecca uit Hamburg. Kollewijn hecht in zijn Bilderdijk-biografie weinig waarde aan de hier opgegeven reden ${ }^{67}$, doch waarschijnlijk is er een kem van waarheid: Schubart, zeer vertrouwd met de Nederlandse situatie, bevond zich in een lastig parket als vertegenwoordiger van een land met een strikt neutralistische politiek. Zijn bemoeienis ten behoeve van een zo controversieel figuur zal hem noch te Den Haag noch te Kopenhagen in dank zijn afgenomen. Dat hij zich het gebeurde als pijnlijk herinnert, lijkt te spreken uit het totaal ontbreken van de naam Bilderdijk in zijn autobiografie waarin een minutieus verslag van de revolutiedagen in Holland - en in zijn overige papieren. ${ }^{68}$ Bilderdijk zelf reageert teleurgesteld op zijn vermeende beschermheer: "de denkwijze, welke die Heer sedert een paar maanden manifesteert, deed [mij] denken, dat hij liever niet met mijne brieven belast zou willen zijn".

Hiermee zijn de Deense plannen voorlopig van de baan, al betreedt de dichter op 26 september 1795, op de terugreis van Engeland naar Duitsland, de dan nog Deense bodem van de havenplaats "Gelukstad" oftewel Glückstadt. ${ }^{69}$ Maar als hij vele jaren later, terug in zijn vaderland, na het vertrek van zijn protector Koning Lodewijk in diepe armoede achterblijft, richt hij opnieuw zijn hoop op de Deense koning, thans Frederik VI, bij een poging een professoraat in de rechten te verwerven aan de pas opgerichte Koninklijke Universiteit van Kongsberg (lees: Christiania, Noorwegen) ${ }^{70}$ Op 10 februari 1812 richt hij een in het Latijn geschreven, maar in het Deens geadresseerde sollicitatie aan D.G. Moldenhawer (1753-1823), Kopenhaags hoogleraar theologie, koninklijk bibliothecaris en "Medlem af Directionen for det lærde Underviisningsvæsen i Danmark og Norge" ["lid van de Directie voor het wetenschappelijk onderwijs in Denemarken en Noorwegen"]. Via de geadresseerde doet hij een beroep op "Potentissimi Regis Daniae benignitatem" ["de welwillendheid van de Almachtige Koning van Denemarken"] teneinde juist in diens rijk een betrekking te verwerven: "Plura sunt quapropter Daniae regnum caeteris praeferam" ["Er zijn verscheidene redenen waarom ik aan het koninkrijk Denemarken de voorkeur zou geven boven andere"]. Opnieuw de idealisering van een staat die op de rand van een staatsbankroet (1813) stond en kampte met groeiend Noors nationalisme. In zijn teleurstelling over de liberale geest in zijn vaderland verheerlijkt Bilderdijk het absolutisme der Deense vorsten; karakteristiek is zijn desinteresse voor Zweden, waar in zijn tijd de opeenvolgende koningen minder consequent absolutistisch waren. Maar hoewel de Deense consul te Amsterdam Dull zich blijkens de brief voor hem borg stelde, had ook dit beroep op het koningshuis geen succes."

Ook in Nederland onderhoudt hij contact met Denen. Constant Baron DirckinckHolmfeld (1799-1880) studeert in 1823 te Leiden, waar Bilderdijk hem tot zijn intimi rekent. $^{72}$ Stellig heeft de pupil zich in zijn leermeester herkend: terug in Kopenhagen ontpopt hij zich als ijverig antidemocratisch en antiliberaal pamflettist op filosofisch, religieus, literair, historisch en politiek terrein. In 1830 introduceert hij Bilderdijk uitvoerig bij het Deense publiek, waarover meer in paragraaf $4 .^{73}$

In 1825 vinden we Bilderdijks naam vermeld In het Alhum van A. Andersen Feldborg. van de Universiteit van Koppenhagen. ${ }^{74}$ Andreas Andersen Feldborg (1782-1838), auteur van de eerste in het Nederlandse verschenen monografie over Denemarken, woonde een tijdlang in ons land om er de nationale geschiedenis te bestuderen. Verbaasd vraagt Bilderdijk "Wat kwaamt ge in Nederland naar 't oude Neêrland zoeken? / Wy. 
Grijzaarts, kenden 't eens, maar zagen 't omgekeerd / En al zijn roem verdween met de oude Letterkloeken / [...] Beklaag, betreur met my den val van Volk en Staat [...]".

Een heel leven lang koestert Bilderdijk dus het beeld van een staatkundig onbedorven Denemarken tegenover het verdorven Nederland, ja, tegenover heel West-Europa. Ook in zijn visie op de Scandinavische mens en cultuur baseert hij zich op deze oppositie. Reeds in 1795 plaatst hij "het Noordelijk schoon" tegenover de "jammerlijke Duitsche gezichten"75 , en nog in 1826 stelt hij de noorderlingen ten voorbeeld aan "het zenuwloos Euroop". ${ }^{76}$ Is het een wonder dat de idylle De Hollandsche Visscher in Noorwegen (1825) de liefdesversmelting bezingt van de archetypische visser, die "door zee en onweêrvlagen / Hollands inborst meê bleef dragen", met de "bloem der schoonen / Die de Noordsche kust bewonen"77?

De taal is al evenzeer onbesmet. In De Noordsche Taal (1822) roemt de dichter de "Godenspraak", en in Het Noorden (1826) spreekt hij de heroën toe:

Aan 't Heldenvuur dat door uwe aders schiet

En sprankels stort en hartdoorgloênde vonken,

Betaamt de zwier der Ooster-weekheid niet,

Noch 't toovergift van Hellas hoerenlonken.

Heur taal zij zang; uw Spraak is Poëzy

Waar ' $t$ hart in voelt, en stroomend uitgedreven,

Een ziel in stor, van dwang en kluisters vrij.

En Heldenmoed door Reuzenkracht gesteven. ${ }^{79}$

De hierin vervatte visie is zeker gestaafd door Bilderdijks belangstelling voor de Oudgermaanse taal en cultuur - waarvoor hij onder andere Rasmus Rask en Saxo Grammaticus bestudeert - en meer in het bijzonder het Oudnoords. In zijn boekerij bevonden zich een editie van de Egils-saga en drie verschillende Edda-uitgaven; in 1822 verschijnt zijn ingrijpende bewerking in christelijke zin van het Eddagedicht Vafthrudnismál, waarin het Oudgermaanse noodlot wordt vervangen door de Goddelijke voorbeschikking. ${ }^{80}$

Verwevenheid van taal- en letterkundige belangstelling kenmerkt ook Bilderdijks belangstelling voor het modeme Deens. "Het Deensch zelf is een Taaltak, die aan onze Letterkundigen geenszins onverschillig mag zijn, en der moeite overwaardig, dat men er zich op toelegge", schrijft hij in 1803 . $^{81}$ Zelf bezat hij liefst drie Deense spraakkunsten; een Deens-Duits woordenboek; een Deens bijbelcommentaar; Holbergs verzameld toneelwerk; Oehlenschlägers drama Aladdin; drie Duitstalige poëtische werken van Baggesen; Schack Staffeldts Nye Digte; en een anonieme bundel Nye originale Skuespil. ${ }^{82}$ Deze verzameling is typerend voor 's dichters ideeën: Holbergs hoofdwerken Jeppe paa Bjerget en Den politiske Kandestøber zijn meestal eenzijdig geïnterpreteerd als aanvallen op de democratie; Oehlenschlägers Aladdin is wel de romantische held bij uitstek; en zowel de veelzijdige Baggesen als de verbitterde lyricus Schack Staffeldt vertoont veel raakpunten met de tijdgenoot en vakbroeder, - meer hierover in paragraaf 4. De Zweedse literatoren zijn opvallend afwezig in de boekerij: afgezien van een woordenboek en twee grammatica's komen in het geheel geen werken in het Zweeds of betreffende Zweden 
voor, terwijl een als zijn vertaling uit het Zweeds aangegeven romance uit 1788 op een mystificatie blijkt te berusten. ${ }^{83}$

\section{Bilderdijk en de Noordse letteren}

\subsection{Ludvig Holberg (1684-1754)}

Kollewijns Bilderdijk-biografie vermeldt het bestaan van "een onbeteekenend stukje [...] dat onze aandacht niet zou verdienen, zoo het niet als de eenige voltooide oorspronkelijke comedie van Bilderdijk eenige merkwaardigheid bezat" ${ }^{" 84}$ : het door de circa achttienjarige rond 1774 geschreven spel De Goudmaker. Het is het verhaal van de gauwdief Grypaart, die samen met zijn maat Pakburg de op goud beluste Heer Garenryk bedriegt met het schijnbare alchemistische succes van 'Arabisch poeder' bij de goudfabricage. Garenryk beloont zijn weldoeners rijkelijk en wordt overstroomd met bezoeken van de heren Pluimstryker en Vleier, die ras weer verdwijnen als blijkt dat na het vertrek van Grypaart en Pakburg het Arabisch poeder nergens in de stad meer te koop is.

Het voor eigen huiskamergebruik geschreven stuk werd door Bilderdijk nooit gepubliceerd, maar op grond van de inhoudsopgave en de fragmenten door Kollewijn meegedeeld, concludeerde in 1922 Jan de Vries (die al eerder op parallellen tussen Holberg en Bilderdijk had gewezen) dat het spel geenszins oorspronkelijk was, doch een bewerking moest zijn van Holbergs Det Arabiske Pulver van 1722. Anders dan Kollewijn waardeer De Vries het stuk om zijn vlotte replieken en uitstekende versificatie. ${ }^{85}$ De Gentse scandinavist Logeman wist het inmiddels verdwenen manuscript op te sporen en bezorgde in 1925 een kritische editie. Hij toont overtuigend aan dat De Goudmaker is gemaakt naar een bestaande Nederlandse prozavertaling uit 1747, die overigens zelf weer naar het Duits is vertaald. Ondanks de herkenbaarheid van de Duitse tussentekst is Bilderdijk echter zeer vrij in de bewerking daarvan. Logeman is iets voorzichtiger in zijn lof dan De Vries, maar toch zeker positief. ${ }^{86}$ Gunstig oordeelt ook Saskia Ferwerda in haar dissertatie Holherg en Holland (1939), waarin zij de levendigheid en oorspronkelijkheid prijst en de bewerking een zeldzame uitzondering noemt op de slapheid of het knoeiwerk in de achttiende- en negentiende-eeuwse vertalingen van Holbergs blijspelen. ${ }^{87}$

Duidelijk kende Bilderdijk op zo jonge leeftijd nog geen Deens, en dit jeugdwerk is zelfs niet als een indirecte vertaling te beschouwen: het maakt kortom geen deel uit van zijn 'Deense' ideeëncomplex. Wel is het waarschijnlijk dat de kennismaking met Holberg voor hem aanleiding is geweest om diens andere komedies te lezen, die zoals vermeld vaak werden geïnterpreteerd als aanvallen op de democratie. Minder aannemelijk is Kollewijns suggestie dat het Kort Verhaal van eene Aanmerklijke Luchtreis (1813) geïnspireerd zou zijn op Holbergs "Klaas Klim", oftewel het utopische reisverhaal Niels Klims underjordiske Reise ${ }^{88}$; geschiedenis en ideeënwereld vertonen geen enkele verwantschap. 
In 1803 publiceert Bilderdijk voor het eerst een vertaling "naar het Deensch": het 28 strofen lange Lentemorgen ${ }^{89}$, een oorspronkelijk als huwelijksgedicht geschreven ode op de Lente als symbool van de Schepping. Hij plaatst het als openingsgedicht in het eerste deel van zijn Poëzy met een nadrukkelijke bedoeling: "Ik kan nogthands niet voorby, op het Dichtstuk, waarmeê mijne Verzameling aanvangt, 's Lezers aandacht byzonder te vestigen. Ik geve 't (gelijk het is) als een Navolging ten Proeve van Deensche Poëzy; en wel, Poëzy van den [...] waarlijk grooten Tullin [...] [I]k zal my gelukkig achten, zoo ik in de Navolging, die ik hier [...] van hem geve, iets mag toebrengen om hem, en de Dichtkunst der Denen, die ik wenschte dat meer bekend ware, in gunstiger dag te stellen, dan mooglijk tot op heden geschied is". ${ }^{90}$

Waarom juist En Maji-Dag (1758) van de Noors-Deense dichter Tullin voor gemeld doel uitgekozen? Het is goed mogelijk dat Bilderdijk bij de door hem zo bewonderde Lessing diens lofprijzing van En Maji-Dag heeft gelezen: idee, ordening en versificatie zijn, zo schrijft Lessing, "so vortrefflich, daß ich nicht weiß, ob wir Deutsche jernals ein solches Hochzeitsgedicht gehabt haben". ${ }^{11}$ Bilderdijk gebruikt vergelijkbare bewoordingen: "een meesterstuk [...] zeker, weet ik niet, ooit een voorbeeld in eenige taal ontmoet te hebben, hetgeen in dat vak, naar mijn smaak zoo volkomen was". ${ }^{92}$

Maar afgezien van deze eventuele aanleiding moet de diepere reden voor de keuze toch de idee van het werk zijn geweest. In de eerste regels roept de dichter zijn muze op, met hem te vluchten uit de stad, "deze melancholieke gevangenis", in de volgende strofen beschreven als een oord van duistemis, redeloosheid, geldzucht, haat en huichelarij. De negende strofe beschrijft 's dichters aankomst op de hellingen van een dal, dat, net bevrijd van de winterlast, zich als een idylle voor hem uitstrekt. Met een sterk sensitief gebruik van stijlmiddelen wordt deze vallei beschreven; de aanvankelijk visueel weergegeven ruimte vult zich met gezang van vogels, die zich overgeven aan minnekozen, niet bekneld door echtelijke banden. De vervoering van de dichter bereikt een hoogtepunt bij het aanhoren van de leeuwerik, die hem in extatisch verlangen brengt naar de hoge Schepper, die zich in dit alles weerspiegelt. De laatste strofen geven het ontwakend diep godsbesef bij de schouwende ik: kan een mens, kroon der schepping, bij het zien van de wederopstanding der natuur, de Lente, twijfelen aan zijn eigen wederopstanding en aan Gods macht en heerlijkheid? ${ }^{93}$ Herkenbare ideeën voor Bilderdijk: de Horatiaanssatirische opening, de huwelijksopvatting, het Lentemotief uit het Pervigilium Veneris, en de natuur als afspiegeling Gods. Herkenbaar ook voor ons binnen het geschetste contrast tussen verdorven cultuur en onbedorven natuur.

Hoe heeft Bilderdijk vertaald: direct of indirect, nauwgezet of vrij? Wat de eerste vraag betreft: het is betrekkelijk gemakkelijk na te gaan of Lentemorgen al dan niet is gemaakt aan de hand van bestaande vertalingen, daar precies bekend is welke vertalingen er van Tullins ode zijn vervaardigd. ${ }^{94}$ Nog in het jaar van publikatie 1758 verschenen een Duitse en Franse vertaling; een Engelse versie kwam pas vijf jaar na die van Bilderdijk. De Duitse en Franse vertolkingen zijn beide in proza en onvolledig, in tegenstelling tot de Nederlandse versvertaling. Bilderdijk moet dus om volledig te hebben kunnen zijn ten minste óók de originele tekst hebben geraadpleegd. Overtuigend is echter de vergelij- 
king van een aantal faux amis. In Lentemorgen ontbreken de foutieve Duitse vertalingen "Drangsalen" (Trængsel = gedrang), "Last" (Last = zonde), "Ruhm" (Røst = stem), etcetera. Het Frans heeft geen expliciete missers, maar de woordenschat wijkt tezeer af van het origineel om de gelijkenis tussen de Deense en Nederlandse tekst te kunnen verklaren: "décide" (vejes : opgewogen), "milliers" (Millioner : duizendduizenden). Anderzijds heeft Bilderdijk de faux amis "Raven" (Ræve = vossen) en "de aard" (Aaret $=$ het jaar), die de Franse en Duitse tekst niet vertonen. Ook uit de handhaving van een aantal allitteraties in de Nederlandse tekst blijkt dat deze rechtstreeks naar het Deens is gemaakt: vergelijk "Dyder - Ducater": "Zilver - Zeden".

In het voorwoord tot Poëzy heet het: "Myne vertaling is vrij, en, ik hope, zoo los, als men vorderen kan om geheel ongedwongen te zijn [...]". ${ }^{95}$ De essentiële wijziging ten opzichte van En Maji-Dag betreft de rol van God. Terwijl bij Tullin het doorbreken van het godsbesef de climax vormt (tot de tweeëntwintigste strofe komt geen directe godsverwijzing voor), is de ik-figuur in Lentemorgen vanaf het begin van godsvrucht vervuld. $\mathrm{Al}$ in de vierde strofe spreekt hij van "'t voedsel, door Gods hand gegeven", en in strofe vijf van "De Godsvrucht van den echten Christen". Het spreekt dat de door Tullin bewerkstelligde doorbraak goeddeels verloren gaat, wanneer bij de eerste aanblik van het lentedal de dichter reeds rept van "'s Scheppers schoonste meesterstukken" en "'t Landschap, door Gods hand gemaald".

Tegenover deze modificatie staat, dat de bewerking de stijlmiddelen van het origineel handhaaft, in tegenstelling tot Franse en Duitse prozaversies. Ter illustratie twee strofen. De dichter heeft zojuist het geluk der minnende vogels bezongen en vervolgt:

Saa tankte jeg om disse smaae Som med sin Elskov Vaaren smykked' Men blev til ny Forundring rykket

Ved det jeg just en Lerke saae,

Som nu i det hun flagred'op

Sit søde Dirlilili trilled'

Og over Redets skjulte Kop med elskovstzendte Vinger spilled'

Al Kunst og Ferdighed forsvandt Saa snart jeg hørte denne lille; Ja hvilken Mester torde spille

Mod denne fedde Musicant?

"O lille søde Fløjtenist! Hvo gav dig disse Egenskaber?"

Sa raabte jeg mod Bjerget hist.

Og Echo svarede: - - en Skaber. 
Zoo riep ik uit in driftvervoering:

Mijn oog betoog zich met een traan;

Een traan, die lucht gaf aan de ontroering!

Een ander voorwerp deed my aan.

Een Leeuwrik deed zich juist bemerken, die, hangende op zijn rappe vlerken,

Om 't kunstig nestjen weemlen bleef;

En, onder 't paarziek ommezwieren,

Zijn lieflijk trillend tierelieren

Uit d' opgezetten gorgel dreef.

\section{$[\ldots]$}

Van waar dat wondre Zangvermogen,

ô Zoete, kleine Fluitenist,

Dat aller hart houdt opgetogen,

En dat geen meester u betwist?

Wie heeft uw zang die samenstemming,

Uw’ gorgel zoo veel kracht van klemming

En zoo veel buigzaamheid met één,

Uw' boezem zoo veel vuur en leven

En zulk een juist gevoel gegeven? -

Wie anders toch dan God-alleen?

De acconsonanties f-l-r ter ondersteuning van het fladderen en zingen van de leeuwerik blijven evenals het onomatopoëtische "Dirlilili trilled"" bewaard. De tweede strofe wijkt meer af: de versificatie met haar allitteraties, parallellismen, en enumeratio is gehandhaafd, maar de lichtvoetige woordspeling met de echo maakt plaats voor orthodoxer tonen en breedvoeriger zegging.

Dit laatste is geen versificatorisch onvermogen, maar een bewuste wijziging. Bilderdijks aanpassingen zijn vast verankerd in zijn vertaalopvattingen: hij zag het vertalen niet, zoals veel van zijn tijdgenoten, als interpretatio, maar als creatio, als gelijkwaardig met het maken van origineel werk, waarin zowel inhoud als vorm naar believen konden worden gewijzigd. Dat deze vertaling van Tullin ook feitelijk als eigen werk werd gewaardeerd, blijkt uit een recensie in de Algemeene Vaderlandsche Letter-Oefeningen: "dat deze Dichter waarlijk zeer bevoegd is om over kunststukken te richten, kan zijn eigen werk, dat wy hier ontvangen, ons opnieuw en ten overvloede wederom bewijzen. Vooral doet hij ons onder deze zijne eigenen arbeid opmerken zijne Navolging van den Deenschen dichter Tullin." 96

\subsection{A.W. Schack Staffeldt (1769-1826)}

"Voor eenige dagen kwamen my Deensche gedichten van Schack Staffeldt in handen. Daar is vry wat schoons in, en in een nieuwen Dichtbondel geef ik er vast eenige proef- 
jens van", aldus Bilderdijk in 1822, in een brief aan Hoffrnann von Fallersleben. ${ }^{97}$ Met de gedichten zijn bedoeld Staffeldts Nye Digte (1808) en met de dichtbundel Bilderdijks Krekelzangen 1 (1822). In deze bundel treffen we twee als zodanig aangegeven vertalingen aan: de romance Bruilofisbrand en de symbolisch-platonische elegie De Lelie en de Daauwdrop. Bij nadere lezing trof ik echter nog een derde vertaling: de eerste twaalf regels van het lange hekeldicht Het Vrijheidsspook dezes Tijds vormen een vrije navolging van een sonnet van Schack Staffeldt. Tenslotte is in Keur van Nederlandsche Letteren (1822) een vertolking opgenomen, - het eveneens symbolisch-platonische Endymion. ${ }^{98}$

De inleiding tot Krekelzangen vermeldt: "De Proefjens van Deensche Poëzy zal men zeker de navolging (van het eene wat meer van naby, van het ander wat vrijer en ruimer) niet onwaardig kunnen vinden. Voorlang trachtte ik de aandacht der onzen naar dien tak van uitheemsche Letterkunde te trekken [...]. Dat deze twee stukjens door my eenigszins uitgebreid zijn, zal hy licht begrijpen, wien mijn dichttrant niet vreemd is. Hoe volkomener taal, hoe meer uitvoerigheid in de denkbeelden zy meêbrengt"."99

De gespleten natuur van de gesmade romanticus Staffeldt móest Bilderdijk wel aanspreken. De disharmonie tussen de wereld van de zinnen en van de geest staat centraal in de lyriek van deze Deense edelman. Platonische verzen en romances drukken gevoelens van ontheemdheid uit en een terugverlangen naar de goddelijke oorsprong. Miskenning - Staffeldts poëzie werd eerst lang na zijn dood naar waarde geschat - ontnam hem elk geloof in de medemens: zijn aanvankelijke enthousiasme voor de Franse revolutie verkeerde ras in de zwartste reactie.

Het pleit voor Bilderdijks fijn gevoel, dat hij ter vertaling juist enige gedichten koos, die door de latere Deense kritiek als toppen in Staffeldts oeuvre zijn aangewezen. ${ }^{\text {I00 }}$ In De Lelie en de Daauwdrop (Liljen og Dugdraaben) valt een dauwdruppel, symbool van het zuivere en onsterfelijke deel der ziel (de geest), vanuit de hemel in de kelk van een lelie, symbool van het sterfelijke zielsdeel (de zinnen). De verlangende bloem sluit haar bladeren, zodat de druppel zich in aardse gevangenschap bevindt. Vergeefs verklaart echter de lelie haar liefde; de ongenode gast gehoorzaamt niet dan de roep des hemels. Door de ochtendzon opent de kelk zich, de dauw stijgt naar boven, terwijl de aardse lelie sterft.

Nauw verwant aan dit thema is de lofprijzing van het Verlangen in Endymion (Nattergalen og Natviolen): de Maangodin geeft de slapende jongeling Endymion met haar kus het eeuwig verlangen naar het goddelijke. Kwade machten voeren Endymion echter naar de onderwereld, en als de godin dit verneemt, wellen uit haar ogen twee tranen, waaraan nachtegaal en nachtviooltje ontspruiten. De gevoelige mens, die de nachtelijke tonen en geuren van respectievelijk vogel en bloem in zich opneemt, ervaart de dromen van Endymion èn het goddelijk verlangen. ${ }^{101}$

Terwijl Bilderdijks versie van het laatste werk inhoudelijk vrijwel geheel met het oorspronkelijke overeenstemt, laat De Lelie en de Daauwdrop een duidelijk verschil zien. Ook bij Bilderdijk staat het verlangen naar de goddelijke oorsprong centraal, maar dat is bij hem niet belichaamd in de verstandelijke geest, doch in het gevoel en het daarop berustend geloof. En in dat geloof speelt de wederopstandingsgedachte een centrale rol. De uitbreiding waarover de inleiding van Krekelzangen spreekt, bestaat dan ook 


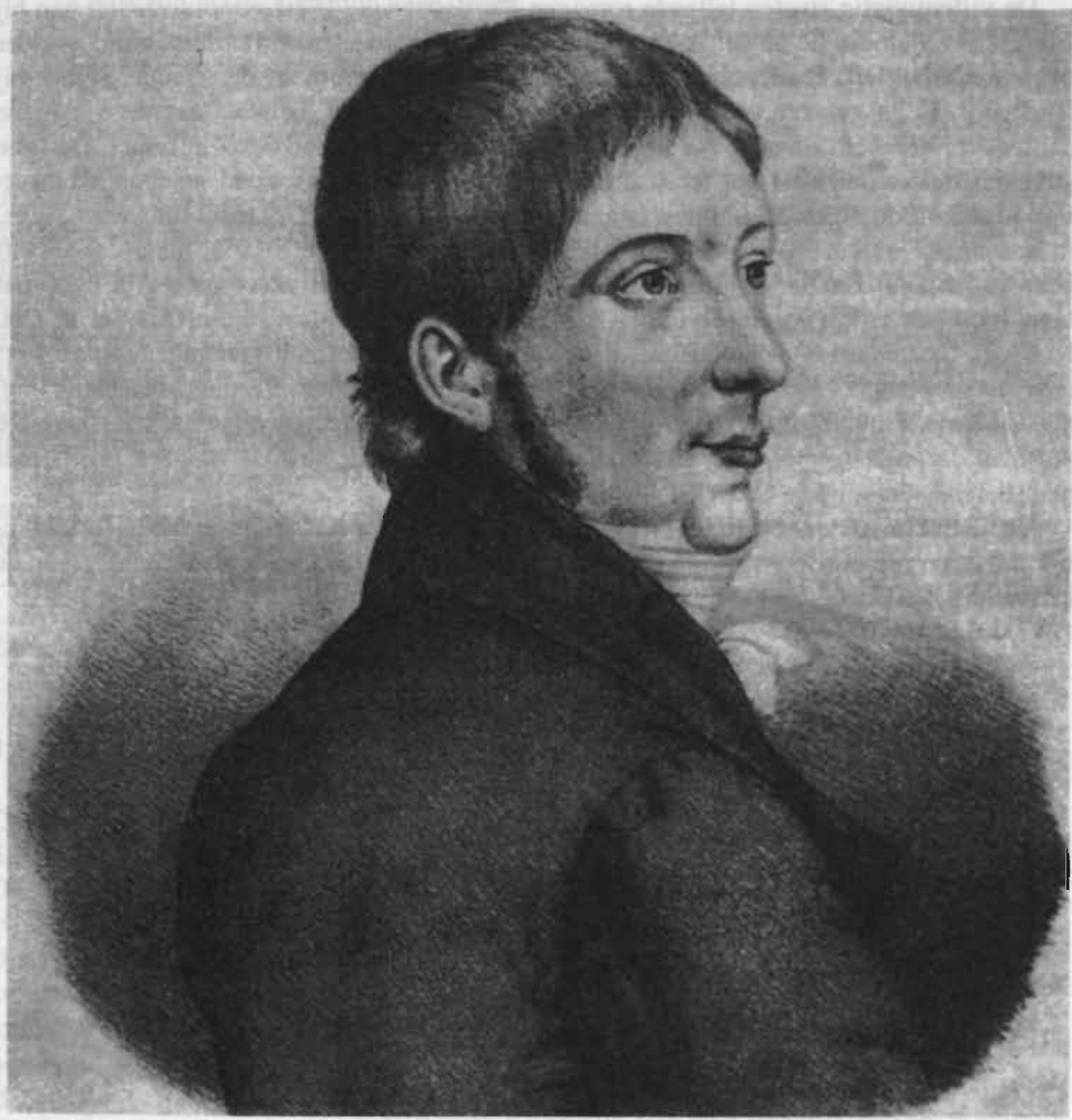

Afbeelding 5. Bilderdijks Deense geestverwant A.W. Schack Staffeldt (1769-1826) . Zijn werk werd door Bilderdijk in Nederland geïntroduceerd, en mogelijk is hij zelf de vertaler van een gedicht van Vrouwe Bilderdijk. Litografie van ca. 1860 naar oudere tekening. (Koninklijke Bibliotheek Kopenhagen). 
uit de bij Staffeldt ontbrekende eindregels: "ô Vergaap u-zelven niet / Zoo u 't slijk zijn vriendschap biedt! / Eenmaal moet gy, na 't verzinken / Weêr in 's hemels gordel blinken, / Als Gods vreêbazuin zal klinken."

De vijfentwintig strofen tellende romance Bruiloftshrand (Elskovshaalet) sluit aan bij Bilderdijks platonische huwelijksopvatting ${ }^{102}$ van de voorbestemde liefdesversmelting der twee wederhelften. De machtige ridder Erland huwt met pracht de schone Signe, bij Bilderdijk Celia geheten. Alle bruiloftsgasten zijn verheugd, behalve Signes versmade aanbidder. Vergeefs waarschuwt Signe de gelukkige bruidegom voor zijn rivaal. De twee gelieven trekken zich na het feest terug in een eenzaam in het woud gelegen slaapvertrek, dat door de afgewezen minnaar in brand wordt gestoken. Driemaal ontwaakt Signe, in een steeds sterkere vuurgloed, en telkenmale waarschuwt ze Erland, maar deze wuift haar angst weg. De liefdesgloed van de bruidsnacht legt een waas voor zijn ogen dat voor hem één wordt met het vuur. Als hij tenslotte de catastrofe beseft, is het te laat. Liefdevol beschermen de jonggehuwden elkaar en de goden zijn genadig: het dak stort neer en verplettert ze in elkaars armen. Op fraaie wijze sluiten de uiterlijke handeling, het toenemende vuur, en de innerlijke, de verzengende liefdesgloed, op elkaar aan. De vorm is die van de folkevise, het middeleeuwse volkslied: strofen van zes regels met afwisselend vier en drie toppen.

Van Bilderdijks vier Staffeldt-bewerkingen is Bruiloftshrand zeker de meest toegankelijke, met de romantiserende folkevise-imitatie vol herhalingen, abrupte wendingen en de eenvoudige, elementaire handeling:

"O sov dog, du Søde, du Hulde, sov ind!

Saa sødt ved din Side jeg hviler.

O sov! thi det er kun Fuldmaanens Skin

Som lyst gjennem Skyeme smiler."

Og over den Bævendes Ansigt han brat

Linene slaaer og hvisker god Nat.

$$
[\ldots]
$$

Med Haaret hun daekker hans Ansigt til, Hans Aande den Martrede kjøler,

Da bliver selv Luen medlidende mild, Med bortvendte Toppe den nøler. Men Taget styrter i knusende Fald Velsignede Død! Du er uden Qual.

"O Slaap, mijn Geliefde, en ontrust u toch niet:

"'t slaapt zoet, aan uw boezem gezegen.

"' $t$ Is ' $t$ schijnsel der Maan dat gy wemelen ziet,

"Dat lacht van de bladers ons tegen." -

Met zijgt hy, van slaap en vermoeidheid verdoofd,

En slingert hun beiden het laken om ' $t$ hoofd. 


\section{$[\ldots]$}

Zijn voorhoofd omwaait zy en zwiert met het hair;

Zijn adem blaast koelte op haar lippen:

De vlam schijnt bewogen voor 't minnende Paar,

En, aarzelend, als rugwaart te glippen.

Maar 't dak stort, doorblakerd, verplettrend ter neêr

En eindigt het jammer. Zy leven niet meer!

Het Vrijheidsspook dezes Tijds is voor Bilderdijk uiteraard de Franse revolutie. Zijn filippica van deze titel omvat vierennegentig versregels, waarvan de eerste twaalf Staffeldts sonnet Til den galliske Jomfru tot voorbeeld hebben gehad. De 'Gallische Maagd', symbool van de Franse revolutie, wordt door Staffeldt afgeschilderd als het rondwarend spook der vrijheid, als de lichtekooi die haar doodbrengende ziekten overdraagt aan ieder die met haar in aanraking komt. Met graagte neemt Bilderdijk de allegorie over: "Bedrieglijk Vrijheidsspook, uit Vrijheids moord geteeld / Blanketselschoon gedrocht, maar naakt, afschuwlijk beeld, / In Frankrijks gruwelpoel by 't moordrot opgetogen", etcetera.

Hoe werden deze voor beide auteurs karakteristieke verzen nu door Bilderdijks tijdgenoten gewaardeerd? Slechts één getuigenis heb ik kunnen vinden. De Recensent, ook der Recensenten laat in een bespreking van Krekelzangen weinig heel van De Lelie en de Daauwdrop: "Een donker mystisch Dichtstukje, dat wel onvertolkt had kunnen blijven." Lof ondervindt daarentegen Bruiloftshrand: "Eene schoone Romance, uit het Deensch". ${ }^{103}$

\subsection{Jens Baggesen (1764-1826)}

De Deense dichter Jens Baggesen is vertegenwoordiger van een periode in de Deense literatuurgeschiedenis waarin classicisme en romantiek, rede en gevoel elkaar bestreden. De veelzijdige Baggesen bracht evenals Bilderdijk vele jaren in Duitsland door en had evenals de laatste weinig op met de contemporaine Duitse letteren. Niettemin is veel van zijn lyriek in het Duits geschreven; het Deens reserveerde hij vooral voor proza, aanvankelijk in de trant van Voltaire, later van Rousseau en Sterne. Als de Deense literatuurhistoricus Vilhelm Andersen schrijft dat Bilderdijk in zijn politieke, religieuze en erotische wispelturigheid opvallend aan Baggesen doet denken ${ }^{104}$, geldt dat toch maar ten dele: ideëel zijn de dichters elkaars tegenpolen. Bilderdijk zou zich moeilijk met de revolutionaire geest van Baggesens Deense werken hebben kunnen verenigen.

Vermoedelijk heeft Bilderdijk in zijn Brunswijkse periode met Baggesens Duitse werk kennisgemaakt. Hij bezat de Gedichte (1803); voorts het epos Parthenais (1807) en de bundel Heideblumen (1808). Ook Baggesens taaltheorieën zullen hem bekend zijn geweest; in een brief van februari 1814 vraagt zijn vriend H.W. Tydeman hem daarover zijn mening: "Ik vind in een joumaal: dat de beroemde Deensche dichter Baggesen de oudheid der Deensche taal aantoont uit derzelver overeenkomst met het Sanskritsch. Dit 
is toch wel denkelijk geene bijzondere overeenkomst maar de algemene der Noordsche talen?"105

Wat vertalingen betreft, is er de raadselachtige mededeling uit 1843 van de Deense bibliograaf Erslew, dat genoemd epos Parthenais in 1808 door Bilderdijk zou zijn vemederlandst. ${ }^{106}$ Helaas noemt Erslew geen bron, en van een dergelijke vertaling is verder niets bekend. Toch is de notitie intrigerend: ze is voorzien van een precies jaartal en Bilderdijk bezat het origineel, dat bovendien te Amsterdam was uitgegeven. Heeft de uitgever op een vertaling gespeculeerd; heeft Bilderdijk plannen gehad en die aan een Deense relatie meegedeeld?

Zeker is in elk geval, dat in de bundel Nasprokkeling (1830) onder de titel De dichterlijke Eeuw een vertolking van een der verzen uit de Gedichte is opgenomen. ${ }^{107}$ Het origineel, getiteld Die deutschen Musenalmanache, is een korte satire op het lage peil der Duitse letteren en op de almanakpoëzie der letterminnende burgers. Bilderdijk, die in De kunst der Poëzy (1809) al had afgerekend met de vaderlandse dichtgenootschappen, maakt de tekst meer algemeen-geldig. Dat overigens de poëtica van beide dichters maar ten dele identiek was, moge blijken uit het hier ter afsluiting gegeven fragment. Baggesens karakteristieke slangelinje, de vloeiende vrije versregel, wordt vervangen door een traditionele rijmende jambische viervoeter:

Wohl verdient das poetische Land vor allen zu heissen

Deutschland; nirgends so viel gab es der Quellen des Hufs.

Sollte man schwören doch, jedes Gebirg, und jeglicher Hügel

Sey ein Parnassos von neun Tönenden Schwestem bewohnt,

Soviel quillen und strömen der Hippokrenen dem Hufschlag [...]

Wel zeker mogen onze dagen

Den bynaam van Poëtisch dragen,

't Baadt alles drok in 't hoefbronnat.

Geen heuvelterpjen kan men toonen,

Waar thands geen Zanggodessen wonen,

Of dat geen Helikon bevat.

Uit veenmoeras en hei' en steenen

Ontspringen blijde Hippokrenen [...]

\section{Denemarken en Bilderdijk}

Na al deze aandacht voor de noordwaarts gerichte belangstelling van een Nederlands dichter, ten slotte een poging tot antwoord op de vraag, wat men daar in het noorden nu wist, las en vond van de bekendste Hollandse literator van zijn tijd. Wat de bekendheid 
betreft hoeft men weinig illusies te koesteren met betrekking tot het grote publiek: onze letteren waren terra incognita voor de gemiddelde Deense lezer, die van circa 1800-1850 zijn eigen literaire Gouden Eeuw beleefde.

Toch heeft een aantal prominente Deense auteurs Bilderdijk gekend, over hem gepubliceerd, hem zelfs eenmaal vertaald, zodat per saldo een selecte groep lezers met persoon en werk heeft kennisgemaakt.

Een eerste aanwijzing voor de bekendheid, ja zelfs invloed van Bilderdijk vinden we bij de eerdergenoemde A.W. Schack Staffeldt (1769-1826). Deze reisde in 1799 door ons land, en gezien zijn grote belangstelling voor vreemde talen en literaturen zal hij zeker van zijn latere vertaler hebben gehoord. Dat hij diens werk ook daadwerkelijk heeft gelezen, wordt gesuggereerd door Vilhelm Andersen, die wijst op de zeer sterke overeenkomst tussen een gedicht uit Poëzy 2 (1803), namelijk Op een dorrend blad, door den wind in mijn hoezem geschud (geschreven in 1796), en een later vers van Staffeldt, Til et vissent Lov, som faldt i Digterens Barm (1818). ${ }^{108}$ Anders dan Andersen meent, is het Nederlandse werk niet van Willem Bilderdijk, doch van diens echtgenote en co-auteur Katharina Bilderdijk-Schweickhardt. ${ }^{109}$

Is Staffeldts gedicht een bewerking naar het Nederlands? De overeenkomst is te treffend om op toeval te berusten. Beide gedichten behelzen een monoloog, gericht tot een herfstblad, - de voorbode van de naderende dood. Aanvankelijk wordt het blad niet als zodanig herkend, maar nadien met vreugde begroet:

Wat zoekt ge, ô dorrend blad, een schuilplaats hier te vinden?

Heerscht kalme rust in 't han waarin een onweêr stormt?

Ontvlucht gy 't hevig woên der felle najaarswinden?

By 't harte, 't geen zijn drift tot enkele onrust vormt!

Ach, koud is 't oppervlak der afgestormde harten,

Al smelt hun binnenst weg van onweerstaanbren gloed!

Gy, vluchling, zoek een borst, die, vrij van zulke smarten,

U. daar zy kalmer zwoegt, tot wiegjen strekken moet! [...]

O blege Flygtling! ikke søg

Hos mig et Ly mod barske Høst.

Thi meer end nys din Fødebøg

Betrygger ei dig dette Bryst.

Koldt er end dette. Sorgens Vraae,

Og Stormen ogsaa gaaer deri!

Gaa derfor, stakkels Pilgrim! gaa

Og søg en Barm, for Sorger fri [...]

Zowel Katharina Schweickhardt als Staffeldt heeft het werk als origineel gepubliceerd: uiteraard is het mogelijk dat beide gedichten in realiteit teruggaan op eenzelfde onbekende bron. Andersen vermeldt - zonder bronaanduiding - dat Staffeldts vers ergens als een 
vertaling naar het Engels is aangegeven, doch dit wordt nergens in de standaardliteratuur over Staffeldt bevestigd.

Is deze relatie tot Bilderdijk onzeker en zijdelings, zeker en rechtstreeks is de betrekking van Bilderdijks eerdergenoemde Deense leerling Constant Dirckinck-Holmfeld (1799-1880) met zijn Leidse leermeester. Onder het pseudoniem C. Amoldsen publiceerde hij in 1830 zijn Bidrag til Kundskab om Holland og den hollandske Nation (zie afbeelding 6), waarin vier bladzijden zijn gewijd aan de dichter. "Schrijver dezes, die Bilderdijk persoonlijk en van zeer nabij heeft leren kennen, is ervan overtuigd dat deze man en zijn dichterstalent een openbaring voor de hele wereld zouden zijn geworden, indien zijn karakter niet was meegesleept door een heftigheid, die hem vaak heeft verbitterd", schrijft Dirckinck, die Bilderdijk de evenknie noemt van Wieland en Byron, hem qua expressie vergelijkt met Grundtvig en qua virtuositeit met Baggesen. Enige reserves tegenover wat al te extreme religieuze opvattingen doen aan de grote bewondering niet af. ${ }^{110}$

Bilderdijks beroemdste Deense collega-tijdgenoot Adam Oehlenschläger (1779-1850) werd in 1842 bezocht door de in Vlaanderen wonende Nederlandse dichter J.C.H. Nolet de Brauwere van Steeland, die in Een reisje in het Noorden (1842) over zijn gastheer noteert: "Met de letterkunde van ons land scheen hij al mede zeer bekend, en sprak met eerbied en bewondering over Bilderdijk"." Inderdaad bevond zich in Oehlenschlägers bibliotheek een exemplaar van De Geestenwareld. Toch moeten we een en ander waarschijnlijk met een korrel zout nemen: bij eerdere gelegenheid had de Deense dichterprins zich aanmerkelijk minder vriendelijk over onze literatuur uitgelaten ${ }^{112}$, en bovendien telt zijn boekerij naast De Geestenwareld, editie Leuven 1842, nog slechts één ander Nederlandstalig werk: Ambiorix, van ... Nolet de Brauwere van Steeland, Leuven 1841. ${ }^{113}$

Toont Oehlenschlägers uitspraak niet meer dan bekendheid met de naam Bilderdijk, grondige kennis spreekt uit de bijdragen van de theoloog-romancier Henrik Scharling (1836-1920). Deze woonde in 1862 in ons land ter voorbereiding van een dissertatie over de moderne Nederlandse theologie. Te Amsterdam logeerde hij bij de koopman van Deense herkomst A.L. Brandt, die connecties had in literaire kringen. ${ }^{114}$ Zowel zijn theologische als letterkundige interesse zette Scharling op het spoor van Bilderdijk. Het in zijn Breve fra Holland (1864) opgenomen overzicht van de Nederlandse literatuurgeschiedenis ruimt maar liefst vijftien pagina's in voor Bilderdijk, door Scharling bestempeld als Nederlands grootste dichter. Na een merendeels aan Da Costa ontleend levensoverzicht volgt een behandeling van het literaire werk, waarin vooral de romances worden geprezen: "men [is] vaak geneigd te denken dat men een Nederlandse Oehlenschläger-bewerking voor zich heeft". De letterkundige invloed van Bilderdijk, zo vervolgt Scharling, is echter veel beperkter dan die van Oehlenschläger: de hoogdravende natuur van de eerste week tezeer af van het Hollandse volkskarakter. Niettemin heeft de dichter zijn moedertaal een onschatbare dienst bewezen: hij heeft laten zien, dat deze "wat platte tongval" zich evengoed als elke andere taal laat buigen in vers en rijm. ${ }^{115}$

In zijn dissertatie Den nyere hollandske Teologi (1865) gaat Scharling, zelf gematigdorthodox, uitvoerig en genuanceerd in op Bilderdijks theologische denkbeelden, die hij verklaart als "een poëtisch verlangen naar een gelovig verleden". Veel groter dan de literaire invloed, aldus Scharling, is dan ook de theologische uitwerking: de Réveilbewe- 


\title{
bidrag
}

11

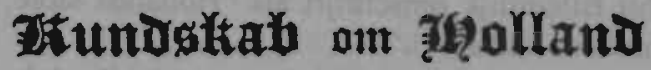

\author{
Dg Den gollandffe Rationt.
}

9rf

e. สt:notosตก.

Sisbenbavm.

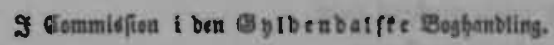

xepti bet etr. Af Resert.

Afbeelding 6. Titelblad van een 'bijdrage tot de kennis van Nederland en de Nederlandse natie', in 1830 gepubliceerd door Bilderdijks Deense' pupil Constant Dirckinck-Holmfeld, onder het pseudoniem C. Arnoldsen. Hierin introduceert hij Bilderdijk bij het Deense publiek. (Koninklijke Bibliotheek Kopenhagen). 


\section{Hoofdstuk III}

ging is karakteristiek voor een deel van de Hollandse natie. ${ }^{116}$

Toen Hans Christian Andersen (1805-1875) in 1866 voor zijn tweede bezoek aan Nederland een logeeradres zocht, was het Scharling die hem introduceerde bij zijn Amsterdamse gastheer Brandt. Wellicht heeft Andersen in dat verband ook Scharlings Breve gelezen; in ieder geval blijkt hij de naam Bilderdijk te kennen, getuige de volgende dagboekregels over een literaire soirée: "De bejaarde Van Lennep droeg met opmerkelijk jeugdig vuur een lang gedicht van Bilderdijk voor (ik meen een vertaling van Walter Scott); hij was heel beeldend in zijn voordracht, maar misschien toch wel een beetje overdreven". Geldt dit oordeel alleen de voordracht, of ook het gedicht? Andersen, die slechts enkele woorden Nederlands verstond, zal het zeker niet vlot hebben kunnen volgen, maar vermeldt de voordracht opnieuw in zijn autobiografie Mit Livs Eventyr (1855-67), waarin hij Bilderdijk omschrijft als "Hollands store, hyldede Digter" ("Nederlands grote, gelauwerde dichter"). ${ }^{117}$

Een duidelijker oordeel vinden we bij de auteur Alfred Ipsen (1852-1922). Deze geestverwant en vertaler van Van Eeden bracht evenals Scharling langere tijd in ons land door, waar hij samenleving en letteren uitvoerig bestudeerde. In zijn studie Holland (1891) heeft hij slechts enkele woorden voor Bilderdijk over: inhoudsloos en onsympathiek. Iets genuanceerder is hij in zijn Nederlandse literatuurgeschiedenis van 1901: hij onderkent het versificatorisch talent, en de lyrische schoonheid in vooral de kleine subjectieve gedichten, - die echter vaak ontsierd worden door een didactisch stempel en smakeloosheden als 'pieterceliebed' in een vers op een bruidspaar Pieter en Celia. In een uitgebreid encyclopedie-artikel uit 1915 blijkt het negatieve eindoordeel overheersend: "versificatorische virtuositeit, maar [...] ongelooflijk onfris en stoffig". ${ }^{118}$

Onverdeeld positief is tenslotte de eerdergenoemde Vilhelm Andersen (1864-1953). Deze criticus sluit in zijn studie Horats $(1-4,1939-1950)$ over de invloed van Horatius op de Westeuropese letteren het hoofdstuk 'Holland' af met Bilderdijk. Met bewondering spreekt hij over diens bewerkingen van de klassieken, en hij geeft ter afsluiting een Deense vertaling van een origineel gedicht - in Horatiaanse trant - van Bilderdijk, Italiaansch Meesterschrift. ${ }^{119}$ Thema is de opvoedende macht van de poëzie, hier belichaamd in de kalligrafie. De uit riet gesneden pen, de Romeinse calamus, dartelt over het papier:

Hier trekt gy voor ' $t$ verwonderd oog

De bocht van 's hemels regenboog.

Of slingert met de sprank

Van Bacchus dartle wijngaard-rank;

Daar sleept ge in stijven zwier

Den statigstillen optocht na,

Van Kerk- of Krijgsbanier.

Snart undres Øjet ved et Sving. saa rundt son Himlens Regnbu-Ring snart gaar I ind og ud,

saa kaadt som Bacchus' Rankers Skud; 
snart stift og statelig

I fylkes som et Fanetog

til Kirke eller Krig.

Andersen vertaalt acht van de veertien strofen, daarbij bewust de prosodie handhavend: "men proeft de zwier van zijn handschrift, dat net zo feestelijk was als dat van Baggesen, in het ritme". Afsluitend laat hij zijn oordeel volgen: "Italiaansch Meesterschrift' noemt Bilderdijk dit gedicht. Nederlandse Schrijfkunst zou het kunnen heten. Men zou het moeten lezen met zijn eigen handschrift vol bogen en ranken en strepen, als een slotvignet op dit hoofdstuk". ${ }^{20}$

\section{Conclusies}

Als in zoveel zaken is Bilderdijk ook op het punt van zijn interesse voor Scandinavië een buitenbeentje in de Nederlandse literatuurgeschiedenis. Tegen de geest der eeuw in bezingt hij de absolute Deense monarchie. Ver vóór Potgieter cum suis ontdekt hij de Scandinavische letteren, waaruit hij als eerste vertaalt volgens zijn creatio-principe, daarbij naar believen zowel de versificatie aanpassend als de inhoud, de laatste in orthodox-christelijke zin. Door dit selectieve principe kan hij zulke uiteenlopende auteurs als Holberg, Tullin, Schack Staffeldt en Baggesen als geestverwant beschouwen. En terwijl de achttiende en vroege negentiende eeuw gelden als het dieptepunt in de Scandinavische interesse voor de Nederlandse letteren, heeft hij als enige Nederlandse literator van zijn tijd enige sporen nagelaten in het Noorden. 


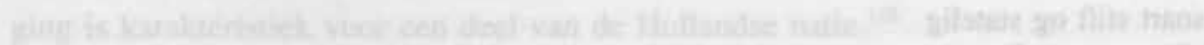

7.

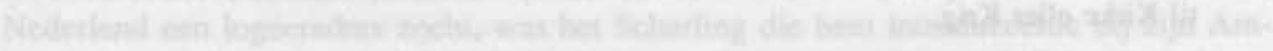

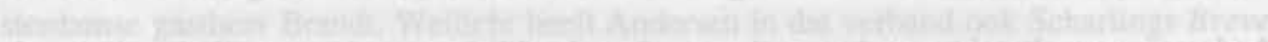

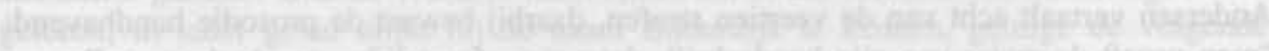

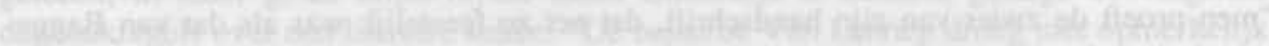

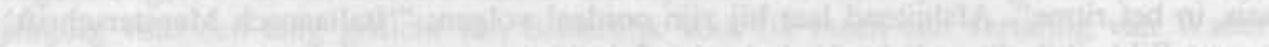

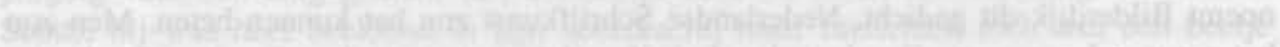

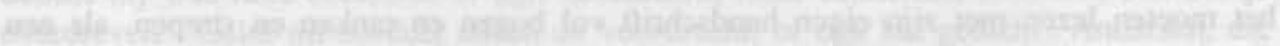

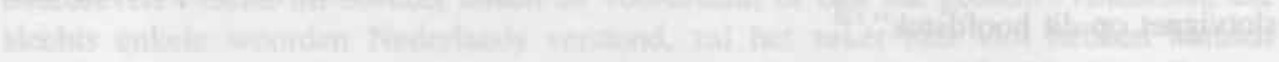

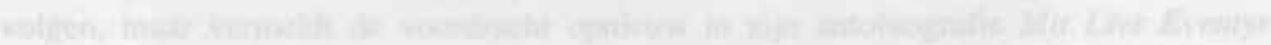

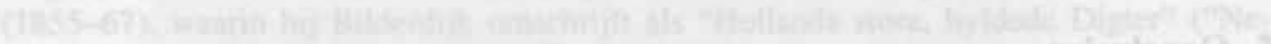

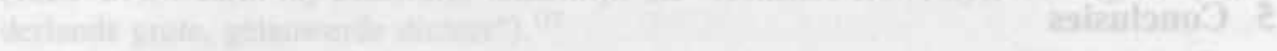

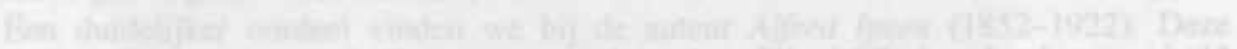

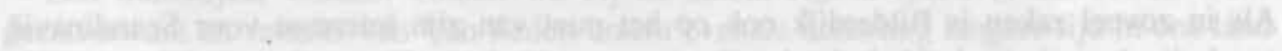

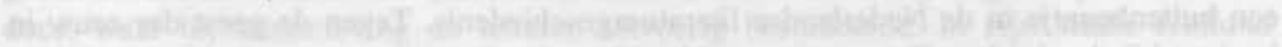

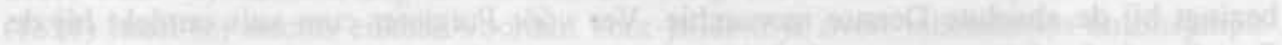

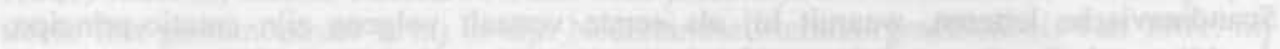

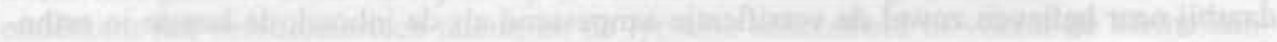

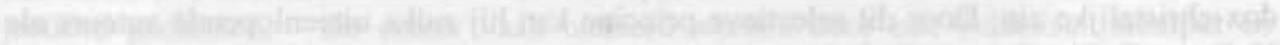

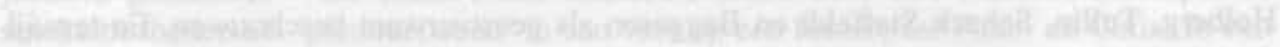
Whathing?

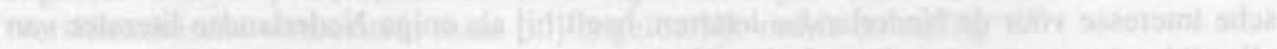

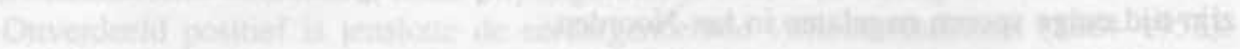

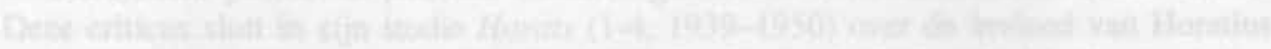

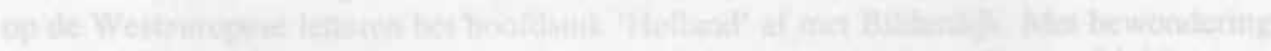

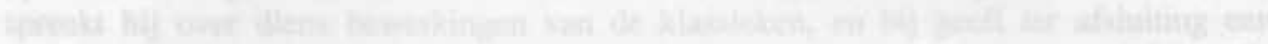

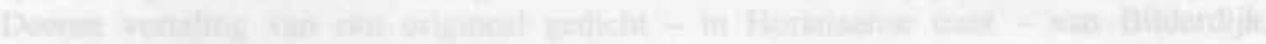

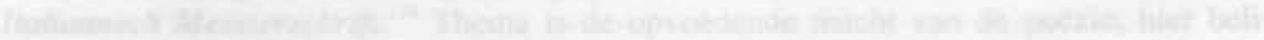

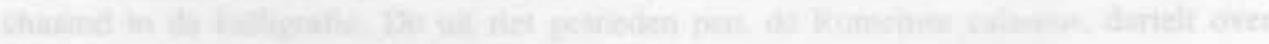

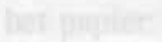

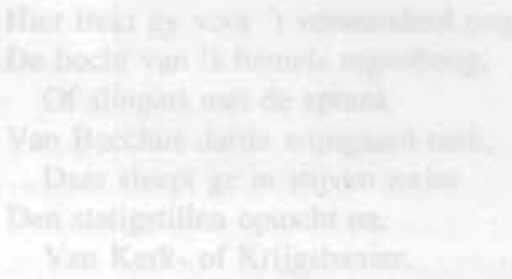

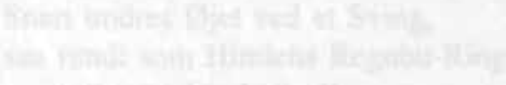

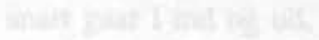




\section{Hoofdstuk IV}

\section{Frederik van Eeden en Scandinavië}

\section{Inleiding}

Toen de vader van de 'moderne doorbraak' in de Scandinavische letteren, de Deense literatuurcriticus Georg Brandes, in 1892 een bezoek aan Nederland bracht, had hij onder andere een ontmoeting met een antal medewerkers van De Nieuwe Gids. In zijn verslag van deze ontmoeting schrijft hij: "De mannen der jonge school, zij die 'De Nieuwe Gids' schrijven, toonden aanzienlijke belangstelling voor de noordsche letterkunde". ${ }^{121}$ Een intrigerende notitie: van noordwaarts gerichte interesse is weinig te merken in de baanbrekende jaargangen 1885-1893. Gorters Balder-figuur is de enige substantiële, en dan nog indirecte, invloed van Noordse letteren. Van Deyssel, die elders beweert een groot bewonderaar van Andersen te zijn, laat daarvan in De Nieuwe Gids niet blijken; één enkele opmerking over de "protestántsch vervelende" Ibsen is te vinden in een opstel over ... Bulgaarse letterkunde. Verweys vertalingen uit het $Z$ weeds dateren eerst van veel later. Netscher, in 1892 al niet meer tot de Nieuwe-Gidskring behorend, en Ary Prins hadden in 1885 een kortdurende briefwisseling met Strindberg gevoerd, maar beider interesse had zich sedertdien in andere richting ontwikkeld. En wat Kloos betreft, diens eerste publikatie over een Scandinavisch auteur, Ibsen, staat in De Nieuwe Gids van ... 1934 . $^{122}$

Brandes' mededeling is dan ook nauwelijks anders te verklaren dan vanuit de kennismaking met die éne Nieuwe-Gidser met wie hij nog decennia contact zou houden: Frederik van Eeden. Hieronder hoop ik enig licht te werpen op de relatie tussen Van Eeden en Scandinavië. Achtereenvolgens komen aan de orde: stimuli vanuit de maatschappij en de persoonlijke omgeving; Van Eedens contacten met Scandinavië en de Scandinaviërs; Van Eeden en de Noordse letteren. 


\section{Stimuli vanuit maatschappij en persoonlijke omgeving}

Frederik van Eedens belangstelling voor het Noorden komt niet uit de lucht vallen: zowel maatschappelijke als familiale omstandigheden hebben deze interesse gestimuleerd. Waren in de jaren 1850-1885 in ons land jaarlijks een klein aantal, meest romantische, Scandinavische werken in vertaling verschenen, vanaf 1885 steeg dit aantal tot enige tientallen per jaar. De vernieuwende wijze waarop auteurs als Ibsen, Bjørnson en Bang persoon en maatschappij beschreven maakte opgang, evenals de neoromantische geest die opsteeg uit de werken van Hamsun en Lagerlöf. Daamaast verscheen een vloed van familie- en streekromans van het tweede plan, die in aantal en populariteit de werken der bovengenoemde auteurs overtroffen.

Een afdoende verklaring voor dit fenomeen is niet makkelijk te geven. Onderzoek in Duitsland, waar het fenomeen zich nog veel sterker voordeed, heeft in elk geval twee factoren aan het licht gebracht: het controversiële karakter van een aantal werken, en het in de ogen der Westeuropeanen idyllische prekapitalistische karakter der onbedorven 'Oergermaanse' samenleving. Rond Scandinavië hing een waas van eenvoud en zuiverheid, die niet alleen uitging van de literatuur. Margaretha Meyboom wijst er in een artikel over Scandinavische literatuur in Nederlandse vertaling op, hoe er een brede stroom van secundaire publikaties verscheen, "toen wij gezien hadden hoeveel wij Hollanders van Deenen, Noren en Zweden konden leren op het gebied van sociale toestanden, vrouwenbeweging, handenarbeid en onderwijs." De wederzijdse doordringing van literatuur en maatschappij blijkt niet alleen uit het maatschappelijk engagement van in ons land populaire auteurs als Bjørnson en Ellen Key, maar ook uit de publikaties van de hand van feministische vertaalsters van Scandinavische literatuur als Betsy Bakker-Nort, Nellie van Kol-Porrey en de genoemde Margaretha Meyboom, over de Scandinavische volkshogeschool, pedagogiek, kunstnijverheidsbewegingen als slöjd en husflid, de Deense coöperatieve beweging, etcetera. ${ }^{123}$

Een van degenen die door het Noorden werd getroffen, was F.W. van Eeden senior, aan wie de zoon veel inspiratie dankt. Vader Van Eedens pangermanisme bracht hem tot studie van de Oudgermaanse literatuur, waarvoor hij zichzelf Deens en IJslands leerde. In zijn studies mijmerde hij over de Germaanse heiligdommen bij Haarlem en over het Vikingrijk in de Nederlanden. Als directeur van het museum voor Kunstnijverheid in Haarlem maakte hij een reis naar het Noorden, en in zijn werk Noorderlicht. Bezoek aan Scandinavië in 1887 propageert hij husflid en slöjd als middel om de nationalistische kunst weer onder het volk te brengen en om de volkskunst ook stoffelijk lonend te maken. Hij wijst op de verwantschap van Nederlanders en Scandinaviërs en bezingt de Deense renaissancevorst Christian IV, die zoveel Nederlandse kunstenaars naar het Noorden haalde: "dat beeld van ijzeren wilskracht en oorspronkelijk leven [...], niet een van die menschen zoals tegenwoordig tot ideaal gesteld worden, van die brave menschen, volgzame schapen der kudde". Hij hoopt nu op een "Noorderstorm vol dennengeur, die Europa zal verfrisschen". Als Nietzscheaan kende hij uiteraard Brandes' baanbrekende Nietzschestudie Aristokratisk Radikalisme, en hij noodde de Deen dan ook te gast te Haarlem. Brandes memoreert de hartelijke ontvangst op maar liefst drie plaatsen in zijn werk. "Wel niemand is in aanraking gekomen met de familie Van Eeden zonder te zijn 
getroffen door haar rijke begaafdheid en hoge trap van beschaving. De vader leek de hoogste ontwikkeling in heel Nederland te bezitten [...] Hij las IJslands en kon, zoals trouwens de hele familie, Deens lezen". ${ }^{124}$

Tot die familie behoorde inmiddels ook Frederik van Eedens eerste vrouw Martha van Vloten, eveneens afkomstig uit een in het Noorden ge:̈nteresseerd gezin. Vader Johannes van Vloten bracht al in 1861, als eerste in ons land, Bjørnson onder de aandacht van het publiek. In zijn Beknopte geschiedenis der nieuwe letteren van 1876 wijdt hij enige tientallen pagina's aan de Scandinavische literatuur. Hij waardeert Holberg en Andersen; Kierkegaard vindt hij begaafd, maar "als mensch en schrijver beide een zonderling". Positief staat hij weer tegenover de jongste auteurs als Brandes, Drachmann en Ibsen.

Op vakantiereizen naar het Noorden vergezelden zijn dochters Kitty en Martha hem, en in 1881 nam ook Martha's verloofde Frederik van Eeden aan een reis naar Kopenhagen deel. Martha van Vloten ontpopte zich als een verdienstelijk vertaalster van Scandinavische schrijvers; reeds in 1885 verscheen een bundel vertalingen van de Noorse auteurs Alexander Kielland, Marie Colban en Kristian Elster. Haar vertaling van Andersens sprookjes, waaraan zij meer dan tien jaar werkte, kwam uit in de tegelijkertijd in tien talen verschenen Werelduitgave (1899-1900) en is de eerste vertaling waarin bewust gestreefd is naar weergave van Andersens literaire kwaliteiten. Op Walden organiseerde zij leesmiddagen rond de Noorse literatuur. Tragisch komt haar aanraking met die literatuur tot uiting in een brief uit de tijd van haar scheiding: "Ik schrijf maar niet langer nu: ik lijk deze weken weer teveel op een Ibsen-figuur en grooter lijden bestaat er niet". ${ }^{125}$

\section{Contacten met Scandinavië en de Scandinaviërs}

Het door vader en schoonfamilie gebaande pad van Nederland naar het Noorden is niet alleen door Van Eeden zelf betreden; Scandinaviërs hebben andersom ook contact met hem gezocht.

Tijdens zijn eerste bezoek aan Denemarken in 1881 is de pas verloofde Van Eeden lyrisch gestemd:

In Kopenhagen! $O$, het is zoo goed; en dat is reeds lang zoo. Het is goed met mij, mijn leven is rijk en heerlijk, mijn geest is kalm en opgewekt. Daarom geniet ik van deze reis, zooals ik nooit tevoren van een reis genoten heb. Er liggen weer bloemen in het boekje, rozen en korenbloemen en ze zullen heerlijke droomen opwekken, alleen daardoor weecedig dat zij voorbij zijn. ${ }^{126}$

Thuisgekomen verdiept hij zich in de Scandinavische letteren, waarover hij onder andere met Busken Huet van gedachten wisselt. Als de Deense schrijver Alfred Ipsen hem in 1890 aanschrijft, volgen een correspondentie en een aantal bezoeken van Ipsen te Bussum. In zijn aan Van Eeden opgedragen monografie Holland (1891) geeft Ipsen een uitvoerig verslag van zijn eerste bezoek. "Wij begonnen te spreken in het Engels, gingen toen over op het Duits, even later ging het gesprek in het Nederlands, en voor de dag ten einde was, spraken we Deens." Ipsen schrijft uitgebreid over Van Eedens sociale opvat- 
tingen, maar vooral over diens poëzie, waarvan hij een voorbeeld geeft met een vertaling van fragmenten uit Ellen. ${ }^{127}$

Het is goed denkbaar dat Brandes ter voorbereiding van zijn bezoek aan Nederland het boek van Ipsen, aanvankelijk een van zijn volgelingen, heeft gelezen. Brandes, die Nederlands kon lezen en onder andere een essay aan de poëzie van Pol de Mont wijdde, was in het algemeen niet erg te spreken over de Tachtiger-poëzie, maar des te meer over Van Eeden, de "reeds toen bekende, later beroemde dichter en mensenvriend". ${ }^{128}$ De contacten tussen Van Eeden en Brandes resulteerden in verscheidene bijdragen van en over eerstgenoemde in het door Brandes' broer Edvard opgerichte links-liberale dagblad Politiken. Deze in cultureel opzicht belangrijkste Deense krant publiceerde achtereenvolgens een bijdrage van Van Eeden over Ibsen in 1898, Brandes' recensie van De kleine Johannes in de Deense vertaling van 1903, een artikel van Van Eeden over Andersen in 1905, en een hele serie artikelen over Van Eedens leven en werk, naar aanleiding van diens voordracht te Kopenhagen in 1910.

$\mathrm{Na}$ Ipsens Ellen-fragmenten en de vertaling van de fabel Het krabbetje en de gerechtigheid in een Deens literair tijdschrift vormt De kleine Johannes, tegelijkertijd in het Deens en het Zweeds verschenen ${ }^{129}$, de eerste grote Van Eeden-vertaling in het Noorden. Brandes prijst het werk om de humor - uiteraard wijst hij op de verwantschap met Andersen - en om het gevoel voor de onderdrukten: "Hoe emstig Frederik van Eeden het slot heeft bedoeld, heeft niet alleen zijn latere produktie, maar heel zijn latere levenswijze getoond". De positieve recensie heeft overigens niet mogen baten voor de verkoop: bij Van Eedens bezoek in 1910 haastte uitgeverij Gyldendal zich de restoplage tegen gereduceerde prijs op de markt te brengen. Een ongedrukte anonieme manuscriptvertaling van IJsbrand, thans bewaard in het toneelarchief van de Koninklijke Bibliotheek te Kopenhagen, heeft niet in een opvoering geresulteerd.

Treft in Denemarken de natuur Van Eeden meer dan de mensen ("Wij zijn goedige lieden, maar een klein, leelijk volk. Zoo zijn de Denen ook ${ }^{* 130}$ ), in Noorwegen raakt hij onder de indruk van land èn volk. Daarmee maakt hij kennis in 1897, bij een bezoek aan de dochter van een vriend, de schrijfster Valborg Isaachsen-Dudok van Heel, domineese in het gehucht Helleland in Zuid-Noorwegen. Van Eeden doet als "buitengewoon correspondent in een Noorsch dal" verslag van zijn indrukken in het Algemeen Handelshlad, waarin hij benadrukt zich onder "rasgenooten" te voelen:

Dat hier grootsch gevormde bergen en bosschen rijk aan allerlei bekoring. helder stroomende bergvloeden en groote, blanke stille meren zijn, dat wist ik, en dat trok mij zeer. Maar wat ik vooral hoopte te vinden, was weinig maar onbedorven menschen. En daarin is mijn verwachting overtroffen [...] er heerscht hier een gastvrijheid en onderlinge hulpvaardigheid die ons beschaafden en rijker gezegenden als barbaren tegenover hen doen staan.

De dominee wordt door de staat in natura betaald: 
Gelukkig zijn er tal van handen bereid om hem te helpen, maar zooals ik zeide, de verstandige, de arbeidzame, zooals mijn goede gastheer, slaat zelf de hand aan de ploeg. Een hoogte van idyllische volmaaktheid als hier werd zelden bereikt.

Hoewel hij blijkens zijn geschriften goed beseft dat de economische verhoudingen van Noorwegen niet over te planten zijn op een hoogontwikkelde samenleving als de Nederlandse, is het toch deze geest van saamhorigheid die hij tracht te bevorderen in zijn geschriften rond de produktieve coöperatie, die juist vanaf 1897 beginnen te verschijnen. Zijn experimenten in deze richting brachten hem in contact met Margaretha Meyboom. Deze propagandiste van de Scandinavische letteren, vooral bekend als Nederlandse vertaalster van Bjømson en Lagerlöf, was als aanhangster van het Deense coöperatieve systeem een coöperatie Westerbro te Rijswijk begonnen. Zij inspireerde Van Eeden tot het opnemen van publikaties over Deense coöperaties in De Pionier, het blad van Gemeenschappelijk Grondbezit. In dit blad schrijft Van Eeden op zijn beurt vol waardering over de beschavende invloed van een hoogstaande vrouw, die op Walden zo node gemist werd: "Het ware te wenschen dat de industriëele bloei van Walden en de huishoudelijke geest van Westerbro vereenigd konden worden". ${ }^{131}$

Walden trekt van zijn kant de belangstelling van het Noorden. In 1905 brengt de bekende Zweedse pedagoge en schrijfster Ellen Key een bezoek aan de kolonie. Haar gastheer toont zich weinig onder de indruk; in zijn dagboek noteert hij alleen dat de bezoekster schor is, en later citeert hij met instemming een vriendin, die opmerkt dat Ellen Key zowat alle goede dingen afschuimt. In hetzelfde jaar heeft hij te Rome een ontmoeting met Nobelprijswinnaar Bjømstjerne Bjørnson, aan de vooravond van diens triomf als geestelijk leider van zijn volk in de strijd om de Noorse onafhankelijkheid. Volgens Van Eeden toonde Bjørnson in een prettig gesprek de behoefte om zijn mystieke wereldbeschouwing te horen. Men kan zich afvragen of de werkelijke verhouding niet andersom was: Bjømson was immers de belichaming bij uitstek van het door Van Eeden korte tijd later gevormde concept Koningschap en Dichterschap. In elk geval treedt de Noor nog maanden later in Van Eedens droom op. ${ }^{132}$

In 1910, het jaar waarin het essay Koningschap en Dichterschap verschijnt, houdt Van Eeden te Kopenhagen een voordracht over 'De hervorming der maatschappij', op uitnodiging van de Deense Hojskole for moderne Samfundsvidenskab en van Politiken, spreekbuis van de politieke partij der Radikalen, die sinds een jaar voor het eerst zitting heeft in de regering. Hoofdpunten van de radicale politiek zijn demilitarisering, vrouwenkiesrecht, belasting op grondwaarde, en sociale hervormingen. Binnen dit kader past een lezing van Van Eeden dus goed.

Met voor die tijd uiterst modeme middelen wordt in Politiken een publiciteitscampagne voor Van Eeden gevoerd, met interviews, citaten uit de internationale pers, poriretten en illustraties. Anne Valeton, een in Kopenhagen wonend nichtje van Van Eedens eerste liefde Henriëtte 'Ati' Valeton-Ortt, geeft een overzicht van leven en werk, en ook de human interest ontbreekt niet. Van Eeden charismatische invloed op vrouwen krijgt aandacht, en in een licht-ironisch versje over Walden heet het: 


\title{
Hoofdstuk IV
}

\author{
Van Eedens Arbejdsvarelse \\ Van Eeden har Husleje delvis spar ' $t$ \\ ved en Hule i Haven at grave. \\ Jeg tror dog, man havde det nok saa rart \\ i sin Tid i Edens Have.
}

\section{[Van Eedens werkkamer}

Van Eeden heeft zich wat huur bespaard

Door een hol in zijn tuin te graven

Maar volgens mij was het toch aangenamer

indertijd in de Tuin van Eeden] ${ }^{133}$

De conservatieve en sociaaldemocratische pers zwijgt in alle toonaarden over dit bezoek.

De lichtgeraakte Van Eeden schrijft in zijn dagboek dat hij geëxploiteerd is door Politi$k e n$, dat op soms smakeloze wijze reclame voor hem heeft gemaakt. Wat hiervan zij, de campagne had succes: er kwamen circa vijthonderd toehoorders, waaronder ministers, professoren en de bekendste socialistische auteurs: Jeppe Aakjær, Johan Skjoldborg en Martin Andersen Nexø. Na afloop van de rede, grotendeels een samenvatting van De blijde wereld, drong het publiek aan op meer en spreker improviseerde nog een half uur door.

Van Eeden sprak in het Duits, maar tijdens het souper na afloop werd op zijn verzoek in het Deens gesproken. De toon der tafelredenaars was lovend, al valt een verwijt van naïviteit te bespeuren in de rede van de revolutionaire socialist Martin Andersen Nexø over de ethische ideologie van "het kind Van Eeden, dat stoeit met de grootste ideeën, zonder zich erom te bekommeren of die ideeën altijd direct kunnen worden overgeplant in de wereld van de werkelijkheid. Wat hem in het klein niet gelukt is, zal eens zegevieen in het groot, in de hele maatschappij." ${ }^{134}$ Het verschil tussen Van Eedens Kleine Johannes en Nexø's socialistische romanheld Pelle de Veroveraar is in dit verband tekenend.

Van Kopenhägen reist Van Eeden door naăr Zweden, waar hij spreekt te Stockholm. Meer dan in Denemarken was daar zijn Kleine Johannes aangeslagen. "Mijn generatie herinnert zich dat boek als een lichtbundel uit een goed en warm hart". schrijft zijn Zweedse vriend Ernst Norlind in zijn memoires. In een Zweedse recensie werd het werk op één lijn gesteld met de Faust en Peer Gynt: "Kleine Johannes met zijn stil en schuchter verlangen, zijn kinderlijke verbazing en zijn warm hartje. wordt daardoor minder een vertegenwoordiger van de menschheid in zijn geheel, dan wel voor een bepaald soor menschen: de fijnste en tegelijkertijd de sterkste, tot welke men onwillekeurig vermoedt. dat de schrijver zelf hoor". De vertaling van 1903 was in 1906 gevolgd door die van De kleine Johannes II en De blijde wereld. ${ }^{135}$

Van Eedens visie op het broedervolk wordt duidelijk door dit succes gekleurd. In het voorwoord van laatstgenoemde vertaling looft hij de innerlijke kracht van de klankrijke Zweedse taal en de interesse en financiële steun uit Zwweden voor zijn maatschappelijk streven, speciaal van een niet nader te noemen weldoener. Van Eeden doelt hier op de Gotenburgse grootindustrieel en liberaal politicus Hjalmar Wijk (1877-1965). Diens 


\section{Den hollandske Berwmthed; dor pas Onsdapt taler if Højskoles}

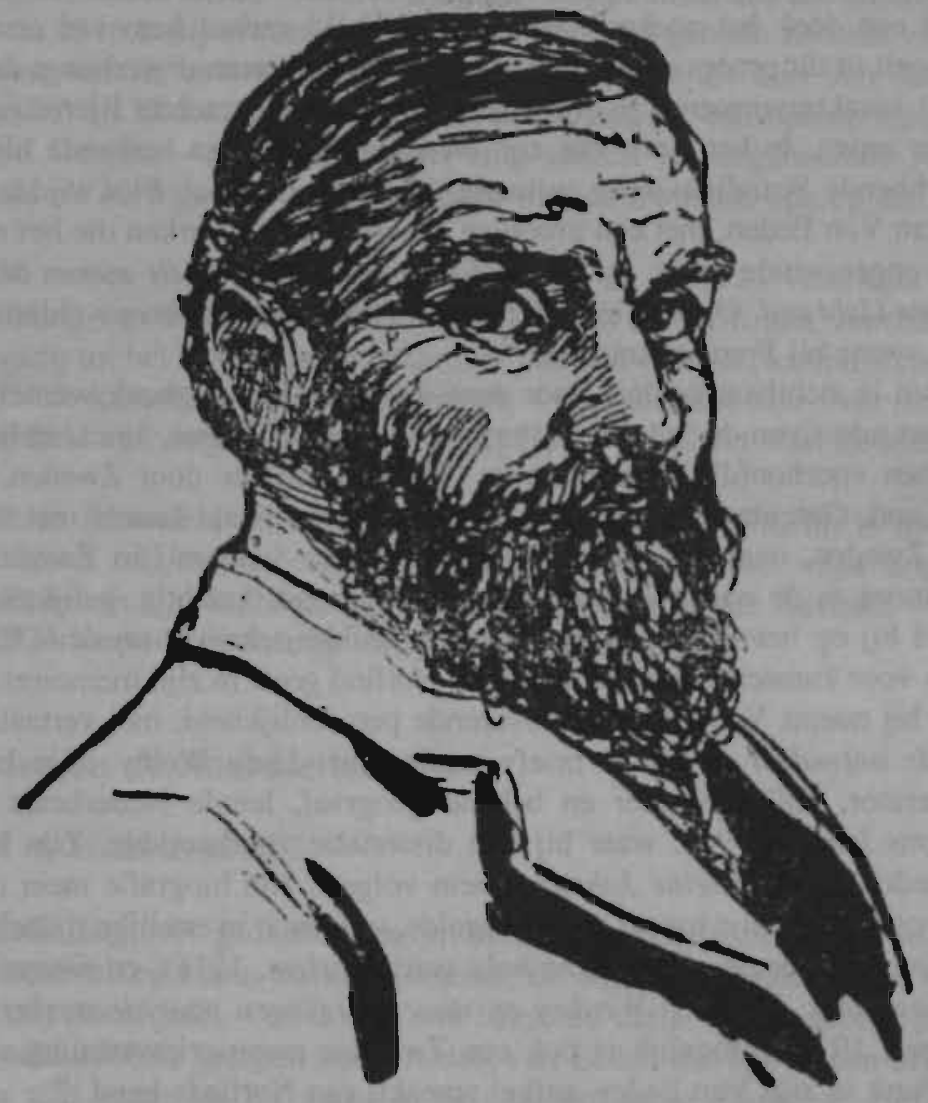

Afbeelding 7. "De Nederlandse beroemdheid, die woensdag zal spreken in de Hogeschool". Portret van Van Eeden in Politiken, 13 februari 1910. (Universiteitsbibliotheek Kopenhagen). 
ondanks de Nederlandse aandoende naam zuiver Zweedse adelsgeslacht had al eerder contact met een Nederlands literator: zijn grootouders Olof en Hilda Wijk waren Potgieters gastheer en -vrouw in 1831. ${ }^{136} \mathrm{Hjalmar}$ Wijk, evenals Van Eeden senior actief in de kunstnijverheid, schonk grote sommen gelds aan culturele en sociale projecten. Van Eeden kreeg van hem van circa 1904 tot 1922 een jaargeld van enige duizenden guldens.

De eveneens uit Gotenburgse koopmanskringen afkomstige literator en internationaal befaamde psychiater Poul Bjerre (1876-1934) had net als Van Eeden in zijn land de psychotherapie geïntroduceerd, waaraan hij een eigen vorm gaf. Volgens hem is niet de aanpassing van een natuurdrift als de seksualiteit kenmerkend voor de mens, maar het streven naar een doel: het zoeken naar saamhorigheid verlost hem van complexen. De literatuur speelt in dit proces een belangrijke rol: goede literatuur verhoogt de levenskennis en werkt karaktervormend. In zijn eigen literaire werk trachtte Bjerre zijn ideeën in daden om te zetten. In het werk van zijn Nederlandse collega herkende hij zich, en in het gezaghebbende Scandinavische culturele tijdschrift Ord och Bild wijdde hij in 1911 een studie aan Van Eeden, met een grondige analyse van de werken die het meest voldeden aan bovengenoemde eisen: De kleine Johannes, Van de koele meren des doods, De nachthruid en IJsbrand. Op zijn initiatief sprak Van Eeden op een psychiatrisch congres te München, waar hij Freud ontmoette. ${ }^{137}$

Van Eeden is zichtbaar gevleid door deze interesse. Het dagboek wemelt van loftuitingen aan het adres van de "edele" en "trouwe" vrienden. Bjerre, "met het hooge, machtige Germanen voorhoofd", organiseert in 1913 een tournee door Zweden. Van Eeden spreekt te Lund, Gotenburg, Stockholm en Uppsala, en maakt kennis met tal van vooraanstaande Zweden, over wie hij zich lyrisch uitlaat: "wat mij in Zweden het meest weldadig aanoet, is de raszuiverheid. Het is een gezond, krachtig, gelijkmatig ras". Te Lund logeert hij op het slot Borgeby, waar de schilder-schrijver-musicus Emst Norlind een gasthuis voor kunstenaars heeft ingericht. Norlind geeft in zijn memoires een impressie van wat hij noemt Van Eedens betoverende persoonlijkheid, met vertaalde fragmenten uit Pauls ontwaken en uit de briefwisseling met Lady Welby. Zijn broer Amold Norlind, literator, volksopvoeder en bekend geograaf, leerde Nederlands tijdens zijn verblijf in ons land in 1906, waar hij zijn dissertatie voorbereidde. Zijn bewondering voor Van Eeden, wiens Kleine Johannes hem volgens zijn biografie meer dan wat ook zijn eigen jeugd in de vrije natuur weerspiegelde, uitte zich in ettelijke tijdschriftartikelen en vertalingen van poëzie, drama (De heks van Haarlem, 1916), en essays (Bij 't licht van de oorlogsvlam, 1916, en Wenken en waarschuwingen voor de werkers in de Van Eeden kolonie, 1921). Mogelijk is ook een Zweedse manuscriptvertaling van IJsbrand waarover Bjerre in zijn Van Eeden-artikel spreekt, van Norlinds hand. ${ }^{138}$

Bij zijn bezoek aan Stockholm krijgt Van Eeden veel aandacht van de pers, en op een soiree te zijner ere zijn diverse notabelen vertegenwoordigd, waaronder de burgemeester. Dergelijke aandacht en contacten leken voor hem niet onbelangrijk. Reeds bij zijn eerste bezoek was gesuggereerd, "dat het niet onmogelijk was, dat ik in aanmerking kwam voor de Nobelprijs. Ik had eenigen tijd nodig voor ik realiseerde wat zulk een geweldige sprong zou beteekenen." Van Eedens ijveren voor Zweedse vertalingen moet zeker in het licht van dit besef worden gezien. Jarenlang probeert Wijk met zijn vele contacten Van 
Eeden voorgedragen te krijgen, maar vergeefs. Rationaliserend schrijft de afgewezene in zijn dagboek, hoe hij de prijs graag zou afwijzen. ${ }^{139}$

Bjerre en Emst Norlind spelen een hoofdrol in de Forte Kreis, de mede door Van Eeden opgerichte kring van Koninklijken van de Geest, die in 1914 te Potsdam bijeenkomt om "een geestelijke atmosfeer te scheppen, waarin nieuwe waarden en verbindingen kunnen ontstaan, een wereld waarin het wetgeverschap, ja het koningschap, onmiddellijk op de dichter zou overgaan". Wijk is als geldschieter in de kring betrokken, en Bjerre laat bij Stockholm een villa voor de Kreisleden bouwen. Groot is de teleurstelling van vooral Bjerre als de Eerste Wereldoorlog een abrupt einde aan het etherische streven maakt. Maar in 1916 is hij alweer tussenpersoon voor een geheim Zweeds vredescomité, dat Van Eeden weet te bewegen tot een vredesmissie met als doel een dialoog Duitsland-Engeland. Van Eeden doet in een persoonlijk gesprek een oproep aan de Engelse premier Lloyd George, - overigens zonder enig succes. Bovengenoemde vertaling van Bij 't licht van de oorlogsvlam hangt uiteraard met de Zweedse oproep aan Van Eeden samen. ${ }^{140}$

Rond 1920 nemen de contacten met het Noorden af. In 1921 verschijnt in Ord och Bild een vertaling van fragmenten uit Het Godshuis in de Lichtstad, voorbode van Van Eedens overgang tot het katholicisme, waarover met name Emst Norlind zich zeer teleurgesteld toont: "de katholieke kerk is despotisch, - gaat men tot haar over dan moet men haar hele apparaat van dogma's aannemen [...] Het is zeker dat Van Eeden geestesziek [was]". ${ }^{141}$

Wijk raakt in financiële moeilijkheden. "Het gaat hem slecht, hij is moedeloos en somber. Het stemt mij ook droef. Wat komt er van me, zonder mijn lang broertje?" schrijft Van Eeden in zijn dagboek. In 1922 verliest zijn trouwste Zweedse vriend al zijn geld, en in 1924 loopt de jarenlange correspondentie ten einde. ${ }^{142}$

\section{Van Eeden en de Noordse letteren}

\subsection{Oudheid en Middeleeuwen}

"Ik had er reeds lang over gedacht, waarom toch de Ur-poesie, al wat van de oude zoogenaamde natuurvolken komt, zooals Homerus, de Bijbel, de Edda, zoo'n ontzachlijke bekoring op mij uitoefende, - en ik had ook bespeurd dat al wat ik groote poëzie vond, iets met die natuurpoëzie gemeen had." Aldus Van Eeden in 1884 in een brief aan Verwey. Net als zijn vader las hij graag in de Oudgermaanse literatuur: zijn bibliotheek bevatte een twintigtal werken met en over Oudgermaanse letteren en cultuur. Op diverse plaatsen in zijn beschouwende werk gebruikt hij beelden uit de Scandinavische mytholoie: in Glückliche Menschheit schrijft hij hoe Londen hem doet denken aan Niflheim, de Noordse hel, in Over woordkunst vergelijkt hij zijn critici met de Azen die zich met Baldur vermaken, en in Koningschap en Dichterschap memoreert hij de helden uit de barbaars-germaanse tijd. ${ }^{143}$

Ook in zijn literaire werk zijn sporen van Noordse invloed te vinden. In het Nietzscheaans getinte gedicht De Noordenwind uit 1885, mede ge:̈nspireerd op Shelleys Ode 
to the Westwind, is de windrichting niet voor niets veranderd: de trotse germanengeest wil "geen weekheid en geen weemoed". Verwey vond dit gedicht strijdig met "s schrijvers geest, maar Van Tricht heeft erop gewezen hoe de heidense toon echter is dan oppervlakkig gezien het geval lijkt. De grondgedachte is terug te vinden in Johannes Viator (1892):

Terug wensch ik het wilde leven. Het groeien van een mensch als een boom tusschen boomen, als een dier tusschen dieren, - één met allen, één met de zee en wind en rotsen, als een mooi sterk reuzenkind onder zijn gelijken, en onder zijn gelijken de sterkste, de heerlijkste, volmaakt in kracht en schoonheid, zooals nu nimmer een mensch volmaakt is. Ik wensch verzonken en verwoest de groote steden, verdelgd het zachte, gemakkelijke leven. Ik haat die teederen, die onbloedigen, alleen sterk door hun veelheid, zooals ongedierte sterk is. ${ }^{14}$

Van Eedens behoefte aan beheersing van het zinnelijke uit zich in verering van de vergeestelijkte en zuivere natuur. Gezien het ascetisch karakter van deze naturverering verwondert het niet, dat hij zijn drama bij uitstek over de beheersing der zinnen, Lioba (1897), situeert in een imaginair Vikingrijk in de Nederlanden, waarin allerlei historische figuren en elementen voorkomen. Zelf suggereert hij dat hij zich niet bewust was van zijn eigen historische kennis: "Hoe wonderlijk weer, dat ik Heriold en Hemming in Holland liet wonen, van niets wetend, en dit bevestigd vind". Het is echter uiterst onwaarschijnlijk dat de zeer belezen Van Eeden met zijn belangstelling deze namen gefantaseerd heeft, te meer daar Heriold en Hemming historisch inderdaad broers waren. In elk geval bestudeert hij tijdens het schrijven van de laatste taferelen de Edda en secundaire literatuur, onder andere van de theoloog L.S.P. Meyboom, de vader van Margaretha. In zijn literaire autobiografie Literatuur en Leeven (1920) stelt hij de zaak eerlijker voor: "Dit hoog gecultiveerde middeneeuwsch Nederland is een denkbare fantasie [...] een kooning Harald of Heriold heeft in Nederland geheerscht, en de namen en plaatsen uit het drama zijn historisch". ${ }^{45}$

Van Eedens toneelopvattingen uit deze periode weerhielden hem ervan, met Lioha een realistisch drama te schrijven: het ging hem erom, cultuurhistorische elementen te gebruiken voor de uitdrukking van een idee. Voor hem is het krachtige natuurleven als dat van de Viking een noodzakelijke fase in de ontwikkeling van de echte mens, die wordt geschetst in de woorden van de stervende koning Harald:

\footnotetext{
Ruw als rots,

wreed als vorstkou en wild als wind is ' $t$ volk

dat voert, in mij. thans 's werelds regiment.

waar harde weerstand van natuur en lot

zijn kracht geweldig prikkelt tot geweld.

maar onder vrede's blauwen hemel bloeit het

met oogst van gouden deugden wonder-mild.
}

De sporen van Oudnoordse invloeden zijn vooral te vinden in het vroege werk. Een laatste duidelijke verwijzing naar de Noordse mythologie is te vinden in Het lied van 
Schijn en Wezen, II (geschreven tussen 1895 en 1910), waarin de wereldboom Yggdrasil wordt geschetst, "die eeuw'ge, schoonbebloemde Boom / in de aarde wortlend, maar in 't Al vertwijgend". ${ }^{146}$

\subsection{Klassicisme en romantiek: Holberg, Oehlenschläger, Andersen, Kierkegaard}

In 1948 wijdde Anton van Duinkerken een artikel aan het blijspel Erasmus Montanus van de Noors-Deense Molière, Ludvig Holberg (1684-1754), waarin hij veronderstelde dat dit stuk "misschien niet geheel onbekend is geweest aan Frederik van Eeden toen hij De student thuis schreef". Is Van Eeden inderdaad schatplichtig aan Holberg? Bij lezing springt een aantal overeenkomsten in het oog: een student die zich in de academische wereld heel wat mans acht, maar zich in zijn geboortedorp moet onderwerpen aan de daar heersende kleinburgerlijke zeden; academische disputen en overdreven gebruik van het Latijn; verzaking van de eenvoudige vroegere geliefde; en een ontknoping doordat de hoofdpersoon wordt geronseld als soldaat.

Toch lijkt directe invloed niet waarschijnlijk. Ten eerste zijn deze motieven zeer algemeen; zowel de Scandinavische als de Nederlandse literatuur is rijk aan studententypen. Van Eeden noemt in Literatuur en Leeven Kneppelhout en Haverschmidt als zijn voorbeelden. De naam Holberg is in geen van zijn geschriften te vinden, en in een interview met Politiken verklaarde hij van de oudere Deense auteurs alleen Oehlenschläger, Andersen en Kierkegaard te hebben gelezen. Ten tweede, en dat is overtuigender, worden de motieven door beide schrijvers zeer verschillend uitgewerkt in omvang en richting. In Holbergs tragikomedie lijdt de snoevende Rasmus Berg een nederlaag door een list van de dorpelingen, terwijl Van Eedens hoofdpersoon Frans van Til juist door eigen list onder de huiselijke plak uitkomt. De academische disputen vormen de kern van Holbergs spot, terwijl ze bij Van Eeden alleen dienen voor de couleur locale. En terwijl Rasmus Berg zijn vroegere geliefde uiteindelijk behoudt, slaagt Frans van Til in zijn opzet, die definitief kwijt te raken. ${ }^{147}$

Is de overeenkomst met Holberg toevallig. anders lijkt het te liggen met Adam Oehlenschläger (1779-1850). Zoals ik al aangaf, las Van Eeden diens werk, en zeker zal hij het hoofdwerk van de Deense romantiek hebben gelezen: het blijspel Aladdin eller Den forunderlige Lampe, en het is annemelijk dat deze klassieke dramatisering hem heeft geinspireerd tot het schrijven van een eigen toneelbewerking van dezelfde naam: Alladin of De Wonderlamp, in een manuscript van 1891 aanwezig in het Frederik van Eedenmuseum. Een directe bewerking uit het Deens is het stuk zeker niet: Oehlenschliggers spel bevat zeer veel scènewisselingen en lyrische intermezzi in verschillende versvormen, terwijl Van Eedens pantomimespel werkt met een voorlezer, wiens proza af en toe wordt onderbroken door muziek. Maar zowel plot als ideeënwereld is dezelfde: de onbezorgde zoon van de natuur, die door tegenslag rijpt tot de voorvechter van het Goede, en daardoor het geluk wint: de toverlamp. De uiteindelijke triomf van de lichtende geest over de duistere machten van koel verstand en egoïsme, nadrukkelijk uitgewerkt in het contrast licht-donker, is kenmerkend voor beide auteurs. 
Van zijn schatplichtigheid aan een ander Deens romanticus, Hans Christiaan Andersen (1805-1875), heeft Van Eeden nooit een geheim gemaakt. In De kleine Johannes wordt de naam Andersen op twee plaatsen genoemd, en in Literatuur en Leeven wordt hij als inspirator vermeld. Van Deyssel vond de invloed zelfs terug in Van Eedens uiterlijk:

[...] een zachte, lieve, jonge-man, met een zekeren bizonderen ernst in zijn gelaatsschijn, en, als men goed keek, met een zeer bizonder aangezicht. Hij leek waarlijk meer dan op iemand anders, op ... Andersen, den Deenschen sprookjes-schrijver, naar mijne meening een der drie of vier grootste dichters van de laatste honderd-vijftig jaar. Ik zal niet zeggen in de gelaatsvormen maar in het geheel der essentiëele gelaatsuitdrukking: ${ }^{148}$

Bij de viering van Andersens honderdste geboortedag in 1905 nodigde Politiken Van Eeden, naast Strindberg en andere door Andersen beïnvloede schrijvers, uit om een artikel te schrijven over zijn relatie met de grote Deen. Van Eeden schrijft hoe Andersen een van zijn lievelingsauteurs was toen hij 10-14 jaar oud was, en dat hij ondanks de slechte vertaling werd bekoord door sprookjes als Duimelijntje, De kleine zeemeermin, De reiskameraad, Het tinnen soldaatje, De nachtegaal, De geschiedenis van een moeder en vooral De nieuwe kleren van de keizer. De combinatie van fantasie èn eeuwige waarheden maakt volgens Van Eeden Andersen tot de grootste sprookjesdichter. Hij erkent de Deen als degene die hem de deur naar het wonderrijk der fantasie heeft geopend. Anderzijds ontkent hij een echte invloed op zijn woordkunst of op zijn werk als zodanig.

Deze laatste uitspraak lijkt in tegenspraak met die uit Literatuur en Leeven; is er nu wel of geen sprake van invloed? Wat de motieven betreft, is in 1975 door Keersmaekers gewezen op overeenkomsten tussen De kleine Johannes en een aantal van Andersens sprookjes, waaronder de door Van Eeden zelf genoemde favorieten: De nachtegaal, De geschiedenis van een moeder en vooral De reiskameraad, met een Johannes als hoofdersoon. ${ }^{149}$

Deze motiefovereenkomsten zijn echter niet de enige. Reeds in 1945 wees Helge Kjargaard op de gelijkenis tussen het sprookje De klok en het einde van De kleine Johannes, - een overeenkomst die nader is hestudeerd door Hans Goudsmit in zijn ongepubliceerde Kopenhaagse doctoraalscriptie van 1961 over de invloed van Andersen op Van Eedens Kleine Johannes. De overeenkomst bestaat hierin, dat een uitverkorene, respectievelijk een koningszoon en 'Zonnezoon' Johannes, achter een geheimzinnige lokstem uit de natuur aangaat: met veel moeite volgt hij het geluid langs overwoekerde paden, tot hij vanaf de top van een rots respectievelijk duin de zon in een machtig religieus visioen in zee ziet ondergaan.

Ook Goudsmit noemt De reiskameraad als inspiratiebron, waarbij hij tevens wijst op de gelijkenis tussen de relatie reiskameraad-Johannes en de relatie Markus-Johannes uit De kleine Johannes II. Noch Goudsmit, noch Keersmaekers noemt echter enige hoofdmotieven uit dit sprookje. die verklaren waarom Van Eeden zich er wel bijzonder tot aangetrokken moest voelen: de in zijn werk zo belangrijke tegenstelling licht-donker, wit-zwart, waarop Van Duinkerken heeft gewezen, is nergens in het oeuvre van Andersen zo nadrukkelijk uitgewerkt. Alleen al de woorden wit en zwart komen 11 respectie- 


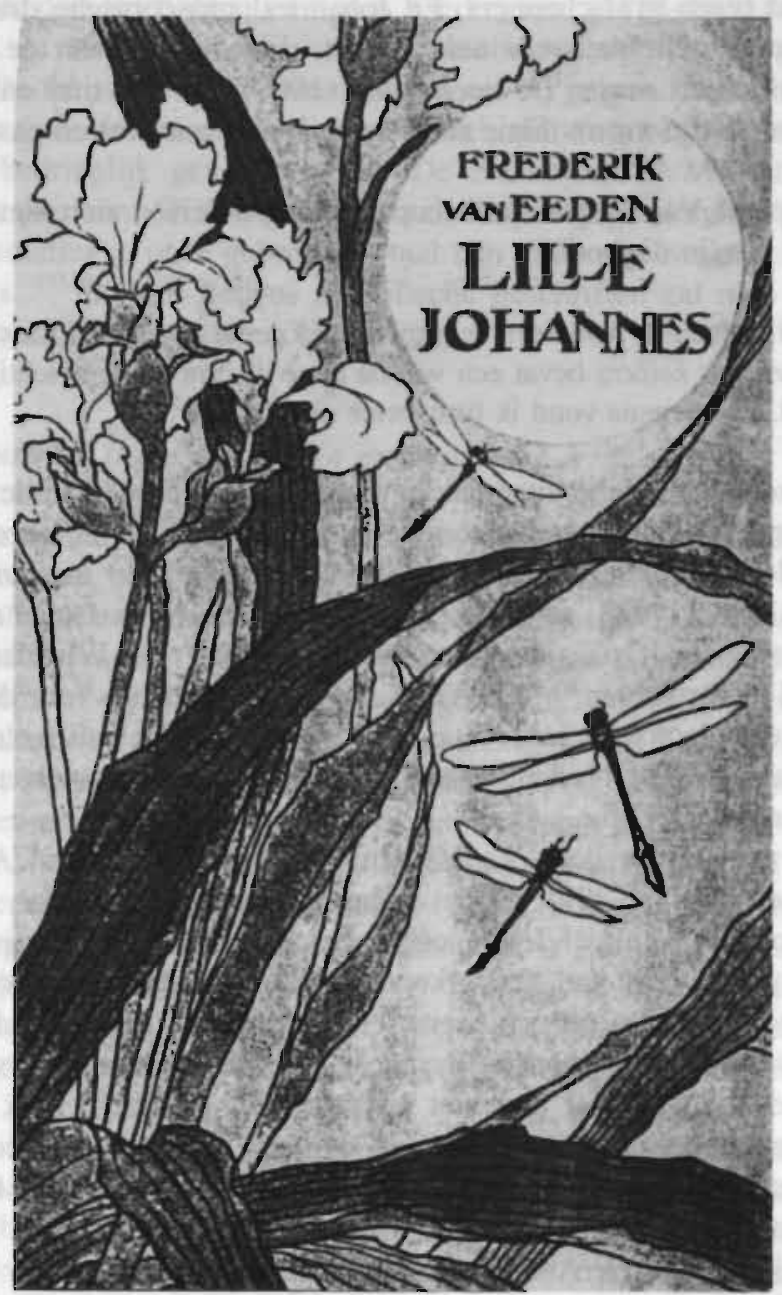

Afbeelding 8. Omslag van de Zweedse vertaling van 'De kleine Johannes' (1903). "Mijn generatie herinnert zich dat boek als een lichtbundel uit een goed en warm hart" (Ernst Norlind). (Universiteitsbibliotheek Utrecht). 
velijk 8 maal in de tekst voor, steeds met een symbolische functie. De hiermee parallel lopende tegenstelling goed-slecht wordt uitgewerkt in 34 maal het woord 'goed' tegenover 29 varianten van 'slecht'. Bovendien spelen in dit sprookje uittreding en droom een belangrijke rol, twee fenomenen waarin Van Eeden van jongsaf zeer geïnteresseerd was. De reiskameraad is in feite de uitgetreden ziel van de dankbare dode die door Johannes wordt beschermd tegen grafschenners. En Johannes' proscopische droom in het begin, waarin hij de latere geliefde reeds anschouwt, doet denken aan de droom van Vico Muralto uit Van Eedens roman De nachtbruid (1909), die zijn titel ontleent aan het feit dat de hoofdpersoon zijn vrouw Elsie eerst in de droom ontmoet en pas daama in werkelijkheid. ${ }^{150}$

Inderdaad beperkt Van Eedens preoccupatie met Andersen zich niet tot zijn jeugd. In 1908 schrijft hij in zijn dagboek:

Ik had wel gelijk toen ik Andersen een universeel genie noemde. Zijn sprookje van De nieuwe klederen des keizers bevat een van de twee of drie allergewichtigste waarheden van onzen tijd. En nergens vond ik haar beter uitgedrukt. ${ }^{15 !}$

Is het gezien deze categorische uitspraak gewaagd om te veronderstellen dat Van Eedens filosofisch concept van Schijn en Wezen mede gebaseerd is op dit lievelingssprookje? In ieder geval is duidelijk hoezeer het toneelstuk Ismea, of de stervende vlinder : een sprookje voor 't toneel (1923) steunt op De kleine zeemeermin. Ismea ruilt haar elfengedaante voor een mensenlichaam om te trachten, de liefde voor Winfried en daarmee een onsterfelijke ziel te verwerven. Maar Winfried kiest uiteindelijk voor de aardse Blanche. Ismea verwerpt een door haar zuster aangeboden tovermiddel uit oerzeeslijm om Winfried voorgoed aan zich te binden, en ze moet sterven; maar om haar getoonde liefde krijgt ze toch een onsterfelijke ziel.

Keren we terug naar de door Van Eeden ontkende invloed van Andersens woordkunst. Kenmerken daarvan zijn: a) het gebruik van voor kinderen begrijpelijke taal (eenvoudige woorden, verklarende toevoegingen, analytische omschrijving in plaats van composita); b) het gebruik van versterkende effecten (partikels, uitroepen, afwijkende woordvolgorde, cursivering, uitroeptekens, etcetera); c) de nauw bij de spreektaal aansluitende syntaxis (polysyndese en/of asyndese, veel pronominale verwijzingen, tussenzinnen, anakoloeten); d) de al dan niet gevarieerde herhaling (vaak in de vorm van tautologie of pleonasme). Het taalgebruik in de voor volwassenen bedoelde Kleine Johannes wijkt hier zeker in menig opzicht van af. Maar Goudsmit wijst toch op duidelijke reminiscenties aan Andersen, vooral in de dialogen en in de indirecte vrije rede. Alleen al de openingszin is typisch Anderseniaans: "Ik zal u iets van den kleinen Johannes vertellen". En men hoeft Van Eedens werk maar naast een sprookje als De reiskameraad te leggen om te zien hoe zinnen als de volgende aan Andersen doen denken: "Dat was een heele wereld voor Johannes"; "Hij dacht [...] hoe gezellig het daar moest zijn"; "Dat was het inderdaad!" Andersens typische uitroepen en herhalingen komen ook in De kleine Johannes overvloedig voor: "Shrrrr-Shrrrr!"; "Kwak-kwak!": "Er is een menschenhuis gebouwd, zoo groot! zoo groot!": "Onder den grond, altijd onder den grond", "Hoe was dat, hoe was dat ook weer". En verklarende toevoegingen staan al evenzeer in Van 
Eedens werk: "Ook moogt ge er den kleinen Johannes nooit over spreken, als ge hem soms ontmoet, want dan schrijf ik niet voor u". Goudsmit concludeert dat Van Eeden weliswaar in beperkte zin van Andersens stijlmiddelen gebruik heeft gemaakt, daar hij niet voor, maar over een kind schreef, maar dat hij zeker ook van de woordkunstenaar Andersen een en ander heeft geleerd. ${ }^{152}$

Het werk van Andersens tijdgenoot Søren Kierkegaard (1813-1855) leert Van Eeden eerst laat kennen. In 1909 krijgt hij van zijn Noorse vriendin Valborg Isaachsen Enten-Eller in een Duitse vertaling. Aanvankelijk leest hij geboeid, daar hij iets van zichzelf herkent: 'Zijn 'persoon' was niet 'uit een stuk', niet vast genoeg, en daardoor werd zijn oprechtheid bedrieglijk gevonden. Zie 'De Nachtbruid'." Maar taal en filosofie spreken hem toch niet aan: "Kierkegaard is taai. Ik heb geen geduld zijn abstracties te volgen. Deze speculaties in onze gebrekkige taal zijn mij zoo onwetenschappelijk, dat ik er van terug deins." ${ }^{.53}$ In Van Eedens filosofische geschriften zal men dan ook verder vergeefs naar de naam Kierkegaard zoeken.

\subsection{De nieuwe letteren. Ibsen, Jørgensen en Strindherg}

Van de jongere Scandinavische literatuur las Van Eeden een aanzienlijk, zij het weinig consistent deel, soms in het origineel, soms in vertaling. Ipsen trof te Bussum werken van de Deense dichter Drachmann en diens landgenoot de sprookjesschrijver Carl Ewald op tafel. In een interview met Politiken noemt Van Eeden bovendien J.P. Jacobsen en Johannes V. Jensen, terwijl zijn bibliotheek nog werken van Andersen Nexø en Ellen Key bevat. Zijn dagboek bevat reacties op de lezing van Bjømson, Ibsen, Lagerlöf, Strindberg, Hedin, Johannes Jørgensen en Lagerkvist. Over het algemeen zijn het korte opmerkingen, afkeurend of lovend. Doch één auteur brengt hem tot een hele reeks ontoezemingen: Ibsen, - terwijl ook Jørgensen en Strindberg vaker worden genoemd. ${ }^{154}$

Van Eedens verhouding tot Ibsen is zonder twijfel de meest problematische uit zijn hele schrijverschap. Aanvankelijk lijkt zijn standpunt vrij duidelijk. Ibsen kon in 1898 zelf lezen wat zijn Nederlandse confrère over hem dacht, in een speciale editie van Politiken, uitgebracht ter gelegenheid van Ibsens zeventigste verjaardag. Van Eeden schrijft Brand, Peer Gynt en De vrouw van de zee in het origineel te hebben gelezen:

De beide eerste interesseerden mij om de originaliteit, de geestigheid en het karakteristiek-Noorsche. Maar ik werd niet getroffen door eenige schoonheid van taal en ik miste dramatische verhevenheid en diepe wijsheid [...]. In het derde, Fruen fra Havet, was al het goede der beide andere werken, de vrije fantasie, het krachtige en spontane, geheel verdwenen en er bleef een plat, zeurig. conventioneel theaterstuk over. Dit benam mij de lust mij in de overige werken te verdiepen. Een opvoering zag ik nooit. Voor zoover ik uit de Duitsche vertalingen die mij onder oogen kwamen kon opmaken, vertoonen de latere werken geen terugkeer tot de oudere, vrije manier, maar zinken ze steeds dieper in theater-conventie en duffe, burgerlijke sfeer. De groote opgang van Ibsen verklaar ik uit het ontbreken van goede, modeme dramatiek, uit zijn Noorsche eigenaardigheid die altijd andere volken bekoort, en uit zijn vulgariseeren van tweedehandse, niet zeer diepe 
moraalfilosofie. Op de literatuur van ons land heeft Ibsen stellig geen invloed gehad [...].

De reeds hier wat dubbelzinnige houding - Van Eeden zegt zich niet verder in Ibsen te willen verdiepen, maar leest hem nog wel degelijk, ook getuige zijn dagboek - neemt dramatische proporties aan als Van Eeden, wiens eigen stukken uit die tijd niet of zonder succes werden gespeeld, uiteindelijk in de jaren 1906-1909 wèl opvoeringen van Ibsens stukken meemaakt. In november 1906 ziet hij Nora:

zijn dát nu stukken die iemand tegenwoordig wereldvermaard maken. Dan is ' $t$ wel droevig gesteld. Waar is de groote dramatische strooming [...] Het is zorgvuldig in elkaar gezet, kunstig, met veel hoofdbrekens zoo bedacht, met allerlei effectjes - brievenbus-dramatiek [...] En waar zulke stukken "wereldlitteratuur" heeten, daar wordt "De Zendeling" geweigerd!! De Zendeling waar tenminste een groote gedachte, een machtige situatie, een diepe algemeen menschelijke grond in is.

Hier lijkt het verzet nog krachtig en ondubbelzinnig. Maar nog geen maand later woont Van Eeden een voorstelling van Hedda Gabler bij, waarop hij heel anders reageert:

Daarop zag ik Hedda Gabler. En dat pakte mij aan. Geweldig. Maar zooals een wild beest aanpakt, mij verschrikkend en tot heftig verweer dwingend. Het is, geloof ik, door en door slecht werk. Maar het is zoo bekwaam en met zulk een duivelsche toewijding gemaakt, dat het den echten kunstenaar tegelijk doet gruwen en ontmoedigt [...] Moet ik ook streken gaan bedenken met verloren manuscripten, juist op tijd stervende tantes, moet ik dramatiek gaan zoeken in societeitsheeren en professors? Dat kan ik niet.

Hij voelt zich totaal verlamd in zijn creativiteit. 's Nachts heeft hij een nachtmerrie: hij doolt in een grauw, winters moeras, hij is doodarm en kan nog slechts door diefstal iets verkrijgen. Hij interpreteert de droom als zijn feitelijke onmacht om de duivelse kunst van Ibsen te bestrijden en vervangen.

Tientallen malen komt men nu in het dagboek passages met verwijzingen naar Ibsen tegen. Van Eedens twijfel is zichtbaar: tegenover zichzelf durft hij zijn gedeeltelijk respect voor Ibsen nauwelijks toe te geven. Elke positieve opmerking wordt onmiddellijk gerelativeerd of ontkracht. Enkele voorbeelden: "Nu begrijp ik waarom men Ibsen zoo hoog stelt. Daar zit tenminste spanning en teekening in, al is 't geen schoonheid"; "het eigen dichterschap, dat men moedig op het spel zet en waagt in den stroom. Ibsen heeft zijn succes daaraan te danken, maar hij doorgrondde niet wat hij deed".

In 1907 ziet hij in Berlijn Die Stützen der Gesellschaft: "Ik zag het interessante stuk in de meesterlijke opvoering met veel genoegen en groote belangstelling. Maar nu weet ik dan ook wel zeker dat als Ibsen een groot dichter is dan ben ik het zeker ook". Merk op, hoe Van Eeden hier Ibsen al grootheid als dichter toekent. En in 1908 wenst hij van Een vijand van ' $t$ volk, dat hij het zelf geschreven had. In 1909 ziet hij tenslotte Spoken, waarvan hij de compositie bewondert, al haast hij zich toe te voegen, dat het als woordkunst natuurlijk niets is. ${ }^{155}$ 
Frederik van Eeden en Scandinavië

Ifsbrand.

In Sragikomedre

of

Frederik van beden

wervat fra hollandsp cedkoment: Duetadan 198 sfiller frit Gong: Buntadame of de tor. Ye. Her hed. Fomel den 3o- Januar 1908. I Fyseland gifoir far tratagenten - Hofinata de 30 sonsere 1908 .

Afbeelding 9. Zijns ondanks paste Van Eeden Ibseniaanse technieken en motieven toe in zijn drama 'IJsbrand' (1908). Op zijn beurt werd dit stuk in het Deens en Zweeds vertaald. Hier het titelblad van de Deense manuscriptvertaling. (Koninklijke Bibliotheek Kopenhagen.)

89 
Langzaam krijgt Ibsen Van Eeden steeds meer in zijn ban. Inmiddels heeft deze de mogelijkheid gezien, "dat een groot dichter iets maakt dat zoo speelbaar is als het werk van Ibsen, en lyrisch en dramatisch zoo hoog staat als het werk van Shelley". Hij wil zonder het contact met het dagelijks leven te verliezen, Ibsens figuren, boven de massa verheven maar wel met die massa verwant, nog verder verheffen en de sferen van het echt schone en grootse verbeelden. In de stukken uit deze tijd komt men de zo gewraakte intrigetechniek uit Hedda Gabler dan ook opeens tegen. Zo is "de juist op tijd stervende tante" in IJshrand - is die Noords aandoende naam toeval? - een juist op tijd stervende oom geworden, en het "verloren manuscript" krijgt de vorm van de na twintig jaar terugevonden aantekeningen bij een heiligenleven van Franciscus, in De Stamhouder. Laatstgenoemd stuk vertoont technisch overeenkomsten met Een vijand van ' $t$ volk: een noodotsdrama waarin de protagonisten in een centrale scène-à-faire met elkaar worden geconfronteerd. Het is geen wonder dat Van Eeden juist over dit stuk zo enthousiast was: nergens in Ibsens werk komt de figuur van de miskende profeet zo sterk naar voren. Kalff noteert nog een overeenkomst tussen Jacobs zelfbeschuldiging aan het eind van Van Eedens stuk, en de rede van Bernick aan het slot van De steunpilaren der maatschappij. Van Eeden had deze beschuldiging zelf al voorzien: "Als men later Reinald ziet, zal men zeggen dat ik uit de 'Stützen' gestolen heb. Maar ik had het stuk gezien noch gelezen. En de schrandere zal het oorspronkelijke gauw herkennen". Wat hiervan zij - Van Eeden 'vergat' wel eens vaker zijn bronnen, zoals we eerder zagen -, opnieuw treft de zelfoverschatting. Er moge niet altijd sprake zijn geweest van directe navolging. maar duidelijk is hoe Van Eeden zijn respect voor Ibsen niet volmondig erkent, en waar hij iets erkent, zijn eigen, miskende superioriteit benadrukt. ${ }^{156}$

Het werk van Johannes Jørgensen (1866-1956) leest Van Eeden in de tijd van zijn bekering tot het katholicisme. Hij heeft ongetwijfeld in de Deen een verwante ziel herkend: stichter van een baanbrekend literair tijdschrift; schrijver van natuurpoëzie, van een roman over een katholieke coöperatie, een studie over Goethe en een heiligenleven van Franciscus; en in de Eerste Wereldoorlog actief als pamflettist tegen het oorlogsgeweld.

Strindberg, ten slotte, lijkt Van Eeden minder aan te spreken. Hij leest in 1913 diens correspondentie met Nietzsche en herkent zich in beider vlagen van waanzin, maar wil zich daar in tegenstelling tot de Zweed niet aan overgeven. In oktober 1920 noteert hij in zijn dagboek hoe zijn toneelstuk Ismea wordt geweigerd en dat blijkbaar alleen de wrange en bittere Strindberg de mensen trekt. Willem Royaards, die Ismea weigerde, regisseert in 1921 de eerste opvoering van Strindbergs Een droomspel in ons land, en in 1923 wordt, onder andere regie, een herziene versie van Ismea alsnog opgevoerd. In haar vernietigende recensie van de première noemt Top Naeff de hoofdfiguur een nakomertje van de hoofdpersoon uit Strindbergs stuk: "Indra's dochter, ach, het kon niet uitblijven, heeft in Nederland school gemaakt". ${ }^{157}$ Hoe aantrekkelijk deze suggestie in het licht van het voorgaande ook klinkt, en hoezeer Van Eeden overigens in een verbeelde droomwereld geïnteresseerd kan zijn geweest, ze lijkt me niet waarschijnlijk. Er is een wereld van verschil tussen het intense medelijden met de hele mensheid van Indra's dochter en de enkelvoudige onbeantwoorde liefde van Ismea voor Winfried. Ook de plot en de revolutinaire techniek van Strindbergs stuk verschillen hemelsbreed van die in Ismea. Nee, 
voor dat stuk had Van Eeden al genoeg ontleend aan een andere Scandinaviër. Van Eedens Noorden is dat van Andersen, - niet dat van Strindberg.

\section{Conclusies}

Frederik Van Eeden is in zijn belangstelling voor het Noorden kenmerkend voor zijn tijd. Het idyllische karakter van de onbedorven Noordse samenleving en de vernieuwende sociale experimenten daar trekken zijn belangstelling. Hij brengt diverse bezoeken aan Scandinavië en leest zowel uit de Oudnoordse literatuur als de moderne letteren.

Uitzonderlijk is Van Eeden echter waar het gaat om zijn bekendheid in het Noorden. Vooral met De kleine Johannes en het Walden-experiment trekt hij de aandacht van de Noordse pers en van bekende Scandinavische persoonlijkheden. Hij heeft contacten met auteurs als Georg Brandes, Bjørnstjerne Bjørnson, Ellen Key en Martin Andersen Nexø, met de politicus Hjalmar Wijk, die zijn werk financieel steunt, en de psychiater-schrijver Poul Bjerre, die het werk van zijn vakbroeder voor het $Z$ weedse publiek analyseert. Tweemaal houdt Van Eeden op uitnodiging van deze relaties een lezingenreeks in het Noorden.

Scandinavische sporen in Van Eedens werk zijn gespreid in tijd, genre en intensiteit. In zijn vroege werk zijn verschillende verwijzingen naar de Oudnoordse literatuur en wereld te vinden. Veronderstelde invloed van Holberg op De student thuis is daarentegen niet aanwezig. Wel is duidelijke verwantschap met Andersen te herkennen in De kleine Johannes en Ismea. Ten opzichte van Ibsen heeft Van Eeden een dubbelzinnige houding: hij bewondert diens techniek en is jaloers op diens succes, maar durft dat tegenover zichzelf nauwelijks toe te geven en geeft af op Ibsens woordkunst. In zijn latere toneelwerk past hij niettemin Ibseniaanse elementen en technieken toe. 


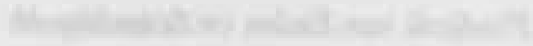

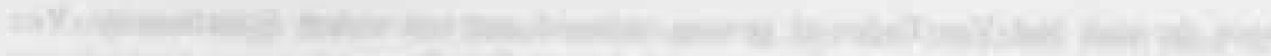
-

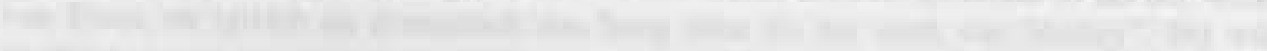
(1) 1

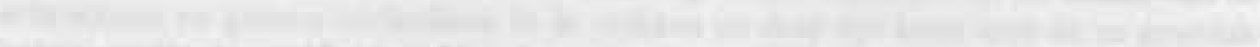

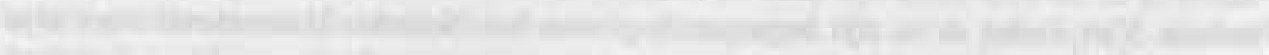
The

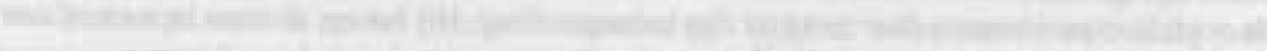

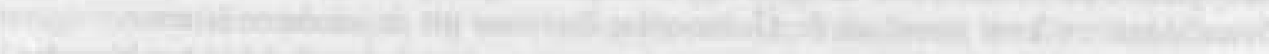

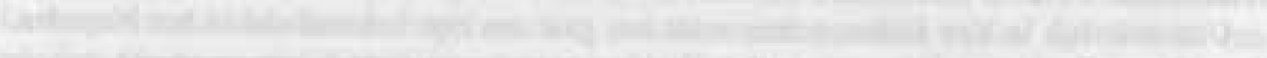
Thent

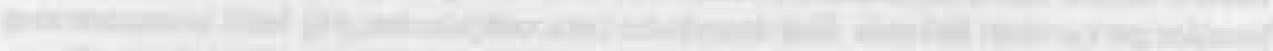

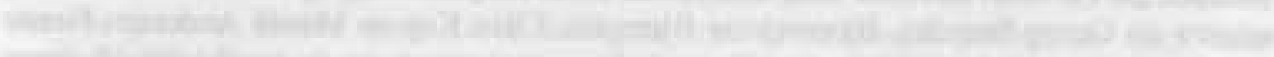

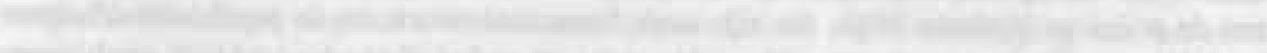
H

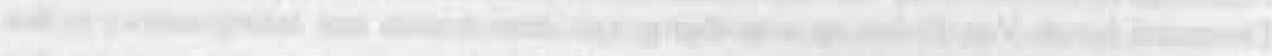
(1)

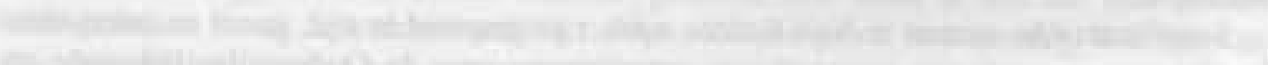

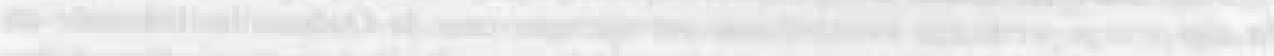
-

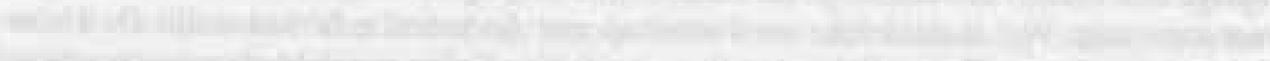

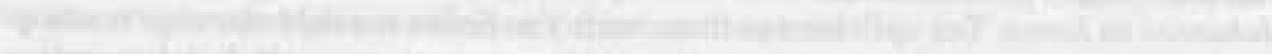

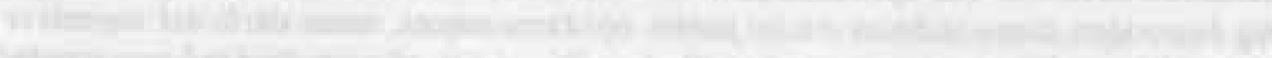
-

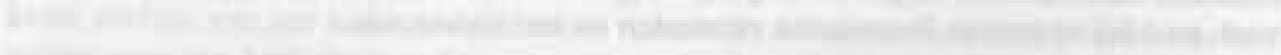
10

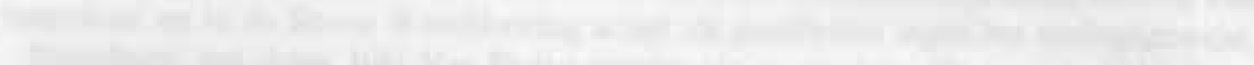




\section{Hoofdstuk V}

\section{Vlaams Scandinavisme en Stijn Streuvels*}

\section{Inleiding}

"Wat elders reeds banaal geworden is, door tot worgens toe herhaald te zijn, is bij ons soms nog geheel nieuw." Deze verzuchting van de Vlaamse schrijver Em. de Bom in zijn studie over Ibsen (1893) betreft de onbekendheid van de Scandinavische letteren bij het Vlaamse publiek. Terwijl in Nederland en Duitsland die letteren tegen de eeuwwisseling furore maakten, was daarvan in Vlaanderen weinig te merken. Nog achttien jaar na De Bom schrijft zijn landgenoot Julius Persyn in zijn overzicht De Noorweegsche Letterkunde, dat deze bij de Vlamingen vrijwel onbekend is. ${ }^{158}$

De cijfers bevestigen dit beeld. Tot aan de Eerste Wereldoorlog verschenen in Nederland 70 vertalingen van H.C. Andersen in boekvorm, van Fredrika Bremer 31, van Bjømson 30, van Ibsen 14 en van Herman Bang 11. Voor Vlaanderen zijn deze getallen resp. $10,1,3,0$ en 0 . Men kan hiertegen inbrengen dat de Vlaamse uitgeverij nog in statu nascendi verkeerde en dat de Nederlandse uitgaven ook door Vlamingen gelezen zullen zijn. Maar ook het aantal vertalingen en secundaire studies, gepubliceerd in literaire tijdschriften, het letterkundig medium bij uitstek in het toenmalige Vlaanderen, blijft ver achter. Tegenover 150 Andersenvertalingen en -studies en 145 Ibseniana in de Noordnederlandse tijdschriften van vóór 1914 staan er respectievelijk 31 en 12 in de Zuidnederlandse. De eerste Ibsen-opvoering in Nederland vond al plaats in 1880, terwijl een poging van De Bom om in 1892 Een vijand van ' $t$ volk te Antwerpen opgevoerd te krijgen mislukte, doordat de spelers, zoals De Bom schrijft, na drie repetities "moesten bekennen, geen zier te begrijpen van dit, nochtans een der minst diepzinnige werken van Ibsen." Voor Strindberg geldt hetzelfde: de eerste Nederlandstalige Strindbergproduktie werd in Nederland gebracht in 1893, - in Vlaanderen in 1912, en dan nog door een Noordnederlands gezelschap. ${ }^{159}$

Men zou dus verwachten dat wanneer Stijn Streuvels in 1910 en 1911 zijn vertalingen van de Noor Bjømson publiceert, deze in een vacuüm terechtkomen. Toch is dat niet het geval. In het onderstaande wil ik proberen duidelijk te maken hoe zowel Scandinavische 
invloeden op Streuvels' oorspronkelijk werk, als de Scandinavica Streuvelsiana (waartoe behalve de Bjørnsonvertalingen ook bewerkingen en vertalingen van Noordse sagen, mythen en volkssprookjes behoren) ${ }^{160}$, en de receptie daarvan, wel degelijk aansluiten op een Vlaamse verwachtingshorizon. Er is namelijk sprake van een specifieke Zuidnederlandse belangstelling voor Scandinavië, - niet bij het grote publiek maar bij een aanzienlijk aantal voormannen van de Vlaamse Beweging.

\section{2 'Het Noorden' in Vlaanderen}

Het 'Scandinavisme' in kringen van de Vlaamse Beweging was niet primair van literaire, maar meer van algemeen-cultuurpolitieke aard. Het werd gekenmerkt door drie verwante aandachtspunten:

- de Vlaams-Noordse taalverwantschap;

- de Vlaams-Noordse stamverwantschap:

- de voorbeeldfunctie van de Noordse cultuur en taalpolitiek voor Vlaanderen.

Dat een verwante kleine taalgemeenschap, eveneens getroffen door een periode van verval na een groots verleden, in staat was gebleken tot vernieuwing van de taal en tot nieuwe culturele hoogtepunten, inspireerde de Vlaamse emancipatoren. In hun strijd tegen het decadente Romaanse Zuiden gold het 'hoge Noorden' letterlijk als het nec plus ultra. Opvallend is dat de elkaar soms fel bestrijdende voormannen van de Vlaamse Beweging in dezen sterk overeenstemmen.

\section{I De liberale kring}

Aanvankelijk was het 'Scandinavisme' in Vlaanderen vooral een aangelegenheid van de liberale flaminganten met hun romantische filologische aandacht voor aan Vlaanderen verwante taalgemeenschappen. De vader van de Vlaamse Beweging, Jan Frans Willems, plaatst als motto boven zijn programmatische verhandeling Over den oorsprong. den Aert, en de Natuerlyke Vorming der Nederduitsche Tael een Oudnoords citaat uit de Konungs Skuggsjá over het belang van het leren van de moedertaal, en vergelijkt in het stuk zelf onder meer de Scandinavische en Nederlandse morfologie. Zijn bibliotheek telde dan ook tientallen originele Scandinavische werken, vooral sagen-edities maar ook modeme literatuur, alsmede woordenboeken en grammatica's. ${ }^{161}$

Was Willems' interesse nog betrekkelijk passief, een actieve studie van de taalverwantschap werd geleverd door de Gentse taalkundige Pierre Lebrocquy. In zijn Analogies Linguistiques (1845) toonde deze aan de hand van Deense, Zweedse en IJslandse voorbeelden en teksten, die hij ook in het Nederlands vertaalde, uitvoerig aan hoezeer de Scandinavische talen dichterbij het Vlaams. Nederlands en Nederduits liggen dan bij het Hoogduits. Lebrocquy beperkte zich niet tot de taalkunde: in De Broederhand. Tijdschrift voor Hoogduitsche. Nederduitsche en Noordsche letterkunde leverde hij een vertaling van het officieuze Deensch volkslied over de onversaagde koning Christian IV, symbool van een groots verleden. ${ }^{162}$ 
Genoemd tijdschrift was opgericht door Lebrocquys vriend Victor-Hubert Delecourt. Deze bestudeerde niet alleen de taalverwantschap, maar trachtte zelfs door spellingvoorschriften meer toenadering te creëren tussen het Vlaams, Nederlands en Nederduits. Zeker stond hem hierbij de eenheid-in-verscheidenheid der Scandinavische talen voor ogen. Hij leerde zichzelf Deens en vertaalde naast werk van Andersen een toneelstuk van de Deense romanticus Oehlenschläger. Als redacteur van De Broederhand nam hij vertalingen op van Oudnoordse sagen, van Oehlenschläger, diens Zweedse pendant Tegnér, en Andersen. Deze keus is niet toevallig: Oehlenschläger en Tegnér zochten als eersten hun inspiratie in de Oudnoordse sagenwereld en de middeleeuwse glorietijd der Noordse rijken, terwijl Andersen had bewezen hoe een kleine natie auteurs van wereldformaat kan opleveren. ${ }^{163}$

Oehlenschläger en Andersen waren favoriet: vertalingen van deze twee verschenen behalve van Delecourt ook van andere bekende maar zeer uiteenlopende flaminganten als K.F. Stallaert, Frans Rens, J. Nolet de Brauwere van Steeland, Ph. Blommaert, J.F.J. Heremans en C.J. Hansen. Oehlenschlägers populariteit culmineerde in diens benoeming tot erelid van het Brusselsch Tael- en Letterkundig Genootschap in 1842. De oorkonde werd hem overgebracht door de dichter Jan Nolet de Brauwere van Steeland, die hierover bericht in Een reisje in het Noorden (1842). De nationaalromanticus Nolet, een uitgesproken tegenstander van Delecourts spellingsideeën, waarover hij een spottend pamflet schreef, deelde toch diens sympathie voor Oehlenschläger, een literair voorman zoals de Vlamingen zo node misten. Vol bewondering schrijft hij over de literaire vorming van zelfs de eenvoudige Denen. Nolet, die in de kunst de synthese bepleitte van de fantasie der Noordse romantiek en de vormschoonheid der klassieke cultuur, gaf de Vlamingen daarvan ettelijke voorbeelden met zijn berijmde bewerkingen van sprookjes van Andersen. ${ }^{164}$

De Gentse filoloog Blommaert zette in zijn Aloude geschiedenis der Belgen of Nederduitschers (1849) een vaag idee uiteen over een verdedigingsverdrag tussen de Nederduitse volken "van Belt tot Noorderzee", om het geweld van grote volken (lees: de Fransen) te kunnen weerstaan. Dit verdrag zou moreel moeten worden versterkt door eigen lettervruchten. Dat Blommaert zich bij deze ideeën liet inspireren door de volkeren aan gene zijde van de Belt is wel zeker: behalve Oehlenschläger vertaalde hij ook uit de Edda, en hij bezat een twintigtal historische en filologische werken uit en over het Noorden, inspiratiebron voor zijn eigen activiteiten rond het Middelnederlands. ${ }^{165}$

Een ander vooraanstaand filoloog, J.F.J. Heremans, kritiseerde in het door hem opgerichte tijdschrift met de symbolische naam Het Taelverhond het immorele karakter van de moderne Franse literatuur, en het lijdt geen twijfel dat hij in hetzelfde blad zijn Andersen-bewerkingen (1847-1852, later uitgebreid tot de eerste Vlaamse Andersen-uitgave in bockvorm, 1857), als positief tegenwicht heeft willen doen gelden. ${ }^{166}$

Het was echter de Antwerpse publicist en latere stadsbibliothecaris Constant Jacob Hansen, die zich zou ontpoppen tot dè voorvechter van het Noorden in Vlaanderen. Hansen, telg uit een Deens geslacht, werd vooral bekend als vader van de 'Aldietsche Beweging , die eigenlijk maar één enthousiast aanhanger kende: Hansen zelf. Zijn ideaal was de versmelting van Vlaams. Nederlands en Nederduits door één gemeenschappelijke spelling. Zijn radicale voorstellen in deze richting kregen zware kritiek, onder andere van 
Nolet en Heremans. Maar Hansen produceerde in zijn Aldietsche spelling ettelijke proeven van vertaling, niet alleen van Nederduitse, maar ook van Scandinavische schrijvers. In zijn Reisbrieven uit Dietschland en Denemark (1860) schrijft hij:

De Vlaming moet zijn dietsche Moedertale tot de rang te verheffen die haar toekomt; zij is niet alleen de weg tot vrijheid, maar ook van eigenwaarde en nationaliteit. Derhalve is van den Suiden niets, maar alles van ons selven en den Noorden te verwachten. Derhalve, en om samen behouden te blijven, moet Vlaamsch op Hollandsch, Nederlandsch op Nederduitsch, en het dryledige Dietsch op Duitsch en Noordsch steunen [...] Mijn hoofddoel is [...] de Opwekking, in breederen sin, des germaanschen volksgeestes in Vlaamsch-Belgien [en] de Voorstelling des Noordschen geestes in al zijner edele Manhaftigheid.

Hansen publiceert de eerste bloemlezing van Scandinavische literatuur in de Nederlanden, Noordsche letteren (1860), met een keuze die in hoge mate is bepaald door zijn cultuurpolitieke opvattingen: Oehlenschläger krijgt een ruime plaats, en titels als Des Noordens Eenheid (Ploug) en De Moedertale (Grundtvig) zijn veelzeggend.

Al werd Hansen als een zonderling gezien, zijn enthousiasme droeg hij over op jongeren uit zijn omgangskring: de gezusters Loveling en Pol de Mont. De Lovelings lazen de Scandinavische talen, vertaalden uit het Deens en waren grote bewonderaars van Andersen, aan wie Virginie Loveling in 1874 een studie wijdde. ${ }^{167}$

\subsection{De internationalistische kring}

De persoon van Pol de Mont illustreert inzake de belangstelling voor het Noorden een verschuiving van een nationalistische in een meer internationalistische en esthetische richting. Aanvankelijk maakt De Mont in navolging van Hansen bewerkingen van Nederduitse èn Scandinavische schrijvers als Andersen en Bjørnson. Hij bewondert Oehlenschlikger en schrijft oorspronkelijke gedichten met titels als Wikingslied, Een Noordsche jongen en Goedroen.

Door de Europese successen van Ibsen en Bjørnson, Drachmann en Jacobsen komt De Mont echter tot het besef dat de nationale letterkunde alleen kan doorbreken wanneer die aansluit bij internationale literaire stromingen. Hij correspondeert hierover met Georg Brandes, de Deense auteur van het gezaghebbende Hauptströmungen der Literatur des neunzehnten Jahrhunderts en de geestelijke vader van de vernieuwing der Scandinavische letteren.

Deze correspondentie resulteert onder andere in Brandes' bezoek aan Vlaanderen in 1892. Brandes ontmoet de leden van het Taalverbond, de 'anti-academie' van de internationalistisch georiënteerde jongeren, en spreekt er over Ibsen met De Bom, die een jaar later zijn Ibsenboek zal publiceren. De Noorse dramaturg werd door De Bom, Van de Woestijne en Vermeylen zeer gewaardeerd. "Al de problemen die de Van-Nu-en-Straksers trachtten op te lossen of zelfs te begrijpen, op ethisch, politiek en sociaal gebied, troffen wij in zijn werk aan", schrijft Van de Woestijne. Vermeylens "Wij willen Vla- 


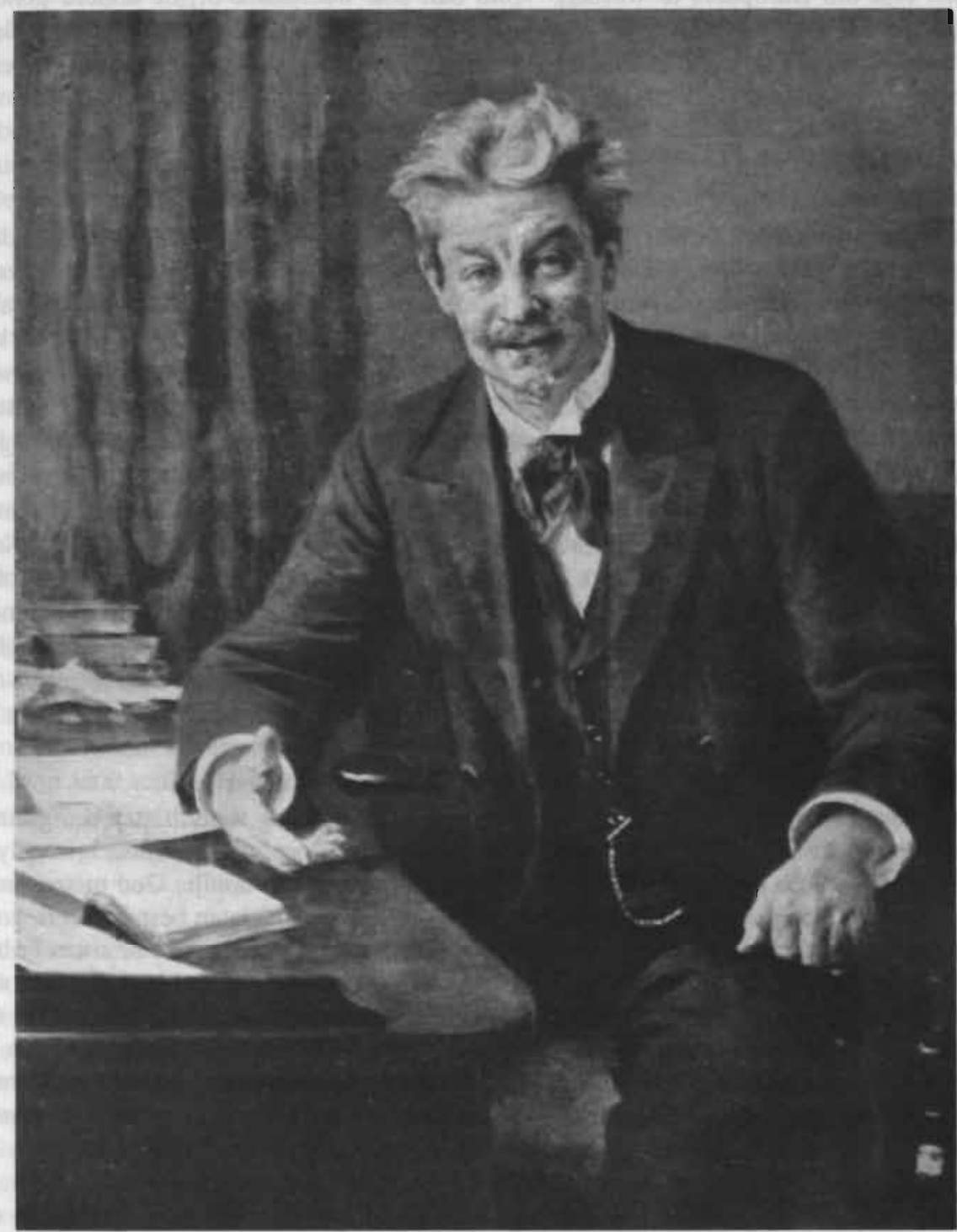

Afbeelding 10. Georg Brandes (1842-1927). de vader van de 'Moderne Doorbraak' in de Scandinavische letteren, werd in 1892 door Vlaamse schrijvers naar België uitgenodigd. Zijn werk opende Streuvels de ogen voor de wereldliteratuur. Zie over zijn relatie tot Van Eeden het vorige hoofdstuk. Schilderij door P.S. Krøyer, 1900. (Museum 'Michael og Anna Anchers Hus'. Skagen). 


\section{Hoofdstuk $V$}

mingen zijn om Europeërs te worden" vond dan ook weerklank bij de andere genoemden, en in 1896 halen Van de Woestijne en De Bom een nieuwe medewerker binnen voor Van Nu en Straks naar aanleiding van diens Noorsche melodieën: Stijn Streuvels. ${ }^{168}$

\subsection{De katholieke kring}

Met Streuvels doet een auteur uit een uitgesproken katholiek milieu zijn intrede in de kringen der Vlaamse 'scandinavisten'. Met uitzondering van De Mont (die datzelfde katholieke milieu al vroeg verliet) waren alle bovengenoemden uit liberale of socialistische, soms zelfs antiklerikale hoek afkomstig. Toch bestond ook in katholieke kring belangstelling voor het Noorden, zij het dat deze in één opzicht afweek. De verwantschap van taal en stam werd ook door de katholieken benadrukt, maar de culturele voorbeeldfunctie van het eigentijdse Scandinavië was beperkt: de Lutherse staatsgodsdienst en het modernisme van Brandes cum suis waren doomen in het katholicke oog.

Streuvels' oom Guido Gezelle las de Scandinavische talen en stimuleerde aan het seminarie te Roeselare de zendingsdrang onder zijn leerlingen door ze die talen te leren. Vlaamse priesters speelden namelijk een belangrijke rol bij het herstel van de katholieke kerk in Noorwegen na 1845. In 1859 werd Gezelle benoemd tot 'Lid van 't Yslandsch Lettergezelschap te Reykjawyk en te Koopenhaven', en als zodanig op het titelblad aangeduid, publiceerde hij in 1860 Een Noordsch en Vlaemsch messehoekske, een volksmis met Noorse tekst annex zijn Vlaamse vertaling. In zijn inleiding zet Gezelle het doel van de uitgave uiteen:

Daer bestaen, myns wetens, geen goede Vlaemsche boeken nog, waerin men eenigszins $k$ an met de Noordsche talen gemeens worden $[\ldots]$ wil-der nogthans ievers, ' $t$ is gelyk wie die Vlaemsch kan, met eigen oogen zien welken band van familie God tussen ons, Katholyke Vlamingen, en onze afgedoolde Noordsche broeders, laten bestaen heeft, zoo leze hy en oordeele in de volgende bladzyden [...] daer hoog in 't noorden, zitten er by geheele volkeren, van onze stam en van onze tale, in de donkerste streken der natuer en in de uiterste duisternissen van kettersche, ja afgodsdienstige dwalingen te leven en te sterven $[\ldots]$ Noordewaerts roepen wy dan ook, en dat in de naem niet alleenelyk van ' $t$ Geloove in God en in zyne H. Kerke, van de Liefde tot onzen evenkersten en tot onzen evenmensch, maer, daer by nog, in name van de tale waerin wy geboren zyn en waerdoor wy - ' $t$ Zuiden niet - maer ' $t$ Noorden toebehoren.

Onder Gezelles 'Scandinavische' leerlingen waren Hugo Verriest en Eugène van Oye, die nog in 1886 zijn oude leermeester te hulp riep bij wat de eerste Vlaamse Oehlenschlägervertaling in boekvorm zou worden. Ook in zijn oorspronkelijk werk gebruikte Van Oye Noordgermaanse stof, - in 1909 schreef hij een drama Balder's Dood. Het Germaanse kreeg hem op den duur zelfs zo in de ban, dat hij zich in de Eerste Wereldoorlog aansloot bij het activistische Jong Vlaanderen, dat streefde naar een Vlaams koninkrijk onder Duitse heerschappij, als "grenswacht van 't machtig Germanendom." 169 
Verriests leerling Albrecht Rodenbach, de jonggestorven leider der 'blauwvoeterij", was de dichter van het drama Gudrun (1882). Veel in dit stuk is ontleend aan Wagners Ring des Nibelungen, maar Rodenbach verplaatst de handeling naar het gebied 'rond de Noordzee', laat er vikingen in rondlopen en er Noordgermaanse goden in aanroepen. De symboliek laat aan duidelijkheid niets te wensen over: het stuk is de verbeelding van de Vlaamse strijd voor wederopstanding. ${ }^{170}$

De tegenstelling Germaans-Romaans kreeg in katholieke kring de extra dimensie van de tegenstelling tussen het gezonde landleven tegenover het ketterse leven in de grote stad. In hun voorkeur voor de heimatliteratuur moesten de katholieken echter niet veel hebben van de Scandinavische modernisten: de kritiek oordeelde de werken van Ibsen "een mengsel van kille liefdeloosheid en anarchistisch liberalisme", Strindberg "in hooge mate onevenwichtig, dikwijls zeer rauw", Jacobsen "buiten positieve moraal en godsdienst", etcetera. Geen wonder dat de Deense bekeerling Johannes Jørgensen met gejuich werd begroet in katholieke kring: hij is de enige Scandinaviër die zich op een brede populariteit in Vlaanderen mocht verheugen. Jørgensen, oorspronkelijk een der trouwste aanhangers van Brandes, was een belangrijk vernieuwer van de Deense poëzie, doch zijn gedichten werden nauwelijks vertaald, - wel zijn hagiografieën van Franciscus van Assisi en anderen. ${ }^{171}$

Een van Jørgensens actiefste vertalers was Maria Elisa Belpaire, motor achter het gezaghebbende Dietsche Warande \& Belfort. Katholieke auteurs waren in het Noorden natuurlijk dun gezaaid, en dus was het zaak die schrijvers te vinden van wie het werk als 'katholiek-naar-de-geest' kon worden ingelijfd. De boerennovellen van de Noor Bjørnstjeme Bjørnson waren voor Belpaire zulk werk. Zij vertaalde Synnфve Solbakken en wijdde in haar studie Het landleven in de letterkunde der XIXe eeuw een hoofdstuk aan de auteur. Bjørnson, die in zijn latere leven en werk het christendom afzwoer, wordt door haar geschilderd als representant van zijn volk: verdoold, maar in de grond toch godsdienstig:

Het Noorsche volk werd, men weet het, door een waar bedrog van zijin geloof heroofd. Ook zijn er vele zielen te goeder trouw en innig vroom gestemd. Tal van gebruiken herinneren aan 't katholicisme [...] Bjömson laat zijn volle recht aan 't godsdienstig gevoel van den Noorschen boer, en uit zijne boeken leeren wij eene kloeke landelijke bevolking kennen, wier eenvoudige zeden opwegen tegen den verpestenden invloed eener bedorven literatuur, tegen de losbandigheid, die in de groote steden heerscht. Gaame zien wij deze hulde brengen aan de vrome inborst van den Noorschen boer door cen schrijver, die, naast Ibsen, de meest gewaagde, de gevaarlijkste stelsels verdedigd heeft. $^{172}$

Geen wonder dat de belangstelling der katholieken vooral uitging naar Noorwegen, het meest landelijke en meest oorspronkelijk 'Germaanse' van de Noordse landen. De internationale erkenning van de Noorse heimatliteratuur, de successen van de Noorse taalparticularisten (die streden tegen de sterk verdeenste cultuurtaal) en de Noorse onafhankelijkheidsstrijd die in 1905 met succes werd bekroond (en waarin Bjørnson een hoofurol speelde), - dat alles moest wel aans!aan bij de Zuidgermaanse broeders, wier emancipa- 


\section{Hoofdstuk $V$}

tiestrijd zo veel moeizamer verliep. De reisverslagen Naar en in Noorwegen (1900) en Naar Noorwegen (1909), van respectievelijk de heimatromancier Van de Wattyne en de kanunnik Lescouhier, getuigen van deze belangstelling. In zijn studie Noorsch en Vlaamsch (1900) toonde de schrijver Omer Wattez, auteur van boerennovellen en de bundel Germaansche beelden uit de heldensagen, de sterke verwantschap van de Vlaamse en Noorse woordenschat aan met zijn vertaling van een fragment uit Bjømsons boerennovelle Arne. En Julius Persyn, jarenlang hoofdredacteur van Dietsche Warande \& Belfort, gaf met zijn boek De Noorweegsche letterkunde (1911) een gids in katholieke geest voor "een familiebezoek bij die Germaansche broeders [...] om onze leesgrage menschen alhier tot hun aller voordeel eens naar elders dan naar Parijs te oriënteeren." ${ }^{173}$

\section{Stijn Streuvels}

In 1884 wordt de dan dertienjarige Frank Lateur, de latere Stijn Streuvels, ingeschreven als inteme leerling van het St. Jan Berchmans Instituut te Avelgem. De strenge sfeer daar bevalt hem slecht en zijn enige toevlucht is de literatuur: hij leest stiekem rijp en groen, en groot is zijn ontsteltenis als een surveillant een boek over schipbreukelingen op Spitsbergen uit zijn handen rukt en in de kachel gooit: nu zal hij nooit de afloop te weten komen! Gelukkig zijn er meer boeken over en uit het verre Noorden. Een andere surveillant houdt een voordracht over de Vlaamse geschiedenis en de Germaanse oudheid, en hierdoor krijgt dat Noorden al gauw een nieuwe dimensie voor de jonge Lateur:

't Noorden! dat woord, ' $t$ is alsof het eene tooverij inhield. Wat een wereld van geheimzinnigheid wekt het gedacht aan verre landen die in gedurige donkerheid gedompeld liggen en waar de natuur in heel haar woestheid er uitziet alsof de reuzen er nog maar rechts een geweldigen sabbath hadden gevierd [...] Toen ik er eerst van gehoord had - als jongen - wilde ik dat land zien. Maar natuurlijk, dat ging niet! En dan vluchtte ik er maar heen met mijn gedachten of liever: ik haalde het Noorden naar mij toe [...]. Ik bemachtigde de Noorsche sagen en heldendichten, ik nam kennis van de Edda $\mathrm{s}$. Nibelungen. Kalewala, Fritjofsage... en mijn tooverwereld ging aan ' $t$ roeren, was bewoond, leefde... en welk een leven! - Voor mij werd dit alles het oerbestaan, de corsprong, de absolute essentie van het germanendom in zijn volle uiting van kracht en zuiverheid, en gelijk men de eigenschappen van 't germaansche ras ziet verflauwen, naarmate men meer naar 't zuiden nadert, wilde ik dat de zuiverheid van ons ras en heel het heldentijdperk in zijn volle schoonheid te zoeken was... in het uiterste Noorden! Al dien kant moest ik de oorsprong van ons ras gaan zoeken. ${ }^{174}$

Onverdeeld enthousiasme dus over de stamverwantschap, geheel volgens bovengeschetste traditie. Maar anderzijds wijkt Streuvels ook af van die traditie. Hij is geboeid door de duistere natuur, die oom Guido Gezelle nog als symbool van de ketterse dwalingen zag. Bovendien brengt zijn schoolvriend Oskar Debeurme hem in aanraking met de door de katholieke kritiek zo verfoeide realistisch-naturalistische Scandinavische letteren. De Hauptströmungen van Brandes openen hem de ogen voor de wereldliteratuur, en thuis hangt hij het portret van Ibsen aan de muur. Naast Ibsen en Bjomson leest hij de Denen 
Bang, Drachmann en Jacobsen en de Noren Garborg en Kielland, auteurs van de zogenaamde 'modeme doorbraak', die althans een tijd lang ingingen op Brandes' eis, "problemen ter discussie te stellen". ${ }^{175}$

Streuvels' eerste gepubliceerde pennevruchten dragen het stempel van de kennismaking met deze schrijvers, deels in thematisch, deels in esthetisch opzicht. In zijn herinneringen schrijft hij hoe hij bewust alvorens te gaan schrijven heeft gezocht naar het onderscheid tussen de levende en dode schoonheid, en hoe hij het algemeen-menselijke vond bij de 'Noren' (lees: Scandinaviërs). Bij wijze van vingeroefening vertaalde hij het werk van die auteurs, - naar zijn zeggen na afloop het geschrevene zorgvuldig verscheurend om beïnvloeding te voorkomen. Tot zijn allereerste verhalen behoren de schetsen Bleekblomke en Sinte-Klaas (1896), voorzien van motto's van respectievelijk Ibsen en Drachmann. Het Ibsen-motto: "Ach, wir sind Erdenmenschen, - weisst Du!", dient uitsluitend ter uitdrukking van de centrale noodlotsgedachte in het verhaal over de verloren paradijs van de kindertijd, - het thema als zodanig is moeilijk typisch Ibseniaans te noemen, evenmin als de impressionistische stijl. Anders ligt het met Sinte-Klaas. Het Drachmanncitaat "Zij stierf en werd begraven" illustreen het noodlot van de door uitputting gevelde arbeidersvrouw, wier altijd dronken man tijdens zijn werk als gastarbeider in het verre Frankrijk verongelukt. Drachmanns sympathie voor het gewone volk, waarvan de natuurlijke levenswijze door de moderne industriële ontwikkelingen werd verstoord, klinkt in dit verhaal door. Ook de naturalistische stijl sluit aan bij die van de jonge Drachmann. Volgens Streuvels-kenner Demedts is voorts een ander vroeg verhaal "Nen avond in de Meie (1895), over het onverklaarbare mystieke doodsverlangen van een kind, qua symboliek verwant met "de neo-romantiek van Jacobsen".

Door toedoen van Debeurme had Streuvels ook de muziek van Grieg leren kennen, en door deze klanken werd hij geïnspireerd tot het schrijven van de impressionistische Noorsche melodieën (1896). Deze stemmingsstukken zonder intrige, met hun evocatie van de geheimzinnige Noordse nacht, zijn door de latere kritiek als on-Streuveliaans beoordeeld, maar ze bewogen Van de Woestijne en De Bom ertoe, de hun tot dan volkomen onbekende Streuvels in de kring van Van Nu en Straks te halen. ${ }^{176}$

Streuvels had de Scandinaviërs leren kennen in Duitse vertaling. Maar in 1899 vraagt hij De Bom om toezending van "een Noorse Spraakkunst (of ' $t$ beste middel gauw Noors en Deens te lezen)". Door de buitenwacht is er wel aan getwijfeld of Streuvels ooit Scandinaviërs in het origineel heeft gelezen. Op een interview-vraag dienaangaande van Karel Jonckheere in 1933 reageerde Streuvels echter verontwaardigd: "lk lees wèl Noorsch, Zweedsch, Deensch [...]".

Wie had gelijk? Streuvels" nagelaten boekerij telt onder de circa 6500 banden 136 Scandinavica: 77 delen moderne literatuur, 28 delen sagen, mythen en volkssprookjes, 7 delen letterkundige geschiedenis, 15 historisch-topografische werken, 6 lexicografische en/of grammaticale werken en 3 delen diversen. Hieronder zijn niet meer dan een zevental originele werken, waaronder Bjornsons Fortallinger en Snorre Sturlasons Kongesagaer. De literaire werken bestaan voomamelijk uit Duitse vertalingen.

Toch moet men niet te snel zijn met conclusies. Ten eerste is van Streuvels bekend dat hij eenmaal gelezen boeken vaak inruilde voor nieuwe: ten tweede is zijn bibliotheek in beide wereldoorlogen geplunderd, zodat de nagelaten boeken niet noodzakelijk repre- 
sentatief zijn voor wat hij heeft gelezen. Zo ontbreken de bovengenoemde Bang. Drachmann, Jacobsen, Garborg en Kielland. En ten slotte is er een middel om te controleren of hij de Scandinavische talen las: een vergelijking van zijn Bjømson-vertalingen met het origineel. En daaruit blijkt dat Streuvels rechtstreeks uit het Noors vertaalde, zoals we in de volgende paragraaf zullen zien. ${ }^{177}$

\subsection{De Bjornsonvertalingen}

Met zijn voorkeur voor Bjørnson lijkt Streuvels op het eerste gezicht geheel aan te sluiten bij de katholieke traditie. Van de 77 delen moderne Noordse literatuur in zijn nalatenschap zijn er liefst 28 van Bjømson. Alleen de 13 delen werken van Selma Lagerlöf kunnen zich hiermee enigszins meten; Andersen en Strindberg (beide 6), Ibsen en Hamsun (5) steken er mager bij af. Bjømson is dan ook in meerdere opzichten een voorbeeld geweest voor Streuvels, die beschrijft hoe de landelijke novellen van deze Noor hem doordrongen van de deerlijkheid van zijn eerste probeersels, en hoe een werk van Bjømson in Duitse vertaling hem zo bekoorde, dat hij de oorspronkelijke versie wilde kennen en Noors leerde. Door Bjørnson kreeg hij ook een andere kijk op het Noorden:

Toen heb ik natuurlijk kennis genomen met de modeme Noorsche letterkunde, en alzoo ook met Björnsön [sic]. Dat was voor mij een heel nieuwe veropenbaring! [...] 't Noorden had voor mij ineens een heel ander uitzicht en gedaante - een andere ziel! Het heldentijdperk was uit, en over heel die woestheid kwam er een waas van warmte; over de hoogvlakten, over de stille meren hing er een zachte, zoele lucht - en daarin leefden, niet de geweldenaars die met rotsblokken vechten, maar een zwijgend, diepdenkend en toch zoo levensblije [sic] volk - en dat volk leerde ik kennen door Bjömson [...] Hij wil de taal ophelpen en de Noorsche kunst in eere herstellen [...] een zoon van zijn volk; zoon van den boer, boer zelf, in de volle natuur gewonnen, erin levend, het leven zijner medemenschen, vertrouwd met hun aard, hun gesteltenis, hun gebruiken, hun begeenten. Door zijne geboorte en gesteltenis was hij in de gunstige omstandigheden om de ziel van zijn volk te begrijpen $[\ldots]$ We hebben hier te doen met een volbloed kunstenaar, iemand van 't eigene ras.

Volle natuur - ziel - volk - eigen taal en kunst - 't eigene ras: al deze concepten passen binnen de Vlaamse, vooral de katholieke visie op het Noorden, in casu Noorwegen.

Van die katholieke visie wijkt Streuvels anderzijds in menig opzicht flink af. Zo veroordeelt hij het Lutherdom niet: hij bewondert het in dit verband zelfs: "De bijbel en de strenge leer van Luther heeft die geesten [= Noren, DG] stevig en van een stuk gemaakt: sober zijn ze van gebaar, karig van woorden." Verder staat hij onverdeeld achter Bjornsons werk, ook dat uit diens antiklerikale periode: terwijl Vlaanderen, schrijft Streuvels, nog versmoord lag onder romantische verhalen zonder letterkundige waarde, schonken Ibsen en Bjørnson "aan hun land een nieuwe, eene eigene letterkunde - drama's en verhalen die van heel de wereld gekend zijn [...] zij schiepen niets dan schoonheid. ${ }^{1178}$ 


\section{STREUVELSVOLKSBOEKEN

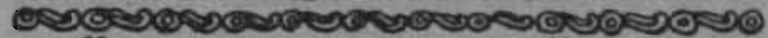
BJÖRNSTJERNE BJÖRNSON EEN VROOLUKEKNAAP

Uit fet Noarsch vertacld STUN STREUVELS

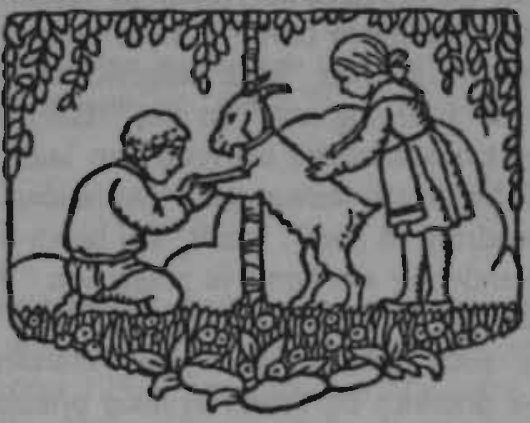

\section{mer Perde herziene uitsarif Uifgave van d:LANNOO teTfielt. len jare O.H= 1925}

Afbeelding 11. Titelblad van de đerde uitgave van 'Een vroolijke knaap' (1925). (Koninklijke Bibliotheek Albert I, Brussel). 


\section{Hoofdstuk $V$}

In 1910 en 1911 verschijnen respectievelijk Streuvels' Bjørnsonvertalingen Kleine Verhalen en Het Bruidslied, in de goedkope Vlaamse reeks Duimpjesuitgaven, die het gewone katholieke volk betaalbare en moreel verantwoorde lectuur wilde voorzetten. Niet voor niets verschenen juist in deze reeks Streuvels' vertalingen van zowel Bjørnson als Tolstoi, twee exemplarische ethische volksopvoeders. Het laatste verhaal uit de eerste bundel, Een vroolijke knaap, werd in 1919 en 1925 afzonderlijk uitgegeven; de tweede bundel werd, aangevuld met enkele korte verhalen uit de eerste, opnieuw uitgegeven in 1930. De uitgaven van 1910, 1925 en 1930 verschenen in afzonderlijke Vlaamse en Nederlandse edities. ${ }^{179}$

Vergelijking van de vertaling met de Noorse brontekst en de in Streuvels' bezit zijnde Duitse vertalingen van Denhardt, Lange en Lobedanz leert nu, dat Streuvels weliswaar met een scheef oog naar de Duitse teksten heeft gekeken als hij inhoudelijk niet uit het Noors kwam, maar dat hij als basis wel degelijk de Noorse tekst heeft gebruikt, die hij veel getrouwer volgt dan zijn Duitse voorgangers. Negatief blijkt dit uit het feit dat zijn vertaling faux amis bevat die in de Duitse tekst ontbreken; positief uit zijn pogingen Bjømsons stilistische vernieuwingen getrouw weer te geven, anders dan zijn Duitse voorgangers. In zijn voorwoord had hij gewezen op de onmogelijkheid, de bondigheid van uitdrukking in de taal der zwijgzame Noren in vertaling te handhaven, maar in vergelijking met de Duitse vertalingen bevat de zijne nauwelijks aanvullingen: "høi og alvorlig" wordt "hoog en emstig", niet "hoch aufgerichtet und mit feierlichem Emst"; "Er der ellers noget?" wordt "Is er nog iets?" en niet "Hast du sonst noch etwas auf dem Herzen?". Ook Bjømsons karakteristieke eenvoud van taal, herhaling en asyndetische nevenschikking handhaaft Streuvels nauwgezet: "'Du holder du godt, du Thord', sagde presten, han så ingen forandring på ham", wordt "Gij houdt u goed, gij Thord, zegde de priester, hij zag geene verandering aan hem" in plaats van "'Du hältst dich gut, Thord', sagte der Pfarrer, der keine Veränderung an ihm wahrnahm / 'Du konservirst dich gut', sagte der Prediger, als er auch nicht die geringste Veränderung an ihm wahrnehmen konnte." Wel is de Noorse dominee bij Streuvels maar priester geworden... ${ }^{180}$

Gezien Streuvels waardering voor Bjwrnsons persoonlijke en literaire kwaliteiten en thematische keuzes dringt de vraag zich op, of zijn eigen werk door deze Noorse auteur is beïnvloed. Streuvels zelf heeft die invloed altijd nadrukkelijk ontkend ${ }^{181}$. en op het eerste gezicht lijken de verschillen met Bjømson groot: de natuur is in het werk van de Noor niet in de eerste plaats dreigend als bij Streuvels, maar minstens zo vaak idyllisch. Het noodlot bij Bjørnson is niet van een Streuveliaanse zinloosheid, maar heeft meestal een louterende werking op de protagonist. Bovendien verschilt Streuvels' overvloedige beschrijvingskunst sterk van de bondigheid van de Noor.

Toch zijn er Bjørnsoniaanse trekken te constateren, en wel in Streuvels' meesterwerk De Vlaschaard (1907), geschreven in de tijd dat hij met Bjørnson bezig was. De feestelijke groepsscènes in de hoofdstukken 'De wiedsters' en 'De slijting'; het gebruik van volksliedjes ter onderbreking en ondersteuning van het proza; de hoogmoed en onverzettelijkheid van de grootste boer uit de omgeving: de bondige stijl in diens replieken; het generatieconflict met de zoon die moderner landbouwmethoden voorstaat; het sociale verschil tussen de gelieven; de onzekerheid van de afgewezen Schellebelle; Vermeulens berouw en loutering na het bijna-doodslaan van Louis; en natuurlijk de allesoverheersen- 
de natuur: - dat alles doet denken aan scènes en motieven uit bijvoorbeeld Synnøve Solbakken en de door Streuvels vertaalde novellen Een vroolijke knaap en De vader (Thord Oeveraas en diens zoon). De kritiek had de thematische verwantschap overigens al onderkend. Nieuwe Wegen, 'letterkundig maandschrift voor het volk', schrijft in 1911 naar aanleiding van de Kleine Verhalen: "Lijk Bjömsons helden draagt Streuvels in hem een hartstochtelijke liefde voor het 'land' met zijn ellende, zijn nijvere gedoe en stralende zegen." 182

Voor zover de receptie valt te reconstrueren aan de hand van de weinige achterhaalbare kritieken, had men niet veel oog voor Streuvels' esthetisch streven met zijn vertalingen, en bleef de aandacht gevangen door de thematiek en de stamverwantschap met de Noren. Nieuwe Wegen spreekt van "een atavisch verwantschap", en bij de heruitgave van Een vroolijke knaap schrijft de katholieke jeugdleider en heimatromancier Emest van der Hallen:

Een boek dat alleszins de mooie vertaling van Streuvels waard is: de geest van het fantastische Noorden leeft erin, grootsch, somber, ruw en geweldig, soms echter idyllistisch en bekoorlijk-frisch. Er is iets in die literatuur dat ons aantrekt: vele trekken heeft ons Vlaamsche temperament gemeen met den Noorling; het volk is er evenals het onze eenvoudig en vroom, doch wat ruw en zonder de decadentie welke de gerafineerde overbeschaving bij andere volkeren meebrengt: heel het boek is de synthese van den Noorschen geest die ons in de kunst zoo lief is. ${ }^{183}$

\subsection{De 'sagen-bewerkingen'}

$\mathrm{Na}$ de Bjømson-bewerkingen houdt Streuvels zich lange tijd verre van Scandinavië. Pas in 1928 neemt hij de draad weer op met het schrijven van De oude Wiking (gepubliceerd 1929 in De Stem, in boekvorm 1931), gevolgd door IJslandse Godensagen (in diverse tijdschriften en in boekvorm, 1933) en Sagen uit het Hooge Noorden (1934).

Deze publikaties zijn niet zozeer uit artistiek als wel uit (cultuur)politiek oogpunt interessant. Hoewel Streuvels ze respectievelijk onder eigen naam, een bewerking van zijn hand en opnieuw onder eigen naam publiceerde, zijn het niet meer dan onbewerkte vertalingen uit de tweede hand, namelijk uit het Frans en het Duits. Zelf schrijft hij later over het werk uit deze periode: "Aan oorspronkelijk werk is er stilstand gekomen, uit oorzaak van innerlijke bekommernissen." Ook in minder creatieve dagen moest hij blijven publiceren.

De oude Wiking werd door Streuvels dus als eigen werk gepubliceerd. Het verhaal is een zeer vrije vertolking van het verslag van de Deense kroniekschrijver Saxo Grammaticus over de laatste dagen van de sagenheld Starkadr (Starkadd), die de Vlamingen al vertrouwd was door het gelijknamige succesvolle toneelstuk van Alfred Hegenscheidt (1897). Eerst in 1993 werd bekend dat Streuvels' 'vertolking' in werkelijkheid een vertaling is van een hoofdstuk uit Le livre des Vikings van Ch. Guyot en E. Wegener ${ }^{184}$ Toch proeft men Streuvels' geestverwantschap met het thema. Met kennelijke sympathie heeft hij gekozen voor het verhaal over de verzwakte maar onverzettelijke held. die alvorens 


\section{Hoofdstuk $V$}

de eigen dood te kiezen zich nog eenmaal in zijn kampglorie verheft. Sleutelscène is een soort omgekeerde gelijkenis van de barmhartige Samaritaan: het tafereel van de zwaar gewond liggende Starkadr, die alle hulp honend afwijst behalve van de vrije boer: "geen staat is eerlijker dan de uwe, geen mensch is beter dan de zoon van den landbouwer, die den bodem vruchtbaar maakt."

De kritiek oordeelde gunstig over dit werk. In de meest uitvoerige recensie, van Anton van Duinkerken, wijst deze op het heidense element in het werk van de katholiek Streuvels, "de dichter der barbaarsche zielsgesteldheid", die hij vergelijkt met de heidense bekeerling die gelooft wat hem gepredikt wordt maar niettemin zijn barbaarse deugden en zijn ontzag voor de natuurmachten heeft behouden. Dit atavisme was echter geenszins een bezwaar voor de katholieke censuur: ook de kanunnik Arthur Boon, voorzitter van het katholieke Davidsfonds en van de Katholieke Vlaamsche Radio-Omroep, was vol bewondering voor wat hij noemde Streuvels' grootse verwerking van een groot episch gegeven. ${ }^{185}$

Dat bij Streuvels keuze uit de IJslandsche Godensagen en Sagen uit het Hooge Noorden naast oprechte belangstelling ook de populariteit van de thematiek een rol heeft gespeeld, lijkt wel zeker. Het zou echter onjuist zijn, deze populariteit van de 'germanenmythe' met zijn nadruk op de verwantschap van ras, volk en taal en de verbondenheid met de grond (waarbij de Scandinaviërs werden gezien als de meest onbedorven representanten) af te doen als louter kenmerkend voor de nationaalsocialistische Blut-undBodentheorie. Deze is namelijk de politieke aberratie van een in brede conservatiefDuitse kring gangbare opvatting, die reeds uit het Tweede Keizerrijk dateert. De golf van vertaalde Scandinavische heimatliteratuur en van Oudnoordse mythen en sagen op de Duitse markt van deze jaren hangt hiermee zeker samen. ${ }^{186}$

Streuvels was geen nationaalsocialistische Blut-und-Bodenadept ${ }^{187}$, maar het gedachtengoed van de verbondenheid van volk en grond alsmede een sterk Germaanse oriëntatie zijn bij hem onmiskenbaar anwezig. Reeds in de Eerste Wereldoorlog was zijn Duitsvriendelijke houding omstreden. In de jaren twintig bepleitte hij amnestie voor de Vlaamse activisten, en in allerlei publikaties, onder andere in zijn essay Veurne-Ambacht benadrukte hij "dat wij aan die grond vast zijn, dat wij er de vervolmaking van ons hele, eigen wezen in terugvinden".

Het succes van reeksen als Thule: Altnordische Dichtung und Prosa, waarin de Oudnoordse literatuur vrijwel compleet in Duitse vertaling verscheen, en Deutsche Volkheit, moeten aanlokkelijk geleken hebben voor Streuvels: zijn IJslandsche Godensagen zijn grotendeels vertaald uit Thule, en blijkens een mededeling achterin had hij in bewerking de uitgaven IJslandsche Heldensagen, IJslandsche Familiesagen en Het Boek van Njal. - die overigens nooit zijn verschenen. De bibliografie achterin telt 36 titels, waarvan 27 Duitse. Behalve uit Thule had hij voor zijn bundel ook vertaald uit Nordische Mythen und Sagen van de Deense onderzoeker Vilhelm Grønbech, die in de jaren dertig als geen ander het 'germanenbeeld' van de Duitsers heeft bepaald, met zijn nadruk op het rijk Midgaard, waar de mensen eer en geluk beleven zolang ze in het heilig verband van hun sibbe leven, tegenover de Udgaard, waar de ontaarden huizen. ${ }^{188}$

Streuvels begint zijn voorwoord met te wijzen op de Germaanse stamverwantschap en het Oergermaans ontzag voor de natuurkrachten (men proeft de verwantschap met zijn 


\section{STIN STREUVELS}

\section{7}

A
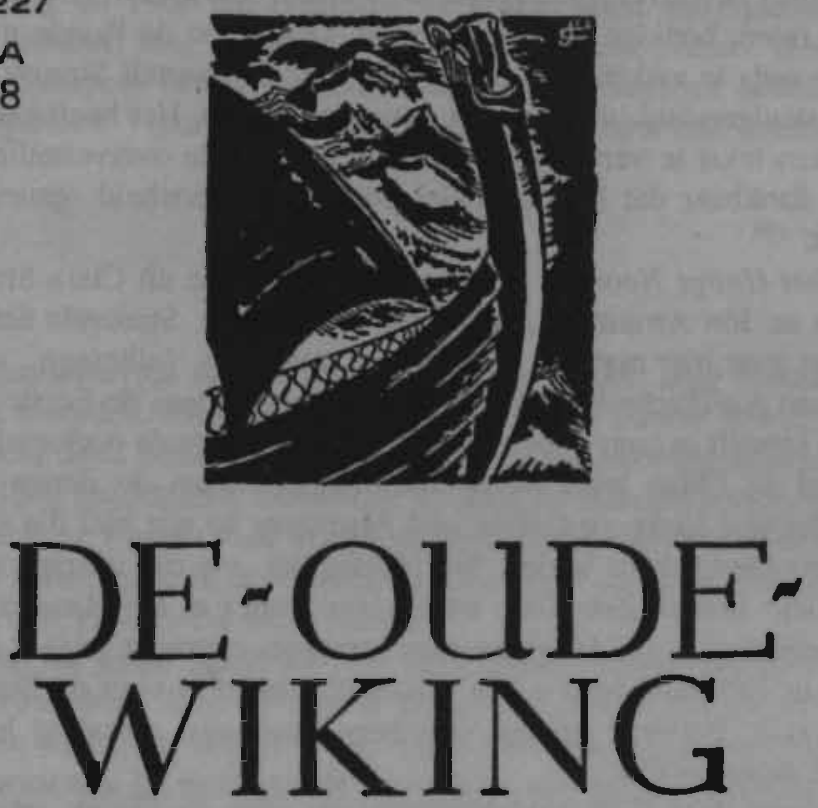

Afbeelding 12. Titelblad van 'De oude Wiking' (1931). (Universiteitsbibliotheek Maastricht). 


\section{Hoofdstuk $V$}

eigen thematiek), en als zijn doel noemt hij:

het merkwaardige kunstwerk uit de Germaansche oudheid aan ons volk bekend te maken en te doen waardeeren, omdat het, buiten zijn ruwe, bonkige en grootsch-elementaire epiek, het denken en doen omvat onzer voorzaten, menschen van ons ras; dit is dus een erfschat die ons van rechtswege eigen is. ${ }^{189}$

De kritiek was ook over dit boek positief. Toussaint van Boelaere waardeert dat de auteur in een tijd van amoreel hedonisme pal staat voor het herö̈sche, en spreekt met bewondering over de mannelijke, gespierde, "Streuvelsche taal", die volkomen overeenstemt met de ruwe, bonkige IJslandse poëzie. Ook Theo de Ronde meent met creatief werk van Streuvels te maken te hebben: "Die verhalen vertelt Streuvels na, in den hem eigen klaren, stevigen stijl, den stijl der gezonde grooten. Het heeft geen zin ze met den oorspronkelijken tekst te vergelijken om na te gaan of de oververtelling getrouw is [...] we zijn hem dankbaar dat hij die oude grootsche schoonheid opnieuw in ons bereik gebracht heeft." 190

Sagen uit het Hooge Noorden is een vertaalde selectie uit Clara Stroebe's Nordische Volksmärchen en Jón Arnason's Isländische Volkssagen. Streuvels titel wekt verkeerde associaties: het gaat hier niet om heldensagen, maar om 'folkesagn', volksverhalen. De eerste editie van Nordische Volksmärchen verscheen tijdens de Eerste Wereldoorlog, en Clara Stroebe schrijft in haar voorwoord dat juist vanwege de oorlogssituatie deze verzameling actueel is: "Man wird wenig Dichtungen finden, in denen Todesverachtung, männlicher Mut und Liebe zu Gefahr und Abenteuer so wie hier die selbstverständliche Grundlage alles Geschehens bilden. Ein Heldenvolk wie das unsrige wird jetzt mit emster Freude diese uralten Zeugnisse heldischen Sinnes in die Hand nehmen." Een zeer gekunstelde redenering - in de opgenomen sprookjes overwint vrijwel steeds de slimheid in plaats van de heldhaftigheid -, die echter illustratief is voor de Duitse beeldvorming rond Scandinavië. Ironisch genoeg verscheen Streuvels' vertaling bij een onbekende uitgeverij met de naam Pax...

Wellicht mede door deze verschijningsvorm ging de kritiek vrijwel aan dit werk voorbij. Jan Vercammen noemt de 'sagen'-titel grootsprakerig, al heeft hij waardering voor de aan Vlaamse sprookjes verwante vertelsels. Echt enthousiast was alleen de recensent van Boekenschouw, die Streuvels vermeende creativiteit roemt: "De schrijver heeft naar de epische mogelijkheden van elk verhaal gespeurd en deze mogelijkheden ten volle uitgebuit." ${ }^{.191}$

\subsection{Hamsun}

In de secundaire Streuvelsliteratuur is herhaaldelijk gewezen op de verwantschap tussen Streuvels en Knut Hamsun. Speciaal diens Markens Grede (Hoe het groeide) werd genoemd in verband met Langs de Wegen. De verwantschap is echter nogal beperkt. In het concrete geval kan de roman van Hamsun, uit 1917, die van Streuvels uit 1902 onmogelijk beïnvloed hebben, terwijl anderzijds nergens blijkt dat Hamsun het werk van 
Streuvels zelfs maar zou kennen, - in de uitvoerige Hamsun-bibliografie van Østby komt diens naam niet voor. Belangrijker is dat ondanks beider 'Agrarromantik und Großstadtfeindlichkeit' de verschillen groter zijn dan de overeenkomsten. Hamsun verheerlijkt en romantiseert de natuur, terwijl Streuvels ook en vooral oog heeft voor de bedreigingen daarvan. Bovendien zijn de hoofdfiguren in de meeste van Hamsuns romans geen boeren of landarbeiders, zoals bij Streuvels.

Zoals bekend koos Hamsun onverdeeld de zijde van de nazi's in de Tweede Wereldoorlog, en als het tijdschrift De Roode Vaan in 1945 naar aanleiding van Hamsuns arrestatie vraagt wanneer Streuvels wordt aangehouden, is dat een overtrokken parallel. Maar Streuvels' opmerking uit 1965 dat Hamsuns werk hem nooit had voldaan, omdat zijn wereld te irreëel aandoet, mag men wel met een korrel zout nemen. Hoe is anders te verklaren dat Piet Schepens hem in hetzelfde jaar zijn Hamsunboek cadeau doet met de handgeschreven opdracht "voor Stijn Streuvels dit boekje over ons beider vriend Knut Hamsun"? ${ }^{192}$

\section{Conclusies}

Stijn Streuvels' Scandinavica sluiten grotendeels aan op een lang bestaande Vlaamse interesse voor het Noorden. Met vele voorlieden van de Vlaamse Beweging, van Willems tot Rodenbach, deelt Streuvels de gerichtheid op de Noordgermaanse broedervolken. De belangstelling gaat daarbij niet zozeer uit naar de taalverwantschap, als wel naar het onbedorven karakter van het volk in zijn verbondenheid met de natuur, in het bijzonder zoals dit naar voren komt in de Oudnoordse literatuur en in de boerennovellen van Bjørnson, die ook zijn eigen werk beïnvloeden.

De voorkeur van de jonge Streuvels voor de moderne Scandinavische schrijvers als Ibsen, Kielland en Jacobsen deelt hij met de kring rond Van Nu en Straks, die de internationale successen van deze schrijvers als inspiratie zag; hij wijkt daarin af van de katholieke kring, waarmee hij wel weer de voorliefde voor de heimatliteratuur deelt. Zijn latere, eigen 'Scandinavische' produktie staat in het licht van deze voorkeur, van de met liefde gemaakte Bjømsonvertalingen tot de ideologisch geladen sagenvertalingen. 'De Vlaamse Hamsun' ten slotte, is hij nauwelijks: niet de politiek omstreden schrijver van wereldformaat, maar de 'nationale' auteur, die als eerste literator de Scandinavische letteren in Vlaanderen heeft weten te populariseren. 


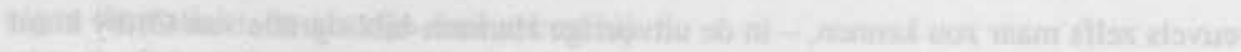

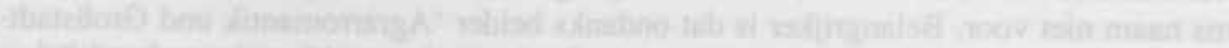
no

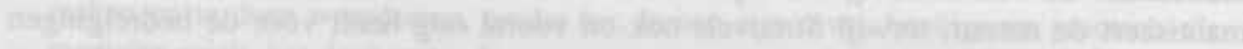

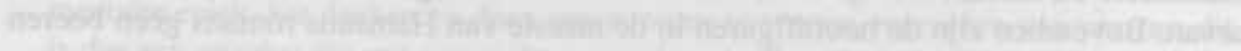

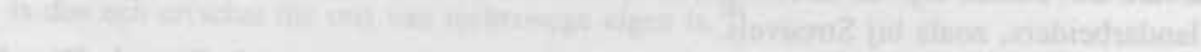

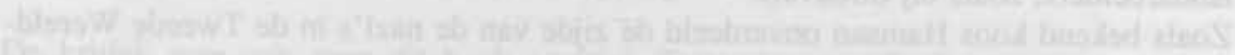

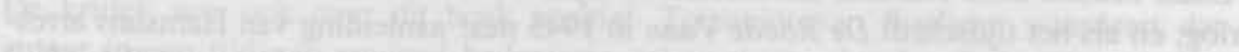

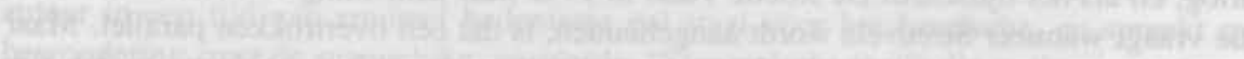

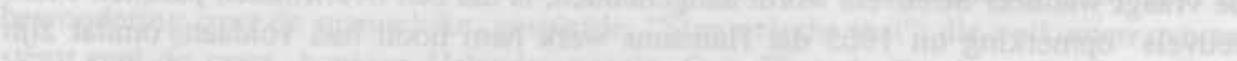

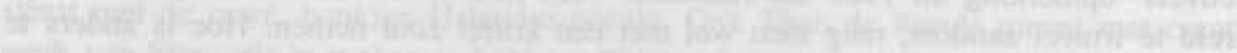

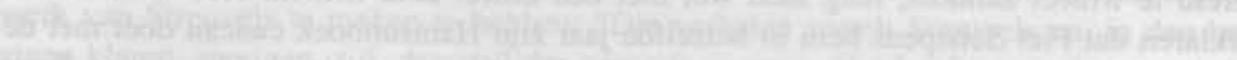

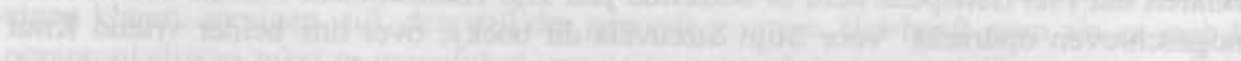

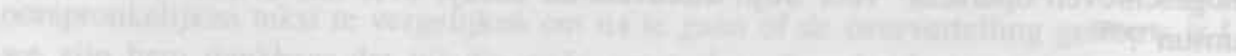

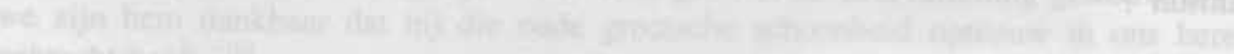

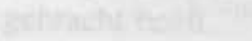

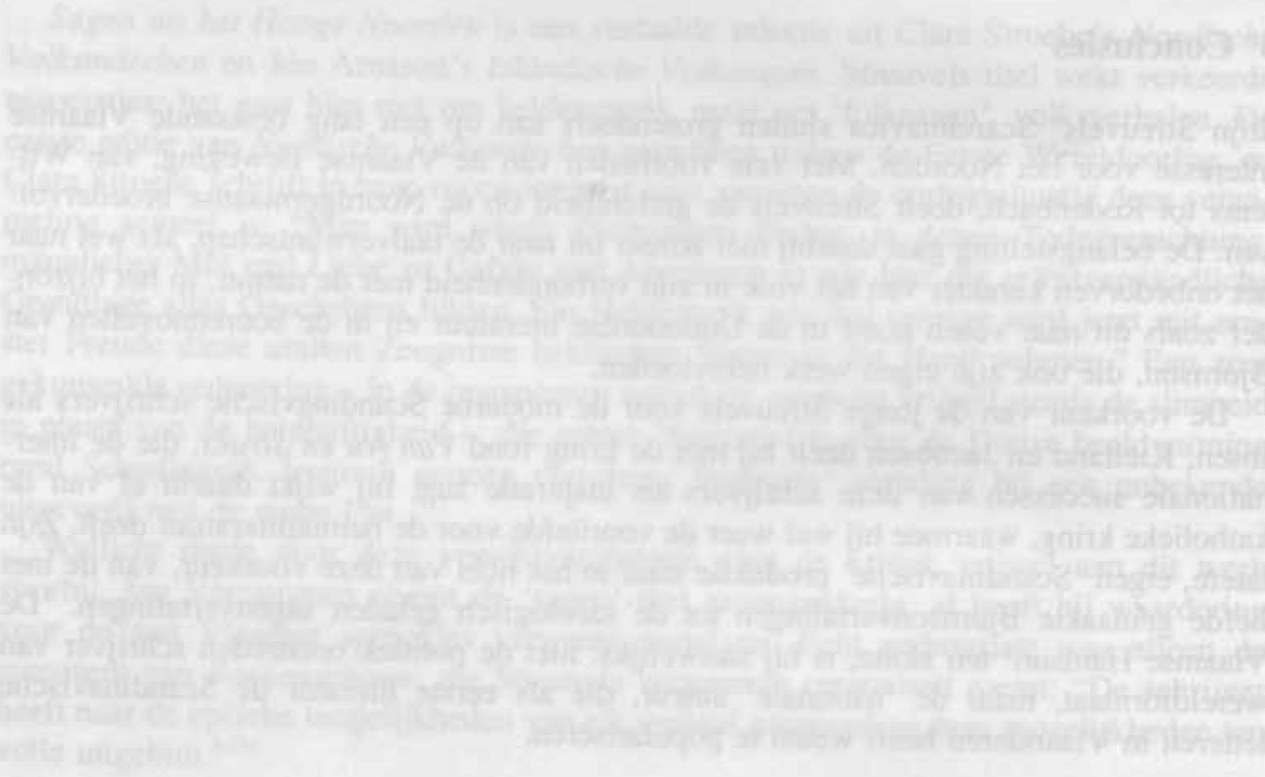

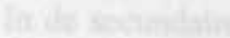

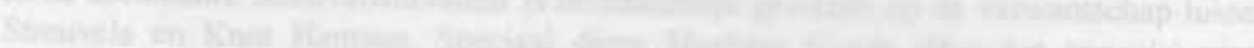

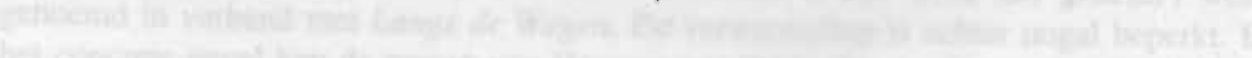

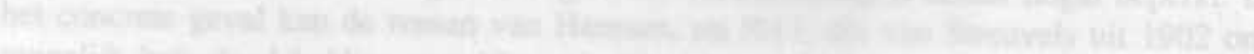

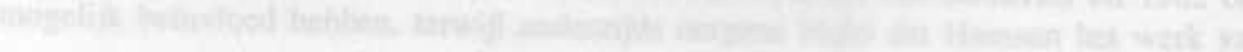




\section{Hoofdstuk VI}

\section{Bestaat de receptie van 'de' Deense litera- tuur in Nederlandse vertaling, 1731-1990?*}

\section{Inleiding}

Het schrijven van een kort artikel over de receptie van een bepaald auteur in vertaling vergt meestal een enorme hoeveelheid documentatie, terwijl complete studies over de receptie van vertaalde auteurs vaak jaren van de onderzoeker vragen. Ondanks deze eisen aan inzet hebben sommigen de moed gehad zich te werpen op de receptie van een bepaalde stroming in vertaling of zelfs van alle uit een taal vertaalde werken uit een bepaalde periode.

Wie weet hoeveel werk alleen al het documenteren kost, laat staan het ordenen daarvan, kan zich daarom afvragen of het zin heeft, zelfs maar te beginnen aan de beschrijving van een niet in tijd of genre beperkte receptie van een complete literatuur. Hieronder wil ik de mogelijkheden, maar ook en vooral de grenzen van die beschrijving laten zien, aan de hand van mijn pogingen, de Deense literatuur in Nederlandse vertaling bloot te leggen. Mijn doel is niet, verslag te doen van een afgerond receptie-onderzoek, maar door middel van concrete cijfers en feiten exemplarisch een idee te geven van de problemen waarvoor een receptiehistoricus zich gesteld ziet, en van een aantal punten die naar mijn ervaring diens aandacht zouden moeten hebben.

Drie vragen krijgen in dit verband de aandacht. Ten eerste: welke werken zijn er precies vertaald en hoe brengt men die in kaart? Ten tweede: in hoeverre geven de vertaalde werken een beeld van 'de' vreemde literatuur? En ten slotte: welke groepen lezers lazen welke werken in welke periode en in hoeverre lieten die werken bij die lezersgroepen een beeld van 'de' vreemde literatuur achter? 


\section{Een bibliografie van 'de' Deense literatuur in Nederlandse vertaling}

Uiteraard moet in dit verband allereerst worden bepaald wat we onder 'de' Deense literatuur verstaan. Eenvoudigweg de som van alle boeken, geschreven in het Deens; de literaire canon; een representatieve groep werken van individuele auteurs; of een bepaalde stijl of sfeer? Voor degenen die het Deens niet beheersen, is er maar één manier om de gedachten hierover te bepalen: de beschikbare vertalingen lezen. De onderzoeker van een weinig verspreide taal als het Deens heeft het in dit opzicht nog relatief gemakkelijk ten opzichte van iemand die de receptie van bijvoorbeeld de Engelse literatuur onderzoekt, waarvan een groot deel in het origineel wordt gelezen. Voor het Deens geldt: slechts de beschikbare vertalingen kunnen de lezer een bepaald beeld verschaffen, een beeld dat hem kan stimuleren of ontmoedigen om vergelijkbare boeken te lezen. Het is daarom van belang te weten, welke vertalingen er überhaupt bestaan; in welke mate ze beschikbaar zijn of waren voor het publiek; en in hoeverre deze vertalingen een algemeen of meer beperkt imago van 'de' Deense literatuur hebben geschapen.

Ter beantwoording van althans de vraag welke vertalingen er überhaupt bestaan, heb ik in samenwerking met de Koninklijke Bibliotheek te Kopenhagen een geannoteerde bibliografie samengesteld van Nederlandstalige literatuur van en over Deense schrijvers, dus van alle achterhaalbare vertalingen en studies, gepubliceerd in de jaren 1731 tot en met 1982. Dansk skonlitteratur i Nederland og Flandern 1731-1982 : Bibliografi over oversattelser og studier, in 1986 onder auspiciën van de Koninklijke Bibliotheek uitgegeven door de Deense bibliotheekcentrale, omvat ruim 2500 titels; daarbij is niet inbegrepen het grootste deel van de publikaties van en over Hans Christian Andersen, waarvan aparte bibliografieën bestaan die samen nog eens circa 900 titels bevatten. ${ }^{193}$ Het begrip 'literatuur' is in mijn bibliografie ruim opgevat: volkssprookjes, streek- en familieromans, stripverhalen en reisbeschrijvingen zijn hierbij inbegrepen. Naast de bibliografische gegevens uit de International Standard Bibliographic Description, als titel, auteurs, plaats, uitgever, jaartal, aantal delen, pagina's, illustraties, formaat, serie, bindwijze, ISBN-nummer etcetera, zijn per nummer ook herdrukken en achterhaalbare recensies vermeld. Er is gestreefd naar volledigheid, die voor de uitgaven in boekvorm vrijwel is bereikt: van de deelpublikaties (artikelen in kranten, tijdschriften etcetera) is in elk geval het essentiële opgenomen vanaf 1910, het jaar dat Nijhoff's Index begon te verschijnen. Alleen de recensies zijn qualitate qua onvolledig opgenomen, daar de meeste kranten en veel algemene tijdschriften niet zijn geïndexeerd. De afzonderlijke publikaties zijn zoveel mogelijk op basis van autopsie beschreven en per nummer is met een codenummer aangegeven uit welke bibliotheek het beschreven exemplaar afkomstig is. Van 1983 tot en met 1990 zijn nog eens ruim 200 vertalingen verschenen, geregistreerd in de te verschijnen brochure Literatuur uit Denemarken 1980-1992, een uitgave van Dansk Litteraturinformationscenter te Kopenhagen, die mede is gebaseerd op mijn gegevens.

Men kan zich natuurlijk afvragen of een positivistisch onderzoek op basis van de aldus verzamelde gegevens een goede manier is om de bovengenoemde vragen te beantwoorden. In zijn studie over de receptie van Scandinavische literatuur in Duitsland tussen 1860 en 1910 kritiseert Walter Baumgartner het 'document-fetisjisme', zoals hij het noemt. ${ }^{194}$ Baumgartner probeert de verwachtingshorizon van de lezers te reconstrue- 
ren door de intenties van een klein aantal schrijvers te vergelijken met de realisaties in de vertalingen en de recensies. Met alle respect voor de interessante resultaten van Baumgartners onderzoek, betwijfel ik toch of die representatief zijn. Baumgartner beperkt zich tot enkele vertalingen van bellettrie, waarvan het maar zeer de vraag is of ze representatief zijn voor de vertalingen uit die periode, terwijl ook de recensies waarschijnlijk noch representatief zijn voor de recensies überhaupt, noch voor de receptie door het publiek. Onderzoek als van Baumgartner zou daarom moeten worden aangevuld met kwantitatieve en kwalitatieve literatuursociologische gegevens betreffende alle andere vertaalde auteurs uit de behandelde periode: hoeveel vertalingen, hoeveel drukken, wat voor oplage per druk, welke uitgevers, welke vertalers, welk publiek, etcetera.

\section{Bibliografisch zoekwerk}

De onderzoeker van 'een' literatuur in vertaling ziet zich dus allereerst gesteld voor het probleem van het opsporen van de vertalingen. Alleen al het vinden van titelgegevens is uitermate lastig. De systematische delen van Brinkman's Catalogus kennen geen ingang op vertalingen naar taal, en slechts via omwegen, bijvoorbeeld op naam van de vertaler, kan men aan de Brinkman gegevens ontlenen. Met de deelpublikaties ligt het nog lastiger: Nijhoff $s$ Catalogus op tijdschriftartikelen heeft wel een ingang op talen, maar loopt niet verder terug dan tot 1910 en bevat natuurlijk ook niet alle tijdschriften, laat staan kranten, waarin vaak vertaalde romans in feuilletonvorm verschenen. Internationale bibliografieën van vertalingen zoals de Index Translationum vertonen genoemde beperkingen in tijd en volledigheid nog veel sterker. Door gebruik te maken van persoonsbibliografieën, onderwerpsbibliografieën, tijdschriftregisters, en de systematische catalogi van bibliotheken en documentatiecentra met verzamelingen op het gebied van de desbetreffende literatuur, kan de onderzoeker trachten in de buurt van het hoogst bereikbare percentage van ongeveer $95 \%$ te komen. Bijzonder nuttig bleek in mijn geval de uitputtende katholieke literatuurgids Lectuur-Repertorium, waarin van vrijwel elk in Nederland en Vlaanderen na 1884 in boekvorm uitgekomen fictioneel werk de oorspronkelijke taal wordt vermeld, plus een morele kwalificatie. ${ }^{195}$

Een groot probleem bij het bibliografisch zoekwerk vormt het feit dat lang niet alle vertalingen rechtstreeks zijn gemaakt. In mijn geval zijn bijna alle vertalingen van vóór 1900 (en nog vele daarna) via het Duits gemaakt; een dergelijke vertaling staat dan op het titelblad vermeld als een vertaling uit het Deens of het Duits of helemaal niet als vertaling. Bovendien worden rechtstreekse en niet-rechtstreekse vertalingen uit het Deens soms op het titelblad aangegeven als vertalingen uit het Noors of Zweeds, en vice versa. Daarbij komt het probleem van anonieme werken en werken onder pseudoniem, die verre van altijd letterlijk vertaald zijn, zodat er nogal wat speurwerk aan te pas komt voordat ze definitief zijn geïdentificeerd. ${ }^{196}$

Tot dat speurwerk behoort bijvoorbeeld het vergelijken van origineel en vertaling teneinde de oorspronkelijke titel op te sporen, die immers lang niet altijd vermeld wordt in de vertaalde uitgave. Gegevens als uitgever, naam van de vertaler, aantal pagina's enzovoort ontbreken maar al te vaak in de bibliografische bronnen, en beschrijving op 
basis van autopsie is dus in veel gevallen noodzakelijk. En daar doet zich dan meteen een nieuw probleem voor. Nederland kent in tegenstelling tot de omringende landen geen wettelijk depot ${ }^{197}$; België wel, doch pas sinds 1965 . De gezochte literatuur is dus niet alleen verspreid over een groot aantal bibliotheken (in mijn geval 35 bibliotheken in Nederland, België, Denemarken en Noorwegen $)^{198}$, maar bovendien is een groot aantal werken in geen enkele openbare verzameling (meer) aanwezig, zoals bleek na raadpleging van de Centrale Catalogus in Den Haag en het doen rondzenden van de nationale en internationale formulieren van het interbibliothecair leenverkeer. In veel gevallen ging het hierbij weliswaar om wat nu meest wordt beschouwd als triviale streek- en familieromans, maar zoals ik dadelijk nog zal aantonen, spelen deze in de receptie van Deense literatuur juist een belangrijke rol. Bovendien is ook van belangrijke auteurs als Oehlenschläger, Andersen, Kierkegaard en Pontoppidan niet elke vertaling in ten minste één bibliotheek terug te vinden. ${ }^{199}$ Van veel vertalingen is nog slechts één exemplaar over: ofwel in de Koninklijke Bibliotheek te Kopenhagen, die haar taak om vertalingen van de nationale literatuur te verzamelen altijd heel serieus heeft opgevat, ofwel in het Scandinavisch Seminarium van de Universiteit Gent, waar wijlen professor Alex Bolckmans een groot aantal Nederlandstalige Scandinavica uit de Openbare Bibliotheek ter plaatse wist te redden, voor deze ze met het oud papier zou meegeven... Voorts ben ik erin geslaagd het aantal autoptisch beschreven werken te vergroten door de medewerking van Jos Groen, destijds eigenaar van het Scandinavisch antiquariaat Erling te Amsterdam, van enige uitgeverijen in Denemarken en Nederland, en door eigen speurwerk in antiquariaten en tweedehandsboekwinkels.

Tabel A: Overzicht aantallen vertalingen in boekvorm, 1731 tot en met $1990^{200}$

Onderstaand overzicht betreft oorspronkelijke uitgaven, exclusief ongewijzigde herdrukken, maar inclusief gewijzigde heruitgaven (nieuw zetsel, nieuwe tekst, nieuwe uitgever).

$A=$ Hans Christian Andersen; Bellettrie = werken van auteurs wier naam wordt genoemd in Dansk Litteraturhistorie of in Brondsted \& Moller-Kristensen.

$\begin{array}{lrrrr}\text { PERIODE } & \text { Belletrie } & \text { Lectuur } & \text { Jeugdlit. } & \text { Totaal } \\ 1731-1800 & 41 & 6 & 0+0 \mathrm{~A} & 47 \\ 1800-1850 & 17 & 8 & 0+6 \mathrm{~A} & 31 \\ 1850-1870 & 13 & 4 & 0+15 \mathrm{~A} & 32 \\ 1870-1880 & 3 & 3 & 0+6 \mathrm{~A} & 12 \\ 1880-1890 & 9 & 4 & 0+6 \mathrm{~A} & 19 \\ 1890-1900 & 18 & 20 & 1+8 \mathrm{~A} & 47 \\ 1900-1910 & 49 & 40 & 15+16 \mathrm{~A} & 120 \\ 1910-1920 & 50 & 15 & 1+20 \mathrm{~A} & 86 \\ 1920-1930 & 81 & 58 & 18+14 \mathrm{~A} & 171 \\ 1930-1940 & 53 & 33 & 26+23 \mathrm{~A} & 135 \\ 1940-1950 & 52 & 28 & 12+35 \mathrm{~A} & 127 \\ 1950-1960 & 29 & 54 & 66+28 \mathrm{~A} & 177 \\ 1960-1970 & 28 & 40 & 53+37 \mathrm{~A} & 158 \\ 1970-1980 & 14 & 22 & 99+56 \mathrm{~A} & 191 \\ 1980-1990 & 54 & 36 & 161+50 \mathrm{~A} & 301 \\ \text { TOTAAL } & 511 & 37 ! & 452+320 \mathrm{~A} & 1654\end{array}$


Tabel B: Overzicht van meest vertaalde auteurs, 1731 tot en met 1990.

Onderstaand overzicht betreft oorspronkelijke uitgaven, exclusief ongewijzigde herdrukken, maar inclusief gewijzigde heruitgaven (nieuw zetsel, nieuwe tekst, nieuwe uitgever).

B: bellettrie; $\mathrm{O}=$ ontspanningslectuur; $\mathrm{J}=$ jeugdliteratuur

\begin{tabular}{|c|c|c|c|c|c|}
\hline H.C. Andersen & JB & 320 & Torry Gredsted & J & \\
\hline Ludvig Holberg & B & 60 & Emma Kraft & J & 9 \\
\hline C. \& V. Hansen & J & 57 & Emil Rasmussen & 0 & What $4 a$ \\
\hline Søren Kierkegaard & B & 48 & Gerda Achen & 0 & 8 \\
\hline Johannes Jørgensen & B & 46 & Jenny Blicher-Clausen & $\mathrm{O}$ & 8 \\
\hline Sven Hassel [Hazel] & 0 & 26 & Else Fischer & $\mathrm{J}$ & 8 \\
\hline Willy Breinholst & 0 & 25 & Britta Munk & J & 8 \\
\hline Karin Michaëlis & BJ & 23 & Adam Oehlenschläger & B & 8 \\
\hline Karen Blixen & B & 22 & Henrik Scharling & B & 8 \\
\hline Kaj Munk & B & 21 & Karin Aabye & O & 8 \\
\hline Herman Bang & B & 20 & Anders Bodelsen & BJ & 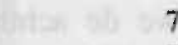 \\
\hline Grete Janus Hertz. & $\mathrm{J}$ & 19 & Suzanne Brogger & B & 7 \\
\hline Jens K. Holm & $\mathrm{J}$ & 18 & Astr. Ehrencron-Müller & B & 7 \\
\hline Poul Nørgaard & J & 18 & Robert Fisker & J & 7 \\
\hline Estrid Ott & $\mathrm{J}$ & 18 & Morten Korch & 0 & 7 \\
\hline Ingeborg Maria Sick & $\mathrm{O}$ & 17 & Ingvald Lieberkind & J & 7 \\
\hline Carl Ewald & $\mathrm{J}$ & 16 & Carl Bernhard & B & 6 \\
\hline Gunnar Gunnarsson & 0 & 15 & Johannes Buchholtz & B & 6 \\
\hline Ole Lund Kirkegaard & J & 15 & Carit Etlar & B & 6 \\
\hline J.P. Jacobsen & B & 14 & Per Flynderswe & $\mathrm{J}$ & 6 \\
\hline Carlo Andersen & OJ & 13 & Peter Freuchen & 0 & 6 \\
\hline Karl Eskelund & 0 & 13 & Karl Gjellerup & B & 6 \\
\hline Jøm Falk-Rønne & 0 & 13 & Cornelia Levetzow & $\mathrm{O}$ & 6 \\
\hline Eilif Mortansson & OJ & 13 & Niels Peder Madsen & $\mathrm{O}$ & 6 \\
\hline Svend Otto & $\mathrm{J}$ & 13 & Børge Mikkelsen & $\mathrm{J}$ & 6 \\
\hline Martin Andersen Nexs & B & 12 & Thomas Olesen Lokken & B & 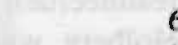 \\
\hline Tom Hill (K. Brunès) & $\mathrm{J}$ & 11 & Johannes V. Jensen & B & 5 \\
\hline Johannes Anker Larsen & B & 10 & Jakob Knudsen & B & 5 \\
\hline Knud Meister & $\mathbf{J}$ & 10 & Aage Kranup Nielsen & 0 & \\
\hline Laurids Bruun & 0 & 9 & Karl Larsen & B & 5 \\
\hline Cecil Bødker & BJ & 9 & Henrik Pontoppidan & B & 10 \\
\hline Walther Christmas & J & 9 & & & \\
\hline
\end{tabular}

De oudste vertaling die op bovengenoemde wijze is opgespoord, dateert van 1731. Tot en met 1990, dus in een periode van 260 jaar, zijn circa 2750 vertalingen verschenen, waarvan ongeveer 1100 in kranten en tijdschriften, en 1654 in boekvorm, dat wil zeggen afzonderlijke uitgaven, - herdrukken niet meegerekend. In de rest van dit artikel zal ik me beperken tot die boekuitgaven.

Zowel absoluut als relatief is dit aantal aanzienlijk. In verhouding tot de 578 vertalingen Nederlands-Deens in boekvorm, verschenen tussen 1653 en 1990 (zie hoofdstuk VIII van dit proefschrift), zijn er bijna drie maal zoveel boeken uit het Deens in het Neder- 
lands vertaald als omgekeerd. Ook in relatie tot vertalingen uit andere talen gaat het hier om aanzienlijke aantallen. Zo verschenen er 3898 boekuitgaven (exclusief herdrukken) van een vertaling Duits-Nederlands in de periode 1900-1960, tegenover 816 Deens-Nederlands, een verhouding van 4,77 op 1, wat tegen de achtergrond van de verschillen in aantallen inwoners van het Duitse en Deense taalgebied en relatieve bekendheid van de literatuur bovenproportioneel voor het laatste gebied is te noemen. In absolute zin zijn de aantallen vertalingen uit het Deens zelfs groter dan die uit het Noors. Van 1850 tot 1970 verschenen 684 vertalingen van werken-voor-volwassenen uit het Deens tegenover 506 uit het Noors, een verhouding van 1,35 op $1 .^{201}$

\section{Periode 1731-1850: Holberg en andere 'Duitsers'}

Het aantal van 1654 werken lijkt voldoende om een in Deense literatuur geïnteresseerde lezer een indruk van die literatuur te geven. Toch ligt de zaak niet zo eenvoudig. Laten we de achttiende-eeuwse vertalingen als voorbeeld nemen. Tot 1800 verschenen 47 vertalingen. Maar de allereerste is meteen al een probleem. Het is een anoniem werk, getiteld De nieuwe Avanturier (zie afbeelding 13), dat het verslag behelst van een reis naar het "Onbekende Zuid-land". De twee delen werden gepubliceerd als een vertaling uit het Deens, maar het origineel is nergens te vinden, dus we hebben vermoedelijk te doen met een mystificatie. ${ }^{202}$ Van de overige 46 vertalingen zijn er niet minder dan 37 van de essayist en blijspelschrijver Ludvig Holberg. Slechts één van deze vertalingen is rechtstreeks uit het Deens gemaakt; de andere zijn of uit het Latijn, waarvan Holberg zich in sommige geschriften bediende, of via het Duits vertaald. In vier vertalingen wordt de naam Holberg niet eens op de titelpagina genoemd. ${ }^{203}$ Zoals Saskia Ferwerda in haar dissertatie Holberg en Holland heeft aangetoond, gingen de vertalers zeer vrij te werk. Slordigheden of onvoldoende begrip van de brontekst (meestal werd het Duits als tussentaal gebruikt) dan wel bewust aangebrachte inhoudelijke en stilistische wijzigingen resulteerden in vertalingen die sterk afweken van het Deense origineel. ${ }^{204}$ Hoe dan ook. Holberg was zeer populair in de Nederlanden: zijn blijspelen beleefden herdruk op herdruk, en verscheidene ervan werden met groot succes opgevoerd. Maar dit alles droeg niet bij tot enige beeldvorming rond 'de' Deense literatuur. Voor de Nederlandse lezer was Holberg onderdeel van de Europese cultuur. De typisch Deense trekjes waren voor hem ofwel onbegrijpelijk ofwel - en dat meestal - verdwenen door ingrijpen van de vertaler. Als gerefereerd wordt aan de Købmagergade, een bekende straat in Kopenhagen. wordt dat in de Nederlandse vertaling "de canal grande te Venetien": en Jørgen Hattemager, de personificatie van de kleine man, wordt gewoon "een dwerg". ${ }^{205}$

De periode tussen 1800 en 1850 leverde 31 vertalingen op. Slechts ến hiervan is nog van Holberg, wiens grote populariteit dus van tijdelijke aard was. Onder de nieuwe namen treffen we bekenden uit de Deense romantiek, zoals Oehlenschläger. Heiberg. Ingemann en Andersen. Nadere beschouwing leert echter dat van Oehlenschläger slechts twee boeken werden gepubliceerd in deze periode: in 1819 en 1822 . Het is überhaupt de vraag of het publiek doorhad dat het werk Treffende verhalen en onderhoudende vertellingen van Adam Gottlob Oehlenschläger, "naar het Hoogduitsch", in feite een Deens 
Bestaat de receptie van 'de' Deense literatuur in Nederlandse vertaling?

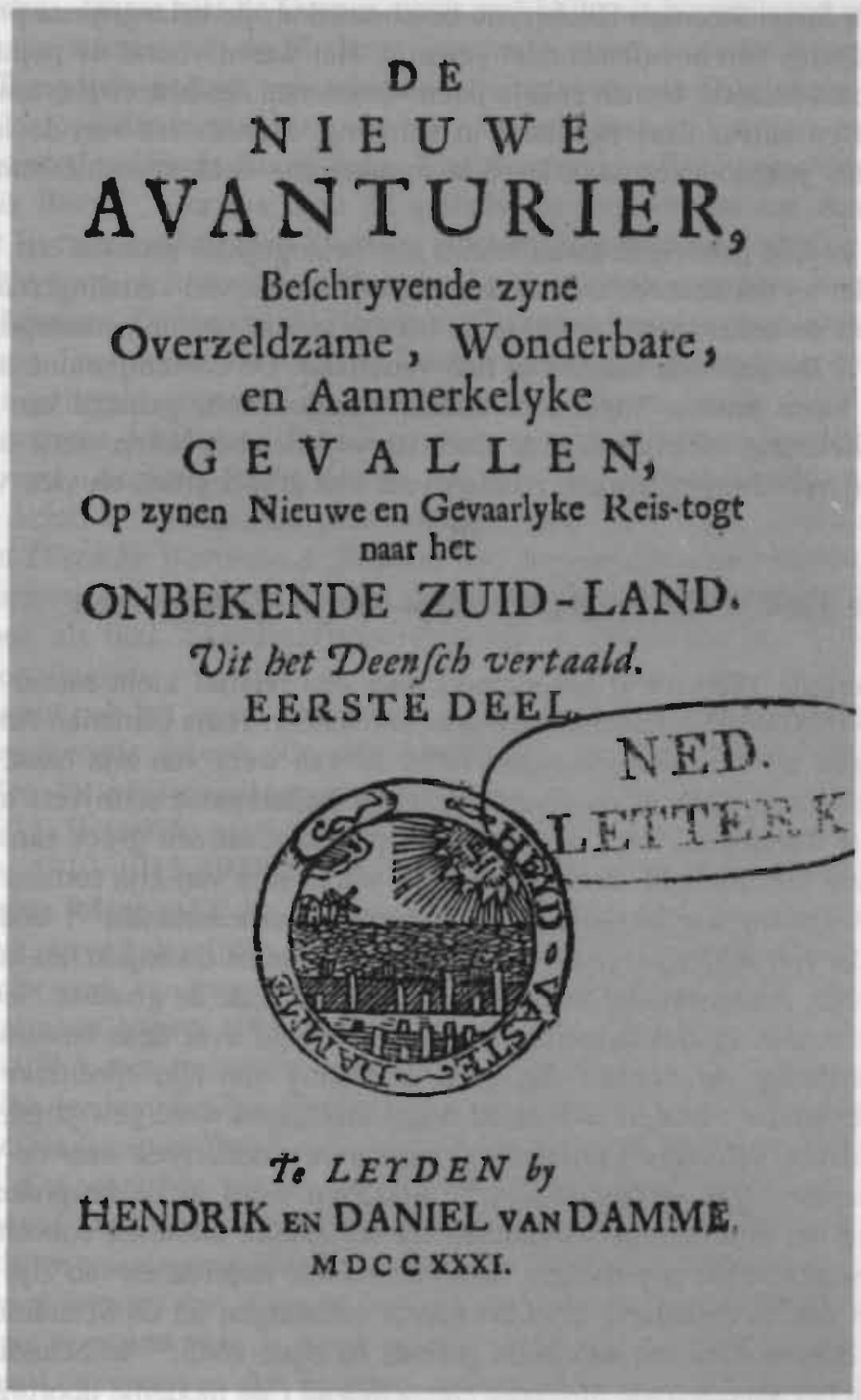

Afbeelding 13. De oudste literaire vertaling Deens-Nederlands (1731): een mystificatie? (Universiteitsbibliotheek Leiden). 
produkt was. Hetzelfde geldt voor diverse werken van Johan Ludvig Heiberg, wiens voornamen op het titelblad werden verduitst tot Johann Ludwig. Van Ingemann werden drie romans vertaald, maar niets van de poëzie die hem in Denemarken zo populair maakte. Van Steen Steensen Blicher, nu beschouwd als de belangrijkste prozaïst van zijn tijd, werd slechts één novellenbundel vertaald. Het waren vooral de populaire epigonen die veel succes hadden: binnen enkele jaren verschenen zes historische romans van de nu totaal vergeten auteur Carl Bernhard in vertaling, evenals zes van de in Denemarken thans nog als jeugdboeken voorlevende romantische heldengeschiedenissen van Carit Etlar.

Over de zojuist gebezigde kwalificaties als 'belangrijkste prozaïst' en 'epigonen' nog het volgende: bij het beoordelen van de representativiteit van vertalingen uit een voorbije periode dient de onderzoeker goed op de hoogte te zijn van de contemporaine populariteit van de desbetreffende auteurs in hun vaderland. De contemporaine en hedendaagse waardering lopen immers nogal eens uiteen, waardoor men geneigd kan zijn een vertaling als willekeurig of triviaal af te doen, terwijl het betrokken werk in het land van herkomst bij verschijning als een meesterwerk kan zijn begroet, en vice versa.

\section{Periode 1850-1920: In de schaduw van H.C. Andersen}

Werd de periode $1800-1850$ gekenmerkt door een relatief klein aantal vertalingen, de jaren 1850-1890 werden gedomineerd door één auteur: Hans Christian Andersen. Van de 63 vertalingen uit deze periode waren liefst 27 van werk van zijn hand. Andersen, die ons land drie maal bezocht en diverse bekende Nederlandse schrijvers als Van Lennep en Ten Kate ontmoette, werd al gauw heel populair, en een groot aantal Nederlandse Anderseniana zag het licht. In de jaren 1840 waren drie van zijn romans vertaald, maar vanaf 1850 werden nog uitsluitend zijn sprookjes vernederlandst ${ }^{206}$, onder andere door Ten Kate, die Het lelijke jonge eendje en andere verhalen dwong in het keurslijf van zijn strakke verzen. Andersen, die begrepen had dat Ten Kate de grootste Nederlandse dichter was, toont zich in zijn autobiografie zeer verheugd over deze bewerking. Voor hem was een berijming op zichzelf dus geen aantasting van zijn specifieke stijl, die door andere Nederlandse vertalers inderdaad nogal ingrijpend werd gewijzigd, zoals blijkt uit het in hoofdstuk vil van dit proefschrift opgenomen onderzoek naar de vertalingen van Reisekammeraten (De reiskameraad). ${ }^{207}$ Andersen werd in de besproken periode niet gewaardeerd om zijn literaire kwaliteiten: de secundaire literatuur concentreerde zich op hetzij zijn wereldwijde populariteit, hetzij de morele implicaties van zijn sprookjes. ${ }^{208}$

Iets later dan in Duitsland stijgt het aantal vertalingen uit de Scandinavische talen in Nederland opeens sterk, en wel in de periode na circa $1885 .{ }^{209}$ In Scandinavië is dit het tijdperk van het zogenaamde Moderne Gennembrud ('de moderne doorbraak') van Ibsen, Bjamson en Strindberg en hun volgelingen. In het kielzog van deze 'groten' volgden bovendien veel meer kleine, vooral auteurs van familie- en streekromans.

Zoals reeds in hoofdstuk IV van dit boek is vermeld, heeft receptie-onderzoek naar de oorzaken van de vergelijkbare stijging van de belangstelling in Duitsland aangetoond dat het controversiële karakter van een aantal werken enerzijds en een vaag ideaalbeeld van 
de onbedorven, prekapitalistische Scandinavische samenleving anderzijds, belangrijke factoren zijn geweest. ${ }^{210}$ Anders dan in Duitsland geldt de plotselinge stijging in aantallen literaire vertalingen in Nederland echter vooral de Noorse literatuur, in iets mindere mate de Zweedse, - maar niet de Deense, zoals wel blijkt uit bovenstaand overzicht. De bekendste Deense auteurs van de Moderne Doorbraak waren vóór 1900 nog nauwelijks vertaald: van Bang drie werken, van Jacobsen slechts twee, van Drachmann één, en van Gjellerup en Pontoppidan niets; tegenover bij voorbeeld zestien, veertien, negen en acht werken van respectievelijk de Noren Jonas Lie, Bjørnstjerne Bjørnson, Alexander Kielland en Henrik Ibsen. ${ }^{211}$ Curieus is in dit verband de uitgave van een novellenbundel (1887) van de Deense realist Steen Steensen Blicher, gepubliceerd onder de naam van... Bjømstjeme Bjørnson, de indertijd in Nederland uitzonderlijk populaire Noor.

Overigens betekent dit niet dat de Noorse en Zweedse literatuur tegenover de Deense werden geplaatst. De Noorse, Zweedse èn Deense literatuur werden onder één Scandinavische noemer gebracht, vertaald door dezelfde vertaalsters (zoals 'Una', Philippine Wijsman, Margaretha Meyboom, Dien Logeman-van der Willigen), gepubliceerd door dezelfde uitgevers (Adriani, Becht, Honig, Sijthoff, Wereldbibliotheek en andere) en besproken in dezelfde tijdschriften (aanvankelijk vooral De Gids, later onder andere Onze Eeuw en Dietsche Warande \& Belfort). De overzichten van vertalingen uit deze periode, samengesteld door respectievelijk Margaretha Meyboom en Lode Baekelmans, hebben dan ook als titel 'Skandinavische literatuur in Nederland' en 'Skandinavische literatuur in vertalingen'.

Na 1900 neemt ook het aantal vertalingen van Deense bellettrie toe, maar nauwelijks van de toonaangevende auteurs. De drie vertalingen van Drachmann verschenen met zulke intervallen dat nauwelijks een totaalbeeld was te verkrijgen voor eenzelfde lezer: 1893-1901-1913. Hetzelfde geldt voor Pontoppidan: 1903-1909-1932-1947, en Johannes V. Jensen: 1910-1913-1937-1963-1979. Alleen Herman Bang was populair, met negen vertalingen tussen 1900 en 1910. Doch slechts twee van deze vertalingen beleefden een herdruk, terwijl dezelfde uitgever een denderend commercieel succes boekte met het sentimentele werk van twee nu totaal vergeten schrijfsters: Jenny Blicher-Clausen met acht vertalingen tussen 1903 en 1907 en in totaal drieëntwintig herdrukken, en Ingeborg Maria Sick met zeventien vertalingen tussen 1903 en 1924 en in totaal dertien herdrukken. Hun werken werden vertaald door dezelfde vertaalster als van Bang, ingebonden in dezelfde Jugendstilbandjes en besproken door dezelfde recensenten in dezelfde tijdschriften ${ }^{212}$ Dit toont hoe vertaler en uitgever de beeldvorming kunnen beïnvloeden: in het moederland Denemarken behoorden Bang enerzijds en de twee vrouwelijke auteurs anderzijds tot totaal verschillende categorieën. De rol van vertaler en uitgever dient in een receptie-onderzoek dan ook een belangrijke plaats te krijgen. In het onderhavige geval hebben we te maken met de meest actieve vertaalster van alle, de hierboven reeds genoemde Dien Logeman-van der Willigen, echtgenote van de hoogleraar Scandinavistiek in Gent Henri Logeman en persoonlijk bevriend met allerlei schrijvers uit het Noorden. Haar invloed op de keuze van de te vertalen werken van Scandinavische auteurs was groot. De uitgeverij was Honig te Utrecht, zojuist al vermeld als een van de belangrijkste uitgevers van Scandinavische literatuur in deze periode. 
Het aantal vertalingen tussen 1910 en 1920 bedraagt 86 , maar dit vrij indrukwekkende cijfer verliest wat van zijn glans als we constateren dat 20 hiervan werk van Hans Christian Andersen betreffen en 23 werk van Johannes Jørgensen. Laatstgenoemde was anders dan in zijn vaderland in de lage landen niet bekend om zijn poëzie of zijn vroege proza, maar om zijn heiligenlevens en reisboeken over Italië. Het Nederlandse en Vlaamse publiek van Jørgensen was strikt beperkt tot de katholieken, die hem niet lazen als Deens literator, maar als religieus inspirator. ${ }^{213}$

Met betrekking tot de receptie van 'een' literatuur in vertaling is het zeker niet voldoende te constateren dat er veel wordt vertaald en dat bepaalde auteurs populair zijn; het gaat erom of de meeste van die vertalingen worden gelezen door een breed publiek. Worden verschillende populaire auteurs slechts door verschillende leeftijdsgroepen of sociale groepen gelezen, dan is er hooguit sprake van auteursreceptie.

\section{Periode 1920-1960: streekromans}

In de periode 1920-1960 verscheen in elk geval, vooral waar het boeken voor volwassenen betreft, de bulk van de vertalingen uit het Deens: 171 tusen 1920 en 1930, 135 tussen 1930 en 1940, 127 tussen 1940 en 1950, en 177 tussen 1950 en 1960. Deze periode had daarom de beste kansen om een algemene indruk van 'de' Deense literatuur achter te laten. En inderdaad kan een trend worden gesignaleerd. Voor het eerst wordt een bepaald inhoudelijk en stilistisch aspect dominant, namelijk het landelijk realisme. Anders dan in Nederland heeft de streekroman zich in Scandinavië lang als gerespecteerd genre weten te handhaven, en schrijvers als Martin Andersen Nexø en Hans Kirk hebben hun beschrijvingen van respectievelijk het leven op Bormholm en rond de Jutse Limfjord ver uitgetild boven wat men in Nederland gewoonlijk onder regionale literatuur verstaat. Vooral Nexø wist hiermee ook in de Nederlanden populariteit te verwerven, zij het primair onder socialistische geestverwanten. Ditte: een menschenleven van Andersen Nexø was de bockuitgave van een eerst als feuilleton in de socialistische kranten $\mathrm{Het}$ Volk (Amsterdam) en Vooruit (Gent) verschenen vertaling. Hans Kirks romans verschenen bij De Arbeiderspers, die zeker in de jaren dertig nog een duidelijk sociaal bepaalde doelgroep had. De landarbeidersroman Diensthaarheid van de literator Jeppe Aakjar, uitgegeven door de socialistische uitgeverij Ontwikkeling (de voorganger van De Arbeiderspers), is zeker voomamelijk in linkse kring gelezen.

De katholieke kritiek onderkent de literaire kwaliteit van deze schrijvers, maar keurt ze om ideologische redenen grotendeels af. De katholieke bibliotheekgids Lectuur-Repertorium kenmerkt Nexø's werken conform de regels van de Kerkelijke Boekenwetten als Verboden Lectuur of Streng Voorbehouden Lectuur: "artistiek hoogstaande romans die echter om hun deprimeerende schildering van de verdorvenheid der menschengemeenschap en de herhaalde godslasteringen, evenals hun revolutionaire tendenz, onbruikbaar zijn". Er is waardering voor Kirks beschrijvingskunst en psychologisch inzicht in $D e$ vissers, maar zijn Dagloners wordt als "een erg rauwen socialistischen roman" weer aangemerkt als Streng Voorbehouden, evenals Aakjærs roman, "met heftig vooruitstrevende, anti-Roomsche tendenz". ${ }^{214}$ 
Bestaat de receptie van 'de' Deense literatuur in Nederlandse vertaling?

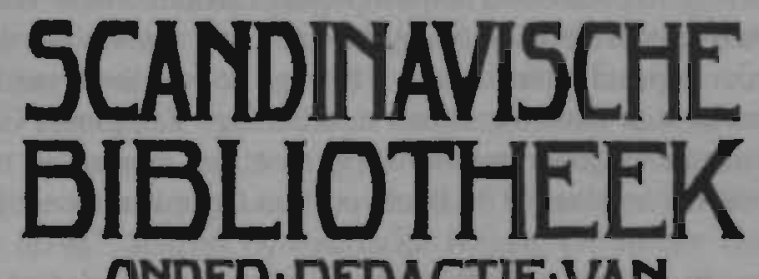
ONDER REDACTIE.VAN PROF·DR·H:LOGEMAN HERMAN

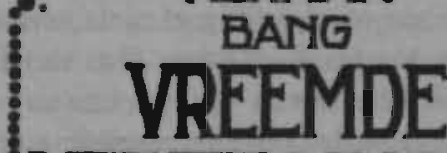
VERTELLINGEN
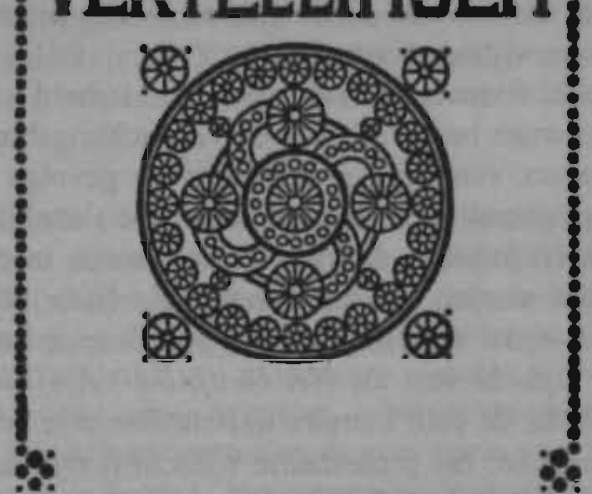

A.W'SYTHOFF'S. UITG.

MAATSCHAPPY 'LEIDEN

Afbeelding 14. Herman Bang niet gepresenteerd als Deens, maar als Scandinavisch auteur (1918). (Privé-collectie). 
Een breder publiek werd bereikt door allerlei regionalistische auteurs van het tweede of derde plan, variërend van literaire 'vertellers' tot auteurs van pure triviaalliteratuur: Marie Bregendahl, Johannes Anker Larsen, Erik Bertelsen, Johannes Buchholtz, J.C.A. Carlsen-Skiødt, Gunnar Gunnarsson, Jørgen Falk-Rønne, Gudrun Gregersen, Thit Jensen, Morten Korch, Erling Kristensen, Thomas Olesen Løkken, Niels Peder Madsen, Harry Søjberg, Karen Aabye en vele anderen. Werk van deze auteurs werd gepubliceerd door uitgeverijen die niet bepaald bekend staan vanwege de kwaliteit van hun literaire fonds, zoals Becht, Bigot \& Van Rossum, Bosch \& Keuning, Van Goor, Gottmer, Voorhoeve en de Zuid-Hollandsche Uitgeversmaatschappij. Ook hier moeten we overigens voorzichtig zijn met al te snelle conclusies: de Becht en Van Goor van toen zijn de Becht en Van Goor van nu niet.

Van de auteurs uit de Deense literaire canon werd naast Andersen Nex $\emptyset$ alleen Karin Michaëlis veel vertaald, maar haar succes was vooral te danken aan haar kinderboeken. Haar werk werd overigens uitgegeven door dezelfde uitgevers als de bovengenoemde: Becht en Van Goor. Van de vernieuwende en zich tot op heden in Denemarken handhavende hoofdauteurs uit deze periode werd weinig of niets vertaald: van Jacob Paludan en H.C. Branner twee romans, van Martin A. Hansen één, van Emil Bønnelycke en Tom Kristensen geen enkele. De presentatie van de weinige literair hoogstaander romans wijkt nauwelijks af van die van de werken der bovengenoemde auteurs van het tweede plan: Elsevier brengt de twee Paludans in dezelfde bandjes en vertaald door dezelfde vertalers als van de commercieel succesvolle Anker Larsen (zeven uitgaven, tien herdrukken) en Falk-Rønne (elf uitgaven, vijftien herdrukken).

Hoewel de 'regionale' romans per saldo een minderheid van al het vertaalde werk vormen, zijn zij in hoge mate bepalend voor de verwachtingshorizon. Het verschil tussen literaire en triviale auteurs verdwijnt grotendeels ten gevolge van de selectie door de uitgevers, de nadruk op inhoud, de vaak neutraliserende vertaling, en last but not least de verwachting bij kritiek en publiek, dat over het algemeen in de literair behoudende en confessionele hoek moet worden gezocht. Terwijl De Gids in de negentiende en in het begin van de twintigste eeuw recensies wijdde aan Deense literatuur, zoekt men in de baanbrekende literaire tijdschriften als Het Getij. De Vrije Bladen en Forum vergeefs naar Deense namen. Onder de echt literaire tijdschriften zijn het vooral de confessionele bladen die ruimte vrijmaken: het protestantse tijdschrift Opwaartsche Wegen en vooral het katholieke Dietsche Warande \& Belfort. Ook de katholieke lectuurgidsen als Boekengids, Lectuur-Repertorium, Boekenschouw, Boekzaal en Idil geven veel besprekingen en artikelen, evenals de levensbeschouwelijke protestantse tijdschriften Stemmen des Tijds en In de Waagschaal. Niet-confessionele kritiek vinden we vooral in het tijdschrift Groot-Nederland, in het Algemeen Handelsblad en de Nieuwe Rotterdamsche Courant. ${ }^{215}$

De belangstelling van deze periodieken betreft niet alleen het Deense, maar het complete Scandinavische gebied. Zo heeft Dietsche Warande \& Belfort een kroniek 'Scandinaafsche Letteren' en bespreekt Opwaartsche Wegen 'Skandinaviese letterkunde'; Boekzaal geeft een 'Overzicht der Scandinavische literatuur' en ook het Algemeen Handelsblad heeft een rubriek 'Scandinavische Literatuur'. ${ }^{216}$

In de recensies van vertalingen uit het Deens zijn nauwelijks verwijzingen naar de Deense literatuur en daarvoor specifiek geachte kenmerken te vinden, anders dan de 
vermelding dat de auteur een Deen is. Vergelijkingen met andere Deense auteurs treft men al evenmin aan. Nee, voor zover een vertaling in een breder kader wordt geplaatst, betreft het karakteristiek geachte trekken van 'de' Scandinavische letteren. Het gaat hierbij om een paradoxale romantische verbondenheid van mens en natuur, waarbij die natuur ondanks haar woestheid en dreigingen per saldo als positief wordt opgevat, en tegenover de vaak verdorven cultuur wordt gesteld. Confrontaties met de harde natuur fungeren als loutering voor de vaak nogal zwaarmoedige hoofdpersoon. In Harry Søibergs trilogie In het land der levenden levert een jonge boer, wiens hoeve wordt bezocht door het noodlot, "tastbaar in de dreiging van de wervelende stormwind op het oogstland", strijd met zichzelf en de natuur, en overwint. "In het land der levenden is juichend vertrouwen in het leven", schrijft Opwaartsche Wegen. De roman Het Geluksland van Jørgen Falk-Rønne "bewijst dat zelfs een van alle beschaving en comfort verwijderd Faröer-eiland, met de meest primitieve levensverhoudingen, toch een geluksland kan worden", aldus Dietsche Warande \& Belfort. Deense, Noorse en Zweedse literatuur worden in dezen als één beschouwd. Thomas Olesens Løkkens Niels Hald-trilogie wordt ingepast in een 'Scandinavisch' kader: "psychologische boerenromans naar het recept van Knut Hamsun", en van de in Noord-Denemarken spelende romans van Johan Skjoldborg wordt vermeld dat "de dichterlijke schoonheid van het Noorsche [sic] landschap met haar stilte en mysterie er telkens een groote rol in speelt" (Lectuur-Repertorium). ${ }^{217}$

Andere aspecten van deze literatuur, zoals de meer of minder expliciete maatschappijkritiek, vallen grotendeels weg doordat uitgevers controversieel werk uit de weg gaan of bedoelde aspecten niet onderkennen. Karakteristiek is in dit verband het voorwoord van de uitgever in een vertaling van een historische roman van Thit Jensen, De koning van 't Sande (1934):

Thit Jensens $[\ldots]$ werk gaat twee totaal-verschillende richtingen uit. In de eene helft harer boeken behandelt ze de uitwassen onzer 19de eeuwsche beschaving, en dit specifiek wat de zogenaamde 'moderne' vrouw er van laat zien, en in de andere daarentegen teekent ze het onveranderlijke, aan de aarde gebonden leven van den boer. Terwijl het eerste, uit den aard der zaak, niet vrij te pleiten is van een ziekelijke neiging om die 'moderne' vrouwelijke psyche uiteen te rafelen, is het andere goed romantisch, en blijkt ze een gezonden, eerlijken kijk te bezitten op de essentieele waarden in het menschelijk leven [...]. De Koning van ' $t$ Sande is hiervan een treffend voorbeeld. ${ }^{218}$

Ook de criticus van Boekenschouw wijst op deze tweedeling in Jensens werk, oordeelt De Koning van 't Sande "een geschikt werk" en plaatst het in een 'Scandinavisch' kader:

Het is een roman, zooals, geloof ik, alleen Scandinavische kunstenaars, die kunnen creëeren: simpel geschreven; overwuifd door een waas van droefgeestigheid; contrasteerend met grimmigen boerentrots; een roman waarin de diepe waarden van het leven worden aangeboord, en waarin ten slotte de realiteit tot een legende verijlt. ${ }^{219}$

Voor zover een beeld gevormd wordt, is dat er een rond die essentiële en diepe waarden van het Scandinavische boerenleven. Inventarisatie van in deze periode verschenen vertalingen uit het Noors en Zweeds door Baekelmans en Bolckmans, en onderzoek naar de 
Nederlandse belangstelling voor Noorse romans door Bouma bevestigt dat ook uit deze talen vooral romans met deze thematiek werden vertaald en gelezen. ${ }^{20}$

Deze als 'typisch Scandinavisch' ervaren literatuur wordt aanvankelijk door de meeste recensenten als positief gewaardeerd. Kritische stemmen zijn duidelijk in de minderheid, en voor zover aanwezig zijn deze zich bewust van de beeldvorming bij het grote publiek. Annie Romein-Verschoor, die als een der weinige recensenten de besproken werken in het origineel leest, wijst er al in 1927 in een bespreking van een roman van Pontoppidan op hoezeer deze afwijkt van een heersend stereotype van 'Scandinavische' literatuur, "een qualificatic, waarmee verhalen over 'kloeke natuurkinderen' en zoetelijke pastorieidylletjes tot een ideaal worden samengesmolten." Uitzonderlijk is de kritiek van Dirk Coster, die het werk van de Noor Hamsun bewondert, maar de rest van de vertaalde Scandinavische romans afdoet als onbelangrijk en middelmatig. ${ }^{221}$

Na de Tweede Wereldoorlog weet het genre zich echter alleen nog als ontspanningslectuur te handhaven, terwijl de kritiek breder wordt. Vermoedelijk heeft een aantal factoren hier een rol gespeeld. Het lijkt waarschijnlijk dat de aanvallen van de Forumgeneratie en hun navolgers op het lage peil van de gemiddelde Nederlandse streek- en familieromans effect hebben gehad op de uitstraling van het verwante Scandinavische genre, en hebben gezorgd voor een ander verwachtingspatroon bij de literaire fijnproever. ${ }^{222}$ Daarbij komt dat de idealisering van de heimatliteratuur en van de 'Noordse' mens door de nationaalsocialisten het genre na 1945 überhaupt nogal in diskrediet heeft gebracht. Ook het inmiddels wat stoffige imago van de bovengenoemde uitgeverijen speelt hoogstwaarschijnlijk een rol; uitgeverijen van moderne literatuur als Querido, De Bezige Bij en Van Oorschot publiceren geen Scandinavische literatuur. In literaire bladen als Criterium, Libertinage, Podium en Maatstaf zoekt men vergeefs naar recensies van en artikelen over de Scandinavische letteren; Critisch Bulletin en De Vlaamse Gids bevatten er slechts enkele, terwijl in voorlichtende tijdschriften als Litterair Paspoort en $H e t$ Boek van $\mathrm{Nu}$ geen recensies van vertalingen verschijnen, maar van originele werken. Slechts de confessionele bibliotheekrecensenten, van de katholieke Boekengids, Boekzaal, Idil en het protestantse Prisma, blijven de vertalingen vrij trouw volgen. ${ }^{23}$

Als gesunkenes Kulturgut zijn de Scandinavische streek- en familieromans nu voorwerp van spot en kritiek. Opvallend is dat in de beeldvorming de zwaarmoedigheid van de romanpersonages geheel de overhand krijgt op meer positieve inhoudelijke aspecten als harmonie van mens en natuur. Dit beeld wordt gekarikaturiseerd door Godfried Bomans in zijn Kopstukken (1947; zie het motto voorin dit proefschrift) - en door Annie M.G. Schmidt in haar cabaretlied Trilogie (1955), "boordevol met van die droeve, van die zwijgende en stroeve, van die noeste woeste boeren op de hoeve". ${ }^{224}$ Door de eenvormige uitgeverspresentatie van Scandinavische literatuur van zeer uiteenlopend gehalte ontkomt nu zelfs het werk van de Deense Nobelprijswinnaar Pontoppidan, door Annie Romein terecht van dit stereotype onderscheiden, niet meer aan het negatieve beeld. In 1947 schrijft het Vlaamse tijdschrift De Kern in een bespreking van Pontoppidans Jonge Liefde en twee Zweedse romans:

Drie boeken van Scandinaven, en het grootste bezwaar is dat het Scandinaafsche boeken zijn, met eeuwig ruischende bosschen, de geur van dennen, haring en stokvisch, en 


\section{HENRIK PONTOPPIDAN}

\section{Jonge Liefde}
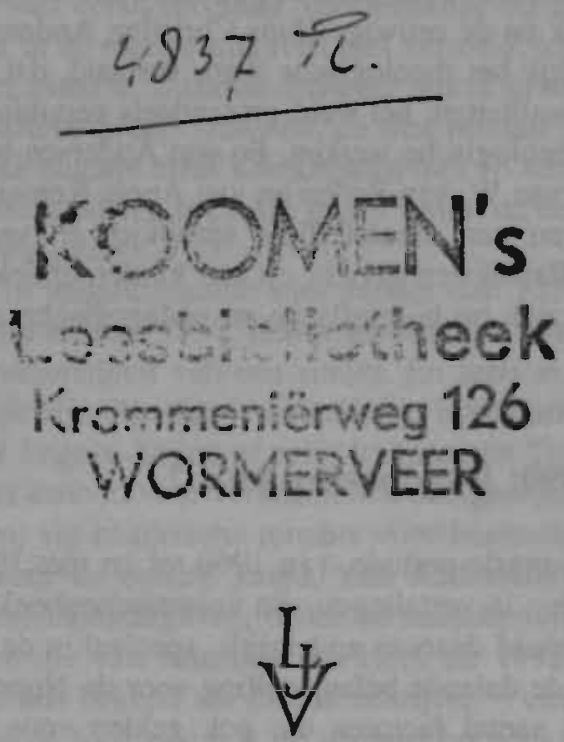

AMSTERDAMA

L. J. VEBN'S UTRGEVRSMAATSCHAPPD N. V.

Afbeelding 15. 'Gesunkenes Kulturgut': werk van Nobelprijswinnaar Pontoppidan neergesabeld door de kritiek en als lectuur in de leesbibliotheek beland. (Privécollectie). 


\section{Hoofdstuk $V I$}

andere dergelijke toebehoorten, en met de onveranderlijke twee soorten menschen, de oermenschen en de cultuurmenschen, die de gemeenschap beu zijn en leniging voor hun kwaal vinden of niet vinden, door terug te gaan naar de ongerepte bronnen enzoovoorts. Dat alles overgoten met een meewarig pessimisme, dat zoo gewild is als onimogelijk. Met eenige overdrijving zou men de Scandinaven de herauten van de veridealiseerde instincten kunnen noemen. [...] Hun eindelooze boeren- en geslachtsromans, die tallooze menschen ten onzent in vervoering brachten, offeren aan de mythos van het "gezonde" natuurleven, dat, van het resultaat te zien, tamelijk ongezond moet zijn. ${ }^{225}$

Hoezeer dit beeld zich decennia lang heeft weten te handhaven, blijkt wel uit het feit dat de streekroman op de Nederlandse bibliotheek- en documentatie-academies tot op de dag van vandaag als typisch Scandinavisch fenomeen wordt aangemerkt. ${ }^{226}$

Natuurlijk waren er ook in deze periode populaire auteurs die niet in dit beeld passen: Kierkegaard, Kaj Munk en de eeuwige Hans Christian Andersen. Maar van Kierkegaard en Munk is voornamelijk het theologische werk vertaald, dat niet primair werd gelezen vanwege de literaire kwaliteiten; het werd grotendeels gepubliceerd door uitgeverijen die zich concentreren op theologische werken. En wat Andersen betreft: op enkele uitzonderingen (de vertalingen van W. van Eeden en van Annie Romein-Verschoor cum suis) na, zijn de talloze uitgaven van afzonderlijke sprookjes en van sprookjesverzamelingen blijkens omslagen en flapteksten gericht op een kinderpubliek. Secundaire Andersenpublikaties concentreren zich op biografische en pedagogische aspecten, en nauwelijks op literaire. ${ }^{227}$

\section{Periode 1960-1990: jeugdboeken en ...?}

Kenmerkend voor de jongste periode, van 1960 tot en met 1990, is naast een hausse in kinderboeken, een daling in vertalingen van volwassenenboeken enerzijds en een toename van de verscheidenheid daarvan anderzijds, speciaal in de bellettrie.

In zijn artikel over de dalende belangstelling voor de Noorse literatuur in deze periode noemt Bouma een aantal factoren die ook gelden voor de Deense: het langzaam doorwerken van een negatief imago bij een breder publiek, de slijtage van het genre streekroman. en het wegvallen van de vooral confessionele steungroepen. Naast deze door Bouma vermelde oorzaken hebben zeker cok de concurrentie van de televisie voor de amusementslectuur en de commercialisering van het uitgeversbedriji - met onder andere cen sterke oververtegenwoordiging van commercieel aantrekkelijke vertalingen uit het Engels - een rol gespeeld. Van het totaal aantal literaire vertalingen per jaar maken die uit de Scandinavische talen in de jaren zeventig nog slechts circa twee procent uit. ${ }^{228}$

Tegenover het verdwijnen van de vertaalde ontspanningslectuur staat de publikatie van literaire reeksen Scandinavisch. en dus ook Deens, werk, uitgegeven door enkele. meest kleine, uitgeverijen met een zuiver literair fonds, met vertalingen en inleidingen van deskundige Scandinavië-kenners: in de zestiger jaren uitgeverij Contact (moderne auteurs als Klaus Rifbjerg, Leif Panduro en Cecil Bodker), eind zeventiger jaren Meulenhoff (klassieken als Herman Bang. Johannes V. Jensen en Martin A. Hansen) en in de 
jaren tachtig Agathon (Herman Bang) en Athabasca (J.P. Jacobsen en William Heinesen). Voorts verschijnen tussen 1967 en 1976 allerlei bloemlezingen, die zich op uiteenlopende doelgroepen richten: modeme poëzie, erotische verhalen $(2 x)$, moderne verhalen, volkssprookjes $(2 \mathrm{x})$ en klassieke literatuur. Karakteristiek voor deze periode is voorts het relatief grote aantal vertalingen van vrouwelijke auteurs, die qua stijl en genre echter sterk verschillen: Karen Blixen, Suzanne Brøgger, Dea Trier Mørch, Kirsten Thorup, Dorrit Willumsen en Hanne Marie Svendsen.

Veel succes hadden deze vertalingen niet. Behalve de bibliotheekrecensies van het Nederlands Bibliotheek- en Lectuurcentrum, Prisma en Boekengids verschenen er weinig of geen besprekingen, en de uitgaven belandden grotendeels bij De Slegte. Alleen Karen Blixen met 20 uitgaven en Suzanne Brøgger met 6 vertalingen waren echt succesvol: zij zijn de enige moderne auteurs wier oeuvre grotendeels in het Nederlands beschikbaar is. Overigens zijn de werken van eerstgenoemde voornamelijk uit het Engels vertaald en werd haar Deense herkomst in de meeste uitgaven niet vermeld, totdat in de jaren tachtig de film Out of Africa furore maakte. Suzanne Brøgger wordt in de eerste plaats gelezen als feminist, door een specifieke groep vrouwen, en niet primair vanwege haar literaire kwaliteiten. Van de klassieke auteurs bleef Kierkegaard met 16 vertalingen in deze periode ook populair, maar opnieuw bij een beperkte groep van in de eerste plaats theologisch en filosofisch geïnteresseerde lezers.

Opvallend is de hausse in jeugdliteratuur: niet minder dan 155 uitgaven tussen 1970 en 1980 en 211 van 1980 tot en met 1990. Kinderen zijn echter niet geneigd, veel aandacht te schenken aan de nationaliteit van een auteur. En zelfs al zouden ze dat willen, dan zou dat vaak onmogelijk zijn doordat de betreffende informatie ontbreekt of doordat het boek vertaald is via het Engels, Duits, of zelfs Italiaans en Tsjechisch. Bovendien is er sprake van een gemêleerd aanbod voor verschillende doelgroepen: van prentenboekuitgaven voor de allerjongsten, via historische romans voor basisscholieren tot 'probleemboeken' en stripverhalen voor de oudere jeugd. Van Andersens sprookjes verschijnen nog vrijwel uitsluitend prentenboekuitgaven; onder de tientallen nieuwe edities sinds het Andersenjaar 1975 is alleen die van Annelies van Hees uit 1992 mede gericht op volwassenen. Ook al is Andersen bekend als Deens schrijver - circa een vijfde van alle vertalingen betreft zijn werk -, toch zijn ook de weinige op volwassenen gerichte uitgaven beland in de jeugdafdeling van de openbare bibliotheek en van de boekhandel.

\section{Conclusies}

De beginvraag luidde: bestaat de receptic van 'de' Deense literatuur in Nederlandse vertaling? Wanneer men de receptie van 'een' literatuur beschouwt als de optelsom van de receptie van individuele auteurs, is het antwoord bevestigend. Er is een overvloed aan vertalingen, en sommige auteurs zijn veel vertaald, druk gerecenseerd, herdrukt, en geanalyseerd in studies. Het is natuurlijk mogelijk de receptie van Holberg. Andersen, Kierkegaard, Jacobsen, Bang en anderen in kaart te brengen, en die in een overzichtswerk te verzamelen, waaruit bij voorbeeld te concluderen valt dat de één meer vertaald 
is dan de ander, of dat de receptie van een bepaalde auteur door respectievelijk recensent en publiek uiteenloopt. ${ }^{229}$

Onder receptie van 'een' literatuur kan men echter ook iets anders verstaan, namelijk een receptie waarbij een gelezen vertaling wordt geplaatst in het kader van de vooraf gelezen vertalingen uit dezelfde taal, en waarbij alle gelezen vertalingen worden opgevat als behorend tot een groter geheel, tot 'een' literatuur. De ene auteur wordt, al dan niet bewust, vergeleken met de ander, er wordt gezocht naar de gemene deler, die uiteraard wordt uitgebreid en gemodificeerd met elke nieuw gelezen vertaling. Op die manier wordt een bepaald beeld gevormd, dat bijvoorbeeld naar voren komt in recensies met verwijzingen naar andere auteurs of naar het typisch nationaal-literaire aspect van de betreffende vertaling. Een dergelijk beeld ontstaat op basis van de selectie, door uitgevers en vertalers, uit de oorspronkelijke literatuur; en de vergelijking tusen de receptie in het moederland en die in het ontvangende land kan ons veel leren over de effecten van die selectie.

Binnen een dergelijke opvatting is het antwoord op de hoofdvraag voorlopig negatief. Althans voor de Deense literatuur geldt dat het indrukwekkende aantal vertalingen géén overheersend en coherent beeld van 'de' literatuur heeft opgeleverd. De meest vertaalde literaire auteurs, Andersen, Holberg, Kierkegaard, Johannes Jørgensen en Kaj Munk, samen goed voor bijna een derde van alle vertalingen, werden casu quo worden gelezen door groepen die in tijd, leeftijd, sociale klasse en religieuze gezindheid sterk uiteenlopen. Andersen mag zich nog steeds verheugen in een grote populariteit, maar hij wordt door volwassenen nauwelijks nog gerecipieerd als literator en het typisch Deense in zijn werk wordt niet afgezet tegen werk van andere Deense auteurs.

Slechts in één opzicht kan men spreken van een algemeen beeld: dat rond de provincialistische sfeer uit de familie- en streekromans uit vooral de periode 1920-1960. Dit beeld is echter niet dat van de Deense literatuur, doch dat van de Scandinavische als geheel. Het trilogieën-imago leeft voort, ondanks Ibsen en Strindberg, maar ook ondanks Jacobsen, Bang en al die anderen uit de Deense canon. Hoe verankerd dat imago is, blijkt wel uit een column van Ten Braven (pseudoniem van de neerlandicus Hans van den Bergh) in Vrij Nederland van 12 april $1986^{230}$, waarin hij het heeft over het begrip streekroman:

Als die term iets betekent, kan het niet voldoende zijn als zo'n roman zich op het platteland afspeelt. Er moeten beslist inhoudelijke kenmerken bijkomen als onwankelbaar geloof, de seizoenen die komen en gaan, winden die om de rotsen waaien en de eeuwige wetten van sterven en baren in de vrije natuur.

Welnu, die stereotiepe om de rotsen waaiende winden zijn afkomstig uit de Nederlandse titel van een in 1936 (!) verschenen deel van Trygve Gullbranssens Noorse trilogie Het geslacht Björndal, die nog altijd wordt herdrukt, en Ten Bravens karakteristiek verschilt verder nauwelijks van die van de hierboven aangehaalde uitgever.

Geen echt 'Deens' beeld dus, alleen een beperkt beeld van de Scandinavische letteren als geheel. Is met deze conclusie onderzoek naar de receptie van een complete literatuur zinloos geworden? Zeker niet. Onderzoek naar de factoren die de vorming van een 
totaalbeeld belemmeren, kan immers evenzeer zinvol zijn. En voor zover in een bepaalde periode een bepaald beeld bij een grotere groep ontstaat, is ook het opsporen van de oorzaken daarvan interessant: in hoeverre heeft de literaire stroming in het ontvangende land een rol gespeeld, in hoeverre de populariteit van een bepaalde auteur, de vertalers, de uitgevers, of de recensenten? Kennis van de literatuur, maar vooral ook van de literatuursociologische situatie in het land van herkomst en in het ontvangende land is voor dergelijk onderzoek onontbeerlijk. 
1:

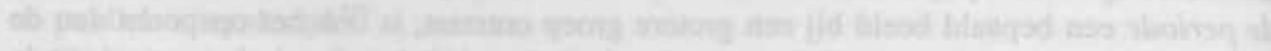

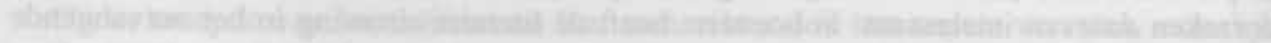

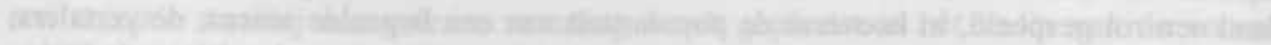

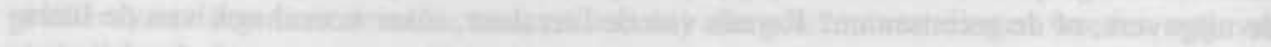
What

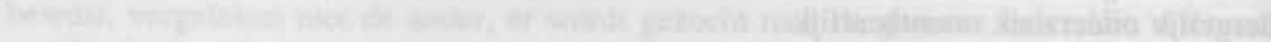

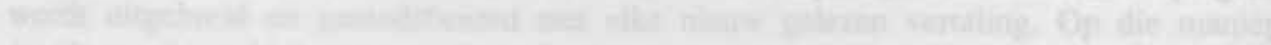
-

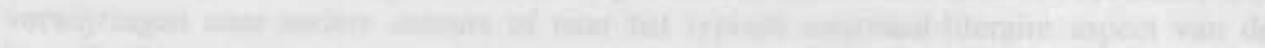

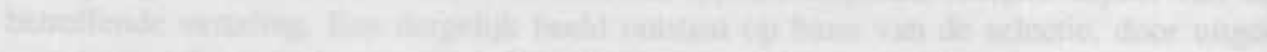

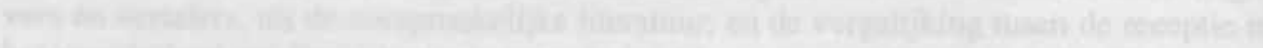

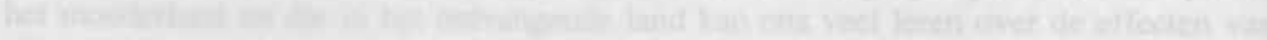

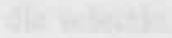

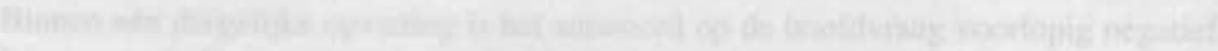

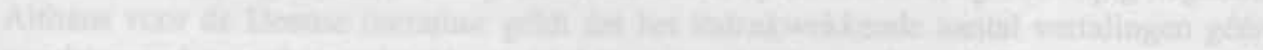

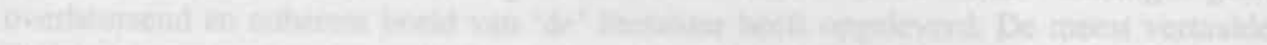

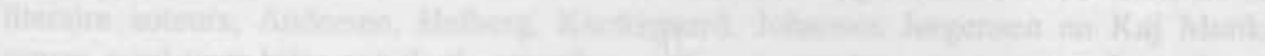

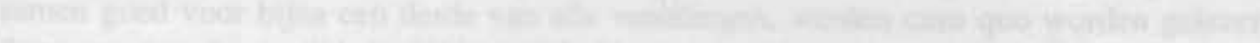
That The

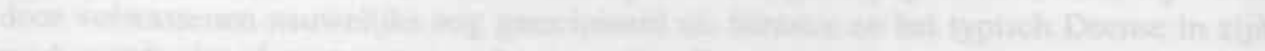
3.

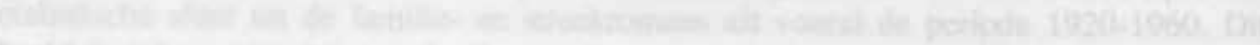

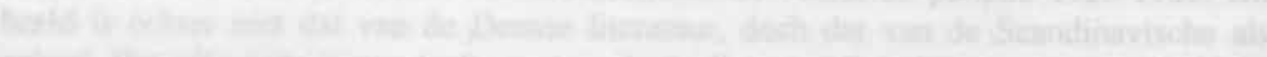

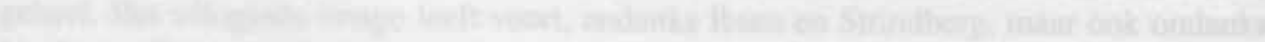

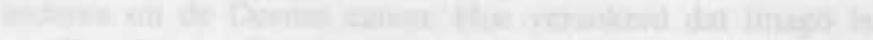

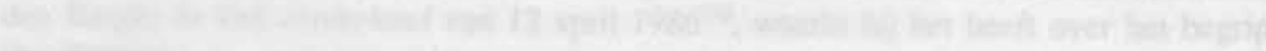

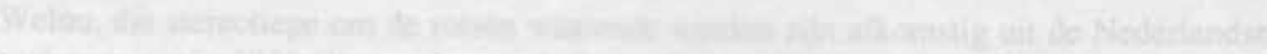

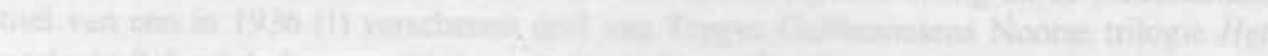

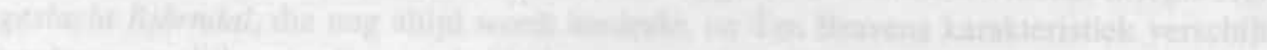

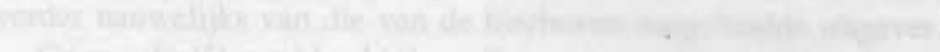

Chat 14: W 


\section{Hoofdstuk VII}

\section{Makkers en kameraden : een analyse van H.C. Andersens Reisekammeraten in zeven- tien Nederlandse vertalingen, 1848-1992}

(in samenwerking met Peter Vingerhoets)

\section{Inleiding}

Met de bijbel en de geschriften van Lenin behoren de sprookjes van Andersen tot de meest vertaalde werken ter wereld. Het Andersen-museum in Odense bezit vertalingen in meer dan honderd talen, en wat het aantal afzonderlijke edities betreft, verslaat Andersen waarschijnlijk beide concurrenten.

Tot en met 1990 zijn alleen al in het Nederlands 320 verschillende uitgaven op de markt gebracht, exclusief ruim honderdvijftig herdrukken, waaraan in totaal meer dan honderdveertig met name genoemde vertalers/bewerkers hebben gewerkt. Weliswaar bevatten vele edities slechts één of enkele sprookjes, maar er zijn tenminste zesentwintig oorspronkelijke bundels met meer dan twintig sprookjes. Al met al bestaan er in totaal ruim zestienhonderd verschillende vertalingen van de diverse sprookjes, en van de bekendste zijn er dan ook tientallen verschillende Nederlandse versies: van Den grimme alling (Het lelijke jonge eendje) bij voorbeeld meer dan tachtig. ${ }^{231}$

De aard van al deze Nederlandse uitgaven is sterk verschillend. Men vindt min of meer nauwgezette vertalingen van de Deense tekst, maar ook sterk ingekorte versies, bijvoorbeeld in prentenboeken, berijmingen, bewerkingen tot toneelstuk, operette of stripverhaal, enzovoort. Rechtstreekse vertalingen uit het Deens staan naast vertaling of bewerking via Frans, Duits, Engels, zelfs Italiaans en Tsjechisch.

Zo te zien is Andersen dus evenals de bijbel een Fundgrube voor vertaalwetenschappelijk onderzoek. Tot voor kort is in de praktijk echter maar weinig van dit onderzoek verricht. Jørgensens 2266 nummers bevattende bibliografie van secundaire Andersenliteratuur bevat slechts 12 titels die rechtstreeks betrekking hebben op vertaalproblematick, 
en dat zijn grotendeels kranteartikelen over een specifieke vertaling. Niet meer dan drie publicisten houden zich iets uitgebreider met het onderwerp bezig: Bredsdorff heeft een hoofdstuk over de kwaliteit van de Engelse Andersen-vertalingen, Albertsen een artikel en Åström een aantal bladzijden over respectievelijk de Duitse en Zweedse vertalingen.

De oorspronkelijke versie van het onderhavige hoofdstuk, geschreven in samenwerking met Peter Vingerhoets en verschenen in 1982, betrof dan ook het eerste onderzoek naar de stilistische aspecten van de Nederlandse Andersen-vertalingen. Sindsdien zijn nog een Groningse en twee Amsterdamse doctoraalscripties over die vertalingen verschenen; de auteur van de Groningse scriptie, Edith Koenders, hield bovendien op een Andersen-symposium te Odense in 1991 een inmiddels gepubliceerde lezing over een door haar verricht onderzoek naar de verschillende doelgroepen van de Nederlandse Andersen-vertalingen. Ook in andere landen en taalgebieden is de laatste tijd initieel vertaalonderzoek verricht, zoals blijkt uit de supplementen op Jørgensens bibliografie. ${ }^{232}$

Hieronder volgt de licht herziene versie van genoemd eerste onderzoek. Mede gezien het geconstateerde gebrek aan secundaire studies impliceerde dat 'eerste' een aantal krachtige beperkingen. Met het oog op de overzichtelijkheid was een analyse van 'de' sprookjes-als-geheel niet wenselijk en binnen het beperkte kader van een artikel bovendien niet mogelijk. Het was daarom van belang, één representatief sprookje te vinden; naar in paragraaf 2 zal worden aangetoond, voldoet de keuze voor deze studie, Reisekammeraten (De reiskameraad), aan de voorwaarde van representativiteit. Een aanvullend praktisch argument voor juist deze keuze was de aanwezigheid van een groot aantal vertalingen: zestien stuks, gespreid over tijd (1848 tot 1975), plaats (Nederland en Vlaanderen) en aard (vertaling respectievelijk bewerking).

De werkwijze is als volgt geweest: allereerst is de Deense tekst geanalyseerd naar inhoud, structuur en stijl, mede aan de hand van secundaire literatuur. Wat de inhoudelijk-structurele kenmerken betreft, zijn alleen die aspecten verdisconteerd, die mogelijk vertaalproblemen met zich meebrengen. Voor de brontekst is de kritische editie van Dal \& Nielsen gebruikt, waarin alle tekstvarianten zijn opgenomen (paragraaf 2 ).

Met behulp van de bibliografie van Juel Moller en Brinkmans Catalogus zijn de bestaande zestien vertalingen opgespoord. Aan de hand van taalgebruik, flapteksten, inleidingen, illustraties en keuze van sprookjes is de primaire doelgroep - kinderen, volwassenen of een 'neutraal' publiek - bepaald (paragraaf 3 ).

Paragraaf 4 geeft een analyse van deze vertalingen naar divergenties, gecategoriseerd volgens het model van Katharina Reiß, plus een interpretatie van de divergenties en een waardering ervan in verhouding tot het door de vertaler beoogde doel. Voor de keuze van het model van Katharina Reiß zij verwezen naar paragraaf 2.3 van de inleiding van dit proefschrift. In paragraaf 5 volgen ten slotte een samenvatting en evaluatie der resultaten.

Een appendix bij dit hoofdstuk bevat een aanvullende analyse van een recente vertaling van Reisekammeraten. In 1992 verscheen voor het eerst sinds de vertaling van W. van Eeden uit 1931 een complete Nederlandse vertaling van Andersens sprookjes, van de hand van Annelies van Hees, docent Deens aan de Universiteit van Amsterdam, die tevens begeleider was van de twee bovengenoemde Amsterdamse doctoraalscripties. 
Welk effect heeft haar grondige kennis van Andersens thematiek en stijl op deze vertaling?

\section{Reisekammeraten - Analyse van de brontekst}

In de periode 1835-1842 verschijnen Andersens eerste sprookjes, onder de titel Eventyr. fortalte for Børn. De auteur schrijft in zijn voorwoord 'til de ældre Læsere' (1837), dat sommige van deze sprookjes zijn ontleend aan volksverhalen die hij in zijn jeugd heeft gehoord, maar dat hij stof en stijl naar believen heeft gewijzigd. ${ }^{233}$ Terwijl het traditionele volkssprookje zich richtte tot een algemeen publiek, zijn Andersens versies primair op kinderen toegesneden: "jeg har ganske skrevet dem saaledes, som jeg vilde fortælle et Barn dem." ["ik heb ze helemaal geschreven zoals ik ze aan een kind zou vertellen"] ${ }^{234}$ Reeds in 1830 had Andersen een volkssprookje, bewerkt tot een novelle voor volwassenen, gepubliceerd: Dodningen. Et fyensk Folke-Eventyr. Het had geen succes, maar toen de auteur rond 1835 zijn karakteristieke sprookjesstijl en -vorm had gevonden, bewerkte hij de inhoud tot Reisekammeraten. Deze bewerking neemt in de secundaire Andersenliteratuur een belangrijke plaats in, omdat het reusachtige verschil zo uitmuntend demonstreert wat de Andersen van 1835 onderscheidt van de literaire epigoon van 1830. Alle voor Andersen zo karakteristieke stijltrekken komen reeds in Reisekammeraten voor, zodat het ook in hoge mate representatief is voor Andersens totale sprookjes-oeuvre.

Terwijl Andersens geheel oorspronkelijke sprookjes in hun ontstaansgeschiedenis één fase kennen en de bewerkingen van volkssprookjes twee, verloopt het ontstaan van Reisekammeraten dus in drie fasen: 1. volkssprookje, 2. novelle voor volwassenen, 3. sprookje voor kinderen. Hieronder zullen we dit proces trachten te volgen door analyse van inhoud en vorm.

\subsection{Het volkssprookje}

Dat Andersen in zijn jeugd een sprookje hoorde over de dankbare dode, die zijn redder helpt met het winnen van cen prinses, is niet verwonderlijk. In Grundtvig 1883 wordt in de inleiding gewag gemaakt van 27 Deense versies van "et meget stort Eventyr - det, som H.C. Andersen har under navnet af 'Rejsekammeraten "' ["een zeer uitgebreid voorkomend sprookje - dat, wat H.C. Andersen heeft onder de naam 'Reisekammeraten'"'] en bovendien van "mange af samme eller lignende Emne fra andre Landes Folkedigtning" ["veel versies met hetzelfde of een vergelijkbaar thema uit de volksliteratuur van andere landen"]. ${ }^{235}$ De Finse sprookjesdeskundige Aarne somt in zijn inventarisatie van wereldsprookjesmotieven in het themacomplex "The grateful Dead" verschillende handelingspatronen en motieven op, waarvan de volgende ook in Andersens versie te vinden zijn:

The grateful dead man. The hero ransoms a corpse from creditors who refuse its burial - Corpse is being held unburied because of nonpayment of debts - Hero pays debt and secures burial of corpse - Through the assistance of the dead man the hero wins the princess and the castle - Disentchantment by beating - Disentchantment by bathing. ${ }^{236}$ 
De Nederlandse Andersen-vertaalster en -biograaf Christine Doorman wijst erop, dat het Semitische sprookje De dankbare dode al duizenden jaren voor Christus ontstond. Grondidee van de vertelling is de volgende. De ziel van de gewone sterveling is tijdens diens leven alleen tijdens de droom in staat, uit het lichaam te treden. Bij zijn dood treedt de ziel definitief uit het lichaam om vrij rond te zwerven of in andere gestalten over te gaan, doch niet dan na een periode van rust in het graf. Rusteloosheid geldt dan ook als vreselijkste vloek en zwaarste straf voor een gestorvene. Naast deze mens staat de adept (tovenaar), die ook tijdens zijn leven en in waaktoestand in staat is, zowel om zijn ziel in anderen te doen overgaan, als om de ziel van een ander in zich te doen binnentreden. Daar deze laatste ziel bevrijd is van de knechtschap van het lichaam, stijgt de kracht ervan ver boven het aardse uit. ${ }^{237}$

Verbinden we deze ideeënwereld met bovenvermelde motieven, dan betekent dit dat Andersens reiskameraad-figuur de uitgetreden ziel van de dankbare dode in zich opneemt en dus als het ware een aspect van die dode is. Dit blijkt ook nadrukkelijk aan het eind, waar de reiskameraad zijn identiteit aan Johannes bekendmaakt: "Den Døde er jeg!" ["Die dode ben ik!"].

Getallensymboliek in het getal drie, speciaal de drie te doorstane proeven, en nevenmotieven als de loutering van de prinses door kastijding (exorcisme) en onderdompeling (doop) wijzen op religieuze inhoud: men denke aan de drie opklimmende trappen der mystiek en de doop als vormen van bevrijding en de weg tot God. Hiernaast staan dan wereldse archetypen als de held en de prinses-in-het-kasteel. Deze vermenging vinden we in de Scandinavische versies terug als een half-christelijke, half noords-mythologische inhoud. Folgesvenden in de verzameling van Asbjømsen, Ligets Hjolp bij Tang Kristensen plus Det fattige Lig en De tre Mark bij Grundtvig bevatten alle enerzijds een kerk(hof)scène, waarin de held zijn geringe bezit opoffert om de dode te doen begraven in gewijde aarde, en anderzijds een nachtelijke ontmoeting met een kwaadaardig bovennatuurlijk wezen, in de twee eerstgenoemde verhalen nader gespecificeerd als trol. ${ }^{238}$

Stijl en structuur zijn zeer eenvoudig, geheel overeenkomstig de "epische wetten", die de Deense sprookjesdeskundige Olrik voor het volkssprookje in zijn oorspronkelijke vorm heeft genoteerd. Concentratie rond een "einsträngige" handeling, schematische figuren, plastische voorstelling, herhaling, sterke contrasten, handelingstoppen (vaak in een opklimmende reeks van drie), komen alle voor. ${ }^{239}$ De tijdsopbouw is strikt chronologisch, de vertelinstantie auctorieel, maar niet commentariërend. Afgezien van geijkte vormen als begin- en slotformules en rituele woordherhalingen, ontbreken 'literaire' stijlfiguren, wat uiteraard mede samenhangt met de wijze van noteren: uit de mond van 'autochtone' vertellers. Om een idee te geven van versie en stijl zoals Andersen ze zo ongeveer kan hebben gehoord, volgt hier het begin van Ligets Hjalp:

Der var en gammel Mand, som havde en Søn, der hed Hans, og han havde en Tjeneste i Byen. Saa blev Manden syg og lod Sønnen kalde hjem til sig. 'A lever ikke ret meget lenge' siger han til ham, 'og derfor har a sendt Bud efter dig. A har ikke anden Arvepart at give dig end 25 Daler i mit Skab og saa en gammel rusten Bøsse, den skyder alt 
det, du sigter efter. Du kan salge, hvad der ellers er i Huset, det er jo ikke meget, men det kan du vel jorde mig for. ${ }^{240}$

\subsection{Dødningen}

Hoe heeft Andersen dit volkssprookje nu in eerste instantie bewerkt? Twee (gedeeltelijk) samenhangende modificaties zijn opvallend: ten eerste is de doelgroep beperkt tot volwassenen (het volkssprookje was niet op een bepaalde leeftijdsgroep gericht), ten tweede zijn vorm en inhoud uitgesproken 'literair'.

Combinatie van deze twee basisveranderingen is direkt te merken aan het woordgebruik. De eenvoudige spreektaal van het volkssprookje wordt bewust vervangen door literaire salonstijl. Wat bij Tang Kristensen heet "saa døde Manden" wordt bij Andersen "den Gamle sov hen i Herren"; "saa vil a betale de Penge" wordt "saa vil jeg gerne give Eder min lille Eiendom", en "hun var saa lam" heet "langsomt og stønnende skred hun fremad". Het hele taalgebruik is niet alleen uitgesproken onkinderlijk, maar bovendien sterk contemplatief gericht: "Alt aandede et frodigt Sommer-Liv; da blev det ham klart i Sjælen, at Døden ikke kunde være Tilintetgjørelse". ${ }^{241}$ Dit laatste voorbeeld is behalve een stilistische wijziging tevens een inhoudelijke toevoeging; de in de handeling vervatte filosofische idee van het volkssprookje wordt hier geëxpliciteerd. Terwijl deze aanvulling nog binnen de algemene inhoud van het volkssprookje valt, zijn er ook toevoegingen van eigen vinding, al heeft Andersen zich daarbij sterk gericht naar de literaire traditie van zijn tijd. D $\phi$ dningen is doorspekt met uitvoerige topografische lokaliseringen en natuurbeschrijvingen, geheel volgens vroeg-negentiende-eeuwse vertelprincipes, maar weinig functioneel gemaakt ten opzichte van de eigenlijke verhaalinhoud.

Dat disfunctionele geldt nog sterker voor de vele verwijzingen naar bekende literaire werken en figuren: "en fortræffelig Regent, og nær beslægtet med Silvio Ruderkonge, der er noksom bekendt af Carlo Gozzi's dramatiske Eventyr 'de tre Pommeranzer"'; "da lod hun, som en anden Turandot, ham [...] henrette", enzovoort. ${ }^{242}$ Ook allusies op de bijbel, zoals de begrafenis van de vader op een vrijdag en de in het marionettentheater vertoonde geschiedenis van Esther en Ahasverus, worden onvoldoende uitgewerkt om wezenlijk functioneel te zijn.

Al met al zijn inhoud noch structuur erg consistent. De tijdsopbouw vertoont allerlei disfunctionele tijdverwijdingen, en er is geen eenheid van handeling. De vertellerinstantic involveert zich af en toe met de lezer ("Vore Vandringsmænd havde...") om dan weer bladzijden lang te verdwijnen. Een gelukkiger ingreep is de individualisering van de hoofdfiguren, die zich onder andere kenmerkt door humoristische opmerkingen, waardoor ze zich onderscheiden van hun archetypische voorbeelden. Ook in die humor richt Andersen zich overigens duidelijk tot een volwassen publiek: "'Hvad vil Du med de Riis?" spurgte Johannes [...] 'Bruge dem naar jeg bliver Kjærtesvend og skal ledsage min Dame', svarede han." ${ }^{243}$ 


\section{Hoofdstuk VII}

\subsection{Reisekammeraten}

In hun onderzoeken naar de verschillen tussen Dødningen en Reisekammeraten wijzen Brandes, Kofoed en Skautrup allen op het verband tussen het verschil in taalgebruik enerzijds en verschil in doelgroep - respectievelijk volwassenen en kinderen - anderzijds. $^{244}$

Naast verschil in doelgroep is echter ook verandering van inhoud en structuur van invloed op het taalgebruik, - een aspect dat bovengenoemde auteurs niet of nauwelijks behandelen. Paragraaf 2.3.1. tracht deze inhoudelijk-structurele kant te belichten. In paragraaf 2.3.2. worden de studies van Jensen en Rubow gebruikt om de representativiteit van het taalgebruik in Reisekammeraten voor Andersens totale sprookjesoeuvre te laten zien. Genoemde studies geven namelijk een gecategoriseerde karakteristiek van Andersens stijl op basis van alle, of althans een zeer groot aantal, sprookjes. Bij de door hen genoemde categorieën zijn steeds karakteristieke voorbeelden uit Reisekammeraten gezocht, en waar mogelijk gaan deze vergezeld van contrasterende voorbeelden uit Dodningen.

De noten achter de hieronder opgenomen Deense Andersen-citaten verwijzen via het notenapparaat achterin naar de pagina's in de editie Dal \& Nielsen.

\subsection{Inhoud en structuur}

Veel van de toevoegingen in Dodningen ten opzichte van het volkssprookje zijn in Reisekammeraten weer verdwenen: de filosofisch-comtemplatieve opmerkingen, topografische lokalisering, natuurbeschrijvingen en literaire allusies. Dit betekent echter geenszins terugkeer naar de volkssprookjesvorm: evenals Dodningen is Reisekammeraten nadrukkelijk gericht op één leeftijdsgroep, in dit geval kinderen, en Andersen gebruikt de bij die groep passende structuur, retoriek en stijl. In deze aanpak is hij echter veel gelukkiger dan in Dødningen; de voor het kinderlijk begripsvermogen noodzakelijke consistente vorm wordt directe literaire winst.

Het handelingsverloop is consequent opgebouwd tussen begin- en slotzin: "Den stakkels Johannes var saa bedrøvet" [...] "Johannes var Konge over hele Riget". De tussenliggende, in duidelijke trekken weergegeven geestelijke en maatschappelijke zegetocht wordt verklaard vanuit twee sleutelprincipes, direct in het begin verwoord door de stervende vader: "Du var en god Søn, Johannes!", sagde den syge Fader, "vor Herre vil nok hjalpe Dig frem i Verden!". ${ }^{245}$ Niet voor niets zijn beide uitspraken voorzien van Andersens karakteristieke uitroepteken: de geschiedenis concentreert zich rond 1. Johannes' goedheid, en 2. Gods hulp. Deze fenomenen hangen uiteraard samen, en in aanzet vinden we ze ook in het volkssprookje en in Dedningen. Men denke aan de betekenis van de naam Johannes: God is genadig. Johannes is de enige die met name wordt genoemd (in het volkssprookje vinden we de vorm Hans); het is de meest voorkomende naam, en representeert als zodanig 'de' mens. (Men denke ook aan Van Eedens Kleine Johannes). De relatie tussen Johannes' en Gods goedheid wordt in Reisekammeraten zeer nadrukkelijk uitgewerkt. De verzekering "Vor Herre/Gud hjwelper mig/dig nok" komt in de loop 


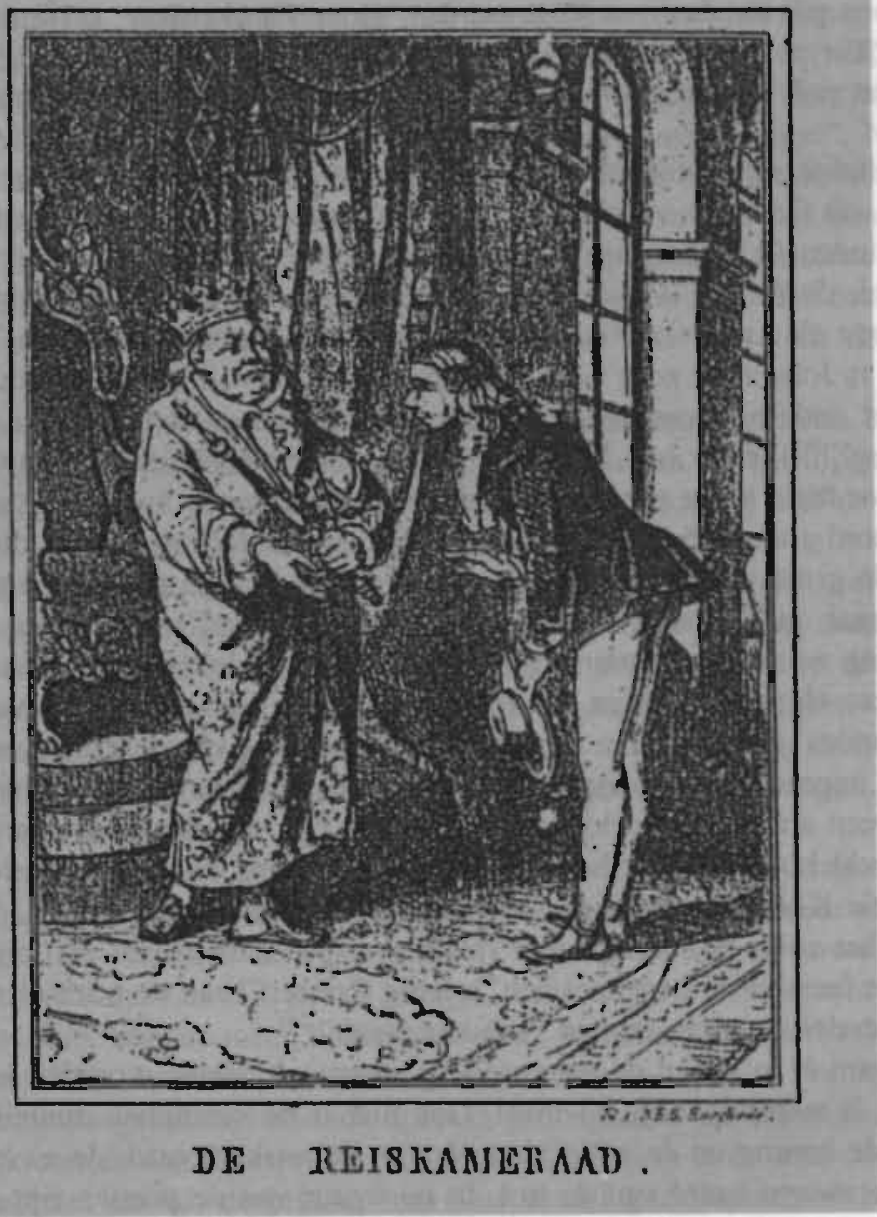

Afbeelding 16. Illustratie bij de oudste Nederlandse vertaling van De Reiskameraad (1848). (Universiteitsbibliotheek Amsterdam). 


\section{Hoofdstuk ViI}

van de geschiedenis vijf maal, Johannes' gebed zes maal voor, en het Deense woord god liefst 34 maal (in Dødningen eenmaal!). Impliciet betekent dit dat de reiskameraad niet alleen een aspect is van de "dankbare dode", maar ook van God (= goedheid). De concentratie van "god" is het sterkst in de fase tot de ontmoeting met de reiskameraad; vergelijk de volgende passage:

\section{Men først gik han hen paa Kirkegaarden, til sin Faders Grav, læste sit Fader vor og sagde: "Farvel Du kjære Fader! Jeg vil altid være et godt Menneske, og saa tør Du nok bede den gode Gud at det maa gaae mig godt."246 (cursivering aangebracht)}

Het gedeeltelijk samenvallen van de twee vaders in de hemel, en de menselijke goedheid als aspect van God, zijn voorbeelden van een onafhankelijkheid van geest en materie, die we ook vinden in de voorspellende droom aan het begin. Deze blijkt later te worden bewaarheid; de droom is qua inhoud overigens een duidelijke reminiscentie aan de bij alle kinderen uit Andersens tijd bekende droom van Jozef uit het Oude Testament. Ander voorbeeld is Johannes' zorg voor andermans graf, terwijl hij denkt aan het graf van zijn vader. Met andere woorden, de reiskameraad is niet alleen de dode in de kerk "Den Døde er jeg!"247), maar ook Johannes' vader, ook de belichaming van Gods goedheid.

Deze goedheid krijgt pas reliëf tegen het contrasterende kwaad. Tegenover de 34 keer dat het woord god voorkomt staan 29 antoniemen, die in hun variatie de geschakeerdheid en deels de groei van het kwade tegenover de eenduidige goddelijke goedheid weergeven: 15 maal ond, 6 maal slem, 2 maal akel, fael, hoeslig en 1 maal styg en galt. De tegenstelling wordt nog verder uitgewerkt in de inhoudelijke contrasten tussen positieve en negatieve elementen; bijna elk verschijnsel heeft zijn tegenpool. Nemen we bijvoorbeeld Johannes' goede daden: tegenover de verzorging van de graven staat de verstoring in de kerk, tegenover zijn vrijgevigheid jegens de bedelaar de inhaligheid van de schuldeisers. Of een ander voorbeeld, het onderaardse rijk van de trol: de berggrot staat tegenover de tocht hoog over de bergen, de trol als koning der onderwereld tegenover "den gode, gamle Konge", de giftige slang-bloemen tegenover de "friske, dejlige Blomster" buiten op het veld, de "sorte Nisser" tegenover de "Kirkenisse" met zijn rode puntmuts, en het hele feest in de berg met het "løjerlig Concert" van de nachtdieren tegenover dat van de vriendelijke elfen en hun "smukke Viser". 248

Interessant is in dezen de tegenstelling zwart-wit. Beide woorden komen vaak in de tekst voor, 8 respectievelijk 11 maal. Ook hier is de symboliek duidelijk: de witte zakdoek van de koning en de witte vleugels van de reiskameraad, de zwarte "nisser" in de berg en de zwarte baard van de trol. In de figuur van de prinses zijn echter beide verwerkt: haar twaalf gezellinnen hebben "hvide Silkekjoler" aan en rijden op "kulsorte Heste": "s nachts vliegt ze " $i$ en stor hvid Kaabe og med lange sorte Vinger", en op de ochtend van de derde dag is ze "ganske bleg, og havde en kulsort Kjole paa." Als ze door Johannes wordt ondergedompeld, voltrekt zich een proces van kwade naar goede prinses via de gestalten van een zwarte en witte zwaan, - de laatste nog met een zwarte (k)ring om de hals. ${ }^{249}$ De prinses is met andere woorden de as van het verhaal, waarin goed en kwaad elkaar ontmoeten. Ze is niet wezenlijk kwaad, maar behekst, en zolang ze behekst is, ziet het wit er ook niet stralend uit: niet "snehvid", maar "kridhvid", met 
aardse in plaats van hemelse symboliek; vergelijk ook "kulsort". Tegenstelling dood-leven vinden we ook in tegenstelling tussen de prinses, "bleg som en Død", en Johannes, "rød i sit Ansigt som et dryppende Blod". ${ }^{250}$

Johannes' goedheid als structuurdragend element blijkt uit zijn hulpvaardigheid, die later wordt overgenomen door de reiskameraad. Daar deze als het ware door Johannes is opgeroepen, zijn beider daden als aspecten van dezelfde, goddelijk geïnspireerde goedheid te beschouwen. De "stakkels Johannes" uit het begin - de woordgroep wordt tot drie maal herhaald - helpt zo direct of indirect andere "stakkels": "den stakkels døde Mand", "den stakkels gamle Kone!", "den stakkels Mand som gjorde den hele Comedie/den stakkels Mand, der eiede Comedien", "den stakkels gamle Konge!". Niet alleen is "stakkels" een sleutelwoord, - vergelijk als oppositie "Den hæslige Prindsesse!" -, maar ook een structuurelement: door de herhaling, bijna steeds aan het eind van een alinea, faseert het de geschiedenis in Johannes' onderscheiden daden. Tenslotte is het een duidelijk voorbeeld van het vertellercommentaar, dat de gevoelens van het toebehorende kinderpubliek opwekt, - vergelijk ook de variant "...hvor den laae død, den smukke Fugl". ${ }^{251}$

Een soortgelijke verweving van oppervlakte- en dieptestructuur ligt in de belangrijke rol van het getal drie: tot drie maal binnen enkele regels wordt de hoofdpersoon "den stakkels Johannes" genoemd, Johannes verricht vóór zijn ontmoeting met de reiskameraad drie maal een goede daad, hij bezoekt drie maal een kerk, ontmoet de reiskameraad op de derde dag. De reiskameraad casu quo Johannes helpen drie personen, eerstgenoemde gebruikt zijn zalf drie maal, hij krijgt drie roeden, en bedient zich in totaal van drie hulpmiddelen (roeden, zwaard en vleugels). Ze komen de prinses tegen op de derde dag dat ze elkaar kennen; de prinses geeft drie raadsels op; en na drie nachtelijke tochten van prinses en reiskameraad wint Johannes de prinses. Op de markt worden drie hele ossen gebraden. Johannes krijgt van de reiskameraden drie zwaneveren en dompelt de prinses drie maal onder, waarna de betovering is verbroken.

Zoals te zien valt, speelt het getal drie een rol in zowel macro- als microstructuur: van de hoofdfasering in drie maal drie dagen, via onderverdeling in episoden als de drie nachtelijke tochten, tot formules als "den stakkels Johannes". Het concrete getal drie wordt niet eens zo vaak genoemd - twaalf maal -, maar als structuurelement is het ook voor een kinderpubliek zonder meer herkenbaar door herhaling van verhaalelementen, plus uiteraard de talloze andere sprookjes waarin het een rol speelt. Vermenging van christelijke en heidense getallensymboliek spreekt genoegzaam uit bovenstaande voorbeelden. Vergelijk ook de aan de mystiek verwante opklimming in de antwoorden op de raadsels: sko, handske, hoved; de prinses met haar twaalf gezellinnen; en het middernachtelijk uur als inleiding op de tochten naar het onderaardse rijk.

\subsubsection{Taalgebruik}

In de studies van Jensen en Rubow wordt als belangrijkste der algemene trekken van Andersens sprookjesstijl de kinderlijke taal genoemd: "Ordbrugen er helt igennem bestem for Bøm; det er ikke just Børnesprog. met det Sprog som interesserer Bømene og 
ganske dækker deres Opfattelsesmaade". Wij hebben ons in onderstaande weergave van de door Jensen en Rubow genoemde karakteristieken beperkt tot die categorieèn die mogelijke vertaalproblemen opleveren. De gegeven voorbeelden en cursiveringen zijn van ons.

De enkele vergelijking van de volgende passages levert al het grootste deel der typische stijlkenmerken op:

\section{Dødningen}

"I Krostuen var der en stor, broget Forsamling, thi en Marionetspiller havde her paa nogle Tønder opreist sit lille Theater. og vilde give Dronning Esters deilige Historie. Johannes og den Fremmede toge sig plads imellem de andre Tilskuere, hvoraf nogle røge Tobak, og andre sladdrede ganske lystigt. En tyk Slagter som lod til at vare den fornemste i Selskabet sad narmest Theateret med sin store Bulbider, der gloede omkap med det øvrige Publikum paa den kongelige Herlighed der nu viste sig."

\section{Reisekammeraten}

"Nede i den store Skjænkestue i Vertshuset var saa mange Mennesker samlede. for der var en Mand, som gjorde DukkeComedie; han havde just stillet sit lille Theater op, og Folk sad rundt omkring for at see den Comedie, men allerforrest havde en gammel tyk Slagter taget Plads. og det den allerbedste; hans store Bulbider, uh den saae saa glubsk ud! sad ved Siden af ham og gjorde Øine, ligesom alle de Andre. ${ }^{.025}$

a. Het gebruik van voor kinderen begrijpelijke en aansprekelijke taal. Eenvoudige woorden: "omkap med det øvrige Publicum" wordt "ligesom alle de andre". Composita worden vervangen door analytische omschrijvingen: "en Marionetspiller" wordt "en Mand, som gjorde Dukke-Comedie" en "en stor Forsamling" wordt "saa mange Mennesker".

b. Het gebruik van versterkende woorden (partikels, uitroepen, superlatieven en andere middelen om nadruk te leggen: woordvolgorde, cursivering, leestekens). Vergelijk het gebruik van "saa": "saa mange Mennesker", "saa glubsk": de uitroep "uh den saae saa glubsk ud!": "taget Plads, og det den allerbedste". De laatste twee voorbeelden tonen tevens het versterkend effect van woordvolgorde en het in Dodningen vrijwel ontbrekende vertellercommentaar.

c. De nauw bij de spreektaal aansluitende symaxis. Deze is gekenmerkt door polysyndese en/of asyndese, een groot aantal pronominale verwijzingen, hoofdzinvolgorde in de bijzin. tussenzinnen, anakoloeten en een zeer gering gebruik van passieve constructies. Vergelijk het gebruik van puntkomma en voegwoorden "og".."men"..."og", de ellips "og det den allerbedste", de tussenzin "uh den saae saa glubsk ud!".

d. De al dan niet gevarieerde herhaling, vaak in de vorm van tautologie of pleonasme. Deze categorie is uiteraard een aspect van de voorgaande: herhaling helpt het kind de draad van het verhaal vasthouden en werkt tevens versterkend. Behalve stijlaspect is het ook structuuraspect: vergelijk het voorbeeld "stakkels" uit paragraf 2.3.1. Tot deze categorie hoort ook het door de verteller oproepen van voorgaande gebeurtenissen of feiten, iets wat ontbreekt in Dodningen. Enige voorbeelden: 
Dodningen

"Fuglene sang saa smukt rundtom i de høie Kastanietræer"

"Johannes greb hende strax i sine Arme"

"[...] Kongen [...]"

"og bad ham derfor ret inderligt at sporge Prindsessen, om hun ikke skulde have tankt paa sine Skoe!",253

\section{Reisekammeraten}

"De smaa Fugle sad oppe i Kastanietræerne og qviddrede 'qui vit, qui vit!' de vare saa fornøiede [...] og derover var de fornøiede"

"Johannes vilde strax at de skulde bare hende hjem, hvor hun boede"

"Den gamle Konge var saa bedrøvet over al den Sorg og Elendighed"

“og bad ham derfor endelig at spørge, om Prindsessen ikke skulle have tankt paa sin Sko! For det var jo det, han havde hørt af Trolden i Bjerget, men han vilde ikke fortalle Johannes noget derom, bad ham bare at sporge, om hun havde tankt paa $\sin$ Sko." 254

\section{De Nederlandse vertalingen}

In onderstaand overzicht van de 16 bundels, waarin een vertaling van Reisekammeraten is opgenomen, is de door ons geschatte doelgroep van de respectieve bundels aangegeven. Dit om na analyse een eventuele relatie tussen aard en doelgroep en vertaling te kunnen nagaan. Deze bepaling van doelgroep is geschied op basis van flapteksten, illustraties, inleidingen, sprookjeskeuze, titels, uitgeverspolitiek, enzovoort. Waar een vertaling zich niet duidelijk tot kinderen $(\mathrm{K})$ of volwassenen (V) richt, is deze als neutraal (N) gekarakteriseerd. Een enkel voorbeeld ter illustratie: de vertaling van A.F. MaitlandVan Bemmelen en Leonore ter Laan kwam in 1961 uit bij Het Spectrum in de Prismapocketserie, -niet in de destijds bestaande jeugdpocketserie Prisma-Juniores. Flaptekst: "Het is een misverstand te menen dat sprookjes uitsluitend iets voor kinderen zouden zijn [...] kinderen kunnen desnoods zonder sprookjes, maar volwassenen hebben sprookjes broodnodig [...] zijn sprookjes vertellen van kinderland aan grote mensen", enzovoort. Het is duidelijk dat hier op een volwassen publiek wordt gemikt.

Om een idee te geven van de 'Wirkungsdauer' van een vertaling is tevens het aantal herdrukken aangegeven; herziene uitgaven zijn zover mogelijk ook ingezien. De cijfers tussen haakjes achter de titels zijn de volgnummers in twee bibliografieèn met Nederlandse Andersen-vertalingen, die respectievelijk de periode vóór en na 1960 dekken. Voor de zeventiende vertaling, die van Annelies van Hees uit 1992, zie paragraaf 5. 
Overzicht van uitgaven met een Nederlandse vertaling van 'Reisekammeraten'.

SJM = bibliografie van S. Juel Møller (1968); DCG = bibliografie van D.C. Grit (1986).

1 NN $1848 \quad K \quad$ Sprookjes van H.C. Andersen. Tweede verzameling. Naar het Deensch. Amsterdam. [Juel Møller vermeldt abusievelijk 1846]) (SJM 8)

2 CdJ $1858 \mathrm{~N}$ Verzamelde vertellingen en sproken van H.C. Andersen. Naar de zesde Hoogduitsche uitgave door $C$. de Jong. Utrecht. $\left[1872^{3}\right]$ (SJM 18)

3 SJA 1874 K Sprookjes van Andersen. Naverteld door S.J. Andriessen. Arnhem. [1895'] (SJM 39)

4 MvE 1899 N Sprookjes van H.C. Andersen. Werelduitgave. Uit het Deensch vertaald door M. van Eeden-van Vloten. Amsterdam. $\left[1955^{8}\right]$ (SJM 63)

5 NN 1906 K Hans Andersen: De reisgezel. Leuven (SJM 73)

6 A/T 1912 K De reiskameraad. Uit het Deensch naar Andersen. Leeuwarden [tekst uit 3 SJA $1895^{4}$, bewerkt door Titia van der Tuuk] (SJM 53/88)

7 CD $1915^{2} \mathrm{~N}$ Sprookjes van Andersen. Uit het Deensch vertaald door Christine Doorman. Utrecht. [1977 $\left.7^{17}\right]$ [in de eerste druk, 1899 , is De reiskameraad niet opgenomen]. (SJM 98)

8 PdB $1920 \mathrm{~N}$ De sprookjes van Andersen. Naar het Deensch bewerkt door Ph.R.F.C. de Bruijn. Zutphen. [1950] (SJM I10)

9 WvE $1931 \mathrm{~N}$ Hans Christiaan Andersen: Sprookjes en vertellingen. Volledige uitgave naar het Deensch door W. van Eeden. Utrecht. [1955'; herzien door Alet Schouten, Bussum 1975, 1991".] (SJM 143)

10 ARV 1941 V Hans Christiaan Andersen: Sprookjes, vertellingen en reisverhalen. Vertaald door P.M. Boer-den Hoed, M. Nijland-v.d. Meer de Walcheren en Annie Romein-Verschoor. Amsterdam. [1967 $]$ (SJM 167)

11 GD 1944 K Sprookjes van Andersen naar Geo Dem. Luik. (SJM 184)

12 MB 1960 K Hans Christiaan Andersen: Sprookjes. Nederlandse bewerking: Margot Bakker. Deventer. [1965']. (DCC 211)

13 MvB 1960 V Hans Christiaan Andersen: Sprookjes. Vertaald door A.F. Maitlandvan Bemmelen en Leonore ter Laan. Utrecht-Antwerpen. [19817] (DCG 217)

14 TES 1961 N Hans Christiaan Andersen: Sprookjes. Uit het Deens vertaald doos T. van Eeden-Schuitemaker. Amsterdam. [1974²] (DCG 216)

15 HL. $1975 \mathrm{~N}$ Sprookjes van Andersen. Vertaling van Harriet Laurey. Haarlem. $\left[1976^{2}\right]$ (DCG 280)

$16 \mathrm{ME} / \mathrm{W} 1975 \mathrm{~V}$ Sprookjes van Andersen. Ivertaling van $M$. van Eeden-ven V!oten 1899, bewerkt door Willem Wilmink]. Amsterdam-Antwerpen. (DCG 279)

17 AvH 1992 N hans Christiaan Andersen: Sprookjes en verhalen. Opnieuw uit het Deens vertaald door Annelies van Hees. Rotterdam. 


\section{Analyse van de Nederlandse vertalingen}

\subsection{Het analysemodel van Katharina Reiß}

In haar studie Möglichkeiten und Grenzen der Übersetzungskritik geeft de Duitse onderzoekster Katharina Reiß een analysemodel, ter voorkoming van onberedeneerde en onsystematische vertaalkritiek, zoals die ook nu nog vaak voorkomt. Zoals in paragraaf 3.2 van de inleiding van dit proefschrift is uiteengezet, is Reiß' brontekstgerichte aanpak om na te gaan of het communicatieve doel van het origineel ook door de vertaling wordt bereikt, niet per se strijdig met meer doeltekstgericht descriptief vertaalonderzoek, zolang aan eventuele consistente afwijkingen geen kwalificatie wordt verbonden, en 'equivalentie' fungeert als tertium comparationis.

Daar het doel van een tekst samenhangt met het tekstrype, veronderstelt vertaalkritiek volgens Reiß eerst analyse van de brontekst naar teksttype: informatief (inhaltsbetont/logisch), expressief (formbetont/ästhetisch) of operatief (appellbetont/dialogisch). Idealiter bepaalt het teksttype vertaalmethode en rangvolgorde der te bewaren tekstaspecten, dat wil zeggen het primaat van respectievelijk inhoud, vorm en boodschap.

Het teksttype is nader verdeeld in tekstsoorten (zo ressorteert onder het expressieve type bijvoorbeeld de literaire prozatekst). Met de tekstsoort varieert de rangorde van de zogenaamde linguale categorieën. Reiß onderscheidt er vier:

- semantische instructies (criterium: semantische equivalentie). Is de 'zin', betekenis van de brontekst bewaard? Passen gekozen woorden en wendingen in de brontekst?

- lexicale instructies (adequaatheid). Zijn vaktermen, sociolect, dialect, 'onvertaalbare woorden', namen, homoniemen, woordspelingen, idioom en spreekwoorden bewaard? Kent de vertaler 'faux amis' en verschillen in woordveld tussen brontaal en doeltaal?

- grammaticale instructies (correctheid). Bij verschil van grammaticaal systeem of aspect heeft de doeltaal hier voorrang.

- stilistische instructies (volledige overeenkomst). Zijn de verschillende taallagen weergegeven: normale stijl van de brontaal, tijdsstijl, individuele stijl? Heeft de vertaler geen 'fouten' uit de brontekst 'verbeterd"?

Behalve linguale onderscheidt Reiß ook extralinguale determinanten:

- situatiecontext in engere zin (namelijk tegenover de totale context). Kan de vertaler zich verplaatsen in de 'situatie' van een bepaalde passage? Kent hij omgangspatroon en taalgebruik van een bepaalde leeftijdsgroep, klasse, cultuurkring? Men denke aan allerlei elliptische tcespelingen.

- vakkennis. Kent de vertaler de genoemde begrippen in hun onderlinge samenhang?

- tijdsaspect. Past het woordgebruik bij de in de tekst beschreven periode casu que de tijd van ontstaan - zonder dat het woordgebruik verder geforceerd aandoet? Een oudere en modeme vertaling van hetzelfde werk moeten in dezen verschillend worden beoordeeld.

- aspect 'plaats' - kennis van de realia. Kent de vertaler genoemde voorwerpen, namen, instellingen, wezens, begrippen, met hun concrete en/of symbolische culturele functie? 
- aspect van de oorspronkelijke recipiënt. De brontekst veronderstelt een geheel van sociaal-cultureel bepaalde kennis bij de lezer, wat zich onder andere uit in allerlei idiomatische wendingen. Bereikt de vertaler via omvorming hetzelfde bij zijn lezer?

- externe invloeden op het taalgebruik van de brontekst: herkomst en scholing van de auteur, de literaire stroming, enzovoort bepalen zowel individuele stijl van een schrijver als het taalgebruik van zijn personages. Heeft de vertaler deze invloeden gerespecteerd?

- affectieve implicaties: zijn humor, sarcasme, opwinding, nadruk, enzovoort bewaard gebleven?

\subsection{De plaats van 'Reisekammeraten' in het analysemodel}

Uitgaande van onze analyse in paragraaf 2 beschouwen we Reisekammeraten als een literaire prozatekst. Dat wil zeggen dat de specifieke vorm in een vertaling, die zich als zodanig - dus niet als bewerking - aandient, volgens Reiß idealiter functioneel equivalent is aan de brontekst.

Andersens specifieke stijl (zie paragraaf 2.3.2) maakt de stilistische instructies de belangrijkste linguale categorie, gevolgd door semantisch/lexicale en grammaticale instructies. De extralinguale determinanten, die in dit geval overigens in allerlei opzichten samenhangen met de linguale, vallen met betrekking tot literaire teksten deels samen. Zo overlappen vele aspecten van 'situatiecontext', 'vakkennis', 'plaats' en 'externe invloeden' elkaar. De analyse in paragraaf 2 geeft aanleiding tot de volgorde: aspect van de recipiënt; kennis van realia; tijdsaspect.

\subsection{De linguale categorieën}

\subsection{Stilistische instructies}

Bij het beantwoorden van de vraag of Andersens stijl in de Nederlandse vertaling is aangehouden, wordt de verdeling van paragraaf 2.3.2 aangehouden.

a. Her gebruik van voor kinderen begrijpelijke en aansprekelijke woorden.

Omwille van de consistentie en ter vermijding van het eventuele verwijt, dat er in het wilde weg zou zijn 'geplukt', zijn alle direct volgende voorbeelden ontleend aan een kort tekstgedeelte, namelijk de eerste drie bladzijden in de editie Dal \& Nielsen. De getallen en letters tussen haakjes achter de vertaling verwijzen naar de lijst van vertalingen in paragraaf 3.

- "det var ligesom om han sov"

- "Hans Far laae død og kold i Sengen"
- "men zou wezentlijk gemeend hebben dat hij sluimerde"

- "zijn vader lag dood en verkild op de sponde" 


\section{Boeken voor Jongens en Meisjes. \\ De Reiskameraad.}

Uit het Deensch naar Andersen.

\section{GEILLUSTREERD.}

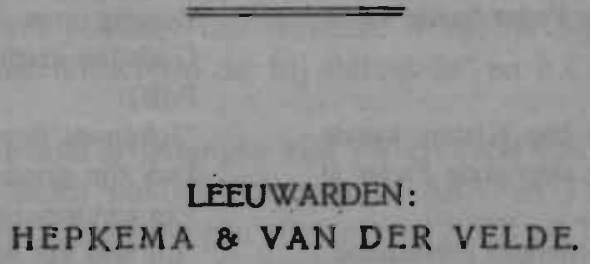

Afbeelding 17. Titelblad van een 'pirateneditie' voor kinderen uit 1912, waarvoor de vertaling en de illustraties uit eerdere uitgaven zijn bijeengegaard. (Koninklijke Bibliotheek Kopenhagen). 
- "Ugen derefter blev den Døde begravet"

- "det gjorde godt i hans Sorg"

- "paa Marken, hvor Johannes gik"

- "hvor han hver Søndag med sin gamle Fader havde varet i Kirke"

- "det klang saa smukt"

- "hele sin Arvepart, der var 50 Rdlr. og et Par Sølvskillinger"

- "Seer Du, hvilken Brud Du har faaet?"

- "han vil [...] lære mig saa meget af alt det Deilige i Himlen, ligesom han larte mig her paa Jorden"

- "saa bedrøvet var han"

- "han græd"

- "Rundt om sang de en Psalme, det klang saa smukt"

- "han vil [...] lære mig saa meget af alt det Deilige i Himlen, ligesom han larte mig her paa Jorden"

- "den gamle Kirke, hvor han hver Søndag med sin gamle Fader havde varet i Kirke"

- "Johannes gik tat bag Kisten, kunde nu ikke mere faae den gode Fader at see"

- "han var langt ud mellem Fremmede"

- "sin Faders Grav, der ogsaa maatte komme til at see ud som disse"

- "nu havde han slet ingen $i$ hele Verden"

- "lære [...] saa meget af alt det Deilige i Himlen"

- "det var just nydeligt, syntes han, [...] den var just et smukt Sovekammer"
- "De week daarop volgende, werd de verledene ter aarde besteld" ( $1 \mathrm{NN}$ )

- "dat verligtte zijn gemoed in zijne treurigheid"

- "op het veld, waardoor hij zijnen weg nam"

- "waarin hij iederen Zondag met zijn vader de plegtige dienst had bijgewoond" (2CdJ)

- "het waren schoone, heilige klanken"

- "zijn geheele erfdeel, hetwelk vijftig thalers en een paar zilveren schellingen bedroeg" ( $3 \mathrm{SJA} ; 6 \mathrm{~A} / \mathrm{T}$ )

- "Zie eens, welke bruid voor u bestemd is!"

- "hij zal mij [...] zo veel doen opmerken van al het schoone in den hemel, gelijk gij hier op aarde deed" (5 NN)

- "hij was onbeschrijflijk bedroefd"

- "hij schreide hartstochtelijk"

- "Om hem heen werd een psalm gezongen, welk gezang zo prachtig klonk" (7 CD)

- "Dan zal hij mij over de heerlijkheid des Hemels onderrichten, juist zooals hij mij op aarde onderricht gaf"

- "de oude kerk [...] waarin hij iederen Zondag met zijnen vader naar de Godsdienstoefening was gegaan" (8 PdB)

- "Johannes liep vlak achter de baar en kon zijn goeden vader [...] niet meer van aangezicht tot aangezicht zien"

- "hij was ver weg in den vreemde

- "het graf van zijn vader, dat er ook wel cens te eenigertijd zoo zou kunnen gaan uitzien" (10 ARV)

- "Nu was hij alleen in het onbekende leven"

- "alle heerlijkheden van het Paradijs beschrijven"

- "Jan bevond dat het inderdaad de prachtigste slaapkamer van de wereld was" (11 GD) 
_ "Rundt om sang de en Psalme"

- "gjemte i sit Belte hele sin Arvepar, der var 50 Rdlr. og et Par Sølvskillinger, dermed vilde han vandre ud $\mathrm{i}$ Verden"

- "Solen skinnede deiligt paa de grønne Træer"

- "Men Johannes gred"

- "de grønne Trær"

- "for at see den gamle Kirke"

- "de vare saa fornøiede, skønt de jo vare med til Begravelsen"

- "Maanen var en rigtig stor Natlampe, høit oppe under det blaa Loft, og den stak ikke Ild i Gardinerne"
- "De mensen om het graf zongen een gezang"

- "stak zijn hele erfdeel bij zich. Groot was het niet: vijftig daalders en nog wat kleinere geldstukken. Maar daarmee wilde hij zijn geluk beproeven"

- "De zon zette de groene bomen in heerlijk licht" (12 MB)

- "Maar Johannes weende"

- "het groene geboomte"

- "om een laatste blik op het oude kerkje te werpen"

- "Ze waren bij de begrafenis geweest, maar ze waren toch blij"

- "Hoog aan het blauwe plafond stond de maan als een groot nachtlicht; en je hoefde niet bang te zijn dat hij de gordijnen in brand zette" (15 HL)

Qua 'kinderlijk' taalgebruik blijven $4 \mathrm{MvE}, 9 \mathrm{WvE}, 14 \mathrm{TES}$ en $16 \mathrm{MvE} / \mathrm{W}$ het dichtst bij Andersen, terwijl de frequentie van 'on-kinderlijke' taal het hoogst is bij $1 \mathrm{NN}, 3$ $\mathrm{SJA}$, SNN, $6 \mathrm{~A} / \mathrm{T}$. Vooral het lexicon varieert van hoog-frequente woorden uit de basiswoordenschat, zoals Andersen ze zelf gebruikt, tot verheven en archaïsche woorden. De gedachte dat wat wij thans aanzien voor on-kinderlijke woorden en wendingen in de oudste vertalingen, in werkelijkheid normale negentiende-eeuwse kindertaal zou zijn, wordt gelogenstraft door $2 \mathrm{CdJ}$, die naast 'volwassen' idioom als hierboven aangehaald, elders in de tekst een veel gewoner taal hanteert. Vergelijk bijvoorbeeld INN, 1848 "Men zou wezentlijk gemeend hebben dat hij sluimerde" en $2 \mathrm{CdJ}, 1858$ "Het was net alsof hij sliep".

De hierboven gesignaleerde wijzigingen zijn verschillend van aard. Overeenkomstig hun doelen op een volwassen publiek hanteren 10 ARV en 13 MvB ingewikkelder, 'volwassener' formuleringen. Daarentegen vervangen $12 \mathrm{MB}$ en $15 \mathrm{HL}$ door hen kennelijk als te gecompliceerd ervaren woorden en wendingen door eenvoudiger vormen ten behoeve van hun kinderpubliek. Opvallend is $8 \mathrm{PdB}$, die alleen inzake religieuze elementen een veel plechtiger woordgebruik hanteert.

Van 1 NN, 3 SJA, 5 NN, 6 A-T, 7 CD en 11 GD valt vooralsnog slechts te constateren, dat ze Andersens taal door de keus van minder frequente woorden buiten de basiswoordenschat om, in mindere of meerdere mate wijzigen in een 'volwassener', 'literairder', 'plechtiger' richting, al spelen de negentiende-eeuwse Nederlandse opvattingen over stijl en inhoud van sprookjes ${ }^{255}$ hierin vermoedelijk een rol.

\section{b. Het gebruik van versterkende woorden en andere middelen tot nadruk}

Ook hier is omwille van samenhang en overzichtelijkheid eenzelfde uitgangspunt genomen, namelijk de vertaling van de volgende passages: 
- "Du var en god Søn, Johannes!", sagde den syge Fader, "vor Herre vil nok hjelpe Dig frem i Verden!"

- "alt det Smukke var borte [...] der var slet ingen hos dem: den stakkels Johannes!"

- "O, hun var saa gammel og gik ganske krum."

- "Det var just en nydelig Komedie, og den var slet ikke sørgelig". 256

Deze voorbeelden, hier voor de gelegenheid gecursiveerd met uitzondering van de reeds door Andersen gecursiveerde naam Johannes, hebben niet slechts een vertelfunctie (gevarieerde herhaling, het betrekken van het luisterende kind in de geschiedenis), maar ook een inhoudelijke functie: de twee sleuteluitspraken van de vader, de naam Johannes, de relatie tot God, vergelijk paragraaf 2.3.1.

Geen der vertalingen handhaaft alle twaalf versterkingseffecten: slechts één ( $1 \mathrm{NN}$ ) houdt vast aan de cursivering van de naam Johannes en vertaalt "slet"in de woordgroep "slet ingen"; slechts vijf vertalers (I NN, 2 CdJ, 3 SJA/6 A-T, 10 ARV, 13 MvB) geven beide uitroeptekens in de eerste zin.

Soms wordt niet het betreffende woord/effect, maar de hele betreffende passage weggelaten, bijvoorbeeld door $3 \mathrm{SJA}$, die voor de laatste zin geeft: "Het was een heel aardige komedie", - idem 6 A-T, 11 GD en 14 TES, van wie de laatste twee bovendien respectievelijk de derde zin in het geheel en het slot van de tweede zin weglaten. Regelmatig wordt de nadruk inhoudelijk gehandhaafd, doch stilistisch gewijzigd: "er was geen sterveling ter wereld bij hen" ( $1 \mathrm{NN}$ ), "Ja waarlijk, het was een schoone komedie" ( 5 $\mathrm{NN}$ ), "Het was zo maar een vrolijke komedie" (13 MvB), "ze was stokoud / Stokoud was ze / Werkelijk stokoud was ze" (10 ARV, $12 \mathrm{MB}, 15 \mathrm{HL})$.

Zelfs als we dit soort wijzigingen meerekenen, blijken zeven vertalingen meer dan de helft der effecten te hebben weggelaten: $3 \mathrm{SJA} / 6 \mathrm{~A}-\mathrm{T}, 4 \mathrm{MvE}, 8 \mathrm{PdB}, 11 \mathrm{GD}, 12 \mathrm{MB}$, $14 \mathrm{TES}$ en $16 \mathrm{MvE} / \mathrm{W}$. De enige vertaling die qua antal dicht bij het origineel komt is $1 \mathrm{NN}$, maar daarin komen als gezegd de nodige stilistische wijzigingen voor.

\section{c. De nauw bij de spreektaal aansluitende syntaxis}

De vertalingen van de volgende zinnen zijn nagegaan:

- "Han laae paa sine Kna foran Sengen og kyssede den døde Faders Haand, graed saa mange salte Taarer, men tilsidst lukkede hans Øine sig og han sov ind med Hovedet paa den haarde Sengefjel."

- "Saa vaagnede han, og alı det Smukke var borte. hans Fader laae dod og kold i Sengen, der var slet ingen hos dem; den stakkels Johannes!"

- "han lovede strax Reisekammeraten, at han vilde give ham alle de Penge, han fik for sin Comedie neste Aften, naar han bare vilde smore fire, fem af hans paeneste Dukker; men Reisekammeraten sagde, at han forlangte slet ikke andet end den store Sabel, han havde ved sin Side, og da han fik den, smurte han sex Dukker"

- "Verten fortalte dem, at Kongen var saadan en god Mand, der aldrig gjorde noget Menneske noget, hverken det ene eller det andet, men at hans Datter, ja Gud bevare os! det var en slem Prindsesse."

- "Aftenen gik ligesom den igaar". 
Bij het beoordelen van syntactische vertaalaspecten spelen uiteraard syntactische structuurverschillen tussen beide talen een belangrijke rol. Zo is ten eerste hoofdzinvolgorde in de bijzin veel normaler in de Deense spreektaal dan in het Nederlands, en maakt ten tweede het Deens bij het possesssief pronomen van de derde persoon onderscheid tussen de reflexieve vorm sin en de niet-reflexieve vorm hans. Op zichzelf is echter het veelvuldig gebruik van pronominale verwijzingen, anakoloeten, poly-en asyndese, actieve in plaats van passieve constructies even gewoon voor de negentiende- èn twintigste-eeuwse Deense en Nederlandse spreektaal als ongewoon voor de literaire schrijftaal.

Alleen $9 \mathrm{WvE}$ en $15 \mathrm{HL}$ handhaven Andersens zinsbouw; alle andere vertalers veranderen in meer of mindere mate komma's in puntkomma's, puntkomma's in punten, nevenschikkende in onderschikkende verbanden en/of vatten bijzinnen samen in een woordgroep. Enkele voorbeelden:

- "Hij lag voor het bed op zijne knieën, kuste de hand van zijn gestorven vader en stortte vele bittere tranen; maar eindelijk gingen zijne oogen dicht en viel hij in slaap, terwijl hij met zijn hoofd tegen den harden bedstijl aanleunde" (3 SJA/6 A-T)

- "Toen werd hij wakker en was alles verdwenen. $\mathrm{Zijn}$ vader lag op het bed, dood en al koud. Er was niemand bij hem. Hij was bitter alleen" (12 MB).

Het zelfde geldt bij de meeste vertalers (INN, 3 SJA/6 A-T, 4 MvE, 8 PdB, 9 WvE, 10 ARV, $11 \mathrm{GD}, 12 \mathrm{MB}, 13 \mathrm{MvB}, 14 \mathrm{TES}, 15 \mathrm{HL}, 16 \mathrm{MvE} / \mathrm{W}$ ) de pronominale verwijzing: "han" wordt "de reiskameraad"/"de man"; "hans" wordt "de"; "at han vilde give ham alle de Penge" verandert in "hem al het geld te geven".

De zin "Værten fortalte dem [...] at hans Datter, ja Gud bevare os! det var en slem Prindsesse", een vermenging van anakoloet plus tussenzin waarna een hoofdzin in plaats van verwachte bijzin, wordt genominaliseerd: op $7 \mathrm{CD}$ na bevatten alle vertalingen een normale hoofdzin, terwijl $3 \mathrm{SJA} / 6 \mathrm{~A}-\mathrm{T}, 11 \mathrm{GD}, 12 \mathrm{MB}$ en 14 TES zelfs de hele tussenzin weglaten (zie hierover nader paragraaf 4.3.2).

De kinderlijke deiktische bijwoordelijke verwijzing met "igaar", waar logisch gezien "foregaaende" (de formulering uit D $\phi$ dningen) had moeten staan, durft geen der vertalers aan: allen hebben de anaforische verwijzing "de vorige dag/avond". Wellicht is deze wijziging te verklaren vanuit de vrees, dat deze formulering - die overigens ook voor de Deense schrijftaal ongewoon is - door de Nederlandse lezer voor een 'fout' van de vertaler zou worden aangezien.

\section{d. De al dan niet gevarieerde herhaling, vaak in de vorm van tautologie of pleonasme}

De volgende passages zijn als uitgangspunt gekozen:

- "Den stakkels Johannes [...] Den stakkels Johannes [...] den stakkels Johannes!"

- "og hvor det vil blive en Glade [...] O hvor det vil blive en Glade!"

- "Jeg vil altid vare et godt Menneske, og saa tør Du nok bede den gode Gud, at det maa gaae mig godt!"

- "et skrakkeligt ondt Veir $[\ldots]$ det onde Veir $[\ldots]$ det onde Veir $[\ldots]$ levende, onde Mennesker [...] levende, slemme Folk [...] det er ondt og slemi"

- "Johannes vilde strax, at de skulde bære hende hjem, hvor hun boede."257 
Alle vertalers hebben ten minste twee van de genoemde vijf gevallen van herhaling geschrapt. Eén vertaler heeft er drie gehandhaafd ( $9 \mathrm{WvE})$, zeven hebben er twee, zes één, en twee (11 GD en $12 \mathrm{MB}$ ) geen enkele. Het begin "in medias res" - er staat "den stakkels Johannes" en niet "stakkels Johannes" -, het oproepen van medelijden bij de lezer/hoorder door middel van herhaling plus de drievoudige formule tonen de veelzijdig stilistische-inhoudelijke functie van het eerste voorbeeld, die in zijn geheel slechts door 1 NN is bewaard; 12 MB herhaalt hier überhaupt niet. Het direct herhaalde "Glæde", een woord uit het belangrijke contrastveld droef-blij, wordt door eenzelfde vertaler weergegeven met verschillende woorden: blijdschap-vreugde, een vreugde-heerlijk, enzovoort. Dit geldt nog sterker voor de kemwoorden "god" en "ond". Slechts vijf vertalingen geven steeds "goed": 4 MvE, 7 CD, 9 WvE, 14 TES en $16 \mathrm{MvE} / \mathrm{W}$. In navolging van de Duitse vertalingen waarnaar ze zijn gemaakt, laten $2 \mathrm{CdJ}$ en $3 \mathrm{SJA} / 6 \mathrm{~A}-\mathrm{T}$ deze hele passage weg. De relatie tussen het "onde Veir" en de "onde Mennesker" gaat eveneens veelal verloren: het weer is onstuimig, akelig, vreeselijk, erg; het is onweer of noodweer; de mensen zijn ondeugend, gemeen, het zijn booswichten; enkele vertalers schrappen herhaling van "ond", en 11 GD schrapı de hele slecht-weer-scène (1 NN, $2 \mathrm{CdJ}, 3 \mathrm{SJA} / 6$ A-T, 5 NN, 8 PdB, 10 ARV, 11 GD, $12 \mathrm{MB}, 15 \mathrm{HL}$ ).

De naïeve vertelwijze in "hjem, hvor hun boede" is evenmin ergens behouden; soms zijn beide onderdelen geïntegreerd in de woordgroep "naar haar huis", waarin echter de inhoud tenminste gedeeltelijk en het retorisch effect geheel verloren gaat.

\subsubsection{Semantische instructies}

Daar het stilistische aspect van de semantische instructies - keuze tussen inhoudelijke equivalenten - al in de voorgaande paragraaf is behandeld, beperken we ons hier tot de concreet-inhoudelijke verwijzingen / weglatingen / toevoegingen ten opzichte van de brontekst.

Onbedoelde semantische verschuivingen treden op als gevolg van onvoldoende kennis van de vreemde taal of van incidentele onopmerkzaamheid. Terecht heeft Katharina ReiB erop gewezen, dat het onsystematisch aanwijzen van afzonderlijke 'vertaalfouten' van deze aard zinloos is, daar een enkele vertaalfout niets zegt over de vertaling als geheel.

lets anders is het natuurlijk, als dergelijke verschuivingen door onvoldoende kennis van de vreemde taal zeer regelmatig voorkomen, en/of wanneer bepaalde sleutelpassages niet als zodanig worden herkend, waardoor literaire effecten verloren gaan.

Een dergelijke verzameling vinden we bij $2 \mathrm{CdJ}$. De elfjes spelen de hele nacht "lige til Solen stod op", maar bij De Jong "tot de zon onder ging". "Han forlangte [...] den store Sabel, han havde ved sin Side" wordt via de door De Jong verkeerd begrepen Duitse versie "den Jener an seiner Seite hatte" (vertaling van Lorck), tot: "de sabel, die iedere pop droeg"; de reiskameraad krijgt dus een hele verzameling poppesabeltjes, waarmee hij later zwanevleugels afhouwt! "Lad vare!". probeert de koning Johannes te weerhouden; "Lass es sein!" schrijft Lorck, en "Welnu, laat het dan maar zo zijn" heet het bij De Jong. Bij Andersen slaat de klok "tre Quarteer til Tolv", - voorbereiding op het middemachtelijk uur -, "eindelijk" slaat bij De Jong de klok "kwartier over twaal- 
ven". "Hvor det Hagler!" sagde Prindsessen ved hvert slag, hun fik af Riset, og det kunde hun have godt af" (een woordspeling met god!) wordt via "und das war ihr schon recht" tot "en met die verklaring was zij tevreden".

Het hierboven geconstateerde misverstaan van Duitse vertalingen casu quo het navolgen van verkeerde interpretaties van het Deens in de Duitse vertalingen vinden we niet alleen bij $2 \mathrm{CdJ}$, de enige die vermeldt naar het Duits te hebben vertaald, maar ook bij 1 NN, 3 SJA/6 A-T en 7 CD, die respectievelijk steunen op de vertalingen van Reuscher, Lorck, en Reuscher plus Lorck. Enige voorbeelden: het spel van de elfjes is "uhyre morsomt" / "allerliebst" (Reuscher èn Lorck) / "allerliefst" (1 NN, 3 SJA/6 A-T), "alleraardigst" (7 CD). De vertaling wordt hier duidelijk in de Biedermeiersfeer getrokken. In het spektakel van de nachtdieren in de berggrot slaat onder andere een uil op zijn buik; verkeerd lezen van het gotische schrift in de Duitse vertaling doet 3 SJA het woord "Eule" opvatten als "Ente": "een eend sloeg zich op het lijf (Leib)", nagevolgd door 7 $\mathrm{CD}$, "eenden sloegen zich op de buik". Bij $7 \mathrm{CD}$ vinden we een aantal bij $2 \mathrm{CdJ}$ geconstateerde wijzigingen in een iets andere vorm terug: "de grote sabel, die één van hen [= de poppen, DG/PV] aan de zijde droeg"; "Het zij zo". Vermoedelijk heeft Christine Doorman, die meerdere boeken uit Zweeds en Deens heeft vertaald, zowel de Deense tekst als Duitse vertalingen en/of oudere naar het Duitse gemaakte Nederlandse vertalingen gebruikt. De hier genoemde voorbeelden zijn tot in de zeventiende druk van 1977 terug te vinden.

Een meer impliciete invloed van de Duitse vertalingen, die tot in de jongste tijd voelbaar is, vormt de kanonisering van de titel. 'Reiskameraad' is tamelijk ongebruikelijke Nederlands, - het Woordenboek der Nederlandsche Taal vermeldt het slechts terzijde, niet als een apart lemma, en geeft als de gebruikelijke termen "reisgenoot" en "reisgezel". De grote meerderheid van de vertalingen heeft echter "reiskameraad", met uitzondering van $2 \mathrm{CdJ}, 6 \mathrm{PdB}, 12 \mathrm{MB}$ ("reismakker") en $5 \mathrm{NN}$ "reisgezel").

De meeste vertalers hebben een redelijk tot goede kennis van de concrete semantische inhoud der Deense woorden. Blunders van het kaliber "I maa gjerne lee med": "I cannot help laughing", waarvan de Engelse vertalingen wemelen ${ }^{258}$, komen dan ook vrij weinig voor. Faux amis leveren bijna alle vertalers af en toe wel moeilijkheden, maar ze zijn meestal zo gespreid dat ze niet hinderlijk zijn voor het semantische beeld als geheel: "nok": "nog"; "alle Folk": "het hele Volk"; "saa" (in de betekenis "dan"): "zo"; "vilde" (betekenis "zou"): "wilde"; "Sø" (betekenis "meer/vijver"): "zee"; "førr" (betekenis "tevoren"): "vroeger": "sin" (betekenis "haar"): "zijn": "Støi": "gestoei"; "Loft": "lucht"; "da" (betekenis "toen"): "daar". De enige die vrijwel al deze faux amis meermalen heeft, is 5 $\mathrm{NN}$, wiens vertaling bovendien gekenmerkt is door een groot aantal syntactische danismen (zie paragraaf 4.3.4). Maar liefst acht vertalingen (1 NN, 2CdJ, 3 SJA/A-T, $7 \mathrm{CD}$, $8 \mathrm{PdB}, 10 \mathrm{ARV}, 13 \mathrm{MvB}$ ) geven "der var [...] en stor Bedrøvelse. Comediehuset blev lukket" weer met "... de schouwburg/het theater bleef gesloten".

Ook het idioom geeft af en toe problemen. De semantische inhoud van "Og det kunde hun have godt af" (vergelijk hierboven) wordt door velen niet doorzien; stilistisch dekkend is alleen 4 MvE-16 MvE/W, die de woordspeling bewaart: "en dat was wát goed voor haar!" Een ander voorbeeld is "Urtekoste". Andersen schrijft: "Hvad vil Du med de Riis?' spurgte Johannes nu sin Reisekammerat. 'Det er tre pæne Untekoste!' sagde 
han, 'dem kan jeg just lide, for jeg er en løierlig Fyr!"”259 Die "Urtekoste" zijn het cadeau van de reiskameraad aan de prinses, - ze krijgt immers "Riis"! "Urtekoste" (veldboeketten of iets dergelijks) wordt echter vertaald met "bezems", "kruidbezems", "heidebezems" en "takkebezems", zelfs met "geesels" (1 NN, 2 CdJ, 3 SJA/6 A-T, 7 $\mathrm{CD}, 8 \mathrm{PdB}, 10 \mathrm{ARV}, 12 \mathrm{MB}, 13 \mathrm{MvB}$ ), waarin behalve de concrete betekenis cok symboliek, verhaalverbanden en humor verloren gaan.

Kenmerkend voor het sprookje is het archetypisch gebruik van het bepalend lidwoord bij figuren en lokaties, dat bij Andersen bovendien vaak tevens vooruitwijzend werkt: "Kongen kunde ikke have det pæenere", "Johannes og Reisekammeraten vilde ikke strax gaae ind i Byen, men bleve i Vertshuset udenfor". 200 Door $1 \mathrm{NN}, 2 \mathrm{CdJ}, 4 \mathrm{MvE}, 10$ ARV, $11 \mathrm{GD}, 12 \mathrm{MB}, 14 \mathrm{TES}, 15 \mathrm{HL}$ en $16 \mathrm{MvE} / \mathrm{W}$ wordt dit gewijzigd in het onbepaalde " $(g) e e n$ koning" en/of "een herberg/logement".

Behalve al deze merendeels onbedoelde semantische wijzigingen bevatten veel vertalingen bewust aangebrachte veranderingen. Deze kunnen worden onderscheiden in de volgende subcategorieën:

- verklarende toevoegingen. Oorzaak is vermoedelijk de vrees dat Andersens tekst niet duidelijk of krachtig genoeg is. Een voorbeeld: "Han skulde bare gjætte tre Ting, hun spurgte ham om" wordt "op voorwaarde dat, hij drie zaken, die zij in hare gedachte had genomen en waar zij zelve hem naar vraagde, wist te raden" (1 NN). Dit soort toevoegingen komt vooral voor bij $1 \mathrm{NN}, 7 \mathrm{CD}, 11 \mathrm{GD}$ en $12 \mathrm{MB}$, af en toe bij $2 \mathrm{CdJ}, 8 \mathrm{PdB}$ en $15 \mathrm{HL}$ : verklaring vanuit de doelgroep kinderen is dus hooguit gedeeltelijk juist.

- weglatingen en inkortingen. De oorzaken zijn hier gevarieerder: reserves ten opzichte van Andersens herhaling en nadruk, de wens om voor een volwassen publiek wat sneller te vertalen, correctie van Andersens 'inhoudelijke fouten'. Voorbeelden van de eerste overweging zijn te vinden in paragraaf 4.3.1., punt $\mathrm{c}$ en $\mathrm{d}$; deze wijzigingen betreffen meestal een enkel woord en zijn het meest frequent. Correctie van Andersen vinden we onder andere bij Annie Romein-Verschoor: de levende marionettenkoningin kan eerst volgens het verhaal niet praten, maar spreekt even later tot de reiskameraad, - welk probleem $10 \mathrm{ARV}$ oplost door de eerste mededeling weg te laten. Inkorting ten behoeve van een volwassen publiek komt het sterkst voor bij 14 TES. Deze categorie wijzigingen is vooral aan te treffen bij $3 \mathrm{SJA} / 6 \mathrm{~A}-\mathrm{T}, 4 \mathrm{MvE}, 11 \mathrm{GD}, 12 \mathrm{MB}, 14 \mathrm{TES}, 15 \mathrm{HL}$ en 16 MvE/W.

- wijzigingen van morele aard. "Jeg vil altid være god" wordt bij 1 NN, $2 \mathrm{CdJ}, 3 \mathrm{SJA} / 6$ A-T, $5 \mathrm{NN}, 8 \mathrm{PdB}, 11 \mathrm{GD}$ en 14 TES gereduceerd tot "Ik zal altijd braaf zijn", waarmee niet alleen het sleutelwoord "goed" verdwijnt, maar ook opnieuw een brave-hendrikkensfeer wordt gecreërd. Vergelijk ook "onde Mennesker": "ondeugende menschen" (2 CdJ). Op 14 TES na zijn dit alle negentiende-eeuwse vertalingen respectievelijk vertalingen in katholieke geest. De laatste groep vermijdt de vertaling van "Prast" (in Johannes eigen, duidelijk Deens aandoende land) met "dominee"; 11 GD heeft "pastoor". En 8 PdB vertaalt "Psalme" met "choraal" en "vrome liederen". Ook de begrafenis, "Ugen derefter", wordt uit religieuze overwegingen in deze vertalingen op een eerder tijdstip geplaatst: "een dag", "eenige dagen", "de volgende dag". Volgens katholiek gebruik is de ruimte tussen dood en begrafenis namelijk kort, terwijl deze volgens Luthers juist zo groot mogelijk is. 'Protestantiserend' of seculariserend zijn daarentegen 9 WvE en 12 
MB, die "Psalme" vertalen met respectievelijk "lied" en "gezang"; 9 WvE laat hypercorrect de "Præster" in het vreemde land als "dominé's" op hun knieën in de kerk liggen.

Overwegingen van preutsheid zijn te vinden bij $C D$, die het aangekondigde opeten van Johannes' ogen weglaat; bij $4 \mathrm{MvE}$ en $12 \mathrm{MB}$, die de tussen Johannes en de reiskameraad uitgewisselde kus vervangen door een omhelzing. Opvallend is de ont-erotisering in de laatste scène door de vertaling van "Brudeseng" met bed, ledikant, of slaapkamer (1 NN, 2 CdJ, 3 SJA/6 A-T, 7 CD, 10 ARV, 14 TES; niet in de katholiek getinte vertalingen).

- bewerking. Op de titelbladen aangegeven karakteristieken als vertaald, bewerkt, naverteld, uitinaar het Deensch (zie paragraaf 3) dekken niet steeds hetzelfde begrip. Het Deens blijkt soms Duits - zie hierboven -, terwijl het 'navertellen' door 3 SJA en de 'bewerking' van $8 \mathrm{PdB}$ vertalingen zijn, die de Deense tekst in elk geval inhoudelijk vrij goed volgen. $\mathrm{Al}$ in mindere mate geldt dit voor de 'bewerking' van $12 \mathrm{MB}$ met haar vele toevoegingen, maar de enige wezenlijke structureel-inhoudelijke bewerking in eigenlijke zin is toch $11 \mathrm{GD}$. Voor een dergelijke bewerking liggen twee motieven voor de hand: verkorting om commerciële redenen en/of aanpassing aan een ander publiek, bijvoorbeeld volwassenen of heel jonge kinderen. De beweegredenen voor GD's bewerking zijn echter volstrekt onduidelijk. Enerzijds kort hij in (begrafenis / hulp aan de bedelaar / elfenfeest enzovoort zijn weggelaten), wat het bewust aangebrachte contrast en de driefasenstrucktuur doorbreekt. Anderzijds voegt hij van alles toe (in de kerk na het betalen van de schuld: "dat is goed mijn jongen! Je hebt als een goed mensch gehandeld! zei een stem naast Jan. Hij draaide zich om maar zag niemand en zeide toen in zichzelf dat de geest van zijn vader bij hem was": intrige verklapt), zodat de totale lengte gelijk blijft. Verdere kenmerken zijn de voortdurende wisseling van subjectief en objectief vertellersperspectief en gebruik van volwassen naast kinderlijk taalgebruik. Andersens uitgekiende volgorde wordt omgekeerd:

Sedert den morgen was de kleine Jan een wees; zijn vader was na een korte ongesteldheid overleden en nu schreide de jongen [...] Wat was hij altijd goed voor mij, dacht de jongen [...] Arme vader, $u$ bent van deze aarde heengegaan...Arme vader! - Arme Jan! Nu was hij alleen in het onbekende leven. En het kind, uitgeput van moeheid, sliep in, het hoofd op den rand van het bed rustende. Een vreemdeling, die het kamertje binnenkwam, had kunnen denken, dat vader en zoon sliepen, na een dag van zwaren arbeid.

Voegen we hieraan toe het volledig dooreen halen van micro- en macrostruktuur ("hij beklaagde zich erover bij zijn kameraad die de bruiloft bijwoonde en vroeg of de zalf uit het kleine potje de gevoelens van zijn bruid niet kon veranderen"), dan blijkt de totale inconsistentic van deze bewerking.

- modernisering. Deze vorm van bewerking vinden we onder andere in 6 A-T ten opzichte van $3 \mathrm{SJA}, 16 \mathrm{MvE} / \mathrm{W}$ ten opzichte van $4 \mathrm{MvE}$, herdrukken van $7 \mathrm{CD}$ en de herziening door Alet Schouten van 9 WvE (zie paragraaf 3). Zowel 6 A-T als 16 $\mathrm{MvE} / \mathrm{W}$ passen vooral de verouderde zegswijzen voorzichtig aan ("Hij ging daarom zitten" in plaats van "Hij zette zich alzoo neer"); $16 \mathrm{MvE} / \mathrm{W}$ herstelt tevens, onder raadpleging van de Deense tekst, 4 MvE's 'preutsheid'. Modemiseringen van de teksten van 


\section{Hoofdstuk VII}

$7 \mathrm{CD}$ en 9 WvE zijn echter zonder respectievelijk zonder grondige raadpleging van de Deense tekst geschied, waardoor onbedoelde 'Verschlimmbesserungen' ontstaan: "ze moest heus eens duchtig met de roe hebben" (woordspeling "at faa Riis") wordt "ze moest heus eens een flink pak slaag hebben" ( $7 \mathrm{CD}, 17 \mathrm{e}$ druk); "wat een vreugde zal dat zijn [...] wat een vreugde zal dat zijn" wordt "wat zullen we blij zijn [...] wat heerlijk zal dat zijn" ( 9 WvE, bewerking Alet Schouten).

- Een heel apart geval van bewerking is ten slotte te vinden in $6 \mathrm{~A} / \mathrm{T}$, een typische 'pirateneditie', waarin herkomst van vertaling noch van illustraties - van tenminste 4 verschillende tekenaars - wordt vermeld. De plaatjes horen voor een deel bij heel andere sprookjes, maar zijn door onderschriften of zelfs door aanpassingen in de tekst geschikt gemaakt. Zo is bij de scène van de stervende zwaan een plaatje van een zwaluw - waarschijnlijk die uit Tommelise [Duimelijntje] opgenomen. Tekst: "zij keken naar boven: een groote witte zwaluw zweefde er in de lucht". Afgezien van de absurditeit van "een groote, witte zwaluw" (een witte raaf!) is dit een doorbreking van de symboliek; de zwaneveren op de rug van de reiskameraad zijn namelijk engelenveren, - vergelijk paragraaf 2.3.1.

\subsubsection{Lexicale instructies}

De vertaling van de volgende gevallen is nagegaan:

- de allitteratie in "qviddrede 'qui vit, qui vit", en "O, Sniksnak"

- de woordspeling in "'Hvad vil Du med de Riis' spurgte Johannes [...] 'den hæslige Prindsesse!' sagde Johannes, "hun skulde virkelig have Riis"'

- idem in "'Man kan ogsaa have for meget af det Gode', sagde Trolden"

- de pregnante betekenis van "Bulbider"

- de symboliek in "kulsort" en "kridhvid"

- ritme, rijm en de woordspeling "Dandser og tramper/Saa skoesaalleme faldera!" in het feestlied. ${ }^{261}$

De allitteratie in "O, Sniksnak" is behalve door $1 \mathrm{NN}$ ("wisje-wasjes") en $2 \mathrm{CdJ}$ (die naar het Duits "Schnikschnak" heeft) door geen der vertalers bewaard, - wat in principe toch mogelijk zou zijn geweest met bijvoorbeeld "kletskoek". De meesten houden het bij "onzin / larie / praatjes".

Bij de vertaling van het vogelgeluid handhaven slechts vier vertalers een vorm van allitteratie: "kweelden Quivit, quivit" (2 CdJ), "tjilpten: Tjiep! Tjiep!" (6 A-T) en "kwinkeleerden: kwiewiet, kwiewiet" (9 WvE/13 MvB).

De woordspeling met "Riis" wordt door de helft der vertalers niet weergegeven: sommigen vertalen respectievelijk "roede" - "een pak slaag", anderen "varens" (!) "roede", weer anderen "wilgetakken" - "met de bezem". Correspondentie "roede - met de roe" of iets dergelijks is te vinden bij 1 NN ("rottingolie"), 2 CdJ, 3 SJA/6 A-T, 4 MvE, 8 PdB, 14 TES en 16 MvE/W. 
De bullebijter wordt als zodanig opgevoerd door $2 \mathrm{CdJ}, 8 \mathrm{PdB}, 9 \mathrm{WvE}, 12 \mathrm{MB}$ en 16 MvE/W; de anderen voeren een buldog, dog, bulhond of hond ten tonele.

Wat de kleuren "kulsort-kridhvid" betreft: zelfs als we naast het verouderde "koolzwart" ook "pikzwart" en "gitzwart" als adequate aardgebonden equivalenten beschouwen (zie paragraaf 2.3.1.), heeft toch slechts $7 \mathrm{CD}$ beide begrippen adequaat weergegeven; de overigen spreken van "zwart" en/of "(sneeuw)wit". "Wit" is een semantische verruiming, "sneeuwwit" associatief inadequaat.

De ambiguïteit in "Man kan ogsaa faae for meget af det Gode" (namelijk de reiskameraad als exponent van het goede) blijft intact in de corresponderende Nederlandse uitdrukking: "je kunt ook teveel van het goede krijgen". Veel vertalers kiezen voor een semantisch equivalente maar idiomatisch inadequate formulering: "Men kan van iets aangenaams ook zat worden op het laatst" (1 NN), "Men kan ook het goede beu worden" ( $5 \mathrm{NN}$ ) en de merkwaardige - Duitse? - volgorde "Men kan ook van het goede teveel hebben" of iets dergelijks ( $2 \mathrm{CdJ}, 3 \mathrm{SJA} / 6 \mathrm{~A}-\mathrm{T}, 4 \mathrm{MvE}, 8 \mathrm{PdB}, 10 \mathrm{ARV}, 13$ $\mathrm{MvB}, 16 \mathrm{MvE} / \mathrm{W})$.

Ten slotte het feestlied. $2 \mathrm{CdJ}$ en $11 \mathrm{GD}$ vermijden hier elk probleem door het überhaupt niet te vertalen. De woordspeling met de meerduidigheid van "faldera" blijft nergens behouden, - er wordt gekozen voor hetzij een juichkreet ("hopheisa, trallalla", 1 $\mathrm{NN}$ ), hetzij een oproep tot kapotdansen van de schoenen. Andersens - bewust? - wat houterige ritme blijft meestal wel bewaard, maar door 10 ARV en $13 \mathrm{MvB}$ wordt de prosodie grotendeels verlaten, en door $8 \mathrm{PdB}$ geheel: "Hier zijn vele aardige meisjes / Die gaame een rondedansje doen / $\mathrm{Zij}$ draaien als een spinnewiel / Mooi meisje draaien maar rond / Danst en springt maar door / Tot de zool van de schoen valt".

\subsubsection{Grammaticale instructies}

In het omvangrijke tekstmateriaal komt een aantal afwijkingen van de Nederlandse grammaticale normen voor, die echter geenszins allemaal als danismen kunnen worden beschouwd: het merendeel is te karakteriseren als "grammaticaal niet correct/gebruikelijk". zonder dat de oorzaak samenhangt met de vertaling vanuit het Deens; als zodanig vallen ze buiten ons bestek.

Ter toetsing van syntactische danismen is een bijna klassiek struikelblok genomen, namelijk de constructie 'ligge/stå/sidde etc. + og + verbum finitum', - in het Nederlands 'liggen/staan/zitten etc. + te + infinitief'. De Deense voorbeelden zijn "stod og støttede" en "stode og grinte". ${ }^{262}$ In 3 SJA/6 A-T, 4 MvE, 8 PdB, 9 WvE, 10 ARV, 16 MvE/W is één van beide keren de constructie 'en + verbum finitum' gebruikt, terwijl 11 GD's bewerking de eerste constructie weglaat.

Als tweede voorbeeld de laatste woorden van de vader "Du var en god Søn, Johannes!", een constructie met preteritum, waar het Nederlands perfectum ofwel preteritum + "altijd" verkiest. De meeste vertalingen gebruiken de Nederlandse standaard - 12 maal perfectum, 2 maal preteritum + altijd; $5 \mathrm{NN}$ heeft echter presens en 9 WvE preteritum. Net als bij de lexicale danismen zijn de gevallen dus nogal gespreid; werkelijke concentratie komt alleen voor bij $5 \mathrm{NN}$ ("den blauwen hemel bovenop", "een opene lijkkist met 
een dooden man in", "het was hij, die zoo erbarmelijk zuchtte", "hoe verschrikkelijk zag het daar uit", enzovoort) Ook bij 9 WvE komen we grammaticale danismen tegen, die wellicht zijn te verklaren vanuit vE's sterk brontekstgerichte vertaalstrategie: naast bovengenoemde gevallen onder andere: "zodra hij het been gewreven had"; "dan kon hij er [i.e raadsels] niet uitkomen", "ik zal wel iets uitvinden, waar hij nooit aan gedacht heeft". De meeste van deze laatste danismen zijn in Alet Schoutens bewerking van vE's vertaling aangepast aan de Nederlandse grammaticale norm.

\subsection{Extralinguale determinanten}

Wegens de al in par. 4.2 gememoriseerde sterke overlapping van linguale en extralinguale aspecten kunnen we ons hier beperken tot enige significante gevallen.

\subsubsection{Aspect van de oorspronkelijke recipiënt (inclusief situatiecontext in engere zin)}

Een aantal vertalers heeft moeite met het zich inleven in bepaalde situaties. Een voorbeeld vormen Johannes' woorden tot de lijkschenners: “'Hvorfor vil I gjøre det!' [verontwaardigde uitroep] [...] det er ondt og slemt, lad ham sove i Jesu navn!'” [aansporing op christelijk-ethische gronden] ${ }^{263}$ De meeste vertalers reduceren de uitroep tot vraag vraagteken - en neutraliseren de aansporing: "laat hem toch slapen". Veel beleefder dan de brontekst zijn $1 \mathrm{NN}$ “'Zegt eens, waarom wilt gij dat doen?', vraagde JOHANNES. 'Dat is immers verfoeijelijk slecht van $u$, laat hem toch in JEZUS naam stilletjes rusten!'”) en 12 MB “'Waarom zoudt u dat doen?' vroeg Johannes. 'Dat is verkeerd en slecht, laat u hem toch rustig liggen"'). Tweede voorbeeld is het intieme "God Morgen, Du!" waarmee de prinses Johannes begroet. ${ }^{264}$ Dit wordt gewijzigd in het neutrale "Goede/goeiemorgen" (3 SJA/6 A-T, 8 PdB), het hiërarchiserende "goeiemorgen, vri(e)nd" (4 MvE, $12 \mathrm{MB}, 14 \mathrm{TES}$ ), of het onverschillige "Hé, ben je daar? goeden morgen" of iets dergelijks (1 NN, $5 \mathrm{NN}, 15 \mathrm{HL}$ ). "Goedemorgen gij/jij" (7 CD, $16 \mathrm{MvE} / \mathrm{W}$ ) is als danisme te beschouwen.

Een ander probleem ligt in de vertaling van geijkte uitdrukkingen, zoals "Velkommen i det Gronne!" ${ }^{265}$; aangezien een gelijkwaardige vaste wending in het Nederlands ontbreekt, zou hier volgens Rei $\beta^{266}$ een "versetztes Äquivalent" op zijn plaats zijn in plaats van de door alle vertalers gekozen letterlijke weergave, die overigens als neutraal beeld voor de Nederlandse lezer begrijpelijk is en niet stoort. De vertaling van de ondoorzichtige uitdrukking "at spytte røde Grise" is daarentegen problematisch. Jensen typeert deze zegswijze voor hevig bloeden als "udpræget folkeligt" - hij vermeldt voorkomst in een slangwoordenboek, met citaten uit Andersen. ${ }^{267}$ Betekenis noch connotatie zijn in de Nederlandse vertaling terug te vinden: 9 WvE heeft "roode varkens laten spuwen", de anderen "afranselen" of iets dergelijks, met als gevolg dat a. de passage pleonastisch wordt (er staat immers: "hun skulde virkelig have Riis" / "hun skulde nok komme til at spytte røde Grise"), en b. de vooruitverwijzing naar "pidskede paa Prindsessen med sit Riis, saa der ordentlig kom Blod" en "pidskede hende saadan med sine tre Riis, saa Blodet dryppede ned paa Jorden" 268 wegvalt. 


\subsubsection{Kennis van realia}

Toetssteen voor de bekendheid met realia is het geheel van figuren uit het Scandinavische volksgeloof: Trold - Nisse - Kirkenisse - sorte Nisser. Met betrekking tot "Trold" is de vertaling "tovenaar" niet adequaat, daar het demonische aspekt van de trol plaatsmaakt voor associaties met Merlijn en punthoeden. Als we er echter van uitgaan dat het Nederlandse woord $\mathrm{trol}$ pas laat is ingeburgerd (ondanks een vindplaats uit 1837 in het WNT is het pas opgenomen in de tiende druk van de grote Van Dale uit 1976), dan kan "tovenaar" in oude teksten worden aanvaard, maar is hij niet meer adequaat in $12 \mathrm{MB}, 1960$. "Trol" treedt behalve bij $9 \mathrm{WvE}$ (1931) pas op vanaf 1961 (13 MvB, 14 TES - met voetnoot - en $16 \mathrm{MvE} / \mathrm{W}$ ). Behalve "tovenaar" treffen we nog aan "kobold" en "kaboutermanneken" (respectievelijk 4 MvE, 1899, achtste druk 1955 / HL 1975!, en $5 \mathrm{NN}, 1906$ ).

Voor "(kirke)nisse" zijn "(kerk)kabouter/dwergje" en "aardmannetje" weliswaar niet geheel dekkend, maar associatief niet verkeerd geladen en waarschijnlijk relatief adequate vertalingen, - wat niet geldt voor "heele kleine meisjes" (4 MvE), "nixjes" (= watergeesten; $4 \mathrm{MvE}, 16 \mathrm{MvE} / \mathrm{W}$ ), "kerkekoboltje" (4 MvE), "elfen" (5 NN), "kerkgeest" (10 ARV) en ... "de oude klokkenist" (8 PdB).

's Poppekonings "Drabanter" worden in de oudere teksten weergegeven met "trawanten", cen woord dat eerst later een negatieve connotatie krijgt. Waar loopt in dezen de grens? Inadequaat is het zeker in $13 \mathrm{MvB}, 1961$, maar ook al in $10 \mathrm{ARV}, 1941$ ? Andere oplossingen zijn semantisch evenmin equivalent: "hofstoet" (4 MvE, $16 \mathrm{MvE} / \mathrm{W}$ ), "dienaren" (8 PdB, 12 MB), "onderdanen" (15 HL), "hofdames" (11 GD); van de vertalingen "soldaten" (7 CD), "schildwachten" (9 WvE) en "lijfwacht" (14 TES) is alleen de laatste geheel dekkend.

Interessant is de vertaling van "Kirketaamene [...] saa ud som smaa rode Bar, nede i alt det Grønne". ${ }^{269}$ Die rode bessen worden blauw bij 2 CdJ, 3 SJA/6 A-T, 8 PdB, onder invloed van de Duitse vertaling; waarschijnlijk is hier sprake van Zuidduitse connotatie vanwege de daar gebruikte leistenen in plaats van bakstenen pannendaken. De DeensNederlandse associatie gaat in elk geval teloor.

\subsubsection{Tijdsaspect}

Zowel de schriftuur als het vertelde dragen het stempel van de negentiende eeuw; over het algemeen houden de vertalers hieraan vast, hoewel er af en toe modemiseringen optreden, al dan niet met het oog op het contemporaine kinderpubliek. Semantisch-stilistisch betekent dit nogal eens vervlakking, bijvoorbeeld "Lysthave": "tuin", in plaats van "lusthof" zoals $1 \mathrm{NN}, 2 \mathrm{CdJ}, 5 \mathrm{NN}$ en $12 \mathrm{MB}$ nog hebben. Dezelfde $12 \mathrm{MB}$ maakt echter "kilometers" van de klassieke sprookjes-mijlen. Johannes" vermogen van 50 Rigsdaler wordt omgerekend in of vervangen door guldens/daalders ( $1 \mathrm{NN}: 70$ gulden, $2 \mathrm{CdJ}$ : 50 daalders; $5 \mathrm{NN}, 6 \mathrm{~A}-\mathrm{T}$ : 15 [?] daalders; $11 \mathrm{GD}, 12 \mathrm{MB}, 3 \mathrm{SJA}$ en 8 PdB rekenen in Thaler). 
Aspecten van tijd, plaats en recipiënt spelen tenslotte een rol in de vertaling van "Sophaen" (81), de trots van iedere prinses: canapé (4 MvE, $16 \mathrm{MvE} / \mathrm{W}$ ), divan (10 ARV).

\section{Samenvatting van de resultaten; conclusies}

Doel van bovenstaand onderzoek was na te gaan in hoeverre de oorspronkelijke intenties van Andersens Reisekammeraten in de Nederlandse vertaling bewaard gebleven zijn, en hoe eventuele modificaties kunnen worden verklaard. Analyse van de brontekst toont een zeer consistente ophouw rond de twee hoofdmotieven; 1. Johannes' goedheid, en 2. Gods hulp. Structuur, symboliek en woordkeuze hangen hiermee samen. Daarnaast blijkt het taalgebruik specifiek afgestemd op kinderen: begrijpelijke taal, versterkende effecten, aan de spreektaal gelieerde syntaxis, en herhaling, - elementen waarmee Andersen literair vernieuwend werkte.

De meeste van de zestien Nederlandse vertalingen (1848-1975) richten zich eveneens op kinderen, of op een qua leeftijd neutraal publiek; drie vertalingen richten zich specifiek op volwassenen. Een analyse van deze vertalingen volgens het model-Reiß leert het volgende:

- de meeste vertalingen normaliseren Andersens stijlvernieuwingen, onder invloed van de gangbare (jeugd-)literaire stijl en/of uit angst dat deze vemieuwingen voor een fout van de vertaler worden aangezien. Voor enkele moderne vertalers daarentegen is Andersen niet kinderlijk genoeg (meer):

- de symboolfunctie van sleutelwoorden en herhaling wordt door veel vertalers niet doorzien;

- op semantisch gebied lijden de oudere vertalingen onder het Duits als intermediair. Nagevolgde Duitse misinterpretaties van de Deense tekst of verkeerd begrepen Duits resulteren in onbedoelde fouten die zich in herdruk tot op heden handhaven. Alle vertalingen tonen enige faux amis, maar fundamenteel onvoldoende kennis van het Deens treffen we slechts in één vertaling:

- vrees dat Andersen niet duidelijk genoeg is leidt herhaaldelijk tot toevoegingen; aanpassing aan een volwassen publiek, 'verbetering' van Andersens 'fouten' of commerciële motieven leiden tot weglating en inkorting:

- morele motieven (religie, preutsheid) staan in enige vertalingen achter wijzigingen in katholieke, protestantse, 'seculariserende' en/of puriteinse zin:

- de beweegredenen achter de enige grondige bewerking zijn volstrekt onbegrijpelijk: enerzijds verlenging, anderzijds verkorting, volwassen naast kinderlijk taalgebruik en een volkomen dooreengegooide structuur, die elke samenhang mist;

- moderniseringen in latere edities van dezelfde vertalingen blijken soms zeer conscientieus; in andere gevallen leiden ze tot 'Verschlimmbesserungen' door niet of niet voldoende raadplegen van de Deense tekst;

- op lexicaal gebied herhalen de resultaten van stilistisch/semantisch onderzoek zich: woordspelingen worden vaak niet doorzien; 


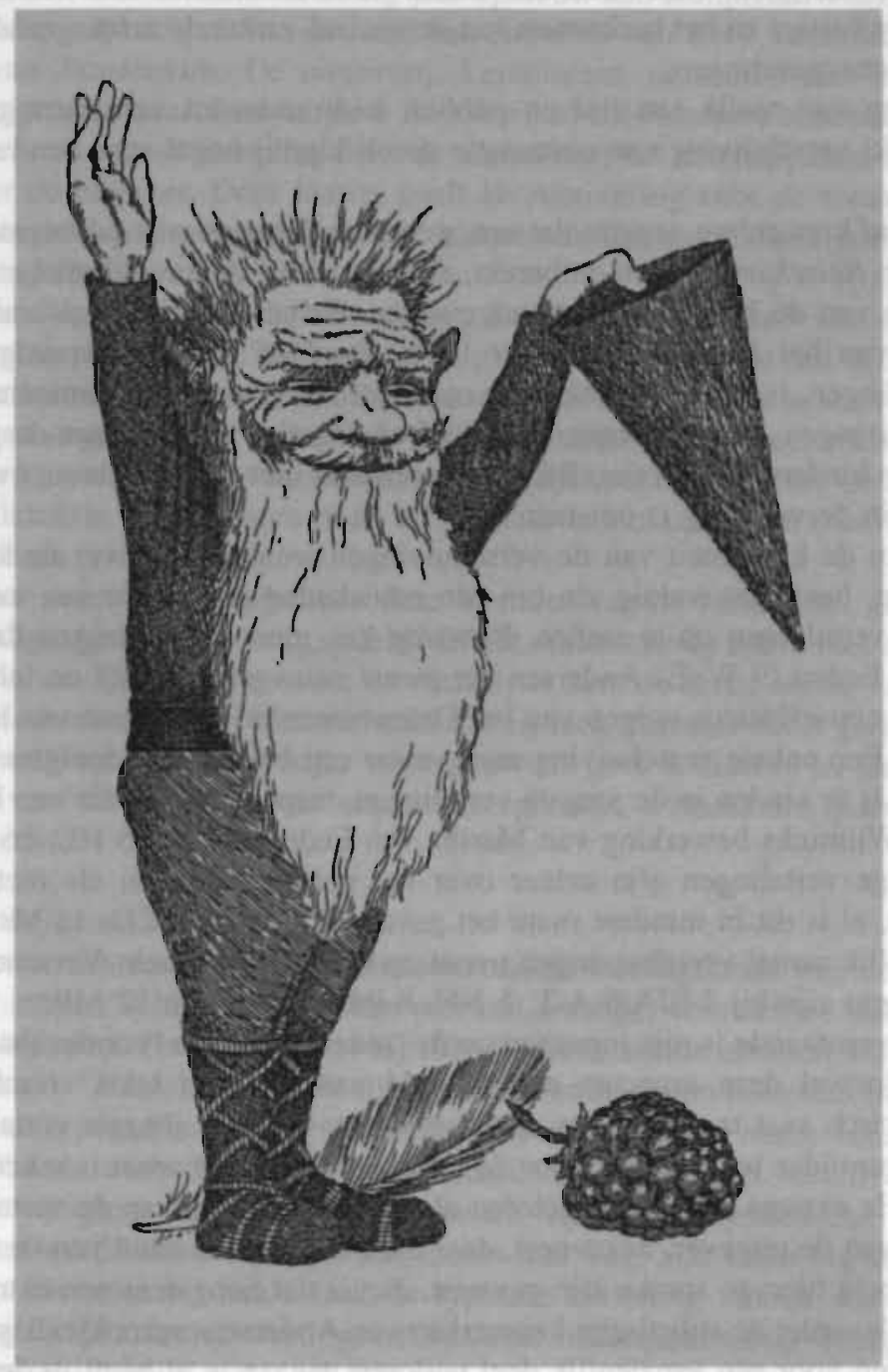

Afbeelding 18. Een figuur uit het Scandinavisch volksgeloof, de 'Kirkenisse': 'kerkekoboltje'. 'kerkgeest', 'oude klokkenist' of 'kerkkabouter'? Illustratie van Fiel van der Veen bij de jongsie vertaling van De reiskameraad (1992). 


\section{Hoofdstuk VII}

- grammaticale danismen komen in veel vertalingen wel voor, doch in storende concentratie in slechts twee vertalingen;

- op het extralinguale vlak heeft een aantal vertalers moeite met het zich inleven in bepaalde situaties en het herkennen van de sociaal-culturele achtergrond van bepaalde idiomatische wendingen;

- aanpassing van realia aan tijd en publiek leidt soms tot verandering van sfeer en symboliek; verschuiving van connotatie speelt hierbij nogal eens een rol.

Concluderend kunnen we zeggen dat een werkelijk functioneel equivalente Nederlandse vertaling van Reisekammeraten ontbreekt, al zijn er zeer sterke onderlinge variaties in de mate waarin van de brontekst wordt afgeweken. Behalve op het vlak van een bewuste aanpassing van het lexicon naar meer 'volwassen' of 'literair' woordgebruik in een aantal vertalingen, is er geen sprake van een consistent, onderling samenhangend geheel van verschuivingen. Een consequent positief of negatief verband met de gerichtheid op de doelgroep kinderen respectievelijk volwassenen is niet te constateren, evenmin als met de tijd waarin de vertaling is ontstaan.

Aangezien de kwantiteit van de verschuivingen weinig zegt over de kwaliteit en de impact ervan, heeft het weinig zin om een nauwkeurige volgorde van meer en minder equivalente vertalingen op te stellen. Ruwweg kan men echter zeggen dat de vertaling van W. van Eeden ( $9 \mathrm{WvE}$ ) Andersen het meest nauwgezet in stijl en inhoud volgt, zij het dat al te consciëntieus volgen van het Deens soms ten koste gaat van het Nederlands (danismen). Een enkele verschuiving meer, maar een beter op de doelgroep toegesneden Nederlands, is te vinden in de jongste vertalingen, respectievelijk die van Harriet Laurey en Willem Wilminks bewerking van Martha van Eedens tekst (15 HL, $16 \mathrm{MvE} / \mathrm{W}$ ).

De overige vertalingen zijn echter over het geheel genomen als niet-equivalent te beschouwen, al is dit in mindere mate het geval bij $4 \mathrm{MvE}, 7 \mathrm{CD}, 13 \mathrm{MvB}$ en 14 TES. Een aanzienlijk aantal verschuivingen treedt op bij Annie Romein-Verschoor (10 ARV), terwijl ze legio zijn bij $3 \mathrm{SJA} / 6 \mathrm{~A}-\mathrm{T}, 5 \mathrm{NN}, 8 \mathrm{PdB}, 11 \mathrm{GD}$ en $12 \mathrm{MB}$.

In het bovenstaande is niet ingegaan op de 'muzikaliteit' en 'voorleesbaarheid' van de vertaling. Hoewel deze aspecten ongetwijfeld van tekst tot tekst verschillen, zijn ze alleen empirisch vast te stellen, en dan nog slechts voor de jongste vertalingen, bij gebrek aan eigentijdse toehoorders voor de oudere teksten. Evenmin is rekening gehouden met eventuele externe negatieve factoren als slechte betaling van de vertaler, haastwerk onder druk van de uitgever, enzovoort, daar deze niet aan de hand van de tekst te bewijzen zijn. Mocht hiervan sprake zijn geweest, dan is dat hoogstens een extra bewijs naast het bovengeleverde: de stilistische kenmerken van Andersens sprookjes zijn in Nederland en Vlaanderen voor een aanzienlijk deel verloren gegaan, - al heeft gezien de populariteit van de grote Deen diens geestelijke erfenis zich zelfs in sterk gewijzigde vertalingen weten te handhaven. 


\section{APPENDIX: De vertaling van Annelies van Hees}

In 1992 verscheen voor het eerst in zestig jaar opnieuw een complete Nederlandse vertaling van Andersens sprookjes, van de hand van Annelies van Hees, docent Deens aan de Universiteit van Amsterdam. De uitgeverij. Lemniscaat, richt zich met haar uitgaven meestal op de jeugd, maar deze uitgave is ook voor volwassenen bedoeld, getuige inhoud en taalgebruik van de inleiding door de vertaalster, het notenapparaat en de verantwoording door de uitgever. Deze laatste geeft als motivering voor de nieuwe vertaling: "Meer dan vroeger bestaat de behoefte het taalgebruik dat specifiek is voor een auteur, tot zijn recht te laten komen."

In haar inleiding zet de vertaalster uiteen, dat zij gepoogd heeft een evenwicht te bewaren tussen respect voor de auteur ("het uitgangspunt was trouw aan de tekst") en de verwachtingen van de moderne lezer. Dat laatste zegt Van Hees na te streven door verduidelijking van negentiende-eeuwse begrippen. Zij deelt voorts mee, stilistisch op één punt bewust te zijn afgeweken van Andersen, namelijk qua interpunctie: de lange zinnen met hun asyndetische verbindingen heeft zij resoluut in stukken gehakt, om de leesbaarheid te bevorderen.

Tot wat voor soort vertaling hebben deze intenties van de vertaalster, gecombineerd met haar grondige Andersen-kennis, geleid'? In het onderstaande zal ik niet alleen kijken naar haar versie van Reisekammeraten: de vertaalster kent de eerste versie van de onderhavige studie en hoewel ik mij niet verbeeld dat zij zich daarnaar heeft gericht, is enige beïnvloeding niet uitgesloten. $\mathrm{Bij}$ wijze van tegenwicht geef ik daarom ter aanvulling een korte analyse van de vertaling van een ander sprookje, Prindsessen paa Arten (De prinses op de erwt).

\section{a. Van Hees' 'Reisgenoot'}

Stilistische instructies. Andersens typische eenvoudige woordgebruik met hoogfrequente woorden blijft intact: ".. hij keek hem aan met een ernstige, vriendelijke blik, hij haalde diep adem en hij stierf. Het leek net of hij sliep." Versterkende effecten worden grotendeels gehandhaafd: "Het was echt een alleraardigste komedie en helemaal niet droevig", maar Andersens typografische nadruk door cursivering van de naam Johannes wordt weggelaten. Wat de nauw bij de spreektaal aansluitende syntaxis betreft: ondanks de aangekondige wijziging van komma's in punten zijn veel asyndetische constructies gebleven: "Toen werd hij wakker en al het moois was weg, zijn vader lag koud en dood in bed, er was niemand bij hen". Ook de typische herhaling vinden we bijna steeds terug, al valt op dat het sleutelwoord 'goed' één keer inadequaat wordt weergegeven met "braaf": "'Ik zal altijd braaf zijn', zei Johannes."

Semantische instructies. Foutieve semantische interpretaties van het Deens komen zoals te verwachten was nergens voor, terwijl ook vormen van bewerking als verklaringen, inkortingen, weglatingen en wijzigingen van moralistische aard ontbreken. Alleen laat Van Hees door hypercorrectie (het Deense woord "præst" moet bijna nooit worden vertaald met "priester") in het vreemde land de dominees op hun knieën in de kerk liggen, iets waartoe uiteraard geen enkele dominee bereid zou zijn. 


\section{Hoofdstuk VII}

Lexicale instructies. De woordspeling "Hvad vil du med de Riis" [...] "hun skulde virkelig have Riis" is verdwenen: "Wat wil je met die takken" [...] "Ze moest eens een flink pak slaag hebben", evenals de pregnante betekenis van "bulbider", dat vertaald is met "buldog" (Deens "buldog" = Nederlands "buldog", Deens "bulbider" = Nederlands "bullebijter"). Daarentegen is de symboliek in "kulsort" en "kridhvid" gebleven: "koolzwart", "krijtwit". En voor het eerst is in een vertaling gepoogd de woordspeling met "faldera" te handhaven: "Dans maar en dans maar / en schoenzool, valderaf, valderaf".

Grammaticale instructies. De doeltekst is binnen de beperkingen van de doeltaal grammaticaal en syntactisch equivalent aan de brontekst.

Extralinguale determinanten. "I Jesu navn!" wordt "in de naam van God!", hetgeen qua gevoelswaarde waarschijnlijk functioneel equivalent is, daar "in Jezus naam" tegenwoordig eerder als negatieve krachtterm wordt gebruikt. Ook voor het overige getuigt de tekst van een goede inleving in de situatiecontext; alleen verdwijnt het aspect "bloed" in de vertaling van de uitdrukking "komme til at spytte røde Grise" : "een pak slaag hebben", waardoor de passage pleonastisch wordt en een vooruitverwijzing wegvalt (zie paragraaf 4.4.1). De Scandinavische realia ten slotte, spelen vertaalster geen parten, terwijl ook algemene negentiende-eeuwse realia als daalders, mijlen en sofa aanwezig blijven.

\section{b. Van Hees' 'Prinses op de erwi'}

Prindsessen paa Erten werd geschreven in 1835, hetzelfde jaar als Reisekammeraten, en vertoont in grote lijnen dezelfde stijl- en structuurkenmerken. De Deense germanist Albertsen heeft in zijn analyse van de brontekst aangetoond, dat ook hier sprake is van eenvoudig woordgebruik, afgestemd op kinderen: "Jeg har næsten ikke lukket mine Øine den hele Nat! Gud veed, var der har varet i Sengen? Jeg har ligget paa noget Haardt, saa jeg er ganske bruun og blaa over min hele Krop! Det er ganske forskrækkeligt!" Versterkende effecten zijn bij voorbeeld te vinden in de herhaalde cursivering van het woord rigtig in alinea 1, en in het bijwoord "saa" in dezelfde alinea: "Saa kom han da hjem igjen og var saa bedrøvet, for han vilde saa gjerne have en virkelig Prindsesse": in de uitroep "Gud" in alinea 3 en 7; en in de uitroeptekens in alinea 2, 3 en 7. De zinsbouw die nauw bij de spreektaal aansluit treffen we onder andere in alinea 4 , over het opmaken van het bed: de hoofdzinnen worden met komma's op elkaar gestapeld, net als de matrassen en de dekbedden. Van herhaling is onder andere sprake in "rigtig Prindsesse" - "rigtig Historie" en in "det var ganske forskrækkeligt!" - "det er ganske forskrakkeligt!".

Behalve het taalgebruik is ook de structuur heel uitgekiend, en taal en opbouw hangen nauw met elkaar samen. De alinea's 5, 6 en 10 zijn heel kort. Het hoogtepunt (het slapen op de erwt) ligt tussen alinea 5 en 6 , maar wordt juist niet weergegeven: doordat de zinnen zo kort zijn, kan de verteller een pauze vol effect leggen na beide alinea's. Alinea 10 markeert de 'moraal' van het verhaal, waar de 'echtheid' wordt benadrukt: het was een 'echte' prinses en ook een 'echt' verhaal. Het sprookje is symmetrisch rond de bewuste nacht opgebouwd. Het einde van alinea 1,3 en 8 is identiek: 'een werkelijke prinses": het verschrikkelijke weer in alinea 2 wordt gespiegeld in de verschrikkelijke nacht van de prinses in alinea 7 . Alinea 4 , over de erwt onder de twintig matrassen en de 
twintig dekbedden, is gekoppeld aan alinea 8, waar het effect en de bedoeling van die erwt duidelijk wordt. En alinea 9 is gelieerd aan 1: de prins heeft zijn echte prinses gevonden, en de verhaalcirkel is daarmee rond. ${ }^{270}$

Annelies van Hees laat bovengenoemde nauwgezetheid in de structuur duidelijk zien. Ze volgt inhoudelijk-structureel Andersens tekst op de voet, heeft de sleutelrol van de woorden 'echt' en 'verschrikkelijk' en de verdeling in alinea's gehandhaafd, anders dan in veel van de oudere vertalingen, waar de sleutelwoorden verschillend worden vertaald en te kort bevonden alinea's aan elkaar worden gelijmd. Ook stilistisch is de vertaling duidelijk brontekstgericht. De stijl sluit nauw aan op die van het origineel: "Ik heb bijna de hele nacht geen oog dichtgedaan! God weet wat erin in dat bed lag. Ik heb op iets hards gelegen en nu ben ik bont en blauw over mijn hele lijf. Het is echt verschrikkelijk!"

Op zinsniveau zijn er daarentegen enige verschuivingen te constateren. De herhaling van "saa" is vervangen door variatie: "Dus ging hij maar weer naar huis, heel bedroefd omdat hij zo graag een echte prinses wilde. De vertaling "jeetje" voor "Gud" is op zich gezien het tuttige karakter van de prinses functioneel equivalent, maar de koppeling aan "Gud" in alinea 7 is verdwenen: daar dwingt de staande uitdrukking tot de vertaling "God weet...". Wat de syntaxis betreft: Van Hees' keus voor het in stukken hakken van asyndetische constructies leidt in dit specifieke geval tot verdwijning van de door Andersen aangebrachte congruentie tussen het stapelen van de zinnen en van de matrassen.

De keuze voor de ook door Andersen geïntendeerde dubbele doelgroep, kinderen en volwassenen, leidt door het verschil tussen de tijd van ontstaan en heden in één geval tot een bijna onvermijdelijk probleem: de Kopenhaagse bourgeois-kinderen uit Andersens tijd kenden de "Kunstkammer", maar weet een jong Nederlands kind wat een "rariteitenkabinet" is?

\section{c. Evaluatie van de vertaling van Annelies van Hees.}

In verhouding tot de voorgaande vertalingen betekent deze vertaling een belangrijke vernieuwing. De enige complete en tot nu toe meest consciëntieuze vertaling, die van Van Eeden, is nu vervangen door een qua taalgebruik meer op het modeme publiek toegesneden tekst, die haar nadrukkelijk geformuleerde doelstelling heeft bereikt: een middenweg te vinden tussen een brontekst- en doelgroepgerichte vertaling, tussen trouw aan Andersen en gerichtheid op het publiek van 1992. Anders dan bij Van Feden leidt de trouw aan de brontekst niet tot danismen. De vertaling is grosso modo functioneel equivalent aan Andersens specifieke stijl en verhaalstructuur (kanttekeningen als de bovenstaande laten deze constatering onverlet) en laat zich toch ook uitstekend lezen als autonome Nederlandse tekst. 


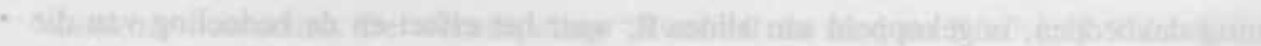

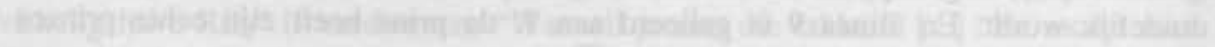

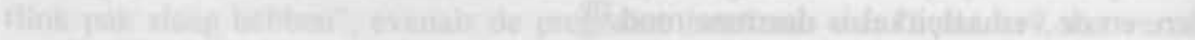

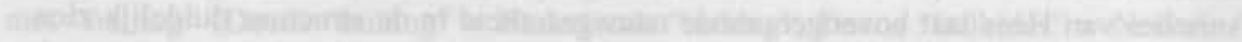

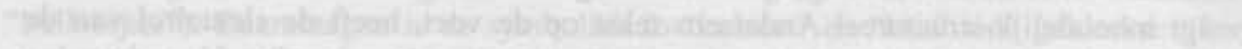

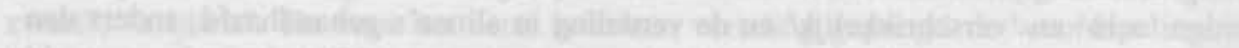

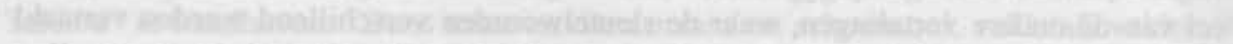

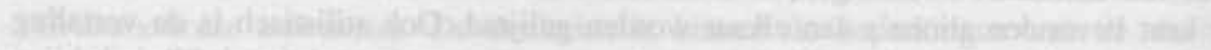

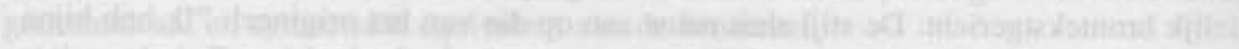

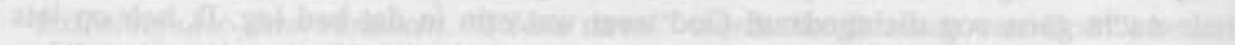

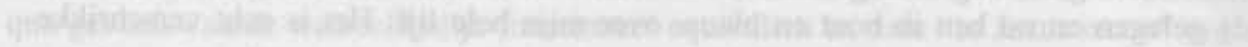

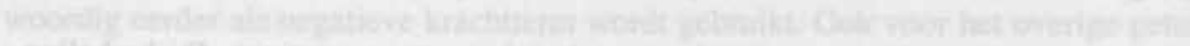

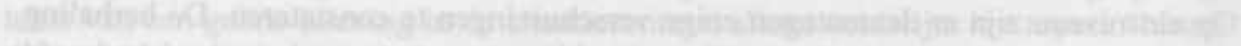

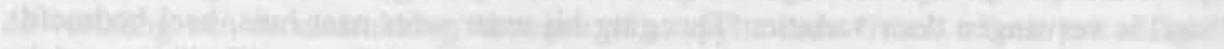

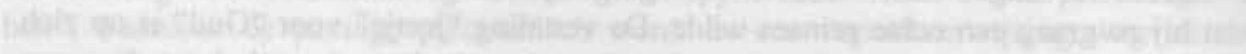

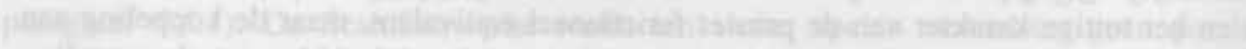
wet In:

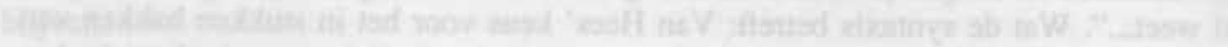

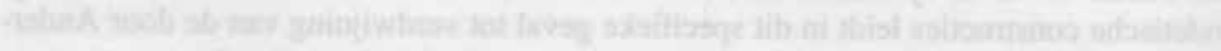

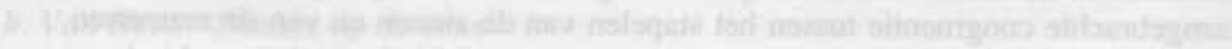

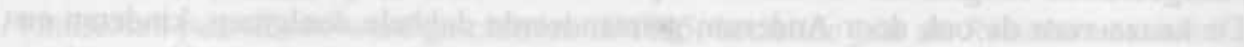

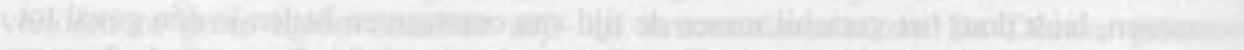

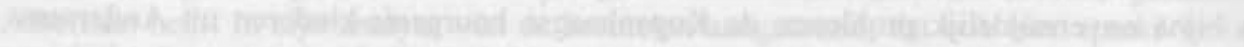

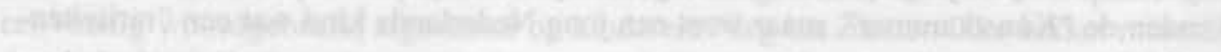

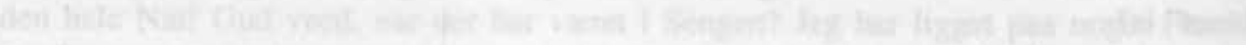

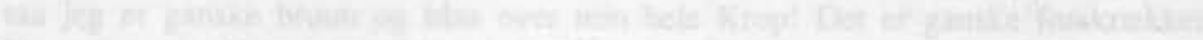

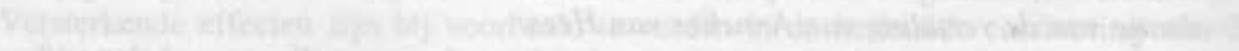

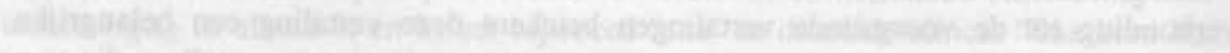

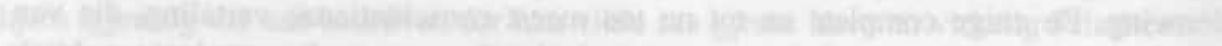

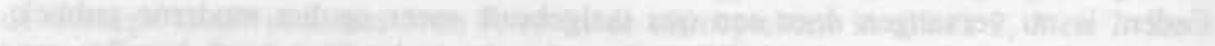

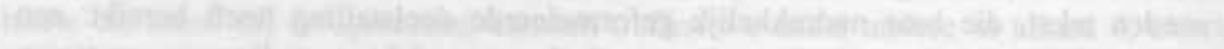

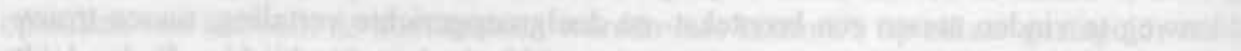

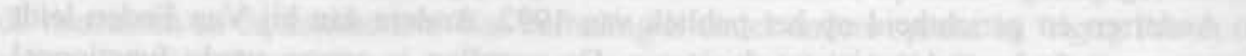

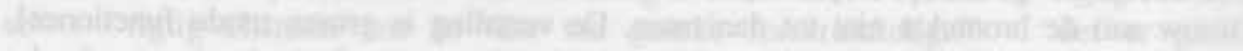

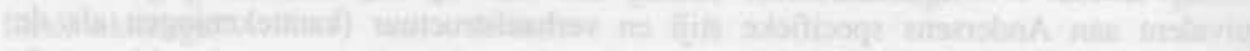

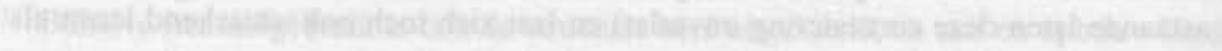

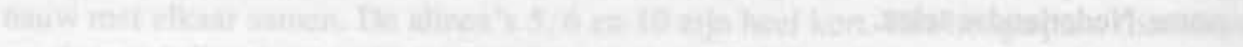

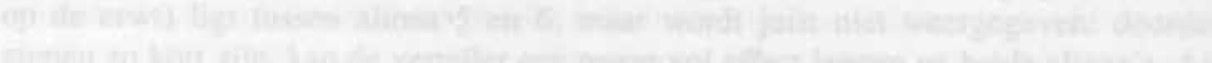

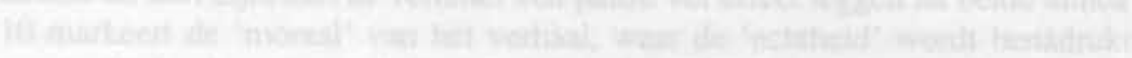




\section{Hoofdstuk VIII}

\section{Nederlandse literatuur in Deense ogen, 1900-1990*}

\section{Inleiding}

Traditionelle fortællere, nogle mere habile end de andre, de fleste bestemt af en bedrøvelig fravær af ironi, humor eller gedigen galskab, nogle desuden af en ærgerligt manglende sans for fortællerøkonomi. Alle mener det hjertelig godt og synes, det er synd for menneskene, specielt for småborgerskabet som skildres i mørke farver: fremmedgjorte af ejendomstrang, uden evne til at tage hånd om deres liv, kontakthammede, fastlåste $\mathrm{i}$ deres håbløshed, men desperat flygtende bag den rolige facade ind i roller fra et liv der er blevet en dæmonisk trussel. Mon ikke Holland også er andre ting? Mon ikke 'Hollandske noveller' fortæller nok så meget om udvælgeren som om hollandsk litteratur? $?^{271}$

[Traditionele vertellers, sommigen vaardiger dan anderen, de meesten gekenmerkt door een bedroevende afwezigheid van ironie, humor of gedegen gekte, enigen bovendien door een ergerlijk wijdlopige verteltrant. Allen menen het heel goed en hebben te doen met de mensheid, speciaal met de kleine burgerij, die in donkere tinten wordt geschilderd: vervreemd door bezitsdrang. zonder het vermogen om het eigen leven richting te geven, sociaal geremd, opgesloten in hopeloosheid, maar wanhopig vluchtend in een rol achter de rustige façade, vanuit een leven dat een demonische bedreiging is geworden. Zou Nederland niet ook uit andere dingen bestaan? Zou 'Hollandske noveller' nict minstens evenveel vertellen over de samensteller als over de Nederlandse literatuur?]

De hier geciteerde Deense recensie uit 1972 leek een in de jaren zeventig in Nederland en Vlaanderen overheersende opvatting te bevestigen: Nederlandstalige schrijvers worden over de grenzen niet erg gewaardeerd. Bij het 25 -jarig bestaan van de Stichting tot bevordering van de vertaling van Nederlands letterkundig werk in 1979 constateerde directeur Joost de Wit zuchtend dat de belangstelling bij de meeste uitgevers minimaal 
was en dat veel uitgegeven teksten niet bleken aan te slaan. ${ }^{272}$ Terwijl in de jaren zeventig Nederlandse vertalingen verschenen van Deense literatoren als H.C. Andersen, Karen Blixen, Anders Bodelsen, Cecil Bødker, Suzanne Brøgger, Sven Holm, Henning Ipsen, Johannes V. Jensen, Søren Kierkegaard, Hans-Jørgen Lembourn, Kaj Munk, Leif Panduro en Klaus Rifbjerg, naast drie literaire bloemlezingen, zag in hetzelfde decennium zegge en schrijve één literaire vertaling van Nederlands werk in Denemarken het daglicht. En wel een bundel novellen, - die bovenstaande recensie meekreeg.

Ik schreef hierboven echter: leek een adagium te bevestigen. Er zijn namelijk ondanks dit alles een aantal paradoxen, die het interessant genoeg maken, een nadere beschouwing aan de Nederlandse literatuur in (Deense) vertaling te wijden:

- in een voorafgaande periode (grofweg tussen 1930 en 1960) zijn vele tientallen Nederlandse romans in het Deens vertaald, waarvan een deel een opvallend succes kende (hetzelfde geldt voor de vertalingen in het Noors en Zweeds);

- in tegenstelling tot de literatuur-voor-volwassenen boekte de jeugdliteratuur in de jaren zeventig wèl succes in Denemarken, daarmee overigens een trend van de jaren zestig voortzettend;

- voor de 'magere' jaren zeventig is een opvallend verschil te constateren met het buurland Zweden: 4x Boon, 1x Geeraerts, 5x Gijsen, 1x Lampo, 1x Multatuli, 1x Vandeloo, $5 \mathrm{x}$ Wolkers, - de laatste een zeer uitgesproken succes bij kritici en publiek;

- in de jaren tachtig heeft de bellettrie zich voorzichtig maar duidelijk weten te herstellen in Denemarken, met vertalingen van Multatuli, Frank Martinus Arion, Etty Hillesum, Anne Frank, Jeroen Brouwers, Harry Mulisch, Bernlef (2x), Cees Nooteboom, Jona Oberski, Oek de Jong, F. Springer, en met een bloemlezing.

Bij het schrijven van de eerste versie van dit hoofdstuk, in 1980, was slechts weinig onderzoek verricht naar de oorzaken van het (gebrek aan) succes van Nederlandse literatuur in andere talen. Afgezien van wat losse opmerkingen in essays van Hermans, Kousbroek en Romein-Verschoor bestond de secundaire literatuur op dit gebied voomamelijk uit een aantal artikelen in de tijdschriften Delta en Ons Erfdeel, waarin ofwel bepaalde deelaspecten worden behandeld (een specifieke vertaling; vertaalpolitiek van de overheid, enzovoort) ofwel de situatie in een hepaald land, meestal over een kortere periode. Hoewel in elk artikel wel een aantal oorzaken en effecten worden genoemd, behandelt geen der auteurs het geheel van potentiële (wan)succesbepalende factoren.

Pas in 1986 verscheen de eerste grondige studie op dit gebied: de dissertatie Dutch novels translated into English van Ria Vanderauwera over het waarom en hoe van alle circa vijftig literaire romanvertalingen in boekvorm, uitgekomen in Engeland en de Verenigde Staten tussen 1958 en 1980 . Vanderauwera geeft een uitvoerige analyse van brontekstgerichte, soms 'scrupuleuze' replica-achtige vertalingen, versus vaak rigoureuze. doelgroepgerichte adaptaties. Zij maakt aan de hand van vele voorbeelden duidelijk dat de vertalingen door de Engelse en Amerikaanse critici beter worden gewaardeerd naarmate de tekst meer in overeenstemming is gebracht met gangbaar romanproza in moderm standaard Engels of Amerikaans, variërend van kommagebruik tot de chronologie van de romangebeurtenissen. Vanderauwera bepleit een pragmatische aanpak: de literaire waarde wordt volgens haar niet zozeer bepaald door intrinsieke kwaliteiten, als wel door de omgeving waarin het werk functioneen. Vanderauwera, afkomstig uit de kring der poly- 
steemtheoretici (zie de inleiding van dit proefschrift) gaat hiermee sterk in tegen de opvatting dat de zo vaak geconstateerde en betreurde mislukkingen in het buitenland primair of zelfs uitsluitend te wijten zijn aan de intrinsieke factoren: kwaliteitsgebreken van de Nederlandse letteren als zodanig.

Zouden deze intrinsieke factoren bepalend zijn, dan is promotie van onze letteren elders immers vechten tegen de bierkaai. Blijkt gebrek aan succes daarentegen af te hangen van extrinsieke factoren, dan is het alsnog de vraag of hierin onontkoombare, structurele, dan wel positief beïnvloedbare invloeden de overhand hebben. Gelden Ria Vanderauwera's conclusies met betrekking tot het Angelsaksische cultuurgebied bij voorbeeld ook voor het Scandinavisch cultuurgebied?

Zonder te pretenderen hieronder allesomvattend onderzoek te bieden, heb ik in elk geval geprobeerd alle traceerbare factoren na te gaan aan de hand van de concrete situatie in Denemarken, en dat zowel over een langere periode, 1900-1990, als met betrekking tot alle typen fictie: bellettrie, ontspanningslectuur en jeugdliteratuur (vergelijk bovengenoemde paradoxen). Het overwicht van bepaalde factoren in de Deense situatie bewijst natuurlijk niet dat deze factoren ook in andere taalgebieden een even belangrijke rol spelen, maar toont in elk geval het niet-noodzakelijke overwicht van andere factoren aan. De waarde van dit onderzoek ligt dan in de mogelijkheid, de resultaten te laten fungeren als 'aangescherpte hypothese' (of als object van kritiek) en als uitgangspunt van een meeromvattend onderzoek.

Naar zal blijken, ligt de eigenlijke problematiek in het bepalen van de onderlinge verhouding der extrinsieke factoren. Inventarisatie van alle in de diverse artikelen genoemde potentiële factoren leert namelijk, dat de daarin aangevoerde argumenten voor uitsluitend intrinsieke factoren nogal mager en betrekkelijk gemakkelijk te weerleggen zijn aan de hand van concrete gegevens. Een uiteenzetting hiervan volgt in paragraaf 2 .

De vraagstelling van het in paragraaf 3 en 4 volgende eigenlijke onderzoek is daarmee voorlopig gereduceerd tot: welke sociale en/of incidentele factoren zijn bepalend voor de beeldvorming rond de Nederlandse literatuur in Denemarken, en voor het (gebrek aan) succes van die literatuur?

Voor de beantwoording van deze vraag ben ik uiteraard eerst nagegaan welke werken in de bewuste periode in het Deens vertaald zijn. Voor het achterhalen van de uiteindelijk gevonden 542 vertalingen in boekvorm heb ik voomamelijk gebruik gemaakt van de Deense nationale bibliografie, Dansk Bogfortegnelse. De internationale Index Translationum beslaat slechts een gedeelte (1949-heden) van de onderzochte periode en is bovendien zeer onvolledig, wat in mindere mate ook geldt voor andere bibliografieën. Morel vermeldt in zijn Bibliographia Neerlandica bijvoorbeeld niet de in het begin van deze eeuw verschenen boekuitgaven van krantefeuilletons, terwijl Het Nederlandse Boek in Vertaling een groot aantal kinderboeken onvermeld laat.

Mijn keuze van de eeuwwisseling als grens heeft te maken met de zich in die tijd sterk wijzigende uitgeverspolitiek, gevolg van de Berner Conventie. Bovendien stond de Deense lezer van 1900 geheel blanco tegenover onze literatuur. Zoals blijkt uit Bibliotheca Danica en de bibliografieën van Munch-Pedersen en Van Assche, zijn van 1653 tot 1900 slechts 36 Nederlandse literaire werken in het Deens vertaald, het laatste in 1888, en afgezien van een aantal Cats-uitgaven in de zeventiende en achttiende eeuw en een 
Conscience-golf in de jaren 1840-50 verdeeld over allerlei auteurs. Geen van deze uitgaven is herdrukt. Ten slotte groeien de Vlaamse en Noordnederlandse literatuur in het begin van deze eeuw meer en meer naar elkaar toe.

De eigenlijke receptie en beeldvorming bij kritici en publiek heb ik trachten te bepalen aan de hand van onder andere 468 recensies, te weten alle achterhaalbare kritieken 1900-1990 van respectievelijk de Deense bibliotheekcentrale en alle grote landelijke dagbladen: Berlingske Tidende, Dagens Nyheder/Nationaltidende, Information, Jyllandsposten, Kristeligt Dagblad, Politiken, Socialdemokraten/Aktuelt, plus de regionale Aarhus Stiftstidende. Voor het achterhalen van deze besprekingen is gebruik gemaakt van de registers van het pedagogisch tijdschrift Vor Ungdom, de bibliotheektijdschriften Den nye litteratur en Bogens Verden; de recensies van de Deense bibliotheeklectoren (Lektørudtalelser fra Indbindingscentralen); de knipseldienst van de Deense openbare bibliotheken; Dansk Avis-Kronik Index en Dansk Artikelindeks; de registers van de Avislasesal van de Kopenhaagse U.B.; en voor de periode 1980-1990 bovendien van de archieven van Gyldendal, Skandinavisk Press en Århus Universitetsforlag.

Verder heb ik gegevens ontleend aan literatuurgeschiedenissen, literaire tijdschriften, flapteksten, advertenties, en aan gesprekken met Tue Gad, voormalig vakreferent Nederlands aan de Koninklijke Bibliotheek van Kopenhagen; wijlen Geerte de Vries, voorheen lector Nederlands aan de Universiteit van Kopenhagen; en medewerkers van de uitgeverij Gyldendal en de voormalige uitgeverij Jespersen \& Pio te Kopenhagen, van de Kopenhaagse universiteitsbibliotheek, van de Nederlandse en de Belgische ambassade in Denemarken, alsmede van de (inmiddels opgeheven) Stichting ter bevordering van de vertaling van Nederlands letterkundig werk, gevestigd te Amsterdam.

$\mathrm{Na}$ een uiteenzetting over intrinsieke versus extrinsieke factoren in paragraaf 2 volgt verslag van het eigenlijke onderzoek in paragraaf 3 en 4 . Paragraaf 3 bevat een aantal inventarisatietabellen van vertalingen tussen 1900 en 1990, waaruit een duidelijke periodisering in vier tijdvakken blijkt. In paragraaf 4 worden na een korte inventarisatie categorieën van potentiële beeldbepalende factoren opgesteld, en zal ik voor elk van deze vier onderscheiden tijdvakken een beschrijving geven van de invloed die de respectieve factoren op de beeldvorming in Denemarken hebben uitgeoefend. Paragraaf 5 bevat conclusies, - over de relatieve waarde waarvan hierboven al gesproken is.

\section{Intrinsieke kwaliteitsgebreken?}

De in paragraaf 1 genoemde essays en artikelen waarin de geringe weerklank van de Nederlandse literatuur in vertaling ter sprake komt, wijzen nogal eens de lage kwaliteit van die literatuur als belangrijke corzaak aan. Sommige auteurs doelen hierbij op essentieel intrinsieke kenmerken van de letterkunde als geheel, anderen op het in het buitenland heersende eenzijdige beeld, gevormd op basis van de concrete vertalingen.

De ten gunste van het eerste standpunt aangevoerde argumenten zijn nogal mager. In een artikelenreeks in Delta wijst Snapper, hoogleraar Nederlands te Berkeley USA, op het wezenlijk provincialistische karakter van alle vooroorlogse Nederlandse literatuur. Achtergrond en thematiek zouden te typisch Nederlands zijn dan dat ze een buitenlander 
konden interesseren: strijd tegen de zee, tegen de Spaanse inquisitie en tegen de Duitse troepen in de Tweede Wereldoorlog [sic!]. De literator en zijn werk waren volgens Snapper internationaal geïsoleerd door de zee aan de ene en de taalgrens aan de andere kant; Multatuli en Heijermans doorbraken als enigen dit isolement en raakten ook als enigen internationaal bekend. Pas na de Tweede Wereldoorlog zou een algemene strijd tegen deze bekrompenheid zorgen voor verandering van het karakter der Nederlandse letteren, zich kenmerkend door een bewust geschapen 'structuurloze structuur', waarin de vervreemding en het gebrek aan identiteit van de modeme mens wordt uitgedrukt.

Soortgelijke uitspraken vinden we bij Chorus: "Alleen in de lyriek bereikten we de top, in de rest waren we tot voor kort tweederangs". Tegenover Snappers nadruk op de inhoud legt Kousbroek het accent op de vorm, in zijn uitspraak dat gebrek aan compositievermogen bij Nederlandse auteurs de vermoedelijke hoofdoorzaak van hun geringe succes elders is. ${ }^{273}$

Nu neemt onze letterkunde in internationaal opzicht zeker een bescheiden plaats in. In tegenstelling tot de Scandinaviërs missen we auteurs van wereldfaam, - die bovendien belangstelling voor minor poets uit dezelfde literatuur konden stimuleren. Veel Nederlandstalige produkten hebben ontegenzeggelijk een provincialistisch karakter. Hangt dat echter samen met thematiek en geografische omstandigheden, zoals Snapper beweert? Als diens voorbeeld, de strijd tegen de zee, te typisch Nederlands is, hoe kon dan de door hem zelf als uitzondering genoemde Heijermans internationaal succes boeken met Op hoop van Zegen? Of wat verklaart dan bijvoorbeeld de internationale faam van Theodor Storms novelle Der Schimmelreiter, waarin de strijd tegen diezelfde Noordzee zo'n belangrijke rol speelt? En wat het isolement tussen zee en taalgrens betreft, geldt dat niet evenzeer voor Scandinavië als geheel, dat minder inwoners heeft dan het Nederlandse taalgebied?

Veel vooroorlogse romans, in casu de 'damesromans', werden reeds door eigentijdse Nederlandse critici en door Annie Romein-Verschoor in haar dissertatie Vrouwenspiegel (1935) bekritiseerd om hun gebrek aan psychologische diepgang en originaliteit, en om hun wijdlopige, epigonistische stijl. Van Boven relativeert deze kritiek in haar recente proefschrift (1992), doch wijst harerzijds op een beperktheid van de damesromans die voortkomt uit ideologische gebondenheid van de schrijfsters aan de cultus van de ware vrouwelijkheid en onvermogen tot reflectie hierop. Maar juist deze romans boekten internationaal succes, terwijl andere vooroorlogse auteurs als Bordewijk, Elsschot, Slauerhoff, Walschap en anderen, die qua thematick, psychologie en stijl ver uitstegen boven provincialisme en beperktheid en die zich wat dat betreft zeker konden meten met buitenlandse literatoren, ondanks hun kwaliteiten niet aansloegen over de grenzen. Alleen van de pözie wordt het niveau over het algemeen hoger geschat, maar deze lijdt nu eenmaal qualitate qua extra aan het euvel van de moeilijke vertaalbaarheid plus geringe commerciële aantrekkelijkheid, zodat ze de buitenlandse lezer meestal überhaupt niet onder ogen kan komen.

Het door Snapper benadrukte verschil in karakter en kwaliteit tussen de produktie van vóór en na 1945 heeft in elk geval niet geleid tot een algemene stijging in hoeveelheid of afzet van naoorlogse vertalingen. De gegeven naoorlogse karakteristiek is al evenmin een intrinsiek kenmerk: er zijn voldoende auteurs, ook van niveau, die zich aan het beeld 
van vervreemding en desolaatheid onttrekken. En dezelfde somberheid, die volgens De Wit in bovengenoemd interview bepalend is voor herkenning en groot succes bij het Poolse publiek, wordt elders juist gezien als belemmerende factor. Bovendien behoren tot onze weinige succesvolle auteurs zowel vooroorlogse als naoorlogse schrijvers: Couperus en Claus in Frankrijk, en Van Ostaijen en Nooteboom in de BRD. Verschillen in verkoop van eenzelfde auteur in diverse landen wijzen evenmin op een relatie tussen intrinsieke kenmerken van de literatuur en (gebrek aan) succes: dezelfde Couperus deed het slecht in Duitsland, en Wolkers' succes met Een roos van vlees in Zweden staat tegenover het fiasco van de Westduitse uitgave. Ten slotte behalen opeenvolgende vertalingen van thematisch verwant werk van dezelfde auteur in hetzelfde land zeer verschillende verkoopresultaten, zoals Hugo Raes in de BRD. Kousbroeks structuurargument wordt voldoende ontzenuwd door het feit dat romans met een uitgesproken hechte compositie, zoals van Vestdijk en Hermans, elders een uiterst lauwe respons kregen. ${ }^{274}$

$\mathrm{Al}$ deze verschillen tussen en binnen de diverse landen tonen wel aan, dat er andere dan intrinsieke factoren in het spel zijn; er bestaat geen noodzakelijk verband tussen kwaliteit van de Nederlanse literatuur-als-geheel en haar vaak geringe succes buiten de grenzen. De situatie verschilt van land tot land en van moment tot moment, zoals Ria Vanderauwera's studie laat zien, en een nadere vergelijking van landen in dezen vooronderstelt studie van de oorzaken van die situaties per land afzonderlijk.

Iets anders dan intrinsieke kwaliteit is natuurlijk de kwaliteit van de concrete vertalingen in verhouding tot het gehalte van overig, omstreeks dezelfde tijd in het betrokken land of taalgebied uitgebracht oorspronkelijk werk en vertalingen uit andere vreemde literaturen. Deze vorm van 'kwaliteit' zal als een der factoren in het onderstaande aan de orde komen.

\section{Inventarisatie van Nederlandse literatuur in Deense vertaling, 1900-1990}

In de periode 1900 tot en met 1990 zijn 542 werken vertaald uit het Nederlands in het Deens. Het gaat hierbij om originele uitgaven in boekvorm, exclusief herdrukken. De titelgegevens zijn opgenomen in een bijlage bij dit hoofdstuk.

Bij de inventarisatie is het begrip 'literair' zo ruim mogelijk opgevat, namelijk als de verzameling van alle teksten met fictioneel karakter. Autobiografieën, essays en puur stichtelijke lectuur zijn niet verwerkt; het dagboek van Anne Frank en de brieven van Van Gogh zijn mede vanwege de literaire kwaliteiten wel opgenomen. De nadere uitsplitsing in bellettrie versus ontspanningslectuur kan niet anders dan op subjectieve en dus aanvechtbare gronden geschieden. Het al dan niet voorkomen in de (inmiddels afgesloten) karthoteek van het Nederlands Letterkundig Museum en literatuurgeschiedenissen is bij gebrek aan beter als eerste criterium gehanteerd. De verkregen verzameling belletrie heb ik nog weer uitgedund door het schrappen van die werken, waarin de concrete inhoud dermate prevaleert boven de structuur, dat mijns inziens niet van belletrie in engere zin kan worden gesproken. Voorbeelden van deze subjectieve weging zijn te vinden door het vergelijken van tabel $\mathrm{B}$ en $\mathrm{C}$ hieronder. Opneming van een auteur in 
de categorie ontspanningslectuur wil anderzijds niet zeggen, dat er binnen die categorie geen grote niveauverschillen zouden bestaan.

De in tabel A, B en C genoemde getallen hebben uitsluitend betrekking op de eerste uitgave van complete romans, novellen of anthologieën; voor herdrukken en anderssoortige uitgaven wordt verwezen naar respectievelijk tabel D en E. De uitgevers bleken desgevraagd niet bereid tot het verstrekken van preciese verkoopcijfers, - slechts tot het aangeven of een bepaalde uitgave al dan niet winstgevend was geweest. Over het algemeen kan men zeggen dat de uitgeverijen alleen tot vervolg op een debuut overgaan, als er een ruime winstmarge op de eerste uitgave is behaald. Uiteraard geldt een en ander nog sterker voor herdrukken. De gemiddelde oplage is 2-3000 exemplaren, bij succesauteurs echter meer: Willy Corsari 10.000 .

\section{Tabel A. Aantallen vertalingen}

In de periode 1900 tot en met 1990 zijn in totaal 542 werken vanuit het Nederlands in het Deens vertaald (originele uitgaven in boekvorm). Voor auteurs, titels en jaartallen: zie de bijlage bij dit hoofdstuk.

\begin{tabular}{lrrrrrrrr} 
Periode & \multicolumn{2}{c}{ Bellettrie } & \multicolumn{2}{c}{ Lectuur } & & Jeugdlit. & & Totaal \\
$1900-1910$ & 3 & $33 \%$ & 2 & $22 \%$ & 4 & $45 \%$ & 9 & $2 \%$ \\
$1910-1920$ & 1 & $7 \%$ & 2 & $14 \%$ & 11 & $79 \%$ & 14 & $3 \%$ \\
$1920-1930$ & 2 & $29 \%$ & 1 & $14 \%$ & 4 & $57 \%$ & 7 & $1 \%$ \\
$1930-1940$ & 20 & $5 \%$ & 35 & $61 \%$ & 2 & $4 \%$ & 57 & $10 \%$ \\
$1940-1950$ & 16 & $18 \%$ & 66 & $73 \%$ & 8 & $9 \%$ & 90 & $17 \%$ \\
$1950-1960$ & 12 & $18 \%$ & 41 & $64 \%$ & 12 & $18 \%$ & 65 & $12 \%$ \\
$1960-1970$ & 8 & $11 \%$ & 12 & $16 \%$ & 56 & $73 \%$ & 76 & $14 \%$ \\
$1970-1980$ & 1 & $2 \%$ & 6 & $7 \%$ & 74 & $91 \%$ & 81 & $15 \%$ \\
$1980-1990$ & 13 & $9 \%$ & 5 & $3 \%$ & 125 & $88 \%$ & 143 & $26 \%$ \\
Totaal & 76 & $14 \%$ & 170 & $32 \%$ & 296 & $54 \%$ & 542 & $100 \%$
\end{tabular}


Tabel B. Meest vertaalde schrijvers ( 3 of meer vertalingen)

( $\mathrm{B}=$ bellettrie; $\mathrm{O}=$ ontspanningslectuur; $\mathrm{J}=$ jeugdliteratuur)

$\begin{array}{llllll}\text { Willy Corsari } & \text { O } & 27 & \text { Wil Huygen } & \text { OJ } & 4 \\ \text { Willy Vandersteen } & \text { J } & 22 & \text { W.G. v.d. Hulst } & \text { J } & 4 \\ \text { Hans Martin } & \text { O } & 20 & \text { Loek Kessels } & \text { J } & 4 \\ \text { Dick Bruna } & \text { J } & 18 & \text { Madelon Lulofs } & \text { B } & 4 \\ \text { Jo van Ammers-Küller } & \text { O } & 13 & \text { Bob de Moor } & \text { J } & 4 \\ \text { Martin Lodewijk } & \text { J } & 13 & \text { H.J.v.Nijnatten-Doffegnies } & \text { O } & 4 \\ \text { Tom Roep } & \text { J } & 12 & \text { Chris Scheffer } & \text { J } & 4 \\ \text { Leonard Roggeveen } & \text { J } & 11 & \text { Jan Terlouw } & \text { J } & 4 \\ \text { Marten Toonder } & \text { J } & 11 & \text { Han Aalberse } & \text { O } & 3 \\ \text { Jaap ter Haar } & \text { J } & 8 & \text { Thea Beckman } & \text { J } & 3 \\ \text { Ina Boudier-Bakker } & \text { O } & 8 & \text { Paul Biegel } & \text { J } & 3 \\ \text { Rie Cramer } & \text { JO } & 8 & \text { Rein Brouwer } & \text { O } & 3 \\ \text { Jan de Hartog } & \text { O } & 8 & \text { Evert Hartman } & \text { J } & 3 \\ \text { Hans Kresse } & \text { J } & 8 & \text { Ary den Hertog } & \text { O } & 3 \\ \text { Els Stam } & \text { J } & 8 & \text { Margriet Heymans } & \text { J } & 3 \\ \text { Anne de Vries } & \text { JO } & 8 & \text { Leonard Huizinga } & \text { O } & 3 \\ \text { Henk Kuijpers } & \text { J } & 7 & \text { Diet Kramer } & \text { JO } & 3 \\ \text { Piet Bakker } & \text { O } & 6 & \text { Leo Legène } & \text { J } & 3 \\ \text { Felicie Jehu } & \text { J } & 6 & \text { Herman de Man } & \text { B } & 3 \\ \text { Dick Laan } & \text { J } & 6 & \text { Dick Matena } & \text { J } & 3 \\ \text { A. Rutgers-v.d.Loeff } & \text { J } & 6 & \text { Multatuli } & \text { B } & 3 \\ \text { Annie M.G. Schmidt } & \text { J } & 6 & \text { Top Naeff } & \text { J } & 3 \\ \text { Janwillem van de Wetering } & \text { O } & 6 & \text { Els Pelgrom } & \text { J } & 3 \\ \text { A. den Doolaard } & \text { B } & 5 & \text { Marijke Reesink } & \text { J } & 3 \\ \text { A.M. de Jong } & \text { B } & 5 & \text { Anke Servaes } & \text { O } & 3 \\ \text { Felix Timmermans } & \text { B } & 5 & \text { C. \& M. Scharten-Antink } & \text { B } & 3 \\ \text { Marie van Zeggelen } & \text { JO } & 5 & \text { Ingrid Schubert } & \text { J } & 3 \\ \text { Abraham Duif } & \text { J } & 4 & \text { W.F.H. Visser } & \text { J } & 3 \\ \text { Johan Fabricius } & \text { B } & 4 & & & \end{array}$

\section{Tabel C. Belletrie}

A. den Doolaard, A.M. de Jong. Felix Timmermans 5

Johan Fabricius, Madelon Lulofs $\quad 4$

Herman de Man, Multatuli, Top Naeff. Carel \& Margo Scharten-Antink 3

Bernlef, Johan Brouwer, Antoon Coolen, Anne Frank, Theun de Vries 2

Frank Martinus Arion, Piet van Aken, Jeroen Brouwers, Jan Campen, Jan Cremer, Maria Dermout, Pierre Dubois, Frederik van Eeden, Willem Elsschot, Marnix Gijsen, Vincent van Gogh, Willem Frederik Hermans, Etty Hillesum, Oek de Jong, Karel Jonckheere, Clare Lennart, Harry Mulisch, A.H. Nijhoff, Cees Nooteboom, Jona Oberski, Marianne Philips, Filip de Pillecijn, Jacques Presser, F. Springer, Stijn Streuvels, Simon Vestdijk, Carel Vosmaer, Gerard Walschap, Constant van Wessem, Johan van der Woude 
Anthologieën: Nyere Flamsk Prosa (romanfragmenten en verhalen van Van Aken, Boon, Brulez, Carlier, Claus, Demedts, Elsschot, Gilliams, Gijsen, Jonckheere, Lampo, De Pillecijn, Raes, Roelants, Ruijslinck, Streuvels, Teirlinck, Timmermans, Vandeloo, Walschap, Van de Woestijne);

Nyere Hollandsk Prosa (romanfragmenten en verhalen van Belcampo, Blaman, Bordewijk, BoudierBakker, Campert, Carmiggelt, Coolen, Couperus, Dermout, Den Doolaard, Hamelink, Helman, Hermans, A.M. de Jong, Koolhaas, Minco, Morriën, Mulisch, Du Perron, Van het Reve, Van Schendel, Slauerhoff, Van Velde, Vestdijk, Wolkers);

Hollandske Noveller (verhalen van Bemlef, Campert, Claus, Hamelink, Hermans, Minco, Raes, Van het Reve, Vandeloo, Wiener, Wolkers).

I kcerlighedens favn (teksten van Auwera, Biesheuvel, Carmiggelt, Claus, De Coninck, Cottenjé, Dorrestein, Geeraerts, 't Hart, T. Hermans, W.F. Hermans, O. de Jong, Koeck, Van Kooten, Morriën, Poppe, Reve, $H$. van Veen, P. van Vliet).

In totaal 76 vertalingen; exclusief 11 jeugdboeken van Toonder, 2 van Last, 3 van Naeff, 2 van Schippers en I van Koolhaas.

\section{Tabel D. Herdrukte auteurs}

De jaartallen geven de 'Wirkungsdauer' van de auteurs aan, dat wil zeggen de periode tussen de publikatie van het eerste boek en de laatste herdruk van eenzelfde schrijver, plus het totaal aantal uitgaven. De lijst is onvolledig, daar Dansk Bogfortegnelse niet alle herdrukken consequent vermeldt.

$\begin{array}{llrllr}\text { Top Naeff } & 1910-1920 & 9 & \text { Vincent v. Gogh } & 1946-1972 & 5 \\ \text { Rie Cramer } & 1914-1975 & 9 & \text { A.Rutgers-v.d.Loeff } & 1949-1989 & 8 \\ \text { Ina Boudier-Bakker } & 1931-1950 & 12 & \text { Anne Frank } & 1952-1988 & 34 \\ \text { Willy Corsari } & 1935-1973 & 47 & \text { Han Aalberse } & 1959-1966 & 10 \\ \text { Hans Martin } & 1939-1980 & 55 & \text { Jef Last } & 1960-1973 & 3 \\ \text { Jan de Hartog } & 1941-1964 & 14 & \text { Cl. Asscher-Pinkhof } & 1964-1973 & 5 \\ \text { A.M.Roothaert } & 1941-1955 & 4 & \text { Leon. Roggeveen } & 1965-1967 & 12 \\ \text { Johan Brouwer } & 1942-1947 & 3 & \text { Dick Bruna } & 1967-1979 & 18 \\ \text { S. Franke } & 1943 & 2 & \text { Hans Kresse } & 1976-1980 & 11 \\ \text { Piet Bakker } & 1944-1976 & 23 & \text { Wil Huygen } & 1977-1989 & 8 \\ \text { Rein Brouwer } & 1944-1946 & 4 & \text { Torn Roep } & 1977-1988 & 18 \\ \text { Anke Servaes } & 1944-1948 & 6 & \text { Ever Hartnan } & 1985-1990 & 4\end{array}$

\section{Tabel E. Diversen}

- Ongepubliceerde vertalingen: 1) Lodewijk de Boer, Zeven manieren om een rivier over te steken en The family (vertaald via het Engels), 2) Frederik van Eeden, IJshrand, 3) Herman Heijermans, Op hoop van zegen en Schakels: manuscripten/typoscripten in de verzameling van de K.B. Kopenhagen. 4) Maurice Gilliams, Elias of het gevecht met de nachtegalen, 5) Herman Teirlinck, Marie Speermalie (zie paragraaf 4.3.3).

- Krante- en tijdschriftpublikaties. Berlingske Tidende: Louis Couperus, De stille kracht (feuilleton, 1903). Illustreret Tidende: verhalen van Multatuli (1901), Samuel Falkland (= Heijermans) (1910-1911), Marie van Zeggelen (1915-1916). Jyllands-Posten: Timmermans (1935-1936). Tidens Stemme: Timmermans (1935). ${ }^{275}$ Perspektiv: Marga Minco (1960). Vindrosen: Holland-nummer met Andreus, Koolhaas, Roland Holst, Vestdijk, Voeten (1961); Jonckheere (1962), Wolkers (1968). 4) Hvedekorn: 
Holland-nummer met poëzie van Campert, Elburg, V.d. Graft, Kouwenaar, Lucebert. Polet, Sleutelaar, Snoek, Vaandrager en Warmond (1965).

- Nederlandse bijdrage in internationale bundel: Anton Koolhaas, Een bloem voor morgen, in I dags fortallinger (1967).

\section{Analyse van de beeldvorming}

\section{I Algemeen}

De in de bovengenoemde secundaire literatuur genoemde stimulerende of remmende extrinsieke factoren worden soms aangetoond aan de hand van concrete gegevens, soms geponeerd in de vorm van een postulaat. Wat sommigen als positief beschouwen - de specifieke sfeer in een bepaald werk, de invloed van een gunstige recensie - wordt door anderen als irrelevant of negatief gezien. Enkele auteurs besteden bewust slechts aandacht aan een enkel aspect, anderen behandelen de diverse factoren slechts zijdelings. Nadere inventarisatie naar frequentie heeft dus weinig zin; hier wordt volstaan met indelen in categorieën. Ziet men af van allerlei causale factoren, dan blijken de factoren als volgt te kunnen worden verdeeld:

- kwaliteitskenmerken van het specifieke vertaalde werk in verhouding tot de in het vreemde land heersende literaire smaak;

- aanwezigheid van documentatie (bekendheid van uitgevers, kritici en publiek met de Nederlandse literatuur in het algemeen);

- particulier initiatief (onder andere persoonlijke relaties van vertalers en consulenten met uitgevers);

- cultuurpolitiek en vertaalpolitiek (overheidsbeleid, subsidiëring van vertalingen);

- uitgeversbeleid;

- aard van de vertaling:

- ontvangst door de kritiek.

Sommige categorieën zijn meer dan andere van invloed op het loutere verschijnen van vertalingen, terwijl andere meer direct beeldvormend lijken. Het enkele verschijnen is als conditio sine qua non echter uiteindelijk minstens zo bepalend voor die beeldvorming. die overigens op haar beurt mede het verschijnen beïnvloedt. Wat de categorie "ontvangst door de kritiek' betreft: deze kan niet alleen het verwachtingspatroon van het publiek, doch ook dat van collega-kritici beïnvloeden: zie paragraaf 4.3.7.

\subsection{Periode 1900-1930}

\subsubsection{Kwaliteitskenmerken in relatie tot de literaire smaak}

Zijn de geringe hoeveelheid en de zwakke weerklank van Deense vertalingen van Nederlands werk in de periode 1900-1930 te verklaren vanuit discongruentie in literaire smaak? Te spreken over zoiets als 'literaire smaak' is een hachelijke zaak. De thans als 
representatief voor de toenmalige smaak beschouwde dichtbundels en novellen van de Deense symbolisten uit de jaren negentig van de vorige eeuw werden bij hun verschijning in niet meer dan enige honderden exemplaren verkocht, terwijl anderzijds werk van literatoren als Balzac, De Maupassant en Toergenjev in enorme oplagen voor een prijs van vijftig øre per stuk als ontspanningslectuur naar het grote Deense publiek uitging. ${ }^{276}$ Literaire stromingen zijn met andere woorden lang niet altijd representatief voor de reële lezershouding van zelfs de intellectuele bovenlaag.

Voor de jaren tussen 1900 en circa 1920 kan men in zoverre iets veiliger van 'de' literaire smaak spreken, dat het neo-realisme van Jacob Knudsen, Johan Skjoldborg en later ook Johan V. Jensen en Martin Andersen Nexø bij een veel breder publiek aansloeg dan alleen het traditionele 'literaire' publiek. ${ }^{277}$ De relatieve eenvoud van hun proza zal daar niet vreemd aan geweest zijn: hun directe wijze van beschrijven vormt een reactie op al de literaire kenmerken van het voorafgaande decennium, als pessimisme, individualisme, 'artisme', symbolisme en vlucht uit de werkelijkheid. Naast deze nieuwe auteurs handhaven zich echter schrijvers uit de oorspronkelijke naturalistische school als Herman Bang en Henrik Pontoppidan, die bepaalde trekken met de 'negentigers' gemeen hebben. Hun lezerspubliek was evenwel minder gespreid dan dat van de neo-realisten. ${ }^{278}$ Van alle in deze periode vertaalde literatoren past een figuur als Streuvels (vertaald 1913) dus redelijk goed in het Deense tijdbeeld, Vosmaer (1900) niet, terwijl zo verschillende auteurs als Couperus (1903), Van Eeden (1903) en Multatuli (1901) redelijk tot matig in het kader passen. Een directe verklaring voor het fiasco van deze Nederlandse auteurs in Denemarken kan dus hoogstens voor Vosmaer (gedeeltelijk) in discongruentie van literaire smaak worden gezocht. De negatieve invloed op de beeldvorming is dan ook meer indirect, namelijk het niet uitkomen van verdere vertalingen. Om door te breken als 'onbekende' literatuur is nu eenmaal kwalitatief overwicht nodig, en het rond 1900 in de marge van de Nederlandse bellettrie opkomende sociaal-realisme en psychologisch realisme van Querido, De Meester, Robbers cum suis kon zich in geen enkel opzicht meten met het bovendien anders geaarde Deense realisme. In Nederland lag het literaire zwaartepunt in deze periode in de lyriek en in de door Knudsen cum suis zo verworpen stromingen. De enige potentiële uitzondering. Heijermans, leed schipbreuk op̣ andere groñden: zie paragraaf 4.2 .5 .

De ontspanningslectuur, die in 1900 zeventig à tachtig procent van alle in het Deens vertaalde literatuur uitmaakt, is veel minder dan de bellettrie aan stromingen onderhevig, en de binnenlandse en buitenlandse produktie vertonen weinig verschillen. Het nauwelijks voorkomen van Nederlands werk hangt dan ook primair samen met de uitgeverspolitiek: zie par. 4.2.5. Gezien de sterke scheiding tussen de geïmpliceerde lezersrol van respectievelijk bellettrie en ontspanningslectuur (dit in tegenstelling tot de periode 1930-1960) kunnen we gevoeglijk zeggen dat de zeer weinige Nederlandse ontspanningsromans, verschenen bij provinciale uitgeverijen, het 'literaire', voomamelijk Kopenhaagse publiek niet onder ogen zijn gekomen.

Wel is er een geval waarin een verkeerd verwachtingspatroon ten aanzien van de in te nemen lezersrol zeer waarschijnlijk negatief heeft gewerkt, namelijk de publikatie van Couperus' De stille kracht als feuilleton in Berlingske Tidende. Couperus' Nederlandse feuilletonsuccessen berustten op sterke identificatiemogelijkheden en/of de cenvoudige 
structuur. Eline Vere verscheen niet voor niets juist in het Haagse dagblad Het Vaderland en was bovendien qua taalgebruik veel natuurlijker dan de latere romans. Na Eline Vere bestaat Couperus' feuilletonproduktie uit wat door hemzelf werd aangeduid als broodschrijverij, - voornamelijk losse schetsen en reisverslagen.

Waar nu een directe identificatiemogelijkheid ontbreekt, en dat was in Kopenhagen ten opzichte van de Indisch-Nederlandse wereld van De stille kracht zeker het geval, resteert uitsluitend het gewone verwachtingspatroon ten opzichte van feuilletons: divertissement. En hoewel bij eenzelfde lezer een op ontspanning ingestelde en een meer literair-esthetische leeshouding verenigd kunnen zijn, was dit ten aanzien van Couperus nauwelijks waarschijnlijk bij de lezers van Berlingske Tidende: de conservatieve bourgeoisie, die al eerder geen goed woord over had voor het werk van Couperus' Deense geestverwant, de 'decadent' Herman Bang. ${ }^{279}$ Een eventuele literaire leeshouding zal dus gehinderd zijn door Couperus' preciositeit, en een waarschijnlijker op divertissement ingestelde leeshouding door de voor hem zo kenmerkende uitweidingen en herhalingen ten koste van de primaire handeling. In tegenstelling tot de schrijfsters Cecile Goekoop en Melati van Java, van wie de vertaalde feuilletons na afloop in boekvorm verschenen, was het hiermee voor Couperus in Denemarken afgelopen; latere pogingen om uitgevers te interesseren mislukten. ${ }^{280}$ Dat het ook anders had kunnen lopen, bewijst de situatie in Noorwegen, waar een directe boekuitgave van Eline Vere werd gevolgd door vertalingen van Majesteit en... De stille kracht.

Zoals bellettrie en ontspanningslectuur in deze periode een strikt gescheiden publiek hebben, heeft ook de Nederlandse jeugdliteratuur haar eigen circuit. Jeugdboeken werden aan het begin van deze eeuw uitsluitend als pedagogisch middel gezien, niet als potentiele literatuur. Het in 1896 door de Duitser Heinrich Wolgast gepubliceerde strijdschrift Das Elend unserer Jugendliteratur, een apologie van het artistieke jeugdboek, vond in Denemarken - anders dan in Duitsland en Zweden - nauwelijks weerklank. Het pedagogische tijdschrift Vor Ungdom besteedde als enige Deense periodiek aandacht aan jeugdliteratuur, en legde de nadruk op opvoedkundige waarden, daarin gesteund door het beleid van de opkomende schoolbibliotheken en jeugdbewegingen. De meeste auteurs van het 'betere' jeugdboek waren dan ook uit het onderwijs afkomstig. Naast deze uiteraard moralistische boeken handhaafden zich in de leespraktijk van de jeugd de als slecht beoordeelde avonturenromans, vaak primair voor volwassenen geschreven triviaalliteratuur. Bij de jeugd stond dit populaire genre duidelijk bovenaan. ${ }^{28 !}$

De vertalingen van Nederlandse jeugdboeken leveren tegen deze achtergrond een verrassend beeld op. Ten opzichte van de overige uit het Nederlands vertaalde werken in deze periode onderscheiden ze zich door een relatief sterke vertegenwoordiging en continuitteit, en binnen het totale Deense jeugdboekenaanbod door kwaliteit en oorspronkelijkheid. Rie Cramer, Top Naeff, Nynke van Hichtum en Marie van Zeggelen zijn de bekendste namen. De laatste twee zijn vertegenwoordigd met respectievelijk in Afrika en Indië spelende geschiedenissen, en onttrekken zich daarmee al aan het destijds gangbare patroon dat vrouwen specifieke meisjesboeken schreven, die zich afspeelden in een gelukkige burgerlijke omgeving. Nynke van Hichtums Ohoehoe (Ohuhue, 1908) beschrijft het harde leven van een kafferjongen. De heersende karakteristiek gold evenmin voor Top Naeff, wier Schoolidyllen (Skole-idyller, 1904) in Nederland wegens de 
beschrijving van 'gemene leraressen' en een vermeende te grote vlotheid in Nederland meermalen op pedagogische bezwaren was gestuit. ${ }^{282}$ Ondanks deze afwijking van het patroon werd de impliciete waarde erkend door Vor Ungdom (zie paragraaf 4.2.7), en de zich sterk op deze kritiek richtende aanschaf van schoolbibliotheken ${ }^{283}$ is ongetwijfeld mede oorzaak van het redelijke tot aanzienlijke succes geweest. Van Marie van Zeggelen werden drie werken vertaald en twee bewerkt; van Top Naeff drie, die alle werden herdrukt. Van de negentien jeugdboeken zijn er veertien vertaald door de destijds bekende en geprezen Deense jeugdboekenschrijfster Emma Kraft, en elf jeugdboeken kwamen uit bij dezelfde uitgevers, Jespersen en Pio (die na hun fusie nog vele tientallen Nederlandse boeken in vertaling zouden uitgeven). Een en ander heeft wellicht voor onderwijzers en bibliothecarissen een min of meer continu beeld opgeleverd van goede Nederlandse kwaliteit.

De visie op Nederlandse literatuur is hierdoor echter geenszins beïnvloed, daar jeugdboeken immers niet met literaire maatstaven werden beoordeeld. Buiten pedagogische kringen was er onder volwassenen al helemaal geen belangstelling voor het jeugdboek. Dagbladkritiek beperkte zich tot de weken rond Kerstmis, waarin enkele 'recensies' van vier à vijf regels per boek strekten tot koopadviezen aan de ouders. Zelfs een blad als Politiken, dat in de Deense literatuurkritiek zo'n belangrijke rol speelt, onttrok zich niet aan dit patroon. Ook wat de jeugdige lezers zelf betreft, hoeven we ons geen illusies te maken over een eventuele beeldvorming. Het sterk intemationale karakter van jeugdliteratuur, in de hand gewerkt door grote aantallen vertalingen en - vaak aan het land aangepaste - bewerkingen, heeft tot gevolg dat de nationaliteit van de auteur voor de jeugdige lezer geen enkele rol speelt. Tenzij sprake is van een zeer bekend auteur onthoudt het kind een boek veel vaker aan de titel dan aan de auteursnaam. In ons concrete geval zijn de zeventien vertalingen bovendien toch veel te ruim gespreid over tijd en doelgroep om een totaalindruk achter te laten bij eenzelfde jeugdige lezer.

\subsubsection{Documentatie}

In 1901 verschijnt in Denemarken voor het eerst een tamelijk uitgebreid en gedocumenteerd overzicht van de Nederlandse letterkunde: een dertig bladzijden lang hoofdstuk in Clausens Illustreret Verdenslitteraturhistorie, van de hand van de Deense schrijver Alfred Ipsen. Deze had al in 1891 een monografie Holland gepubliceerd en kende onder andere Frederik van Eeden persoonlijk. Diens Kleine Johannes wordt door Ipsen geprezen, evenals Multatuli's Max Havelaar en Vosmaers romans. Daarentegen kunnen Coupenus stilistische kwaliteiten voor hem niet opwegen tegen de zwakke karakters, "som altfor meget synes at sygne hen i lutter Stemning og Lyrik" ["die al te veel lijken weg te kwijnen in louter stemming en lyriek"]. Streuvels wordt in het geheel niet genoemd, overigens begrijpelijk, want diens hoofdwerken dateren van na 1901.

Bij een poging, het effect van deze informatie vast te stellen, moeten we onderscheid maken tussen het verschijnen van vertalingen en de ontvangst ervan. De nog in hetzelfde jaar als de literatuurgeschiedenis bij dezelfde uitgeverij, Gyldendal, verschenen Multatulivertaling, in 1903 gevolgd door Van Eeden, zou kunnen wijzen op invloed van Ipsen. 
Deze was als enige Deense deskundige op het gebied van de Nederlandse literatuur tevens de meest aangewezen uitgeversconsulent, en zijn inzet voor met name Van Eeden heeft verder gereikt dan loutere documentatie. ${ }^{284}$ Wat Multatuli betreft, zal echter de exceptionele sensatie die de Duitse Havelaar-vertaling kort tevoren had teweeggebracht en die door verscheidene recensenten wordt gememoreerd, ongetwijfeld van doorslaggevende betekenis zijn geweest voor deze uitgave. Hetzelfde geldt voor de vertaling van Vosmaers Amazone, in 1900 uitgebracht in een voor die tijd zeer grote oplage ${ }^{285}$ van 4000 exemplaren; de inleiding van de uitgave vermeldt een voorafgaande Franse, Duitse en Engelse vertaling. Wezenlijk positieve invloed op receptie en verkoop heeft dit alles niet gehad: zie de paragrafen 4.2.5 en 4.2.6. Het ontbreken van verdere documentatie bestendigt ondertussen natuurlijk de indruk van een onbelangrijke literatuur zonder Europees perspectief, met als gevolg een negatief verwachtingspatroon ten opzichte van eventuele vertalingen.

\subsection{3/4.2.4 Particulier initiatief: cultuur-en vertaalpolitiek}

Inzake de factoren particulier initiatief en cultuur- en vertaalpolitiek kunnen we betrekkelijk kort zijn. Van een gerichte overheidspolitiek is geen sprake, terwijl de positieve maar voor beeldvorming en receptie uiteindelijk beperkte rol van Alfred Ipsen hierboven ter sprake is gebracht. Emma Kraft speelt in zoverre een sleutelrol, dat zij niet alleen verantwoordelijk is voor veertien van de negentien jeugdboekvertalingen, maar tussen 1917 en 1924 voor alle vertalingen uit het Nederlands überhaupt. Haar eigen jeugdboeken waren steeds zeer positief ontvangen, en op de lijst van voor bibliotheken meest aanbevolen werken van 1910 neemt zij qua aantal de tweede plaats in met dertien stuks. Vor Ungdom prijst in elke recensie van haar vertalingen het voortreffelijke Deens en de op kinderen afgestemde stijl. Doordat zij meer op de voorgrond trad (van Ipsen verschenen geen vertalingen in boekvorm), was haar invloed op de verkoop ongetwijfeld groter; maar het effect op de beeldvorming was per saldo even beperkt, zoals we aan het eind van paragraaf 4.2.1 zagen.

Andere particuliere initiatieven zoals een eerste leerboek Nederlands van M. Meyboom en I. Tvede (1906) hebben geen direct effect op vertalingen gehad. Hetzelfde geldt voor een arrangement van het dagblad Politiken rond Van Eeden in 1910. Kjærgaard vermeldt abusievelijk 1902 en suggereet verband met het uitkomen van De kleine Johannes, maar in werkelijkheid ging het om een voordracht uit De blijde Wereld en een uiteenzetting van het Walden-experiment. Literaire motieven ontbraken bij organisator Cavling. "Ik begon [...] te bemerken", schrijft Van Eeden , "dat ik in handen van een politieke partij was gevallen. Ik ben feitelijk geëxploiteerd door Politiken, het radicale blad. Alleen dat blad heeft reclame voor mij gemaakt, soms op zeer smakelooze wijze." Het evenement trok dan ook veel belangstelling, maar bracht geen nieuwe vertalingen met zich mee. Terwijl bij voorbeeld in Zweden De heks van Haarlem in vertaling uitkwam (1916), berust in de toneelafdeling van de Koninklijke Bibliotheek te Kopenhagen slechts een nooit voor opvoering gebruikte manuscriptvertaling van IJsbrand. 


\subsubsection{Uitgeversheleid}

Gezien het voorafgaande zal het niet verbazen dat er bij Deense uitgevers weinig belangstelling bestond voor de Nederlandse letteren. De discongruentie tussen het Deense en Nederlandse neorealisme, onbekendheid met de literatuur bij gebrek aan vroegere vertalingen, en het vrijwel ontbreken van vertalers en consulenten staan tegenover een groot aanbod van Duits en Engels werk van gezochte inhoud en niveau plus een navenant aanbod van vertalers. Zoeken naar geschikt Nederlands werk was alleen maar tijdrovend.

Dit beleid geldt nog sterker ten aanzien van de ontspanningslectuur: het patroon van lage prijzen en dus een noodzakelijke hoge omzet, schakelt het Nederlands vrijwel uit. Een uitzondering als Cecile Goekoops Hilda van Suijlenhurgh was dan ook opgevallen door een enorm verkoopsucces in Nederland: zes drukken in één jaar. ${ }^{286}$ lets dergelijks geldt voor destijds in ons land zeer populaire auteurs als Kees Meekel en Melati van Java. Overigens verschenen de ontspanningsromans niet bij de grotere uitgeverijen, maarr respectievelijk als boekuitgaven van eerst als feuilleton in de provinciale pers verschenen romans, en bij een katholieke uitgeverij.

De enige min of meer consistente politiek wordt gevoerd op het gebied van jeugdboeken, door uitgeverij Jespersen (zie paragraaf 4.2.1); per saldo is deze voor de beeldvorming uiteindelijk toch weinig effectief.

Het geheel overziend kunnen we zeggen dat het uitgeversbeleid commercieel en onsamenhangend is. Een Deense pendant van de Nederlandse non-commerciële Wereldbibliotheek (de 'Maatschappij tot Verspreiding van goede en goedkoope Lectuur', opgericht in 1905), die zoveel Scandinaviërs op de Nederlandse markt heeft gebracht, ontbreekt.

\subsubsection{Aard van de vertaling}

De Deense uitgave van de Max Havelaar leek alles mee te hebben: voorpubliciteit, documentatie voorhanden, publikatie door de meest gerenommeerde literaire uitgeverij. uitgebreide recensies op de dag van verschijnen, in Politiken zelfs op de voorpagina. Toch liep het boek volstrekt niet: nog in 1907 trachtte Gyldendal vergeefs de restoplage in een nieuw omslagje te slijten aan de abonnees van haar 'læsekreds'. Een blik in de vertaling zelf verklaart veel. Vertaler Carl Michelsen, van wie geen enkele andere vertaling uit het Nederlands bekend is, meldt in zijn voorwoord dat hij "af Hensyn til danske Lasere (har) tilladt sig at forkorte den oprindelige Tekst og med velberaad Hu undgaaet saa mange malajiske og javanesiske Ord som muligt" ["zich met het oog op de Deense lezers heeft veroorloofd, de oorspronkelijke tekst te verkorten en met weloverwogen omzichtigheid zoveel mogelijk Maleise en Javaanse woorden heeft vermeden"]. De gevolgen van deze actie zijn zeer ingrijpend: meer dan een kwart is geschrapt, onder andere de Barbertje-scène, Frits' liefdesgedicht, grote delen van het pak van Sjaalman en van Droogstoppels commentaren. Allerlei voor Multatuli zo typerende tussenopmerkingen zijn weggelaten of 'keurig' syntactisch geïntegreerd. Typografische eigenaardigheden ontbreken eveneens: de beroemde latste scène bijvoorbeeld is gezet uit één letter, zon- 
der regels wit, spaties, cursiveringen en kapitalen, zelfs zonder een vraagteken achter de laatste wanhoopsvraag. Wie de Nederlandse Havelaar erbij neemt, kan zich blindelings het effect van de Deense voorstellen.

Politikens recensent noemt het boek moeilijk om in te komen, en het lijkt niet gewaagd te veronderstellen dat Michelsens vertaling daar mede debet aan is. De critici, die uiteraard geen Nederlands kenden, konden de rigoureuze ingrepen niet opmerken, en de recensies zijn meer gekenmerkt door obligate eerbied voor "den berømte hollandske Roman, som er gaaet gennem hele Europa" ["de beroemde Nederlandse roman, die heel Europa is doorgegaan"] en literair-historische verwijzingen naar Rabelais, Lessing, Dickens en Heine, of door het trekken van parallellen met de sociale actualiteit, dan door groot enthousiasme voor het werk zelf. ${ }^{287}$

Heijermans, de ander door Snapper genoemde uitzondering op de onbekendheid van de Nederlandse literatuur van voor 1945, ontbreekt, paradoxaal genoeg ook op grond van de aard van de (manuscript-)vertaling. De Europese triomfen van $O p$ hoop van zegen waren in Kopenhagen opgevallen, en Politiken meldt een harde strijd tussen twee theaters om de rechten van het stuk. Op 28 oktober 1909 ging Haabet in première in Det $\mathrm{Ny}$ Teater, maar na drie opvoeringen al werd het van het repertoire afgevoerd. "Det er forhaabentlig en sjælden Undtagelse paa vore bedre Scener at finde en Oversættelse, der i en saadan Grad som denne forfladiger og udvisker, ja rent ud forvansker Originalens Karakter. Ikke to replikker i Trek var gengivet med den oprindelige Farve og Styrke" ["Het is hopelijk een zeldzame uitzondering dat men op de planken van onze betere theaters een vertaling vindt die zó sterk het karakter van het origineel vervlakt en vervaagt, ja ronduit verdraait. Nog geen twee opeenvolgende clausen waren weergegeven met de oorspronkelijke kleur en kracht"], schrijft de recensent van Politiken, die het stuk wel in de Duitse versie gekend zal hebben. Hij vervolgt met kritiek op gedeeltelijk uit de slechte vertaling voortvloeiende regiefouten: Jo als een lief klein meisje zonder enige tragiek, Kniertje als een gezellig-lachend, bezorgd moedertje. ${ }^{288}$ Heijermans, die zich erg druk maakte om de vertalingen van zijn werk - hij verhuisde er zelfs om naar Berlijn moet deze verdeensing ontschoten zijn. Maar een volgende. nadrukkelijk door hem geautoriseerde en vee! getrouwere manuscriptvertaling van Schakels (Lanker), dat zich evenals dat van Haabet in de toneelafdeling van de K.B. Kopenhagen bevindt, heeft de schade niet meer kunnen herstellen, - het stuk is nooit opgevoerd. Het zou überhaupt tot 1973 duren voor er met The family van Lodewijk de Boer weer Nederlands werk op de Deense planken verscheen.

Blijkt hier een duidelijk negatieve invloed van de aard van de vertalingen van bellettristisch werk, over die der vertalingen van ontspanningslectuur en van de receptie daarvan kan ik bij gebrek aan kritieken en de meeste originelen zelf, niets met zekerheid zeggen. Veel gunstiger zal het waarschijnlijk niet geweest zijn, al kunnen tekst en publiek misschien iets meer verdragen in dit opzicht. Wat ten slotte de waardering van de kwaliteit Emma Krafts kinderboekenvertalingen betreft, die is hierboven al genoemd. 
Nederlandse literatuur in Deense ogen, 1900-1990

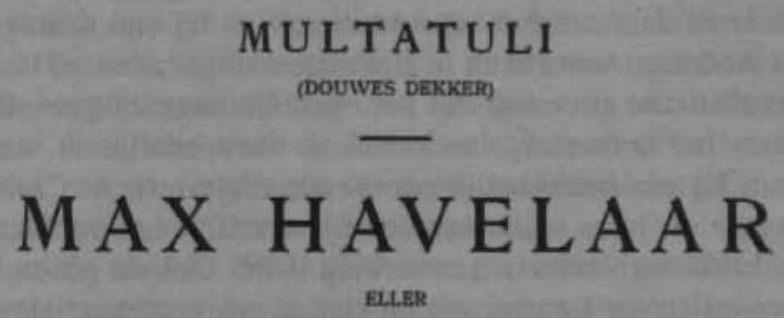

DET HOLLANDSKE HANDELSSELSKABS KAFFEAUKTIONER

OVERSAT FRA HOLLANDSK

Ap

CARL MICHELSEN

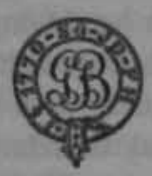

KøBENHAVN

GYLDENDALSKE BOGHANDELS FORLAG

7R. eAcoks nogThrexes?

1901

Afbeelding 19. De Max Havelaar-vertaling uit 1901. Pas in 1981 zou een tweede vertaling volgen. (Privé-collectie). 


\subsubsection{De kritiek}

Negatieve invloed op de beeldvorming is mogelijk mede uitgegaan van bovengenoemde recensies van Multatuli, maar zéker van het oordeel over Heijermans. En een positieve recensie van de vertaling van De kleine Johannes van de hand van de beroemde literatuurcriticus Georg Brandes in Politiken heeft voor zover na te gaan weinig invloed gehad: anders dan in Zweden werd ze niet opgevolgd door andere Van Eeden-vertalingen. Het gaat hier om een geautoriseerde vertaling, die het origineel getrouw navolgt, en qua stijl en inhoud hier en daar aansluit bij Andersen ${ }^{289}$ Is bij zijn weinige Deense lezers de vergelijking met Andersen soms extra in zijn nadeel uitgevallen, of heeft de discongruentie met de neo-realistische stroming van het ogenblik negatief gewerkt?

Bij Vosmaer is het ontbreken van kritieken vermoedelijk te verklaren doordat de vertaling uitkwam bij een betrekkelijk onbekende uitgeverij, A. Christiansen; bij Streuvels door de uitgave als losse editie van een tijdschrift, - een publikatievorm die zelden voor bespreking in de dagbladen in aanmerking komt. Ook de gebundelde feuilletons en overige ontspanningslectuur kwamen uit bij kleine, meest provinciale uitgeverijen. Vooral in het geval van bellettrie echter, staat 'geen kritiek' gelijk met negatief effect: door het wegvallen van de kleine maar desondanks voomaamste kans om een groter publiek te wijzen op het bestaan van een Nederlandse kwaliteitsproduktie blijft het negatieve of in het beste geval blanco verwachtingspatroon ongewijzigd.

Niels Kristensen, de drijvende kracht achter Vor Ungdom en de meest invloedrijke criticus binnen school- en bibliotheekwezen ${ }^{290}$ was steeds positief over de Nederlandse jeugdboeken. Top Naeffs Schoolidyllen, schrijft hij, "mangler den Bredde og smaalige Udpenslen som Bøger for Piger ellers saa ofte har, og [...] fremtræder i klart og godt Sprog" ["mist de breedvoerigheid en het kleingeestige uitsmeren van details, die men anders zo vaak in meisjesboeken vindt, en wordt gekenmerkt door een heldere en zuivere taal"]. Nynke van Hichtum wordt geprezen om haar helderheid, en Marie van Zeggelens boeken komen volgens hem bij uitstek in aanmerking voor schoolbibliotheken. ${ }^{291}$ Voor het effect van deze kritieken zie men par. 4.2.1.

\subsection{Periode 1930-1960}

\subsubsection{Kwaliteitskenmerken in relatie tot de literaire smaak}

Op het eerste gezicht is het nogal merkwaardig dat deze periode als geheel een vrijwel continu 'succes' voor de vertalingen oplevert (zie tabel A). In bellettristisch opzicht vormen de drie decennia, waar de Tweede Wereldoorlog middenin valt, immers noch in Nederland, noch in Denemarken een eenheid, terwijl ook de respectieve literaire stromingen in beide landen soms nogal uiteenlopen. Vergelijk bijvoorbeeld de jaren dertig: in Denemarken nadruk op het drama en de geëngageerde zogenaamde 'collectieve romans", waarin niet een individu maar een groep de hoofdrol speelde, en in Nederland op de lyriek en op sterk uiteenlopende vormen van meer rond individuen geconcentreerde romans. 
Nadere bestudering van de lijst vertalingen toont dan ook aan dat de eenheid elders gezocht moet worden. Literaire auteurs die zich tot op heden in Nederland hebben gehandhaafd, zoals Elsschot, Gijsen, Vestdijk en Walschap, hadden destijds in Denemarken geen succes en verdwenen er na één vertaling van het toneel. Daarentegen hadden auteurs die naar tegenwoordige opvatting de toets der literaire kritiek nauwelijks kunnen doorstaan, veel succes: Ina Boudier-Bakker, A. den Doolaard, A.M. de Jong, Herman de Man, Carel \& Margo Scharten-Antink.

De letterkundig gezien marginale positie van deze laatsten bemoeilijkt het trekken van een scherpe grens tussen hen en de topsellers van de periode, Willy Corsari en Jo van Ammers- Küller. Literaire en 'triviale' kenmerken in het werk van deze twee schrijfsters onderscheiden zich hooguit gradueel van Ina Boudier cum suis. Annie Romein-Verschoor heeft in haar dissertatie over de 'successchrijfsters', wier werk het wezenlijk bestanddeel uitmaakt van de vertalingen uit deze periode, al in 1935 gewezen op het typisch patroonbevestigende karakter van hun romans.

In tegenstelling tot de periode $1900-1930$ is er geen sterk verschil in 'circuit' tussen bellettrie en ontspanningslectuur: beide verschijnen bij gerenommeerde uitgeverijen (zie 4.3.5.) en beide worden vrij frequent besproken (zie 4.3.7.). Deze combinatie van a) een sterk gestegen aantal uitgaven, b) publiek succes, c) een breed overlappingsgebied literatuur - lectuur, en d) een consistenter besprekingspolitiek, zorgt dat er voor het eerst zowel bij critici als bij een gespreid publiek een beeld van 'Nederlandse literatuur' ontstaat. Naar hieronder zal blijken, speelt de eigenlijke bellettrie in deze beeldvorming geen enkele rol; ontspanningsromans en marginale literatuur zijn volledig bepalend voor het verwachtingspatroon, dat bij een literair geïnteresseerd publiek sterk negatief gekleurd is.

Deze opmerkingen kunnen worden geëxtrapoleerd naar de situatie in Noorwegen en Zweden. Dezelfde auteurs die in Denemarken succes hadden, vonden ook in groten getale hun weg naar het Noorse en Zweedse publiek, waarbij Denemarken meestal als bruggehoofd fungeerde..$^{292}$ In 1939 schreef Menno ter Braak een artikel over de Nederlandse literatuur in het Zweedse tijdschrift Bonniers litterära Magasin, waarin hij scherpe kritiek leverde op het eenzijdige beeld dat de Scandinavische lezers van de Nederlandse letteren kregen als gevolg van het overwicht van de goedkope ontspanningslectuur en het ontbreken van veel belangrijke namen. Hetzelfde geldt voor Noorwegen, waar de Noorse neerlandicus Kåre Langvik-Johannessen tot in de jaren zestig bij "serieuze lezers en kritici" een negatieve indruk van de Nederlandse literatuur signaleerde als gevolg van de overvloed aan 'succesromans' uit deze periode. ${ }^{293}$

Zomin als de schone letteren heeft jeugdliteratuur invloed op de beeldvorming. Het isolement ten opzichte van de volwassenenliteratuur handhaaft zich, zij het dat in enkele boeken voor oudere meisjes, onder andere van de hand van ... Jo van Ammers en Willy Corsari, duidelijk wordt voorbereid op de damesroman. Het relatieve aandeel in het totaal aan vertalingen loopt sterk terug. Ook de kwaliteit is minder, en pas in de tweede helft van de jaren vijftig is een stijging merkbaar, onder meer doordat dan vertaalster Clara Hammerich enigszins de rol van Emma Kraft ovemeemt met vertalingen van onder andere An Rutgers van der Loeff en Annie M.G. Schmidt. 


\subsubsection{Documentatie}

Na Ipsens bijdrage van $1901 \mathrm{kwam}$ er decennia lang geen nieuwe secundaire literatuur over de Nederlandse letteren los. De oppervlakkige overzichtjes in diverse handboeken over wereldliteratuur zijn duidelijk uit de tweede hand. De germanist Louis Hammerich startte weliswaar in 1926 het onderwijs Nederlands aan de Kopenhaagse universiteit, maar de hieruit voortvloeiende publikaties bewogen zich op taalkundig gebied. De enige uitzondering was een studie uit 1941 van Hammerichs leerling Tue Gad, over het kind in de Nederlands literatuur tussen 1860 en 1940. Denkbare invloed hiervan op het vertaalwerk van Hammerichs vrouw Clara is echter uitgebleven: de door Gad behandelde werken zijn nadien niet vertaald, ofwel zij waren dat in een enkel geval (Anne de Vries' Bartje) tevoren al. De uitgave was ook te beperkt om in bredere kring de aandacht te trekken.

Dat was iets meer het geval met de uitvoerige descriptieve studie Holland-Danmark (1945), waarin betrekkingen op allerlei terreinen tussen beide landen aan de orde komen. Bibliothecaris Helge Kjærgaard geeft hierin een 65 bladzijden lang overzicht van de wederzijdse literaire relaties. Documentatie over de Nederlandse literatuur als zodanig is daarmee echter nauwelijks gegeven, omdat het beschreven corpus vertalingen nu juist zo volstrekt niet-representatief is. En terwijl Kjærgaard met betrekking tot oudere literatuur wèl wijst op die eenzijdigheid - wel contemporaine vertalingen van Cats, niet van Hooft of Vondel -, noemt hij geen namen van gemiste modernere auteurs. Zijn kennis van de originele nieuwere literatuur lijkt nogal beperkt. Zo omschrijft hij de Multatulivertaling als "voortreffelijk" en rekent hij de Franstalige Charles de Coster tot de Nederlandse auteurs, - mogelijk in navolging van Dansk Bogfortegnelse. Van de sinds 1927 vertaalde auteurs geeft hij enkel de namen, zonder verder onderscheid: Elsschot naast De Hartog naast Martin. Een kans om bij voorbaat in Nederland geïnteresseerden te informeren en om uitgevers te stimuleren tot het uitbrengen van geavanceerde auteurs is hiermee gemist. Het is niet zozeer de gegeven informatie in dit standaardwerk als wel het gebrek aan aanvullende gegevens dat negatief werkt. De enige 'documentatie' hiemaast bestaat uit de vertalingen zelf: gebrek aan vertalingen van werkelijk eigentijdse literatuur maakt het bijvoorbeeld voor de critici bijna onmogelijk, een uitgave in Europees perspectief te platsen íde zeer schaarse pogingen vallen hovendien nogal bizar en willekeurig uit: Scharten-Antink vergeleken met Dickens en Bang. Antoon Coolen met J.P. Jacobsen. Pierre Dubois met Lagerkvist, Vestdijk met Hesse, Gijsen met Blixen). Zegge en schrijve éénmaal blijkt een eriticus buiten de vertalingen om op de hoogte van Nederlandse literatoren, namelijk G. Roger-Henrichsen, die het ontbreken van Van Oudshoorn en Van Schendel nadrukkelijk betreurt. ${ }^{294}$

Illustratief voor het totale gebrek aan kennis zijn ook fouten van uitgevers met betrekking tot de meest simpele gegevens. Zo presenteent uitgeverij Jespersen \& Pio het echtpaar Carel \& Margo Scharten-Antink in de reclame als én persoon, die wordt omschreven als "de grootste thans levende Nederlandse auteur". En Gyldendal noemt Marnix Gijsen op de omslag van Joachim van Babylon een beroemd Nederlands hoogleraar en politicus [sic!]. 


\subsection{3 / 4.3.4 Particulier initiatief; cultuur- en vertaalpolitiek}

Ook in deze periode behoeft de gerichte overheidspolitiek geen aparte behandeling: die bestaat namelijk niet. Van particulier initiatief is echter des te meer sprake. Na Emma Krafts overlijden in 1925 verschijnt er twee jaar lang geen enkele vertaling, maar in 1927 vangt dan de hier behandelde periode eigenlijk al aan, doordat dan de eerste vertaling - Scharten-Antink - uitkomt van een duo dat er in totaal 12 zal produceren: Ingeborg Tvede en Anne Valeton Kjeldgaard. De jaren 1928 en 1929 brengen het eerste vertaalwerk (A.M. de Jong, Jo van Ammers) van Clara Hammerich, die bij haar overlijden in 197281 vertalingen uit het Nederlands op haar naam zal hebben staan.

Alledrie de vertaalsters waren al eerder actief voor de Nederlandse cultuur geweest: Ingeborg Tvede als co-auteur van het eerste leerboek Nederlands voor Denen (zie 4.2.3), Anne Valeton als ziel van de Dansk-hollandske Forening. ${ }^{295}$ Clara Hammerich was de echtgenote van Louis Hammerich, al genoemd als instigator van het universitaire onderwijs Nederlands in Denemarken, en auteur van de eerste Nederlandse grammatica (1931). Beide duo's vonden hun eerste uitgever in Halfdan Jespersen, die gehuwd was met een Nederlandse; uitgever Hasselbach, bij wie onder andere Jo van Ammers-Küller uitkwam, behoorde tot de persoonlijke vriendenkring van de Hammerichs. ${ }^{296}$ De combinatie van wederzijdse persoonlijke initiatieven, het gelijktijdig optreden van drie bekwame vertalers plus de commerciële speurzin van de beide uitgevers zorgt voor een stroomversnelling en 'ontdekking' door collega-uitgevers, waardoor ook andere actieve vertaalsters emplooi vinden: Bodil Anker Larsen met in totaal 40, Hedda Syberg Løvland met 33 vertalingen. Het duo Tvede \& Valeton bracht onder andere Willy Corsari en Herman de Man onder Deense ogen. Het is echter vooral Clara Hammerich geweest die zich bijzonder heeft ingespannen voor uitgave van bepaalde auteurs. Soms betrof dat persoonlijke vrienden als Kitty de Josselin de Jong en Anne de Vries, soms ook literatoren als Couperus en Gezelle. De laatste twee interesseerden echter geen uitgever, terwijl twee reeds in opdracht vervaardigde vertalingen van Gilliams en Teirlinck tenslotte alsnog niet werden uitgegeven. In het geval van Elsschot en Walschap had Clara Hammerich meer succes, terwijl haar literaire bloemlezingen uit de jaren zestig eveneens te danken zijn aan haar grote inzet. ${ }^{297}$

Het is daarom extra jammer dat deze belangrijkste en invloedrijkste vertaalster, medeoprichtster en bestuurder van de Deense vertalersbond, voorzitster van PEN-Denemarken, lid van de Maatschappij der Nederlandse Letterkunde sinds 1933, vertaalster van meer dan 300 boeken (Fallada, Zweig, Hoel, Priestley en vele andere), zoveel opdrachten heeft aanvaard tot het vertalen van literair weinig of niets betekenende familie- en streekromans, zoals de 14 boeken van Jo van Ammers-Küller, de 8 van Ina Boudier-Bakker, werk van Cor Bruijn, Mien Labberton, Marie Schmitz en vele vergelijkbare anderen. "Der hersker i dette Land en grundfestet Overtro med Hensyn til Aandslivet i Holland. Den gaar ud paa, at hollandsk Litteratur bestaar af store, tykke og ligegyldige Romaner. Det er ikke mindst Clara Hammerichs Skyld. Den moderlige og muntre Professorinde har udruget i Pundevis af den Slags Romaner." ["Er heerst in dit land een diepgeworteld bijgeloof met betrekking tot het geestesleven in Nederland. Dat bijgeloof houdt in dat de Nederlandse literatuur bestaat uit grote, dikke en onbeduidende romans. Dat is niet het 
minst de schuld van Clara Hammerich. De moederlijke en montere professorsvrouw heeft kilo's van dat soort romans titgebroed"], aldus een recensent in Nationaltidende. ${ }^{298}$ Naar aanleiding van Clara's uitspraak "gid dog så meget muligt af al verdens fremmede herlighed må komme ind til vort lille læseglade land!" ["moge toch zo veel mogelijk van al 's werelds vieemde heerlijkheid tot ons kleine leesgrage landje komen!"] schrijft de Deense germanist en vertaalwetenschapper Leif Albertsen in zijn boek Littercer Oversat. telse: "skal vi virkelig ønske os så meget som muligt af verdens fremmede herlighed, når glansen går tilsvarende af den?" ["Moeten we ons werkelijk zoveel mogelijk van 's werelds vreemde heerlijkheid wensen, als de glans er navenant van afgaat?"] ${ }^{299}$ Haar positieve invloed op het doen uitkomen van Nederlands literair werk is op deze wijze immers helaas meer dan negatief gecompenseerd door een averechts effect op de beeldvorming. Veel tweederangsschrijvers zijn verschenen in het kielzog van háár topsellers: nu kregen Manja Beukman, Anna van Gogh-Kaulbach, Am. van Hoogstraten-Schoch, Nina de Kempenaer, H. van Nijnatten-Doffegnies, Anke Servaes en anderen elders een kans.

\subsubsection{Uitgeversheleid}

Veel markanter, maar ook veel directer negatief dan in de jaren 1900-1930 is de rol van de uitgevers. Als Scharten-Antink en Jo van Ammers eenmaal blijken aan te slaan bij het publiek, werpen Jespersen en Hasselbalch zich met hun concurrenten op deze en verwante successchrijvers. Zo weet Gyldendal al meteen de rechten voor de volgende SchartenAntinks te veroveren.

Hoezeer commerciële overwegingen hierbij overheersen, blijkt wel uit het feit dat sommige uitgeverijen uitsluitend met 'succesauteurs' komen: Schønberg met Corsari en Martin, Grafisk Forlag eveneens met Corsari plus De Hartog, Roothaert en anderen. Anderen komen wel met financieel minder aantrekkelijke uitgaven, maar die verdrinken dan in een zee van goedkope ontspanningsromans, die dergelijke uitgaven ruim dekken. Zelfs een uitgever als Gyldendal, die een naam heeft op te houden op literair gebied, beweegt zich in zijn 'Nederlandse' produktie aan de onderkant van de bellettrie: MadeIon Lulofs, Herman de Man, Marianne Philips tegenover één Gijsen en één Presser. Het in 4.3.1 gesignaleerde brede overlappingsgebied literatuur - lectuur blijkt uit het feit, dat beide verschijnen bij gerenommeerde uitgeverijen: Jan de Hartog èn Marnix Gijsen bij Gyldendal, Jo van Ammers èn Simon Vestdijk bij Hasselbalch, Piet Bakker èn Pierre Dubois bij Jespersen \& Pio. Ook in de concrete presentatie vervagen kwaliteitsverschillen: Jespersen brengt Scharten-Antink uit in een serie "hoofdwerken uit de moderne wereldliteratuur', naast onder andere Rilke, - een overwaardering die zelfs vanuit historisch relativisme niet te verdedigen is.

Bovengenoemde uitgeverijen zijn te zamen verantwoordelijk voor bijna tweederde van de uitgaven in deze periode. De 'kleintjes' op Nederlands terrein richten zich echter al evenzeer op commercieel aantrekkelijke auteurs, - vaak degenen die al eerder succes boekten bij een van de groten: Skandinavisk Bogforlag (Bakker), Uhlman (Lulofs), Korch (Corsari) enzovoort. Uitzonderingen als Hoffenberg (Clare Lennart) en A.O.F.'s 
Bogkreds (Walschap) brengen niet meer dan dat ene Nederlandse werk, waardoor hun invloed op de beeldvorming irrelevant is. Juist de losse uitgaven van de kleine en nietgespecialiseerde uitgeverijen blijken meestal onbesproken te blijven in de pers (zie 4.3.7). Een consistent literair fonds, waarin bij eenzelfde uitgever enkele oeuvres in plaats van losse uitgaven op de markt verschijnen, ontbreekt.

Daar het verwachtingspatroon nu eenmaal bepaald wordt door de gemiddelde produktie van een uitgever, hebben bepaalde meer literaire vertalingen een extra handicap als ze bij een 'verkeerde' uitgever terechtkomen. Zo verschijnt A.H. Nijhoffs Twee meisjes en $i k$ temidden van allerlei Martins en Corsari's bij Schønberg in een uiterst zoetelijke omslag. Branner geeft naast Anna van Gogh-Kaulbach en Nina de Kempenaer, ook Theun de Vries uit: De vrijheid gaat in 't rood gekleed wordt als Frankrigs sorte søn gepresenteerd met een schreeuwerige voorplaat. "Bogen er langt bedre end omslaget varsler" ["het boek is veel beter dan het omslag doet vermoeden"], schrijft de bibliotheekrecensent in Bogens Verden. ${ }^{300}$

Omgekeerd haakt de literaire geïnteresseerde op den duur af: het door een groot aanbod van vrijwel identieke romans geschapen verwachtingspatroon zorgt voor een in literair opzicht negatief beeld. De tientallen Corsari's, Boudiers en Van Ammersen plus de weinig complexe structuur van wat gemiddeld aan bellettrie wordt vertaald (Antoon Coolen, Johan Fabricius, Herman de Man, Felix Timmernans en anderen) overheersen totaal. Weliswaar leeft bij de critici het besef dat er een betere produktie in Nederland moet bestaan (vgl. 4.3.7), maar die krijgen ze nu eenmaal niet onder ogen. De weinige fijn-literaire vertalingen verschijnen dermate incidenteel, dat de indruk niet essentieel wordt gewijzigd. Nog aan het eind van de hier behandelde periode schrijft de bekende Deense criticus Bent Mohn naar aanleiding van Vestdijk dat van de Nederlandse literatuur in Denemarken alleen Willy Corsari cum suis bekend zijn ... ${ }^{301}$

\subsubsection{Aard van de vertaling}

De competentie van de vertaler is gemiddeld aanzienlijk gestegen ten opzichte van de voorafgaande periode. Aanwezigheid van een markt voor Nederlands werk is mede gevolg èn oorzaak van de inspanning van de in 4.3.2 genoemde vertaalsters. Daarnaast ligt de kracht van de enkele vertalingen van Deense auteurs als Ingeborg Buhl en Kai Flor vooral in de 'hertaling' in de eigen taal. De vertalers-in-het-groot binden zich voornamelijk aan ontspanningsromans, al hebben allen ook literaire vertalingen gemaakt: de anderen richten zich meer uitsluitend op bellettrie: Peter Hellum (Timmermans). M. van Rheden (Gijsen), Soffy Topsoe (Lulofs), Else Tryde (Johan Brouwer).

Bij het naslaan van recensies op vertaalkritiek blijkt de vertaling meestal niet eens aangeroerd te worden. Daar de critici geen Nederlands kennen en dientengevolge origineel en vertaling niet kunnen vergelijken, kan men dit gebrek nog betrekkelijk positief uitleggen: 'je merkt de vertaling niet' is een impliciete waardering, die overigens eens letterlijk gemaakt wordt over een vertaling van Clara Hammerich. ${ }^{302}$ Voor zover kritiek geleverd wordt, kan deze dus uitsluitend betrekking hebben op de 'leesbaarheid' van de Deense tekst en niet op de onderliggende brontekst. Clara Hammerich, bekend van haar 
vertalingen uit het Engels en Duits, krijgt op deze wijze een unaniem positieve kritiek: voortreffelijk (naar aanleiding van Den Doolaard), het zeer natuurlijk Deens van de vertaling (Bakker), uitstekend (Huizinga), meesterlijk (Walschap), enzovoort. De overige beroepsvertalers worden zelden genoemd. Bodil Anker Larsen krijgt eenmaal lof (Jan Mens) en eenmaal kritiek (Van der Woude), terwijl de dames Tvede \& Valeton en Løvland het geheel zonder opmerkingen moeten doen. Van de 'kleintjes' wordt alleen M. van Rhedens 'knappe' vertaling van Marja Roc gewaardeerd, terwijl in de (positieve) recensies van Gijsens Joachim van Babylon in haar vertaling zelfs de Nederlandse herkomst niet wordt gememoreerd. 303

Een direct negatief effect van de vertaling zoals bij Heijermans en Multatuli blijft uit. Anderzijds is een positieve waardering van de vertaling een noodzakelijke maar geen voldoende voorwaarde voor een positief effect. Uiteindelijk wordt immers het gehalte van de romans van Jan Mens cum suis er niet door verhoogd.

\subsubsection{De kritiek}

Ten opzichte van de vorige periode is een zeer sterke stijging in aantal en frequentie van besprekingen zichtbaar. Deze algemene tendens heeft inzake de vertalingen uit het $\mathrm{Ne}$ derlands tot gevolg dat ruim zestig procent van alle uitgaven wordt besproken, meestal in meer dan één krant. Eenzelfde percentage kritieken ten bate van bibliotheekaanschaf is te vinden in het tijdschrift Bogens Verden, opgericht in 1918.

Hoe is de houding van de kritici tegenover het gesignaleerde eenzijdige aanbod? Op het eerste gezicht lijkt dit redelijk goed ontvangen te worden. In de oorlogsjaren bijvoorbeeld, wanneer de commerciële uitgeverspolitiek leidt tot een kwantitatief hoogtepunt, komen 62 vertalingen uit, waarvan er 44 worden besproken in 86 recensies, verdeeld over dagbladen van zeer verschillende signatuur, en over diverse lectoren van de bibliotheekcentrale. In al deze besprekingen worden slechts twee vertalingen alom gekraakt, namelijk A.M. de Jongs Evangelie van de haat - "et litterært misfoster" ["een literaire miskraam"] - en Johan van der Woudes Anatomie - "absolut ingen Berigelse af vor Oversættelseslitteratur" ["absoluut geen verrijking van onze vertaalde literatuur"]. Voor het overige houden lof en kritiek binnen recensies of tussen besprekingen van hetzelfde werk elkaar in evenwicht, dan wel valt het oordeel zonder meer positief uit. Dat laatste gebeurt niet alleen met bijvoorbeeld Tita's vlucht van Jonckheere en Een mens van goede wil van Walschap, maar ook met Ciske de Rat van Piet Bakker en Hollands Glorie van Jan de Hartog. De laatste twee worden bewierookt - "bare han havde været dansk" ["was hij maar een Deen"] schrijft Bogens Verden over De Hartog ${ }^{304}$ - en handhaven zich in de herdruk tot in de jaren zeventig, tonend hoe het oordeel van criticus en publiek in dit geval overeenstemmen. Canonisering van Piet Bakker blijkt uit opname van fragmenten in een schoolbloemlezing uit de werelditeratuur, Glimt af verdenslitteraturen, 1961. Ook de bekende successchrijfsters krijgen waardering voor hun "zeer onderhoudende" boeken.

Tegenover deze schijnbaar positieve indruk staat echter, dat als in diezelfde periode de totale Nederlandse produktie ter sprake komt, er in vrijwel alle bladen heel andere 
Nederlandse literatuur in Deense ogen, 1900-1990

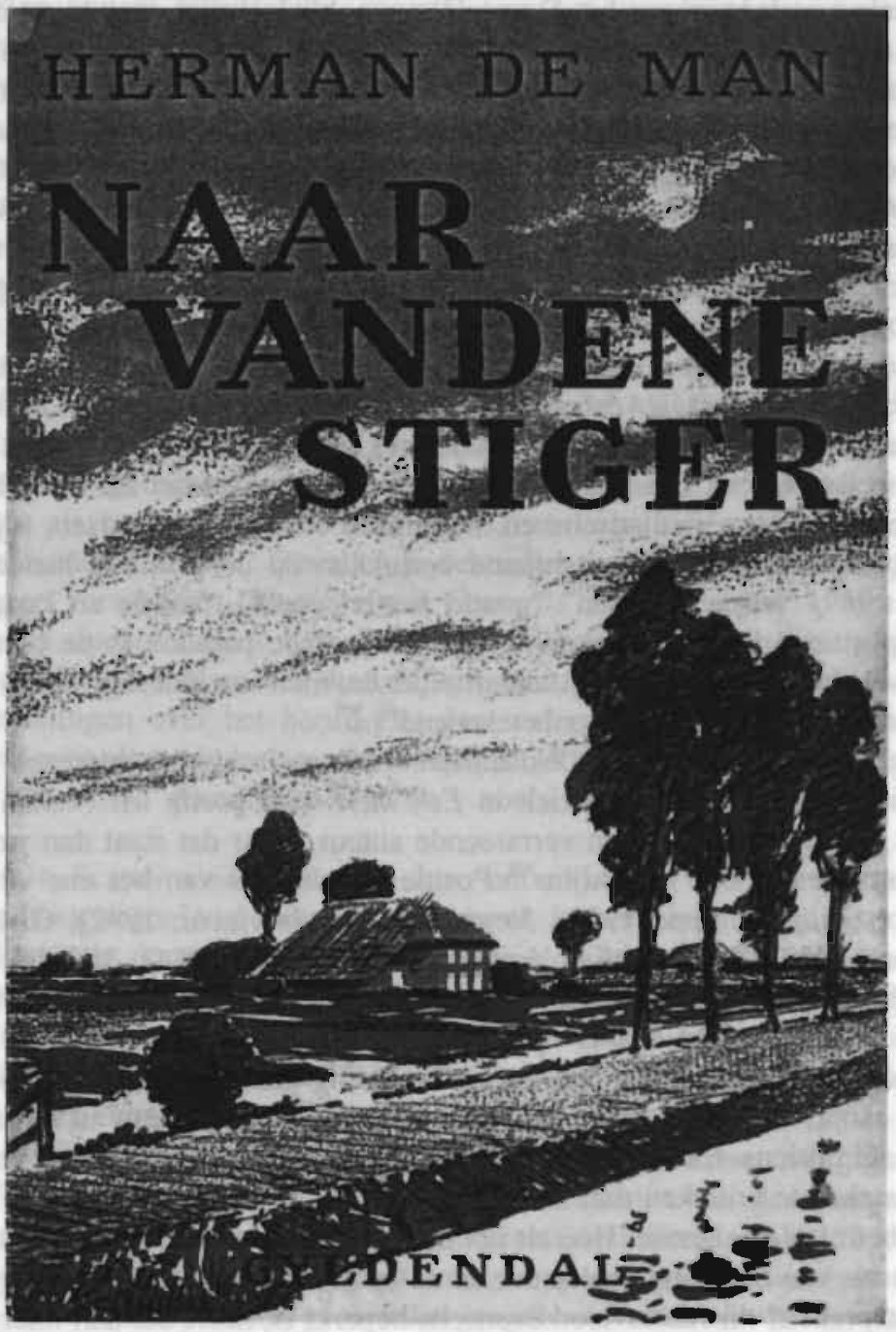

Afbeelding 20. Omslagillustratie van C. Hjuler voor de vertaling van 'Het wassende water' van Herman de Man (1933). (Privé-collectie). 
geluiden klinken. "Skal man dømme efter de hollandske Romaner, vore Forlæggere bringer til den danske Laseverdens Kendskab, faar man nærmest den Indtryk, at Hollands moderne Litteratur hovedsagelig bestaar af store træge Familieromaner og andre ureflekterende Underholdningsromaner" ["te oordelen naar de Nederlandse romans die onze uitgevers voorleggen aan het Deense lezerspubliek, krijgt men bijna de indruk dat de moderne Nederlandse literatuur hoofdzakelijk bestaat uit dikke trage familieromans en andere onnozele amusementslectuur"]; "det patenterede hollandske Slægtsromanmønster" ["het gepatenteerde Nederlandse familieromanpatroon"]; "har vi virkelig Papirmangel?" ["hebben we werkelijk papiergebrek?"]: "de komplet ligegyldige og nærmest overflodige hollandske Oversættelsesromaner" ["de volstrekt onbetekenende, zo niet overbodige uit het Nederlands vertaalde romans"]. ${ }^{305}$ In zijn kroniek over de Nederlandse romans op de Deense markt van 1944 schrijft G. Roger-Henrichsen dat hij alleen vanwege de papierrantsoenering de te bespreken romans niet uit het raam heeft gegooid. ${ }^{306}$

Het paradoxale verschil in toon met die van de meeste individuele recensies is mijns inziens te verklaren uit het in 4.3 .6 geschetste verwachtingspatroon. Een criticus die voor de twintigste maal een 'damesroman' ter bespreking krijgt van een der bekende schrijfsters, weet welke lezersrol van hem verwacht wordt. Hoewel net als in de besprekingen van bellettrievertalingen realistische en structurele criteria overheersen, zijn die in het geval van ontspanningslectuur uitsluitend betrokken op de primaire handeling. "Boeiend", "amusant", "fraaie schetsen" "goede zomerlectuur", "solide en knap" luiden de gemiddeld positieve karakteristieken. Typerend voor de paradox is de opmerking over een roman van Ina Boudier: "meget underholdende, men saa inderligt ligegyldigt" ["heel onderhoudend, maar zo volstrekt onbetekenend"]. ${ }^{307}$

Zeker, een literator als Gerard "Wolschap" wordt nadrukkelijk geprezen om de originaliteit, visionaire kracht en pathetiek in Een mens van goede wil (vertaald 1941), en gekenmerkt als een vruchtbare en verrassende auteur, maar dat staat dan wel te lezen in de éne kranterecensie die verschijnt. ${ }^{308}$ Positieve recensies van het ene vertaalde werk van Elsschot (Tsjip, vertaald 1937), Jonckheere (Tita's vlucht, 1942), Gijsen (Joachim van Babylon, 1952). Dubois (Een vinger op de lippen, 1954). Vestdijk (De bruine vriend. 1958) en Presser (De nacht der girondijnen, 1959) trekken al evenmin de aandacht, door hun gespreidheid over tijd en krant. In veel gevallen wordt nu juist van de bellettrie niet eens vermeld dat het om een vertaling gaat, laat staan vanuit welke taal. Stijging in aantal recensies hoeft dus nog niet te wijzen op een navenant gegroeide invloed van de criticus. Clara Hammerich geeft zelf ook voorbeelden van vertalingen die ondanks uitstekende kritieken niet aansloegen. ${ }^{309}$

Dat wat betreft de bellettrie. Hoe zit het met de negatieve invloed van het veel grotere aantal recensies van ontspanningslectuur en de op grond hiervan gedane negatief-generaliserende uitspraken? Als de invloed eveneens beperkt is, heeft dat dan inteme oorzaken. zoals opvallendheid en bereikbaarheid van de recensies, of meer inteme, met het oordeel zelf samenhangende oorzaken?

Om met de externe te beginnen: het merendeel van de recensies is kort, zo' $n 300$ woorden, meestal weggedrukt door omvangrijker besprekingen van niet-Nederlands werk. Slechts circa tien procent is opvallend groot, dat wil zeggen bevat meer dan zo'n duizend woorden, en het zijn meestal net deze artikelen die negatief van toon zijn, zoals de 
'kronieken' in Politiken. Ook foto's als aandachttrekker zijn uiterst schaars, meestal archieffoto's van veelgerecenseerde auteurs. Geen der kranten onderscheidt zich hierin positief van de andere.

Inventarisatie van besprekingen uit eenzelfde blad leert dat de diverse vertalingen voortdurend aan andere recensenten, meestal van het tweede plan, worden gegeven, onafhankelijk van het literaire of puur diverterende karakter van het werk. In Berlingske Tidende bijvoorbeeld gemiddeld 4 recensenten per 10 opeenvolgende kritieken, in Information 5, in Kristeligt Dagblad 7. Een uitzondering als de gezaghebbende auteur en criticus Jacob Paludan schreef een aantal positieve recensies van bellettrie, - echter niet voor zijn rubriek in Politiken, doch voor de regionale Aarhus Stiftstidende, met een veel kleiner literair geïnteresseerd publiek. Andere invloedrijke auteurs-recensenten als Tom Kristensen en Hans Kirk hebben elk zegge en schrijve één Nederlands werk besproken. Dit alles plus de onbekendheid met de Nederlandse taal en letteren bij de critici leidt tot een grote inconsistentie. Typerend hiervoor is de opmerking van een criticus die tevoren geen enkel Nederlands boek had gerecenseerd: "Igen en daarlig Hollæender" ["Alweer een slechte Nederlander"]. Hier zijn we aangeland bij de interne oorzaken: oordelen worden niet eens altijd gebaseerd op reële lezing van een groter aantal romans, maar op vage indrukken als besprekingen door collega's van voorgaande vertalingen, of lezing van een enkele andere roman. Opvallende bestseller-auteurs, van wie elk jaar cén of meer vertalingen verschijnen (maar liefst 4 Corsari's in het ene jaar 1938) worden op deze wijze huns ondanks maat van alle dingen, waardoor een literair geïnteresseerd publiek van critici en lezers op den duur bij voorbaat gedesinteresseerd raakt en belangwekkender vertalingen over het hoofd ziet dan wel verkeerd beoordeelt. De recensies zijn met andere woorden minder oorzaak dan uitdrukking van een al aanwezige, zichzelf versterkende indruk, - "grundfestet Overtro", zoals dat hierboven (4.3.4) al werd genoemd.

Ook elders in Scandinavië deed zich deze ontwikkeling voor. In zijn artikel 'Het Nederlands in Noorwegen' signaleert Kåre Langvik-Johannessen hoe in deze periode de Nederlandse literatuur door de vertalingen van "de Noordnederlandse sukses-schrijvers en niet het minst de suksesschrijfsters - [...] in een erg slechte reputatie is geraakt" bij de Noorse kritiek. Daartegenover stonden slechts weinige belletrie-vertalingen, "die iedere keer uitstekende recensies haalden, maar toch niet de nederlandse literatuur bij de recensenten konden rehabiliteren. ${ }^{310}$

De recensies van Nederlandse jeugdboeken ten slotte blijven even marginaal als in de jaren 1900-1930: afgezien van wat aankondigingen verschijnen er geen besprekingen in de Deense pers, en zelfs nauwelijks in de bibliotheektijdschriften: van de 22.2 jeugdboeken worden er maar 5 besproken. In combinatie met de spreiding in de tijd (van 1932-1944 en van 1952-1957 verschijnt zelfs geen enkel jeugdboek) maakt dit het onwaarschijnlijk dat zelfs bij pedagogen een beeld rond Nederlandse jeugdboeken is ontstaan. 


\subsection{Periode 1960-1980}

\subsubsection{Kwaliteitskenmerken in relatie tot literaire smaak}

Terwijl in de jaren vijftig een naar de vorm vrij traditionele Deense romankunst en avantgardistisch modernisme een groot respectievelijk klein publiek trekken, brengt het volgende decennium een brede variëteit aan experimenten met tot dan buitenliteraire vormen als protestsongs, beatpoëzie, reportageromans, maatschappijkritische detectives, feuilletonexperimenten en televisiedrama. Beeldbepalende auteurs als Anders Bodelsen, Christian Kampmann, Leif Panduro en Klaus Rifbjerg bereiken hiermee een veel breder publiek dan het strikt literaire, getuige oplagen van vele tienduizenden exemplaren. Panduro bleek in 1964 de meest gelezen schrijver na steadysellers als Morten Korch, Sven Hazel en J. Bech Nygaard ${ }^{311}$ en zijn dood in 1977 veroorzaakte een welhaast nationale rouw.

Dit is de achtergrond waartegen we de Nederlandse vertaalde romans en novellen van de jaren 1960-1980 moeten zien. Het naoorlogse deel van de periode 1930-1960 was in feite een nasleep van het vóór en in de oorlog opgebouwde succes van de ontspanningsromans: de jaren 1945-1960 kenmerken zich door herdrukken van Bakker en BoudierBakker plus nieuwe uitgaven van oude bekenden als Corsari, De Hartog, Lulofs en Roothaert.

Tegen 1960 wijzigt dit patroon zich snel. Het aantal jeugdboeken neemt toe: verschenen er in de twaalf jaar tussen 1945 en 19578 jeugdboeken, van 1957 tot 1961 zijn dat er 15. Daarentegen daalt het aandeel van de literatuur voor volwassenen krachtig: van gemiddeld 8 vertalingen per jaar in de jaren veertig, via 5 in de jaren vijttig, tot 3 in de jaren zestig en bijna 0 in de jaren zeventig. De bekende 'dames' ruimen het veld; slechts Willy Corsari weet zich nog tijdelijk te handhaven in goedkope pocketherdruk. En hoewel juist in de jaren zestig met de uitgave van bloemlezingen meer moeite dan ooit tevoren wordt gedaan voor de bellettrie, zakt ook het aandeel daarvan absoluut en relatief sterk.

Steeds meer wordt de literaire smaak bepaald door externe factoren, waarvan vooral de opkomst van de televisie en de rationalisering van het uitgeversbedrijf te noemen zijn. Wat de opkomst van de televisie betreft, deze heeft weliswaar niet de verwachte algemene daling in leesactiviteit gebracht, maar nu juist wel op het kerngebied van de Nederlandse export: "konkurrencen fra TV synes på længere sigt især at have ramt pressen og på bogmarkedet kun den brede underholdningsroman" ["de concurrentie van de televisie lijkt op langere termijn vooral de pers te hebben getroffen en op de boekenmarkt alleen de breedvoerige amusementsroman"]. ${ }^{3 ! 2}$ Televisieseries op basis van ontspanningsromans trekken een publiek dat voorheen die romans zelf las. Uitgeverijen leggen zich toe op verkorte 'TV-uitgaven' met foto's uit de serie, vaak gedistribueerd via boekenclubs.

Rationalisering en marketing worden steeds meer bepalend voor het al dan niet verschijnen van boeken. Opheffingen, fusies en specialisering bepalen de produktie. Uitgeverij Hasselbalch verdwijnt, Jespersen \& Pio specialiseert zich geheel in jeugdboeken (zie verder 4.4.5). Pocketboeken en andere goedkope uitgaven doen hun intrede. Hiervoor is een hoge omzet noodzakelijk, zodat wat bellettrie betreft op zeker wordt ge- 
speeld met hoogwaardige klassieken uit de Deense en de bekende buitenlandse literatuur, dat wil zeggen vooral de Engelse, Duitse en overige Scandinavische letteren, meest heruitgaven uit het eigen fonds. De goede kwaliteit en lage prijs van bijvoorbeeld Gyldendals pocketserie Tranebøger maakt ze tot een bijna onoverwinnelijke concurrent voor de dure vertalingen van klassieken uit een onbekende literatuur. Wat bovendien reëel aan nieuwere Nederlandse auteurs wordt vertaald, is qua vorm en soms ook inhoud gemiddeld duidelijk traditioneler dan de contemporaine produktie (zie 4.4.7).

Wat er nog aan ontspanningsromans uitkomt, verdwijnt geheel naar de gespecialiseerde kioskromanproduktie. Deze heeft in tegenstelling tot de ontspanningslectuur uit de vorige periode geen literaire pretenties, en richt zich ook op een ander publiek. Men treft deze uitgaven zelden in bibliotheken of in de dagbladkritiek; de verkoop verloopt geheel autonoom. Willy Corsari, voorheen tot het overlappingsgebied literatuur - lectuur behorend, komt zo in het 'triviale' circuit terecht, dat zich nadrukkelijk van het literaire onderscheidt, net als in de jaren 1900-1930. Ze wordt nu dan ook uitgebracht door Winther, Denemarkens grootste uitgever in het genre. De grote Nederlandse steadyseller is echter Hans Martin, die ondanks sterk negatieve kritiek van de bibliotheeklectoren (zie 4.4.7) nummer drie staat op de lijst van in Denemarken meest gelezen vertaalde auteurs, na Nevil Shute en John Steinbeck en vóór Margit Söderholm en A.J. Cronin. De totale verkoop van de 55 Deense drukken van zijn boeken ligt ver boven het miljoen, en van zijn meest succesvolle werk Vrijgevochten zijn in Denemarken 130.000 exemplaren verkocht, - resultaten die hij in Nederland zelf nooit heeft behaald. ${ }^{313}$

Het grote verschil met de scherpe scheiding bellettrie - triviaalliteratuur van een halve eeuw eerder is echter, dat beide auteurs tevoren twintig jaar lang in normale uitgaven alleen in de gewone boekwinkels lagen, waardoor ze nog lange tijd meebepalend blijven voor het beeld dat een meer literair geïnteresseerd publiek van de Nederlandse letteren heeft; een beeld dat nog versterkt wordt door herdrukken van Piet Bakker (Jespersen \& Pio) en Jan de Hartog. Het zijn precies deze vier namen die de wat oudere Denen van nu blijken te kennen als het om Nederlands werk gaat; ook uit de openbare bibliotheken zijn de 'dames' thans verdwenen, en slechts in de hoofdbibliotheken rest er wat de ouderen betreft nog wat werk van Coolen, Den Doolaard, Anne de Vries en Theun de Vries.

Ten slotte de jeugdliteratuur. Vanaf de tweede helft van de jaren zestig groeit de algemene aandacht hiervoor sterk. Onderzoeksprojecten worden opgezet, speciale tijdschriften rond jeugdboeken opgezet, in de pers wordt frequenter en serieuzer gerecenseerd. Esthetische en psychologische beoordelingscriteria krijgen de overhand, terwijl morele maatstaven op den duur een wending van bijna 180 graden maken. ${ }^{3 / 4}$

Enkele gespecialiseerde uitgevers brengen in korte tijd enige tientallen kwalitatief goede Nederlandse jeugdboeken uit (zie 4.4.5), zodat voor het eerst bij een grotere groep volwassenen beeldvorming rond 'Nederlandse jeugdliteratuur' optreedt. Over de gevolgen hiervan voor de totale beeldvorming zie paragraaf 4.4 .7 en de conclusies in paragraaf 5. 


\subsubsection{Documentatie}

Louis Hammerich is de auteur van twee inleidingen bij de door zijn vrouw verzorgde bloemlezingen van twintigste-eeuws Vlaams respectievelijk Noordnederlands proza (1966 en 1968), en als zodanig de eerste die Ipsens informatie van 1901 wezenlijk aanvult.

De waardering voor de beide bundels varieen - zie 4.4.7. - en dat geldt ook voor de inleidingen. Terwijl Politiken de inleiding voor de Vlaamse bundel prijst, noemt Information de introductie tot de Noordnederlandse anthologie onsamenhangend en causerend. ${ }^{315}$ Beide meningen worden niet verder toegelicht. Mijns inziens is geen der beide inleidingen erg gelukkig uitgevallen. Onderstaande inventarisatie is in geen Deense kritiek te vinden, maar geeft weer welk beeld een Deen die zich op deze inleidingen baseert, van de Nederlandse letterkunde krijgt.

Positief is Hammerichs poging, de Vlaamse letterkunde in een Europees kader te plaatsen, maar juist binnen dat kader is een scheiding Vlaams-Nederlands voor de jongste periode oneigenlijk, - zie hierover ook 4.4.3. Weliswaar noemt Hammerich in het Vlaamse deel Noordnederlandse namen (omgekeerd niet), maar deze zijn verre van representatief. Anne de Vries en Antoon Coolen worden genoemd, terwijl de samenwerking Noord-Zuid in Forum en de namen Ter Braak en Du Perron ontbreken. Van de dertien bladzijden wordt nog geen halve gewijd aan de naoorlogse Vlamingen: van Boon wordt slechts vermeld dat hij 'grotesk' is, van Claus dat hij het puberteitsprobleem behandelt. De namen Michiels en Geeraerts ontbreken, terwijl Het afscheid (1957), Het boek Alfa (1963) respectievelijk Ik ben maar een neger (1961) toch zeker tot Nyere Flamsk Prosa behoren. Mutatis mutandis geldt hetzelfde voor het Noordnederlandse deel, al zijn de individuele schrijvers hier wat uitgebreider behandeld. Vooral de informatie over vooroorlogse auteurs is echter duidelijk gebaseerd op Clara Hammerichs keuze in plaats van andersom. Zo wordt Ina Boudier vergeleken met Proust, terwijl een representatief auteur als Vestdijk wordt gekarakteriseerd als vitalist. Dankzij adviezen van mede-redactrice Geerte de Vries, de toenmalige lector Nederlands aan de universiteit van Kopenhagen, zijn nacorlogse schrijvers minder eenzijdig vertegenwoordigd in de bundel zelf, maar Hammerich verwijt de jongste generatie voomamelijk hun directe beschrijving van seksuele handelingen. De indeling van de gekozen verhalen en fragmenten naar thema wordt ook in de inleiding gevolgd, waardoor een ontwikkeling in de tijd vaak moeilijk valt te doorzien.

Bijdragen in het Nederland-nummer van het literaire tijdschrift Vindrosen (1961) van de hand van Adriaan van der Veen en Jan de Zanger behandelen respectievelijk de literaire 'scene' en de Nederlandse letterkundige tijdschriften, maar geven geen nieuwe informatie over stromingen of auteurs. De Zanger schreef tevens een voorwoord van vier bladzijden bij zijn bundel vertalingen van naoorlogse verhalen (1971), maar dit was evenals Geerte de Vries' op zichzelf overzichtelijke resumé van de literatuurgeschiedenis - samen met een aantal lemmata over de bekendste auteurs opgenomen in Gyldendals Litteraturleksikon (1974) - noodgedwongen te kort om meer dan enkele grote lijnen en een reeks namen te geven.

Genoemde manco's zijn binnen het geheel van factoren relatief onbelangrijk en dus niet direkt negatief, maar enig positief effect is evenmin merkbaar. Hoe weinig effectief 
de informatie überhaupt is, blijkt bijvoorbeeld uit het feit dat ondanks Hammerichs betrekkelijk lange uiteenzetting over de Frans-Belgische literatuur, waarin Charles de Coster als eerste wordt genoemd, twee recensenten hun bespreking beginnen met de opmerking dat Tijl Uilenspiegel toch de bekendste figuur uit de Vlaamse letterkunde is... ${ }^{316}$

Tegenover deze beperkte informatie aan het publiek staat echter een sterke uitbreiding van de voorlichting aan uitgevers. De jaarlijkse uitgeversbeurzen te Frankfurt en Bologna - de laatste voor jeugdboeken -, literaire agenten, uitgaven en bezoeken van de Stichting ter bevordering van de vertaling van Nederlands letterkundig werk (zie 4.4.3) geven uitgevers een veel bredere oriëntatiemogelijkheid dan in voorgaande periodes. Dat dit behalve voor jeugdliteratuur echter weinig effect sorteert, heeft oorzaken waarop hieronder zal worden ingegaan.

\subsection{3 / 4.4.4 Particulier initiatief; cultuur- en vertaalpolitiek}

In de loop van de jaren vijftig komt in België en Nederland voor het eerst iets van een internationaal cultuurbeleid van de grond, onder andere door het sluiten van culturele verdragen en overeenkomsten en door de oprichting van twee volledig gesubsidieerde instellingen voor vertaalpromotie: de Dienst ter verspreiding van Nederlandse literatuur in het buitenland te Brussel en de Stichting ter bevordering van de vertaling van Nederlands letterkundig werk te Amsterdam. De concrete financiële steun is echter bijzonder beperkt. Culturele instituten als British Council, Goethe-Institut of Alliance Française hebben geen Nederlandse pendant; de Stichting voor Vertalingen had in 1980 voor haar wereldomvattende activiteit na aftrek van personeels- en administratiekosten 250.000 gulden per jaar ter beschikking. Het voor de vertaalpolitiek zeer belangrijke tijdschrift Delta ('a review of arts, life and thought in the Netherlands') met zijn voortreffelijke vertalingen van Nederlandse verhalen en poëzie, werd in 1973 opgeheven. Desondanks bereikte resultaten zijn voornamelijk te danken aan zuiver persoonlijke inzet van ambassadepersoneel en van vertegenwoordigers van beide instellingen.

Nederland en Denemarken hebben geen cultureel verdrag, en de ambassade te Kopenhagen beschikte tot 1969 ook niet over een cultureel attaché. In dat jaar werd een 'cultureel adviseur' benoemd, van wie het werkterrein eerst in 1977 werd omschreven in een minder ver strekkende culturele samenwerkingsovereenkomst. Met betrekking tot vertalingen werd hierin opgenomen dat beide partijen geïnteresseerd zijn in de vertaling van elkanders literatuur en dat vertalingen van meer dan normaal belang voor het Deense publiek ook van Deense zijde gesubsidieerd kunnen worden. Een bestaand BelgischDeens cultureel verdrag wijdde geen nadere aandacht aan vertalingen; culturele zaken worden waargenomen door de eerste ambassade-secretaris.

Gezien deze geringe armslag bestond de concrete activiteit van de beide diensten en ambassades eigenlijk geheel uit het aansluiten bij particulier initiatief. De twee enige subsidies van respectievelijk Vlaamse en Nederlandse zijde, beide overigens de grootste tot dan toe verleende, gingen dan ook naar Clara Hammerichs bloemlezingen, waarvan de Noordnederlandse tevens van Deense zijde werd gesteund. Inzet van beide fronten 
kan op zichzelf niet genoeg gewaardeerd worden; zonder Clara Hammerich en de overheid zou het überhaupt niet gekomen zijn tot deze uitgave, waardoor voor het eerst de mogelijkheid tot een breder overzicht ontstond.

Hoe is deze mogelijkheid nu inhoudelijk door de overheid benut? De waardering daarvan is verschillend. Jan Deloof noemt in zijn artikel Wat is er mis met onze vertaalpolitiek? juist deze twee bundels als voorbeeld van een ongelukkige gescheiden presentatie van 'Vlaamse' en 'Nederlandse' literatuur, die volgens hem het negatief bepaalde provincialistische imago versterkt. Betere samenwerking tussen de beide subsidiërende instellingen had dit kunnen voorkomen. ${ }^{317}$ (Deloofs indruk wordt ten dele door de Deense pers bevestigd, zie 4.4.7). Van Vlaamse zijde heeft men zich bovendien nogal bemoeid met de op te nemen auteurs. ${ }^{318}$ De door Vlaanderen gewenste opname van zoveel mogelijk auteurs leidt tot fragmentatie, zoals van Elsschot, van wie Het dwaallicht compleet werd vertaald... op het laatste hoofdstuk na! Voor de Deense lezer zijn de ontbrekende zes bladzijden in deze bundel van driehonderd pagina's toch representatiever dan bijvoorbeeld een verhaal van L.B. Carlier. Clara Hammerich vermeldt in haar memoires dat ze uit reactie op deze Vlaamse bemoeienis erop gestaan heeft, in de Nederlandse pendant fragmenten uit zes eerder door haar vertaalde romans te mogen opnemen, van respectievelijk Ina Boudier, Antoon Coolen, Maria Dermout, A. den Doolaard, A.M. de Jong en Jacoba van Velde. Genoemde auteurs nemen samen een derde deel van de tekst in, en het kwartet Boudier-Coolen-Den Doolaard-De Jong bevestigt nog weer eens het in Denemarken gevestigde verwachtingspatroon. Een en ander ten koste van de betere keuze uit het werk van negentien overige auteurs, van wie korte romanfragmenten en soms ingekorte - verhalen zijn opgenomen.

Geen van beide bundels kwam in de gewone boekhandel, al waren ze eventueel te bestellen; ze waren primair bedoeld voor scholen, bibliotheken en andere instanties. Het toenmalige Belgische Ministerie van Nederlandse Cultuur kocht hiertoe een groot deel van de oplage van de Vlaamse bundel op, terwijl het Dansk-Hollandsk Selskab, dat de Nederlandse bundel mee-gesubsidieerd had en tegen gereduceerde prijs aan de eigen leden aangeboden, na enkele maanden de restoplage van de uitgever overnam en gratis verspreidde op scholen. Bedoeling van deze politiek was het bereiken van mensen op sleutelposities, in de hoop dat dat nieuwe vertalingen, voor een breder publiek, met zich mee zou brengen.

Dat laatste is helaas nauwelijks of niet gebeurd: de enige uitgave in deze zin is de bundel Hollandske noveller (1971), verzorgd door Jan de Zanger. Deze Nederlandse auteur, vertaler van Deense schrijvers als Bødker, Panduro en Rifbjerg, en winnaar van de Gyldendal Oversatterpris (de vertalersprijs van uitgeverij Gyldendal) voor het jaar 1970, had zich in de jaren zestig samen met de Deense schrijver Erik Stinus ingezet voor het vertalen en publiceren van Nederlandse verhalen en poëzie in de literaire tijdschriften Vindrosen en Hvedekorn. Het laatste tijdschrift bevatte poëzie van vooral de Vijftigers. van wie enkele via de Cobra-beweging een culturele geestverwantschap met Denemarken hadden. Plannen om bij uitgeverij Borgen een bundel modeme Vlaamse poëzie het licht te doen zien, verzorgd door Erik Stinus, Geerte de Vries en Jan de Zanger, strandde doordat Erik Stinus zich terugtrok. Hollandske noveller is door De Zanger zonder hulp van Stinus vertaald; uitgeverij Gyldendal zou voor correctie van De Zangers rompverta- 


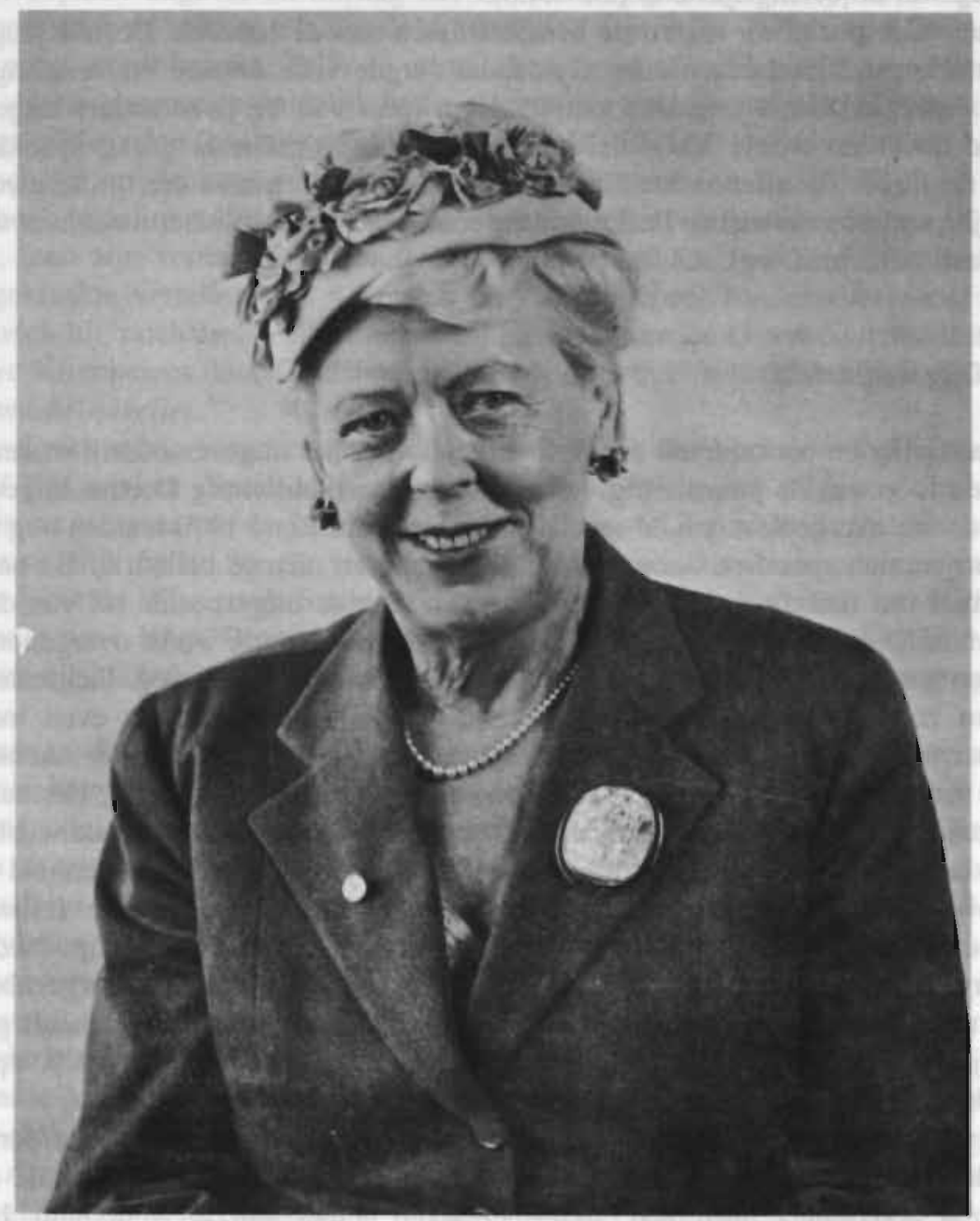

Afbeelding 21. Clara Hammerich (1894-1972) vertaalde tussen 1928 en 1971 eenentachtig werken uit het Nederlands in het Deens. (Uit: Taal en Tongval, jg. 1973). 
ling zorgdragen. De publieke reikwijdte van de bundel leek vrij groot: vrij evenwichtig van samenstelling, beperkte omvang, lage prijs dankzij uitgave als pocket in Gyldendals serie buitenlandse novellen. De desondanks unaniem negatieve kritieken en slechte verkoop hadden dan ook heel andere oorzaken, waarvan de bijzonder slecht uitgevallen vertaling wel de belangrijkste is (zie 4.4.6).

Aanzienlijk positiever waren de bemoeienissen van de bekende Deense jeugdboekenauteur Thøger Birkeland, die bij Gyldendal zorgde voor uitgave en vertaling via het Engels van een Dick Brunareeks van elf delen (plus vier bij twee andere uitgeverijen), gevolgd door een Annie M.G. Schmidtreeks. Naast Birkelands gezag speelde hierbij echter de direct opvallende kwaliteit van vooral de illustraties een grotere rol bij de eigenlijke verkoop, terwijl de beeldvorming rond de volwassenliteratuur er niet wezenlijk door werd beïnvloed (vgl. 4.4.7).

\subsubsection{Uitgeversheleid}

Rationalisering en concentratie zijn kenmerkend voor het uitgeversbedrijf in deze periode. In de loop van de jaren zestig verdwijnen circa vijfentwintig Deense uitgevers, terwijl onder de overgeblevenen de specialisatie toeneemt. Rond 1970 houden nog maar zes uitgeverijen zich specifiek bezig met het uitgeven van nieuwe bellettrie. De neiging tot het nemen van risico's wordt steeds minder, en daar de uitgespeelde rol van de Nederlandse familie- en streekromans niet door een andere categorie wordt overgenomen, valt een regelmatige Nederlandse produktie voor volwassenen geheel weg. Incidentele uitgaven van zowel ontspanningslectuur als bellettrie zijn gebaseerd op even incidentele (kas)successen in Nederland: Aalberses Boh \& Daphne-romans, Piet van Akens destijds actuele Kongoroman De Nikkers, Jan Cremers bestseller Ik Jan Cremer, Hermans' Donkere kamer van Damokles. Uitzonderingen op deze regel hebben een aanwijsbare oorzaak, zoals Clara Hammerichs veertigjarig vertalersjubileum, ter gelegenheid waarvan een novelle van De Pillecijn werd uitgegeven, en het feit dat uitgever Jespersen "på grund af sin hollandske mor ikke kunne gå ram forbi" ["vanwege zijn Nederlandse moeder niet buiten schot kon blijven"] en derhalve de overigens zwaargesubsidieerde Noordnederlandse anthologie uitbracht. De enige uitgever die een risico heeft genomen, namelijk met een keuze uit Multatuli's brieven, is nu juist de inmiddels opgeheven Hasselbalch. ${ }^{319}$

De vertalingen van Aalberses drie boeken bleken bestsellers en beleefden diverse herdrukken, maar voomamelijk op buitenliteraire gronden. Nadat de seksuele discussie over haar hoogtepunt heen was, in Denemarken eerder dan in Nederland, bleek het succes niet blijvend. Uitgeverij Vendelkær kwam acht jaar na de Bob \& Daphne-golf met een sterk ingekone versie van Jan Cremer, die echter geen enkel schokeffekt meer teweegbracht. Het werd in slechts éen krant, Jyllandsposten, besproken. Potentiële 'literaire' lezers merkten het hierdoor niet eens op, ook al niet door het verwachtingspatroon tegenover de 'goedkope' pocketuitgave van een kleine uitgeverij.

Een vergelijkbaar geval, maar qua negatief effect veel sterker, is de uitgave van Hermans' Donkere kamer van Damokles. Uit wanbegrip voor de inhoud bracht Gylden- 
dal deze onder bij een dochterondememing. Spektrum, gespecialiseerd in spionage-, oorlogs- en misdaadromans. Hermans werk wordt in de flaptekst dan ook als een keiharde verzetsroman gepresenteerd, terwijl de slecht getekende voorplaat Osewoudt en Marianne in een bedscène toont, - door het venster zien ve jachtvliegtuigen langsscheren. Ook hier hepalen uitgever en omslag het verwachtingspatroon: de typische Spektrumlezer wordt door de inhoud teleurgesteld, terwijl de eigenlijke doelgroep door deze presentatie nooit wordt bereikt. Zelfs de critici, die eventueel hadden kunnen wijzen op de literaire waarde, laten zich duidelijk leiden door oppervlakkige indrukken: "hårdkogthed. skørtejagt, gåder uden løsning og en krast skurrende slutning" ["een hardboiled boek vol rokkenjacht en onopgeloste raadsels, met een pijnlijk knarsend einde"]. ${ }^{320}$ Geen wonder dat het boek totaal niet verkocht. Deze behandeling van Hermans kreeg nog een staartje in 1971, toen zijn verhaal Een wonderkind of een total loss uitkwam in een door de kritiek gekraakte vertaling (zie 4.4.6.) en bovendien geheel zonder voorkennis van de auteur: noch hij, noch Jan Wolkers bleek bij navraag door de Deens-Nederlandse recensent Tove Kirchheiner door Gyldendal benaderd, laat staan betaald te zijn voor opname in Hollandske noveller. ${ }^{321}$

De gesignaleerde wansuccessen, waarvan de oorzaak dus voor een deel bij de uitgevers zelf ligt, maken diezelfde uitgevers huiverig voor nieuwe uitgaven, zeker in de economische recessie van de jaren zeventig. Via de in 4.4 .2 genoemde instanties zijn de uitgevers redelijk op de hoogte van de Nederlandse produktie, maar een rondgang van directeur Joost de Wit van de Stichting ter bevordering van de vertaling van Nederlands letterkundig werk langs Deense uitgeverijen haalde niets uit. De verklaring hiervan ligt echter niet uitsluitend op het economisch vlak, zoals in het onderstaande nog nader zal blijken.

Tegenover de onsamenhangende en onachtzame politiek van hierboven staat het beleid met betrekking tot jeugdboeken uit deze periode. De Deense uitgevers volgen aandachtig wie de jaarlijkse jeugdboekenprijzen in Nederland wint, zoals blijkt uit de door hen uitgebrachte vertalingen van C.E. Pothast-Gimberg, W.F.H. Visser, Paul Biegel, Mies Bouhuys. Siny van Iterson, Henk Barnard, Jaap ter Haar, Annie M.G. Schmidt. Karel Eykman en Guus Kuijer. Daarbij spelen natuurlijk ook commerciële motieven mee, maar hierdoor is in ieder geval sprake van consistentic. Voor de meeste van deze auteurs wordt de uitgave door een tweede of derde gevolgd, voor Jaap ter Haar en Annie M.G. Schmidt zelfs door vele, wat mee aanleiding is tot het uitbrengen van andere Nederlandse jeugdboekenauteurs. Met name een gespecialiseerde uitgeverij als Artakon maakt zich hiervoor opvallend sterk. De kritiek prijst de "hollandske bomebøger som forlaget Artakon har specialiseret sig i" ["Nederlandse kinderboeken, waarin uitgeverij Artakon zich heeft gespecialiseerd"]. ${ }^{22}$ Naast Artakons 20 uitgaven staat eenzelfde aantal van Jespersen \& Pio, die in deze periode naast de Noordnederlandse anthologie aan nieuwe uitgaven alleen nog met jeugdliteratuur kwam. Ten slotte is er een aantal kleine. in prentenboeken gespecialiseerde uitgeverijen. Over effecten van dit alles op de beeldvorming zie 4.4.7. 


\subsubsection{Aard van de vertaling}

In meer dan één opzicht lijkt deze periode op die van 1900-1930: een gering en inconsistent aanbod op de volwassenenmarkt, gecombineerd met gebrek aan goede vertalers. Hoezeer deze twee omstandigheden samenhangen, blijkt wel uit het feit dat na de dood van Clara Hammerich in 1972 geen enkele van de tien door haar van vertalingen voorziene uitgeverijen meer met Nederlands werk komt, behalve dan Jespersen, waar "den eneste danske forlægger, der kan læse hollandsk" ["de enige Deense uitgever die Nederlands kan lezen" $]^{323}$ zelf voor de vertaling van enige kinderboeken zorgt. De andere actieve vertaalsters uit het tijdvak 1920-1960 zijn al eerder van het toneel verdwenen: de laatste vertalingen van Bodil Anker Larsen en Hedda Lovland dateren van respectievelijk 1964 en 1966.

Deze generatie wordt in de jaren zestig en zeventig niet door een nieuwe opgevolgd. Else Westh Neuhard (Presser, Van Aken, Hermans, Aalberse) en Jan de Zanger (Aalberse, Koolhaas, Hollandske noveller) brengen het niet verder dan die 4 respectievelijk 3 vertalingen van - voor een deel - bellettrie, terwijl het grote aantal jeugdboeken en de weinige ontspanningslectuur wordt vertaald door een veelvoud van personen, die zich noch door kwantiteit noch door activiteit op het terrein van de bellettristische vertaling onderscheiden.

Jan de Zanger had al eerder uit in plaats van in zijn moedertaal vertaald. Zijn bundel Nederlandse poëzie in Zweedse vertaling werd aan een vernietigende kritiek onderworpen door Amy van Marken, die De Zanger gebrek aan zelfkritiek verweet. ${ }^{324}$ Evenmin als destijds De Zangers Zweedse assistent bij het samenstellen van deze poëziebundel, beheerste Gyldendals Deense revisor het Nederlands voldoende om de rompvertaling, in casu van Hollandske noveller, tot een goed einde te brengen. "Oversattelsen er en stadig kilde til irritation. Udgiveren synes ganske at mangle øre for mundret dansk og trods det nederlandske sprogomrădets beskeden repræsentation på det danske bogmarked, er bogen ingen naturlig anskaffelse" ["De vertaling is een voortdurende bron van irritatie. De samensteller lijkt total geen oor te hebben voor idiomatisch Deens, en ondanks de bescheiden vertegenwoordiging van het Nederlandse taalgebied op de Deense boekenmarkt is dit boek geen vanzelfsprekende aanschaf"], schrijft de bibliotheeklector. Tove Kirchheiner, die als enig Deense recensent goed Nederlands kent, wijst op talloze blijken van onvoldoende kennis van het Deens, zoals het niet kennen van elementaire verschillen tussen 'gøre', 'lave' en 'foretage sig'; het vertalen van alle interjecties met 'nåh'; en hollandismen als "vil du rakke tante Sofie din lille hånd" in plaats van "sig så paent goddag til tante Sofie". De titel van Jan Wolkers' Serpentina's petticoat wordt tot Serpentinas underkjole [Serpentina's onderjurk], een volkomen overbodige verandering waardoor een belangrijk effect bij de lezer uitblijft. Kirchheiner verwijt De Zanger, zelf zijn gebrek aan nuanceringsvermogen niet te hebben ingezien, en Gyldendal met een dergelijke vertaling in zee te zijn gegaan: "en skam for de implicerede forfattere, såvel for os alle der ser hen til en frugtbar kontakt mellem dansk og hollandsk kultur" ["zonde voor zowel de betrokken auteurs als al degenen die uitzien naar een vruchtbaar contact tussen de Deense en de Nederlandse cultuur"]. ${ }^{325}$ De andere recensies zijn identiek van toon; en er moet toch echt heel wat gebeuren met verhalen als Het adres van Marga 
Minco, Het wandelend woud van Jacques Hamelink of de al eerder genoemde teksten van Hermans en Wolkers, voordat een criticus tot een zo negatief oordeel komt als de recensie waarmee dit artikel begint. Als hier al niet hetzelfde geldt wat Amy van Marken naar aanleiding van De Zangers Zweedse bundel schreef, namelijk dat die voor jaren onze kansen bedorven heeft, dan is toch in elk geval een belangrijke kans tot het bereiken van een groot publiek gemist.

Minder kritiek was er op de vertalingen van Aalberse, Van Aken, Hermans en Presser (1959-1961) van de hand van Else Westh Neuhard, echtgenote van een Vlaamse medewerker en consulent van Gyldendal. Toch gaf ook dit vertaalwerk eens aanleiding tot een opmerking over "den sobre [...] stil, der er blevet en del mishandlet af oversætterinden" ["de sobere stijl, die hier en daar is mishandeld door de vertaalster"] ${ }^{326}$

De slechte respons van de critici op dit soort vertalingen en de mede daaruit voortvloeiende slechte respons bij het publiek, en dus het uitblijven van nieuwe uitgaven, betekende gebrek aan emplooi voor potentiële vertalers en gebrek aan stimulans om zich op het Nederlands te gaan toeleggen. Deze negatieve wisselwerking wordt echter versterkt door externe factoren, zoals de relatief slechte betaling van literaire vertalers. Enkele potentieel geschikte jongeren, oud-studenten Nederlands uit Kopenhagen, werden na Denemarkens toetreding tot de Europese Gemeenschappen in 1972 ingeschakeld te Brussel en Luxemburg en raakten daardoor als vertaler verloren voor de Deense literaire markt.

Hoezeer een en ander met persoonlijke omstandigheden samenhangt, toont de - toevallige - aanwezigheid van drie actieve vertaalsters-consulenten in Zweden, en van de oorspronkelijk uit Vlaanderen afkomstige Zweedse uitgever Coekelberghs, die Geeraerts, Gijsen en Lampo uitbracht. Genoemde personen hadden samen een hoofdaandeel in het relatief grote aantal Zweedse vertalingen van de jaren zeventig, zoals in de inleiding genoemd. Ondanks het incidenteel-persoonlijke karakter van de omstandigheden bewerkstelligen deze dat er in Zweden wèl een zeker emplooi is. Aanwezigheid van gekwalificeerde vertalers is geen garantie voor succes, maar wel een noodzakelijke voorwaarde, en bij voorbeeld in het geval van Wolkers is dat succes in Zweden ook inderdaad bereikt.

In de Deense impasse kunnen de jeugdboekenvertalers geen soelaas bieden, - bij gebrek aan ervaring en/of kunnen. Liefst zestien van de achtentwintig jeugdboekenvertalers hebben slechts eén of twee vertalingen geleverd, en slechts vier van hen meer dan vijf vertalingen. De meesten houden zich aan én auteur - deeltjes uit een serie -, terwijl vooral in de prentenboeken het verband met de Nederlandse brontekst wel zeer los is. Ik vermoed dat veel vaker dan wordt vermeld (Bruna en Diekmann bij Gyldendal, AsscherPinkhof bij Unitas, Duif bij Hulst, Elsing bij Nyt Nordisk Forlag) gewerkt is via een derde taal. Direct negatieve invloed heeft dit alles niet, althans niet in de kritiek: de resultaten geven geen aanleiding tot positieve, maar evenmin vaker dan één maal tot negatieve opmerkingen. Enige uitzondering is Clara Hammerich, wier goede naam niet vreemd geweest zal zijn aan de lof, die ze enkele keren voor haar vertalingen van jeugdboeken krijgt toegezwaaid. 


\subsubsection{De kritiek}

Ten opzichte van de vorige periode daalt het aantal dagbladkritieken van volwassenenliteratuur sterk, zowel absoluut als relatief. Nog slechts 8 van de 27 uitgaven voor volwassenen worden besproken, dat is ongeveer $30 \%$ tegenover ruim $60 \%$ in de periode tussen 1930 en 1960. De relatieve daling komt vooral doordat de ontspanningslectuur geheel op buiten-literair terrein belandt (zie paragraaf 4.4.1) en daarmee ook uit de besprekingskolommen verdwijnt. Ook het aantal besprekingen door diverse dagbladen van een zelfde vertaling daalt: een krant als Berlingske Tidende wijdt in al deze twintig jaar slechts twee besprekingen aan Nederlandse literatuur.

Van de bellettrie-uitgaven worden de meeste althans wel ergens gerecenseerd, - alleen De Pillecijn en Timmermans niet. Theoretisch is het gunstig voor de beeldvorming dat de ontspanningslectuur niet langer wordt gerecenseerd, maar in werkelijkheid komt hier niet veel van terecht door een veel te grote spreiding in de tijd en de negatieve toon van de meeste recensies: alleen Van Aken en Multatuli worden unaniem positief beoordeeld. Voorzover de kritiek al directe invloed heeft op de beeldvorming, spelen de uitvoerige besprekingen van Clara Hammerichs anthologieën, verschenen in 6 respectievelijk 5 landelijke dagbladen, vermoedelijk de grootste rol. De bewuste recensies zijn gemengd van toon. Zo schrijft Politikens recensent naar aanleiding van de Vlaamse bundel dat een aantal uitstekende verhalen zijn idee van een wat grove boerenliteratuur heeft gewijzigd en noodt tot meer, en in Information worden Gijsen en Claus geprezen. ${ }^{327}$ Daarentegen is Aktuelt minder enthousiast over de aansluiting bij de eigen literatuur: "Set i sammenhang med den modeme europaiske prosa må den flamske dog stadig siges at være mere 'forsigtig', måske ligefrem en smule mere 'provinsiel' end både den tyske for ikke at sige vor egen, reverenter talt! Der findes ingen formel modernisme, ingen eksperimenter, ingen fornyende bestrabelser" ["Gezien in relatie tot het moderne Europese proza, moet het Vlaamse toch nog worden gekarakteriseerd als meer 'voorzichtig', misschien zelfs een beetje 'provincialer' dan het Duitse, om niet te zeggen ons eigen, met permissie! Er is geen formeel modernisme, er zijn geen experimenten, geen pogingen tot vernieuwing"]. ${ }^{328}$ Deze bezwaren tegen de keuze vinden we ook terug in recensies van de Noordnederlandse bundel, die in het 'revolutionaire" jaar 1968 verscheen: "eksperimenterende prosa er bandlyst. $\mathrm{Og}$ så traditionel kan litteratur fra Holland, provoernes hjemland, da heller ikke vare?" ["experimenteel proza is taboe. En zo traditioneel kan literatuur uit Nederland, het land van de provo's, toch niet zijn?"']. ${ }^{329}$ Ook Kristeligt Daghlad mist de provo's, die Louis Hammerich in zijn inleiding wel had genoemd, maar waardeert "en mangde godt oplæsningsstof" ["een flinke hoeveelheid goed voorleesmateriaal"]. ${ }^{330}$ Zowe! Politiken als Information bekritiseert de fragmentarische opbouw ("i verste fald disse romanudsnit, der er en uting at sammenligne med ingenting".) ["het ergst zijn al die romanfragmenten, - onvoorstelbare ondingen"], plus dikte en prijs van het boek. Wat het prijsbezwaar betreft: de politiek om zich primair te richten op bibliotheken is in elk geval wel gelukt. Naar aanleiding van de Vlaamse bundel schrijft de bibliotheeklector, dat de bloemlezing bedoeld is voor specifiek geïnteresseerden, maar in elk geval door de hoofdbibliotheken moet worden aangeschaft. Dat advies geeft hij ook voor de Nederlandse bundel, die hij karakteriseert als een statige, misschien wat bloede- 
loze, maar opmerkelijke bloemlezing, waarvan de beste bijdragen (Vestdijk, Koolhaas, Minco, Wolkers, Hermans, Hamelink, Blaman og Van het Reve) hopelijk tot nieuwe vertalingen leiden.

De invloed van deze gemengde kritieken en van de sterk negatieve oordelen over De Zangers bundel is waarschijnlijk voomamelijk indirect: de onder andere hieruit voortvloeiende matige tot slechte verkoop stimuleert de uitgevers niet tot het uitbrengen van nieuwe vertalingen. Voor de oudere generatie blijft daardoor de Nederlandse literatuur gelijk aan Bakker-Corsari-De Hartog-Martin, terwijl ze voor de jongeren weer net zo'n terra incognita is als voor de Deen van 1900 (uitgezonderd, voor sommigen, misschien Hans Martin, van wie de verkoop totaal niet wordt beïnvloed door de zeer negatieve kwalificaties van de bibliotheeklectoren als: ordinaire trivialiteiten, slechte smaak, snobisme en zedeprekerij). Voor de bellettrie hebben besprekingen van de bibliotheekcentrale in grote lijnen hetzelfde effect als de dagbladpers: Hermans zal men vergeefs in een bibliotheek zoeken, en de positief gerecenseerde keuze uit Multatuli's brieven is in de kast met biografieën beland...

Aanzienlijk beter staat het met de jeugdliteratuurkritiek: 63 van de 130 uitgaven worden besproken, dat is $48 \%$, bovendien meestal in diverse kranten. De toon van de recensies is opvallend positief. Als meest kenmerkende kwaliteiten worden de genuanceerde karaktertekening, de verteltechniek, de fantasie en de goede illustraties genoemd. "Hollandske børnebøger er ved at komme i søgelyset, især de mange moderne eventyrforfattere. Der fabuleres behersket uden helt at slippe jordforbindelsen" ["Nederlandse kinderboeken komen steeds meer in de schijnwerpers te staan, speciaal de vele moderne sprookjesschrijvers. Er wordt beheerst gefantaseerd, zonder dat de verbinding met de aarde geheel wordt losgelaten"]. ${ }^{331}$ Van vrijwel alle door de bibliotheekcentrale besproken boeken wordt aanschaf nadrukkelijk aanbevolen, met in grote lijnen dezelfde argumenten als van de pers. Uiteraard is ook hier de kritiek niet alleenbepalend voor het effect. Ondanks goede recensies belanden sommige jeugdboeken in de uitverkoop, en volgens een jeugdbibliothecaresse worden de aanwezige Nederlandse jeugdboeken matig uitgeleend. De door schoolbibliothecarissen, - die zeer belangrijke afnemers zijn - geëiste minimum-lettergrootte maakt volgens de uitgevers de uitgave van te dikke boeken als van Jan Terlouw economisch te riskant. Anderzijds toont het grote aantal wèl verschenen uitgaven aan, dat het uitbrengen van kwalitatief goede boeken voor de jeugd door de bank genomen rendabel is, en dat kwaliteit en commercieel succes elkaar niet hoeven uit te sluiten.

De door het aantal uitgaven en de uitgebreide (zie 4.4.1) positieve aandacht ontstane verbreding van perspectief bij volwassenen - voor de jeugd zelf is nationale herkomst van het boek even irrelevant als altijd - blijft echter beperkt tot de jeugdliteratuur zelf. Minder nog dan de waardering van Nederlandse ouders voor Astrid Lindgren op zichzelf leidt tot het lezen van Strindberg of Lagerkvist, zal waardering voor een Deense vertaling van Annie M.G. Schmidt leiden tot interesse van Deense volwassenen voor de nauwelijks nog te vinden Vestdijk of Multatuli, dan wel tot herijking van het door Hans Martin cum suis geschapen beeld. 


\subsection{Periode 1980-1990}

\subsection{Kwaliteitskenmerken in verhouding tot de literaire smaak}

In de jaren tachtig is het literaire spectrum zowel in Denemarken als in de Nederlanden zeer breed; naar uit onderstaande zeer globale inventarisatie blijkt, valt een overheersende tendens in geen van beide taalgebieden aan te wijzen. In Denemarken handhaven de veelzijdige Klaus Rifbjerg en de psychologisch realist Anders Bodelsen hun grote populariteit, terwijl vooral vrouwelijke auteurs hun naam voorgoed vestigen met aandacht trekkende, maar qua stijl en thematiek uiteenlopende romans: Dea Trier Mørch, Kirsten Thorup, Hanne Marie Svendsen en Dorrit Willumsen. Experimenteel proza komt onder andere van Per Hultberg en Sven Åge Madsen. De discussie over de Deense identiteit in een zich wijzigend Europees en mondiaal bestel uit zich in allerlei biografische romans over Deense historische figuren, onder andere van de cultuurcriticus Henrik Stangerup, diens zuster Helle Stangerup en Mette Winge. Onder de jongste prozaïsten valt vooral Peter Høeg op, met een zeer geschakeerde vertelkunst, variërend van fantastische vertellingen tot psychologische roman. De poëzie varieert sterk, zowel qua vorm en taalgebruik (van zeer toegankelijk tot uiterst hermetisch) als qua thematiek (van persoonlijke identiteitsproblematiek tot de taal als uitdrukkingsvorm zelf).

In Nederland en Vlaanderen is het beeld al even diffuus, met - zeer globaal gesproken - werk van gevestigde namen als Bernlef, Claus, Haasse, Hermans, Mulisch, Nooteboom en Reve; van vormgerichte 'academisten' als Frans Kellendonk, Dirk Ayelt Kooiman, Doeschka Meijsing en Nicolaas Matsier; van uiteenlopende 'autobiografen' als Jeroen Brouwers, Maarten ' $t$ Hart, A.F.Th. van der Heijden en Monica van Paemel; van al even uiteenlopende vrouwelijke auteurs met een al dan niet feministische thematiek, als Tessa de Loo, Hermine de Graaf, Renate Dorrestein en Kristien Hemmerechts; van 'hermetische' prozaïsten als Willem Brakman en Gerrit Krol; in de poëzie werk van de rumoerige 'Maximalen' als Joost Zwagerman en Tom Lanoye naast dat van ingetogener dichters als Rutger Kopland en Wiel Kusters; en in de essayïstiek van een rijke variatie aan auteurs, onder wie Hugo Brandt Corstius, Jeroen Brouwers, Rudy Kousbroek, Gerrit Komrij en Renate Rubinstein.

Er is dus een overeenkomst zichtbaar in de Deense en Nederlandse verscheidenheid, maar daarmee is ook ongeveer alles gezegd. Stijging van het aantal auteurs en titels gaat gepaard met een daling van het percentage lezers van literatuur. In beide landen leest een steeds kleiner wordende groep veel literatuur, en het grote publiek steeds minder. Economisch riskante literaire uitgaven in Denemarken staan onder druk, nu de honderden bibliotheken zich niet langer verplichten van elke Deenstalige bellettrie-uitgave, waaronder vertalingen, ten minste één exemplaar af te nemen.

Des te opvallender is het dat in de jaren tachtig 143 vertalingen Nederlands-Deens zijn verschenen, dat is $26 \%$ van alle vertalingen sinds 1900 . Weliswaar is hiervan het overgrote deel jeugdboeken, waaronder veel stripboeken, maar er zijn ook 13 bellettrie-uitgaven: Multatuli, Max Havelaar; Frank Martinus Arion, Dubbelspel; Etty Hillesum, Het verstoorde leven; Anne Frank, Verhaaltjes en gebeurtenissen uit het achter- 
huis; Jeroen Brouwers, Bezonken rood; Harry Mulisch, De aanslag; Bernlef, Hersenschimmen; een bloemlezing I karlighedens favn ('Het leven is liefde'); Cees Nooteboom, Rituelen; Jona Oberski, Kinderjaren; Oek de Jong, Cirkel in het gras; F. Springer, Bougainville; Bernlef, Vallende ster. Een aanzienlijke stijging ten opzichte van 1 uitgave in de jaren zeventig.

De meeste van de bovengenoemde in het Deens verschenen werken zien we dan ook tevens in Noorse en Zweedse vertaling. ${ }^{332}$ De verklaring hiervoor is onder andere te zoeken in de plotselinge populariteit van een aantal Nederlandse auteurs op de Engelse en vooral de Duitse boekenmarkt, waarnaar de Scandinavische zich traditioneel sterk richt: Bernlef, Harry Mulisch en vooral Cees Nooteboom, wiens werk in Duitsland vele malen herdrukt is.

Maar er zijn meer factoren. Zo is er de komst van een aantal gekwalificeerde vertalers. Ook de thematiek speelt een rol. Blijkens de recensies is de exotische koloniale problematiek in de romans van Multatuli, Arion, Brouwers en Springer voor de Deense lezer aantrekkelijk (heel anders dan in de periode 1900-1930, zie 4.2.1). Een ander intrigerend thema blijkt de Tweede Wereldoorlog, die ook in Denemarken de literaire gemoederen blijft bezighouden (onder andere bij Anders Bodelsen en Tage Skou-Hansen) in het werk van Hillesum, Anne Frank, opnieuw Brouwers, Mulisch en Oberski.

Ik ben het daarom maar ten dele eens met de conclusie van Kris Van de Poels artikel over vooral deze periode, verschenen in Dietsche Warande en Belfort (1992): 'Nederlandse literatuur in Deense vertaling, een magere oogst'. Allereerst heeft Van de Poel slechts 53 van de 143 vertalingen getraceerd; voorts gaat zij voorbij aan de kwaliteit van veel der jeugdboeken (zie 4.5.3); en ten slotte is ook de receptie in verhouding tot de voorafgaande periodes aanzienlijk gunstiger, zoals hieronder zal blijken.

\subsubsection{Documentatie}

In 1980 verscheen het handboek van de Oslose hoogleraar Nederlands Kåre LangvikJohannessen, Litteraturen i Nederlandene giennom 800 ar. de eerste in een Scandinavische taal geschreven Nederlandse literatuurgeschiedenis sinds Hollands litteraturhistoria van Martha Muusses (Stockholm 1947). Dit handboek, dat door de Deense hoofdbibliotheken is aangeschaft, gaat onder andere in op Scandinavisch - Nederlandse literaire relaties en geeft achterin een overzicht van Scandinavische vertalingen van Nederlandse hellettrie. De nadruk ligt sterk op de historische letterkunde: slechts circa tien procent van de tekst behandelt de twintigste eeuw.

Kris Van de Poel, lector Nederlands aan de universiteit van Århus, bezorgde in 1987 de bloemlezing I karlighedens fawn, een bundel teksten over het thema liefde, van de hand van moderne Vlaamse en Nederlandse auteurs (zie par. 3, tabel C). Elke vertaling is voorzien van een korte bio-bibliografische aantekening.

Het Scandinavisch Vertaal- en Informatiebureau te Groningen geeft sinds 1985 Scandinavian Newsletter uit, een orgaan voor Scandinavisch - Nederlandse culturele evenementen, dat anders dan de naam doet vermoeden ook gericht is op een Scandinavisch publiek, en aandacht schenkt aan Nederlandse literatuur in Scandinavische vertaling. 
Ook buiten deze publikaties om blijkt dat ettelijke recensenten in deze periode zich beter documenteren en op de hoogte blijken van de contemporaine Nederlandse letteren; sommigen van hen kunnen zelfs het origineel lezen (zie 4.5.7).

\subsection{3/4.5.4 Particulier initiatief: cultuur- en vertaalpolitiek}

Een Nederlandse filmweek, in 1980 mede georganiseerd door de culturele afdeling van de Nederlandse ambassade te Kopenhagen, had een bijzonder gunstig effect. De film Max Havelaar van Fons Rademakers kreeg jubelende kritieken, onder andere van de bekende schrijver Anders Bodelsen in Politiken, en werd een jaar later bekroond met een 'Bodil' (de Deense Oscar) voor de beste buitenlandse film. Dit succes inspireerde uitgeverij Hekla tot het uitbrengen van een nieuwe vertaling van Max Havelaar (1981), die positieve recensies kreeg en goed verkocht werd, en in het kielzog hiervan tot de uitgave van nog twee romans met koloniale thematiek, Dubhelspel van Frank Martinus Arion en Bougainville van F. Springer. Ter gelegenheid van de Multatulivertaling verschenen er uitvoerige essays van de Zweedse criticus Ame Melberg in Information en van Diederik Grit in Politiken, terwijl Hella Haasse een Multatulilezing kwam houden voor het Deense PEN-centrum. Andere schrijvers die Kopenhagen bezochten, ditmaal ter promotie van hun eigen werk, waren Frank Marinus Arion (1983), die interviews kreeg in Politiken, Weekendavisen en Information, en Oek de Jong (1987).

Het Nederlandse ministerie van WVC en de Stichting ter bevordering van de vertaling van Nederlands letterkundig werk organiseerden in 1984 in Amsterdam een symposium van Nederlandse en Scandinavische literaire vertalers, dat onder andere resulteerde in de oprichting van bovengenoemde Scandinavian Newsietter. Aanwezig waren onder meer Gerard Kruisman (onder het pseudoniem Gerard Cruys vertaler van Multatuli en Arion) en Birthe Lundsgaard (vertaalster van Hillesum, Brouwers en Mulisch), naast de Deense literator Niels Brunse en de Deense literatuurhistoricus Torben Brostrøm, die over het evenement een uitvoerig stuk schreef in Information, waarin ook het verwrongen beeld van de Nederlandse literatuur in Denemarken aan de orde kwam.

De bovengenoemde Stichting heeft de uitgave van een aantal vertalingen gesubsidieerd, terwijl de Nederlandse Taalunie de uitgave van Kris Van de Poels bloemlezing steunde. Van de Poel hield tevens een promotiecampagne onder Deense uitgevers, die voor de jeugdliteratuur positief resultaat opleverde. ${ }^{333}$

\subsubsection{Uitgeversbeleid}

De krappe markt zorgt voor verschillende uitgeversstrategieën naast elkaar. Ofwel een puur commercieel beleid, blijkend uit de risicoloze uitgaven van stripboeken (22 vertalingen van Willy Vandersteens Suske en Wiske bijvoorbeeld) en detectives (6 vertalingen van Janwillem van de Wetering). Ofwel een risicospreidingspolitiek: vertalingen met subsidie van de Stichting ter bevordering van de vertaling van Nederlands letterkundig werk (Multatuli en Arion bij een kleine literaire uitgeverij als Hekla) en/of vertalingen 
van elders redelijk succesvolle schrijvers bij grote uitgeverijen die tegen een stootje kunnen (zoals Mulisch bij Gyldendal).

Opvallend is dat van een consistent beleid nog weinig sprake is. De enige uitgeverij met een herkenbare lijn is Hekla, met drie 'koloniale' romans (Multatuli, Arion en Springer) en twee romans van Bernlef. De bovengenoemde vijf werken met een oorlogsthema verschijnen bij vier verschillende uitgeverijen. Opbouw van een oeuvre in vertaling ontbreekt, anders dan in Zweden, waar na Wolkers' romans ook die van Maarten 't Hart successievelijk worden vertaald, met niet alleen een commercieel succes dat blijkt uit herdrukken, maar ook een cultureel effect: Wolkers' Een roos van vlees en 't Harts De kroongetuige zijn er beide verfilmd, door de Zweedse regisseur Jon Lindström. ${ }^{334}$

Op het gebied van de jeugdliteratuur is daarentegen sprake van een samenhangende politiek. Naast de vele stripboekuitgevers zijn vier uitgeverijen actief met uitgaven van gerennommeerde en veelal met gouden en zilveren griffels bekroonde jeugdboekenschrijvers: Sommer \& Sørensen brengt vier boeken van Jan Terlouw, twee van Thea Beckman, drie van Evert Hartman en een van Tony Vos-Dahmen von Buchholtz; Munksgaard komt eveneens met werk van Thea Beckman, Els Pelgrom (3x), Simone Schell en een reeks 'probleemromans' voor de oudere jeugd; Gyldendal met Tonke Dragt, Thea Dubelaar, Joke van Leeuwen, Selma Noort (2x), Rindert Kromhout en Ingrid Schubert; en Høst met Hans Stolp en Jan de Zanger (2x). Dat van diverse auteurs meerdere werken worden uitgebracht, demonstreert dat ook de uitgave van omvangrijke werken als die van Thea Beckman en Jan Terlouw commercieel haalbaar is, en het vergroot uiteraard de naamsbekendheid.

De romans hadden verschillend succes. Multatuli en De Jong verkochten goed, terwijl de verkoop van de rest varieerde van redelijk tot matig. Arion, Multatuli en de bloemlezing belandden in de nationale boekenuitverkoop. In 1992 waren de beide Bernlefs, Nooteboom, Oberski en Springer nog in de reguliere boekhandel verkrijgbaar. De gemiddelde omlooptijd van het Deense boek in de boekhandel bedraagt momenteel circa anderhalf jaar. ${ }^{335}$

\subsection{Aard van de vertaling}

Een gunstige ontwikkeling in deze periode is dat zich een aantal gekwalificeerde vertalers op de markt aandient. De in Kopenhagen wonende Nederlandstalige vertaler Gerard Kruisman (vertaler uit het Russisch en Deens - onder andere van Johannes V. Jensen en Suzanne Brøgger - en winnaar van de Aleida Schotprijs voor vertalingen) werkt samen met zijn Deense collega Grete Bentsen aan vertalingen van Multatuli en Arion. Geerte de Vries oud-lector Nederlands aan de universiteit van Kopenhagen, verzorgt onder het pseudoniem Greta Grootenboer samen met Anne E. Jensen de vertaling van F. Springer. De aan de Kopenhaagse universiteit opgeleide Neerlandici Birthe Lundsgaard (Hillesum, Brouwers, Mulisch) en Tim Kane (Nooteboom, jeugdboeken van Van Leeuwen, Dragt en De Zanger) zijn actief naast letterkundig geschoolde Denen die jarenlang in Nederland hebben gewoond: Tove Kirchheiner-Galatius (De Jong), Birte Carlé (Bernlef), Kirsten Rahbek (Oberski, jeugdboekenauteurs als Dragt en Hartman). 
De vertalingen kenmerken zich door een primair brontekstgerichte strategie, met veel aandacht voor de stilistische nuances en de structuur van het origineel, maar anderzijds met oog voor de doelgroep waar het syntaxis en idioom betreft. In de vele recensies wordt als gewoonlijk weinig aandacht besteed aan de vertaling als zodanig, maar voor zover dat gebeurt is het bijna steeds positief: fijnzinnig (Kruisman), uitstekend (Lundsgaard), uitgebalanceerd (Kane), gevoelig (Carlé), uitstekend en vlot lezend (Kirchheiner). Alleen de vertaling van de studenten Nederlands uit Århus in de bloemlezing van Kris Van de Poel wordt tweemaal bekritiseerd wegens neerlandismen in woordkeus en stijl. Opvallend is dat voor het eerst recensenten met kennis van het Nederlands daadwerkelijk vertaling en brontekst vergelijken: de gelauwerde Deense vertaler en auteur Niels Brunse, en Birte Carlé, zelf vertaalster van Bernlef.

De aangeleverde vertaling van Springer werd door uitgeverij Hekla niet geaccepteerd en grondig bewerkt. Uit onvrede hiermee weigerde de Deense vertaalster haar naam als zodanig te laten afdrukken. De aard van deze bewerking is onbekend, maar dit voorbeeld toont wel de vaak verborgen rol van de uitgever in de vertaling aan.

Gyldendal koos er in overleg met vertaalster Birthe Lundsgaard voor, De Aanslag uit te brengen onder de titel Et tilfalde ('een voorval', zoals Mulisch het zelf in de proloog aanduidt) ter vermijding van associaties met een keiharde roman, zoals hierboven beschreven naar aanleiding van de vertaling van Hermans' Donkere kamer van Damokles. Deze titelwijziging had echter het onbedoelde gevolg dat associaties uitbleven met Fons Rademakers' met een Oscar bekroonde verfilming, die in Denemarken draaide onder de titel Attentatet.

\subsubsection{De kritiek ${ }^{336}$}

Opvallend ten opzichte van de vorige periode is de ruime aandacht die de literaire vertalingen krijgen, niet alleen van de lectoren van de Deense bibliotheekcentrale, maar ook en vooral van de grote landelijke bladen als Aktuelt, Berlingske Tidende, Information. Politiken, Jyllandsavisen en Weekendavisen, en in een aantal gevallen ook in de regionale bladen. Onder de recensenten treffen we bekende auteurs en letterkundigen aan als Niels Brunse, Henning Ipsen, Johan de Mylius en Bent William Rasmussen. De kritieken zijn vaak opvallend lang (meerdere malen een halve tot hele pagina) en regelmatig voorzien van een portret. Ze schenken aandacht aan de auteur, de inhoud, de problematiek en vooral het bredere literaire kader. De geringe representatie van de Nederlandse literatuur in Denemarken wordt keer op keer betreurd, en deze vertalingen worden verwelkomd. Recensies uit de laatste jaren verwijzen herhaaldelijk naar de eerder in het onderhavige decennium verschenen vertalingen uit het Nederlands.

Maar het belangrijkste is dat al deze recensies voor het overgrote deel bijzonder positief zijn. Multatuli krijgt naast de twee reeds genoemde essays zes recensies, waarvan vijf het als een qua stijl en problematiek nog steeds actueel meesterwerk begroeten ("Het was meer dan tijd dat dit boek in het Deens beschikbaar was", schrijft Henning Ipsen). Alleen Johan de Mylius mist vaart in de handeling, evenais in Dubbelspel van Arion. Deze krijgt behalve de bovenvermelde interviews acht kritieken, waarvan er zes 


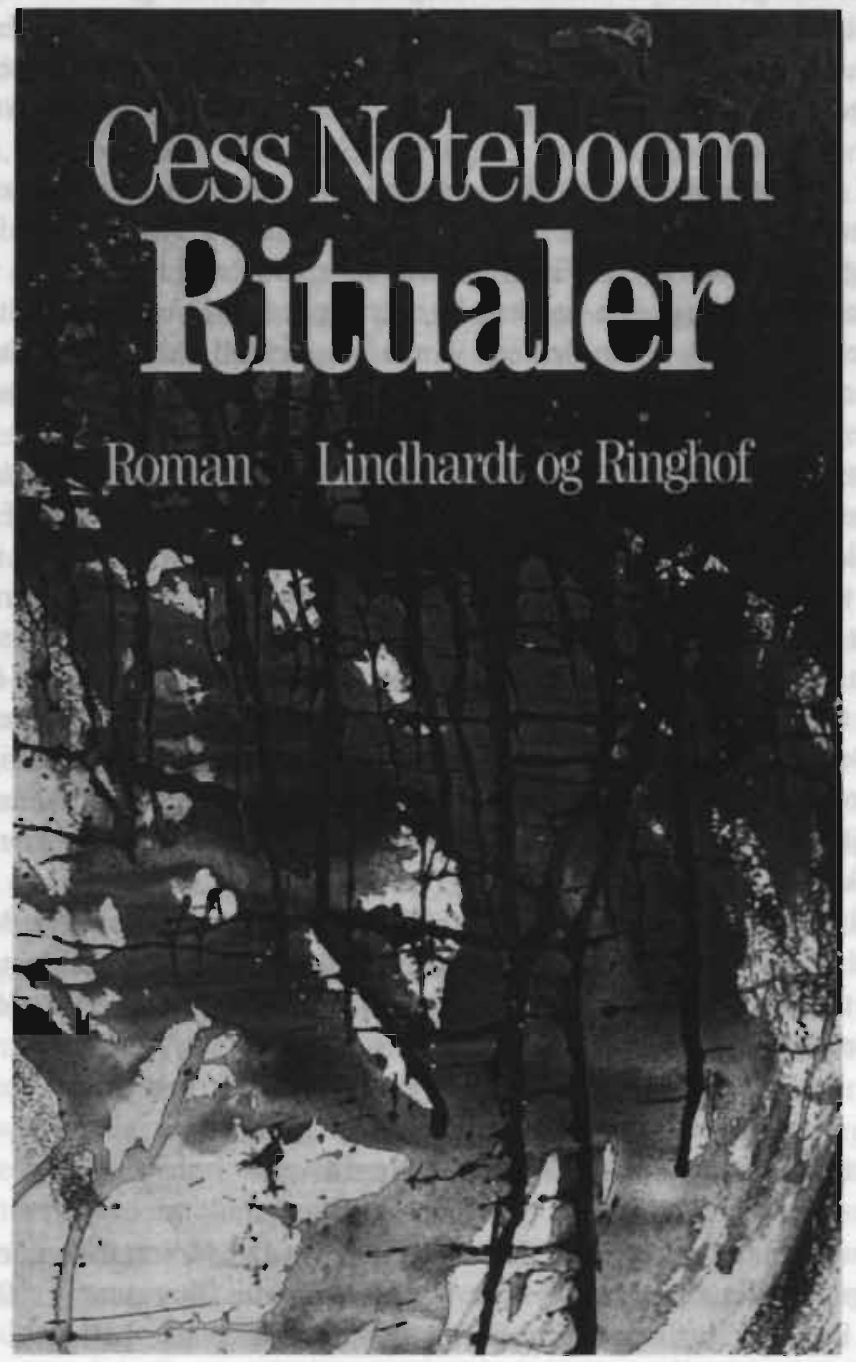

Afbeelding 22. De spelling van Nederlandse schrijversnamen kost soms wat moeite... Na protest van een Deense recensent kwam uitgever Lindhardt \& Ringhof inderhaast met een nieuw omslag. 
de "uitstekende kwaliteit" prijzen van een qua thematiek en setting ongewoon werk. Etty Hillesum krijgt een paginagroot artikel in Berlingske Tidende en nog zeven andere recensies ("aangrijpend", "fascinerend als kunstwerk en als historisch document"; alleen Politiken heeft enige moeite met de sterk godsdienstige inslag). In de besprekingen van Brouwers (acht recensies, zeven positief), Mulisch (maar liefst veertien recensies, alle zeer lovend), Oberski (zes recensies, vijf positief) en Bemlef (vier recensies, drie positief) valt regelmatig het woord meesterwerk. Ook de twee recensies van Springer zijn gunstig.

Gemengd zijn de vier reacties op Nooteboom: twee recensenten prijzen stijl en structuur van deze zowel "on-Deense" als "on-Nederlandse" roman, de andere twee vinden hem aan de gemaniëreerde en te intellectuele kant. Ook de bloemlezing van Kris Van de Poel (zes recensies) krijgt een gemengde ontvangst: het initiatief wordt geprezen, maar de veelheid en de kwaliteit van de keus worden wisselend beoordeeld. De vertaling krijgt eveneens een verschillende waardering, van lof voor het goede Deens tot kritiek op neerlandismen.

Zeer omstreden is alleen de vertaling van Oek de Jongs Cirkel in het gras. Van de zeven recensies, tamelijk tot zeer uitvoerig, zijn er vier uiterst negatief: "dom geklets". "had in het land van herkomst moeten worden gebruikt om er dijken mee te dichten", "ontzettend vervelend". Aktuelt spreekt van langdradige "koelkastliteratuur": het type literatuur dat een volledige beschrijving van de inhoud van de koelkast geeft zodra de deur daarvan. opengaat. De ongeloofwaardige plot, het intellectualisme en het ouderwetse en zware taalgebruik krijgen eveneens zware kritiek. Twee andere recensies zijn wat gemengd. De bibliotheeklector daarentegen is positief: "lezenswaardig, tot nadenken stemmend, onderhoudend, maar niet gemakkelijk". De bibliotheekaanschaf heeft dus waarschijnlijk niet onder de kritiek geleden. Ook de verkoop liep goed ${ }^{337}$, ondanks of wellicht dank zij de felle reacties.

De jeugdliteratuur ten slotte, wordt uitsluitend gunstig besproken. Met uitzondering van de stripboeken wordt vrijwel elke uitgave door de bibliotheeklector gerecenseerd, uiteraard soms met kanttekeningen, maar steeds met een positief eindoordeel, wat ook geldt voor de minder talrijke krantenrecensies. ${ }^{338}$

\section{Samenvatting der resultaten; conclusies}

Doel van bovenstaand onderzoek was na te gaan welke factoren bepalend zijn voor het over het algemeen matige succes van de Nederlandse literatuur in Deense vertaling. 1900-1990. Daar de intrinsieke kwaliteit van de Nederlandse bellettrie uit deze periode niet onderdoet voor de gemiddelde kwaliteit elders (zie paragraaf 2: ze wordt in de concrete gevallen ook niet door de Deense kritiek betwist), moet dit wansucces nader verklaard worden uit de verwrongen beeldvorming bij het Deense publiek, een beeldvorming waarop waarschijnlijk het bij tijden grote aanbod van ontspanningslectuur en jeugdliteratuur invloed uitgeoefend heeft. Vraagstelling werd daarmee, welke sociale en/of incidentele factoren bepalend zijn voor het beeld dat de Deen van 'de' Nederlandse literatuur heeft. 
Inventarisatie van vertalingen leert dat er vier periodes te onderscheiden zijn: $\mathbf{I}$. 1900-1930: zeer weinig vertalingen van zowel bellettrie, ontspanningslectuur als jeugdliteratuur, zij het relatief veel van de laatste categorie; II. 1930-1960: kwantitatieve bloei van ontspanningslectuur en in iets mindere mate bellettrie, tegenover een relatief sterke daling van jeugdliteratuur; III. 1960-1980: geleidelijke daling tot het nulpunt van de volwassenenproduktie tegenover een hausse in jeugdboeken, vooral voor de jongere kinderen; IV. 1980-1990: licht maar duidelijk herstel van de literaire produktie, die van hoge kwaliteit is, plus een zich voortzettende stijging van jeugdboekuitgaven, voomamelijk voor de wat oudere jeugd (zowel in Nederland bekroonde jeugdboeken als stripboeken).

Voor elk van deze vier periodes zijn de diverse potentiële beeldvormende factoren in kaart gebracht, zoals die zijn geïnventariseerd uit de fragmentarische secundaire literatuur op het gebied van Nederlandse letteren in vertaling.

De beeldvorming rond bellettrie in het tijdvak 1900-1930 werd niet beïnvloed door de twee andere categorieën vertalingen, daar deze een volstrekt eigen circuit en publiek hadden. Met betrekking tot bellettrie kan men beter spreken van afwezigheid van welk beeld dan ook, iets wat in de praktijk natuurlijk negatief werkt. Een commercieel gerichte uitgeverspolitiek, mikkend op bekende namen, en discongruentie van Deense en Nederlandse literaire stromingen zijn hier weliswaar mede oorzaak, maar veel belangrijker als negatieve factor zijn de ongelukkige presentatie respectievelijk slechte vertalingen van Couperus, Multatuli en Heijermans, waar geen enkele stimulans tot vervolg van uitging. Daardoor ontstond noch de continuïteit, noch de consistentie die voor blijvende aandacht in de pers en voor een positieve beeldvorming bij het publiek een noodzakelijke voorwaarde is. Dat namelijk kwaliteit en commercieel succes elkaar niet hoeven uit te sluiten, bewijzen in dezelfde periode de succesvolle initiatieven van Emma Kraft, die zorgde voor een consistent aanbod van goede jeugdboekvertalingen.

De hausse in vertalingen tussen 1930-1960 is een ander voorbeeld van gecombineerde commerciële uitgeverspolitiek en persoonlijk initiatief, zij het hier met een voornamelijk negatief effect. Het gelijktijdig optreden van drie goede vertaalsters rond 1930, plus de 'ontdekking' van de succesvolle dames- en streekromans door een aantal bekende uitgeverijen zorgt voor een breed overlappingsgebied van ontspanningslectuur en tweederangsbellettrie, waarin de eigenlijke, representatieve literatoren niet vertegenwoordigd zijn. De overvloed van het genre bepaalt volledig het negatieve totalbeeld in de pers, en een literair geïnteresseerd publiek haakt hierdoor op den duur bij voorbaat af. Het is vooral te betreuren dat een bekwaam en invloedrijk vertaalster als Clara Hammerich zoveel van dit tweederangswerk heeft geaccepteerd. Haar weinige echt literaire vertalingen vallen temidden van die tientallen ander niet meer op, en bereiken hierdoor de eigenlijke doelgroep niet. Gespreidheid in de tijd en enorme hiaten maken een totaalbeeld van de contemporaine Nederlandse bellettrie onmogelijk; enig tegenwicht in de vorm van documentatie van andere zijde ontbreekt. De jeugdliteratuur, sterk terugvallend na Emma Krafts overlijden, blijft geheel binnen het eigen terrein.

In de jaren 1960-1980 geeft de opkomst van de televisie Neerlands succesartikel een stevige knauw; en de restanten verdwijnen in de kioskromanproduktic. Wat nog aan bellettrie wordt vertaald is ernstig gehandicapt door de beeldvorming uit de vorige perio- 
de, door discongruentie tussen de Deense literatuur en wat gemiddeld aan Nederlandse literatuur op de Deense markt komt, en door rationalisering in het uitgeversbedrijf (concurrentie van goedkope pocketseries). De fragmentarische inleidingen en selectie in Clara Hammerichs in principe zo belangrijke anthologieën zijn mede een gevolg van de politiek van de Vlaamse en Nederlandse subsidiërende instellingen. De oude generatie vertalers valt in de loop der jaren geheel weg en vindt geen eigenlijke opvolgers; een bijzonder slechte vertaling van een aantal korte verhalen betekent in de jaren zeventig het dieptepunt van de Nederlandse literatuur op de Deense markt, met alle vicieuze gevolgen vandien. De weinige geschikte vertalers zijn inmiddels door ander, beter betaald werk bezet. Het op zich grote aantal jeugdboekvertalingen werpt geen nieuw licht werpt op de letterkundige produktie voor volwassenen.

De jaren 1980-1990 geven echter een licht herstel te zien voor de bellettrie. Succes in andere Europese landen, de komst van gekwalificeerde vertalers en aandacht voor bepaalde thematiek zorgen voor dertien vertalingen, die veel aandacht krijgen en over het algemeen opvallend gunstig worden besproken. De kritiek blijkt beter geïnformeerd over de Nederlandse letteren, en de verkoop loopt in een aantal gevallen goed. Ook de kwaliteit van de keuze aan jeugdboeken en de vertaling daarvan stijgt. Daartegenover staat een veelheid aan stripboeken van wisselend kaliber.

Concluderend kunnen we zeggen dat van de onderzochte categorieën beeldbepalende factoren de overwegend commerciële uitgeverspolitiek een vrij constante en onvermijdelijke factor is. In principe kan echter aan deze politiek door persoonlijke bemoeienis zowel een positieve als een negatieve draai gegeven worden, die beide zelfversterkend werken. Daarmee hangt de beeldvorming primair af van persoonlijke factoren. In het bovenstaande hebben we voomamelijk voorbeelden van de negatieve ontwikkeling gezien. Slechte vertalingen die kansen voor belangrijke auteurs hebben bedorven; activiteit van goede vertalers ten gunste van zeer middelmatige romans; gebrekkige bemoeienis van de vertaalinstanties, enzovoort. Gevolg is een slechte pers, desinteresse bij een literair geïnteresseerd publiek en op den duur een nulpunt in alle opzichten.

Omgekeerd blijkt in de jaren tachtig dat goede vertalers en consulenten in beginsel een ontwikkeling kunnen stimuleren, waarbinnen kwaliteit en commercieel succes elkaar niet hoeven uit te sluiten. Natuurlijk zal niet elke vertaling van niveau cen succes kunnen worden dankzij de inzet van een enkele vertaler en/of consulent. Maar het is primair díens kwaliteit en inzet die kan zorgen voor de basisvoorwaarden voor een adequate beeldvorming: continuïteit en consistentie. 


\section{Hoofdstuk IX}

\section{Besluit}

Doel van het voorafgaande onderzoek was een beschrijving te geven van een aantal literaire banden tussen de Nederlanden en Scandinavië van de zeventiende eeuw tot heden, ter beantwoording van de vraag wat voor beeld lezers uit het ene gebied hebben gekregen van de literatuur van het andere gebied, en wat voor rol individuele auteurs, als subject en/of object in die beeldvorming hebben gespeeld. Welke persoonlijke contacten zijn er geweest, wat was er bekend van de andere literatuur, wat is er vertaald, hoe is er vertaald, en welke sporen van de ene literatuur zijn er in de andere te vinden? Het onderzoek, in de vorm van zeven exemplarische case-studies, concentreert zich achtereenvolgens rond afzonderlijke auteurs en rond 'de' betrokken literaturen.

Concluderend kunnen we met betrekking tot de onderzochte auteurs vaststellen dat een viertal steunpilaren van de Nederlandse letterkunde belangstelling heeft ondervonden in en/of interesse heeft gehad voor Scandinavië: Vondel, Bilderdijk, Van Eeden en Streuvels. De sporen van deze interesse (persoonlijke contacten, vertalingen, verwantschappen en voor een deel ook invloeden) laten zich duidelijk traceren en zijn representatief voor de rol die de betrokken auteurs in de Nederlandse literatuurgeschiedenis spelen: de uitstraling van de Nederlandse cultuur in de zeventiende ecuw, het ingaan tegen 'de geest dezer eeuw' rond 1800 , de interesse voor sociale vernieuwing rond 1900 , en gevoelde verwantschap tussen de Vlaamse en Noordse emancipatiestrijd in de negentiende en het begin van de twintigste eeuw. Elk heeft, zij het verschillend qua wijze en intensiteit, bijgedragen tot de beeldvorming: Vondel en Van Eeden vooral tot het beeld van Nederlandse literatuur in Scandinavië; en Bilderdijk en Streuvels tot het beeld van Scandinavische letteren in Nederland en/of Vlaanderen.

Wat diepgaande wederzijdse relaties tussen 'de' respectieve literaturen betreft, zijn de conclusies echter bescheiden. De Nederlandse letteren in Denemarken en de Deense letteren in de Nederlanden (waarbij respectievelijk de Deense receptie en de Deense literatuur in veel opzichten representatief zijn voor de Scandinavische als geheel) hebben aan weerszijden slechts weinig blijvende sporen achtergelaten. Hoewel in de zeventiende eeuw een grote belangstelling voor de Nederlandse cultuur in Scandinavië bestond en van het eind van de negentiende eeuw tot ver in onze eeuw een algemene belangstelling 
voor het Noorden in de Nederlanden, zijn belangrijke invloeden van de ene literatuur op de andere afwezig. Van 'de' receptie van de ene literatuur in het andere taalgebied is al evenmin sprake. Voor een representatief beeld van de bellettrie zijn de verschillende vertaalstrategieën te divers, en lopen de doelgroepen van de vele honderden vertalingen in tijd, leeftijd en sociale of religieuze achtergrond te ver uiteen. (De verschillende vertaalstrategieën blijken onder andere uit een representatieve analyse van de Nederlandse Andersen-vertalingen, samen goed voor een vijfde van alle vertalingen uit het Deens). Een commerciële uitgeverspolitiek met eenzijdige belangstelling voor bepaalde thema's en genres (in het bijzonder familie- en streekromans) vestigt in bepaalde periodes een stereotiep beeld, dat onder andere in recensies, voorwoorden en parodieën naar voren komt, en laat het er in andere periodes geheel bij zitten wat de Scandinavische bellettrie in Nederland, respectievelijk de Nederlandse bellettrie in Scandinavië betreft. Persoonlijke initiatieven van gekwalificeerde vertalers blijken een weliswaar onvoldoende maar in elk geval noodzakelijke voorwaarde om aldus gevestige stereotypen om te buigen of af te breken. De groeiende belangstelling voor de neerlandistiek in Scandinavië en voor de scandinavistiek in de Nederlanden kan daartoe hopelijk het hare bijdragen. 


\section{Bijlage}

\section{Lijst van literaire vertalingen Nederlands- Deens in boekvorm, 1900-1990}

1900

1. Vosmaer, Carel, Amazonen. Vertaling Mathilde Paulli. København, A. Christiansen, 1900. [Amazone, 1880]

1901

2. Multatuli [ps. van E. Douwes Dekker], Max Havelaar. Vertaling Carl Michelsen. København, Gyldendal, 1901. [Max Havelaar, 1860]

1903

3. Eeden, Frederik van, Den lille Johannes, Vertaling Gerda Vedel. København, 1903. [De kleine Johannes, 1887]

4. Melati van Java [ps. van N.M.S. Sloot], Brogede Vimpler. Vertaling Gerda Vedel. Næstved, 1904 Nastved Tidende, 1903. [Bonte wimpels, 1897]

5. Jong van Beeck en Donk, Cécile [Goekoop-]de, Hilda van Suijlenburgh. Vertaling Gerda Vedel. Aalborg. Aalborg Tidende, 1904. [Hilda van Suijlenburgh, 1898]

6. Naeff, Top. Skoleidylier. Vertaling Emma Kraft. København, E. Jespersen, 1904 [1910²; 1920]. [Schoolidyllen, 1900]

1908

7. Naeff. Top, Tvillingerne. Ventaling Emma Kraft. København, E. Jespersen, 1908 [1910²; 19203]. [De tweelingen, 1905]

8. Hichtum, Nienke van [ps. van Sjoukje Bokma de Boer] Ohuhue. Vertaling Emma Kraft. 1909 Kobenhavn, E. Jespersen, 1908. [Ohoehoe, 1899]

9. Zeggelen, Marie C. van, Det gyldne Svard. Vertaling Emma Kraft. København, E. Jespersen, 1910 1909. [De gouden kris, 1908]

10. Jager Meezenbroek, E. de, Da Toto var tretten. Vertaling Emma Kraft. Kabenhavn, E. Jesper1911 sen, 1910. [Toen Else dertien was, 1909]

11. Meekel, Kees, Blomsterflor. Vertaling Oskar V. Andersen. København, Katholsk Bogsalg. 1911. [Adel, 1909] 
12. Zeggelen, Marie C. van, Fortallinger fra fjerne Lande. Vertaling Emma Kraft. Kobenhavn, E. 1913

Jespersen, 1911. [Jong Java's lief en leed, 1904]

13. Streuvels, Stijn [ps. van Frank Lateur], Julebarnet. Vertaling Oscar V. Andersen. København, Varden, 1913. [Het Kerstekind, 1911]

1914

14. Cramer, Rie, Efteraar. Vertaling A.D. Schmidt. Kobenhavn, V. Pio, 1914. [Herfst, 1911]

15. Cramer, Rie, Foraar. Vertaling A.D. Schmidt. Kobenhavn, V. Pio, 1914. [Lente, 1910]

16. Cramer, Rie, Sommer. Vertaling A.D. Schmidt. København, V. Pio, 1914. [Zomer, 1910]

17. Cramer, Rie, Vinter. Vertaling A.D. Schmidt. København, V. Pio, 1914. [Winter, 1911]

18. Naeff, Top, Foller. Vertaling Emma Kraft. København, E. Jespersen, $1914\left[1914^{2} ; 1920^{3}\right]$. [Het veulen, 1903]

1916

19. Cramer, Rie, Dukkemor. Vertaling Kai Friis-Møller. København, E. Jespersen, 1916. [?]

1917

20. Burmester, Marie, Du har sejret, Galilazer! Vertaling H.I.F.C. Matthiesen. Fredericia, Lohse, 1917. [Galilëer, gij hebt overwonnen, 1907]

1918

21. Jehu, Felicie, Kan Nelly rammes? Vertaling Emma Kraft. København, Prior, 1918. [Nel, de ontembare, 1905]

22. Jehu, Felicie, Lille Agnes. Vertaling Emma Kraft. København, Prior, 1918. [?]

1919

23. Jehu, Felicie, Agnes Slawonsky. Vertaling Emma Kraft. København, Prior, 1919. [Agnes Slawonski, 1917]

1921

24. Jehu, Felicie, Professorens Drenge. Vertaling Emma Kraft. København, Prior, 1921. [De 'jongens' van professor van Leeuwen, 1912]

1923

25. Jehu, Felicie, Veninderne. Vertaling Emma Kraft. København, Prior, 1923. [Van zeven meisjes, 1903]

26. Jehu, Felicie, Venindernes Børn. Vertaling Emma Kraft. København, Prior, 1923. [Lief en leed, 1904]

27. Zeggelen, Marie C. van, Bo og Lodi. Vertaling Emma Kraft. København, Prior, 1923. [Het zeeroversjongetje, 1920]

1927

28. Scharten-Antink, Carel \& Margo, Et Husfuld Mennesker. Vertaling Ingeborg Tvede \& Anne Valeton Kjeldgaard. Kobenhavn, Jespersen \& Pio, 1927 [Een huis vol menschen, 1908]

1928

29. Jong, A.M. de, Merinus Gejsens Barndom. Vertaling Clara Hammerich. København, Jespersen \& Pio, 1928. [Het verraad, 1925]

1929

30. Ammers-Küller, Jo van, De Oprørske. Vertaling Clara Hammerich. København, Hasselbalch, 1929. [De opstandigen, 1925]

1930

31. Ammers-Küller, Jo van, Paa Skillevejen. Vertaling Clara Hammerich. København, Hasselbalch, 1930. [Vrouwenkruistocht, 1930]

1931

32. Ammers-Küller, Jo van, Maskerade. Vertaling Clara Hammerich. København, Hasselbalch. 1931. [Maskerade, 1919] 
33. Boudier-Bakker, Ina, Det forjattede Land. Vertaling Clara Hammerich. København, Jespersen \& Pio, 1931. [Het beloofde land, 1903]

34. Koning, Jeanne, Vovehals. Vertaling Clara Hammerich. København, 1931. [De dolle avonturen van Waaghalsje, 1930]

35. Marxveldt, Cissy van [ps. van Cissy de Haan], Borgmesterens Tvillinger. Vertaling Clara Hammerich. København, Jespersen \&i Pio, 1931. [De stormers, 1925]

1932

36. Ammers-Küller, Jo van, Eva og AEblet. Vertaling Clara Hammerich. København, Hasselbalch, 1932. [De appel en Eva, 1932]

37. Ammers-Küller, Jo van, Tantalus. Vertaling Clara Hammerich. København, Hasselbalch, 1932. [Tantalus, 1928]

38. Boudier-Bakker, Ina, Det banker paa Doren. Vertaling Clara Hammerich. København, Jespersen \& Pio, 1932 [1933²; volksuitg. 1936; 1942³ 1950']. [De klop op de deur, 1930]

39. Scharten-Antink, Carel \& Margo, Lykken haenger som en Drueklase. Vertaling Ingeborg. Tvede \& Anne Valeton Kjeldgaard. København, Gyldendal, 1932. ['t Geluk hangt als een druiventros, 1918].

1933

40. Ammers-Küller, Jo van, Ej blot til Lyst. Vertaling Clara Hammerich. Kobenhavn, Hasselbalch, 1933. [Het huis der vreugden, 1922].

41. Man, Herman de [ps. van Salomon Hamburger], Naar Vandene stiger. Vertaling Ingeborg Tvede \& Anne Valeton Kjeldgaard. København, Gyldendal, 1933. [Het wassende water, 1925]

42. Ammers-Küller, Jo van, Ildprøven. Vertaling Clara Hammerich. Kø̧benhavn, Hasselbalch, 1934. [Frans van Altena's vuurproef, 1920]

43. Ammers-Küller, Jo van, Jenny Heysten. Vertaling Clara Hammerich. København, Hasselbalch, 1934. [Jenny Heysten, 1923]

44. Fabricius, Johan, Komedianter drog forbi. Vertaling Bodil Anker Larsen. København, Martin, 1934. [Komedianten trokken voorbij, 1931]

45. Man, Herman de, Vagabonder. Ventaling Ingeborg Tvede \& Anne Valeton Kjeldgaard. København, Gyldendal, 1934. [De kleine wereld, 1932]

46. Ammers-Küller, Jo van, Prins Inkognito. Vertaling Clara Hammerich. København, Hasselbalch, 1935. [Prins Incognito, 1935]

47. Boudier-Bakker, Ina, Hjertets Armod. Vertaling Clara Hammerich. København, Jespersen \& Pio, 1935. [Armoede, 1909]

48. Corsari, Willy [ps. van Wilhelmina A. Douwes-Schmidt], Ene, men stark. Vertaling Ingeborg Tvede \& Anne Valeton Kjeldgaard. Kobenhavn. Schonberg, 1935 [1944; $1948^{7}$; $1954^{10}$; nw. uitg. 1954]. [De man zonder uniform, 1933].

49. Doolaard, A. den [ps. van Comelis Spoelstra], Drueplukkerne. Vertaling Bodil Anker Larsen. København, Martin, 1935. [De druivenplukkers, 1931]

50. Doolaard, A. den, Orientekspres. Vertaling Bodil Anker Larsen. København, Martin, 1935. [Orient Express, 1934]

51. Fabricius, Johan, Mariettas Søn. Vertaling Bodil Anker Larsen. København, Martin, 1935. [Melodie der verten, 1932]

52. Lulofs, Madelon, Gummi. Vertaling Soffy Topsøe. København, Gyldendal, 1935. [Rubber, 1931]

53. Scharten-Antink, Carel \& Margo, Kaerlighedens Under. Vertaling Ingeborg Tvede \& Anne Valeton Kjeldgaard. København, Gyldendal, 1935. [Het wonder der liefde, 1931] 
54. Timmermans, Felix, Delphinerne. Vertaling Peter Hellum. København, Schønberg, 1935. [Anne-Marie, 192!]

1936

55. Ammers-Küller, Jo van, Konge, Dame, Knezgt. Vertaling Clara Hammerich. København, Hasselbalch, 1936. [Heeren, knechten en vrouwen, I: De patriotten, 1934]

56. Boudier-Bakker, Ina, Fru Jacoba. Vertaling Clara Hammerich. København, Jespersen \& Pio, 1936. [Vrouw Jacob, 1935]

57. Corsari, Willy, Laurian Ostars Offer. Vertaling Ingeborg Tvede \& Anne Valeton Kjeldgaard. København, Schønberg, 1936 [1944²]. [De zonden van Laurian Ostar, 1931]

58. Fabricius, Johan, Dansen om Galgen. Vertaling Bodil Anker Larsen. København, Martin, 1936. [De dans om de galg. 1934]

59. Timmermans, Felix, Livsglade. Vertaling Peter Hellum. København, Schønberg, 1936. [Pallieter, 1916]

60. Vries, Theun de, Rembrandr. Vertaling Bodil Anker Larsen. København, Branner, 1936. [Rembrandt, 1931]

1937

61. Ammers-Küller, Hjerter er Trumf. Vertaling Clara Hammerich. København, Hasselbalch, 1937. [Heeren, knechten en vrouwen, II: De Sans-Culotten, 1936]

62. Boudier-Bakker, Ina, Øjets Spejl. Vertaling Clara Hammerich. København, Jespersen \& Pio, 1937. [Het spiegeltje, 1917]

63. Campert, Jan, Havet tier. Vertaling Hedda Syberg. København, Schønberg, 1937. [Wier, 1935]

64. Corsari, Willy, Vejen til Scutari. Vertaling Ingeborg Tvede \& Anne Valeton Kjeldgaard. København, Schønberg. 1937. [De weg naar Scutari, 1936]

65. Coolen, Antoon, De tre Brødre. Ventaling Clara Hammerich. København, Jespersen \& Pio, 1937. [De drie gebroeders, 1936]

66. Elsschot, Willem [ps. van Alfons de Ridder], Adele. Vertaling Clara Hammerich. København, Jespersen \& Pio, 1937. [Tsjip, 1934]

67. Man, Herman de, En Damper $i$ Taage. Vertaling Ingeborg Tvede. København, Gyldendal, 1937. [Een stoombootje in de mist, 1933]

68. Philips, Marianne, Det handte $i$ Wien. Vertaling Bodil Anker Larsen. København, Gyldendal, 1937. [Bruiloft in Europa, 1934]

69. Vries, Anne de, Bartje. Vertaling Clara Hammerich. København, Fremad, 1937. [Bartje, 1935]

70. Timmermans, Felix, Paa Forhaand Tak. Vertaling Clara Hammerich. København, Schønberg. 1937. [Boerenpsalm, 1935]

1938

71. Ammers-Küller, Jo van, Vundet Spil. Vertaling Clara Hammerich. København, Hasselbalch, 1938. [Heeren, knechten en vrouwen, III: De getrouwen, 1938]

72. Boudier-Bakker, Ina, Mødre. Vertaling Clara Hammerich. København, Jespersen \& Pio, 1938. [Aan de overkant, 1920; De moeders, 1925; Paul, 1937]

73. Corsari, Willy, Fodtrin pau Trappen. Vertaling Hedda Syberg. København, Schønberg. 1938 [nw. uitg. 1964]. [Voetstappen op de trap, 1937]

74. Corsari, Willy. Inden tre Dage. Vertaling Hedda Syberg. København, Schønberg, 1938. [Binnen drie dagen, 1935]

75. Corsari, Willy, Maaneskinsonatens Mysterium. Vertaling Hedda Syberg. København, Schønberg, 1938. [Het mysterie van de Mondscheinsonate. 1934]

76. Corsari, Willy, Et Skih uden Havn. Vertaling Ingeborg Tvede \& Anne Valeton Kjeldgaard. Kobenhavn, Schonberg. 1938 [1944; $1947^{5}$ ]. [Schip zonder haven, 1938]

77. Corsari, Willy, Den ubekendte Medspiller. Vertaling Hedda Syberg. Kobenhavn, Schonberg, 1938. [De onbekende medespeler, 1931] 


\section{Bijlage: Lijst van literaire vertalingen Nederlands-Deens, 1900-1990}

78. Gogh-Kaulbach, Anna van, Gifte Folk. Vertaling Bodil Anker Larsen. København, Branner, 1938. [Menschen in 't huwelijk, 1931]

79. Huizinga, Leonhard, Den stromliniede Verden. Vertaling Hedda Syberg. København, Schønberg, 1938. [De gestroomlijnde wereld, 1936]

80. Labberton, Mien, Det store Spørgsmaal. Vertaling Clara Hammerich. København, Hagerup, 1938. [De groote vraag. 1937].

81. Lulofs, Madelon, Kuli. Vertaling Soffy Topsce. Kobenhavn, Gyldendal, 1938. [Koelie, 1932]

82. Made, J.A. van der, Losepenge. Vertaling Hedda Syberg. København, Aschehoug, 1938. [Tweehonderd gulden voor Darja Wledinskaja, 1937]

1939

83. Boudier-Bakker, Ina, Den store Vej. Vertaling Clara Hammerich. København, Jespersen \& Pio, 1939. [Aan den grooten weg, 1939]

84. Corsari, Willy, Kun et Nummer. Vertaling Hedda Syberg. København, Schønberg, 1939 [$1944^{2}$ ]. [Nummers, 1932]

85. Hertog, Ary den, Kvinder til Jacatra. Vertaling Clara Hammerich. København, Jespersen \& Pio, 1939. [Vrouwen naar Jacatra, 1934]

86. Huizinga, Leonhard, Fjerde Generation. Vertaling Hedda Syberg. Kobenhavn, Schønberg. 1939. [Het vierde geslacht, 1937]

87. Martin, Hans, Tidevand. Vertaling Hedda Syberg. København, Schønberg, 1939 [1953²; nw. uitg. 1961; 1974²]. [Getijden, 1938]

1940

88. Ammers-Küller, Jo van, Elselina. Vertaling Clara Hammerich. København, Hasselbalch, 1940. [Elzelina, 1940]

89. Corsari, Willy, Karlighed tilgiver. Ventaling Hedda Syberg. København, Schønberg, 1940. [Terugkeer tot Thera, 1934]

90. Hoogstraten-Schoch, Amanda van, En Moders Kamp. Vertaling Amélie Agger. København, Lohse, 1940. [Gouden teugels, 1927]

91. Josselin de Jong, Kitty de, Familien paa Enk. Vertaling Clara Hammerich. København, Jespersen \& Pio, 1940. [De appel en de stam, 1939]

92. Martin, Hans, Frigjort. Vertaling Hedda Syberg. København, Schønberg, 1940 [1943 ${ }^{10}$; $1967^{17}$; nw. uitg. 1975]. [Vrijgevochten, 1937]

93. Vries, Anne de. Hilde. Vertaling Clara Hammerich. København, Jespersen \& Pio, 1940. [Hilde, 1939]

1941

94. Bunnik, Piet van. Chauffor Maes i Ilden. Vertaling Anne Valeton Kjeldgaard. København, Branner, 1941. [Chauffeur Maas in het vuur, 194I]

95. Corsari, Willy, Gesst i sit eget Hjem. Vertaling Hedda Syberg. Kobenhavn, Schønherg, 1941 [1944 ]. [Een gast in uw huis, 1940]

96. Cramer, Rie, Kvinder. Vertaling Hedda Syberg. København, Schønberg, $\left.1941[194]^{2}\right]$. [Wij, zij en jij. 1937]

97. Eysselsteijn, Ben van, Skabnen satter Kurs. Vertaling Bodil Anker Larsen. Kobenhavn, H.P. Hansen's Bogtrykkeri, 1941. [Tusschen Zuiderkruis en Poolster, 1937]

98. Hartog. Jan de. Hollands Sonner. Vertaling Bodil Anker Larsen. København, Gyldendal, 1941 [1944 $; 1949^{\mathrm{R}}$ : $1954^{\circ}: 1959^{10}$ ]. [Hollands Glorie, 1940]

99. Jong, A.M. de, Uroligt Blod. Vertaling Hedda Syberg. København, Schønberg, 1941. [Poeske, 1941]

100. Nesna, Hans, Hollands Skeebnetime. Vertaling Clara Hammerich. København, Jespersen \& Pio. $1941\left[194 !^{2}\right]$. [Toen het Vaderland riep.... 1940] 
101. Roothaert, A.M., Telefon til Dyrlagen. Vertaling Bodil Anker Larsen. København, Branner, 1941 [nieuwe uitg. Kbh., Grafisk Forlag, 1955]. [Dr. Vlimmen, 1939]

102. Vries, Anne de, Bartje søger Lykken. Vertaling Clara Hammerich. København, Jespersen \& Pio, 1941. [Bartje zoekt het geluk, 1940]

103. Walschap, Gerard, Et Menneske der vil det Gode. Vertaling Clara Hammerich. Kobenhavn, Fremad, 1941. [Een mens van goeden wil, 1936]

1942

104. Brouwer, Johan, Philip Wilhelm. Vertaling Else Tryde. København, Erichsen, $1942\left[1947^{2}\right]$. [Philips Willem, 1940]

105. Brouwer, Johan, Johanna den Vanvittige. Vertaling Hedda Syberg. København, Erichsen, 1942. [Johanna de Waanzinnige, 1940]

106. Bruijn, Cor, Strandens Folk. Vertaling Clara Hammerich. København, Jespersen \& Pio, 1942. [Sil de strandjutter, 1940]

107. Corsari, Willy, Alt for Peter. Vertaling Hedda Syberg. København, Schønberg, 1942. [Alleen maar Peter, 1935]

108. Eysselsteijn, Ben van, Romance i F-dur. Vertaling Bodil Anker Larsen. Fredericia, Nordiske Landes Bogforlag, 1942. [Romance in F-dur, 1934]

109. Huizinga, Leonhard, Den 7. Dag. Vertaling Clara Hammerich. København, Schønberg. 1942. [De zevende dag, 1941]

110. Jonckheere, Karel, Tita flygter. Vertaling Bodil Anker Larsen. København, Westermann, 1942. [Tita vlucht, 1941]

111. Jong, A.M. de, Hadets Evangelium. Vertaling Hedda Syberg. København, Schønberg. 1942. [Het evangelie van de haat, 1923]

112. Kaaden, J.C. [Soewamo] van der, Barns Ojne. Vertaling Hedda Syberg. København, Schønberg, 1942. [De oogen van Roosje Radena, 1934]

113. Toonder, Jan Gerhard, En Fremmed $i$ Babylon. Vertaling Bodil Anker Larsen. København, Branner, 1942. [Vreemdeling in Babylon, 194I]

114. Ammers-Küller, Jo van, Huset med de to Døre. Vertaling Clara Hammerich. København, Hasselbalch, 1943. ['Ma', 1943]

115. Franke, S., Sarina. Vertaling Bodil Anker Larsen. København, Branner, 1943 [1943²]. [Njai Sarina, 1941]

116. Hertog, Ary den, Magrige Holland. Vertaling Clara Hammerich. København, Hirschsprung. 1943. [Machtig Holland, 1941]

117. Houwink, Net, Host i Juni. Vertaling Bodil Anker Larsen. Kobenhavn, Branner, 1943. [Herfst in juni, 1941]

118. Jong. A.M. de, Rivaler. Vertaling Hedda Syberg. Kobenhavn, Schønberg, 1943. [De vreende broeders, 1940]

119. Mens, Jan, Café 'Guldskillingen'. Vertaling Bodil Anker Larsen. Reitzel, 1943. [De Gouden Reael, 1940]

120. Mondria, Henk, Vejen hjem. Vertaling Erik Bertelsen. København, De Unges Forlag. 1943. [Thuisvaart, 1941]

121. Roc. Marja, Oven over Skyerne. Vertaling M. van Rheeden. København, Gyldendal-Nordisk Forlag, 1943. [Door wolken omhoog, 1940]

122. Stuwe, Eline van [ps. van Jacqueline Reyneke van Stuwe], Residenshotellet. Vertaling Hedda Syberg. Kobenhavn, Schonberg, 1943. [Hotel De Residentie, 1930]

123. Toonder, Margje, Hvordan vi klarer den. Vertaling Bodil Anker Larsen. Kobenhavn, Samleren, 1943. [De wind waait weg, 1942] 
1944

124. Bakker, Piet, Frans. Vertaling Clara Hammerich. København, Jespersen \& Pio, 1944 [1946"; nw. uitg. 1948; nw. uitg. 1962; 19737; 1976 ]. [Ciske de rat, 1941]

125. Bakker, Piet, Frans vokser op. Vertaling Clara Hammerich. København, Jespersen \& Pio, 1944 [1946³ nw. uitg. 1948; 19766]. [Ciske groeit op. 1943]

126. Brouwer, Rein, Dug over tørstigt Land. Vertaling Bodil Anker Larsen. København, Branner, 1944 [1944²]. [Dauw over dorstig land, 1941]

127. Kramer, Diet, Urolige Hjerte, Vertaling Bodil Anker Larsen. København, Grafisk Forlag. 1944. [Onnustig is ons har, 1939]

128. Legène, P.M., Blandt Sorte og Brune. Vertaling Leo Legène. København, Lohse, 1944. [Van boschnegers en roodhuiden, 1932]

129. Legène, P.M., Den hrudte Tomahawk. Vertaling Leo Legène. København, Lohse, 1944. [De gebroken tomahawk, 1939]

130. Nijnatten-Doffegnies, H.J. van, Lysets og Skyggernes Hus. Vertaling Nis Degerbol og Annie Holch Justesen. København, Gyldendal, 1944. [Huis van licht en schaduw, 1939]

131. Robberzz, Dignate, Jikkemien. Vertaling Erik Bertelsen. København, De Unges Forlag, 1944. [Jikkemien, 1941]

132. Servaes, Anke [ps. van Anna Geertruida Valkhoff-Wijdom], Søster Lisheth. Vertaling Ingeborg Gad. København, De Unges Forlag, 1944 [1944³ 19454]. [Kinderzaal, 1936]

133. Woude, Johan van der, I Galgen med Dr. Knox! Vertaling Bodil Anker Larsen. København, Branner, 1944. [Anatomie, 1942]

134. Zeggelen, Marie C. van, Claude og Catharine. Vertaling Anne Valeton Kjeldgaard. København, Naver, 1944. [Een liefde in Kennemerland, 1936]

135. Baardman, C., Aaike fra Rørskovene. Vertaling Erik Bertelsen. København, De Unges Forlag [Lohse], 1945. [Een lied van den Biesbosch, 1944]

136. Bakker, Piet, Branding. Vertaling Clara Hammerich. Odense, Skandinavisk Bogforlag, 1945 [nw. uitg. 1965]. [Branding, 1941]

137. Brouwer, Rein, Men Solen sejrede. Vertaling Bodil Anker Larsen. København, Branner, 1945. [Maar de zon overwon, 1942]

138. Hettema jr., H., Mordet paa Rogma-State. Vertaling Anne Valeton Kjeldgaard. København, Naver, 1945. [De moord op Rogma-State, 1942]

139. Jong. A.M. de, Fadrenes Synd. Vertaling Hedda Syberg. København, Schønberg, 1945. [De heks van de Riethoek, 1942]

140. Josselin de Jong, Kitty de, Svaret. Vertaling Clara Hammerich. København, Jespersen \& Pio, 1945. [Het antwoord, 1932]

141. Kanter, Rinke, Det folgende Slagtled. Vertaling Nathalie Tuxen. Odense, Skandinavisk Bogforlag. 1945. [Het andere geslacht, 1941]

142. Kramer. Diet, Ruth. Vertaling Bodil Anker Larsen. København, Grafisk Forlag, 1945. [Begin, 1932]

143. Kempenaer. Nina de. Kvinde er Kvinde varst. Vertaling Anne Valeton Kjeldgaard. København, Branner, 1945. [Ina komt thuis, 1941]

144. Lulofs, Madelon, Den anden Verden. Vertaling Soffy Topsøe. København, Uhlmanske Forlag. 1945 [De andere wereld, 1934]

145. Nijnatten-Doffegnies, H.J. van, Den bandlyste Gaard. Vertaling Nis Degerbøl \& Annie Holch Justesen. København, Gyldendal, 1945. [Moeder Geerte, 1939]

146. Rossum, Rie van, Seminariets fjerde Klasse. Vertaling Marijke \& Carl Håkonsson. København, Lohse, 1945. [De kloof zonder brug. 1934] 
147. Timmermans, Felix, Altertavlen med de hellige tre Konger. Vertaling Gudrun Schou. Kobenhavn, Fischer, 1945 [privédruk]. [Driekoningentriptiek, 1923]

148. Welsenes, Ajjon van, Verdens yngste Piloter. Vertaling Bodil Anker Larsen. Kobenhavn, Branner, 1945. [En de Aalscholver vloog... 1938]

149. Wilma [ps. van Wilhelmina Vermaat], Lillemor Stine. Vertaling Anna Edv. Petersen. København, Lohse, 1945. [Moeder Stieneke, 1926]

1946

150. Aerde, Rogier van [ps. van A. van Rijen], Kain. Vertaling Soffy Topsøe. Kobenhavn, Thorkild Beck, 1946. [Kain, 1941]

151. Bakker, Piet, Frans bliver Mand. Vertaling Clara Hammerich. København, Jespersen \& Pio, 1946 [nw. uitg. 1948; 1976²]. [Ciske de man, 1946]

152. Brouwer, Rein, Og stort blev Livet. Vertaling Bodil Anker Larsen. København, Branner, 1946. [En groot werd het leven, 1944]

153. Corsari, Willy, De af os. Vertaling Hedda Syberg. København, Schønberg. 1946. [Die van ons, 1946]

154. Gogh, Vincent van, Breve $i$ udvalg. Vertaling Kai Flor. København, Berlingske Forlag, 1946 [1959']. [Brieven aan zijn broeder, 1914].

155. Hertog, Ary den, Mor Sigbrit. Vertaling Clara Hammerich. København, Hirschsprung, 1946. [Sybrech Willemsdochter, 1945]

156. Huygens, Charles, Lys og skygge. Vertaling Kai Flor \& Vilhelm Jung. Kobenhavn, Aller, 1946. [Licht en schaduw, 1942]

157. Kramer, Diet, Flint. Vertaling Bodil Anker Larsen. København, Grafisk Forlag, 1946. [De bikkel, 1935]

158. Legène, P.M., Gudebarnet Tani. Vertaling Leo Legène. København, Lohse, 1946. [Tani, het godenkind, 1942]

159. Lulofs, Madelon, Ballade $i$ Budapest. Veraling Soffy Topsøe. København, Uhlmanske Forlag, 1946. [De kleine strijd, 1941]

160. Mondria, Henk, Lauge den sorgløse. Vertaling Erik Bertelsen. København, De Unges Forlag, 1946. [Louwke de zorgeloze, z.j.]

161. Schmitz, Marie, Den store Hjemve. Vertaling Clara Hammerich. Odense, Skandinavisk Bogforlag, 1946. [Het groote heimwee, 1929]

162. Servaes, Anke, Fru Lisbeth. Vertaling Ingeborg Gad. København, De Unges Forlag, 1946. [Kinderen die over zijn, 1937]

163. Fabricius, Johan, Damonernes $\emptyset$. Vertaling Bodil Anker Larsen. København, Rosenkilde \& Bagger, 1947. [Eiland der demonen, 1941]

164. Toonder, Jan Gerhard, Ung Mand slaar sig igennem. Vertaling Clara Hammerich. Odense, Skandinavisk Bogforlag, 1947. [Een man zet door, 1939]

165. Vries, Anne de, Rotteungen. Vertaling Clara Hammerich. Kobenhavn, Fremad, 1947. [Ratje, een jongen van de straat, 1934]

1948

166. Corsari, Willy, Manden, der kom tilbage. Vertaling Hedda Lovland. København, Schønberg, 1948. [De man die niet mocht terugkeren, 1947]

167. Corsari, Willy, Vik vinder. Vertaling Bodil Anker Larsen. København, Korch, 1948. [Wiek wint, 1932]

168. Grée, Marie-Louise [Doudart] de la, Geni eller svindler. Vertaling Ulf $\emptyset$ stergaard. Kobenhavn. Schultz, 1948. [Emmaüs, 1947]

169. Kempenaer, Nina de, Lykkens lunefulde Spil. Vertaling Anne Valeton Kjeldgaard. København. Branner, 1948. [De sprong naar het geluk, 1942] 
170. Selleger-Elout, J.M., Klude-Lise. Vertaling Bodil Anker Larsen. København, Det danske Forlag, 1948. [Lijsje Lorresnor, 1932]

171. Servaes, Anke, Mor Lisbeth. Vertaling Ingeborg Gad. København, De Unges Forlag, 1948. [Moeder Liesbeth, 1938]

172. Vries, Theun de, Frankrigs sorte Søn. Vertaling Bodil Anker Larsen. København, Branner, 1948. [De vrijheid gaat in ' $t$ rood gekleed, 1945]

173. Wessem, Constant van, Jagt paa Bonaparte. Vertaling Bodil Anker Larsen. København, Branner, 1948. [Jacht op Bonaparte, 1940]

1949

174. Bakker, Piet, Barndom $i$ Gyden. Vertaling Clara Hammerich. København, Jespersen \& Pio, 1949. [Jeugd in de Pijp, 1946]

175. Corsari, Willy, Viks vidunderbarn. Vertaling Bodil Anker Larsen. Kobenhavn, Branner \& Korch, 1949. [Wiek's wonderkind, 1934]

176. Geest, K. van der, Rejsen rundt Kap Horn. Vertaling Erik Bertelsen. København, De Unges Forlag, 1949. [De reis rond Kaap Hoom, 1940]

177. Rutgers van der Loeff-Baseau, An, Nybyggerbørn. Vertaling Clara Hammerich. København, Haase, 1949 [1957 ${ }^{3}$. [De kinderkaravaan, 1949]

1950

178. Corsari, Willy, Elskede nar. Vertaling Hedda Løvland. København, Schønberg, 1950. [Geliefde dwaas, 1949]

179. Maros, Antal [ps. van Antal Sivirsky], En lages hjerte. Vertaling Johan Wøller. København, Böthner, 1950. [Nomadenbloed, 1948]

180. Martin, Hans, Den store dårskab. Vertaling Hedda Lovland. Kobenhavn, Schønberg. 1950 [19534; nw. uitg. 1977]. [De grote dwaasheid, 1950]

181. Toonder, Marten, Tom Puss pa eventyr. Vertaling Clara Hammerich. København, Politikens Forlag, 1950. [Tom Poes' vertellingen, 1949]

182. Vreugdenhil, Jacoba M., Pigen Lientje. Vertaling Anna Edv. Petersen. København, Lohse, 1950. [Een meisje als Lientje, 1947]

183. Beukman, Manja, Elisabeth og Kanada. Vertaling Hedda Løvland. København, Schønberg, 1951. [Ik was de bruid van een Canadees, 1950]

184. Boudier-Bakker, Ina, Guld af strủ. Vertaling Clara Hammerich. København, Jespersen \& Pio, 1951. [Goud uit stro, 1950]

185. Hartog, Jan de, Stella. Vertaling Bodil Anker Larsen. København, Grafisk Forlag, 1951 [19523: nw. uitg. 1964]. [Stella, 1950]

186. Lange-Praamsma, Max de, Guld-Else. Vertaling Erik Bertelsen. København, De Unges Forlag. 1951. [Goud-Elsje, 1946]

187. Martin, Hans, Braending. Vertaling Hedda Løvland. København, Schønberg. 1951 [1964; nw. uitg. 1974]. [Branding. 1951]

188. Nijhoff, A.H., To piger og jeg. Vertaling Hedda Lovland. København, Schønberg, 1951. [Twee meisjes en ik, 1931]

1952

189. Corsari, Willy. Denne ene forestilling. Vertaling Hedda Lovland. København, Schønberg. 1952. [Deze ene voorstelling, 1951]

190. Frank, Anne, En ung piges daghog. Vertaling Hedda Løvland. København, Grafisk Forlag.

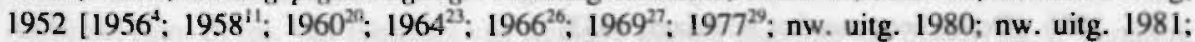
19883]. [Het Achterhuis, 1947]

191. Gijsen, Marnix, Joakim og Susanne. Vertaling M. van Rheden. København, Gyldendal, 1952. [Het boek van Joachim van Babylon, 1947] 
192. Hartog, Jan de, Maria. Vertaling Bodil Anker Larsen. København, Grafisk Forlag, 1952. [Mary, 1951]

193. Martin, Hans, Højt spil. Vertaling Erik Bertelsen. København, Schønberg, 1952 [nw. uitg. 1975]. [Hoog spel, 1952]

1953

194. Coolen, Antoon, Under Guds himmel. Vertaling Clara Hammerich. Kobenhavn, Jespersen \& Pio, 1953. [Kinderen van ons volk, 1928]

195. Corsari, Willy, En ekspres standsede. Vertaling Hedda Løvland. København, Grafisk Forlag, 1953 [nw. uitg. 1960]. [Een express stopte..., 1938]

196. Corsari, Willy, Illision. Vertaling Hedda Løvland. København, Grafisk Forlag, 1953. [Illusies, 1953]

197. Doolaard, A. den, Digerne brister. Vertaling Clara Hammerich. København, Hirschsprung. 1953. [Het verjaagde water, 1947]

198. Gogh, Vincent van, Breve om religion og kunst. Keuze en vertaling H.P. Rohde. Kobenhavn, Thaning og Appel, 1953 [nw. uitg. 1972]. [Verzamelde brieven, 1952].

199. Hartog. Jan de, Thalassa. Vertaling Bodil Anker Larsen. København, Grafisk Forlag, 1953. [Thalassa, 1951]

200. Martin, Hans, Den evige laengsel. Vertaling Erik Bertelsen. København, Schønberg, 1953 [nw. uitg. 1976]. [Het verlangen, 1953]

201. Roothaert, A.M., Vindeltrappen. Vertaling Bodil Anker Larsen. København, Branner \& Korch, 1953. [De wenteltrap, 1949]

202. Vries, Anne de, Vi lever kun een gang. Vertaling Clara Hammerich. København, Jespersen \& Pio, 1953. [Wij leven maar eens, 1951]

1954

203. Bakker, Piet, Kidnappet. Vertaling Clara Hammerich. København, Jespersen \& Pio, 1954. [Kidnap, 1952]

204. Corsari, Willy. När bare jeg har dig. Vertaling Hedda Løvland. København, Grafisk Forlag. 1954 [nw. uitg. 1963]. [Zolang jij bij me bent, z.j.]

205. Corsari, Willy, En ubuden gesst. Vertaling Hedda Løvland. København, Grafisk Forlag, 1954. [Dooden dansen niet, 1939]

206. Dubois, Pierre, Med fingeren pả lazhen. Vertaling Clara Hammerich. København, Jespersen \& Pio, 1954. [Een vinger op de lippen, 1952]

207. Hartog, Jan de, Den lille ark. Veraling Bodil Anker Larsen. København, Grafisk Forlag, 1954 [heruitg. m. titel Srormflod. Kbh., Skrifola, 1963]. [De kleine ark, 1953]

208. Kampen, Anthony van, Junglens pimpernel. Vertaling Erik Bertelsen. København, Nyt Nordisk Forlag, 1954. [Jungle Pimpemel, 1949]

209. Martin, Hans, Marga. Vertaling Erik Bertelsen. København, Schønberg. 1954 [nw. uitg. 1976]. [Marga, 1954]

1955

210. Martin, Hans, Den fjerne vej. Vertaling Erik Bertelsen. København, Schønberg, 1955 [nw. uitg. 1976]. [De verre weg, 1955]

211. Overduin, Jan, Lejesvend og hyrde. Vertaling Anna Edv. Petersen. Kobenhavn, Lohse, 1955. [Huurling en herder, 1951]

212. Doolaard, A. den, Albanerdrengen. Vertaling Clara Hammerich. København, Hirschsprung. 1956. [De herberg met het hoefijzer, 1933]

213. Lennart, Clare. Den rosenrøde stad. Vertaling Clara Hammerich. København. Hassing. 1956. [Stad met rose huizen, 1954] 


\section{Bijlage: Lijst van literaire vertalingen Nederlands-Deens, 1900-1990}

214. Martin, Hans, Ambolten. Vertaling Erik Bertelsen. København, Schønberg, 1956. [Het. aambeeld, 1956]

215. Roothaert. A.M., Dyrlagen forelsker sig. Vertaling Bodil Anker Larsen. København, Grafisk Forlag, 1956. [Vlimmen contra Vlimmen, 1953]

216. Rutgers van der Loeff-Basenau, An, I kamp mod lavinerne. Vertaling Clara Hammerich. København, Haase, 1956. [Lawines razen, 1954]

217. Corsari, Willy, Charles og Charlotte. Vertaling Hedda Lovland. Kobenhavn, Schonberg, 1957. [Charles en Charlotte, 1956]

218. Corsari, Willy, Djavvelen trakker $i$ rrådene. Vertaling Hedda Lovland. København, Grafisk Forlag, 1957. [Moorden en marionetten, 1955]

219. Doolaard, A. den. Landet bag Guds ryg. Vertaling Clara Hammerich. København, Hirschsprung, 1957. [Het land achter Gods rug. 1956]

220. Hartog, Jan de, Lagen. Vertaling Bodil Anker Larsen. København, Grafisk Forlag, 1957 [nw. uitg. m. titel Junglelagen. Kbh., Skrifola, 1964]. [Gods Geuzen (I), 1947]

221. Laan, Dick, Prik og hans venner. Venaling Clara Hammerich. København, Jespersen \& Pio, 1957. [Pinkeltje en zijn vriendjes, 1949]

222. Laan, Dick, Priks eventyr. Vertaling Clara Hammerich. København, Jespersen \& Pio, 1957. [De avonturen van Pinkeltje, 1939]

223. Martin, Hans, Sensommer. Vertaling Erik Bertelsen. København, Schønberg, 1957 [nw. uitg. 1977]. [Late zomer, 1957]

224. Mees, Cornelie, Demeters datter. Vertaling Clara Hammerich. København, Jespersen \& Pio, 1957. [Demeters dochter, 1957]

225. Nijnatten-Doffegnies, H.J. van, Henni. Vertaling Hedda Lovland. Kobenhavn, Grafisk Forlag, 1957. [Henne, 1946]

226. Schmidt, Annie M.G., Den flyvende elevator. Vertaling Rachel Hjorth. Kobenhavn, Fremad, 1957. [Abeltje, 1953]

227. Velde, Jacoba van, Den store sal. Vertaling Clara Hammerich. København, Fremad, 1957. [De grote zaal, 1953]

1958

228. Elsing, Johan-Mark [ps. van Frans Beckers], Afrikas dyre-paradis. Vertaling Lisheth \& Torben Wolf. København, Nyt Nordisk Forlag, 1958. [?]

229. Hartog, Jan de, Trommerne. Vertaling Bodil Anker Larsen. København, Grafisk Forlag. 1958 [nw. uitg. Kbh., Skrifola. 1964]. [Gods Geuzen (II), 1947]

230. Laan. Dick, Prik i Zoo. Vertaling Clara Hammerich. Kobenhavn, Jespersen \& Pio. 1958. [Pinkeltje in Artis, 1952: Pinkeltje en het grote huis, 1953]

231. Laan, Dick, Prik pâ rejse. Vertaling Clara Hammerich. København, Jespersen \& Pio, 1958. [Pinkeltje op reis, 1950]

232. Martin, Hans, Varfftet. Vertaling Erik Bertelsen. København, Schønberg. 1958 [nw. uitg. 1977]. [De werf, 1958]

233. Rutgers van der Loeff-Basenau, Den dodsdomte landsby. Vertaling Clara Hammerich. Kobenhavn, Haase, 1958. [Ze verdrinken ons dorp. 1957]

234. Vestdijk, Simon, Min brune ven. Vertaling Ingeborg Buhl. København, Hasselbalch, 1958. [De bruine vriend, 1935]

235. Aalberse, Han. B. [ps. van Johannes van Keulen], Boh og Daphnes karlighed. Bd. I. Vertaling Else Westh Neuhard. København, Borgen, 1959 [1964 ${ }^{3}$ ]. [De liefde van Bob en Daphne (I). 1955] 
236. Corsari, Willy, Halskademordene. Vertaling Hedda Løvland. København, Grafisk Forlag. 1959. [De man die er niet was, 1959]

237. Dermout, Maria, De titusinde ting. Vertaling Clara Hammerich. Kobenhavn, Hirschsprung. 1959. [De tienduizend dingen, 1956]

238. Elsendoorn, Jo, I Coyamas fodspor. Vertaling Clara Hammerich. København, Haase, 1959. [In het spoor van Coyama, 1960]

239. Laan, Dick, Prik i Afrika. Vertaling Clara Hammerich. København, Jespersen \& Pio, 1959. [Pinkeltje gaat naar Pinkeltjesland, 1956]

240. Martin, Hans, Marianne. Vertaling Erik Bertelsen. København, Schønberg, 1959. [Marianne, 1959]

241. Nijnatten-Doffegnies, H.J. van, Jorden er mit fadreland. Vertaling Hedda Løvland. København, Grafisk Forlag. 1959. [De aarde is mijn vaderland, 1957]

242. Presser, Jac., Urettens tjener. Vertaling Else Westh Neuhard. København, Gyldendal, 1959. [De nacht der Girondijnen, 1957]

1960

243. Aalberse, Han. B. [ps. van Johannes van Keulen], Bob og Daphnes karrlighed. Bd. II. Vertaling Else Westh Neuhard. København, Borgen, 1960 [1964 ${ }^{3}$. [De liefde van Bob en Daphne (II), 1957]

244. Blom, Toos, Kun et skipperharn. Vertaling Karen Nørreby. København, Forlaget Danmark, 1960. [Alles in de wind, 1957]

245. Hartog, Jan de, Lagen vender tilbage. Vertaling Bodil Anker Larsen. København, Grafisk Forlag. 1960 [nw. uitg. m. titel Junglelagen vender hjem. Kbh., Skrifola, 1964]. [Gods Geuzen (III), 1947]

246. Hulst, W.G. van de, Prinsen og parykmageren. Vertaling Karen Nørreby. København, Forlaget Danmark, 1960. [De pruikenmaker en de prins, 1948]

247. Hulst, W.G. van de, Rosemarie. Vertaling Ida Høst. København, Lohse, 1960. [Rozemarijntje, 1933]

248. Hulst, W.G. van de, Rosemarie $i$ skole. Vertaling Ida Høst. København, Lohse, 1960. [Rozemarijntje naar school, 1934]

249. Laan, Dick, Prik og adelstenen. Vertaling Clara Hammerich. København, Jespersen \& Pio, 1960. [Pinkeltje en de flonkersteen, 1957]

250. Last, Jef, Bontot og hans ven. Vertaling Clara Hammerich. København, Jespersen \& Pio, 1960 [1974²]. [I Bontot en I Koese. 1958]

251. Martin, Hans, Voven. Vertaling Bodil Anker Larsen. Kobenhavn. Schønberg, 1960. ISchering en inslag. 1960]

1961

252. Aken, Piet van, Magtens pris. Vertaling Else Westh Neuhard. København, Gyldendal, 1961. [De nikkers, 1959]

253. Hermans, Willem Frederik, Damokles mørke kammer. Vertaling Else Westh Neuhard. København. Spektrum, 1961. [De donkere kamer van Damokles, 1958]

254. Hulst, W.G. van de, Rosemarie og Rode-Peter. Vertaling Ida Høst. Kobenhavn, Lohse, 1961. [Rozemarijntje en Rooie Pier, 1941]

255. Martin, Hans, Det korteste strú. Vertaling Bodil Gad. Kobenhavn, Schønberg, 1961 [nw, uitg. 1978]. [Het kortste eind, 1961]

256. Rhijn, Aleid van, Stormfloden. Vertaling Selma Houstrup Jensen. Kobenhavn, Hemov, 1961. [Een helikopter daalde, 1959]

257. Rutgers van der Loeff-Basenau, An, Da lyset blev borte. Vertaling Karen Norreby. Kobenhavn, De Unges Forlag, 1961. [Het licht in je ogen, 1956] 
258. Timmermans, Felix, Under lykkens tag. Vertaling Thomas Rasch. København, Hasselbalch, 1961. [Minneke Poes, 1943]

1962

259. Corsari, Willy, Børn og elskere. Vertaling Hedda Løvland. København, Grafisk Foriag, 1961. [Kinderen en minnaars, 1961]

260. Duif, Abraham, Det gyldne ceble. Vertaling Ivan Rønn. København, Adolph Holst, 1962. [?]

261. Duif, Abraham, Lille Tommys skib. Vertaling Ivan Rønn. København, Adolph Holst, 1962. [Het schip van Klein-Jan, 1954]

262. Duif, Abraham, Lises have. Vertaling Ivan Rønn. København, Adolph Holst, 1962. [De tuin van Ineke, 1954]

263. Duif, Abraham, Tre små elefanter. Vertaling Ivan Rønn. København, Adolph Holst, 1962 [De olifantjes gaan uit, 1954]

264. Martin, Hans, Lovfaldstid. Vertaling Bodil Gad. København, Schønberg, 1962. [Herfsttij, 1962]

1963

265. Aalberse, Han B., Bob og Daphnes karlighed. Bd. III. Vertaling Erik Stinus \& Jan F. de Zanger. København, Borgen, $1963\left[1966^{4}\right]$. [Liesbeth en de wereld van Bob en Daphne, 1959].

266. Diekmann, Miep, Bogen til min datter. Vertaling Erik Bertelsen. København, Erichsen, 1963. [Als je het nog niet wist, 1962]

267. Martin, Hans, Arven. Vertaling Bodil Gad. København, Schønberg, 1963 [nw. uitg. 1978]. [Het erfdeel, 1963]

268. Pillecijn, Philip de, Narvarelse. Vertaling Clara Hammerich. København, Gad, 1963. [De aanwezigheid, 1937]

269. Pothast-Gimberg, C.E., Eslet Corso. Vertaling Selma Houstrup Jensen. København, Høst, 1963 [Corso het ezeltje, 1959]

270. Vries, Anne de, Panokko og hans venner. Vertaling Clara Hammerich. København, Jespersen \& Pio, 1963. [Panokko en zijn vrienden, 1955]

1964

271. Asscher-Pinkhof, Clara, Stjernehørn. Vertaling Kirsten \& Paul Hoffmann. København, Unitas, $1964\left[1973^{3}\right]$. [Sterrekinderen, 1946]

272. Asscher-Pinkhof, Clara, Tirsa. Vertaling Bodil Gad. København, Høst, $1964\left[1971^{2}\right]$. [Tirsa, 1952]

273. Diekmann, Miep, Store planer. Vertaling Selma Houstrup Jensen. København, Høst, 1964 [Gewoon een straatje, 1959]

274. Martin, Ilden slukkes. Vertaling Bodil Gad. København, Schønberg, 1964 [nw. uitg. 1980]. [Het kortste eind, 1961]

275. Rutgers van der Loeff-Basenau, An, Grukerdrengens flugt. Vertaling Clara Hammerich. København, Haase, 1964. [Vlucht, Wassilis, vlucht!, 1962]

276. Vries, Anne de, Panokko i urskoven. Vertaling Clara Hammerich. København, Jespersen \& Pio, 1964. [Panokko en de wildernis, 1956]

1965

277. Martin, Hans, Kun en danserinde. Vertaling Bodil Gad. København, Schønberg, 1965 [nw. uitg. 1980]. [Danseresje, 1911]

278. Mok, Maurits, Lektor Lykke og hans flojte. Vertaling Majken Jacoby. København, Artakon, 1965. [De fluit van Dr. Kwekkeltee, 1962]

279. Roggeveen, Leonard, Hans Jakoh. Vertaling Henderika Meden. København, Artakon, 1965 [1968 ${ }^{2}$ ]. [Hier is... Jan-Jaap, 1937] 
280. Vries, Anne de, Panokko og de hvide mennesker. Vertaling Clara Hammerich. Kobenhavn, Jespersen \& Pio, 1965. [Panokko en de witte mensen, 1957]

281. Wilkeshuis, C., Lille hvide fjer. Vertaling Henderika Meden. Kobenhavn, Artakon, 1965. [Kleine sneeuwveer, 1961]

1966

282. Andreus, Hans [ps. van Johan Wilhelm van der Zant], Fortallinger. Vertaling Tanja Nilsson \& Kirsten Bech. København, Artakon, 1966. [Kinderverhalen, 1963]

283. Feder-Tal, Karah, Guldringen. Vertaling Karen Stampel. København, Høst, 1966. [Waar bleef de ring?, 1962]

284. Hammerich, Louis L., \& Clara Hammerich [red.], Nyere flamsk prosa. Kobenhavn, Nordisk Sprog- og Kulturforlag, 1966. Vertaling Clara Hammerich. [romanfragmenten en verhalen van Van Aken, Boon, Brulez, Carlier, Claus, Demedts, Elsschot, Gilliams, Gijsen, Jonckheere, Lampo, De Pillecijn, Raes, Roelants, Ruyslinck, Streuvels, Teirlinck, Timmermans, Vandeloo, Walschap. Van de Woestijne]

285. Martin, Hans, Mysteriet pả sydhavsøen. Vertaling Bodil Gad. København, Schønberg. 1966. [De menschaap, 1919]

286. Roggeveen, Leonard, Hans Jakoh bygger en snemand. København, Artakon, 1966. [Jan-Jaap maakt een sneeuwpop, 1947]

287. Roggeveen, Leonard, Hans-Jakob har fodselsdag. København, Artakon, 1966. [Jan-Jaap is jarig, 1938]

288. Roggeveen, Leonard, Hans Jakob og dyrene. København, Artakon, 1966. [Jan-Jaap en zijn beesten, 1939]

289. Roggeveen, Leonard, Okki flytter. København, Artakon, 1966. [Okkie gaat verhuizen, 1940]

290. Roggeveen, Leonard, Okki i sneen. København, Artakon, 1966. [Okkie in de kou, 1934]

291. Roggeveen, Leonard, Okki og fuglene. København, Artakon, 1966. [Okkie en de vogels, 1940]

292. Roggeveen, Leonard, Okki og hans venner. Kobenhavn, Artakon, 1966. [Okki en zijn vriendjes, 1934]

293. Roggeveen, Leonard, Okki Pebernød. København, Artakon, 1966. [Okkie Pepernoot, 1934]

294. Roggeveen, Leonard, Okki ved råd. København, Artakon, 1966. [Okkie weet raad, 1934]

295. Visser, W.F.H., Niku bli'r kurêr. Vertaling Clara Hammerich. København, Haase, 1966. [Niku de koerier, 1963]

296. Visser, W.F.H., Niku - sigøjnerdrengen. Vertaling Clara Hammerich. København, Haase, 1966. [Niku de zigeunerjongen, 1962]

1967

297. Biegel, Paul, Nogleblomsten. Vertaling Louk Frølund. København, Artakon, 1967. [Het sleutelkruid. 1964]

298. Bruna, Dick, I cirkus. Vertaling Hans-J. Nielsen. Kobenhavn, Vinten, 1967. [Cirkus, 1962]

299. Bruna, Dick, Katinka $i$ cirkus. Vertaling Hans-J. Nielsen. Kobenhavn, Vinten, 1967. [Nijntje, 1955]

300. Bruna, Dick, En lille prins. Vertaling Hans-J. Nielsen. København, Hagerup, 1967. [De koning, 1962]

301. Bruna, Dick, Misse Katti. Vertaling Hans-J. Nielsen. København, Vinten, 1967. [Poesje Nel, 1959]

302. Roggeveen, Leonard, Hans Jakob og toget. København, Artakon, 1967. [Jan-Jaap heeft een trein, 1952]

1968

303. Cremer, Jan, Jeg - Jan Cremer. Vertaling Knud E. Jensen. København, Stig Vendelkær, 1968. [Ik Jan Cremer, 1964] 
304. Haar, Jaap ter, Boris. Vertaling Clara Hammerich. København, Jespersen \& Pio, 1968. [Boris, 1966]

305. Haar, Jaap ter, Lotte fär nye venner. Vertaling Erik Jensen. København, Jespersen \& Pio, 1968. [Lotte krijgt nieuwe vrienden, 1966]

306. Haar, Jaap ter, Lotte $i$ zoologisk have. Vertaling Erik Jensen. København, Jespersen \& Pio, $1968\left[1973^{2}\right]$. [Lotte in de dierentuin, 1966]

307. Haar, Jaap ter, Lotte og den lille elefant. Vertaling Erik Jensen. København, Jespersen \& Pio, 1968. [Lotte met Roegan op stap, 1966]

308. Hammerich, Clara \& Geerte de Vries [red]. Nyere hollandsk prosa - Sluserne äbnes. Vertaling Clara Hammerich. København, Jespersen \& Pio, 1968. [romanfragmenten en verhalen van Belcampo, Blaman, Bordewijk, Boudier-Bakker, Campert, Carmiggelt, Coolen, Couperus, Dermout, Den Doolaard, Hamelink, Helman, Hermans, De Jong, Koolhaas, Minco, Morriën, Mulisch, Du Perron, Van het Reve, Van Schendel, Slauerhoff, Van Velde, Vestdijk, Wolkers]

309. Iterson, S.R. van, Adjudanten på lastvognen. Vertaling Astrid Jensen. København, Borgens Forlag, 1968. [De adjudant van de vrachtwagen, 1967]

1969

310. Bamard, Henk, Bongo. Vertaling Erik Jensen. København, Jespersen \& Pio, 1969. [Bongo, 1965]

311. Bouhuys, Mies, Fortcellinger. Vertaling Tanja Nilsson \& Kirsten Bech. København, Artakon, 1969. [Kinderverhalen, 1964]

312. Haar, Jaap ter, Lotte og onkel Nille. Vertaling Erik Jensen. København, Jespersen \& Pio, 1969. [Lotje mee met oom Nijltje, 1967]

313. Multatuli, Drømmen om Insulinde. Vertaling Ingeborg Buhl. København, Hasselbalch, 1969. [keuze uit de brieven, 1845-1887]

314. Scheffer, Chris, Pinni forlader den store skov. København, Artakon, 1969. [Puntje gaat weg uit het grote bos, 1962]

315. Scheffer, Chris, Pinni og Fluks. København, Artakon, 1969. [Puntje en Vlegel, 1962]

316. Scheffer, Chris, Pinni og Søren. København, Artakon, 1969. [Puntje en Spido, 1962]

317. Scheffer, Chris, Pinni og Søren tager til byen. København, Artakon, 1969. [Puntje en Spido gaan naar de stad, 1962]

318. Visser, W.F.H., Niku på flugt. Vertaling Clara Hammerich. København, Haase \& Søn, 1969. [Niku de zwerver, 1965]

1970

319. Haar, Jaap ter, Bart. Vertaling Erik Jensen. Kobenhavn, Jespersen \& Pio, 1970. [Bart, 1968]

320. Maran. Tim, Menneskeaderen fra Tjarinti. Vertaling Clara Hammerich. København. Borgen, 1970. [De menseneter van Tjarinti, 1969]

321. Stam, Els, Mads og Mette. Vertaling Ellen Kirk. Køhenhavn, Lademann, 1970 !nw. uitg. Kbh., Sesam, 1975]. [Mark en Mieke, 1969]

322. Stam, Els, Mads og Mente $i$ den hvide skov. Vertaling Ellen Kirk. København, Lademann, 1970 [nw. uitg. Kbh., Sesam, 1975]. [Mark en Mieke in het sneeuwbos, 1969]

323. Stam. Els, Mads og Mette i parken. Vertaling Ellen Kirk. København, Lademann, 1970 [nw. uitg. Kbh., Sesam, 1975]. [Mark en Mieke zoeken Lapje, 1969]

324. Stam. Els, Mads og Mette på torvet. Vertaling Ellen Kirk. København, Lademann, 1970 [nw. uitg. Kbh., Sesam, 1975]. [Mark en Mieke gaan naar de markt, 1969]

325. Biegel, Paul, Den lille kaptajn. Vertaling Clara Hammerich. København, Carlsen, 1971. [De kleine kapitein, 1971]

326. Bruna, Dick, I skole. Vertaling Thøger Birkeland. København, Gyldendal, 1971 [1977²]. [De school, 1964] 
327. Bruna, Dick, Jeg kan lase. Vertaling Thøger Birkeland. København, Gyldendal, 1971. [Ik kan lezen, 1965]

328. Bruna, Dick, Jeg kan tälle. Vertaling Thøger Birkeland. København, Gyldendal, 1971. [Telboek, 1968]

329. Chanowski, Thijs, Fablernes verden. Vertaling Tonny Lützer. Bagsværd, Interpresse, 1971. [De Fabeltjeskrant, 1969]

330. Clinge Doorenbos, J.P.J.H., På bondegården. København, Litas, 1971 [Boerderijdieren, 1958]

331. Haar, Jaap ter, Bart med geologerne i Yukon. Vertaling Erik Jensen. København, Jespersen \& Pio, 1971. [Bart met de geologen naar Yukon, 1968]

332. Hollandske noveller. Red. en vertaling Jan de Zanger. København, Gyldendal, 1971. [verhalen van Bernlef, Campert. Claus, Hamelink, Hermans, Minco, Raes, Van het Reve, Vandeloo, Wiener, Wolkers]

333. Postma, Paul, Kasper har fodselsdag. Vertaling Maria Wiuff. København, Notabene, 1971. [Jan Klaassen krijgt een feestneus, 1968]

334. Reesink, Marijke, Ønske-ballonerne. Vertaling Ib Permin. København, Høst \& Søn, 1971. [De wensballonnen, 1971]

1972

335. Bruna, Dick, Fortael en historie. Vertaling Thøger Birkeland. København, Gyldendal, 1972. [Boek zonder woorden, 1968]

336. Bruna, Dick, Aggget. Vertaling Thøger Birkeland. København, Gyldendal, 1972. [Het ei, 1962]

337. Bruna, Dick, Jeg kan loese mere. Vertaling Thøger Birkeland. København, Gyldendal, 1972. [Ik kan nog meer lezen, 1969]

338. Diekmann, Miep, Jossy bliver indianer. Vertaling Ragna Kaiser. København, Gyldendal, 1972. [Jossy wordt een indiaan, 1968]

339. Heymans, Margriet, Pernilles pony. Vertaling Martin Berg. København, Berg, 1972. [Hollidee de circuspony, 1972]

340. Koolhaas, Anton, Dykkeren og den forsvundne fisk. Vertaling Erik Stinus \& Jan de Zanger. København, Borgen, 1972. [Stiemer en Stalma, 1939]

341. Reesink, Marijke, Hans og dragen med de tolv hoveder. Vertaling Eva Glistrup. København, Høst, 1972. [Diederik en de dieren, 1969]

342. Schmidt, Annie M.G., Kattepigen frøken Minus. København, Jespersen \& Pio, 1972. [Minoes, 1970]

1973

343. Barnard, Henk, Marokkaneren og siameseren. Vertaling Iver Jespersen. København, Jespersen \& Pio, 1973 [De marokkaan en de kat van tante Da, 1972]

344. Bruna, Dick, EEhler. Vertaling Thøger Birkeland. København, Gyldendal, 1973. [De appel, 1953]

345. Bruna, Dick, Fisken. Vertaling Thøger Birkeland. København, Gyldendal, 1973. [De vis, 1962]

346. Bruna, Dick, Den lille fugl. Vertaling Thøger Birkeland. København, Gyldendal, 1973. [Vogeltje, 1959]

347. Corsari, Willy, Den hitre vin. Vertaling Hedda Løvland. Glostrup. Winther, 1973. [De bittere wijn, 1966]

348. Heymans, Margriet, Peter Rodnase og roverne, Vertaling Martin Berg. København, Berg. 1973. [Jan Klaassen en het roverskind, 1973]

349. Last, Jef, Tjubek $i$ iigerskoven. Vertaling Iver Jespersen. København, Jespersen \& Pio, 1973. [Tjubek in het Tijgerbos, 1972] 
350. Bruna, Dick, Dyr $i$ vores land. Vertaling Thøger Birkeland. København, Gyldendal, 1974. [Dierenboek, 1972]

351. Bruynestein, Dick, Banan-Børge. København, Interpresse, 1974. [Appie Happie, 1971].

352. Haar, Jaap ter, Berends lille verden. Vertaling Iver Jespersen. København, Jespersen \& Pio, 1974. [Het wereldje van Beer Ligthart, 1973]

353. Reesink, Marijke, Hesten der sprang højest. Vertaling Eva Glistrup. København, Høst \& Søn, 1974. [Grauwstaartje, toverpaardje, 1974]

\section{5}

354. Bruna, Dick, Dyr $i$ andre lande. Vertaling Thøger Birkeland. København, Gyldendal, 1975. [Dierenboek (II), 1972]

355. Heymans, Margriet, Rikke i rodehuset. Vertaling Martin Berg. København, Berg, 1975. [Kattekwaad en popperommel, 1975]

356. Vries, C.M. de, Drengens drømme. Vertaling Knud Tagholt. Århus, Aros, 1975. [De jongen met de mooie jas, 1971]

357. Kessels, Loek, Historien om en lille bil. København, Sesam, 1976 [Een leuk verhaal met een auto, 1976]

358. Kessels, Loek, Historien om en lille flyvemaskine. København, Sesam, 1976 [Een leuk verhaal met een vliegtuig, 1976]

359. Kessels, Loek, Historien om et lille skib. København, Sesam, 1976 [Een leuk verhaal met een boot, 1976]

360. Kessels, Loek, Historien om et lille tog. København, Sesam, 1976 [Een leuk verhaal met een trein, 1976]

361. Kresse, Hans, Tordenbetvingerne. Vertaling Freddy Milton. København, Carlsen, 1976 [1977²]. [De meesters van de donder, 1973]

362. Kresse, Hans, Vindens sønner. Vertaling Freddy Milton. København, Carlsen, $1976\left[1977^{2}\right]$. [De kinderen van de wind, 1973]

1977

363. Huygen, Wil, Nisser i hverdag og fest. Vertaling Vagn Simonsen. København, Sesam, 1977 [1977² nw. uitg. 1982; nw. uitg. 1983; nw. uitg. $1988 \mathrm{~m}$. titel Áret rundt hos nisserne]. [Leven en werken van de kabouter, 1976]

364. Kuijer, Guus, Tre forfizrdelige dage. Vertaling Iver Jespersen. Køhenhavn, Jespersen \& Pio, 1977. [Drie verschrikkelijke dagen, 1976]

365. Lauryssens, Stan, De skcebnesvangre händ. Vertaling Hedda Lovland. Glostrup. Winther, 1977. [De Eichmann-erfenis, 1976].

366. Lodewijk, Martin, Te for to. Vertaling Freddy Milton \& Eva Ekelöf. Bagsværd, Williams, 1977. [Twee voor thee, 1972]

367. Roep, Thom, Eventyret om Gammelpot og den forkalede prinsesse. Vertaling Tonny Lützer. Bagsværd, Williams, 1977 [1982²; 19883]. [De verwende prinses, 1977]

368. Roep. Thom, Eventyret om Gammelpot og hemmeligheden om den skjulte dal. Vertaling Tonny Lützer. Bagsværd, Williams, 1977 [1982²: 1988 $]$. [Het verborgen dierenrijk, 1977]

369. Stam, Els, Mads og Mette i cirkus. Vertaling Ellen Kirk. København, Sesarn, 1977. [Mark en Mieke in het circus, 1972]

370. Stam, Els, Mads og Mette klader sig ud. Vertaling Ellen Kirk. København, Sesam, 1977. [Mark en Mieke spelen toneel, 1972]

371. Stam, Els, Mads og Mette hjolper mor. Vertaling Ellen Kirk. København, Sesam, 1977. [Mark en Mieke helpen moeder, 1972] 
372. Stam, Els, Mads og Mette larer at svømme. Vertaling Ellen Kirk. Kobenhavn, Sesarn, 1977. [Mark en Mieke leren zwemmen, 1972]

1978

373. Bruna, Dick, Miffi $i$ zoologisk have. Vertaling Thøger Birkeland. København, Gyldendal, 1978. [Nijntje in de dierentuin, 1955]

374. Bruna, Dick, Miffi pả legepladsen. Vertaling Thøger Birkeland. København, Gyldendal, 1978. [Nijntje in de speeltuin, 1975]

375. Cramer, Rie, Om dit og dat. Vertaling Christopher Maaløe. København, Carlsen, 1978. [Van dit en van dat, 1978]

376. Cramer, Rie, Pylle nylle. Vertaling Christopher Maaløe. København, Carlsen, 1978. [Bont en blij. 1978]

377. Cramer, Rie, Søs og jeg. Vertaling Christopher Maaløe. København, Carlsen. 1978. [Zus en ik. 1975]

378. Kresse, Hans, Ondskabens vej. Vertaling Freddy Milton. København, Carlsen, 1978. [De gezellen van het kwaad, 1975]

379. Kresse, Hans, Ulvekaldet. Vertaling Freddy Milton. København, Carlsen, 1978. [De zang van de prairiewolven, 1975]

380. Roep. Thom, Eventyret om Gammelpot og den lumske lage. Vertaling Tonny Lützer. Bagsværd, Williams, 1978 [nw. uitg. Bagsvard, Interpresse, 1983]. [De valse heelmeester. 1978]

381. Roep, Thom, Eventyret om Gammelpot og porten til østen. Vertaling Tonny Lützer. Bagsvard, Williams, 1978 [nw. uitg. Bagsværd, Interpresse, 1983]. [De poort naar Oost, 1978]

382. Schmidt, Annie M.G., Farfars briller. Vertaling Jette Ahm. København, Gyldendal, 1978. [De bril van opa, 1974]

383. Schmidt, Annie M.G., Høje huse - lave huse. Vertaling Jette Ahm. København, Gyldendal, 1978. [Hoog en laag, 1972]

384. Schmidt. Annie M.G., Jennie flytter ind. Vertaling Jette Ahm. København, Gyldendal, 1978. [Het lege huis, 1974]

385. Schmidt, Annie M.G., En tunnel i Holland. Vertaling Jette Ahm. København, Gyldendal, 1978. [De tunnel, 1973]

386. Verroen, Dolf, Alle mand op $i$ traet. Vertaling Else Westh Neuhard. København, Sommer \& Sørensen, 1978 [nw. uitg. Kbh., Alle Bøms Bogklub, 1978]. [Allemaal de boom in, 1976]

1979

387. Bruna. Dick. Miffis fødselsdag. Vertaling Thøger Birkeland. Kabenhavn, Gyldendal, 1979. [Het feest van Nijntje, 1971]

388. Bruna, Dick, Miffi $i$ sneen. Veraling Thagger Birkeland. Kobenhavn, Gyldendal, 1979. [Nijntje in de sneeuw, 1963]

389. Evenhuis, Gertie, Hvad med mig? Vertaling Bent Faurby. København, Munksgaard, 1979. [En waarom ik niet?, 1978]

390. Kresse, Hans, Guldet i hjergene. Vertaling Freddy Milton. Kobenhavn, Carlsen, 1979. [De welp en de wolf, 1976]

391. Kresse, Hans, Hoxvens pile. Vertaling Freddy Milton. København, Carlsen, 1979. [De weg van de wraak, 1975]

392. Kuijer. Guus, Smide med dukkerne. Vertaling Lene Meyer. København, Borgen, 1979. [Met de poppen gooien, 1975]

393. Kuijpers, Henk, Krimimuseet. Vertaling Claus Jorgensen. Bagsvæerd, Interpresse, 1979. [Het misdaadmuseum, 1974]

394. Meulenbelt, Anja, Skammen forhi. Vertaling Jo Wille. Peter Vingerhoets, Eva Højbak \& Bodil Romme. Arhus, Modtryk, 1979. [De schaamte voorbij. 1974] 
395. Roep. Thom, Eventyret om Gammelpot og skakten til nordpolen. Vertaling Claus Jorgensen. Bagsværd, Williams, 1979. [De schacht naar Noord, 1979]

396. Roep. Thom, Eventyret om Gammelpot og tảgesømonsteret. Vertaling Claus Jørgensen. Bagsvard, Williams, 1979. [Het monster van het mistmeer, 1979]

397. Wetering, Janwillem van de, Døden på diget. Vertaling Hans Hansen. Glostrup. Winther. 1979. [De gelaarsde kater, 1976]

398. Wetering, Janwillem van de, Outsider. Vertaling Hans Hansen. Glostrup. Winther, 1979. [Het lijk in de Haarlemmer Houttuinen, 1975]

399. Wetering, Janwillem van de, Vindheksen. Vertaling Hans Hansen. Glostrup. Winther, 1979. [Buitelkruid, 1976]

1980

400. Beckman, Thea, Min far hor i Brasilien. Vertaling Kurt Juul. København, Munksgaard, 1980. [Mijn vader woont in Brazilië, 1974]

401. Curtis, Cécile, Imme Dros, Harry Geelen [et al.]. Dyrenes dal: den skurkagtige sommerfugl. Vertaling Anita Aagaard. Ølstykke, Savik, 1980. [Niemands dal: een vlerk van een vlinder. 1980]

402. Huygen, Wil, Nisser. Vertaling Freddy Milton. København, Carlsen, 1980. [kinderboek, gebaseerd op: Leven en werken van de kabouter, 1976]

403. Kresse, Hans, Frihedens pris. Vertaling Freddy Milton. København, Carlsen, 1980. [De prijs van de vrijheid, 1979]

404. Kresse, Hans, Slavejagerne. Vertaling Freddy Milton. København, Carlsen, 1980. [De gierenjagers, 1978].

405. Kruis, Jan, Birte, Bent og børnene (1). Vertaling Freddy Milton. København, Carlsen, 1980. [Jan, Jans en de kinderen, 1972]

406. Kuijpers, Henk, Mestervarket. Vertaling Claus Jørgensen. Bagsværd, Interpresse, 1980. [Het meesterwerk, 1978]

407. Roep, Thom, Eventyret om Gammelpot og broen til vesten. Vertaling Tore Bahnson. Bagsvard, Williams, 1980. [De weg naar West, 1980]

408. Schubert, Ingrid \& Dieter, Der er en krokodille under min seng. Vertaling Ulla Warren. København, Gyldendal, 1980. [Er ligt een krokodil onder mijn bed, 1980]

409. Smet, Peter de, Al magt til generalen. Vertaling Per Vadmand. Bagsværd, Interpresse, 1980. [Alle macht aan de generaal, 1980]

410. Wilkeshuis, Cornelis, Den bedste gave. Vertaling Rita van Bilsen. København, Sommer \& Sørensen, 1980. [Het mooiste geschenk, 1977]

1981

411. Kruis, Jan, Birte, Bent og bornene (2). Vertaling Freddy Milton. København, Carlsen, 1981. [Jan, Jans en de kinderen, 1972]

412. Kuijpers, Henk, Spøgelsesskibets hemmelighed. Vertaling Niels Søndergaard. Bagsvard, Interpresse, 1981. [De terugkeer van de Noorderzon, 1979]

413. Kuijpers, Henk, Spøgelsesskihet vender tilbage. Vertaling Niels Sø̋ndergaard. Bagsvard, Interpresse, 1981. [De wraak van het vrachtschip. 1979]

414. Lodewijk, Martin, Sagen om de knuste glas. Vertaling Per Vadmand. Bagsværd, Interpresse, 1981. [Dossier Onderwater, 1977]

415. Multatuli, Max Havelaar. Vert. Grete Bentsen \& Gerard Cruys [ps. v. Gerard Kruisman]. København, Hekla, 1981. [Max Havelaar, 1860]

416. Roep, Thom, Eventyret om Gammelpot, vejen til syden. Vertaling Niels Søndergaard. Bagsværd, Interpresse, 1981. [De zee naar Zuid, 1981] 
1982

417. Briel, Dick, Mysteriet om Tacho-planten. Vertaling Tore Bahnson. Bagsværd, Interpresse, 1982. [Het mysterie van de Tachoplant, 1981]

418. Huygen, Wil, Nissernes hemmelige bog. Vertaling Vagn Simonsen. København, Sesam, 1982. [De oproep der kabouters, 1981]

419. Kuijpers, Henk, Cirkus Santekraam. Vertaling Niels Søndergaard. Bagsværd, Interpresse, 1982. [Circus Santekraam, 1981]

420. Lodewijk, Martin, Sagen om nattevagten. Vertaling Per Vadmand. Bagsværd, Interpresse, 1982. [Dossier Nachtwacht, 1980]

421. Roep. Thom, Eventyret om Gammelpot og festen på Falkensteen. Vertaling Jussi [Olsen]. Bagsværd, Interpresse, 1982. [Horyn de flierefluiter, 1982]

422. Schippers, Wim T., Varre end fanden selv. Vertaling Jussi Olsen. Bagsværd, Runepress, 1982. [Sjef van Oekel in de bocht, 1980]

1983

423. Arion, Frank Martinus, Dobbelispil. Vertaling Grete Bentsen \& Gerard Cruys. København, Hekla, 1983. [Dubbelspel, 1973]

424. Beckman, Thea, Jorden rundt med Korilu. Vertaling Gyda Skat Nielsen. København, Sommer \& Sørensen, 1983. [Met Korilu de griemel rond, 1970]

425. Beckman, Thea, Korstog i jeans. Vertaling Gyda Skat Nielsen. København, Sommer \& Sørensen, 1983. [Kruistocht in spijkerbroek, 1973]

426. Briel, Dick, Rustgranaten. Vertaling Tore Bahnson. Bagsværd, Interpresse, 1983. [De roestgranaat, 1982]

427. Hillesum, Etty, Et kranket liv. Vertaling Birthe Lundsgaard Sørensen. København, Lindhardt \& Ringhof, 1983. [Het verstoorde leven, 1981]

428. Kuijpers, Henk, Uhyret fra Fladmarsken. Vertaling Niels Søndergaard. Bagsværd, Interpresse, 1983 [Het monster van de Moerplaat, 1982]

429. Lodewijk, Martin, Dodens palads. Vertaling Niels Søndergaard. Bagsværd, Interpresse, 1983. [De laatste vechter, 1979]

430. Lodewijk, Martin, Sagen om 30 airs ventetid. Vertaling Per Vadmand. Bagsværd, Interpresse, 1983. [Dossier Leeuwenkuil, 1979]

431. Roep, Thom, Eventyret om Gammelpot og smuglerborgen. Vertaling Edith Månsson. Bagsvard, Interpresse, 1983. [De tanden van Casius Gaius, 1983]

432. Schubert, Dieter, Jakoh som sømand. Vertaling Karin Robson. København, Carlsen, 1983. [Ravestreken, 1982]

433. Toonder, Marten, Tom Puss og hr. Brumme. Vertaling Marjonne Jakobsen. København, Carlsen, 1983. [Tom Poes en de tere heer, 1971]

434. Toonder, Marten, Tom Puss og snemandene. Vertaling Svend Juel Jakobsen. København. Carlsen, 1983. [Tom Poes en de ijzige heinen, 1981]

435. Toonder, Marten, Tom Puss og uhyret fra Hopdalen. Vertaling Marjonne Jakobsen. København, Carlsen, 1983. [Tom Poes en het monster van de hopvallei, 1962]

436. Toonder, Marten, Tom Puss og vandskollingen. Vertaling Svend Juel Jakobsen. København, Carlsen, 1983. [Tom Poes en de woelwater, 1977]

437. Vandersteen, Willy, De forheksede pirater. Vertaling Jette Bak. København, Skandinavisk Press, 1983. [De gevemiste zeerovers, 1980]

438. Vandersteen, Willy, Den magiske stråle. Vertaling Jette Bak. København, Skandinavisk Press, 1983. [De sprietatoom, 1948].

439. Vandersteen, Willy, Den scelsomme ring. Vertaling Jette Bak. København, Skandinavisk Press. 1983. [De wilde weldoener, 1971]. 


\section{Bijlage: Lijst van literaire vertalingen Nederlands-Deens, 1900-1990}

440. Vandersteen, Willy, Jungleblomsten. Vertaling Jette Bak. København, Skandinavisk Press, 1983. [De junglebloem, 1971]

441. Vandersteen, Willy, Robotterne fra rummet. Vertaling Jette Bak. København, Skandinavisk Press, 1983. [De wolkeneters, 1971]

442. Vandersteen, Willy, Texas' skraek. Vertaling Jette Bak. København, Skandinavisk Press, 1983. [De Texasrakkers, 1960]

443. Vos, Ida, De er jo ikke anderledes. Vertaling Iver Jespersen. København, Jespersen \& Pio, 1983. [Wie niet weg is wordt gezien, 1975]

1984

444. Frank, Anne, Fortaellinger og handelser fra baghuset. Vertaling Hans Jakob og Anita Aagaard. København, Grafisk Forlag, 1984. [Verhaaltjes en gebeurtenissen uit het Achterhuis, 1982]

445. Krever, Jetty, Ulykken. Vertaling Jette Skovbjerg. København, Munksgaard, 1984 [1985²]. [Het ongeluk, 1982]

446. Lodewijk, Martin. Sagen om hekseringen. Vertaling Per Vadmand. Bagsværd, Interpresse, 1984. [Dossier Heksenkring, 1977]

447. Schell, Simone, Der var engang. Vertaling Jette Skovbjerg. København, Munksgaard, 1984. [Zeezicht, 1979]

448. Terlouw, Jan, Hvordan man bliver konge. Vertaling Bente Kromann. København, Sommer \& Sørensen, 1984. [Koning van Katoren, 1971]

449. Terlouw, Jan, Krigens sidste vinter. Vertaling Gyda Skat Nielsen. København, Sommer \& Sørensen, 1984. [Oorlogswinter, 1972]

450. Toonder. Marten, Panda på opdagelsesrejse; Panda og det tunge vand. Vertaling Per Vadmand. København, Carlsen, 1984. [Panda en de meester-ontdekkingsreiziger, 1973; ?]

451. Toonder, Marten, Panda som racerkorer; Panda og enehoeren. Vertaling Per Vadmand. København, Carlsen, 1984. [Panda en de kalkerkar; Panda en de geheimzinnige kluizenaar. 1984]

452. Toonder, Marten, Tom Puss og de summende kugler. Vertaling Per Vadmand. København, Carlsen, 1984. [Tom Poes en de brombollen, 1980]

453. Toonder, Marten, Tom Poes og efterligneren. Vertaling Per Vadmand. København, Carlsen, 1984. [Tom Poes en de namaker, 1975]

454. Vandersteen, Willy, Abernes fest. Vertaling Jette Bak. København, Skandinavisk Press, 1984. [De apekermis, 1965]

455. Vandersteen, Willy, Ballonmysteriet. Vertaling Freddy Milton. København, Skandinavisk Press, 1984. [De zingende zwammen, 1960]

456. Vandersteen, Willy, Byen $i$ skyen. Vertaling Jette Bak. København, Skandinavisk Press, 1984. [?]

457. Vandersteen, Willy, Cirkuskongen. Vertaling Eva Rothenborg. København, Skandinavisk Press, 1984. [De circusbaron, 1955]

458. Vandersteen, Willy. Den farlige trolddomsurl. Vertaling Eva Rothenborg. København. Skandinavisk Press, 1984. [?]

459. Vandersteen, Willy, Den forunderlige hest. Vertaling Eva Rothenborg. Kobenhavn, Skandinavisk Press, 1984. [Het rijmende paard, 1963]

460. Vandersteen, Willy, Den graedende ruderdame. Vertaling Eva Rothenborg. København, Skandinavisk Press, 1984. [De kaartendans, 1962]

461. Vandersteen, Willy, Den magiske saks. Vertaling Jette Bak. København, Skandinavisk Press, 1984. [De kale kapper, 1971]

462. Vandersteen, De smó kobberfolk. Vertaling Jette Bak. København, Skandinavisk Press, 1984. [De koperen knullen, 1981]. 
463. Vandersteen, Willy, Det katastrofale spil. Vertaling Freddy Milton. København, Skandinavisk Press, 1984. [De gekke gokker, 1972]

464. Vandersteen, Willy. Det mystiske land. Vertaling Jette Bak. København, Skandinavisk Press, 1984. [Het mini-mierennest, 1971]

465. Vandersteen, Willy, Guldcirklen. Vertaling Jette Bak. København, Skandinavisk Press, 1984. [De gouden cirkel, 1960]

466. Vandersteen, Willy, Puppetross ulyksalige guld. Vertaling Jette Bak. København, Skandinavisk Press, 1984. [?]

467. Vandersteen, Willy, Rumagget. Vertaling Freddy Milton. København, Skandinavisk Press, 1984. [Het zoernende ei, 1967]

468. Vandersteen, Spøgelsesborgen. Vertaling Jette Bak. København, Skandinavisk Press, 1984. [De maffe maniak, 1977]

469. Vandersteen, Willy. Spøgelsesskibet. Vertaling Jette Bak. København, Skandinavisk Press. 1984. [De kleppende klipper, 1956].

1985

470. Brouwers, Jeroen, Rødt bundfald. Vertaling Birthe Lundsgaard Sørensen. København, Gyldendal, 1985. [Bezonken rood, 1981]

471. Capteyn, Willem, Sanne. Vertaling Birthe Lundsgaard Sørensen. København, Gyldendal, 1985. [Sanne, 1983]

472. Hartman, Evert, Krig uden venner. Vertaling Brigitte Brix. København, Sommer \& Sørensen, $1985\left[1986^{2}\right]$. [Oorlog zonder vrienden, 1979]

473. Lodewijk, Martin, Sagen om søndagsbarnet (I). Vertaling Per Vadmand. Bagsværd, Interpresse, 1985. [Dossier Zondagskind, 1978]

474. Matena. Dick. Som faderen, så sønnen. Vertaling Per Vadmand. Bagsværd, Interpresse, 1985. [De wraak van Zwarte Gorre, 1973]

475. Roep. Thom, Eventyret om Gammelpot og drilledyret. Vertaling Edith Månsson. Bagsvard. Interpresse, 1985. [De laatste plager, 1985]

476. Terlouw, Jan, Pjotr. Vertaling Søren H. Madsen. København, Sommer \& Sørensen, 1985. [Pjotr, 1977]

477. Terlouw, Jan, Verdens bedste onkel. Vertaling Torben Nilsson. København, Sommer \& Sørensen, 1985. [Oom Willibrord, 1981]

478. Toonder, Marten, Panda og den automatiske kammertjener; Panda og det mystiske fyrtärn. Vertaling Per Vadmand. København, Carlsen, 1985. [Panda en de meesterknutselaar, 1973; Panda en de verdwijn-machine, z.j.]

479. Willems, Liva, Nej. Pedro, nej. Vertaling Inge Just Møller. København, Fremad, 1985. [Nee, Pedro, nee, 1982]

1986

480. Kuijpers, Henk, Tordendragens død. Vertaling Niels Søndergaard. Bagsværd, Interpresse. 1986. [De ondergang van de donderdraak, 1986]

481. Mulisch, Harry, Et tilfoelde. Vertaling Birthe Lundsgaard Sørensen. København, Gyldendal, 1986. [De aanslag. 1982]

482. Lodewijk. Martin, Sagen om sywsoveren. Vertaling Per Vadmand. Bagsvard, Interpresse, 1986 [nw. uitg. 1986]. [Dossier Zevenslaper, 1978]

483. Lodewijk, Martin, Sagen om søndagsharnet (2). Vertaling Per Vadmand. Bagsværd, Interpresse. 1986. [Dossier Zondagskind, 1981]

484. Moor, Bob de, Havets drage. Vertaling Litten Hansen. København, Serieforlaget, 1986. (De zeedraak, 1980]

485. Moor, Bob de, Den uovervindelige Armada. Vertaling Litten Hansen. København, Serieforlaget, 1986. [De onoverwinnelijke armada, 1978] 
486. Noort, Selma, Loki tør! Vertaling Birthe Lundsgaard Sørensen. København, Gyldendal, 1986. [Ik hoef niet op schoot, 1980]

487. Pelgrom, Els, Lille Sofies markelige rejse. Vertaling Jette Skovbjerg. København, Munksgaard, 1986. [Kleine Sofie en lange Wapper, 1984]

488. Pelgrom, Els, Vi skal nok klare det! Vertaling Jette Skovbjerg. København, Munksgaard, 1986. [Voor niets gaat de zon op, 1982]

489. Toonder, Marten, Panda og händfisken; Panda som blikkenslager; Panda og spøgelsessiottet. Vertaling Per Vadmand. København, Carlsen, 1986. [Panda en de handvis, z.j.; Panda en de meesterzakenman, 1986; Panda en de spokenmeester, 1973]

490. Vos-Dahmen von Buchholtz, Tony, Duft af vild lavendel. Vertaling Inger Boriis. Frederiksberg. Sommer \& Sørensen, 1986. [De geur van de macchia, 1982]

491. Wetering, Janwillem van de, Dedsvenner. Vertaling Ole Estrup. Århus, Klim, 1986. [De dood van een marktkoopman, 1977]

492. Wijn, Piet, Frandeløs. Vertaling Hanne Larsen. København, Donna, 1986. [Alleen op de wereld, 1983]

1987

493. Banen, Jan, Den dag, da isen brod op. Vertaling Jette Skovbjerg. København, Munksgaard, 1987. [Een winter om nooit te vergeten, 1984]

494. Barnard, Henk, Her er jeg sà. Vertaling Hannemarie S. Koster \& Lene Milthers. Aarhus, Modtryk, 1987. [Hier ben ik dan..., 1982]

495. Bernlef, J. [ps. van Hendrik Jan Marsman], Hjernespind. Vertaling Anna Worm. København, Hekla, 1987. [Hersenschimmen, 1984]

496. Eykman, Karel, Hjertesorg. Vertaling Marijke Snell. Valby, Borgen, 1987. [Liefdesverdriet, 1983]

497. Haas, Rick de, Gas på glatis. Vertaling Peter Lind. København, Høst, 1987. [Gat in de zandbak, 1987]

498. Henkes, Hans, Kan du høre mig? Vertaling Ove Kreisberg. København, Ibis, 1987. [Hoor je me niet?, 1981]

499. I karlighedens favn. Red. Kris Van de Poel. Vertaling Charlotte Brask e.a. Aarhus, Aarhus Universitetsforlag, 1987. [Het leven is liefde, 1987; teksten van Auwera, Biesheuvel, Carmiggelt, Claus, De Coninck, Cottenjé, Dorrestein, Geeraerts, 't Hart, T. Hermans, W.F. Hermans, O. de Jong, Koeck, Van Kooten, Morriën, Poppe, Reve, Van Veen, Van Vliet]

500). Lodewijk, Martin, Sagen om terror i Ronterdam. Vertaling Per Vadmand. Bagsvaerd, Interpresse, 1987 [nw. uitg. 1987]. [De gesel van Rotterdam. 1981]

501. Moor, Bob de, Guld i sigte! Vertaling Litten Hansen. København, Serieforlaget, 1987. [Koers naar het goud, 1982]

502. Nooteboom, Cees, Ritualer. Vertaling Tim Kane. København, Lindhardı \& Ringhof, 1987. [Rituelen, 1980]

503. Oberski, Jona, Barneår. Vertaling Kirsten Rahbek. København, Tideme Skifter, 1987. [Kinderjaren, 1978]

504. Roep, Thom, Eventyret om Gammelpot og peherheksene. Veraling Edith Mânsson. Bagsvard, Interpresse, 1987. [De heksen van eergisteren, 1986]

505. Smet, Peter de, Den mageløse general. Vertaling Nieis Søndergaard. København, Serieforlaget. 1987. [De machteloze generaal, 1977]

506. Terlouw, Jan, Fiengsel uden lås. Vertaling Søren H. Madsen. Frederiksberg. Sommer \& Sørensen, 1987. [Gevangenis met een open deur, 1986]

507. Wetering, Janwillem van de, Gribhen. Vertaling Ole Eistrup. Århus, Klim, 1987. [De straatvogel, 1982] 


\section{8}

508. Hafkamp, Corrie, Den mystiske hund. Vertaling Marijke Snell. Virum, Jette Ahm, 1988. [Het raadsel van de hond, 1987]

509. Hartman, Evert, Det usynlige lys. Vertaling Kirsten Rahbek. Frederiksberg, Sommer \& Sørensen, 1988. [Het onzichtbare licht, 1982]

510. Jong, Oek de, Cirkel i grasset. Vertaling Tove Kirchheiner-Galatius. København, Gyldendal, 1988. [Cirkel in het gras, 1985]

511. Lodewijk, Martin, Sagen orn Wu Manchus ojne. Vertaling Per Vadmand. Bagsværd, Interpresse, 1988. [De ogen van Wu Manchu, 1981]

512. Matena, Dick, Den hvide hjorns grotter. Vertaling Per Vadmand. Bagsværd, Interpresse, 1988. [De grotten van de witte beer, 1987]

513. Matena, Dick, Solens Søn. Vertaling Per Vadmand. Bagsværd, Interpresse, 1988 [nw. uitg. 1988]. [De zoon van de zon, 1987]

514. Moor, Bob de, Den hvide død. Vertaling Litten Hansen. København, Serieforlaget, 1988. [De gedoemde reis, 1987]

515. Pelgrom, Els, Elefantbjerget. Vertaling Jette Skovbjerg. København. Munksgaard, 1988. [De olifantsberg, 1985]

516. Roep. Thom, Eventyret om Gammelpot og roverne fra Dalby. Vertaling Edith Månsson. Bagsvard, Interpresse, 1988. [Op het spoor van kwade zaken, 1988]

517. Schuber, Ingrid, Den lille heks med de store fodder. Vertaling Ib Schifter Schou. Bagsværd, Bømenes nye Bogklub, 1988. [Platvoetje, 1986]

518. Springer, F. [ps. van Carel Jan Schneider], Bougainville. Vertaling Greta Grootenboer Ips. van Geente de Vries] [\& Anne E. Jensen]. København, Hekla, 1988. [Bougainville, 1981]

519. Vissinga, Heleen, Min hemmelighed. Vertaling Marijke Snell. Virum, Jette Ahm, 1988. [Het geheim, 1987]

520. Zanger, Jan de, Om så med vold. Veraling Tim Kane. København, Høst, 1988. [Desnoods met geweld, 1986]

\section{9}

521. Beer, Hans de, Den lille ishjorn i de varme lande. Vertaling Ejgil Søholm. Kobenhavn, Apostrof, 1989. [Een ijsbeer in de tropen, 1987]

522. Biegel, Paul, Den rode prinsesse. Vertaling Hanne Würtz. Randers, Thode, 1989. [De rode prinses, 1987]

523. Huygen, Wil [\& Rien Poortvliet], Bogen om natnissen; alfahethog for sovedyr og sovetryner. Vertaling Vagn Simonsen. Kobenhavn, Sesam, 1989. [Het boek van Klaas Vaak en het ABC van de slaap, 1988]

524. Jong. Trude de, Lola. Vertaling Jette Skovbjerg. København, Munksgaard, 1989 [Lola de beer, 1987].

525. Kromhout [van der Meer], Rinder, Sidste chance. Vertaling Ludo Leroy \& Nina Malinovski. København, Gyldendal, 1989. [Loop voor je leven, 1987]

526. Leeuwen, Joke van, Bobbels hemmelige plan. Vertaling Tim Kane. København, Gyldendal, 1989. [Het verhaal van Bobbel die in een bakfiets woonde en rijk wilde worden, 1987]

527. Lodewijk, Martin, Dødskorsel til Monte Carlo. Vertaling Per Vadmand. Bagsvard, Carlsen, 1989. [Dodenrit naar Monte Carlo, 1988]

528. Lodewijk, Martin, Sagen kunsten stiger; samt sagerne om rogbomben og resten af verden minus én. Ventaling Per Vadmand. Bagsvzerd, Interpresse, 1989. [Drie avonturen, 1982]

529. Peters, Lidy, Jeg er ikke din far. Vertaling Mogens Jensen. København, Munksgaard, 1989. [Je hebt me verraden, 1987]

530. Rutgers van der Loeff-Basenau, An, Rossy. Vertaling Kirsten Rahbek. Bagsvard, Carlsen, 1989. [Rossy, dat krantenkind, 1952] 
531. Stolp, Hans, Den gyidne fugl. Vertaling Tim Kane. København, Høst, 1989. [De gouden vogel, 1987]

1990

532. Bernlef, J., En stjerne falder. Vertaling Birte Carlé. København, Hekla, 1990. [Vallende ster, 1989]

533. Dragt, Tonke, Februartårnene. Vertaling Tim Kane. København, Gyldendal, 1990. [De torens van februari, 1973]

534. Dragt, Tonke, Brevet til kongen. Bd. I-II. Vertaling Kirsten Rahbek. Bagsvæerd, Carisen, 1990. [De brief voor de koning, 1962]

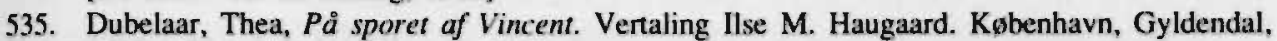
1990. [Op zoek naar Vincent, 1990]

536. Hartman, Evert, I morgen er jeg rask igen. Vertaling Kirsten Rahbek. Frederiksberg, Sommer \& Sørensen, 1990. [Morgen ben ik beter, 1987]

537. Kuijpers, Henk, Mode-mysteriet. Vertaling Niels Søndergaard. Bagsværd, Interpresse, 1990 [nw. uitg. 1990]. [Moordende concurrentie, 1990]

538. Mol, Pauline, Den lille jogger. Vertaling Lars-Henrik Olsen. København, Sesam, 1990. [De kleine jager, 1990]

539. Noor, Selma, Bare en skolepige. Vertaling Ludo Leroy \& Nina Malinovsky. København, Gyldendal, 1990. [Meer dan een zwijgend schoolkind, 1988]

540. Schippers, Wim T., Draebernullermaendene gär amok. Vertaling Per Vadmand. Bagsværd, Interpresse, 1990. [Sjef van Oekel in de bocht (II), 1980]

541. Wetering, Janwillem van de, Slagregn. Vertaling Ole Eistrup. Århus, Klim, 1990. [De zaak Usbreker, 1985]

542. Zanger, Jan F. de, For en halv pose lakrids. Vertaling Tim Kane. København, Høst, 1990. [Voor een halve zak drop, 1984]. 


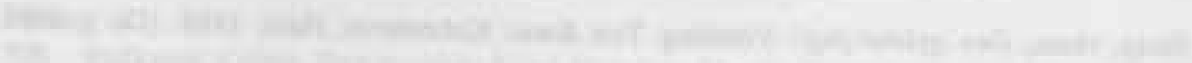

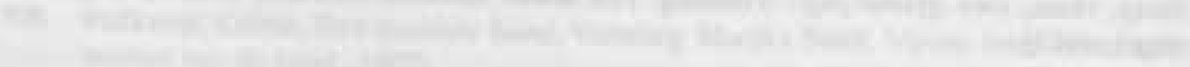

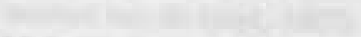

(19) (20)

the

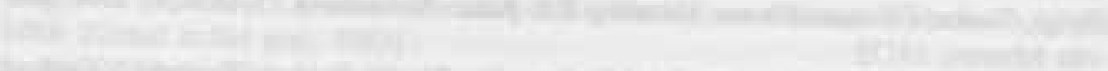

and

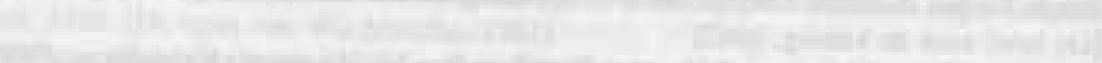

(19)

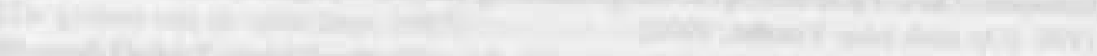

-

ant

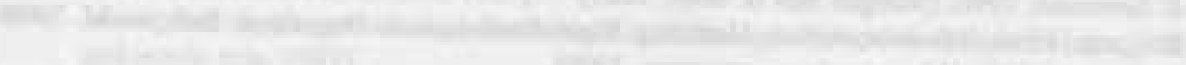

47. (1)

10

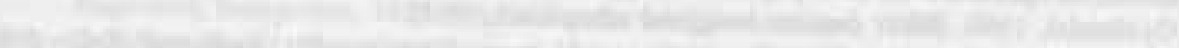
-

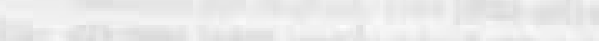

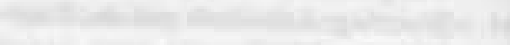
T)

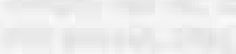




\section{Noten}

\section{Noten bij hoofdstuk I: Inleiding}

1. Wrangel; Kjærgaard; Ferwerda; Reeser 1976 (waarin oudere studies over Andersen en Nederland zijn verwerkt); Claes; Van den Bos. Betreffende Vondels gedichten over Scandinavië: Persyn 1929 en 1930, Langvik-Johannessen 1953 en 1954, Brachin 1961 en Becker. Over Potgieter en het Noorden: De Raaf, Verwey 1910, Krijn, Boer-den Hoed 1959 [a] en [b]. Luger 1971, Reeser 1971 en Brachin 1975. Zie voor overige artikelen over de culturele en literaire relaties de overzichten in Boer-den Hoed 1952 en 1962, Bolckmans 1964 en Hermans; sindsdien verschenen nog Van Assche en Luger 1985. Over vertalingen: Meyboom 1911, Baekelmans, Meuleman, Gad, Van Marken, Bolckmans 1973 en Bouma. Voor de - beperkte - invloed van de Oudscandinavische (Oudnoordse) letteren in de Nederlanden, waarop dit boek slechts zeer zijdelings ingaat, zie men Van den Toom 1958 en 1966.

2. Pichois 7-38; Dyserinck, 9-48.

3. Dyserinck, 49-64, 90-102.

4. Dyserinck, 113-125; Van Luxemburg, 276; Van den Bos, 31-33; Van Gorp 1991. 77-78.

5. Boer-den Hoed 1952, passim.

6. Fokkema, 343.

7. Dyserinck, 125-133; Van Gorp 1991, 133.

8. Schram, 97-110; Kloek 1985, 43-80; Dyserinck, 73-76; Van Luxemburg, 126-128.

9. Jauß, 1-23; Mandelkow, 40-42; Kloek 1985, 50-55; Schram, 109-110.

10. Schram, 102-108; De Vriend, 37-47.

11. Schram, 110-115; Van Gorp 1991, 116-117, 336.

12. Anbeek, 75-83; Kloek 1978, 104-105.

13. Even-Zohar; Van Gorp 1985, 256-271; Van Gorp 1991, 312-313.

14. Korpel, 9-13; Vanderauwera; Grit 1986 [a], 268-269: Van Leuven, 93-96.

15. Van den Broeck \& Lefevere, 150-153; Van Leuven, 49-50, 89-90.

16. Lambert \& Van Gorp; Van Leuven, 91-94.

17. Van Leuven, 40-50.

18. Van Leuven, 48-50; Van Gorp 1991, 432-434.

19. Zie voor een nadere uiteenzetting van Reiß' opvattingen hoofdstuk VII van dit proefschrift.

20. Van Leuven, 131-135.

\section{Noten bij hoofdstuk II: De Vondelreceptie in Scandinavië}

* De eerste versie van de tekst van dit hoofdstuk verscheen als Grit 1992 in het Tijdschrift voor Skandinavistiek. Essentiële wijzigingen ten opzichte van deze versie zijn in de noten verantwoord. Ik dank cand. mag. Willy Dähnhardt, Kopenhagen, dr. Gunilla Dahlberg. Gotenburg, en prof.dr. Kăre Langvik-Johannessen, Oslo, voor informatie cver resp. Vondeliana in de K.B. Kopenhagen, Zweedse Vondelopvoeringen, en Vondelreceptie in Noorwegen. 
21. Zie hiervoor Fabricius en Wrangel (passim).

22. Vondels eigen gedichten op het Noorden komen slechts binnen het geschetste kader (Vondelreceptie in Scandinavië) aan de orde. Voor aparte studies over deze gedichten zie men Persyn 1929 en 1930, Langvik-Johannessen 1953 en 1954, Brachin 1961 en Becker.

23. Price, 44.

24. Zie Fabricius en Wrangel. Over de kennis van het Nederlands in het Noorden: Muller 259, 289301.

25. Over Vondels reizen: Persyn 1929 en 1930. Voor Vondels negatieve Vondelbeeld vgl. o.a. WB I, 439; id. III, 187, 191-193; id. IV, 308, 617; id. V, 864-865; Salemans \& Schaars, 1128-1129; Spies in Vondel 1987 [b], I, 126-130; id. II, 38-42. Over Christina: WB V, 360, 469, 471, 593 , $817,919$.

26. Over Van Dijck: Wrangel 1897, 12-14 [= Wrangel 1901, 23-25]; Brandt, 21; Hoek, 195-201. De gedichten op Gustav Adolf: WB III, 194, 359, 360-366, 367, 377-379, 392-393.

27. Wrangel 1897,4 [= Wrangel 1901 , 9]; Fabricius, 84-85.

28. WB V, 264, 354-360, 468-471, 590-594; id. X, 275; Wrangel 1897, 100, 119 [= Wrangel 1901, 191, 227-228]; Quillet, 156, 163-164. Langvik-J. 1953, 151-152. De Vrieze, 345, 356. Vossius, IX-XI, 168. Ook de KB Kopenhagen bezit veel contemporaine Vondeldrukken van onbekende herkomst.

29. WB V, 817-818, 819, 917, 922; id. VIII, 222-224. Langvik-J. 1953, 153.

30. Kjargaard, 197; Brandt, 48; Melles, 155-160. DBL, 3. udg., IX, 391-394; Bobe, 431-432. WB VIII, 610-624; brief Rigsarkivet Kopenhagen, 23 november 1990. WB VIII, 620.

31. In de eerste versie (Grit 1992) beweerde ik dat de troep in 1651 en 1653 door Frederik III was uitgenodigd om te spelen voor het Deense hof. Zie echter noot 35.

32. Noordam, 47-48; $W B$ V, 536-537.

33. Noordam, 43, 47, 50. WB VIII, 612-613, 618, 624; $D B L, 3$. udg., V, 164-167; Persyn 1930. 267. WB III, 614. Voor Zweeds Vondelbezit zie Wrangel 1897, 202 [= Wrangel 1901, 390], en Römelingh, 344.

34. Signatuur K.B. Kopenhagen Danske Afd. $35-363-4^{\circ}$. Bibliotheca Danica, V, register.

35. In de eerste versie van deze studie (Grit 1992) beweerde ik op gezag van Krogh dat de troep in 1651 en 1653 ook voor het Deense hof in Kopenhagen is opgetreden. Ten onrechte, in zoverre dat Gunilla Dahlberg (1984 [b], 309-311) heeft aangetoond dat van een bezoek in 1651 niets vaststaat, terwijl het door Krogh genoemde optreden te Kopenhagen in de zomer van 1653 niet kan hebben plaatsgevonden, daar de troep toen aantoonbaar in Zweden was. Ik acht het echter zeer wel denkbaar, dat de troep op de heenreis naar en/of de terugreis uit Zweden (dus in het voorjaar of najaar 1653) ook te Kopenhagen heeft gespeeld. Een levensschets van Van Fornenbergh uit 1702 vermeldt dat zijn hechte theatertroep reeds vór 1655 vele jaren in de Nederlanden, Duitsland, Denemarken, Pruisen, Polen en Zweden had gereisd [Albach 70, 127; Dahlberg 1993. 394; cursivering van mij. DG]. Het lijkı erg onwaarschijnlijk dat deze vermelding alleen zou slaan op het ene optreden voor het Deense koningspaar in 1649 in het hertogdom Holstein. dat weliswaar was gelieerd aan het Deense rijk, maar daar formeel niet toe behoorde. Gezien het latere enthousiaste onthaal door Frederik III van de troep bij haar optreden te Kopenhagen in 1666 (op doorreis naar Zweden!) is het niet waarschijnlijk dat zowel de vorst als Van Fornenbergh zich een dergelijk optreden op weg naar of van Zweden in 1653 zou hebben laten ontgaan.

36. Muller, 258-259; over Van Fomenbergh c.s. de studie van Albach, i.c. 64-70, en Dahlberg 1993; Krogh. 148, 151; over de datering 1654 (i.p.v. 1653) van De Tooneelbroeders Dahlberg. 1984 [b].

37. Zie over de interpretatie van externe gegevens de kritische kanttekeningen bij ouder onderzoek het recente werk Dahlberg 1993, 369-400. Albach, 101, 149; Junkers, 157-161, 211. 
38. Albach veronderstelt dat Jordis een pseudoniem van een der toneelspelers is; deze veronderstelling nam ik over in Grit 1992. In de nadien verschenen studie van Gunilla Dahlberg (1993) wijst deze er echter op dat Jordis reeds als authentiek dichter wordt vermeld door J. te Winkel, De ontwikkelingsgang der Nederlandsche letterkunde IV (1924), 140. Dahlberg geeft aanvullende bibliografische informatie. Jordis' activiteiten te Stockholm blijken uit Zweedse archieven (Dahlberg 1993, 172-174).

39. Albach, 101-106; Wieselgren, 78; Beyer, in Stiernhielm, 77, 82.

40. Dahlberg 1984 [a], 31-33; Albach, 149, 171.

41. Overskou, 121; Wieselgren, XXXII-III.

42. Aftenposten, 13, 18, 21 april 1970; Dagbladet, 16, 20 april 1970.

43. Lundgaard Simonsen, 98, 169, 227, 259; Molkenboer, 155-156; Arrebo, bd. I, 13; Paludan $1887,462-463$.

44. Paludan 1887, 328-329, 454-455; Bobé, 432; Worm (ms. KB Kopenhagen, Nks 921, $2^{\circ}$ ); Andersen 1942, 322.

45. Tigerstedt, 44; Spegel 1685, 4; id. 1962, 21-22; Wrangel 1897, 205 [= Wrangel 1901, 396]; Dahlberg 1984 [a], 35.

46. Wrangel 1897, 206 [= Wrangel 1901, 399]; over het auteurschap van Phaëton: Dahlberg 1976, 105; voor de tekst: Lejonkulans Dramer, 311-341. Wieselgren, 76-79. Mijn twijfels over de invloed van Vondel in Grit 1992 worden gedeeld door Gunilla Dahlberg in haar nadien verschenen studie (Dahlberg 1993, 420).

47. WB X, 89 (r. 1456-1460); Lejonkulans Dramer, 355 (r. 665-668).

48. Ferwerda, 194 en register; Dirckinck-H., 29-30; Scharling 1864, 124-129. Over Dirckinck-H. en Scharling zie ook hoofdstuk III, par. 4 , in dit boek.

49. Schmidt Degener, 135-145; Hedberg, 71-76, 91-93 (citaat: 72-73). Over de opvoering: Laurin, 597. Gauffin 1925, 19-21, 24-26. Gauffin 1936, 71-80, 119-133. Laurin, 598-600; Svensson, 317.

50. Friese, 48. WB V, 867; Gauffin 1936, 78-79. Muusses 1937. Randel, 141-219 (citaat: 165-166). WB III, 388.

51. Randel, 162; Muusses 1947, 51-59 (citaat: 55); Andersen 1942, 319-322 (citaat: 321 ).

52. Over Holm als dichter: Bolckmans 1989, 74-75. De vertaling van De Havenschenderij achter Langvik-J. 1954, 303-304 en, samen met de Rey van Burghzaten, in Langvik-J. 1979 [a], 13-16.

53. De vertaling van Wiltzangk in Morgenbladet, 10-12-1979. Lucifer compleet in Vondel 1987 [a]. Recensies van de Lucifervertaling: Eilif Eide in Bergens Tidende, 30-10-1987; Halvard Holmboe in Drammens Tidende, 26-9-1987; Knud Ljøgodt in Nationen, jan. 1988; Jan E. Askersi in Steinerskolen 1990, nr. 2, 39. Interview met Lange-Fliflet in Studvest 1988, nr. 2, 11. Over de 'Noortsche waterval': Verdenius en Michels.

54. Paludan 1887, 456, 462. Langvik-J. 1957, 267. Römelingh, 344.

55. Paludan 1887, 328-329, 462-463; Paludan 1896, 264-265. Brandes 1892 [a], 227. Ipsen 1901. 246-249.

56. Wrangel 1897, 13-14, 99-100, 119, 193, 205-207 [= Wrangel 1901, 24-25, 190-191, 226-228, $372-374,396-402]$.

57. Lunding 1940, 23-24, 44-51; id. 1951, 71-73; id. 1962, 93-94; Rens, 255-258.

58. Krogh, 148, 152, 158, 176; Kjærgaard, 196-198, 202, 229, 235; bibliografie van Langvik-J.'s wetenschappelijke publikaties: Porteman, 13-19.

59. Frænkl in Aftenposten, 27-5-1964; Steffensen, 290-293; Koppang in Kirke og Kultur 1964, 569 571: Blekastad in Morgenbladet, 6-11-1964. Voor een overzicht van de Nederlandse en Vlaamse recensies zie men de Bibliografie van de Ned. Taal- en Literatuurwetenschap.

60. O.a. in: Aarhus Stiftstidende, 29-12-1953; Aftenposten, 28 \& 29-3-1957; Morgenbladet, 7-121951, 16-2-1952, 19-4-1952, 20-7-1960, 8 \& 10-12-1979 en 29-6-1982. Over de Vondellezin- 
gen in Oslo: Langvik-J. 1979 [b], 313. Recensies van Langvik-J. 1980: Olav Haugann in Dag og Tid, 17-9-1981, Helge Nordahl in Morgenblader 27-2-1981 en Jan W. Dietrichson in Edda 1981, 335-336.

61. Eller, 290-296; Dahlberg 1984 [b]: id. 1993, 369 e.v.; Sørensen; Kraggerud; Otterloo. Voor een reactie op Kraggerud: Langvik-J. 1987, 283-291.

\section{Noten bij hoofdstuk III: Bilderdijk en Denemarken}

* De eerste versie van de tekst van dit hoofdstuk verscheen als Grit 1984 in De nieuwe Taalgids. Essentiële wijzigingen ten opzichte van đie versie zijn in de noten verantwoord. Met dank aan Paul Roosjen, die Bilderdijks in het Latijn gestelde brief aan Moldenhawer (zie noot 71) voor mij vertaalde.

62. Kjærgaard, 226; Boer-den Hoed 1952, 237-238; id. 1962, 126-127; Van de Putte, 337. Statistiek en bibliografie: Meyboom 1911, 45 .

63. Kjærgaard, 238.

64. DW VIII, $417-425$.

65. Dat hier sprake is van een autograaf, blijkt allereerst uit de gedetailleerde overeenkomst tussen dit Deense fractuurschrift en dat in het adres in Bilderdijks sollicitatiebrief uit 1812 (zie noot 71). Voorts blijkt het uit de woorden die Bilderdijk noteerde boven een afschrift van de begeleidende brief aan Schubart: "Copie d'une lettre, jointe à quelques Exemplaires en Maroquin doré, et addressée a Monsieur le Baron de Schubart, Envoié de Sa Majesté le Roi de Dannemarc et de Norvège auprès de LL.HH.PP. etc. etc. etc." (Bosch, 246). Het exemplaar te Kopenhagen is gebonden in een originele band van rood marokijn met goudopdruk; vergelijk ook de tekstovereenkomst tussen de opdracht en de hier geciteerde notitie.

66. Ten Brummeler, 170, 175, 183, 189, 195, 209, 214, 220-222.

67. Kollewijn I, 236.

68. Autobiografie en papieren bewaard in resp. de Koninklijke Bibliotheek en het Rijksarchief te Kopenhagen. Over Schubart: DBL, 2. udg., XXI, 387-390.

69. Van Zonneveld, 56; Ten Brummeler, 245.

70. De in 1811 opgerichte eerste universiteit van Noorwegen zou aanvankelijk haar zetel hebben in Kongsberg, maar in 1812 werd de 'Kongelige Frederiks Universitet' definitief te Christiania (het huidige (Oslo) gevestigd. Zie de artikelen 'Kongsberg Bergseminar' en 'Universitetet i Osto' in Aschehougs Konversasjonsleksikon, 5. udg., resp. bd. XI, Oslo 1970, 508 en bd. XIX, Oslo 1972, 408-409.

71. Bilderdijk 1836-1837, IIJ, 191-195. Bilderdijks afschrift van de brief bevindt zich in de U.B. Leiden, sign. L.k. 1620. In de transcriptie in Bilderdijk 1836-1837 staat abusievelijk A. Moldenhawer; het manuscript vermeldt echter da [i.e. von] Moldenhawer. Tevens vermeldt Bilderdijk 1836-1837 niet het in het Deens geschreven adres (vgl. noot 65), dat in het manuscript onderaan de eerste pagina staat geschreven.

72. Kollewijn II, 235.

73. Over Dirckinck-Holmfeld: $D B L, 3$. udg., III, 645.

74. DW I, 424.

75. Ten Brummeler, 208.

76. DW XIV, 149.

77. DW XIV, 104-105.

78. DW XIII, 312.

79. DW XIV, 148-149. 
80. DW XIII, 302-308; hierover Van den Toom 1966, 226-227. Bilderdijks boekerij in Catalogus, 5 (nr. 68), 15 (nr. 154), 52 (nr. 571), 66 (nrs. 826-827), 69 (nr. 909).

81. $D W X V, 89$.

82. Catalogus, 6 (nr. 21), 52 (nr. 567-570), 66 (nr. 839-840), 67 (nr. 853-855), 69 (nr. 910-911).

83. Catalogus, 14 (nr. 130), 53 (nr. 581), 54 (nr. 608). In de eerste versie van deze studie noemde ik slechts én grammatica, doch dr. J. Noordegraaf wees mij in een brief d.d. 10 april 1988 op nr. 581. Op Bilderdijks Zweedse mystificatie werd ik geattendeerd door dr. F. De Tollenaere in een brief d.d. 1 december 1984. Zie voorts Noordegraaf, 90 en De Tollenaere, 43-44. De door Bilderdijk bewonderde Zweedse filosoof Swedenborg schreef uitsluitend in het Latijn.

84. Kollewijn I, 445.

85. De Vries 1921, 97; id. 1922, 204-207.

86. Logeman, X-XII, XVII-XIX.

87. Ferwerda, 128, 136.

88. Kollewijn II, 33-44.

89. DW VIII, 73-81.

90. $D W X V, 89$.

91. Lessing, 126.

92. $D W \times V, 89$.

93. Tullin, 79-87 (+ aantekeningen, id., 221-238).

94. Tullin, 246.

95. $D W X V, 89$.

96. Op Bilderdijks vertaalopvattingen wordt uitvoerig ingegaan in het recente proefschrift van Korpel (passim, i.c. 66). Algemeene Vaderlandsche Letter-Oefeningen, 1804, nr. 1, 345.

97. Bilderdijk 1836-1837, 222-223.

98. $D W I, 303-308,459-461 ; D W$ XIII, 298-300; $D W$ X, 174-177; Schack Staffeldt II, 327-332; id. I, 41 ; id. II, 251-255.

99. DW XV, 209-210.

100. Brøndsted, 111; Stangerup, 250.

101. Over de symboliek: Stangerup, 252-254.

102. Vgl. Meeuwesse, 70.

103. De Recensent, ook der Recensenten, jg. 16 (1823), nr. 1, 37.

104. Andersen 1942, 349.

105. Catalogus, 67 (nrs. 853-855); Bilderdijk 1867, 7.

106. Erslew, 46.

107. DW XIV, 205; Baggesen, 174-175.

108. Andersen 1942, 351.

109. Bilderdijk 1860, 429-430; Schack Staffeldt II, 394-395. Katharina Bilderdijk las zelf ook Scandinavische talen (Catalogus, afd. K.W. Bilderdijk, 91 (nr. 1365), 92 (nr. 1390).

110. Dirckinck-Holmfeld, 33-36.

111. Nolet, 62.

112. Kjargaard, 229.

113. Bibliotheca Oehlenschlägeriana, nr. 965 en 966.

114. DBL. 2. udg., XXI, 62-66; Kjærgaard, 228-229; Reeser 1976, 42.

115. Scharling 1864, 131-146.

116. Scharling 1865, 42-48.

117. Reeser 1976, 49; Andersen 1951, II, 304.

118. Ipsen 1891, 137; id. 1901, 253-254; id. 1915, 216.

119. DW XIII, 254-257.

120. Andersen 1942, 349-351. 
Noten bij hoofdstuk IV: Frederik van Eeden en Scandinavië.

* De eerste versie van de tekst van dit hoofdstuk verscheen als Grit 1988 [a] in De nieuwe Taalgids. De voorliggende versie wijkt hier slechts op ondergeschikte punten van af.

121. Brandes 1892, 252; Nederlandse vertaling in Los en Vast, jg. 27 (1892), 363-392, i.c. 381.

122. Van Deyssel 1931, 388-389, id. 1889, 301. Verwey vertaalde een Zweedse roman in 1914 (Uyldert, 255) en Zweedse poëzie in 1920, in de bundel Poëzie in Europa. Over Netscher, Prins en Strindberg: Claes 1980, 82-90 en Luger 1985, passim.

123. Statistiek van Scandinavische letteren in Nederland na 1850: Meyboom 1911. Over de receptie in Duitsland: Gentikow. Over de niet-literaire Scandinavica: Meyboom 1911, 47-48.

124. Van Eeden 1886, 44-46; id. 1888, 19-21, 50-53, 110-111. Brandes 1892, 253-254: id. 1903, 186; id. $1908,309$.

125. Van Vloten 1876, 413-416, 518-519. Van Eeden 1946, 10, 16, [33]. Over Martha van Eedens Andersen-vertaling zie hoofdstuk VII van dit proefschrift. Dr. Annelies van Hees en dr. Harry G.M. Prick attendeerden mij na publikatie van de eerste versie van dit hoofdstuk op het antikel van Nijland-Verwey over de Van Vlotens en Scandinavië, waarin meer details over hun belangstelling te vinden zijn.

126. Daghoek 1, 90-91.

127. Winkels, 150; Ipsen 1891, 145-158.

128. Brandes 1892, 252-253; id. 1908, 309.

129. Voor bibliografische gegevens zie het appendix na noot 157.

130. Brieven, 62.

131. Van Eeden 1897 [a]. 236; id. 1897 [b]; id. 1906. Meyboom 1906; Becker \& Frieswijk, 339.

132. Dagboek II, 613, 615, 795, 1068; Van Eeden 1979, 174.

133. Politiken, 12-19 februari 1910.

134. Politiken, 17 februari 1910.

135. Norlind, 265; de recensie aangehaald in M. Meybooms tijdschrift Scandia, jg. 1 (1904), 78.

136. Over Potgieter en Hilda Wijk schreef Alber Verwey in De Beweging (Verwey 1910).

137. Over Bjerres theorieën: Landquist.

138. Dagboek II, 1069-1072; III, 1307-1310, Fogelklou, 96. De door Fogelklou genoemde artikelen over De kleine Johannes heb ik niet kunnen achterhalen; voor Norlinds (eveneens grotendeels onvindbare) vertalingen van Van Eedens poëzie zie Dagboek III, 1304 en het appendix na noot 157. Bjerre, 172.

139. Daghoek II, 1072; III, 1308: IV, 1885, 1954; Kalff, 324.

140. Over de Forte-Kreis en de vredesmissie nadere gegevens bij Van der Put.

141. Norlind, 273; Daghoek IV, 1954.

142. De brieven van Wijk aan Van Eeden berusten in het Van Eeden-museum in de U.B. Amsterdam.

143. De brief aan Verwey in Mededelingen van het Frederik van Eeden-genoorschap XI (1948), 3. Bibliotheek, nrs. 14 (2 werken), 118, 152, 351, 516, 519 (14 werken); Van Eeden 1913, 34; id. 1902, 331; id. 1910 [a]. 21.

144. Geciteerd in Van Tricht, 76.

145. Dagboek I, 379-380; Van Eeden 1920, afl. IX, 7.

146. Van Eeden 1910 [b], 119.

147. Ook een motiefovereenkomst tussen Holbergs Jeppe paa Bjerget en Van Eedens Don Torribio berust op toeval.

148. Van Eeden 1920, afl. VII, 2; Van Deyssel 1931, 388.

149. Keersmaekers, 277-280; K. noemt verder nog Kleine Klaus en Grote Klaus, De geschiedenis van het Jaar. Ole Dromenman en De Tuin van het Paradijs. 
150. Kjærgaard, 231-232; Goudsmit, 41-49. Voor een nadere analyse van De Reiskameraad zie hoofdstuk VII van dit proefschrift.

151. Daghoek II, 933.

152. Goudsmit, 27-31.

153. Dagboek II, 1002-1003.

154. Ipsen, 147; Politiken, 16 februari 1910; Bibliotheek, nrs. 64, 221, 462 (4 nrs). Zie voorts Dagboek IV, register.

155. Over Van Eeden en Ibsen zie ook Verwey, 193-195, 202-206, en Baeck, 44-45, 57-64; na publikatie van de eerste versie van dit hoofdstuk verscheen het gedetailleerde artikel van José Rozenbroek, dat de hier gegeven bevindingen bevestigt. De meningen van Nederlandse literatoren over Ibsen uit Politikens Ibsennummer werden door M. Meyboom terugvertaald voor De Nederlandsche Spectator, jg. 39 (1898), 214-219. Van Eedens oorspronkelijke Nederlandse tekst hier is naar het manuscript in de U.B. Oslo (Sign. Ms.fo. 965). Daghoek I, 320; II, 709, 715 $717,719-721,753,759-760,765,784,809,861,913,919-921,925-926,1020-1021$.

156. d'Oliveira, 62-63; Van Eeden 1910 [c], voorwoord [V-VII]; over de toneeltechnische overeenkomsten Baeck, 60. Kalff, 328; Dagboek II, 765.

157. Dagboek IV, 1874-1875; Naeff, 122.

Appendix: Van Eeden in vertaling.

a. Deens:

- 1891, 'Ellen'. In: Ipsen, Alfred, Holland, København. P. 151-158. [Fragmenten uit: Ellen, 1891]

- 1895-1896, 'Krabben og retfærdigheden'. In: Illustreret Tidende. København. Jg. 1895-1896, Nr. 27, p. 413-414. [Het krabbetje en de gerechtigheid, 1886]

- 1903, Den lille Johannes. [Vertaling Gerda Vedel]. København. [De kleine Johannes I, 1887]

- [ca. 1908], IJsbrand. En Tragi-Komedie. [Manuscript Koninklijke Bibliotheek Køpenhagen]. [Jusbrand, 1908]

b. Zweeds:

- 1903, Lille Johannes. [Vertaling Jane Lindblad]. Stockholm. [De kleine Johannes I, 1887]

- 1906, En lycklig värld. [Vertaling Ida Bäckmann]. Stockholm. [De blijde wereld, 1903]

- 1906, Ut blandt människorna. [Vertaling Amalia Fahlstedt]. Stockholm. [De kleine Johannes II, 1905]

- 1916, Häxan från Haarlem. [Vertaling Amold Norlind]. Stockholm. [De heks van Haarlem, 1915]

- 1916, Vid skenet av krigslägan. [Vertaling Amold Norlind]. Stockholm. [Bij 't licht van de oorlogsvlam, 1916]

- 1921, 'Ljusstaden'. [Vertaling A.L.W.] In: Ord och Bild. Stockholm. Jg. 30, p. 411-416. [íragment uit: Het godshuis in de lichtstad, 1921]

- 1921. Välstand och lycka genom frivilligt samarbete. [Vertaling Amold Norlind]. Kävlinge. [Wenken en waarschuwingen voor de werkers in de Van Eeden-kolonie, 1912]

- 1929, 'Psyke'. In: Amold Norlind, Skapande liv. Stockholm. P. 9-11. [? (poëzie)]

- 1939, [zonder titel]. In: Emst Norlind, Borgehyminnen. Lund. P. 265-271. [fragmenten uit: Pauls ontwaken, 1913, en de briefwisseling met Lady Welby (uit Med. FvE-Genootschap, 1939)].

- Zie voorts noot 137 en 138.

c. Noors:

- 1977, Lille Johannes. [Vert. Kåre Langvik-Johannessen]. Lysaker. [De kleine Johannes I, 1887] 


\section{Noten bij hoofdstuk V: Vlaams Scandinavisme en Stijn Streuvels}

* De eerste versie van de tekst van dit hoofdstuk is op 24 maart 1990 gepresenteerd als lezing voor de Maatschappij der Nederlandse Letterkunde, Zuidelijke Afdeling, te Maastricht, en gepubliceerd als Grit 1991 in Spiegel der Letteren. De in dit proefschrift opgenomen versie verschilt slechts in details van de eerste; nieuw is alleen de recente ontdekking van Streuvels' plagiaat in De oude Wiking (zie noot 184). Met dank aan drs. Hilda van Assche, Brussel; de heer Gaby Gyselen, voormalig directeur Prov. Dienst voor Cultuur, Brugge; dr. Amy van Marken, Amsterdam; en lic. Marc Somers, AMVC Antwerpen, voor bibliografische gegevens en archiefhulp.

158. De Bom, 1; Persyn 1911, 1; vgl. ook Baekelmans 1961, 5-6.

159. Cijfers gebaseerd op Bibliografie van de Vlaamse tijdschriften in de 19de eeuw, Ten CateSilfwerbrand, Claes, Grit 1986 [b], Juel Møller, Meuleman, Reeser 1977 en Roemans. Over Een vijand van ' 1 volk: De Bom, 3 .

160. Sporen van Streuvels in Scandinavië zelf zijn te verwaarlozen. Slechts één vertaling in boekvorm kwam uit, namelijk een Deense venaling van Het kerstekind (Juleharnet, Kobenhavn 1913). In het katholieke Deense tijdschrift Varden verschenen in de jaren 1905-1911 acht vertalingen van verhalen uit de bundels Lenteleven, Dagen en Open lucht, en in het tijdschrift Jule-Kerten in 1906 en 1912 vertalingen uit Lenteleven. In het Noors verscheen eerst in Streuvels' sterfjaar een fragment uit Ingoyghem, in een bloemlezing De lave land forteller (Oslo 1969). In het Zweeds ontbreekt voor zover ik heb kunnen nagaan zelfs elke vertaling, ondanks het feit dat Streuvels drie maal is genomineerd voor de Nobelprijs, in 1903, 1937 en 1953. Over Streuvels en de Nobelprijs zie het artikel van Diana van Dijk en Gé Vaartjes, 'Vergeefse moeite', in: Literatuur, jg. 1993, nr. 1, p. 10-13.

161. Willems, 2, 220. Over Willems' boekerij: Bolckmans 1978, 251-253.

162. Lebrocquy, 346-388; De Broederhand 1845, 293.

163. Over Delecourts taalstrijd: Simons, 29-54. Bibliografie Vl. ts. 19e eeuw (dl. De Broederhand).

164. Grit 1986 [b], 175-177; Reeser 1977, 91-96; Bibliografie VI. ts. 19de eeuw. Nolets pamflet: $Z$ of $S$ (1846). Nolet 56, 62. Over Nolets kunstopvatting: Vlasselaers, 225-226.

165. Blommaert, VII-VIII; vgl. Simons, 59-62. Bolckmans 1978, 253-254.

166. Vlasselaers, 128; Juel Moller, 36; Bibliografie VI. ts. 19de eeuw.

167. Over Hansen: Simons, 139-147. Hansen 1860 [a], IX-XII. Over de Lovelings: Simons, 222, 230-236. Virginie Lovelings studie over Andersen in De Toekomst, jg. 1874.

168. Meir, 33, 53-54, 112, 125. Willekens, 308-312; De Bom, 101. Venstermans, 31; Minderaa, 130; VW IV, 1200.

169. Baur, 178; D’haen, 180. Gezelle, 1860, 5-6. Verriest, 140; Gezelle 1935-1937, 201-205: Willemsen, $30-31$.

170. Van den Toorn 1958, 96-101.

171. De geciteerde kritiek is afkomstig uit de eerste editie van het katholieke Lectuur-Repertorium op werken uit de periode 1884-1934. dat zich voor een cordeel over de oudere werken baseert op contemporaine recensies (a.w., 10).

172. Belpaire, 223, 226.

173. Persyn 1911, 1.

174. VW II, 1745-1746, VW IV, 1167-1170; Demedts, 41. Bjømson 1910, I-II. De Pillecijn, 46.

175. VW II, 1493, VW IV, 1168-1169.

176. Streuvels 1982, 33-37, 55-64. Demedts, 87, 113-114: De Pillecijn, 55.

177. Schepens 1980, 23, 34. Jonckheere, 21. Gegevens over de boekerij: Schepens z.j. Demedts, 199, 295.

178. Schepens z.j: VW II, 1502-1503, Bjomson 1910, III-IV, VII, IX. 
179. Voor nadere bibliografische gegevens: Roemans \& Van Assche, en Schepens 1980. Streuvels' tekstwijzigingen in de edities van 1925 en 1930 betreffen het Nederlands, niet of nauwelijks de vertaling als zodanig.

180. Bjømson 1910, IX-X. De voorbeelden zijn uit het verhaal Faderen (Der Vater / De vader) in Bjømson z.j. [a] en [d], 1893 en 1910.

181. Streuvels 1982, 73-74.

182. Nieuwe Wegen 1910, 71. Ook het begin van Streuvels' Minnehandel (1903) doet Bjømsoniaans aan.

183. Boekengids 1925, nr. 1821. Vgl, idem 1930, nr. 7363, en De Schelde, 7-3-1930.

184. Over Streuvels' plagiaat naar Guyot en Wegener: Van Straten, 74-77. Voor overige bibliografische gegevens over Streuvels' sagenpublikaties: Schepens 1980, die De oude Wiking ten onrechte een vertaling uit het Noors noemt.

185. Over Hegenscheidts Starkadd: Van den Toorn 1958, 101-104. Recensies van De oude Wiking: Van Duinkerken in De Tijd, 16-1-1932; Boon in Boekengids 1932, nr. 9082. Voont: Boekzaal der geheele wereld 1932, 164; Elsevier's Geill. Maandschrift, jg. 42 (1932), 358; Nieuwe Rott. Courant, 25-11-1931; Roeping, jg. 10 (1931-1932), 251.

186. VW IV, 1366. Over het Germanenbeeld in Duitsland: Gentikow, 245-247, en Von See, passim.

187. Over Streuvels en het nationaalsocialisme vgl. nader Smits, passim.

188. Over Grønbechs invloed in Duitsland: Von See, 354.

189. Streuvels 1933, 15.

190. Algemeen Handelsblad, z.d. [knipsel Streuvelsarchief AMVC]; Dietsche Warande en Belfort, jg. 35 (1935), II, 809. Voorts: Boekengids, jg. 1934, nr. 11.475; Boekenschouw, jg. 1934, nr. 173; Groot-Nederland, jg. 32 (1934), 280; Nieuwe Rott. Courant, 2-12-1933.

191. Stroebe, IX. De Tijdstroom, jg. 5 (1934), 129; Boekenschouw, jg. 1935, nr. 213.

192. De Pillecijn, 58. Over thematische verschillen tussen Hamsun en Streuvels: Meijer, 284-285. Schepens 1980, 113-114. Dernedts, 357. Piet Schepens' boek met opdracht bevindt zich in het Streuvels-museum 'Het Lijstemest' te Ingooigem.

Noten bij hoofdstuk VI: Bestaat de receptie van 'de' Deense literatuur in Nederlandse vertaling 1731-1990?

* De eerste versie van de tekst van dit hoofdstuk werd als lezing gepresenteerd op 31 oktober 1986 te Antwerpen, op een symposium van de Contactgroep Vertaalwetenschap van het Belgisch Nationaal Fonds voor Wetenschappelijk Onderzoek, en als Grit 1988 gepubliceerd in de bundel Literatuur van elders. Een Engelse samenvatting verscheen in het Deense tijdschrift Tordenskjold [Grit 1989].

Voor dit proefschrift is de tekst sterk uitgebreid - met name op het punt van naamlijsten, cijfermateriaal, recensies en literatuurverwijzingen -, en aangevuld voor de periode 1982-1990.

193. Grit 1986 [b]: Juel Moller; Jørgensen 1970 e.v.; Reeser 1976 en 1977. Recensies van Grit 1986 [b]: Richard Juhre in Bogens Verden 1986, p. 504-505: B. Luger in Dokumentaal 1987, p. 41 43, Joris Taels in Boekengids 1988, p. 299-300. Vgl. ook. Jørgensen 1987 en Grit 1987.

194. Baumgartner, 13-14.

195. Het eerste Lectuur-Repertorium kwam uit in 1934-1936 en bestreek de periode 1884-1934, dus de periode vanaf de verderop in dit artikel te bespreken sterke stijging in aantallen vertalingen uit de Scandinavische talen.

196. Enige voorbeelden: De vredevorst van Carit Etlar, "naar het Zweedsch": De zoon van den luchtschipper van Emma Kraft, "naar het Noorsch". Anoniemen: Zijn nichtje, "naar het Deensch 
van J.": Dicky, "naar het Deensch door Christine Doorman"; Vliegende boden, "naar eene Deensche novelle".

197. Het nog jonge Depot van Nederiandstalige Publikaties (opgericht 1974) in de K.B. te Den Haag werkt op basis van vrijwillige donaties door de uitgevers en is dus niet compleet, wat nog veel sterker geldt voor de in diezelfde bibliotheek aanwezige Centrale Catalogus.

198. Voor een lijst van deze bibliotheken zie Grit 1986 [b], XIV.

199. Zie de provenance-aanduiding bij de beschrijvingen van de werken van deze auteurs: Grit 1986 [b], nrs. 2481-2504, 182-442, 1542-1720 en 2174-2189.

200. De getallen verschillen minimaal van die in Grit 1988 [b], omdat ik nadien nog enige omissies ontdekte en enkele ongedateerde werken alsnog wist te dateren. De cijfers voor de periode 1980-1982 zijn hier geïntegreerd in de cijfers voor 1980-1990.

201. Voor gegevens over de vertalingen uit het Duits: Elema, 225, en uit het Noors: Bouma, 49. De cijfers zijn niet helemaal vergelijkbaar, daar Elema ook stichtelijke werken meetelt en Bouma zich enerzijds voor de oudere periode grotendeels baseert op de onvolledige bibliografie van Meuleman (Meuleman 1937) en anderzijds heruitgaven meetelt; maar ze geven toch een redelijk betrouwbare indicatie van de verhoudingen.

202. Grit 1986 [b], nr. 2083.

203. Grit 1986 [b], nrs. 1164-1203.

204. Ferwerda, 71-135.

205. Ferwerda, 82-83.

206. Juel Møller, nrs. 1-55.

207. Reeser 1976, 74; Grit \& Vingerhoets (zie hoofdstuk VII van dit proefschrift).

208. Reeser 1976, 9-18, 40-41.

209. Voor een statistisch overzicht zie Meyboom 1911, dat overigens grote lacunes vertoont. Zie voorts Meuleman.

210. Zie de studies van Baumgartner en Gentikow.

211. Cijfers ontleend aan Meuleman.

212. Grit 1986 [b], 39-40, 44-45, 163-164. Hier ontbreekt bij Jenny Blicher-Clausen de vertaling Inga Heine (1902, zesde druk 1918).

213. Het strikt katholieke karakter van de receptie is duidelijk te destilleren uit de namen van de uitgeverijen, de vertalers en de recensenten. Zie Grit 1986 [b], nr. 1436-1529.

214. Lectuur-Repertorium, 17-44; id., Suppl. I, 1956; id. Suppl. II, 335. In de tweede uitgave van Lectuur-Repertorium wordt de ideologische veroordeling aangescherpt: "communistische tendenzen" (a.w., 1367).

215. Gegevens ontleend aan Grit 1986 [b]; kleine recensies zijn hierin niet als apart nummer opgevoerd, maar als noot aan het besproken werk toegevoegd. Voor bibliografische bronnen, gebruikt bij het opsporen der recensies zie men de lijst voorin Grit 1986 [b], 1-3. Zie voorts Meuleman en Bouma voor recensies van Noorse literatuur.

216. Zie Grit 1986 [b]. 7-14 ("Generel sekundærlitteratur"). De rubriek in het Algemeen Handelshlad was van Annie Romein-Verschoor: 22 afleveringen in de jaren 1926-1929.

217. Opwaartsche Wegen, jg. 5 (1926-1927), 230; Dietsche Warande en Belfort, jg. 29 (1929), 677: Lectuur-Repertorium, 1020, 1237.

218. Thit Jensen, De Koning van 't Sande, Leuven 1934, 5. Lectuur-Repertorium, 712.

219. Boekenschouw, jg. 28 (1934-1935), 318.

220. Baekelmans 1929. Bolckmans 1973 en, voor de Noorse literatuur, Bouma.

221. Algemeen Handelshlad, 26-11-1927; over Dirk Coster zie Bouma, 58-59.

222. Vgl. bijvoorbeeld Menno ter Braaks essay 'Provincialisme - regionalisme' (Ter Braak, Verzameld Werk, dl. 5, 106-112).

223. Zie noot 215. 
224. Schmidt, 286-287.

225. J.D.L., 'Scandinavische romans', in: De Kern, 13-4-1947.

226. Mondelinge mededeling van mw. E. Bastings, docente aan de Rijkshogeschool Maastricht, studierichting Bibliotheek en Documentaire Informatievoorziening.

227. Grit 1986 [b], nrs. 1542-1720, 1983-2028, 324-378.

228. Bouma, 61-62. Voor het percentage zie Bolckmans 1973, 10.

229. Voor Kierkegaard is dit inmiddels gebeurd in het proefschrift van Van den Bos over de Kierkegaardreceptie in Nederland tussen 1880 en 1930.

230. Herdrukt in Ten Braven, 65-67 (citaat: 68).

Noten bij hoofdstuk VII: Makkers en kameraden, - een analyse van H.C. Andersens Reisekammeraten in zeventien Nederlandse vertalingen, 1848-1992

* De eerste versie van de tekst van dit hoofdstuk, geschreven in samenwerking met Peter Vingerhoets, destijds lector Nederlands aan de universiteit van Aarhus, verscheen als Grit \& Vingerhoets 1982 in het Tijdschrift voor Skandinavistiek. De hier opgenomen tekst is enigszins aangepast conform de in de inleiding uiteengezette vertaalwetenschappelijke principes, en aangevuld met een analyse van de in 1992 verschenen vertaling van de hand van Annelies van Hees.

Met dank aan mus.ass. Erling Gormsbøl, H.C. Andersens Hus, Odense, wijlen dr. Hans Reeser, Amsterdam, en lic. Leen Wille, UB Gent, voor hun hulp bij het oplossen van bibliografische problemen, en dr. Amy van Marken, Amsterdam, voor suggesties en commentaar naar aanleiding van het concept van de eerste versie.

231. Voor preciese getallen zie Juel Møller, Grit 1986 [b], Koenders en het vorige hoofdstuk.

232. Deze scripties betreffen de vertalingen van Den lille havfrue (Femke Muller en Sonja Kos, Amsterdam 1989) en Klods-Hans (Edith Koenders, Groningen 1990). De lezing van Koenders is in 1993 gepubliceerd (zie de bibliografie).

233. Dal \& Nielsen, 19.

234. Bille \& Bøgh, 292.

235. Grundtvig 1883, 8.

236. Aarne, nrs. 505-508 (volgorde aangepast).

237. Doorman, 89-91.

238. Asbjømsen, 204-217; Tang Kristensen, 64-69; Grundtvig 1854, 77-80 en 105-108.

239. Olrik, 66-82.

240. Tang Kristensen, 64.

241. Ed. Dal \& Nielsen, 192.

242. Ed. Dal \& Nielsen, 201.

243. Ed. Dal \& Nielsen, 198.

244. Brandes, passim; Kofoed, 30-38; Skautrup, 236-245.

245. Ed. Dal \& Nielsen, 67.

246. Ed. Dal \& Nielsen, 68.

247. Ed. Dal \& Nielsen, 84

248. Ed. Dal \& Nielsen, 69-71, 75, 79.

249. Ed. Dal \& Nielsen, 76, 78, 83, 84 .

250. Ed. Dal \& Nielsen, 76, 81 .

251. Ed. Dal \& Nielsen, 67, 70, 72-76.

252. Rubow, 176. Ed. Dal \& Nielsen, 199, 73.

253. Ed. Dal \& Nielsen, 192, 198, 201, 205.

254. Ed. Dal \& Nielsen, $68,72,75,80$. 
255. Reeser 1976. 10-12.

256. Ed. Dai \& Nielsen, 67, 72-73.

257. Ed. Dal \& Nielsen, 67, 68, 70, 72.

258. Bredsdorff, 490 e.v.

259. Ed. Dal \& Nielsen, 72.

260. Ed. Dal \& Nielsen, 69, 75.

261. Ed. Dal \& Nielsen, 68,$70 ; 72,76 ; 82 ; 73 ; 76 ; 83$.

262. Ed. Dal \& Nielsen, $70,77$.

263. Ed. Dal \& Nielsen, 70.

264. Ed. Dal \& Nielsen, 80.

265. Ed. Dal \& Nielsen, 69.

266. Reiß, 81-84.

267. Jensen, 18.

268. Ed. Dal \& Nielsen, 78, 81.

269. Ed. Dal \& Nielsen, 74.

270. De gegevens van deze korte analyse zijn grotendeels ontleend aan Albertsen 1970, 77-80.

\section{Noten bij hoofdstuk VIII: Nederlandse literatuur in Deense ogen, 1900-1990}

* De eerste versie van de tekst van dit hoofdstuk verscheen als Grit 1980 in het Tijdschrift voor Skandinavistiek. Die versie betrof de periode 1900-1980; de voorliggende tekst is aangevuld met gegevens tot en met 1990. Tevens is in dit boek als bijlage een complete lijst van literaire vertalingen Nederlands-Deens in boekvorm opgenomen. Ik ben dank verschuldigd aan dr. Amy van Marken, Amsterdam, en wijlen drs. Geerte de Vries, Kopenhagen, voor hun commentaar op het concept van de eerste versie.

271. Politiken, 21-2-1972.

272. NRC Handelsblad, 11-12-1979.

273. Snapper, 3, 34-36, 39-40; Chorus, 87; Kousbroek, 179.

274. De Wit, 201; Morel, 405-406; Klimaszewska, 207; De Vin, 20-21; Hillner, 99; De Vin, 18, 21; Van Marken, 68; Vincent, 362. "De rest van de wereld vindt onze literatuur te somber", artikel in NRC Handelsblad, 11-12-1979.

275. Gegevens over de Timmermans-vertalingen kreeg ik in een een brief d.d. 19-1-1993 van dr. Victor Claes, die een artikel over Timmermans en Scandinavië voorbereidt.

276. Msller-Kristensen, 158, 169.

277. Moller-Kristensen, 159-160.

278. Msiller-Kristensen, 156, 184 e.v.

279. Møller-Kristensen, 181.

280. Hammerich 1973, 100.

281. Winge $1976,29-30,100,192$ e.v., 286 e.v.

282. Daalder, 117.

283. Winge 1976, 155-158, 177.

284. Vgl. Kjærgaard, 235.

285. Vgl. Møller-Kristensen, 157.

286. Romein-Verschoor 1935, 70.

287. Politiken, 8-11-1901; Socialdemokraten, 9-11-1901. De Zweedse Multatulivertaling van 1902 vertoont in navolging van de Deense eveneens grote lacunes: zie Luger 1973, p. 33-34.

288. Politiken, 29-10-1909.

289. Brandes 1903. Keersmaekers, 275, en hoofdstuk IV van dit proefschrift. 
290. Winge 1976, 155-158, 177.

291. Vor Ungdom 1905, 509; idem 1910, 473; idem 1912, 410 (o.a.)

292. Zie voor de Noorse en Zweedse vertalingen Morel, 470-72, 478-484.

293. Ter Braak; Langvik-Johannessen 1971, 62.

294. Politiken, 4-10-1943.

295. Kjærgaard, 249.

296. Hammerich 1973, 81-83.

297. Hammerich 1973, 87, 99, 111; Pée, 101; zie ook par. 4.4.3.

298. Nationaltidende, 4-11-1942.

299. Albertsen, 87-88.

300. Bogens Verden 1948, 224.

301. Information, 8-3-1958.

302. Kristeligt Dagblad, 14-5-1943.

303. Information, 11-3-1953; Socialdemokraten, 31-12-1952.

304. Bogens Verden 1941, 331.

305. Respectievelijk: Kristeligı Dagblad, 3-3-1943; Nationaltidende, 29-9-1943; Socialdemokraten, 15-12-1942; Bogens Verden 1944, 326.

306. Politiken, 30-1-1945.

307. Bogens Verden 1939, 390.

308. Socialdemokraten, 4-5-1941.

309. Hammerich 1973, 97.

310. De eenmalige recensent: Aage Rasmussen in Kristeligt Dagblad, 16-11-1944. Langvik-Johannessen 1971, 62.

311. Hertel, 283.

312. Hertel, 208.

313. Hertel, 283, en flaptekst op de latere pocketuitgaven van Martin. In Grit 1980 wordt als Martins meest succesvolle roman abusievelijk Getijden in plaats van Vrijgevochten genoemd.

314. Winge $1973,65-74$.

315. Politiken, 12-2-1966; Information, 8-4-1969.

316. Hammerich 1966, 9-12; Information, 25-2-1966; Aktuelt, 7-3-1966.

317. Deloof, 9-10.

318. Hammerich $1973,99$.

319. Over ontwikkelingen in de Deense uitgeverswereld Hertel, 301. Citaat: Hammerich 1973, 100.

320. Information, 6-4-1962.

321. Information, 8-2-1972.

322. Jyllandsposten, 9-2-1968.

323. Hammerich 1973, 112.

324. Van Marken, 69.

325. Information, 8-2-1972.

326. Bogens Verden 1960, 392.

327. Politiken, 22-1-1966; Information, 25-2-1966.

328. Aktuelt, 7-3-1966.

329. Politiken, 19-12-1968.

330. Kristeligt Dagblad, 29-7-1969.

331. Jyllandsposten, 17-9-1969.

332. Zie de rubriek 'Het Nederlandse Boek in Vertaling' in het tijdschrift Ons Erfdeel.

333. De Multatuli-essays: Melberg in Information, 28-4-1982; Grit in Politiken, 6-2-1982. Brostrøms essay in Information, 27-9-1984. Van de Poel 1992, 355.

334. Over deze verfilmingen: Wikén Bonde, 19. 
335. Van de Poel 1992, 354-355.

336. De vermelde recensies over de periode 1980-1990 zijn slechts voor een deel geregistreerd in Dansk Artikelindeks, maar zijn bijna alle te vinden in het knipselarchief in de centrale van de: openbare bibliotheek te Kopenhagen. Slechts de daar ontbrekende recensies van Mulisch en van de bloemlezing I karlighedens favn heb ik aangevraagd bij de uitgeverijen.

337. Mondelinge mededeling van Kris Van de Poel, september 1988.

338. Zie voor de vindplaats van deze recensies noot 336 .

339. In de periode 1991-1993 zijn aan bellettrie de volgende werken in het Deens vertaald: $M$. Februari, De zonen van de horizon; Margriet de Moor, Eerst grijs, dan wit, dan blauw; Cees Nooteboom, Het volgende verhaal. In voorbereiding zijn Deense uitgaven van J. Bernlef, Eclips en M. Möring. Het grote verlangen. 


\section{Literatuur}

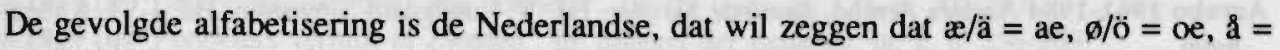
aa. Dubbele namen zijn gealfabetiseerd op de eerste naam. Vlaamse namen zijn gealfabetiseerd op de hoofdnaam en niet op de voorvoegsels De of Van.

Aarne $1961^{2}$ Antti Aame. The types of the folktale. A classification and bibliography. Translated and enlarged by Stith Thompson. Helsinki.

Åström $1972 \mathrm{H}$. Åström, Andersen på svenska. Eskilstuna

Albach 1977 Ben Albach, Langs kermissen en hoven. Ontstaan en kroniek van een Nederlands toneelgezelschap in de 17de eeuw. Zutphen.

Albertsen 1970 Leif Ludwig Albertsen, 'Die Deutschen und ihr Märchendichter Andersen.' In: Anderseniana, 3 rk. I:1, p. 71-87.

- 1972 Litterar oversattelse. København.

Anbeek 1978 Ton Anbeek, 'Receptie-esthetika en receptie-geschiedenis. Enkele problemen.' In: Receptie-esthetika. Grondslagen, theorie en toepassing. Red. R.T. Segers. Amsterdam. P. 75-83.

Andersen 1845 H.C. Andersen. Märchen. Gesammtausgabe, Zweite Sammlung. Aus dem Dänischen übertragen von Julius Reuscher. Berlin.

- 1847-1853 Gesammelte Märchen. Vom Verfasser selbst besorgte Ausgabe. Übersetzt von Carl B. Lorck. Leipzig.

- 1848 Sprookjes. Tweede verzameling. Naar het Deensch. Amsterdam.

- 1858 Verzamelde vertellingen en sproken. Naar de zesde Hoogduitsche uitgave door C. de Jong. Utrecht.

- 1874 Sprookjes. Naverteld door S.J. Andriessen. Amhem.

- 1878 Breve. Ed. C.St.A. Bille \& N. Bøgh. Kjøbenhavn.

- 1899 Sprookjes. Werelduitgave. Uit het Deensch vertaald door M. van Eeden-van Vloten. Amsterdam.

- 1906 De reisgezel. Leuven.

- 1912 De reiskameraad. Uit het Deensch naar Andersen. Leeuwarden.

- 19152 Sprookjes. Uit het Deensch vertaald door Christine Doorman. Utrecht.

- 1920 Sprookjes. Naar het Deensch bewerkt door Ph.R.F.C. De Bruijn. Zutphen.

- 1931 Sprookjes en vertellingen. Volledige uitgave naar het Deensch door W. Van Eeden. Utrecht.

- 1941 Sprookjes, vertellingen en reisverhalen. Vertaald door P.M. Boer-den Hoed, M. Nijland-v.d. Meer de Walcheren en Annie Romein-Verschoor. Amsterdam.

- 1944 Sprookjes. Naar Geo Dem. Luik.

- 1951 Mit Livs Eventyr. Ed. H. Topsøe-Jensen. Bd. I-II. København. [Oorspronkelijk 1855, met supplement 1867].

- 1960 Sprookjes. Nederlandse bewerking Margot Bakker. Deventer. 


\section{Literatuurlijst}

- 1960 Sprookjes. Vertaald door A.F. Maitland-van Bernmelen en Leonore ter Laan. Utrecht-Antwerpen.

- 1961 Sprookjes. Uit het Deens vertaald door T. van Eeden-Schuitemaker. Amsterdam.

- 1963 Eventyr. Bd. I: $1835-42$ (samt 'Dødningen' 1830 og 'Lykkens Kalosker' 1838). Ed. Erik Dal og Erling Nielsen. København.

- 1975 Sprookjes. Vertaling van Harriet Laurey. Haarlem.

- 1975 Sprookjes van Andersen. [Vertaling van M. van Eeden-van Vloten 1899, bewerkı door Willem Wilmink]. Amsterdam-Antwerpen.

- 1992 Sprookjes en verhalen. Opnieuw uit het Deens vertaald door Annelies van Hees. Rotterdam. Andersen 1942 Villhelm Andersen, Horats. Bd. III. København.

Arrebo 1961-1984 Anders Arrebo, Samlede Skrifter. Ed. V. Lundgaard Simonsen. Bd. I-VI. København.

Arnoldsen 1830 C. Amoldsen [ps. v. Constant Dirckinck-Holmfeld], Bidrag til Kundskab om Holland og den hollandske Nation. Kjsbenhavn.

Asbjørnsen $1876^{2}$ P.C. Asbjørnsen, Norske Folke-Eventyr. Ny Samling. Kjøbenhavn.

Van Assche 1985 Hilda Van Assche. 'Conscience in Scandinavië. Een bibliografische verkenning'. In: Hulde-album dr. F. van Vinckenroye. Hasselt. P. 299-310.

Avis 1940-1980 Avis-Kronik Index. København.

Baeck 1982 Mario Baeck, Omtrent de sociale ideeëndrama's van Frederik van Eeden. Gent.

Baekelmans 1929 Lode Baekelmans, 'Skandinavische literatuur in vertalingen'. In: Dietsche Warande en Belfort. Jg. 29, p. 661-675.

- 1961 'Woord vooraf'. In: Knut Hamsun, Verzameld Proza. Dl. 1, p. 5-6. Hasselt.

Baggesen 1803 Jens Baggesen, Gedichte. Bd. 2. Hamburg.

Baumgartner 1979 Walter Baumgartner, Triumph des Irrealismus. Rezeption skandinavischer Literatur im ästhetischen Kontext Deutschlands 1860-1910. Neumünster.

Baur 1930 F. Baur, Uit Gezelles leven en werk. Brugge.

Becker 1972-1973 Jochen Becker, "'Deas supereminet omneis": zu Vondels Gedichten auf Christina von Schweden und der bildenden Kunst'. In: Simiolus, nr. 6, p. 177-208.

Becker \& Vrieswijk 1976 Frans Becker \& Johan Vrieswijk, Bedrijven in eigen Beheer. Kolonies en produktieve associaties in Nederland tussen 1901 en 1958. Nijmegen.

Belpaire $1902\left[1923^{2}\right]$ Maria Elisa Belpaire, Het landleven in de letterkunde der XIXe eeuw. Antweirpen.

Bibliografie 1983-. Bibliografie van de Vlaamse tijdschriften in de 19de eeuw. Gent.

Bibliotheca 1850 Bibliotheca Oehlenschlägeriana. Kjøbenhavn.

Bibliotheca 1961-1963 Bibliotheca Danica. Systematisk fortegnelse over den danske litteratur fra 1482 til 1830. Bd. I-V. København.

Bibliotheek 1934 Bibliotheek van wijlen Dr. Frederik van Eeden. Amsterdam.

Bilderdijk 1860 Katharina Wilhelmina Bilderdijk, De Dichtwerken. DI. 3. Haarlem.

Bilderdijk 1793 Willem Bilderdijk, De Alleenheersching: Aan het volk van Denemarken. Z. pl.

- 1836-1837 De Brieven. Ed. W. Messchert. DI. 1-5. Amsterdam.

- 1867 De Briefwisseling mes M. en H.W. Tydeman. DI. 2. Sneek.

- 1857-1859 De Dichtwerken [afgekort DW]. Ed. Is. Da Costa. DI. 1-15. Haarlem.

- 1925 De Goudmaker. Blijspel. Ed. H. Logeman. Gand-Paris.

Bille \& Bøgh Zie: Andersen, H.C., 1878.

Bjerre 1911 Poul Bjerre, 'Frederik van Eeden'. In: Ord och Bild, jg. 20, p. 167-76.

Bjørnson z.j [a] Bjømstjerne Bjømson, Ausgewählte Werke, Zweiter Bund: Bauern-Novellen. Aus dem Norwegischen von Edmund Lobedanz. Leipzig.

- z.j. [b] Der Brautmarsch. Deutsch von Wilhelm Lange. Leipzig. 
- z.j. [c] Ein fröhlicher Bursch. Deutsch von H. Denhardt. Leipzig.

- z.j. [d] Kleine Erzählungen. Deutsch von H. Denhardt. Leipzig.

- 1893 Fortallinger. Kjøbenhavn.

- 1910 Kleine Verhalen. Uit het Noorsch vertaald door Stijn Streuvels. Maldegem.

- 1911 Het Bruidslied. Uit het Noorsch vertaald door Stijn Streuvels. Maldegem.

Blommaert $1849 \mathrm{Ph}$. Blommaert, Aloude geschiedenis der Belgen of Nederduitschers. Gent.

Bobé 1945 Louis Bobé, 'Personlige forbindelser'. In: Holland-Danmark [z.d.], II, p. 357-450 [p. 426-427: 'Vondel'].

Boer-den Hoed 1952 P.M. Boer-den Hoed, 'De studie van de Scandinavische invloeden op de Nederlandse literatuur', In: Neophilologus, jg. 36, p. 234-240.

- 1959 [a] 'Een onbekende brief van Potgieter'. In: De Gids, jg. 123, p. 203-207.

- 1959 [b] 'Potgieters verblijf in Zweden'. In: Spiegel der Letteren, jg. 2, p. 256-269.

- 1962 'Scandinavian Studies in the Netherlands'. In: Scandinavica, jg. 1, nr. 2, p. 122-137.

Bogens 1918-. Bogens Verden. Tidsskrift for dansk Biblioteksvaesen. København.

Bolckmans 1964 Alex Bolckmans, 'Nordic Studies in Belgium'. In: Scandinavica, jg. 3, nr. 1, p. 110-120.

- 1973 'Scandinavische literatuur in Nederlandse vertaling'. In: Linguistica Antverpiensia, jg. 7, p. 726.

- 1978 'De Vlaamse Beweging en Scandinavië. Enkele beschouwingen over de Gentse groep'. In: idem, From Nordic tales to science fiction. Ghent 1988. P. 249-254. [Over Willems en Blommaert].

- 1989 'Middelnederlands toneel in Noorse vertaling'. In: Liber amicorum Käre Langvik-Johannessen [zie aldaar], p. 73-83.

De Bom 1893 Emmanuel de Bom, Henrik Ihsen en zijn werk. Nota's. Gent.

Van den Bos 1989 G.D. van den Bos, Sporen van Kierkegaard. De Nederlandstalige Kierkegaardliteratuur tussen 1880 en 1930. (Diss. K.U. Nijmegen). Z.pl.

Bosch 1955 J. Bosch, Mr. W. Bilderdijks briefwisseling. DI. 1 (1772-1794). Wageningen.

Bouma 1976 L.H. Bouma, 'Het afnemen van de belangsteling voor de Noorse literatuur in Nederland'. In: Forum der Letteren, jg. 17, p. 46-63.

Van Boven 1992 Erica van Boven, Een hoofdstuk apart. 'Vrouwenromans' in de literaire kritiek 1898-1930. (Diss. Groningen). Amsterdam.

Ter Braak 1939 Menno ter Braak, 'De senaste årens holländska litteratur'. In: Bonniers litterära Magasin, jg. 6.

Brachin 1961 Pierre Brachin, 'Vondel und Gustav-Adolf". In: Unterscheidung und Bewahrung. Festschrift für Hermann Kunisch. Berlin. P. 41-45.

- 1975 'Potgieter et la littérature suédoise'. In: idem, Faits et valeurs. La Haye. P. 146-155.

Brandes 1869 Georg Brandes, 'H.C. Andersen som Eventyrdigter.' In: Samlede Skrifter. Bd. II (1899). København. P. 82-116.

- 1892 [a] 'Belgien'. In: Samlede Skrifter. Bd. XI (1902). København. P. 215-240.

- 1892 [b] 'Holland'. In: Samlede Skrifter. Bd. XI (1902). København. P. 241-259.

- 1903 'Frederik van Eeden' [oorspr. recensie van Den lille Johannes]. In: Samlede Skrifter. Bd. XVII (1906). København. P. 186-89.

- 1908 Levned, Bd. III. Snevringer och Horizonter. København.

Brandt 1932 Geeraerdt Brandt, Het leven van Joost van den Vondel. Ed. P. Leenderiz Jzn. 's-Gravenhage.

Ten Braven 1987 Ten Braven [ps. van Hans van den Bergh], Lekkere literatuur. Amsterdam.

Bredsdorff 1954 E. Bredsdorff, 'De engelske oversattelser af H.C. Andersens eventyr 1846-1875.' In: H.C. Andersen og England. Kobenhavn. P. $489-523$ [aangevuld met betrekking tot nieuwere 


\section{Literatuurlijst}

vertalingen: idem, 1978, 'H.C. Andersen på engelsk.' In: idem, Fra Andersen til Scherfig. Kobenhavn].

Brieven 1907 Brieven van Frederik van Eeden. Fragmenten eener briefwisseling uit de jaren 1889. 1899. Amsterdarn.

Brinkman's 1846-. Brinkman's catalogus van boeken en tijdschriften. Leiden [etc.].

Van den Broeck \& Lefevere 1979 Raymond Van den Broeck \& André Lefevere, Uirnodiging tot de vertaalwetenschap. Muiderberg.

Brøndsted \& Møller Kristensen $1982^{\circledR}$ M. Brøndsted \& Sv. Møller Kristensen, Danmarks Litteratur. København.

Ten Brummeler Andriesse 1873 J.C. ten Brummeler Andriesse, Mr. W. Bilderdijk's Eerste Huwelijk, naar zijne briefwisseling met vrouw en dochter (1784-1807). Leiden.

Catalogus 1832 Catalogus eener merkwaardige verzameling van boeken $/ \ldots$ / nagelaten door $M r . W$. Bilderdijk. Amsterdam.

Ten Cate-Silfwerbrand 1977 Ragnhild ten Cate-Silfwerbrand, 'Receptionen av Fredrika Bremers verk i Nederländerna'. In: Studies in Skandinavistiek. Aangeboden aan Amy van Marken. Red. A.M.L. Marquart Scholtz e.a. Groningen. P. 71-87.

Chorus $1967^{5}$ A. Chorus, De Nederlander uiterlijk en innerlijk. Leiden.

Claes 1980-1983 Victor Claes, 'De ontdekking van August Strindberg in het Nederlands taalgebied.' In: Handelingen van de Kon. Zuidned. Mij. voor Taal- en Letterkunde en Geschiedenis, jg. 34, p. 75-133; jg. 35, p. 47-66; jg. 36, p. 5-31; jg. 37, p. 30-48.

Daalder $1967^{2}$ D.L. Daalder, Wormcruijt met suyker. Historisch-critisch overzicht van de Nederlandse kinderliteratuur. Schiedam.

Dagboek zie: Eeden, Frederik van, 1971-1972.

Dahlberg 1976 Gunilla Dahlberg, "Dän swänska Theatren". Studier kring văr första teatertrupp. dess scen och repertoar. (Diss. Gotenburg). Göteborg.

- 1984 [a] "'Lang leef Carolus, in zyn Coningryck". Jan Baptist van Fomenberghs troep aan het koninklijk hof te Stockholm in de jaren zeventig van de $17 \mathrm{e}$ eeuw'. In: Scenarium. Nr. 8, p. 26-36.

- 1984 [b] 'Vondels Gedicht "De Tooneelbroeders van den Aertshertoge Leopoldus" und die Truppe Fornenberghs im Jahre 1653'. In: De Nieuwe Taalgids, jg. 77, p. 304-318.

- 1993 Komediantteatern i 1600-talets Stockholm. Stockholm.

Dal \& Nielsen zie: Andersen, H.C. 1963.

Dansk 1841-. Dansk Bogfortegnelse. København[-Ballerup].

Dansk 1933-1944 Dansk Biografisk Leksikon. 2. udg. Red. Povl Engelstoft. Bd. I-XXVI. København.

Dansk 1964-1965 Dansk litteraturhistorie. Red. P.H. Traustedt. Bd. I-IV. Kobenhavn.

Dansk 1979-1984 Dansk Biografisk Leksikon. 3. udg. Red. Sv. Cedergreen Bech. Bd. I-XVI. København.

Dansk 1981-. Dansk Artikelindeks 1979- . Ballerup.

DBL. zie: Dansk Biografisk Leksikon.

Deloof $1973 \mathrm{~J}$. Deloof, 'Wat is er mis met onze vertaalpolitiek?'. In: Ons Erfdeel jg. 16, nr. 2, p. 5 13.

Demedts 1971 André Demedts, Stijn Streuvels. Brugge.

Van Deyssel 1899 Lodewijk van Deyssel [onder ps. F.H.], 'Varia - De Bulgaarsche letterkunde'. In: De niewwe Gids. jg. 4. p. 299-305.

- 1931 'Over Van Eeden'. In: De briefwisseling tussen Frederik van Eeden en Lodewijk van Deijssel. Ed. H.W. van Tricht \& Harry G.M. Prick. $1982^{2}$ 's-Gravenhage. P. 387-93.

D'haen 1987 Christine D'haen, De wonde in 't hert. Guido Gezelle: een dichtersbiografie. Tielt. 
Dirckinck-Holmfeld zie: Amoldsen, C.

Doorman 1920 Christine Doorman, Uren met Andersen. Baarn.

Van Duinkerken 1948 Anton van Duinkerken, 'Weemoed van het blijspel. Erasmus Montanus'. In: De Tijd, 12 juni.

DW zie: Bilderdijk 1857-1859.

Dyserinck 1977 Hugo Dyserinck, Komparatistik. Eine Einführung. Bonn.

Van Eeden 1886 F.W. van Eeden, Onkruid. [Reprint 1974]. Haarlem.

- 1888 Noorderlicht. Bezoek aan Scandinavië in 1887. Haarlem.

Van Eeden 1891-1977 Frederik van Eeden, [vertalingen in het Deens, Zweeds, Noors] zie Appendix na noot 157: 'Van Eeden in vertaling'.

- 1891 Alladin of De Wonderlamp. [Manuscript Frederik van Eeden-museum, sign. 1051].

- 1897 [a] Frederik van Eeden, 'Uit een Noorsche Pastorie'. In: Algemeen Handelshlad, 25 juli \& 1 augustus, av.

- 1897 [b] 'Werk en Brood, II'. In: Studies III (1897), Amsterdam.

- 1898 [over Ibsen]. In: Politiken, 20 maart 1898. [Ned. ms. in UB Oslo, Ms.fo. 965].

- 1902 'Over Woordkunst, II'. In: Studies IV (1904). Amsterdam. P. 322-47.

- 1905 'Om Andersen'. In: Politiken, 2 april 1905.

- 1906 'Westerbro'. In: De Pionier, jg. 4, 16 juni.

- 1910 [a] 'Koningschap en dichterschap', In: Studies VI (1918). Amsterdam. P. 8-43.

- 1910 [b] Het lied van Schijn en Wezen, II. Ed. H.W. van Tricht, 1954. Zwolle.

- 1910 [c] 'I Paleis van Circe. Amsterdam.

- 1913 Glückliche Menschheir. Berlin.

- 1920 Literatuur en Leeven. Amsterdam.

- 1971-1972 Dagboek 1878-1923. Ed. H.W. van Tricht. 4 dln. Culemborg.

- 1979 Dromenhoek. Ed. Dick Schlüter. Amsterdam.

- $1980^{3}$ De geestelijke verovering der wereld. Amsterdam.

Van Eeden 1946 Hans van Eeden, 'Martha van Vloten. Een levensschets'. In: Mededelingen van het Frederik van Eeden-Genootschap, nr IX, p. 3-27.

Elema 1973 Literarischer Erfolg in sechzig Jahren. Eine Beschreibung der bellettristischen Werke, die zwischen 1900 und 1960 aus dem Deutschen ins Niederländische übersetzt wurden. Assen.

Eller 1971 Povl Eller, Kongelige portretmalere i Danmark 1630-82. (Diss.) København.

Erslew 1843 Th.H. Erslew, Almindeligt dansk Forfatterlexicon. Bd. 1. Kjøbenhavn.

Even-Zohar 1979 Itamar Even-Zohar, 'De relaties tussen primaire en secundaire systemen in het literaire polysysteem'. In: Vertaalwetenschap. Red. A. Lefevere \& R. Vanderauwera. Leuven. P. 713.

Fabricius zie: Holland-Danmark.

Ferwerda 1939 Saskia Ferwerda, Holherg en Holland (Diss. G.U. Amsterdam). Zutphen.

Fogelklou 1945 Emilia Fogelklou, Arnold [i.e. Amold Norlind]. Stockholm.

Fokkema 1977 D.W. Fokkema, 'Methode en programma van de vergelijkende literatuurwetenschap.' In: Teksthoek Algemene Literatuurwetenschap. Red. W.J.M. Bronzwaer e.a. Baarn. P. 337-350.

Friese 1968 Wilhelm Friese, Nordische Barockforschung. München

Gad 1941 Tue Gad, Individ og Milieu $i$ nederlandske Barneskildringer fra 1860 til 1940, København.

- 1954 'Dansk litteratur i hollandsk oversættelse'. In: Fund og Forskning i Det kongelige Biblioteks Samlinger, jg. 1, p. 64-76. 


\section{Literatuurlijst}

Gauffin 1925 Axel Gauffin, 'Claudius Civilis. En målning och dess öden'. In: Nationalmusei årsbok, jg. 9, p. 1-34.

- 1936 Batavernas Sammansvärjning. Stockholm.

Gentikow 1978 Barbara Gentikow, Skandinavien als präkapitalistische Idylle. Rezeption gesellschaftskritischer Literatur in deutschen Zeitschriften 1870 bis 1914. Neumünster.

Gezelle 1860 Guido Gezelle, Een Noordsch en Vlaemsch messeboekske. Rousselaere.

- 1935-1937 Volledige Dichtwerken. Jubileumuitgave. DI. VI: Brieven van, aan en over Gezelle, I. Briefwisseling Gezelle-Van Oye. Amsterdam.

Goudsmit 1961 Hans Goudsmit, Frederik van Eeden. 'De kleine Johannes' med sarligt henhlik på inflydelse fra H.C. Andersens eventyr. København [ongepubl. scriptie: Specialebibliotek Københavns Universitet Amager, sign. Tysk 277].

Van Gorp 1985 H. van Gorp, 'De utopie van een allesomvattende literatuurgeschiedschrijving'. In: Spiegel der Letteren, jg. 27, p. 245-262.

- e.a. $1991^{4}$ Lexicon van literaire termen. Leuven.

Grit 1980 Diederik [C.] Grit, 'Nederlandse literatuur in Deense ogen, 1900-1980'. In: Tijdschrifı voor Skandinavistiek, jg. 1, nr. 2, p. 29-103.

- 1982 'Multatuli og det hollandske paradoks'. In: Politiken, 6-2-1982 (Politikens kronik).

- 1984 'Bilderdijk en Denemarken'. In: De Nieuwe Taalgids, jg. 77, p. 493-507.

- 1986 [a] [recensie van:] 'Ria Vanderauwera: Dutch novels translated into English'. In: De Nieuwe Taalgids, jg. 79, p. 266-269.

- 1986 [b] Dansk skonlitteratur i Nederland og Flandern 1731-1982. Bibliografi over oversattelser og studier. Deense letteren in Nederland en Vlaanderen 1731-1982. Bibliografie van vertalingen en studies. Udgivet af Det kongelige Bibliotek. Ballerup.

- 1987 'H.C. Andersen i Nederland og Flandern -- en gang til'. In: Bogens Verden, jg. 69. p. 241 242.

- 1988 [a] 'Frederik van Eeden en Scandinavië'. In: De nieuwe Taalgids, jg, 81, p. 125-143.

- 1988 [b] 'De receptie van 'een' literatuur in vertaling: bestaat die en is ze beschrijfbaar?'. In: Literatuur van elders. Over het vertalen en de studie van vertaalde literatuur in het Nederlands. Red. Raymond Van den Broeck. Leuven. P. 47-56.

- 1989 'Does Danish literature have an image in the Netherlands and Flanders?' In: Tordenskjold, jg. 1, nr, 2, p. 14-15.

- 1991 'Vlaams Scandinavisme en Stijn Streuvels'. In: Spiegel der letteren, jg. 33, p. 149-169.

- 1992 'De Vondelreceptie in Scandinavië'. In: Tijdschrift voor Skandinavistiek, jg. 13, nr. 1, p. 5590.

Grit \& Vingerhoets 1982 Diederik Grit \& Peter Vingerhoets, 'Makkers en kameraden. Een stilistische analyse van H.C. Andersens Reisekammeraten in zestien Nederlandse vertalingen'. In: Tijdschrifi voor Skandinavistiek, jg. 3, nr. 1, p. 31-79.

Grundtvig 1854 Svend Grundtvig, Gamle danske Minder i Folkemunde. 1. Hefte. Kjøbenhavn.

- 1883 Danske Folkeeventyr. Kjøbenhavn.

Guyot \& Wegener 1924 Ch. Guyot \& E. Wegener, Le livre des Vikings. Paris.

Hammerich 1966 Clara \& Louis Hammerich, Nyere Flamsk Prosa. København.

- 1973 Duo. Clara og Louis Hammerichs erindringer. København.

Hammerich \& De Vries 1968 Clara Hammerich \& Geerte de Vries, Nyere Hollandsk Prosa. Sluserne åbnes. Kobenhavn.

Hansen 1860 [a] C.J. Hansen, Reisbrieven uit Dierschland en Denemark. Gent.

- 1860 [b] Noordsche Letteren. Talen, letterkunden, overzettingen. Gent.

Hedberg 1927 Tor Hedberg. Rembrandts Son. Stockholm. 
Hermans 1991 Theo Hermans, Studies over Nederlandse vertalingen. Een bibliografische lijst. 'sGravenhage.

Hertel 1972 Hans Hertel, 'Det litterære system i Danmark'. In: Robert Escarpit, Bogen og leseren. Litteratursociologi. København. P. 163-306.

Hillner 1968 Jürgen Hillner, 'Toestand en perspektieven van de Nederlandse literatuur in Duitsland'. In: Ons Erfdeel, jg. 12, nr. 2, p. 99-105.

Hoek 1966 D. Hoek, Haags leven bij de inzet van de Gouden Eeuw. Rondom Mr. Jacob van Dijck. Assen.

Holland-Danmark 1945 Holland-Danmark. Forbindelserne mellem de to Lande gennem Tiderne. Red. Knud Fabricius e.a. Bd. I-II. København.

Huygens 1946 G.W. Huygens, De Nederlandse lezer en zijn publiek. (Diss.) Amsterdam.

Ipsen 1891 Alfred Ipsen, Holland. København.

- 1901 'Nederlandene'. In: Illustreret Verdenslitteraturhistorie. Red. Julius Clausen. Bd. II. København. P. 233-264.

- 1915 'Bilderdijk'. In: Salmonsens Konversations Leksikon. Bd. 3. København.

Jauß 1967 Hans Robert Jauß, 'Literatuurgeschiedenis als een provocatie voor de literatuurwetenschap'. In: De wetenschap van het lezen. Tien jaar theorie der literaire receptie. Red. Marijke Buursink e.a. 1978. Utrecht. P. 1-28.

Jensen 1929 Anker Jensen, Studier over H.C. Andersen Sprog. Haderslev.

Jørgensen 1970 Aage Jørgensen, H.C. Andersen Litteraturen 1875-1968. Aarhus. [Supplementen: 1973, 1978, 1982, 1986, 1991].

- 1987 'H.C. Andersen i Nederland og Flandern'. In: Bogens Verden, jg. 69, p. 41-42 [n.a.v. Grit 1986 [b]].

Jonckheere 1936 Karel Jonckheere, 'Bij Streuvels - den lezer - den bibliofiel - den bibliothecaris'. In: Het Boek in Vlaanderen 1936, p. 18-27.

Juel Møller 1968 Sv. Juel-Møller, Bidrag til H.C. Andersens Bibliografi. Bd. II: Bøger på nederlandsk, frisisk og afrikaans. [Bibliografie van vertalingen tot 1960]. København.

Junkers 1936 Herbert Junkers, Niederländische Schauspieler und niederländisches Schauspiel im 17. und 18. Jahrhundert in Deutschland. Haag.

Jørgensen lees: Joergensen

Kalff 1927 G. Kalff jr., Frederik van Eeden. Groningen-Den Haag.

Keersmaekers 1975 A.A. Keersmaekers, 'Frederik van Eedens Kleine Johannes I, Shakespeare en Andersen'. In: De nieuwe Taalgids, jg. 68, p. 275-281.

Kjærgaard 1945, Helge Kjærgaard, 'Litteraturen'. In: Holland-Danmark [zie aldaar] Bd. II, p. 185250.

Klimaszewska 1977 Zofia Klimaszewska, 'Nederlandse taal en letteren in Polen.' In: Ons Erfdeel, jg. 20, nr. 2, p. 203-212.

Kloek 1978 J.J. Kloek, 'Vielen de Juffrouwen van 'erzelven? Of: Is receptiegeschiedenis mogelijk?'. In: Receptie-esthetika. Grondslagen, theorie en toepassing. Red. R.T. Segers. Amsterdam. P. 87107.

- 1985, Over Werther geschreven... Nederlandse reacties op Goethes Werther, 1775-1800. (Diss. Utrecht). DI. 1-2. Utrecht.

Koenders 1993 Edith Koenders, 'H.C. Andersens eventyr på hollandsk - børme og/eller voksenlitteratur?' In: Andersen og verden. Indlag fra den forste internationale H.C. Andersen-konference, 2531. august 1991. Red. Johan de Mylius, Aage Jørgensen og Viggo Hjørnager Pedersen. Odense. P. 217-227. 


\section{Literatuurlijst}

Kofoed 1967 Niels Kofoed, 'Den alvorlige eventyrstil - H.C. Andersen som omarbejder.' In: Studier i H.C. Andersens fortallekunst. København. P. 30-38.

Kollewijn 1891 R.A. Kollewijn, Bilderdijk. Zijn leven en zijn werken. DI. 1-2. Amsterdam.

Korpel 1992 Luc Korpel, Over het nut en de wijze der vertalingen. Nederlandse vertaalreflectie (1750-1820) in een Westeuropees kader. (Diss. Univ. v. Amsterdam). Amsterdam-Atlanta.

Kousbroek 1979 Rudy Kousbroek, De waanzin aan de macht. Anathema's 4. Amsterdam.

Kraggerud 1984 Egil Kraggerud, 'Om Vondels imitatio'. In: Edda, jg. 84, p. 253-255.

Krijn 1939 S.A. Krijn, 'Potgieters bewerkingen naar het Zweeds'. In: Tijdschrift voor Nederlandsche Taal- en Letterkunde, jg. 58, p. 69-108.

Kristensen, Tang zie: Tang Kristensen

Krogh 1945 Torben Krogh, 'Teatret'. In: Holland-Danmark [zie aldaar], Bd. II, p. 47-183.

Lambert \& Van Gorp 1985 J. Lambert \& H. van Gorp, 'On describing translations'. In: The manipulation of literature. Studies in literary translation. Red. T. Hermans. London-Sydney. P. 4253.

Landquist 1924 J. Landquist, 'Poul Carl Bjerre'. In: Svenskt Biografiskt Lexicon. Bd. 4. Stockholm. P. 505-508.

Langvik[-]Johannessen 1953 Kåre Langvik[-]Johannessen, 'Barokk-fyrster sett med barokk-dikterens øyne. En studie over Joost van den Vondels dikt til Gustav Adolf og Kristina'. In: Ord och Bild, jg. 62, p. 145-154.

- 1954 'Vondel og Danmark-Norge'. In: Edda, jg. 54, p. 273-302.

- 1957 'Een eigenhandig Vondel-manuscript te Trondheim'. In: Spiegel der Letteren, jg. 1. p. 266268.

- 1963 Zwischen Himmel und Erde. Eine Studie über Joost van den Vondels biblische Tragödie in gattungsgeschichtlicher Perspektive. (Diss. Oslo). Oslo-Zwolle.

- 1971 'Het Nederlands in Noorwegen'. In: Ons Erfdeel, jg. 1, nr. 3. p. 60-67.

- 1979 [a] Joost van den Vondel 1587-1679. Ved 300-ärsminnet for dikterens død. Oslo.

- 1979 [b] 'Vondel, de universele tragedie-dichter'. In: Vlaanderen, jg. 28, p. 313-318.

- 1980 Litteraturen i Nederlandene gjennom 800 àr. Oslo.

- 1987 Het treurspel spant de kroon. De tragiek bij Vondel. Wommelgem.

Laurin 1936 Carl G. Laurin, 'Omkring "Batavernas sammansvärjning"'. In: Ord och Bild, jg. 45, p. 593-600.

Lebrocquy 1845, Pierre Lebrocquy, Analogies linguistiques. Brussel.

Lectuur-Repertorium 1934-1936 Lectuur-Repertorium. [le uitg.]. 2 dln. Antwerpen. [Supplemeni I, 1939: Supplement II, 1946; 2e uitg. 1952-1954; Supplement 1952-1966, 1968-1970; Supplement 1967-1978, 1980-1981].

Lejonkulans Lejonkulans Dramer, Bd. VII. Phaëton, Hippolitus, Valete Theatren. Ed. Evald Ljunggren e.a. Uppsala.

Lektørudtalelser 1963- Lektørudtalelser fra Indbindingscentralen. [Bibliotheekrecensies op kaart t.b.v. de Deense openbare bibliotheken]. Kobenhavn[-Ballerup].

Lessing 1892 G.E. Lessing. Sämtliche Schriften. Ed. Karl Lachmann. DI. 8. [Reprint 1968]. Stuttgart.

Van Leuven-Zwart 1992 Kitty M. van Leuven-Zwart, Vertaalwetenschap. Ontwikkelingen en perspectieven. Muiderberg.

Liber 1989 Liber Amicorum Käre Langvik-Johannessen Red. K. Porteman e.a. Leuven.

Logeman zie: Bilderdijk 1925.

Lorck zie: Andersen 1847

Luger 1971 Bemt Luger, 'Potgieter een markies van Carabas?'. In: De nieuwe Taalgids, jg. 64, p. 203-207.

- 1973 'Multatuli in Scandinaviē'. In: Geschriften van het Multatuli-Genootschap, nr. XIII, p. 5-34. 
- 1985 'Prins, Netscher en Strindberg'. In: Bzzlletin, nr. 129, p. 67-70.

Lundgaard Simonsen 1955 Vagn Lundgaard Simonsen, Kildehistoriske undersøgelser i Anders Arrebos forfatterskah. (Diss. Kopenhagen). København 1955.

Lunding 1940 Erik Lunding, Das schlesische Kunstdrama. København.

- 1941 'Stand und Aufgaben der deutschen Barockforschung'. In: Orbis Litterarum, jg. 6, p. $27-91$.

- 1962 'Assimilierung und Eigenschöpfung in den Lustspielen des Andreas Gryphius'. In: Stoffe, Forme, Strukturen. Ed. Albert Fuchs e.a. München.

Van Luxemburg $1988^{6}$ Jan van Luxemburg e.a., Inleiding in de literatuurwetenschap. Muiderberg.

Mandelkow $1970 \mathrm{Karl}$ Robert Mandelkow, 'Problemen van de werkingsgeschiedenis'. In: De wetenschap van het lezen. Tien jaar theorie der literaire receptie. Red. Marijke Buursink e.a. 1978. Utrecht. P. 47-62.

Van Marken 1969 Amy van Marken, 'De kulturele betrekkingen tussen Nederland en Skandinavië'. In: Ons Erfdeel, jg. 13, nr. 1, p. 65-70.

Meeuwesse 1960 K. Meeuwesse, 'Willem Bilderdijk in het Paradijs (2)'. In: De Nieuwe Taalgids, jg. 53, p. 66-73.

Meijboom zie: Meyboom

Meijer $1978^{2}$ Reinder P. Meijer, Literature of the Low Countries. The Hague.

Meir 1932 George Meir, Pol de Mont. Amsterdam.

Melles $1951 \mathrm{~J}$. Melles, Joost van den Vondel. De geschiedenis van zijn leven. Utrecht.

Meuleman 1937 B.A. Meuleman, Norge i Nederland. Katalog over böker og tidsskriftartikler om norske forhold. Leiden. [Bibliografie van Norvegica in Nederland en Vlaanderen].

Meyboom 1906 Margaretha Meyboom, [Ingezonden brief n.a.v. Van Eeden 1906]. In: De Pionier, jg. 4, 7 juli.

- 1911 'Skandinavische literatuur in Nederland'. In: De Boekzaal, jg. 5, p. 45-49.

Michels 1936 L.C. Michels, 'De "Noortsche" waterval'. In: Vondelkroniek, jg. 7, p. 79-80.

Minderaa 1942 P. Minderaa, Karel Van de Woestijne. Zijn leven en werken. Amhem.

Møller-Kristensen $1970^{2} \mathrm{~Sv}$. Møller-Kristensen, Digteren og samfundet i Danmark i det 19. ärhundrede. Bd. II. København.

Molkenboer 1950 B.H. Molkenboer, De jonge Vondel. Amsterdam.

Morel 1962 P.M. Morel, Bibliographia Neerlandica II: Translations of Dutch literature 1900-1957. The Hague.

Muller 1922 J.W. Muller, 'De uitbreiding van ons taalgebied in de 17e eeuw.' In: De Nieuwe Taalgids, jg. 15, p. 161-193, 245-260, 298-309.

Munch-Pedersen 1976 E. Munch-Pedersen, Bibliografi over oversattelser til dansk 1800-1900 af prosafiktion fra de germanske og romanske sprog. København.

Muusses 1937 Martha Muusses, 'Holländskt skaldejubileum'. In: Dagens Nyheter, 17 november.

- 1947 Hollands Litteraturhistoria. Stockholm.

Møller-Kristensen lees: Moeller-Kristensen

Naeff 1923 Top Naeff, Dramatische Kroniek. Dl. 4. Amsterdam.

Nederlandse 1958-1986 Het Nederlandse Boek in Vertaling. Bibliografie van vertalingen van Noorden Zuidnederlandse werken. Ed. E. van Raan e.a. 's-Gravenhage.

Nederlandse 1987-1991 'Het Nederlandse Boek in Vertaling. Bibliografie van vertalingen van Noorden Zuidnederlandse werken.' In: Ons Erfdeel, jg. 1987-1991.

Nijland-Verwey 1954-1955 Mea Nijland-Verwey. 'Een Nederlandse letterkundige familie en het Noorden'. In: Amsterdams tijdschrift voor letterkunde, jg. 2, p. 78-85, 124-137.

Nolet de Brauwere van Steeland $1843^{2}$ J.C.H. Nolet de Brauwere van Steeland, Een reisje in het Noorden. Rotterdam. [le uitgave: Leuven 1842]. 
Noordam 1940 N.F. Noordam, De Republiek en de Noordse Oorlog 1655-1660. Assen.

Noordegraaf $1989 \mathrm{~J}$. Noordegraaf, 'De droom der rede. Willem Bilderdijk en de taalkundige traditie'. In: Bilderdijks boekenwijsheid. Red. M. van Hattum en J. Zwaan. Amsterdam. P. 83-96.

Norlind 1939 Emst Norlind, Borgebyminnen. Lund.

Ny 1956 Ny illustrerad svensk litteraturhistoria. Bd. II. Ed. E.N. Tigerstedt. Stockholm.

Nye 1923-1931 Den nye litteratur. [Tijdschrift]. København.

d'Oliveira 1907 E. d'Oliveira, '80 en '90 aan het woord. [Heruitgave 1966]. Amsterdam.

Olrik 1921 Axel Olrik, 'Sagnets Bygning: de episke Love.' In: idem, Nogle Grundsatninger for Sagnforskning. København. P. 66-82.

Otterloo 1989 Gerrit Otterloo, 'De geboorte van de Vondeliaanse alexandrijn'. In: Liber amicorum Käre Langvik-Johannessen [z.d.], p. 135-142.

Overskou 1854 J. Overskou, Den danske Skueplads. Bd. I. Kjøbenhavn.

Paludan 1887 Julius Paludan, Fremmed Indfydelse paa den danske Nationalliteratur $i$ det 17. og 18. Aarhundrede. Bd. I. Kjøbenhavn 1887.

- 1896 Danmarks Litteratur mellem Reformationen og Holberg. Kjøbenhavn.

Pan 1859 J. Pan, 'Aanwijzing der oude en nieuwere dichters door [...] Bilderdijk overgebragt of nagevolgd'. In $D W$ 15, p. 317-622.

Pée 1973 W. Pée, 'Clara Hammerich-Flensborg 1894-1972'. In: Taal en tongval, jg. 25, p. 101-105.

Persyn 1911 Julius Persyn, De Noorweegsche letterkunde. Antwerpen.

- 1929 'Vondel's eerste Deensche reis'. In: Hooger Leven, jg. 3, p. 151-152.

- 1930 'Vondel's tweede Deensche reis'. In: Hooger Leven, jg. 4, p. 116-118, 276-277.

Pichois \& Rousseau 1972 C. Pichois \& A.M. Rousseau, Vergelijkende Literatuurwetenschap. Utrecht.

De Pillecijn 1943 F. de Pillecijn, Stijn Streuvels en zijn werk. Tielt.

Van de Poel 1989 Kris Van de Poel, 'Nederlandse literatuur in Deense vertaling van 1841 tot 1988: In: Handelingen Tiende Colloquium Neerlandicum, Gent 1988. Woubrugge. P. 101-107.

- 1992 'Nederlandse literatuur in Deense vertaling: een magere oogst.' In: Dietsche Warande en Belfort, jg. 137, p. 350-355. [Vooral over de periode 1980-1990].

Porteman zie: Liber amiconum Kåre Langvik-Johannessen.

Price $1987^{2}$ J.L. Price, Nederlandse cultuur in de Gouden Eeuw. Utrecht-Wijnegem.

Psilander 1934 Hjalmar Psilander. 'Vondel'. In: Nordisk Familjehok. 3, ed. Stockholm. Bd. 20, kol. 737.

Van der Put 1946 Karel van der Put, 'De Forte-Kreis. Een voorbeeld van bovennationale samenwerking'. In: Van Eeden 1980.

Van de Putte 1976 Guy Van de Putte, 'Kulturele betrekkingen tussen de Nederlanden en Denemarken'. Af1. 2. In: Ons Erfaeel, jg. 1976, p. 355-50.

Quillet 1982 Bernard Quillet, Christina van Zweden. Een uitzonderlijke vorst. Schoten.

De Raaf 1910 K.H. de Raaf, 'Uit Potgieters jongelingsjaren'. In: De Nieuwe Gids, jg. 25, p. 569 e.v. Van Raan zie: Het Nederlandse Boek in Vertaling 1958-1986.

Randel 1938 Ane Randel, Efterklangar frä främmande lyror. Stockholm.

Reeser 1971 Hans Reeser. 'H.C. Andersens persoon en werk door Potgieter beoordeeld'. In: De nieuwe Taatgids, jg. 64, p. 208-214.

- 1976 Andersen op reis door Nederland. Zutphen.

- 1977 'Andersen in Nederlandse vertaling. 1839-1875. Proeve van een bibliografie van vertaalde werken, opgenomen in tijdschriften, almanakken, jaarboeken en andere mengelwerken'. In: Studies 
in Skandinavistiek. Aangeboden aan Amy van Marken. Red. A.M.L. Marquart Scholtz e.a. Groningen. P. 89-99.

Reiß 1971 Katharina Reiß, Möglichkeiten und Grenzen der Übersetzungskritik. München.

Rens 1966 Lieven Rens, 'Over het probleem van de invloed van Vondel op de drama's van Andreas Gryphius'. In: Hand. Kon. Zuidned. Mij. voor Taal- en Letterkunde en Geschiedenis. DI. XX, p. 251-266.

Reuscher zie: Andersen 1845.

Roemans 1934 Rob Roemans, Bibliografie van de moderne Vlaamsche literatuur 1893-1930. Eerste Deel: de Vlaamsche tijdschriften. Kortrijk.

Roemans \& Van Assche 1972 Rob Roemans \& Hilda Van Assche, Bibliografie van Stijn Streuvels. Werk in Boekvorm. Antwerpen.

Römelingh $1986 \mathrm{~J}$. Römelingh, Een rondgang langs Zweedse archieven. 's-Gravenhage.

Romein-Verschoor 1935 Annie Romein-Verschoor, Vrouwenspiegel. Een literair-sociologische studie over de Nederlandse romanschrijfsters na 1880, (Diss. R.U. Leiden). Utrecht.

- 1947 Slib en wolken. Stromingen en gestalten van de nieuwste Nederlandse literatuur, Amsterdam.

Rozenbroek 1988 José Rozenbroek, "'Zulke draadjes kan ik niet knoopen”. Frederik van Eeden en Henrik Ibsen'. In: Voortgang. Jaarboek voor de neerlandistiek, dl. IX, p. 37-58.

Rubow 1927 Paul Rubow, H.C. Andersens Eventyr. København. [Speciaal p. 167-193].

Salemans \& Schaars 1990 Ben J.P. Salemans \& Frans A.M. Schaars, Concordantie op het dramatisch werk van Joost van den Vondel. Di. II. Assen.

Schack Staffeldt 1843 A.W. Schack Staffeldt, Samlede Digte. Ed. F.L. Liebenberg. Bd. 1-2. Kjøbenhavn.

Scharling 1864 Henrik Scharling, Breve fra Holland. Kjøbenhavn.

- 1865 Den nyere hollandske Teologi. (Diss. Kopenhagen). Kjøbenhavn.

Schepens z.j. Luc Schepens, Plaatsings-catalogus van de bibliotheek van Stijn Streuvels in museum 'Het Lijsternest'. [Manuscript, aanwezig in het Provinciaal Gouvemement van West-Vlaanderen, Prov. Dienst voor Cultuur, Brugge].

- 19803 Kroniek van Stijn Streuvels. Brugge.

Schmidt 1987 Annie M.G. Schmidt, Tot hiertoe. Amsterdam.

Schmidt Degener 1919 F. Schmidt Degener, 'Rembrandt en Vondel'. In: idem, Phoenix. Amsterdam 1942. P. 97-163.

Schram 1991 Dick Schram, 'Receptietheorie'. In: Literatuur en context. Een inleiding in de literatuurwetenschap. Red. Peter Zeeman. Nijmegen. P. 79-135.

Schuytvlot 1987 A.C. Schuytvlot, Catalogus van werken van en over Vondel, gedrukt voor 1801 en aanwezig in de Universiteitshihliotheek van Amsterdam. Nieuwkoop.

Von See 1987 Klaus von See, 'Kulturkritik und Germanenforschung zwischen den Weltkriegen'. In: Historische Zeitschrift, Band 245, p. 343-362.

Simons 1982-1985 Ludo Simons, Vlaamse en Nederduitse literatuur in de 19de eeuw. (Diss). DI. 12. Gent.

Simonsen, Lundgaard zie: Lundgaard Simonsen

Skautrup 1953 Peter Skautrup, Det danske Sprogs Historie. Bd. 3. København.

Smits 1988 Kathryn Smits, 'Stijn Streuvels, ein flämischer Dichter im Netz des Nationalsozialismus'. In: Zeirschrift für deutsche Philologie, jg. 107, p. 572-585.

Snapper 1971 J.P. Snapper, Post-war Dutch literature: a harp full of nails. Amsterdam. [tevoren verschenen in 4 afl. in Delta, jg. XII-XIII, 1969-1971].

Sørensen 1972 [1979²] Hans Sørensen, 'Vondel - Nederlands nasjonaldikter'. In: idem, Klassicismen (1600-tallet). (Verdenslitteraturhistorien, bd. 4). Oslo. P. 468-474. [oorspr. Deense uitgave: København 1972]. 


\section{Literatuurlijst}

Spegel 1685 Haqvin Spegel, Guds Werk och Hwila. Stockholm.

- 1962 Guds Verk och Vila. Ed. Bernt Olsson. Stockholm.

Stangerup 1940 Hakon Stangerup, Schack Staffeldt. København.

Steffensen 1965 Steffen Steffensen, 'Die biblische Tragödie Vondels und der Barock'. In: Orbis Litterarum, jg. 20, p. 291-296.

Stiernhielm \& Columbus 1955 Georg Stiemhielm \& Samuel Columbus, Spel om Herculis wägewal. Ed. Agne Beijer e.a. Stockholm.

Van Straten 1993 Hans van Straten, Opmars der plagiatoren. Amsterdam.

Streuvels 1933 Stijn Streuvels, IJslandsche Godensagen. Bewerkt door -. Amsterdam.

- 1971-1973 Volledig Werk. DI. I-IV. Brugge.

- 1982 Uit-lust-met-de-penne. Ed. Luc Schepens. Beveren.

Stroebe 1915 Clara Stroebe, Nordische Volksmärchen. I. Teil: Dänemark / Schweden. Jena.

Svensson 1937 Georg Svensson, 'Claudius Civilis'. In: Bonniers litterära Magasin, jg. 1937, p. 316317.

Sørensen lees: Scerensen

Tang Kristensen 1897 Evald Tang Kristensen, Eventyr fra Jylland. Fjerde Samling. Aarhus.

Ten tijde 1985. Ten tijde van de Tachtigers. Ed. Peter J.A. Winkels. 's-Gravenhage.

Tigerstedt zie: Ny illustrerad svensk litteraturhistoria.

De Tollenaere 1981 F. de Tollenaere, 'Semantiek en etymologie'. In: Tijdschrift voor Nederlandse Taal- en Letterkunde, jg. 97, p. 41-48.

Van den Toorn 1958 M.C. van den Toom, 'De Oudgermaanse achtergrond in Rodenbachs "Gudrun" en Hegenscheidts "Starkadd"'. In: De Vlaamse Gids, jg. 42, p. 96-104.

- 1966 'De Germaanse Oudheid als inspiratiebron voor de Nederlandse Romantiek'. In: De nieuwe Taalgids, jg. 59, p. 219-32.

Toury 1979 Gideon Toury, 1979. 'Literatuur in vertaling - Systeem en norm: voor een doeltekstgerichte aanpak van de literaire vertaling'. In: Vertaalwetenschap. Red. A. Lefevere \& R. Vanderauwera. Leuven. P. 32-52.

Van Tricht 1934 H.W. van Tricht, Frederik van Eeden. Denker en strijder. Amsterdam.

Tullin 1972 Christian Braunmann, Samtlige Skrifter. Ed. Harald Noreng. Bd. 1. Oslo.

Unger 1888 J.H.W. Unger, Bihliographie van Vondels Werken. Amsterdam.

Uyldert 1955 Maurits Uyldert, Dichterlijke strijdbaarheid. Amsterdam.

Vanderauwera 1985 Ria Vanderauwera, Dutch novels translated into English. The Transformation of a "Minority" Literature. (Diss. UIA Antwerpen). Amsterdam.

Venstermans $1965 \mathrm{~J}$. Venstermans, August Vermeylen. Brugge.

Verdenius 1936 A. Verdenius, 'Vondels Lucifer en Vergilius'. In: Vondelkroniek, jg. 7, p. 1-7.

Verhoeven \& Van de Poel 1987 Jo Verhoeven en Kris Van de Poel, Databank Nederlandse lireratuur in Deense vertaling. Tweede uitgave. Aarhus. [bibliografie van fictie en non-fictie voor volwassenen, 1841-1987; 330 titels].

Verriest $1903^{2}$ Hugo Verriest, Twintig Vlaamsche koppen. Rousselaere.

Verwey 1910 Albert Verwey, 'Potgieter en Hilda Wijk'. In: De Beweging, jg. 1, p. 325-335.

- 1939 Frederik van Eeden. Santpoort.

De Vin 1978 Daniël de Vin, 'Vertalingen voor Neckermann'? De modeme Nederlandse literatuur in Duitse veraling. 1965-1977'. In: Ons Erfdeel, jg. 21, nr. 2, p. 16-28.

Vincent 1977 Paul Vincent, 'De Nederlandse kultuur in Groot-Brittannië: enige recente ervaringen'. In: Ons Erfdeel, jg. 20, nr. 3, p. 357-362.

Vlasselaers 1985 Joris Vlasselaers, Literair bewustzijn in Vlaanderen 1840-J893. Leuven. 
Van Vloten 1861 Johannes van Vloten, 'Noordsche Dorpsvertellingen'. In: De Nederlandsche Spectator. Nieuwe serie, jg. 2, p. 297-298. [recensie van Bjømson].

- 1876 Beknopte geschiedenis der nieuwe letteren. Amsterdam.

- Vondel 1660 [Joost van den] Vondel, Triomf over Fünen. Koppenhagen. [Enig bekend exemplaar: K.B. Kopenhagen, sign. Danske Afd. 35-363-4\%].

- 1927-1937 [Joost van den] Vondel, De Werken. Ed. J.F.M. Sterck e.a. DI. I-X. (Wereldbibliotheekuitgave). Amsterdam.

- 1987 [a] Lucifer. En tragedie. I gjendiktning fra nederlandsk ved Albert Lange Fliflet. Oslo.

- 1987 [b] Twee zeevaart-gedichten. Ed. Marijke Spies. DI. I-II. Amsterdam-Oxford-New York.

Vor 1879-1952 Vor Ungdom. Tidsskrift for Opdragelse og Undervisning. København.

Vossius 1971 Isaac Vossius, 'Bibliothecae Christinianae Catalogus'. Ed. Chr. Callmer. In: Acta Bibliothecae Regiae Stockholmiensis. Bd. XI. Stockholm. P. I-XIV, 1-208.

De Vriend 1978 G. de Vriend, 'Wolfgang Iser: fiktionele teksten en open plekken'. In: Receptieesthetika. Grondslagen, theorie en toepassing. Red. R.T. Segers. P. 37-47.

De Vries 1974 Geerte de Vries, [overzicht van de Nederlandse literatuurgeschiedenis en lemmata over de belangrijkste Ned. auteurs]. In: Gyldendals Litteraturleksikon. Ed. H. Harmer e.a. Bd. I-IV, Kobenhavn.

De Vries 1921 Jan de Vries, 'Holberg og Holland'. In: Holherg Aarbok 1921. København-Kristiania. P. 94-111.

- 1922 'En hollandsk oversettelse av "Det arabiske Pulver"”. In Holberg Aarbok 1922. KøbenhavnKristiania. P. 204-07.

De Vrieze 1975 F.S. de Vrieze, 'Academic relations between Sweden and Holland'. In: Leyden University in the seventeenth century. Leiden. P. 344-365.

VW zie: Streuvels 1971-1973.

Wattez 1899 Omer Wattez, Noorsch en Vlaamsch. Gent.

WB zie: Vondel 1927-1937.

Wieselgren 1909 Oscar Wieselgren, Bidrag till kännedomen om 1600-talsdramat $i$ Sverige. (Diss.) Uppsala 1909.

Wikén Bonde 1993 Ingrid Wikén Bonde, 'What do the Swedes see in Dutch literature?' In: Scandinavian Newsletter, nr. 7, p. 19-20.

Willekens 1960 Em. Willekens, 'Georg Brandes en Vlaanderen'. In: De Vlaamse Gids, jg. 44, p. 306-15.

Willems 1837 Jan Frans Willems, 'Over den Oorsprong, den Aert, en de Natuerlyke Vorming der Nederduitsche Tael'. In: Belgisch Museum, jg. 1837, p. 3-20, 209-223.

Willemsen 1969 A.W. Willemsen, Het Vlaams-nationalisme. Utrecht.

Winge 1973 Mette Winge, Dansk hornebogskritik, København.

- 1976 Dansk bornelitteratur 1900-1945. (Diss.). København.

Winkels zie: Ten tijde van de Tachtigers.

De Wit 1977 Joost de Wit, 'Achtergronden van de Poolse bundel'. In: Ons Erfdeel, jg. 20, nr. 2, p. 198-202.

Woordenboek 1882-. Woordenboek der Nederlandsche Taal. 's-Gravenhage.

Wrangel 1897 E. Wrangel, Sveriges litterära förbindelser med Holland särdeles under 1600-ıalet. Lund.

- 1901 De betrekkingen tussen Zweden en de Nederlanden op het gebied van letteren en wetenschap, voornamelijk gedurende de zeventiende eeuw. Leiden. [Vertaling van Wrangel 1897]. 


\section{Literatuurlijst}

Van Zonneveld 1981 Peter van Zonneveld, 'Willem Bilderdijk, de verliefde balling'. In: Maatstaf. jg. 29 , nr. $8-9$, p. $52-63$.

Åström lees: Aaström. 


\section{Summary in English}

The aim of this dissertation is to examine literary relations between the Low Countries, the Netherlands and Flanders, and the Scandinavian countries from the seventeenth century to the present day. Hitherto, the major publications on this subject have focused on the relations of a handful of Scandinavian authors - Holberg, Andersen, Kierkegaard and Strindberg - with the Netherlands and their reception there. Little regard has been paid to traffic in the other direction except for a few articles on the Dutch writer Potgieter's relation with Sweden. Furthermore, the relationship between the Netherlandic and Scandinavian literatures has been given but scant attention in scattered articles and other publications, usually inventories of translations.

The present study, which is historical-descriptive in character, tries to fill the major gaps left by these publications. It aims at answering the question of the image left in the minds of the readers from one of these linguistic areas by the literature of the other, and of the role played by individual authors (whether as subjects or objects) in the creation of this image. What personal contacts were made, what was known about the other literature, which works have been translated, how and with what effect, and what are the traces left by the one literature in the other?

This thesis does not pretend to offer an exhaustive treatment of these questions, but is made up of seven exemplary case studies, all of which have been published previously elsewhere. In the first half of the book, the focus is on individual authors, four pillars of Netherlandic literature: Joost van den Vondel (1587-1679), Willem Bilderdijk (1756-1831), Frederik van Eeden (1860-1931) and Stijn Streuvels (1871-1969). In the second half focus shifts to the literatures in their entirety: an investigation of the limits of reception-research into 'the' reception of Danish literature in Dutch translation 1731-1990; an analysis of H.C. Andersen's fairy tale Reisekammeraten in seventeen Dutch translations, 1846-1992; and a study of the reception of Dutch literature in Danish translation, 1900-1990. As appears from these studies, the image of Danish literature in the Low Countries coincides to a great extent with that of Scandinavian literature as a whole, and the limited reception of Dutch literature in Denmark is largely identical to its reception in the rest of Scandinavia.

A discussion of research models used in comparative literature, reception theory and translation studies shows that they are only of limited use for the purposes of this study. The distance in time between the topics dealt with in the separate studies (from the seventeenth century until the present day) and the resulting considerable variation in the quantity and character of the reception sources available makes it impossible to classify, relate and interpret the data collected within one and the same model. Besides, many of 
the models presented prove to be rather pretentious and unpractical. This applies especially to the research model of reception history developed by Jauß and to the models of the so-called polysystem theory, which is related to both reception theory and translation studies. Inasmuch as this dissertation has links with comparative research, it is particularly with that of the French comparatist school.

On the other hand, this study does link up with polysystem theory as far as its focus on target culture and the descriptive principle is concerned. The emphasis is on the role of one author or literature in the target culture. As far as the translations described are concerned, there is no normative view taken of what makes a 'good' translation; it is the norms of the translators and critics that are analysed. Thus, the equivalence criterion in Katharina Reiß's model of translation criticism, which is used for the analysis of Andersen's Reisekammeraten in Dutch translation, is not so much a norm as the tertium comparationis for a neutral description of the shifts in the target text in relation to the source text.

This book does not present an alternative all-embracing model. It is selective in its approach, adapting the methodology per case study to the character of the available sources, although in all cases the aim has of course been to document and clarify the data and relations presented. The research has been 'systemic' in so far as as many aspects of the literary relations as possible have been involved. The study is of an empirical-documentary character, with all the consequent restrictions in availability of material - although every effort has been made to trace as much material as possible. In this respect, the aim has not been to build up just a positivist collection of data, but to establish the relations between these data and to put them in a broader cultural and historical context.

In the seventeenth century, cultural contacts between the Netherlands and the Nordic countries were unilaterally directed to the North. Dutch and Flemish architects, painters and scholars were engaged by Danish and Swedish kings. Knowledge of Dutch was widespread in the North. Unlike Dutch architecture, painting and philology, however, Dutch literature seems to have made little impact on Scandinavia.

This latter image needs to be adjusted as far as the reception of the person and work of the Dutch baroque poet Vondel is concerned. As appears from several primary and secondary sources, Vondel was read in the original and admired by contemporary Nordic kings and dignitaries, some of whom met him personally on his journeys to Denmark and Sweden. His plays were performed in Copenhagen and Stockholm by touring theatre companies, both in the original and in German versions. Several prominent Danish and Swedish renaissance and baroque poets (Arrebo, Bording, Spegel and others) were acquainted with his work and may have been influenced by him in the matter of word formation.

In the eighteenth century, Nordic interest in Vondel disappeared, but about 1900 the thread was taken up again by Swedish, Danish and Norwegian philologists and translators, who were especially interested in the relation between Vondel and Scandinavia, and in Vondel as a European baroque poet. 
In the eighteenth and early nineteenth centuries there was little contact between Dutch and Flemish authors and the Nordic countries. Nevertheless, half a century before the Dutch critic Potgieter introduced modern Scandinavian literature to the Netherlands in the 1840 s, the poet Bilderdijk, who in so many ways opposed the spirit of his age, appears to have shown his admiration for Scandinavia in word and deed. An ardent monarchist and anti-revolutionary, his poems sang the praises of Danish absolutism and unspoiled Nordic society, the very antipode of his corrupt homeland. He taught himself Danish and read both Old Norse and modem Scandinavian literature. He tried twice to settle in Scandinavia: as court poet in Copenhagen and as a professor of law at the university of Kongsberg (read: Christiania) in Norway.

In his youth he adapted one of Holberg's comedies, and at an advanced age he translated poems of like-minded Norwegian and Danish authors (Tullin, Schack Staffeldt and Baggesen), in which nature is glorified, the French Revolution rejected and literary imitation ridiculed. As he emphatically stated in his introduction to these translations, his aim was to make Danish poetry better known to the Dutch public.

Bilderdijk's strong opposition to the Dutch culture of his time helps at least to explain why he had few direct followers in his interest in Scandinavia. On the other hand, he did leave some traces in the North: there were contemporary Danish writers among his pupils and admirers, and as late as 1943 his poetry was translated into Danish by the famous critic Vilhelm Andersen.

Frederik van Eeden grew up during an age in which German and Dutch interest in Scandinavia was rapidly growing. Both his own family and his family-in-law travelled around the Nordic countries and read Scandinavian authors in the original. The idyllic character of Scandinavian society and its social and cultural experiments attracted their attention. For his part, Van Eeden attracted the attention of Scandinavian authors like Ellen Key, Bjømstjerne Bjørnson and Martin Andersen Nexø with his novel De kleine Johannes and his social experiments with the Walden agricultural colony. Thanks to lasting personal contacts with Georg Brandes, the father of the Modern Breakthrough in Scandinavian literature, several contributions by and about Van Eeden appeared in the Danish daily Politiken. Van Eeden twice toured Scandinavia, delivering lectures on his social experiments. Six of his works appeared in Swedish translations. A Swedish industrialist supported his social projects financially, and the Swedish psychiatrist and writer Poul Bjerre analysed the work of his Dutch colleague for the Scandinavian public.

Van Eeden's original work shows affinity with H.C. Andersen in his novel De kleine Johannes and his play Ismea, with Oehlenschläger in his play Alladin, and with the world of Vikings in his play Lioba. On the other hand, there appears to be no reason to suppose that Holberg's Erasmus Montanus had any influence on Van Eeden's play De student thuis. Van Eeden's attitude towards Ibsen is ambiguous: he admires Ibsen's technique and is jealous of his success, hardly daring to admit it, and, while critical of Ibsen's literary qualities, he nevertheless applies Ibsenian elements and techniques in his later plays. 
Unlike the Dutch and German general public, readers in Flanders did not show much interest in Scandinavian literature during the second half of the nineteenth century. Hardly any translations were published and literary magazines did not pay much attention to Scandinavia. Nevertheless, some Flemings did show interest in the Nordic countries, namely the leaders of de Vlaamse Beweging (the 'Flemish Movement', i.e. the political, cultural and linguistic emancipation movement in French-dominated Belgium). These leaders saw a link between the Flemish-Nordic kinship in language, race and people, and the exemplary function of Scandinavian cultural and linguistic policy for Flanders. They were inspired by the revival of a related small language community, following a period of decline after a great medieval past. The father of the Flemish Movement, Jan Frans Willems, read and studied the Scandinavian languages, as did several other prominent leaders, mostly liberal romantic philologists. Their favourite writers were Oehlenschläger and Tegnér, who glorified the medieval empires of the Nordic peoples, and H.C. Andersen, the world-famous representative of a small Germanic country.

The 'internationalist' circle within the Flemish Movement, concentrated around the literary journal Van $\mathrm{Nu}$ en Straks, sought an alliance with the Modern Breakthrough writers and contacted Georg Brandes, who the Catholic circle, by contrast, did not want to have anything to do with, even though they also emphasized the Flemish-Nordic linguistic and racial kinship. It was especially the Norwegian regional novels that attracted Catholic attention.

As a Catholic contributor to Van Nu en Straks, Stijn Streuvels united the several points of view mentioned above. He read the modern Scandinavian authors, first in German, and after having learned Norwegian, in the original. With his translations of Bjømson's country novellas he managed for the first time to interest a broad Flemish public in Scandinavian literature. Moreover, Bjømson's work was reflected in the motifs and stylistic features of Streuvels' novel De Vlaschaard. Streuvels' later translations of Nordic sagas and Scandinavian folk tales had an ideological emphasis on racial relationship between Flemings and Scandinavians.

Unlike Van Eeden. Streuvels did not find any response in the Nordic countries. Suggestions that the work of Knut Hamsun was influenced by him, or vice versa, prove unfounded.

In the period between 1731 and 1990, 1654 separate editions of literary translations from Danish into Dutch were published in the Netherlands and Flanders. This appears from a general bibliography of Danish literature in Dutch translation and a special bibliography of Dutch Andersen translations. Interestingly enough, however, these translations did not leave a representative image of Danish literature on the consciousness of the Dutch and Flemish reading publics. In the eighteenth century, 37 of the 46 translations were of works by Ludvig Holberg, in which typical Danish features had disappeared. During the first half of the 19th century. only a few works of the great Danish romantic and realistic writers were translated, whereas the period 1850-1890 was dominated by H.C. Andersen, with 27 of the 63 translations. Translations of Danish authors of the Modern Breakthrough in Scandinavian literature were few and far between, whereas female 
writers of trivial novels achieved resounding and lasting successes. The years 1910-1920 were once more dominated by H.C. Andersen, and the Catholic convert Johannes Jørgensen, who addressed two totally different publics.

During the period 1920-1960, no less than 610 translations appeared. This was the first period to offer an image of a specifically Danish literature because of the large number of regional novels. This, however, was not a typically 'Danish' image, but a general Scandinavian one. Works of high and of low quality were brought out by the same publishers. In the beginning, this genre was received positively by the (usually confessional) critics, but after the Second World War, it was criticized and parodied. Since the average Dutch regional novel was of a relatively low level, readers of belleslettres ended up with low expectations regarding Nordic literature. Exceptions like Kierkegaard, Kaj Munk and Andersen were directed towards specific target groups and did not affect this image.

In 1960-1990 there is a greater diversification, but the number of translations decreases sharply, with the notable exception of books for children, who pay hardly any attention to the geographical or cultural background of the translations, however.

As a result, there is no homogeneous reception of Danish literature as such: the various popular authors and genres have specific readerships that vary strongly as to time, age, and social and religious background, and which therefore do not have a representative image of the translations available, let alone of Danish literature as a whole. This does not of course mean that further investigation into more restricted forms of reception, such as the reception of specific authors or movements, may not serve some useful purpose.

Compared with the countless translations of Hans Christian Andersen's fairy tales into more than one hundred languages, very little research has been carried out into the nature of these translations. Hence this attempt to analyse seventeen Dutch translations of the fairy tale Reisekammeraten (The Fellow Traveller), published between 1848 and 1992. With the help of Katharina Reiß's analysis model, the shifts shown by translations vis-à-vis the source text are described, and an attempt is made to explain them.

An analysis of the source text shows the fairy tale's consistent structure and characteristic narrative technique. Many of the original puns disappear in translation, as do the key words and repetitions, which in Andersen's work usually have a symbolic function. Moreover, the language is often normalized towards the style of the standard children's book, possibly because of the translator's fear that deviant usage might be considered his mistake.

The fact that German was an intermediate language and poor knowledge of Danish lead to unintentional shifts in the older and some of the more recent translations respectively. On the other hand, intentional additions and omissions can often be explained by fear of Andersen's 'vagueness', 'correction' of his 'mistakes', and commercial and moral/religious motives. Sometimes, the linguistic usage of older translations is modernized in more recent editions. In some of these modernizations, 'realia' are adapted to time and public. 
There is no consistent system of interrelated shifts. Many of the shifts do not result from an intended adaptation, but from inaccuracy or lack of insight regarding, for example, the symbolic function of certain key words. In a few cases, shifts are simply due to insufficient knowledge of the source language. As appears from the present study, there is no consistent relation with the translation's target group, children or adults, or with the period in which the translation is produced. On the other hand, there are considerable differences in the type and number of shifts. The consistency is strongest in the two complete translations of Andersen's fairy tales: the source text oriented translation by Van Eeden (1931) and the recent translation by Annelies van Hees (1992), which aims at a balance between source text orientation and target group orientation.

Netherlandic literature does not generally fare well in translation. Examination of the possible causes of the lack of success of this literature in Danish translation between 1900 and 1990 (542 separate editions) shows that it is not the quality of the literature as such that is responsible for the poor response, but the distorted image that the translations themselves leave behind.

During the period between 1900 and 1930 the paucity of consultants and good translators determined the fate of the few translations published. The works of Multatuli, Heijermans and Couperus were translated and presented in a way that did not inspire new translations.

In the years 1930-1960 a number of active female translators produced a large quantity of very popular light reading (family novels) and, to a lesser extent, of belleslettres. However, the predominance of the former category and the non-representative choice of the latter conspired to create a bad impression on the critics and the 'literary' public. Against this background the few literary translations of note did not attract sufficient attention. It appears that a similar phenomenon took place in Norway and Sweden.

A sharp reduction in the translation of both light novels and belles-lettres during the period 1960-1980 was at least partly due to competition from television and inexpensive paper-back editions of English and German works in translation. There were also internal factors, however: two important anthologies, published with Belgian and Dutch govemment grants, were criticized because of the quality of the selection, and a third anthology (in paperback) because of the inferior quality of the translation.

The period 1980-1990, however, shows a small but marked recovery as far as belleslettres (13 different translations) is concerned, not only as a result of certain Dutch authors' successes in other European countries, but also thanks to the initiative of a number of consultants and the appearance of qualified translators, who also are responsible for the translation of high-quality children's books. Both the belles-lettres and the children's books have received ample critical attention and have largely been accorded positive reviews.

The vicious circle that characterizes most of the ninety years dealt with (bad presentation, little success, even fewer translations, lack of interest on the part of translators, etc.) is due not only to the publishers commercial policies, but also to individual persons and initiatives. At the same time, individuals and their initiatives can 
also break the circle, as has been shown in the last decade: their activities hardly form a sufficient condition for continuity and consistency, but they are an essential part of it.

As far as the individual authors are concemed, we may conclude that four pillars of the literature of the Low Countries received interest in Scandinavia and/or were interested in Scandinavia: Vondel, Bilderdijk, Van Eeden en Streuvels. The traces of this interest (personal contacts, translations, kinship and in some cases influences) are clearly visible, and they are representative of the role that these authors play in the history of Netherlandic literature: the charisma of Dutch culture in the seventeenth century, the opposition to 'the spirit of the age' around 1800, the interest in social experiments around 1900, and the experience of kinship between the Flemish and Nordic emancipation movements in the second half of the nineteenth and the beginning of the twentieth century. Vondel and Van Eeden contributed to the image of Dutch literature in Scandinavia; Bilderdijk and Streuvels to the image of Scandinavian literature in the Low Countries.

As far as profound mutual relations between the literatures as such are concerned, however, our conclusions are modest. Netherlandic literature in Denmark and Danish literature in the Low Countries have left little remaining traces on either side, - Danish reception and Danish literature in many respects being representative of Scandinavian reception and Scandinavian literature as a whole. Although there was a lively Scandinavian interest in Netherlandic culture during the seventeenth century and a general Netherlandic interest in Scandinavia in the first half of this century, the literatures show no exchange of influences. For a representative image of the belleslettres, the several translation strategies are too varied, and the target groups of the many hundreds of translations are too diverse in time, age and social or religious background. (The various translation strategies are illustrated by a representative analysis of Dutch Andersen translations, together constituting about one fifth of all translations from the Danish.) The commercial policies of most publishers and a one-sided interest in certain themes and genres (especially family novels and regional novels) result in some periods in a stereotype image (apparent from reviews, prefaces and parodies, etc.), while other periods evince a total lack of Netherlandic interest in Scandinavian belles-lettres and vice versa. Personal initiatives of qualified translators may not be sufficient to break down this stereotype, but they are an essential condition for continuity and consistency. May the growing interest in Netherlandic studies in Scandinavia and the growing interest in Scandinavian studies in the Low Countries contribute to this. 


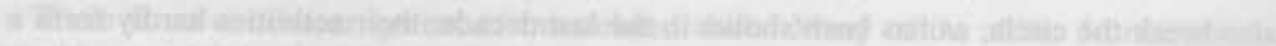

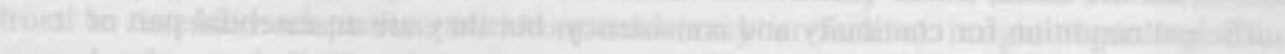

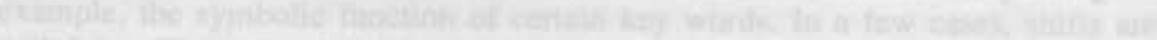

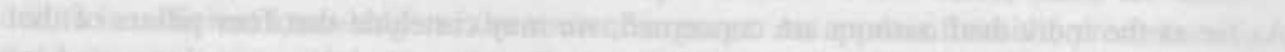

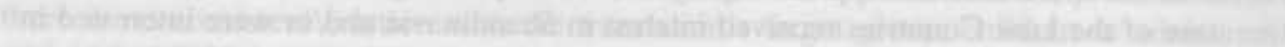

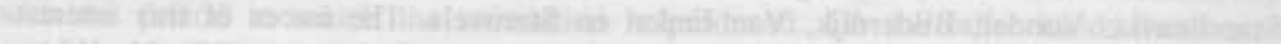

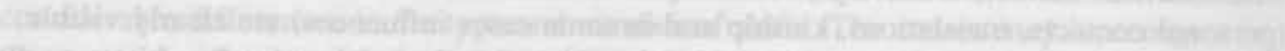

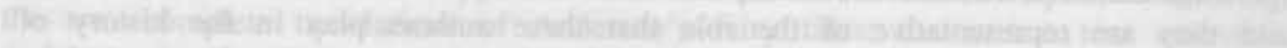

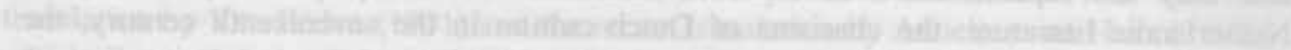

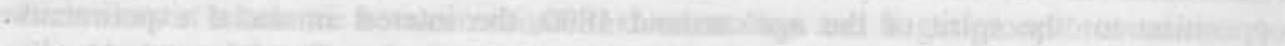

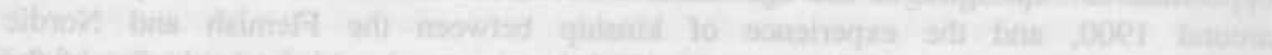

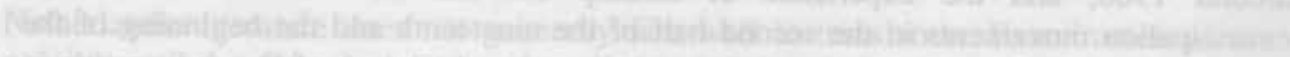

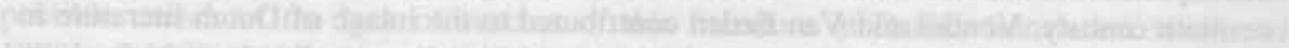

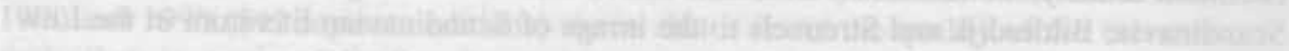

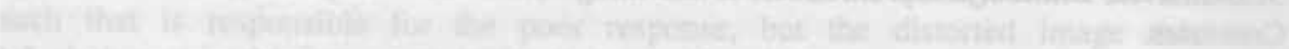

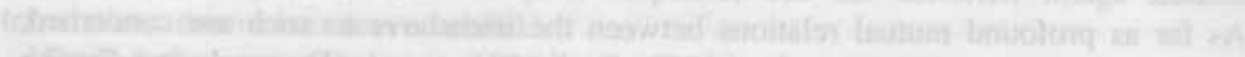

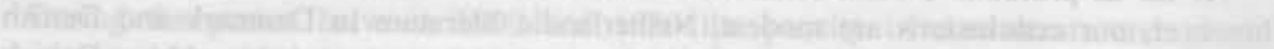

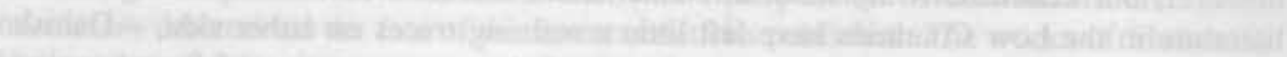

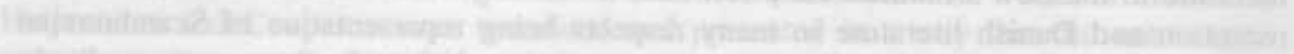

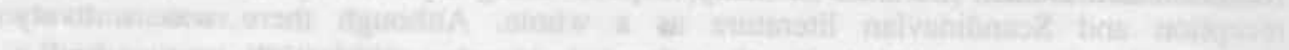

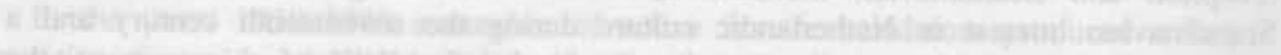

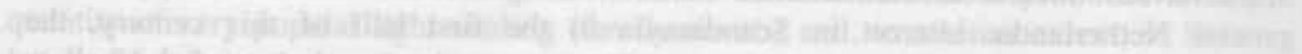

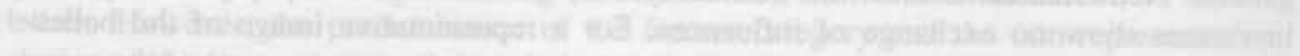

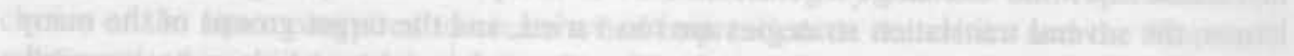

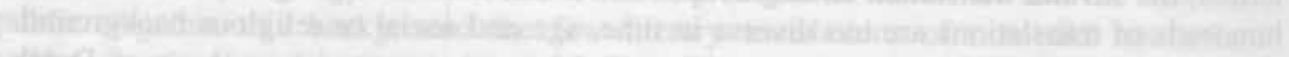

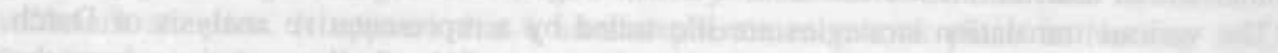

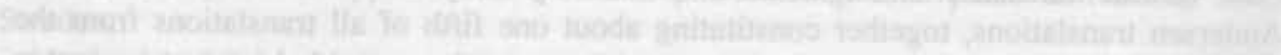

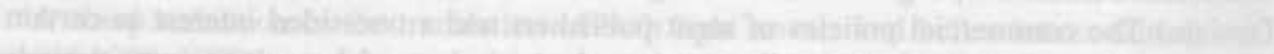

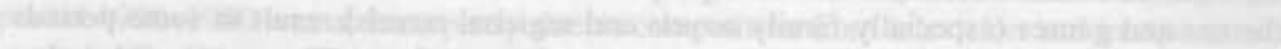

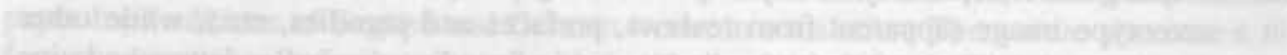

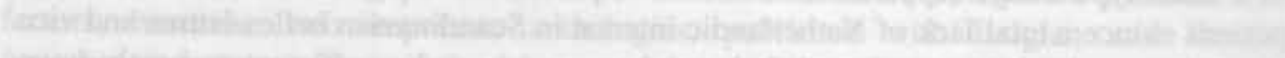

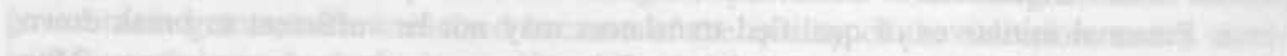

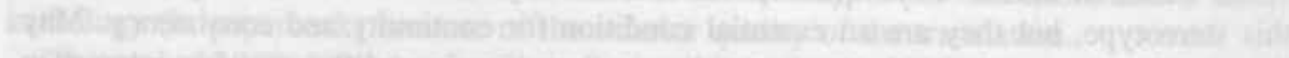

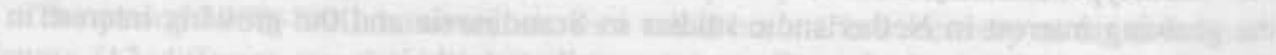

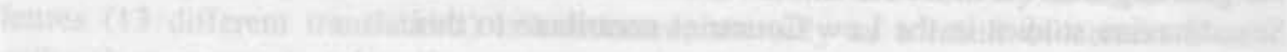

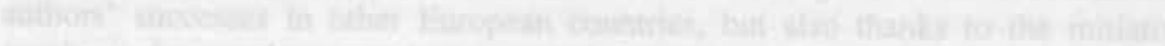

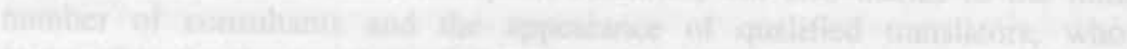




\section{Resumé på dansk}

Nærværende studie forsøger at give et billede af litterære forbindelser mellem Nederlandene og Skandinavien, fra 1600-tallet til i dag. Tidligere publikationer over dette emne har især fokuseret på forbindelser og/eller receptionen af nogle få nordiske forfattere (Holberg, H.C. Andersen, Kierkegaard og Strindberg) i Nederlandene, mens den omvendte forbindelse kun har været genstand for et par artikler, især vedrørende forfatteren Potgieters forbindelser med Sverige. Også relationeme mellem 'de' nederlandske og nordiske litteraturer som helhed er bare beskrevet i nogle få kapitler og artikler, der som regel bare har en inventariserende karakter.

Det foreliggende historisk-deskriptive arbejde forsøger at udfylde et antal huller i ovennævnte fremstillinger. Det prøver at besvare spørgsmålet hvilket billede læsere fra det ene område $\mathrm{i}$ tidernes $1 \emptyset \mathrm{b}$ har fået af litteraturen fra det andet område, og hvilken rolle særskilte forfattere, som subjekt og/eller objekt, har spillet i billeddannelsen. I denne forbindelse behandles beslægtede spørgsmål som: hvilke personlige kontakter har der været; hvad vidste man om den anden litteratur; hvad er der blevet oversat; hvordan har man oversat og med hvilken effekt; og hvilke spor af den ene litteratur findes der $\mathrm{i}$ den anden?

Bogen prætenderer ikke at behandle disse spørgsmål udtømmende, men har form af en række 'case studies', som tidligere er blevet offentliggjort som særskilte artikler. Dens første halvdel nærmer sig emnet fra forfatternes side, nærmere bestemt fire af Nederlandenes litteraturs støtter: Joost van den Vondel (1587-1679), Willem Bilderdijk (1756-1831), Frederik van Eeden (1860-1932) og Stijn Streuvels (1871-1969). Anden halvdel nærmer sig emnet fra litteraturens side: henholdsvis en studie over grænserne for receptionsforskning i 'den' danske litteratur i nederlandsk oversættelse 1731-1990; en analyse af H.C. Andersens eventyr Reisekammeraten i sytten nederlandske oversættelser, 1848-1992; og en studie over receptionen af nederlandsk litteratur i dansk oversættelse, 1900-1990. Som det fremgår af undersøgelsen, er billedet af dansk litteratur som sådan i Nederlandene stort set identisk med billedet af den nordiske litteratur som helhed, mens det begrænsede billede af nederlandsk litteratur i Danmark stort set stemmer overens med billedet i det øvrige Skandinavien.

En oversigt over komparative, receptionsteoretiske og oversættelsesvidenskabelige forskningsmodeller viser, at disse kun i begrænset omfang er brugelige for den foreliggende undersøgelse. Spredningen i tid (1600-tallet til i dag) gør det på grund af store forskelle i receptionskildemes kvantitet og karakter umuligt at samle, forbinde og fortolke dem inden for én og samme model. Desuden viser det sig at mange af de præsenterede modeller er ret prætentiøse og i praksis næppe brugelige. Dette gælder især 


\section{Resumé}

for Jau $\beta^{\prime}$ receptionshistoriske forskningsmodel samt for modellerne der bruges inden for den såkaldte polysystemteori, en teori som er tilknyttet både receptionsteorien og oversættelsesvidenskaben. For så vidt den foreliggende undersøgelse tilslutter sig komparatismen, er det især den franske skoles forskning.

Polysystemteoriens fokusering på modtagerkulturen og deskriptive udgangspunkt er dog overtaget. Væaten ligger på den enkelte forfatters eller den ene litteraturs rolle $\mathrm{i}$ modtagerkulturen. Med hensyn til de beskrevne oversættelser indtages der ikke noget normativt standpunkt om hvad der er en 'god' oversættelse, men de metoder og normer der bruges af oversættere, anmeldere og andre kulturformidlere analyseres og beskrives. Ekvivalenskriteriet fra Katharina Reiß' oversættelseskritiske model, som bruges til at analysere H.C. Andersens eventyr i nederlandsk oversættelse, er altså ikke nogen norm, men tertium comparationis for objektivt at kunne fastslå, hvilke forskydninger oversættelsen viser over for originalteksten.

Studien prasenterer ikke nogen alternativ altomfattende model, men går eklektisk til værks, idet den pr. 'case study' tilpasser metodikken til de forhåndenværende kilders karakter. Selvfølgelig er der i denne forbindelse stræbt efter kontrollerbarhed af data og signalerede forbindelser. 'Systemisk' er værket for så vidt så mange aspekter af de litterære forbindelser som muligt inddrages. Undersøgelsen har en empirisk-dokumentarisk karakter, som giver forskellige resultater pr. case study, hvilket skyldes variationeme i materialets disponibilitet og præg. Jeg har dog hele tiden forsøgt at efterspore alt det forhåndenvarende materiale, ikke for blot at anlægge en positivistisk samling af data, men for at forbinde disse data indbyrdes og at sætte dem $\mathrm{i}$ bredere kulturhistoriske rammer.

I 1600-tallet var de kulturelle forbindelser mellem Nederlandene og Skandinavien ensrettet fra syd til nord. Danske og svenske fyrster tog flamske og hollandske bygmestre, malere og videnskabsmænd i deres tjeneste, og kendskab til det nederlandske sprog var vidt udbredt $\mathrm{i}$ de nordiske lande. Dog syntes den nederlandske litteratur i modsatning til bygge- og malerkunst næppe at have efterladt sig spor i Skandinavien.

Dette negative billede med hensyn til litteraturen trænger til nuancering, når det drejer sig om receptionen af forfatteren Vondels person og værk. Som det fremgår af forskellige primære og sekundære kilder, blev Vondel læst på nederlandsk og beundret af samtidige nordiske fyrster og rangspersoner, som for en dels vedkommende har mødt ham personligt på hans rejser til Danmark og Sverige. Vondels skuespil opførtes i København og Stockholm på nederlandsk og tysk af omrejsende teatertrupper. Flere fremstående danske og svenske renæssance- og barokdigtere (Arrebo, Bording, Spegel og andre) har kendt hans værker og har muligvis været under indflydelse af ham på orddannelses-området.

I 1700-tallet forsvandt den nordiske interesse, men omkring 1900 blev tråden taget op igen af svenske, danske og norske filologer og oversættere, som især viste interesse for relationen Vondel : Skandinavien og for Vondel som europæisk barokkunstner, - en interesse som eksisterer den dag i dag. 
I 1700- og begyndelsen af 1800-tallet var der næppe tale om forbindelser mellem nederlandske forfattere og Norden. Som den nordiske litteraturs gennembrud i Nederland betragtes generelt forfatteren Potgieters bog Het Noorden (1836-1840). Dog viste digteren Bilderdijk, der i så mange henseender modsatte sig tidens ånd, allerede et halvt århundrede tidligere sin beundring for Skandinavien i ord og geming. Som ildfuld monarkist og anti-revolutionær besang han $\mathrm{i}$ sine originale digte den danske enevælde og det ufordærvede danske samfund, modsat det komumperede Holland. Han lærte sig selv dansk og læste både den oldnordiske og den moderne skandinaviske litteratur. To gange forsøgte han at bosætte sig i Norden, som hofdigter i København og som professor $\mathrm{i}$ jura i Kongsberg i Norge.

I sin ungdom bearbejdede han et skuespil af Holberg, og med det udtrykkelige ønske om at gøre den danske digtekunst mere kendt oversatte han senere $i$ livet digte af åndsbeslægtede norske og danske forfattere (Tullin, Schack Staffeldt og Baggesen), hvori naturen forherliges, den franske revolution kritiseres sønder og sammen og den litterære epigonisme bespottes.

Bilderdijks uoverensstemmelse med tidsånden forklarer nok delvis at han ikke fik direkte efterfølgere i sin interesse for Skandinavien. Til gengæld har han efterladt nogle spor i Norden: samtidige danske forfattere (Dirckinck Holmfeld, Scharling) hørte til hans elever og beundrere, og så sent som i 1943 blev han oversat til dansk af Vilhelm Andersen.

Frederik van Eeden voksede op i en tid hvor den tyske og nederlandske interesse for Skandinavien tiltog stærkt. Både hans egen familie og hans svigerfamilie rejste rundt i Norden og læste nordiske forfattere på originalsprogene. Det nordiske samfunds idylliske karakter og dets fornyende sociale og kunstneriske eksperimenter tiltrak sig deres opmærksomhed. På sin side tiltrak Van Eeden sig nordiske forfatteres opmærksomhed med romanen De kleine Johannes og sit andelsselskab Walden, blandt andet hos Ellen Key, Bjørnstjerne Bjørnson og Martin Andersen Nexø. Takket være hans kontakter med Georg Brandes, Det Moderne Gennembruds fader, offentliggjordes flere bidrag af og om Van Eeden i det danske dagblad Politiken. To gange drog Van Eeden på en foredragsturné i Norden, og i Sverige udkom seks forskellige Van Eeden-oversættelser. En svensk industrimand og politiker støttede hans sociale eksperimenter og den svenske psykiater/forfatter Poul Bjerre analyserede sin nederlandske kollegas værk for det nordiske publikum.

I Van Eedens originale værker er slægtskabet med H.C. Andersen synligt $i$ De kleine Johannes og i skuespillet Ismea; med Oehlenschläger i skuespillet Alladin og med vikingverdenen i skuespillet Lioba. En formodet indflydelse fra Holberg på komedien De student thuis er imidlertid ikke begrundet. Over for Ibsen har Van Eeden en ambivalent holdning: han beundrer Ibsens teknik og er jaloux på hans succes, men tør næppe erkende dette over for sig selv, og han kritiserer Ibsens ordkunst. I sine senere skuespil anvender han dog Ibsenianske elementer og teknikker.

I modsætning til det nederlandske og tyske publikum havde det flamske i 1800-tallets anden havdel næppe nogen interesse for Skandinavien. Der udkom næsten ingen 
oversættelser i Flandern, og også i de litterære tidsskrifter findes meget lidt. Alligevel var der interesse for Norden, nærmere bestemt hos føreme for De Vlaamse Beweging (den politiske og kulturelle flamske emancipationsbevægelse). Deres opmærksomhed blev tiltrukket af flamsk-nordisk slagtskab i sprog, race og folk, og af den skandinaviske kultur- og sprogpolitiks funktion som forbillede. De blev inspireret af et beslægtet lille sprogsamfunds opblomstring efter en periode med forfald, som var fulgt efter middelalderens storhedstid.

Allerede den flamske bevægelses fader, Jan Frans Willems, læste og studerede de skandinaviske sprog, fulgt af flere andre fremstående, for det meste liberale, romantiskfilologiske 'flaminganter'. Deres favoritter var Oehlenschläger og Tegnér, som jo besang de oldnordiske rigers glorie, samt H.C. Andersen, den verdensberømte repræsentant for et lille germansksproget land.

Den 'internationalistiske' kreds omkring tidsskriftet Van Nu en Straks søgte tilslutning til det Moderne Gennembrud, og havde kontakt med Georg Brandes. Den katolske kreds derimod var ikke begejstret over de modeme forfattere; men også katolikkerne lagde vægt på slægtskabet hvad angår sprog og folk. Især de norske bondenoveller tiltrak sig deres opmærksomhed.

Forfatteren Stijn Streuvels forenede som katolsk medarbejder af Van Nu en Straks de forskellige indfaldsvinkler. Han læste de moderne forfattere først på tysk; derp̊̊ lærte han sig selv norsk, og med hans oversættelser af Bjørnsons bondenoveller lykkedes det for ham som den første at interessere et bredt flamsk publikum for skandinavisk litteratur. Bjømsons vark genspejles desuden $\mathrm{i}$ motiver og stiltræk $\mathrm{i}$ hans roman De Vlaschaard. Streuvels' senere bearbejdelser af oldnordiske gude- og heltesagn og skandinaviske folkesagn er ideologisk præget i deres eftertryk på raceslægtskabet mellem flamlændere og skandinavere.

I modsætning til Van Eeden har Streuvels ikke fundet genklang i Norden. Påstået indflydelse fra eller på Knut Hamsuns værker synes ikke at være til stede.

I perioden 1731-1990 er der udkommet 1654 selvstændige nederlandske udgaver med en litterær oversattelse fra dansk til nederlandsk. Dette fremgår af en bibliografi over dansk skønlitteratur i nederlandsk oversattelse, samt en bibliografi over nederlandske H.C. Andersen-oversættelser, med senere tilføjelser. Til trods for dette store antal har oversættelserne som helhed ikke efterladt et representativt billede af 'den' danske litteratur hos det nederlandske og flamske læserpublikum.

I 1700-tallet var 37 ud af de i alt 46 udgaver oversættelser af Holbergs værker, hvori de typisk danske træk var forsvundet. I 1800-tallets første halvdel blev kun ganske få varker af de store danske romantikere og realister oversat, mens perioden 1850-1890 domineredes af H.C. Andersen, med 27 ud af de 63 oversættelser. For så vidt Det Moderne Gennembruds danske forfattere overhovedet blev oversat, skete det med en stor spredning over tiden, mens nogle kvindelige forfattere af trivialliteratur opnåede stor og langvarig succes. Årene 1910-1920 domineredes af både H.C. Andersens eventyr og helgenbiografierne af den katolske konvertit Johannes Jørgensen - to genrer der rettede sig mod to totalt forskellige lasergrupper. 
I tidsrummet 1920-1960 udkom der i alt 610 oversættelser. Denne periode frembød for første gang et globalt billede af 'den' danske litteratur som følge af hjemstavnsromanens overvægt. Her er imidlertid ikke tale om et specifikt 'dansk', men et generelt skandinavisk billede, som blandt andet fremgår af anmeldelseme. Kvalitativt højt- og lavtstående værker offentliggjordes af de samme forlag, og på grund af den nederlandske hjemstavnsromans generelt lave niveau er forventningen hos det litterært dannede publikum tilsvarende lav. Undtagelser som Kierkegaard, Kaj Munk og H.C. Andersen rettede sig mod specifikke målgrupper, og ændrede ikke det generelle billede.

Årene 1960-1990 frembyder en større diversifikation, men det konkrete antal af oversættelser går stærkt ned, undtagen oversættelser af børne- og ungdomslitteratur, hvis målgrupper dog næppe har interesse for oversættelsernes geografiske eller kulturelle oprindelse.

Receptionen af 'den' danske litteratur i Nederlandene eksisterer altså ikke: de forskellige populære forfattere og genrer retter sig mod målgrupper som er vidt forskellige hvad angår tid, alder og social eller religiøs baggrund, og som ikke får noget reprasentativt billede af de forhåndenværende oversættelser, endsige af den danske litteratur som helhed. Ikke desto mindre kan det være nyttigt at undersøge mere begrænsede former for reception, såsom receptionen af særskilte forfattere eller strømninger.

I forhold til de utallige oversættelser af H.C. Andersens eventyr til mere end 100 sprog findes der kun ganske få undersøgelser af oversættelsernes karakter. Derfor gøres der her et forsøg på at analysere sytten nederlandske oversættelser af eventyret Reisekammeraten, udkommet mellem $1848 \mathrm{og} 1992$. Ved hjælp af Katharina Reiß' analysemodel beskrives de forskydninger i forhold til originalteksten, der manifesterer sig i oversættelsen, og der søges efter en forklaring på disse forskydninger.

En analyse af grundteksten viser eventyrets konsistente struktur og karakteristiske fortællemåde. Det fremgår, at mange ordspil forsvinder i oversættelse, ligesom nøgleord og gentagelser, der ofte har en symbolsk funktion hos Andersen. Desuden normaliseres sproget som oftest i retning af den gængse (ungdoms-)litterære stil, muligvis af frygt for at afvigende sprogbrug ville blive anset for oversætterens fejl.

Tysk som mellemled og manglende kendskab til dansk er ârsag til utilsigtede afvigelser $\mathrm{i}$ henholdsvis de ældre og nogle af de nyere oversættelser, mens tilsigtede tilføjelser og udeladelser blandt andet skyldes frygt for Andersens 'uklarhed'. 'forbedring' af hans 'fejl', moralsk-religiøse og kommercielle motiver. Af og til moderniseres æxldre oversættelser i nyere udgaver, hvorved også 'realia' tilpasses tid og publikum.

Der er ikke tale om konsistente, sammenhængende forskydninger. Mange af disse forskydninger er iøvrigt ikke resultatet af en målbevidst tilpasning. men af sjusk og mangel på indsigt $i$ for eksempel nøgleordenes symbolfunktion, og en enkelt gang manglende kendskab til kildesproget. Der er ikke tale orn nogen konsekvent satsning på forskellige målgnupper - børn eller voksne -, eller sammenhæng med oversættelsemes forskellige tilblivelsesår. Til gengæld er der store forskelle i forskydningemes karakter og kvantitet. Konsistensen er størst i de to eneste fuldstændige eventyr-oversættelser: W. van Eedens kildesprog-orienterede oversættelse fra 1931, og oversættelsen af Annelies 
van Hees (1992), som straber efter ligevægt mellem kildesprog- og målgruppe-orientering.

Nederlandenes skønlitteratur i oversættelse har som regel kun haft begrænset succes. En undersøgelse af årsageme til mangel på succes for nederlandsk litteratur i dansk oversættelse mellem 1900 og 1990 (542 særskilte udgaver) viser, at den væsentlige faktor ikke er den nederlandske litteraturs kvalitet som sådan, men det forvrængede billede som de konkrete oversættelser efterlader hos det fremmede publikum.

Mangel på konsulenter og gode oversættere bestemte i perioden 1900-1930 de få oversættelsers skæbne. Multatuli, Heijermans og Couperus blev oversat og præsenteret på en ganske utilfredsstillende måde, hvad der ikke inspirerede til nye oversættelser.

I årene 1930-1960 tilvejebragte nogle dygtige og aktive oversættere et stort udbud af meget efterspurgte underholdningsromaner, og i mindre grad af skønlitteratur. Overvægten af slægts- og egnsromaner fra den første kategori og det ikke-repræsentative udvalg af den anden efterlod imidlertid et dårligt indtryk hos anmeldere og det 'litterære' publikum. Mod denne baggrund var de få lødige skønlitterære oversættelser ikke iøjnefaldende nok.

Stærk tilbagegang for oversættelser af både underholdningslitteratur og skønlitteratur i perioden 1900-1980 skyldes blandt andet konkurrencen fra henholdsvis fjernsynet og billigbogsudgaver af oversættelser fra de kendte sprog. Men også mere interne årsager spiller en rolle: to vigtige antologier, udgivet med belgisk og nederlandsk statsstøtte, kritiseredes for deres mangelfulde indledninger og udvalg, og en tredje antologi i billigbogsudgave for dens dårlige oversættelse.

Årene 1980-1990 viser en let, men tydelig genrejsning af skønlitteraturen (13 udgaver), som følge af bestemte nederlandske forfatteres succes $i$ andre europæiske lande, men også takket være nogle aktive konsulenter og (især) gode oversættere, som også sørger for oversættelse af kvalitativt gode bøme- og ungdomsbøger. Både skønlitteraturen og børne- og ungdomslitteraturen anmeldes udførligt og stort set meget gunstigt.

Den selvforstærkende virkning i størstedelen af det omtalte tidsrum (dårlig præsentation, ringe succes, endnu færre oversættelser, manglende interesse hos oversættere, og så videre) skyldes delvis den kommercielle forlagspolitik, men især enkelte personers ensidige initiativer. At en sådan virkning principielt også kan vendes i positiv retning, viser det seneste årti: konsulentemes og oversætternes aktiviteter er en ganske vist ikke tilstrakkelig, men i hvert fald nødvendig betingelse for kontinuitet og konsistens.

Afsluttende kan det med hensyn til de undersøgte forfattere slås fast, at fire skelsættende nederlandsksprogede forfattere har tiltrukket sig interesse fra og/eller vist interesse for Skandinavien: Vondel, Bilderdijk, Van Eeden og Streuvels. Spor af denne interesse (personlige kontakter, oversættelser, åndsfællesskab og for en del også påvirkninger) er tydeligt synlige og repræsentative for den rolle, som de pågældende forfattere har spillet i nederlandsk litteraturhistorie: den nederlandske Guldalders udstråling i 1600-tallet: kampen mod 'tidsånden' omkring 1800; interessen for sociale fornyelser omkring 1900; og en fornemmelse af slægtskab mellem den flamske og den nordiske frigørelseskamp i 1800-tallets anden halvdel og 1900-tallets begyndelse. Vondel og Van Eeden har bidra- 
get til billeddannelsen omkring nederlandsk litteratur i Skandinavien, og Bilderdijk og Streuvels til billeddannelsen omkring nordisk litteratur i Nederlandene.

Hvad angår dybtgående forbindelser mellem de respektive litteraturer, er konklusioneme imidlertid beskedne. Den nederlandske skønlitteratur i Danmark og den danske skønlitteratur i Nederlandene har på begge sider kun efterladt ganske få varige spor - og det viser sig at dette også gælder for nederlandsk skønlitteratur i Norden og nordisk litteratur i Nederlandene i det hele taget. Skønt 1600-tallets Norden viste stor interesse for nederlandsk kultur og skønt Nederland i 1800-tallets slutning og 1900-tallets begyndelse viste en generel interesse for Skandinavien, er der ingen vigtige indflydelser fra den ene litteratur på den anden tilstede. Der er heller ikke tale om det ene sprogområdes konsistente reception af 'den' hele litteratur fra det andet område. For et representativt billede af skønlitteraturen divergerer de forskellige oversættelsesstrategier alt for meget, og er der alt for store forskelle i tid, alder og social eller religiøs gruppe mellem de forskellige målgrupper for de hundredvis af oversættelser. (Oversættelsesstrategieme fremgår blandt andet af en repræsentativ analyse af de nederlandske H.C. Andersenoversættelser, som tilsammen udgør cirka en femtedel af samtlige oversættelser fra dansk). En kommerciel forlagspolitik med ensidig interesse for bestemte emner og genrer, især slægts- og egnsromaner, sørger mellem cirka 1920 og 1960 i begge sprogområder for et stereotypt billede af den fremmede litteratur. I andre perioder er forlagene fuldstændig ligeglade med henholdsvis nordisk litteratur $\mathrm{i}$ Nederlandene eller nederlandsk litteratur i Norden. Personlige initiativer fra kvalificerede konsulenter og oversættere er en ganske vist utilstrækkelig, men i hvert fald nødvendig betingelse for at kunne nedbryde sådanne stereotypier. Den voksende interesse for nederlandskstudiet $i$ Skandinavien og skandinavistikken i Nederland og Flandern kan forhåbentlig yde et positivt bidrag i denne henseende. 


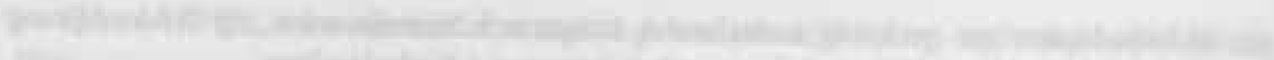

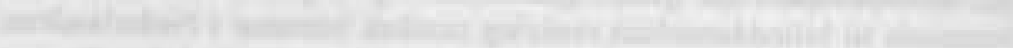

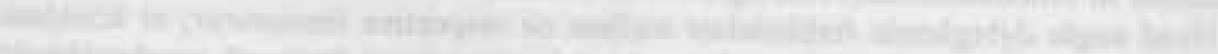
and

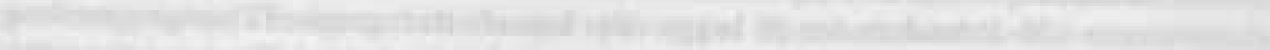
-

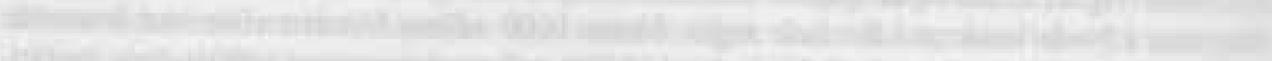

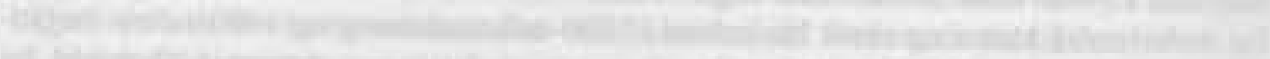

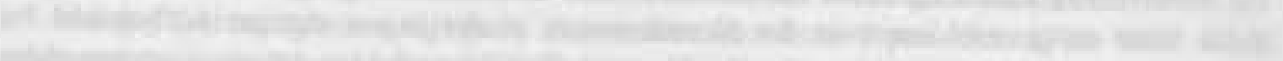

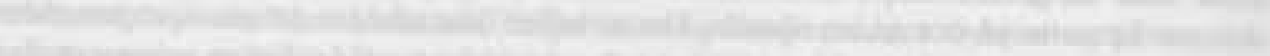

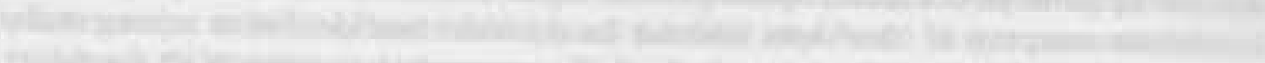

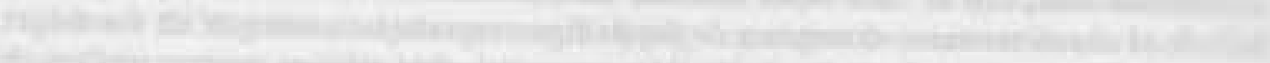

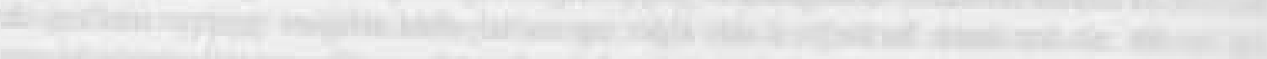

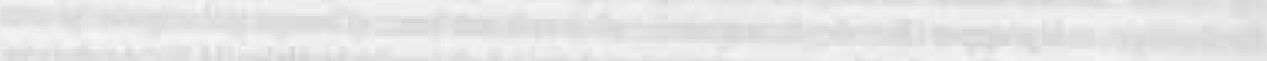

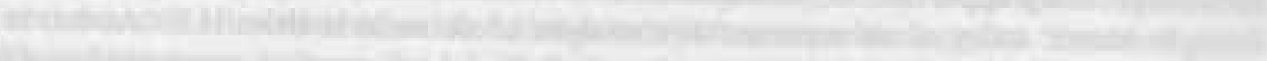

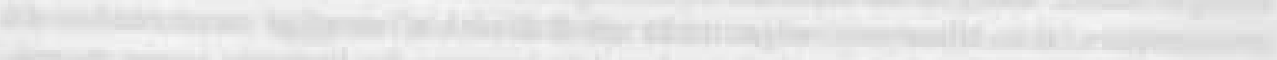
Then Thate Tate

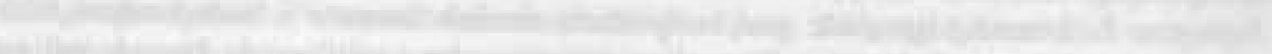

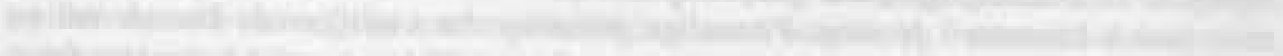

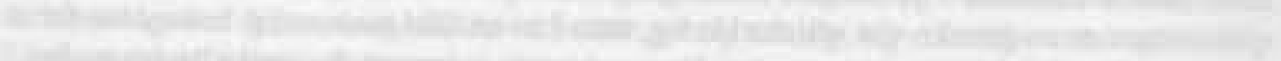

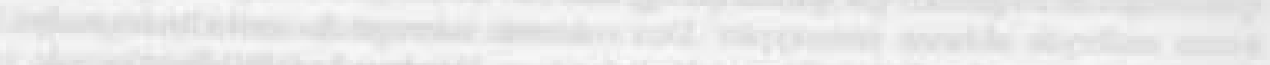
rat -

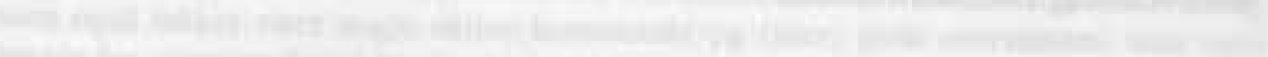

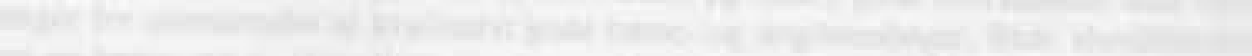




\section{Personenregister}

Het register bevat de persoonsnamen uit de hoofdstukken I tot en met IX en de Noten. De alfabetisering is de Nederlandse, dat wil zeggen dat $æ / \ddot{a}=a e, \emptyset / \ddot{o}=\infty e, a=a a . ~ B i j$ dubbele namen wordt gealfabetiseerd op de eerste naam. Vlaamse namen worden gerangschikt op de eigenlijke naam en niet op de voorvoegsels De of Van.

A

Aabye, K. 115, 122

Aakjær, J. 78, 120

Aalberse, H.B. 172-173, 198, 200-201

Aame, A. 133, 251

Åström, H. 132

Achen, G. 115

Aken, P. v. 172-173, 198, 200-202

Albach, B. 14, 36, 242-243

Albertsen, L.L. 132, 186, 252-253

Ammers-Küller, J. v. 172, 183, 185-187

Anbeek, T. 21, 241

Andersen, C. 115

Andersen, H.C. $13,15,18,22,24,28$, $53,70,73,75-76,83-87,91,93,95-$ $96,102,112,114-116,118,120,126-$ $128,131-160,165,180,241,248$

Andersen, V. $38,43,48,65,67,70$, 243, 245

Andersen Feldborg, A. 56

Andersen Nexø, M. 78, 91, 115, 120, 122,175

Andreus, H. 173-174

Andriessen, S.J. 142, 147-157, 160

Anker Larsen, B. 185, 188, 200

Anker Larsen, J. 115, 120

Apel, F. 24

Arion, F.M. 166, 172, 204, 206-207
Amoldsen, C. [ps.] zie Dirckinck-Holmfeld, $C$.

Arrebo, A. 37-38, 243

Asbjørnsen, P.C. 134, 251

Askerøi, J.E. 243

Assche, H. v. 167, 241, 248-249

Asscher-Pinkhof, C. 173, 201

Åström lees Aaström

Auwera, F. 173

B

Baeck, , M. 247

Bäckmann, I. 247

Baekelmans, Lode 119, 123, 241, 248, 250

Baggesen, J. 27, 53, 57, 65-66, 68, 71, 245

Bakker, M. 142, 147-157, 160

Bakker, P. 172-173, 186, 188, 192, 193 , 203

Bakker-Nort, B. 74

Baldensperger, F. 16

Balzac, H. de 175

Bang, H. 74, 93, 101-102, 115, 119 , $121,126-128,175-176,184$

Bamard, H. 199

Bartas, G. du 37, 38

Bastings, E. 250 
Baumgartner, W. 112-113, 249, 250

Baur, F. 248

Bech Nygaard, J. 192

Becker, F. 246

Becker, J. 241-242

Beckman, T. 172, 207

Beijer, A. 36, 243

Belcampo, 173

Belpaire, M.E. 99, 248

Bentsen, G. 207

Bergh, H. v.d. zie Braven, ten

Bernhard, C. 115

Bernlef, J. 166, 172-174, 204-205, 207, 210,254

Bertelsen, E. 122

Beukman, M. 186

Beuningen, C. v. $32-33$

Biegel, P. 172, 199

Biesheuvel, J.M.A. 173

Bilderdijk, W. 15-16, 18, 27, 39, 53-71, 244-245

Bilderdijk-Schweickhardt, K.W. 63, 67, 245

Bille, C.S.A. 251

Birkeland, T. 198

Bjerre, P. 80-81, 91, 246

Bjømson, B. 18, 53, 74, 77, 87, 91, 93 $94,96,99-105,109,118-119,248-$ 249

Blaman, A. 173, 203

Blekastad, M. 50, 243

Blicher, S.S. 118-119

Blicher-Clausen, J. 115, 119, 250

Blixen, K. 115, 127, 166, 184

Blommaert, Ph. 95, 248

Blon, M. le, 31-32

Bobé, L. 242-243

Bodelsen, A. 115, 166, 192, 204-206

Bødker, C. 115, 126, 166, 196

Bøgh, N. 251

Bønnelycke, E. 122

Boer, L. de 173, 180

Boer-den Hoed, P.M. 18, 142, 241, 244
Bolckmans, A. 114, 123, 241, 243, 248, 250-251

Bom, E. de 93, 96, 98, 101, 248

Bomans, G. 124

Boon, A. 106

Boon, L.P. 166, 173, 194

Borch, O. 37, 47

Bordewijk, F. 169, 173

Bording, A. 37-38

Bos, G. v.d. 14, 241, 251

Bosch, J. 244

Boudier-Bakker, I. 172-173, 183, 185 , $187,190,192,194,196$

Bouhuys, M. 199

Bouma, L.H. 14, 124, 126, 241, 250-251

Boven, E. v. 169

Braak, M. ter 183, 194, 250, 253

Brachin, P. 241-242

Brakman, W. 204

Brandes, E. 76

Brandes, G. 39, 47-48, 73-76, 91, 96$101,136,182,243,245,251-252$

Brandt, A.L. 68

Brandt, G. 242

Brandt Corstius, H. 204

Branner, H.C. 122

Braven, ten 128, 251

Bredsdorff, E. 132, 252

Bregendahl, M. 122

Breinholst, W. 115

Bremer, F. 53, 93

Broeck, R. v.d. 241

Brostrøm, T. 206, 253

Brøgger, S. 115, 127, 166, 207

Brøndsted, M. 114, 245

Brouwer, J. 172-173, 187

Brouwer, R. 172-173

Brouwers, J. 166, 172, 204-207, 210

Bruijn, C. 185

Bruijn, Ph.R.F.C. de 142, 147-157, 160

Brulez, R. 173

Brummeler Andriesse, J.C. ten 244

Bruna, D. 172-173, 198, 201

Brunse, N. 206, 208 
Bruun, L. 115

Brøgger lees Broegger

Brøndsted lees Broendsted

Buchholtz, J. 115, 121

Buhl, I. 187

Byron, G.G. Lord 68

Bødker lees Boedker

Bøgh lees Boegh

Bønnelycke lees Boennelycke

C

Campert, J. 172-173

Campert, R. 173-174

Carlé, B. 207-208

Carlier, L.B. 173, 194

Carlsen-Skiødt, J.C.A. 122

Carmiggelt, S. 173

Cate-Silfwerbrand, R. ten 248

Cats, J. 29, 38, 47-48, 167, 184

Catullus 43

Cavling, H. 178

Chorus, A. 169, 252

Christian IV 31, 74, 94

Christian VII 54-55

Christina van Zweden 30-32, 34, 42, 47$48,50,242$

Christmas, W. 115

Claes, V. 14, 241, 246, 248, 252

Claus, H. 170, 173, 194, 202, 204

Colban, M. 75

Coekelberghs, 201

Coninck, H. de 173

Conscience, H. 168

Coolen, A. 172-173, 184, 187, 193, 194, 196

Corsari, W. 171-173, 183, 185-187, 191192, 203

Costa, I. da 68

Coster, C. de 184, 194

Coster, D. 124, 250

Cottenjé, M. 173

Couperus, L. 170, 173, 175-177, 185 , 211
Cramer, R. 172-173, 176

Cremer, J. 172, 198

Cronin, A.J. 193

Cruys, G. [ps.] zie Kruisman, G.

D

Daalder, D.L. 252

Dähnhardt, W. 241

Dahlberg, G. 14, 51, 241-244

Dal, E. 136, 144, 251-252

Dass, B. 47

De Bom, E. zie Bom, E. de

De Coninck, H. zie Coninck, H. de

De Coster, C. zie Coster, C. de

De Mont, P. zie Mont, P. de

De Pillecijn, F. zie Pillecijn, F. de

De Ronde, T. zie Ronde, T. de

De Tollenaere, F. zie Tollenaere, F. de

De Vin, D. zie Vin, D. de

Debeurme, O. 100-101

Delecourt, V.H. 95, 24, 248

Deloof, J. 196, 253

Dem, G. 142, 147-157, 160

Demedts, A. 101, 173, 248-249

Denhardt, H. 104

Dermout, M. 172-173, 196

Deyssel. L. v. 73, 246

D'haen, C. 248

Dickens, C. 180,184

Diekmann, M. 201

Dietrichson, J.W. 244

Dijck, J. v. 30-31, 242

Dijk, D. v. 248

Dirckinck-Holmfeld, C. 39, 56, 68-69. 243, 244-245

Doolaard, A. den 172-173, 183, 188. 193. 196

Doorman, C. $133,142,147-157,160$, 250-251

Dorrestein, R. 173, 204

Drachmann, H. 75, 96, 101-102, 119

Dragt, T. 207

Du Bartas, G. zie Bartas, G. du 


\section{Personenregister}

Dubelaar, T. 207

Dubois, P. 172, 184, 186, 190

Duif, A. 172, 201

Duinkerken, A. v. 83, 106, 246, 249

Dyserinck, H. 17-18, 241

E

Eeden, F. v. 15-16, 18, 27, 70, 73-91, $97,136,172-173,175,177-178,180$, 246-247

Eeden, F.W. v. 74

Eeden, H. v. 246

Eeden, W. v. 126, 132, 142, 147-157

Eeden-Schuitemaker, T. v. 142, 147-157, 160

Eeden-van Vloten, M. v. zie Vloten, M. v.

Ehrencron-Kidde, A. zie EhrencronMïller, A.

Ehrencron-Müller, A. 115

Eide, E. 243

Elburg. J. 174

Elema, H. 250

Eller, P. 50, 244

Elsing, J.M. 201

Elsschot, W. 169, 172-173, 183-185, 190,196

Elster, K. 75

Erslew. Th. H. 66, 245

Eskelund, K. 115

Etlar, C, 115, 249

Even-Zohar, I. 22-23, 241

Ewald, C. 87, 115

Eykman, C. 199

\section{F}

Fabricius, J. 172. 187

Fabricius, K. 242

Fahlstedt, A. 247

Falk-Ronne, J. 115, 122-123

Falkland, S. zie Heijemans, $H$.

Fallada, H. 185
Fallersleben, A.H. Hoffmann v. zie Hoffmann v. Fallersleben, A.H.

Februari, M. 254

Feldborg, A. Andersen zie Andersen Feldborg, A.

Ferwerda, S. 14, 58, 116, 241, 243, 245 , 250

Fischer, E. 115

Fisker, R. 115

Fliflet, A. Lange zie Lange Fliflet, A.

Flor, K. 187

Flyndersøe, P. 115

Fogelklou, A. 246

Fokkema, D.W. 18, 241

Fornenbergh, J.B. v. 33-34, 36-37, 39 , 242

Frænkl, P. 50, 243

Franciscus van Assisi 99

Frank, A. 166, 170, 172-173, 204-205

Franke, S. 173

Frederik III, 32-35, 49, 242

Frederik VI 54, 56

Freuchen, P. 115

Freud, S. 80

Frieswijk, J. 246

G

Gad, T. 168, 184, 241

Garborg. A. 101, 102

Gauffin, A. 40-42, 243

Geeracrts, J. 166, 173, 194

Gentikow, B. 246, 249-250

Gersdorff, J. 33

Gezelle. G. 98. 100, 185, 248

Gijsen, M. 166, 172-173, 183-184, 186188, 190, 201-202

Gilliams, M. 173, 185

Gjellerup, K. 115, 119

Goekoop-de Jong van Beeck en Donk, C. 176,179

Gogh, V. v. 170, 172-173

Gogh-Kaulbach, A. v. 186-187

Gormsbol, E. 251 
Gorp, H. v. 23, 241

Gozzi, C. 135

Gorter, H. 73

Goudsmit, H. 84, 86, 247

Graaf, H. de 204

Graft, G. v.d. 174

Gredsted, T. 115

Gregersen, G. 122

Grieg, E. 101

Grit, D.C. 142, 206, 241-253

Groeben, N. 21

Groen, J. 114

Grønbech, V. 106, 249

Groot, H. de 31-32

Grootenboer, G. [ps.] zie Vries, G. de

Grundtvig, N.F.S. 68,96

Grundtvig. S. 133-134, 251

Gryphius, A. 48

Grønbech lees Groenbech

Gullbranssen, T. 128

Gunnarsson, G. 115, 122

Gustav Adolf 30, 31, 42, 48, 50, 242

Guyot, Ch. 105, 249

Gyselen, G. 248

\section{H}

Haar, J. ter 172, 199

Haasse, H. 204, 206

Hallen, E. v.d. 105

Hamelink, J. 173, 201, 203

Hammerich, C. 183-187, 190, 194-198. $200,202,211,252-253$

Hammerich, L.L. 184, 194, 201-202, 252-253

Hamsun, K. 13, 18, 74, 102, 108-109. 124,249

Hansen, C. 115

Hansen, C.J. 95-96, 248

Hansen, M.A. 122, 126

Hansen, V. 115

Hart, M. 't 173, 204, 207

Hartman, E. 172-173, 207-208
Hartog, J. de 172-173, 184, 186, 188 , 192-193, 203

Hassel [Hazel], S. 115, 192

Hasselbalch, S. 185

Haugann, O. 244

Haverschmidt, F. 83

Hazel, S. zie Hassel, S.

Hedberg. T. 40, 243

Hedin, S. 87

Hedvig Eleonora 36

Hees, A. v. $127,132,141-142,158$, $161-163,246,251$

Hegenscheidt, A. 105, 249

Heiberg, J.L. 116, 118

Heidenreich, D.E. 36

Heijden, A.F.Th. v.d. 204

Heijermans, H. 169, 173, 175, 180, 182 , 188,211

Heine, H. 180

Heinesen, W. 127

Hellum, P. 187

Helman, A. 173

Hemmerechts, K. 204

Heremans, J.F.J. 95-96

Hermans, Theo 241

Hermans, Toon 173

Hermans, W.F. 166, 170, 172-173, 198201, 203

Hertel, H. 253

Hertog, A. den 172

Hertz. G.J. 115

Hesse, H. 184

Heymans, M. 172

Heyns, Z. 37

Hichtum, N. v. 176, 182

Hill, T. 115

Hillesum, E. 166, 172, 204-207, 210

Hillner, J. 252

Hjuler, C. 188

Hoge, P. 204

Hoek, D. 242

Hoel, S. 185

Höveln, C. v. 36

Hoffmann v. Fallersleben, A.H. 62 
Holberg, L. 13, 16, 18, 27, 39, 53, 57$58,71,75,83,115-116,127-128,246$ Holm, H. 44, 243

Holm, J.K. 115

Holm, S. 166

Holmboe, H. 243

Homerus 81

Hooft, P.C. 184

Hoogstraten-Schoch, A. v. 186

Horatius 43, 48, 59, 70

Huizinga, L. 172, 188

Hulst, W.G. v.d. 172

Hultberg, P. 204

Huygen, W. 172-173

Huygens, Ch. 41

Huygens, Const. 38, 44

Humboldt, W. v. 24

Høeg lees Hoeeg

I

Ibsen, H. 13, 18, 73-76, 87-91, 93, 96, $99,100-102,109,118-119,128,247$ Ingemann, B.S. 116,118

Ipsen, A. 48, 70, 75, 87, 177-178, 194, $243,245-246,247$

Ipsen, H. 166, 184, 208

Isaachsen-Dudok van Heel, V. 76, 87 Iser, W. 19, 20, 21

Iterson, S. v. 199

J

Jacobsen, J.P. 96, 99, 101-102, 109.

$115,118,127-128,184$

JauB, H.R. 19-21, 241

Jehu, F. 172

Jensen, A. 136, 139-140, 156, 252

Jensen, A.E. 207

Jensen, J.V. 87, 115, 126, 166, 175 . 207

Jensen, T. 122-123, 250

Jespersen, H. 185

Jespersen, I. 198, 200
Jørgensen, Aa. 131-132, 249

Jørgensen, J. 87, 90, 99, 120, 128

Jonckheere, K. 101, 172-174, 188, 190, 248

Jong, A.M. de 172-173, 183, 185, 188, 196

Jong, C. de 142, 147-157

Jong, O. de 166, 172-173, 205-207, 210

Jong van Beeck en Donk, C. de zie Goekoop-de Jong van Beeck en Donk, C.

Jordis, H. 36, 243

Josselin de Jong, K. de 185

Juel Møller, S. 28, 132, 141-142, 248251

Juhre, R. 249

Junkers, H. 242

Jørgensen lees Joergensen

$\mathbf{K}$

Kalff, G. 90, 247

Kampmann, C. 192

Kane, T. 207-208

Karl X Gustav 32, 33

Karl XI 36

Kate, J.J.L. ten 118

Katz zie Cats, J.

Keersmaekers, A. 84, 246, 252

Kellendonk, F、 204

Kempenaer, N. de 186-187

Kessels, L. 172

Key, Ellen 74, 77, 91

Kielland, A. 75, 101-102, 109, 119

Kierkegaard, S. $75,83,87,114-115$, $126-128,166,251$

Kingo, T. 38, 48

Kirchheiner, T. 199, 200, 208-209

Kirk, H. 120, 191

Kirkegaard, $\mathrm{O}$. Lund zie Lund Kirkegaard, $O$.

Kjergaard, H. 14, 32, 48, 50, 84, 184. 241-245, 247, 252-253

Klimaszewska, S. 252 
Kloek, J.J. 20-21, 241

Kloos, W. 73

Kneppelhout, J. 83

Knudsen, J. 115, 175

Koeck, P. 173

Koenders, E. 132, 251

Kofoed, N. 136, 251

Kol-Porrey, N. v. 74

Kollewijn, R.A. 58, 244, 254

Kolmodin, O. 38

Komrij, G. 204

Kooiman, D.A. 204

Koolhaas, A. 173, 174, 200, 203

Kooten, K. v. 173

Kopland, R. 204

Koppang, O. 50, 243

Korch, M. 115, 122, 192

Korpel, L. 22, 241, 245

Kos, S. 251

Kousbroek, R. 166, 169-170, 204, 252

Kouwenaar, G. 174

Kraft, E. $115,177-178,180,183,185$, 211,249

Kraggerud, E. 51, 244

Kramer, D. 172

Krarup Nielsen, A. 115

Kresse, H. 172-173

Krijn, S. 241

Kristensen, E. 122

Kristensen, E. Tang zie Tang Kristensen, E.

Kristensen, N. 182

Kristensen, T. 122, 191

Krøyer, P.S. 97

Krogh, T. 48, 242-243

Krol, G. 204

Kromhout, R. 207

Kruisman, G. 206-208

Kruse, W. 38

Krøyer lees Kroeyer

Kuijer, G. 199

Kuijpers, H. 172

Kusters, W. 204
L

Laan, D. 172

Laan, L. ter 141-142

Labberton, M. 185

Lagerkvist, P. 87, 184, 203

Lagerlöf, S. 74, 77, 87, 102

Lambert, J. 23, 241

Lampo, H. 166, 173, 201

Lange, W. 104

Lange Fliflet, A. 44-47, 243

Langvik-Johannessen, K. 32, 37, 44-47, 50-51, 183, 191, 205, 241-244, 247. 253

Lanoye, T. 204

Larsen, Anker zie Anker Larsen

Larsen, K. 115

Last, J. 173

Lateur, F. zie Streuvels, S.

Laurey, H. 142, 147-157, 160

Laurin, C. 40,243

Le Blon, M. zie Blon, M. le

Lebrocquy, P. 94-95, 248

Leeuwen, J. v. 207

Lefevere, A. 241

Legène, L. 172

Lemboum, H.J. 166

Lenin, V.I. 131

Lennart, C. 172, 186

Lennep, J. v. 70, 118

Lescouhier, D.F. 100

Lessing, G.E. 59, 180, 245

Leuven-Zwart, K. v. 24-25, 241

Levetzow, C. 115

Levy, J. 24

Lie, J. 119

Lieberkind, I. 115

Lindblad, J. 247

Lindgren, A. 203

Lindström, J. 207

Ljøgodt, K. 243

Lloyd George, D. 81

Lobedanz, E. 104

Lodewijk, M. 172 


\section{Personenregister}

Lodewijk Napoleon 56

Løkken, T. Olesen zie Olesen Løkken, $\mathrm{T}$.

Løvland, H. zie Syberg [Løvland], H.

Logeman, H. 58, 119, 245

Logeman-van der Willigen, D. 119

Loo, T. de 204.

Lorck, C.B. 150-151

Loveling, R. 96, 248

Loveling, V. 96, 248

Lucebert 174

Luger, B. 241, 246, 249, 252

Lulofs, M. 172, 186-187, 192

Lund Kirkegaard, O. 115

Lundgaard Simonsen, V. 37, 243

Lunding, E. 48, 243

Lundsgaard, B. 206-208

Luxemburg, J. v. 241

Løkken lees Loekken

Løvland lees Loevland

\section{M}

Madsen, N.P. 115, 122

Madsen, S.Aa. 204

Maitland-van Bemmelen, A.F. 141-142, 147-157, 160

Man, H. de $172,183,185-188$

Mandelkow, K.R. 20, 241

Mander I, K. v. 32

Mander III, K. v. 32-33, 49-50

Maria Eleonora 34

Marken, A. v. 200-201, 241, 248, 251253

Martin. H. 172-173, 184, 186-187, 193. 203, 253

Matena, D. 172

Matsier, N. 204

Maupassant, G. de 175

Meekel, K. 179

Meester, J. de 175

Meeuwesse, K. 245

Meijboom zie Meyboom

Meijer, R.P. 249
Meijsing, D. 204

Meir, G. 248

Meister, K. 115, 119

Melati van Java 176, 179

Melberg, A. 206, 253

Melles, J. 242

Mens, J. 188

Meuleman, B.A. 241, 248, 250

Meyboom, L.S.P. 82

Meyboom, M. 74, 77, 178, 241, 244, $246,247,250$

Michaëlis, K. 115, 122

Michels, L.C. 243

Michelsen, C. 179-180

Michiels, I. 194

Mikkelsen, B. 115

Milton, J. 47

Minco, M. 173, 201, 203

Minderaa, P. 248

Møller-Kristensen, S. 114, 252

Mørch, D. Trier zie Trier Mørch, D.

Möring, M. 254

Mohn, B. 187

Moldenhawer, D.G. 56, 244

Molkenboer, B.H. 243

Mont, P. de 76, 96, 98

Moor, B. de 172

Moor, M. de 254

Morel, P.M. 252-253

Morriën, A. 173

Mortansson, E. 115

Mulisch, H. 166, 172, 204-208, 210, 254

Muller, F. 251

Muller, J.W. 242

Multatuli 166, 169, 172-173, 175, 177 179, 181-182, 188, 198, 202-204, 206-207, 208, 211, 252-253

Munch-Pedersen, E. 167

Munk, B. 115

Munk, K. 115, 126, 128, 166

Muusses, M. 42-43, 205, 243

Mylius, J. de 208

Møller-Kristensen lees Moeller-Kristensen 
Mørch lees Moerch

$\mathbf{N}$

Naeff, T. $90,172-173,176,177,182$

Nesse, A.M. 44

Netscher, F. 73, 246

Neuhard, E. Westh zie Westh Neuhard, E.

Nex $\emptyset$, M. Andersen zie Andersen Nex $\emptyset$, M.

Nicander, A. 38

Nielsen, A. Krarup zie Kranup Nielsen, A.

Nielsen, E. 136, 144, 251

Nietzsche, F. 74, 81, 90

Nijhoff, A.H. 172, 187

Nijland-v.d. Meer de Walcheren, M. 142

Nijland-Verwey, M. 246

Nijnatten-Doffegnies, H.J. v. 172, 186

Norgaard, P. 115

Nolet de Brauwere van Steeland, J.C.H. $68,95-96,245,248$

Noordam, N.F. 242

Noort, S. 207

Nooteboom, C. 166, 170, 172, 204-205, 207-208, 254

Nordahl, H. 244

Norlind, A. 80, 246-247

Norlind, E. 78, 80-81, 85, 246-247

Nygaard, J. Bech zie Bech Nygaard, J.

Norgaard lees Noergaard

$\mathbf{0}$

Oberski, J. 166, 172, 205, 207, 210

Oehlenschläger, A.G. $57,68,83,95-96$, 98, 114-116

Østby, A. 109

Olesen Løkken, T. 115, 122-123

Oliveira, E. d', 247

Olrik, A. 134, 251

Ostaijen, P. v. 170

Ott. E. 115
Otto, S. 115

Otterloo, G. 51, 244

Oudshoom, J. v. 184

Overskou, T. 36, 243

Ovidius 38

Oye, E. v. 98

$\mathbf{P}$

Paemel, M. v. 204

Palmskiöld, E. 47

Paludan, Jac. 122, 191

Paludan, Jul. 47, 243

Panduro, L. 126, 166, 192, 196

Pée, W. 253

Pelgrom, E. 172, 207

Perron, E. du 173, 194

Persyn, J. 93, 100, 241-242, 248

Philips, M. 172, 186

Pichois, C. 241

Pillecijn, F. de 172-173, 198, 202, 248249

Ploug, C. 96

Poel, K. v.d. 205-208, 210, 254

Polet, S. 174

Pontoppidan, H. 114-115, 119, 124-125, 175

Poppe, A. 173

Porteman, K. 243

Potgieter, E.J. 13, 15, 53, 71, 241, 246

Potharst-Gimberg, C.E. 199

Presser, J. 172, 186, 190, 200-201

Prick, H.G.M. 246

Priestley, J.B. 185

Prins, A. 73, 246

Proust, M. 194

Psilander, H. 48

Put. K. v.d. 246

Putte, G. v.d. 244

Q

Querido, I. 175

Quillet, B. 242 
$\mathbf{R}$

Raaf, K.H de 241

Rabelais, F. 180

Rademakers, F. 206, 208

Rahbek, K. 207

Randel, A. 42-43, 243

Raes, H. 170, 173

Rask, R. 57

Rasmussen, Aa. 253

Rasmussen, E. 115

Rasmussen, B.W. 208

Rebolledo, B. de 33

Reeser, H. 14, 241, 245, 248-252

Reesink, M. 172

ReiB, K. 24-25, 28, 132, 143, 156, 241 , 252

Rembrandt 40-41, 48

Rens, F. 95

Rens, L. 48, 243

Reuscher, J. 151

Reve, G.[K. v.h.] 173, 203-204

Rheden, M. v. 187,188

Rifbjerg, K. 126, 166, 192, 196, 204

Rijndorp, J. v. 36

Rilke, R.M. 186

Robbers, H. 175

Roc, M. 188

Rodenbach, A. 28, 99, 109

Roelants, M. 173

Roemans, R. 248-249

Römelingh, J. 242-243

Roep, T. 172-173

Roger-Henrichsen, G. 184, 190

Roggeveen, L. 172-173

Roland Holst, A. 174

Romein-Verschoor, A. 124, 126, 142, 147-157, 159-160, 166, 169, 183, 250, 252

Ronde, T. de 108

Roosjen, P. 244

Roothaert, A.M. 173, 186, 192

Rousseau, J.J. 65

Royaards, W. 90
Rozenbroek, J. 247

Rubinstein, R. 204

Rubow, P. 136, 139, 251

Rutgers v.d. Loeff-Basenau, A. 172-173, 183

Ruiter, M. de 34

Ruyslinck, W. 173

$\mathbf{S}$

Salemans, B.J.P. 242

Saxo Grammaticus 57, 105

Schaars, F.A.M. 242

Schack Staffeldt, A.W. 18, 27, 53, 57 , $61-63,67,71,245$

Scharling, H. 39, 68, 70, 115, 243, 245

Scharten-Antink, C. \& M. 172, 183-186

Scheffer, C. 172

Schell, S. 207

Schendel, A. v. 173,184

Schepens, P. 109, 248-249

Schippers, W.T. 173

Schleiermacher, F. 24

Schmidt, A.M.G. 124, 172, 183, 198$199,203,251$

Schmidt Degener, F. 40, 243

Schmitz, M. 185

Schouten, A. 142, 154

Schram, D. 241

Schubart, H. 54, 56, 244

Schubert, I. 172, 207

Schuytvlot, A.C. 33

Scott, W. 70

See, K. v. 249

Sehested, E. 33

Servaes, A. 172-173, 186

Shakespeare, W. 16, 47

Shelley, P.B. 81

Shute, N. 193

Sick, I.M. 115, 119

Simons, L. 248

Skautrup, P. 136, 251

Skjoldborg, J. 78, 123, 175 
Skou-Hansen, T. 205

Slauerhoff, J.J. 169, 173

Sleutelaar, H. 174

Snapper, J.P. 168-169, 180, 252

Snoek, P. 174

Snorre Sturlason (Snorri Sturluson) 101

Söderholm, M. 193

Søiberg, H. 122, 123

Sørensen, H. 50, 244

Somers, M. 248

Sophia Amalia, 34

Spegel, H. 38, 48

Spies, M. 242

Spinoza, B. de 40

Springer, F. 166, 172, 205-208, 210

Staffeldt, A.W. Schack zie Schack Staffeldt, A.W.

Stallaert, K.F. 95

Stam, E. 172

Stangerup, Hakon 245

Stangerup, Helle 204

Stangerup, Henrik 204

Steffensen, S. 50, 243

Steinbeck, J. 193

Sterne, L. 65

Stiernhielm, G. 243

Stinus, E. 196

Stolp, H. 207

Storm, T. 169

Straten, H. v. 249

Streuvels, S. 15-16, 18, 27, 93-94, 97. 98-109, 172-173, 175, 182, 248-249

Strindberg, A. 13, 73, 84, 87, 90-91, 93, $99,102,118,128,203,246$

Stroebe, C. 108,249

Struensee, J.F. 54

Svendsen, H.M. 127, 204

Svensson, G. 41, 243

Swedenborg, E. 245

Sweelinck, J.P. 44

Syberg [Løvland], H. 185, 188, 200

Söderholm lees Soederholm

Søjberg lees Soeiberg

Sørensen lees Soerensen

\section{T}

Taels, J. 249

Tang Kristensen, E. 134-135, 251

Tégner, E. 53, 95

Teirlinck, H. 173, 185

Terlouw, J. 172, 203, 207

Thorup, K. 127, 204

Tieghem, P. v. 16

Tigerstedt, E.N. 243

Timmermans, F. 172-173, 187, 202, 252

Toergenjev, I.S. 175

Törnqvist, G.J. 18, 38

Tollenaere, F. de 245

Tolstoi, L. 104

Toonder, M. 172, 173

Toorn, M.C. v.d. $241,245,248-249$

Topsøe, S. 187

Toury, G. 22-23

Toussaint van Boelaere, F.V. 108

Tricht, H.W. v. 82, 246

Trier Mørch, D. 127, 204

Tryde, E. 187

Tullin, C.B. 27, 53, 59, 71, 245

Tuuk, T. v.d. $142,145,147-157,160$

Tvede, I. 178, 184, 188

Tydeman, H.W. 65

Tömqvist lees Toernqvist

U

Una [ps. v. Y. Braunius Oeberius-Meyer] 119

Unger, J. 33

Uyldert, M. 246

V

Vaandrager, C.B. 174

Vaartjes, G. 248

Valeton, A. zie Valeton Kjeldgaard, A.

Valeton Kjeldgaard, A. 77, 184, 188

Valeton-Ortt, H. 77

Van Aken, P. zie Aken, P. v. 
Van Assche, H. zie Assche, H. v.

Van de Poel, K. zie Poel, K. v.d.

Van de Putte, G. zie Putte, G. v.d.

Van de Wattyne, F. zie Wattyne, F. v.d.

Van de Woestijne, K. zie Woestijne, K. v.d.

Van den Broeck, R. zie Broeck, R. v.d.

Van der Hallen, E. zie Hallen, E. v.d.

Van Gorp, H. zie Gorp, H. v.

Van Ostaijen, P. zie Ostaijen, P. v.

Van Oye, E. zie Oye, E. v.

Van Paemel, M. zie Paemel, M. v.

Vandeloo, J. 173

Vanderauwera, R. 22, 166, 167, 241

Vandersteen, W. 172, 206

Vedel, G. 247

Veen, A. v.d. 194

Veen, F. v.d. 159

Veen, H. v. 173

Veen, J. v.d. 38

Velde, J. v. 173, 196

Venstermans, J. 248

Vercammen, J. 108

Verdenius, A. 243

Vermeylen, A. 96

Verriest, H. 98, 248

Verwey, A. 73, 81, 82, 241, 245

Vestdijk, S. 170, 172-174, 183, 184, 186-187, 190, 194, 203

Vin, D. de 252

Vincent, P., 252

Vingerhoets, P. 28, 131-132, 250-251

Visser, W.F.H. 172, 199

Vlasselaers, J. 248

Vliet, P. v. 173

Vloten, J. v. 75, 246

Vloten, K. v. 75

Vloten, M. v. $75,142,147-157,159-$ 160,246

Voeten, B. 174

Voltaire 65

Vondel, J. v.d. 14-17, 26, 27, 29-51, 184, 241-243

Vos-Dahmen v. Buchholtz, T. 207
Vosmaer, C. 172, 175, 177-178, 182

Vossius, G. 31

Vossius, I. 31-32, 242

Vriend, G. de 241

Vries, A. de 172, 184-185, 193, 194

Vries, G. de 168, 194, 196, 207, 252

Vries, J. de 58, 245

Vries, T. de 41, 172, 187, 193

Vrieze, S. de 242

W

Walschap, G. $169,172-173,183,185$, $187-188,190$

Wattez, O. 100

Wattyne, F. v.d. 100

Wegener, E. 105, 249

Welby, V. 80,247

Wellek, R. 17

Wessem, C. v. 172

Westerbaen, J. 38

Westh Neuhard, E. 200-201

Wetering, J.W. v.d. 172, 206

Wieland, C.M. 68

Wiener, L.H. 173

Wieselgren, O. 36, 38-39, 48, 243

Wijk, Hilda 80, 246

Wijk, Hj. 78, 80-81, 91, 246

Wijk, O. 80

Wijsman, Ph. 119

Wikén Bonde, I. 253

Wilamowitz-Möllendorf, U. v. 24

Wille, L. 251

Willekens, E. 248

Willems, J.F. 28, 94, 109, 248

Wilmink, W. 142, 147-157, 159-160

Willumsen, D. 127, 204

Winge, M. 204, 252-253

Winkel, J. te 243

Winkels, P.J.A. 246

Wit, J. de 165, 199, 252

Witt, C. de 54

Witt, J. de 54

Woesthoven, C.R. 54, 56 
Woestijne, K. v.d. 96, 98, 101, 173

Wolf, A. 36

Wolgast, H. 176

Wolkers, J. 166, 170, 173-174, 199-203, 207

Worm, M. 38, 243

Woude, J. v.d. 172,188

Wrangel, E. 14, 38, 48, 241-243

$\mathbf{Z}$

Zanger, J. de 194, 196, 200, 201, 207

Zeggelen, M.C. v. $172-173,175,177$, 182

Zonneveld, P. v. 244

Zwagerman, J. 204

Zweig, S. 185

$\emptyset$ stby lees Oestby

Aabye, K. zie onder A

Aakjær, J. zie onder A 


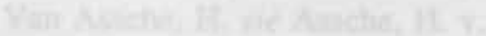

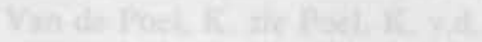

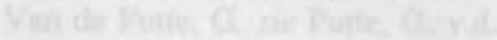

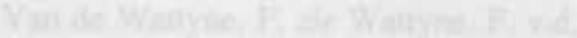

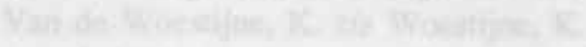
natiat

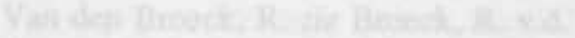

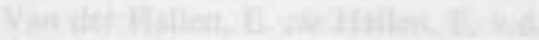

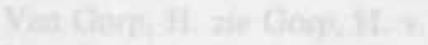

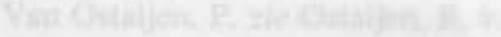

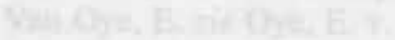

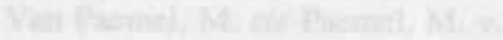

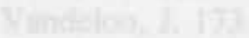

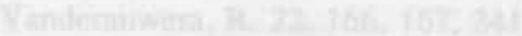

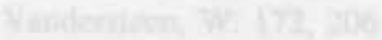

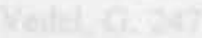

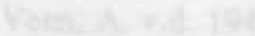

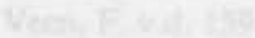

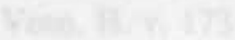

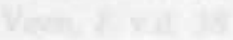

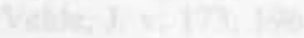

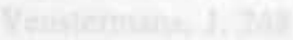

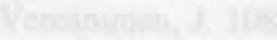

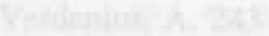

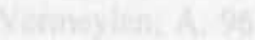

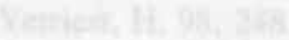

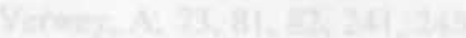

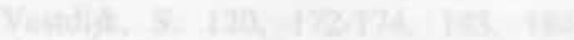

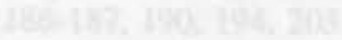

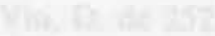

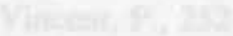

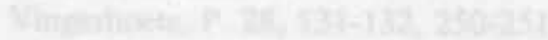

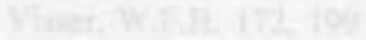

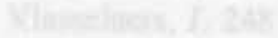

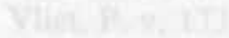

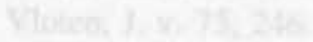

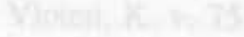

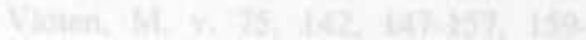

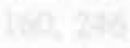

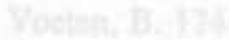

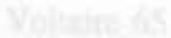

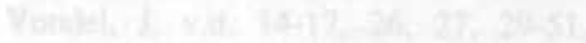

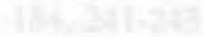

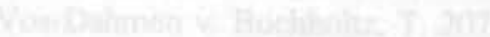

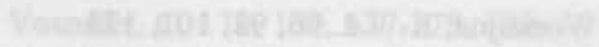

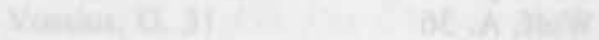

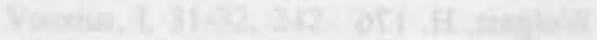

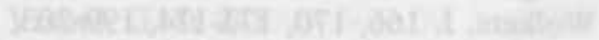

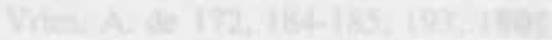

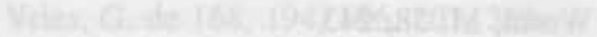

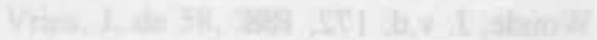

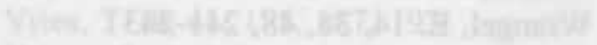

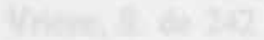

(1)

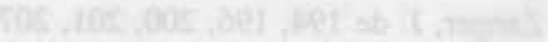
3hiL

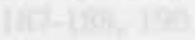

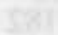

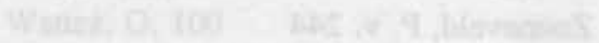

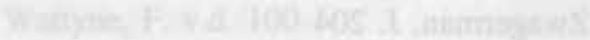

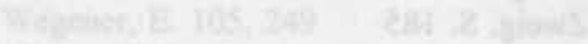

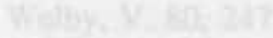

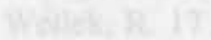

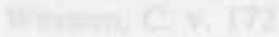

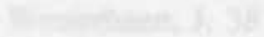

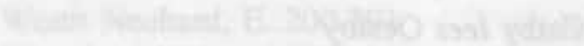

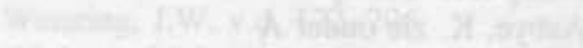

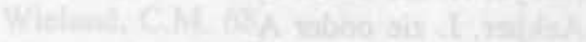

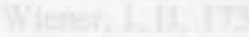

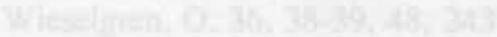

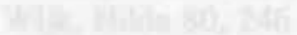

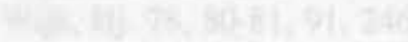

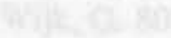

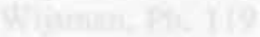

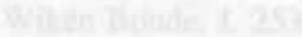

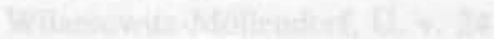

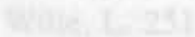

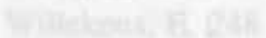

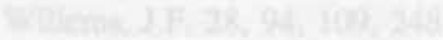

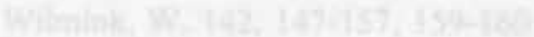

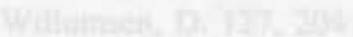

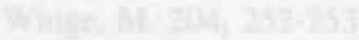

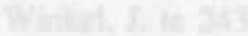

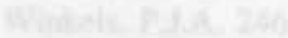

ran

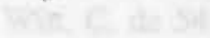

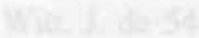

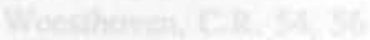




\section{Lijst van afbeeldingen}

1. Titelblad Kopenhaagse uitgave van Triomf over Funen (1660) 35

2. Titelblad Noorse vertaling van Lucifer (1987) 45

3. Portret van Frederik III van Denemarken door Karel van Mander III (ca. 1657) 49

4. Opdracht van Bilderdijk aan Christian IV van Denemarken (1793) 55

5. Portret van A.W. Schack Staffeldt (ca. 1860) 63

6. Titelblad van C. Amoldsen, Bidrag til Kundskab om Holland (1830)

7. Portret van F. van Eeden in Politiken (1913) 79

8. Titelblad Zweedse vertaling van De kleine Johannes (1903) 85

9. Titelblad Deense manuscriptvertaling van IJsbrand (ca. 1908) 89

10. Portret van Georg Brandes door P.S. Krøyer (1900) 97

11. Titelblad van B. Bjømson, Een vroolijke knaap (1925) 103

12. Omslag van S. Streuvels, De oude wiking (1931) 107

13. Titelblad oudste literaire vertaling Deens-Nederlands (1731) 117

14. Titelblad H. Bang, Vreemde vertellingen (1918) 121

15. Titelblad H. Pontoppidan, Jonge liefde (1947) 125

16. Illustatie bij de oudste vertaling van Reisekammeraten (1848) 137

17. Titelblad uitgave De Reiskameraad (1913) 145

18. Illustratie bij de jongste vertaling van Reisekammeraten (1992) 159

19. Titelblad Deense vertaling van Multatuli, Max Havelaar (1901) 181

20. Titelblad Deense vertaling van H. de Man, Het wassende water (1933) 189

21. Portret van de vertaalster Clara Hammerich (1894-1972) 197

22. Titelblad Deense vertaling van C. Nooteboom, Rituelen (1987) 209 


\section{nggniblsgdts nev telin.}

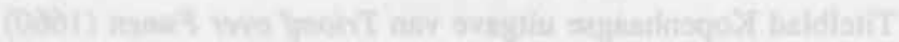

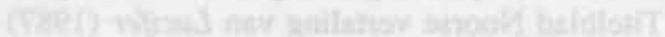

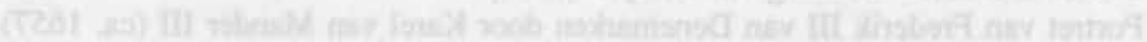

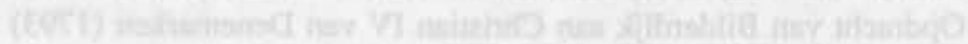

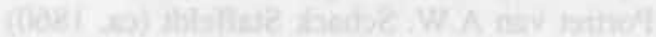

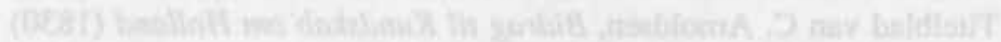

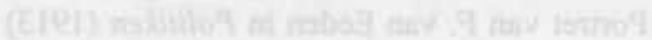

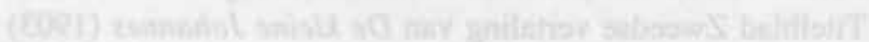

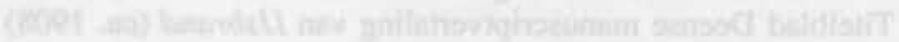

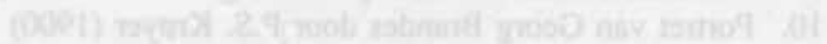

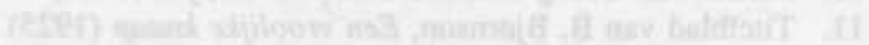

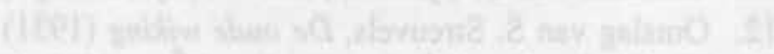

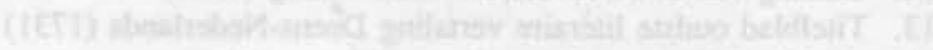

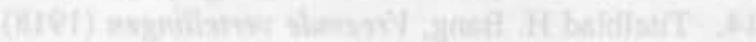

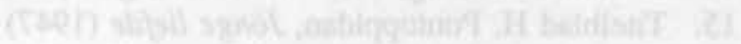

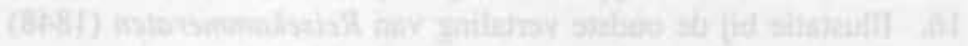

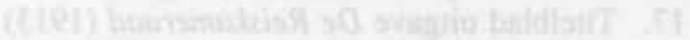

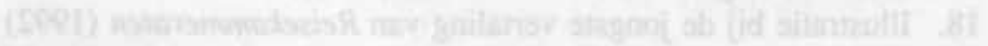

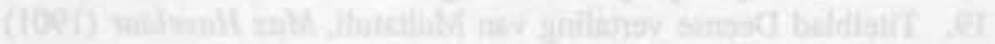

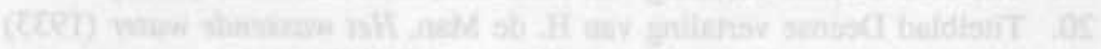

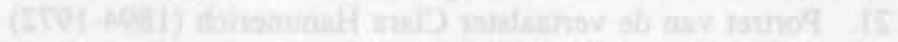




\section{Curriculum vitae}

Diederik Christoph Grit (Groningen, 22 maart 1949) behaalde in 1967 zijn diploma gymnasium-alfa. Hij studeerde aan de Rijksuniversiteit Groningen Nederlandse taal- en letterkunde, met als bijvakken Noorse en Deense letterkunde. In 1975 legde hij het doctoraalexamen af.

Van 1972 tot 1979 was hij leraar Nederlands aan het St. Maartenscollege te Haren (Gn.) en van 1979 tot 1982 lector Nederlandse letterkunde aan de universiteit van Kopenhagen. Sinds 1982 is hij als docent Nederlands en documentatie verbonden aan de Opleiding Tolk-Vertaler te Maastricht, thans een faculteit van de Hogeschool Maastricht. Tevens is hij freelance werkzaam als beëdigd vertaler Deens en Noors.

Naast de in dit proefschrift verzamelde artikelen publiceerde hij een bibliografie van Deens-Nederlandse literaire vertalingen, en artikelen over literatuurgeschiedenis, jeugdliteratuur en (ver)taaldidactiek, in Nederlandse, Vlaamse en Deense periodieken en bundels. Hij participeert sinds 1985 in de contactgroep Vertaalwetenschap van het Belgisch Nationaal Fonds voor Wetenschappelijk Onderzoek en werd in 1990 gekozen tot lid van de Maatschappij der Nederlandse Letterkunde.

Diederik Grit is sinds 1974 gehuwd met Noortje Jansen, en heeft twee dochters, Anne (Kopenhagen 1980) en Leonie (Maastricht 1984). 


\section{Driewerf zalig Noorden}

Over literaire betrekkingen tussen de Nederlanden en Seandinavię

\section{Diederik C. Grit}

Wat voor beeld hebben lezers in het Nederlands en Scandinavisch taalgebied zich in de loop der tijden van elkanders literaturen gevormd? En welke rol hebben individuele auteurs als subject en/of object in die beeldvorming gespeeld? Met deze vragen als uitgangspunt behandelt dit boek in zeven exemplarische deelstudies een aantal onderbelichte aspecten van de literaire betrekkingen tussen de Nederlanden en Scandinavië van de zeventiende eeuw tot heden. Kreeg in bestaande publikaties over dit onderwerp vooral de rol van individuele Scandinavische schrijvers de aandacht, hier gaat de belangstelling uit naar de rol van Nederlandstalige auteurs (Vondel, Bilderdijk, Van Eeden en Streuvels). Daarnaast komt het beeldvormende aspect van vertalingen aan de orde in onderzoek naar de receptie van 'de' Deense literatuur in Nederlandse vertaling en vice versa, en in een analyse van de verschillende vertaalstrategieèn in zeventien Nederlandse vertalingen van eenzelfde sprookje van Hans Christian Andersen. 